88056894
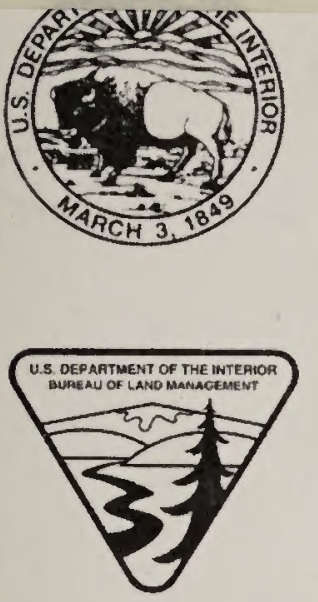

Department of the Interior bureau of Land Management

Coos Bay District 1300 Airport Lane North Bend, OR 97459

\title{
Coos County Natural Gas Pipeline \\ Draft Environmental Impact Statement
}

$\begin{array}{ll}\text { Ciiiiii } & \text { Cooperating Agency } \\ \text { PO Box } 2946 \\ \text { of Army Corps } \\ \text { of Engineers \& }\end{array}$

\section{Project Proponent}

Coos County Board of Commissioners 250 N. Baxter

Coquille, Oregon
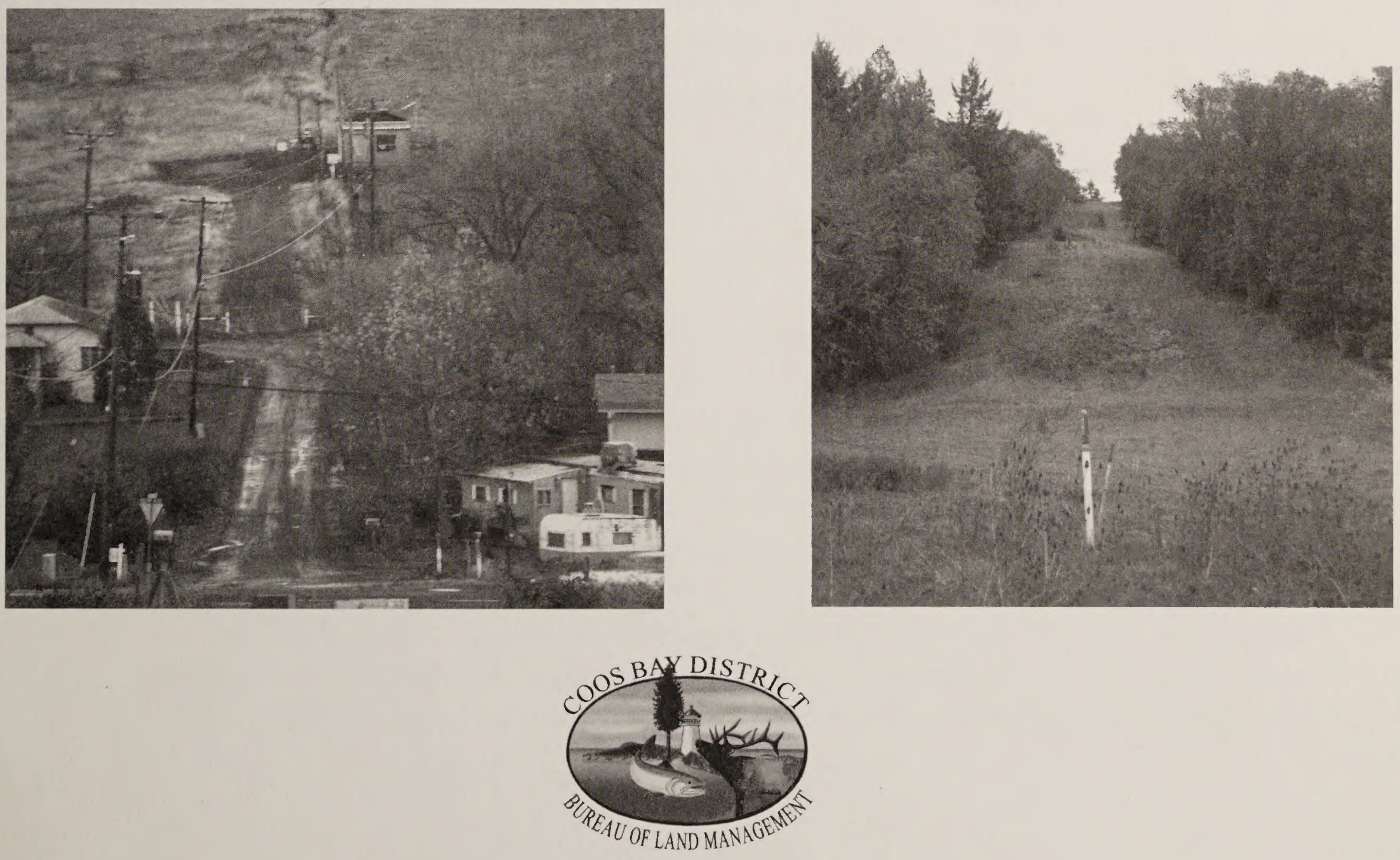
As the Nation's principal conservation agency, the Department of the Interior has responsibility for most of our nationally owned public lands and natural resources. This includes fostering the wisest use of our land and water resources, protecting our fish and wildlife; preserving the environmental and cultural values of our national parks and historical places, and providing for the enjoyment of life through outdoor recreation. The Department assesses our energy and mineral resources and works to assure that their development is in the best interest of all our people. The Department also has a major responsibility for American Indian reservation communities and for people who live in Island Territories under U.S. administration.

BLM/OR/WA/PL-02/002+1792

Comments, including names and street addresses of respondents, will be available for public review at the Coos Bay District Office, 1300 Airport Lane, North Bend, during regular business hours (7:45 a.m. to 4:30 p.m.), Monday through Friday, except holidays. Individual respondents may request confidentiality. If you wish to withhold your name or street address from public review or from disclosure under the Freedom of Information Act, you must state this prominently at the beginning of your written comment. Such requests will be honored to the extent allowed by law. All submissions from organizations or businesses, and from individuals identifying themselves as representatives or officials of organizations or businesses, will be made available for public inspection in their entirety. 


\section{United States Department of the Interior}

\section{BUREAU OF LAND MANAGEMENT COOS BAY DISTRICT \\ 1300 AIRPORT LANE \\ NORTH BEND, OREGON 97459-2000}

Home page: www.or .blm.gov/coosbay E-mail: cos_bay @or.blm.gov Telephone: (541)756-0100 Toll Free: (888) 809-0839 Fax: (541) 751-4303

In Reply Refer to:

2800

Dear Interested Party:

Enclosed for your review and comment is the Draft Environmental Impact Statement for issuing a BLM right-of-way permit to Coos County for construction, operation, and maintenance of a 12inch natural gas transmission pipeline. The proposed natural gas transmission pipeline would connect to the Williams Gas Pipeline at a meter facility southwest of Roseburg, in or near Section 33 Township 27 South, Range 6 West in Douglas County and would terminate at Ocean Boulevard in the city of Coos Bay (Section 27 Township 25 South, Range 13 West). Under the proposed action the pipeline would be buried within the existing rights-of-ways of the Pacific Corp. (PP\&L) and Bonneville Power Administration (BPA) electric transmission lines, and within the existing roadbed of the Coos Bay Wagon Road. The total length of the pipeline is approximately 60 miles, with approximately 3.0 miles located on BLM-administered lands.

The natural gas transmission pipeline will deliver gas to distribution facilities built by Northwest Natural Gas in the Coos Bay and North Bend communities. Smaller 6-inch or 4-inch laterals will be built off the mainline to serve the cities of Coquille, Myrtle Point, and perhaps Bandon at a later date. The location of the laterals has not been finalized, but is anticipated to follow the location of existing powerline, State highway, or railroad rights-of-way. Locations of the distribution lines within the city limits are not known at this time, but are anticipated to be located within existing road rights-of-way.

You are invited to review and comment on the range and adequacy of the draft alternatives and associated environmental effects. For comments to be most helpful, they should relate to specific concerns or conflicts that are within the legal responsibilities of the BLM.

Public meetings will be held during the comment period. To ensure local community participation and input, public meetings will be held in Coos Bay and at other locations if requested. At least 15 days public notice will be given for activities where the public is invited to attend. Specific dates and locations of meetings and comment deadlines will be announced through the local news media, newsletters, the BLM web site (www.or.blm.gov/coosbay), and the Coos County web site (http://www.co.coos.or.us). 
The comment period will end 60 days after publication of the Environmental Protection Agency's Notice of Availability of this draft environmental impact statement in the Federal Register. Comments on the draft EIS should be received on or before the end of the comment period. Written comments should be sent to Bob Gunther, Project Coordinator, Coos Bay District, BLM, 1300 Airport Lane, North Bend, OR 97459. Documents pertinent to this proposal may be examined at the Coos Bay District Office in North Bend, Oregon, and local libraries.

Comments, including names and street addresses of respondents, will be available for public review at the Coos Bay District Office during regular business hours 7:45 a.m. to 4:30 p.m., Monday through Friday, except holidays, and may be published as part of the Final EIS. Individual respondents may request confidentiality. If you wish to withhold your name or street address from public review or from disclosure under the Freedom of Information Act, you must state this prominently at the beginning of your written comment. Such requests will be honored to the extent allowed by law. All submissions from organizations and businesses, and from individuals identifying themselves as representatives or officials of organizations or businesses, will be available for public inspection in their entirety.

We appreciate your help in the review process, and look forward to your continued interest and participation. For additional information or clarification regarding this document or the review process, please contact Bob Gunther at (541) 751-4295.

$$
\text { Sue Re Rehardsor }
$$

Sue E. Richardson

District Manager 


\section{BOARD OF COMMISSIONERS}

250 No. Baxter Street, Coquille, Oregon 97423

(541) 396-3121 Ext.247

FAX (541) 396-4861 / TDD (800) 735-2900

E-Mail: nwhitty@co.coos.or.us

December 4, 2001

Sue Richardson

District Manager

US Bureau of Land Management

1300 Airport Lane

North Bend, OR 97459

\section{Re: $\quad$ Coos County Gas Pipeline}

Dear Sue:

Over the past two years, the Coos County Board of Commissioners has worked with BLM in the development of the proposed natural gas pipeline from Roseburg to Coos Bay. The Environmental Impact Statement has minimized impacts to people and habitat, as well as reducing the estimated cost from the original concept.

This project was conceived as a means to improve the economic climate of the county. The project was approved by a "double majority" of county voters in November 1999. The County has taken a leadership role, and will own the pipeline for the benefit of its constituents. The state legislature supported the pipeline project with two significant funding grants. The local gas utility, local industries and citizen leaders have been very supportive.

We believe the introduction of natural gas into Coos County will benefit the community in several ways. Natural gas is the preferred fuel of most industrial, commercial and residential utility energy users in the US because of low cost and clean combustion. Natural gas is produced domestically in the US and Canada, and long-term supply appears to be more secure than all other energy resources. Natural gas will allow existing Coos County energy users to operate more competitively, and is a critical key to any future economic growth.

We believe that the project as defined in the EIS will best utilize the public lands, power and road corridors to minimize impacts to the environment. We look forward to working with BLM to successful completion of this vital public works project.

Sincerely,
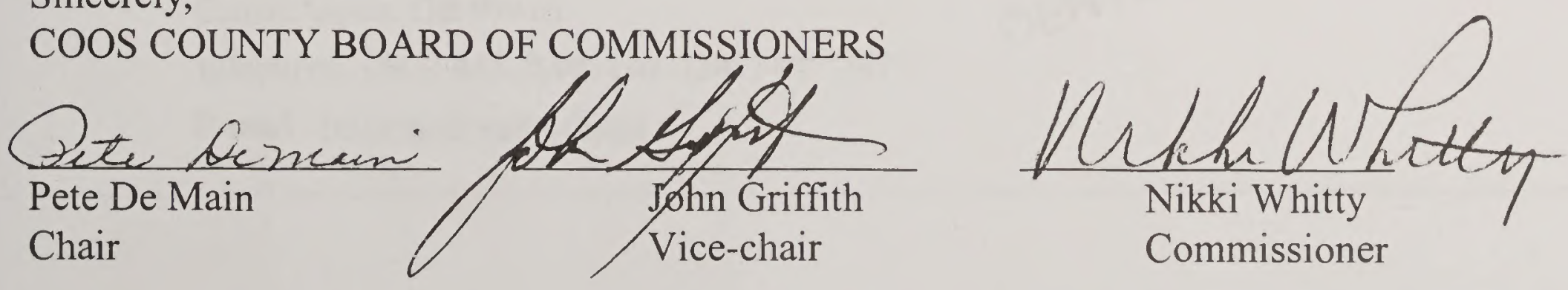



\section{Abstract}

\section{Coos County Natural Gas Pipeline}

Draft Environmental Impact Statement

1. Responsible Agency: United States Department of the Interior, Bureau of Land Management (Lead Agency) and

Department of Defense, Army Corps of Engineers (Cooperating Agency)

2. $\operatorname{Draft}(\mathrm{X})$

3. Administrative Action $(\mathrm{X})$
Final ( )

\section{Legislative Action ( )}

4. Abstract: This draft EIS addresses the effects of constructing a proposed natural gas pipeline approximately 60 miles in length from near Roseburg, Oregon, to Coos Bay, Oregon. The proposed action includes crossing approximately 3.0 miles of federal land administered by the Bureau of Land Management. This document analyzes the proposed action as compared to two alternatives, including no action. The proposed action includes the construction, operation and maintenance of a 12-inch diameter natural gas pipeline within existing rights-of-way designated for road or utility corridors. Suitable habitat for three federally protected species (the marbled murrelet, the northern spotted owl and the bald eagle) is adjacent to the proposed action corridor. The proposed action pipeline would cross 188 streams, 1 wetland and is adjacent to approximately 2 miles of floodplain. This document discusses Direct, Indirect and Cumulative effects, including socio-economic impacts, and addresses agency and public concerns.

5. Date comments must be received: The comment period will end 60 days after publication of the Environmental Protection Agency's Notice of Availability of this draft environmental impact statement in the Federal Register. The close of the 60-day comment period will be announced in news releases, legal notices, individual mailings, and on the Coos Bay District and Coos County webpages (www.or.blm.gov/coosbay and http://www.co.coos.or.us.)

6. For Further Information contact:

Bob Gunther, Project Coordinator

1300 Airport Lane

North Bend, OR 97459

Telephone: (541) 751-4295, Fax: (541)751-4303

E-mail: Bob Gunther@or.blm.gov

For technical information contained in the EIS contact:

Brian Cox, Senior Scientist

Biological Information Specialists, Inc.

P.O. Box 27

Camas Valley, OR 97416

Telephone: (541) 445-2008, Fax: (541) 445-2877

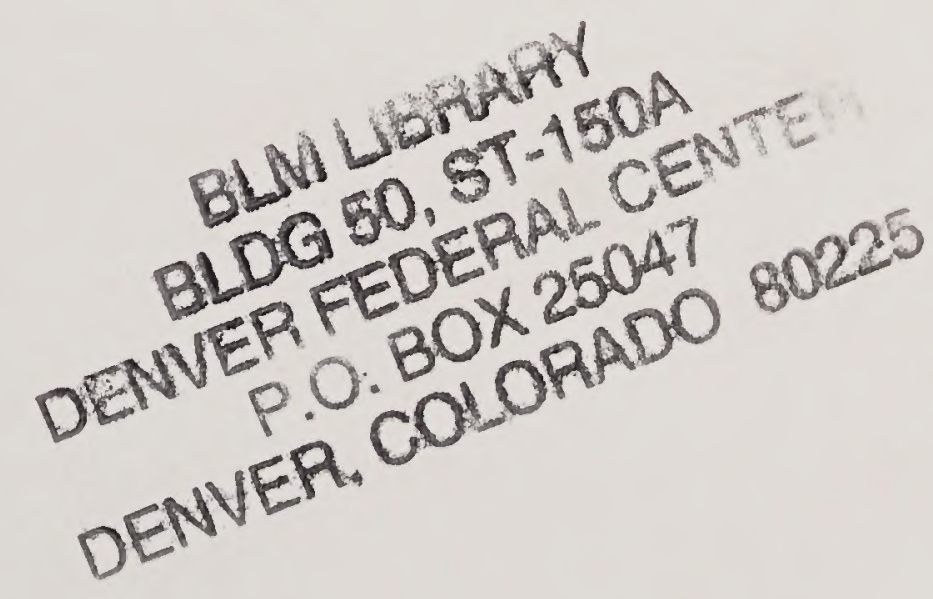

E-mail: bisbrian@wanweb.net 
Summary 


\section{Summary}

The Coos County Board of Commissioners is proposing to construct and operate and maintain a natural gas pipeline between Roseburg and Coos Bay, Oregon. This pipeline would begin at an existing natural gas pipeline a few miles south of Roseburg and terminate in the city of Coos Bay where a distribution facility would be built. This pipeline would be approximately 60 miles long and have a capacity of 70 million cubic feet of natural gas per day. The entire pipeline would be located within existing road and utility rights-of-way (ROW). Approximately 3.0 miles of the pipeline would cross lands within utility rights-of-way managed by the U.S. Department of Interior, Bureau of Land Management (BLM).

Coos County contracted three independent consulting corporations (Pipeline Solutions, Inc., Industrial Gas Service, Inc.) as professional advisors and (Biological Information Specialists, Inc.) for preparation of this environmental impact statement (EIS).

To gain easements on public and privately owned lands, the Coos County Board of Commissioners filed an application with the BLM for a perpetual and renewable right-of-way in May 2000, and filed an application with Bonneville Power Administration (BPA) for consent to construct portions of the natural gas line within BPA utility corridors in August 2000.

Coos County submitted an application to the U.S. Army Corps of Engineers for permission to construct the pipeline across streams and wetlands in November 2000.

\section{Agency Roles and Decisions to be Made}

Numerous agencies are involved in EIS preparation, consultation and permitting decisions for the pipeline project, as shown in Table S-1.

The Bureau of Land Management serves as Lead Agency. The Secretary of the Interior, through the BLM, is mandated to process Mineral Leasing Act (MLA) applications across federal lands. Assuming the Record of Decision (ROD) selects the proposed action for construction of the pipeline, BLM will then issue authorization (right-of-way grant) under the MLA for use of federal lands. 
Table S-1. Overview of Permit, Approval and Consultation Requirements for the Proposed Action

\begin{tabular}{|c|c|}
\hline Agency & Permit/Authority \\
\hline \multicolumn{2}{|l|}{ Federal Government } \\
\hline \multirow[t]{4}{*}{$\begin{array}{l}\text { U.S. Department of the Interior, } \\
\text { Bureau of Land Management } \\
\text { (BLM) }\end{array}$} & $\begin{array}{l}\text { Record of Decision (ROD)/ } \\
\text { Minerals Leasing Act: Title 1, Section } 28 \text { (c)(2) of the Mineral Leas- } \\
\text { ing Act of } 1920 \text {, as amended, November 16,1973 authorizes the Sec- } \\
\text { retary of the Interior to grant or renew rights-of-way (ROW) or } \\
\text { permits and to enter into agreements with other land-managing federal } \\
\text { agencies for the processing of applications for pipelines to transport } \\
\text { oil natural gas, synthetic liquid or gaseous fuels, or refined products } \\
\text { produced therefrom. }\end{array}$ \\
\hline & Right-of-way (ROW Grant/Minerals Leasing Act) \\
\hline & Notice to Proceed \\
\hline & Consultation \\
\hline \multirow{3}{*}{$\begin{array}{l}\text { U.S. Army Corps of Engineers } \\
\text { (ACOE) }\end{array}$} & Cooperating Agency \\
\hline & Section 404 \\
\hline & Section 7 Permit \\
\hline \multirow{2}{*}{$\begin{array}{l}\text { U.S. Department of the Interior, } \\
\text { Fish and Wildlife Service } \\
\text { (USFWS) }\end{array}$} & Consultation and Concurrence \\
\hline & Section 7/Endangered Species Act \\
\hline
\end{tabular}

\section{All Land Owners Along the Pipeline ROW}

\begin{tabular}{|l|l}
\hline Bonneville Power Administration & ROW and consent to build sections of a natural gas pipeline within
\end{tabular} (BPA)

BPA utility corridors

Private land owners

ROW ownership agreements 


\section{Need for Action}

Lacking natural gas, cities within Coos County currently depend on electricity, heating oil, propane and wood for its fuel needs. In most cases, natural gas is more efficient and less expensive than electricity, oil or propane. In February 1999, ECONorthwest published a study forecasting the economic impacts of natural gas supplied to Coos County. ECONorthwest, forecasting the dynamic efficiency effect of the proposed action, estimates that by the tenth year, consumers will save over \$6.7 million a year. Coos County ballot measure \#6-63 (November 1999) authorized funds for construction of a natural gas pipeline.

\section{Purpose of the Proposed Action}

The purpose of the proposed action is to gain a perpetual or renewable right-of-way easement for the construction, operation and maintenance of a natural gas pipeline across BLM-managed lands.

\section{Alternatives Analyzed in the Environmental Impact Statement (EIS)}

\section{Proposed Action: Natural Gas Pipeline}

The proposed action responds to the above-stated Purpose and Need by transporting natural gas from Roseburg, Oregon, to Coos Bay, Oregon, at a lower cost than other alternatives.

The proposed natural gas pipeline would originate at an existing Williams Gas pipeline just south of Roseburg, extend southwest for approximately 60 miles where it would terminate at a distribution facility that would be built in Coos Bay. The proposed action would include construction of pipeline laterals supplying natural gas to the communities of Coquille, Myrtle Point and possibly Bandon. The routes of these laterals are not yet finalized. Approximately 3.0 miles of the preferred pipeline route would cross BLM-managed lands within BPA utility ROW. The remainder of the pipeline would be located within the rights-of-way of the Coos Bay Wagon Road (CBW Road), other public roads and utility rights-of-way crossing privately owned properties. The pipeline would cross 188 streams and 1 wetland.

The pipeline would be a 12 -inch diameter pipe, operating at a pressure from 500 to 800 pounds per square inch (psi). With the exception of line markers, test stations, bridge crossings and valve settings, the pipeline would be buried for its entire length.

\section{No Action}

For the purposes of this EIS the "No Action Alternative" is defined as the BLM would not grant Coos County a discretionary Right-of-Way permit for construction, operation and maintenance of the natural gas pipeline on lands administered by the BLM. Affects addressed in the EIS associated with the No Action Alternative assume that the present conditions remain as they currently exist, that is, the pipeline would not be constructed.

However, if the Proposed Action as described in the EIS is denied, Coos County will proceed with plans to construct, operate and maintain the natural gas pipeline within public roads and private easements included in the Proposed Action, avoiding crossing Federal land as necessary. Obtaining a right-of-way permit for crossing federal lands would not be necessary. Segments C, E and G of the described Proposed Action would be built, mostly in the Coos Bay Wagon Road. Approximately 86 percent of the proposed route would be built in the location described in the EIS Proposed Action. This re-route would result in the construction of approximately 4.0 additional miles of pipeline and cost an estimated $\$ 2.3$ million dollars more than the proposed action.

\section{The Hwy 42 Alternative}

This alternative would deliver natural gas from near Roseburg to Coos Bay by constructing a pipeline under or beside the road bed of Oregon Hwy 42 for approximately 83 miles. This route would cross sensitive wildlife areas and be located within difficult construction zones for approximately 7 miles. Construction would be more difficult due to the existing fiber optic cables buried on each side of the road. Construction along Hwy 42 would result in considerable traffic delays for an extended period of time. 
This route would cross 209 streams and 9 wetlands. A route summary of environmental and economic impacts is given in Table S-2.

Table S-2. Impacts and Route Summary Including No Action

\begin{tabular}{|l|c|c|c|}
\hline \multicolumn{1}{|c|}{ Alternative } & Proposed Action & Hwy 42 & No Action \\
\hline \hline Total length (miles) & 59.1 & 82.7 & 63.1 \\
\hline Total stream crossings & 188 & 209 & 188 \\
\hline Total wetlands crossed & 1 & 9 & 1 \\
\hline Federally listed species & No Impact & No Impact & No Impact \\
\hline Survey and Manage species & No Impact & No Impact & No Impact \\
\hline Estimated Costs & \$3 million & \$48 million & \$36.3 million \\
\hline
\end{tabular}

\section{Alternatives Considered but Eliminated from Detailed Study}

Alternatives to the proposed action that were determined not to meet the need included alternative sources of natural gas; Compressed Natural Gas (CNG), Liquefied Natural Gas (LNG), Pacific Gas Transmission (PGT) and an alternative route following Hwy 38. All of these alternatives were rejected because they were not economically feasible.

\section{Potential Impacts}

Five categories were used to evaluate potential impacts to the natural and built environments: negative impact, no negative impact, no anticipated impact, no effect and beneficial impact. For the resources discussed in this EIS, potential impacts from construction and operation are estimated to be "negligible short-term" to "no effect." 


\section{List of Acronyms Used Within this Document}

ACEC - Area of Critical Environmental Concern

ACS - Aquatic Conservation Strategy

AD - $\quad$ Anno Domini

AMA - Adaptive Management Area

API - American Petroleum Institute

BA - Biological Assessment

BIS - Biological Information Specialists

BLM - Bureau of Land Management

BMP - Best Management Practice

BP - Before Present

BPA - Bonneville Power Administration

CBW- Coos Bay Wagon

CEQ - Council on Environmental Quality

CHU - Critical Habitat Unit

CFR - Code of Federal Regulations

cfs - cubic feet per second

CNG - Compressed Natural Gas

CR - County Road

CSZ - Cascadia Subduction Zone

CWTD - Columbian White-Tailed Deer

DEQ - Department of Environmental Quality

DOT - Department of Transportation

EA - Environmental Assessment

ECA - Equivalent Clearcut Area

ECP - Erosion Control Plan

EIS - Environmental Impact Statement

EPA - Environmental Protection Agency

ERMA - Extensive Recreation Management Area

ESA - $\quad$ Endangered Species Act (1973)

FLPMA - Federal Land Policy and Management Act

FONSI - Finding of No Significant Impact

FSEIS - Final Supplemental Environmental Impact Statement

GIS - Geographical Information System

GLO - General Land Office

ha - hectares 


\begin{tabular}{|c|c|}
\hline HUC - & Hydrologic Unit Code \\
\hline IDT - & Inter-disciplinary Team \\
\hline \multicolumn{2}{|c|}{ IMPLAN - Impact Analysis for Planning } \\
\hline km - & kilometer \\
\hline $\mathbf{k V}$ - & kilovolt \\
\hline Kw - & Kilowatt \\
\hline LNG - & Liquefied Natural Gas \\
\hline LRMP BO & - Land Resource Management Plan Biological Opinion \\
\hline LSR - & Late Successional Reserve \\
\hline LSOG - & Late Successional-Old-Growth \\
\hline LWD - & Large Woody Debris \\
\hline mi - & miles \\
\hline MAOP - & Maximum Allowable Operating Pressure \\
\hline MOP - & Maximum Operating Pressure \\
\hline NEPA - & National Environmental Protection Act (1969) \\
\hline NMFS - & National Marine Fisheries Service \\
\hline NRHP - & National Register of Historic Places \\
\hline NFP - & Northwest Forest Plan \\
\hline NTU - & Nephelometric Turbidity Unit \\
\hline $\mathrm{O \& C}-$ & Oregon and California (land designation) \\
\hline O\&M - & Operation and Maintenance \\
\hline ODF - & Oregon Department of Forestry \\
\hline ODFW - & Oregon Department of Fish and Wildlife \\
\hline ODOT - & Oregon Department of Transportation \\
\hline OMP - & Operation and Maintenance Plan \\
\hline ONHP - & Oregon Natural Heritage Program \\
\hline OPUC - & Oregon Public Utilities Commission \\
\hline OSHA - & Office of Safety and Health Administration \\
\hline PDC - & Project Design Criteria \\
\hline PE - & Polyethylene \\
\hline POC - & Port Orford Cedar \\
\hline pH - & Potential of Hydrogen \\
\hline PP\&L - & Pacific Power and Light \\
\hline psi - & pounds per square inch \\
\hline psig - & pounds per square inch gauge \\
\hline PUE - & Public Utility Easement \\
\hline RCYBP - & Radiocarbon Years Before Present \\
\hline RMP - & Resource Management Plan \\
\hline
\end{tabular}




\footnotetext{
ROD - Record of Decision

ROW - Right-of-Way

SC - Species of Concern

SCADA - Supervisory Control and Data Acquisition

SDP - Site Discovery Probes

SHPO - State Historic Preservation Office

SMYS - Standard Maximum Yield Strength

SWOCC - Southwest Oregon - Coos County

T\&E - $\quad$ Threatened and Endangered

TMDL - Total Maximum Daily Load

T\#\#S, R\#\#W, Sec. \#\# - Township \#\# South, Range \#\# West, Section \#\#

USDI - United States Department of Interior

USFWS - United States Fish and Wildlife Service

USGS - United States Geological Service

VRM - Visual Resource Management

WA - Watershed Analysis

WAU - Watershed Analysis Unit
} 


\section{Table of Contents}

\section{Chapter $1 \quad$ Purpose and Need}

Summary of Chapters within this Document 2

Purpose and Need 3

Summary of Scoping and significant issues of the EIS 3

Conformance with BLM Resource Management Plan EIS $\quad 4$

Authorizing Actions and Relationship to Statutes and Regulations 4

Inter-relationship with Other Projects 4

Interdependencies $\quad 5$

Chapter 2 Alternatives Including the Proposed Action

$\begin{array}{ll}\text { Description of Proposed Action } & 7\end{array}$

Location of the Proposed Action $\quad 8$

Description of the Proposed Action Corridor 9

$\begin{array}{ll}\text { Pipeline Laterals } & 10\end{array}$

$\begin{array}{ll}\text { Lateral Routes } & 10\end{array}$

Proposed Action - Utility Corridors and the CBW Road 13

No Action Alternative $\quad 14$

Hwy 42 Alternative (the South Route) 14

$\begin{array}{ll}\text { Alternatives Considered But Rejected } & 15\end{array}$

\section{Chapter $3 \quad$ Affected Environment}

$\begin{array}{ll}\text { Introduction } & 17\end{array}$

$\begin{array}{ll}\text { General Setting of the Proposed Action } & 17\end{array}$

$\begin{array}{ll}\text { Environment } & 18\end{array}$

Climate 18

Air Quality 18

Geology 18

$\begin{array}{ll}\text { Natural Resources } & 19\end{array}$

Cultural Resources (Including Native American Religious Concerns) 19

Soils 19

Proposed Action Vegetation 19

$\begin{array}{ll}\text { Forest Types } & 19\end{array}$

Vegetation of the Hwy 42 Alternative Route $\quad 20$

Farmlands, Prime and Unique $\quad 20$

$\begin{array}{ll}\text { Floodplain } & 20\end{array}$ 
Water Quality, Quantity and Domestic Use

Waters Along the Hwy 42 Alternative Route

Wild and Scenic Rivers

Wilderness or Wilderness Study Areas

Wildlife

Federally Listed, Proposed or Candidate Species 21

BLM Special-Status Species $\quad 24$

Survey and Manage Species $\quad 25$

General Wildlife Groups $\quad 26$

Human Environment 28

Area of Critical Environmental Concern (ACEC) 28

Public Health and Safety $\quad 28$

Environmental Justice $\quad 28$

Socio-economics in Coos County 28

Socio-economics within the Proposed Action 28

Waste - Solid or Hazardous 29

Land Uses 30

Transportation $\quad 31$

Utility Corridors $\quad 34$

Encumbrances $\quad 35$

\section{Chapter $4 \quad$ Environmental Consequences}

$\begin{array}{ll}\text { Introduction } & 37\end{array}$

Proposed Action Effects Summation 38

$\begin{array}{ll}\text { Environment } & 39\end{array}$

Air Quality 39

$\begin{array}{ll}\text { Natural Resources } & 40\end{array}$

Cultural Resources (Including Native American Religious Conerns) 40

$\begin{array}{ll}\text { Soils } & 40\end{array}$

Vegetation 41

Floodplains $\quad 45$

Wild and Scenic Rivers 45

Wildlife 45

Aquatic Ecosystem 51

Human Environment $\quad 65$

Areas of Critical Environmental Concern (ACEC) 65

Socio-economics 65

Environmental Justice $\quad 74$ 
Public Health and Safety

Waste - Solid or Hazardous

Land Uses

Transportation 76

Utility Corridors

Conflicts with Other Plans

Impacts Summary Table

Chapter 5 Consultation and Coordination

List of Contributors

Organizations Consulted

List of Appendices

Appendix A Geotechnical Engineering Report

Registration Stamp and Table of Contents

List of References

Appendix B Cultural Resources

Introduction

References Cited

Appendix C Maps

Appendix D Agency Management Plans for Resources Adjacent to the Proposed Action

Visual Resource Management

Riparian Reserve and Aquatic Conservation Strategy Management

Watershed Management Plans

\section{Appendix E Aquatic Conservation Assessment}

Evaluation of Consistency with Watershed Analysis

Evaluation of Consistency With NMFS' March 18, 1997 Plan-Level Biological Opinion

Rationale Used in Completing the Checklist for Documenting Environmental Baseline and the Effects of Proposed Action(s) on Relevant Indicators with Respect to the E. Fork Coquille Watershed

Rationale Used in Completing the Checklist for Documenting Environmental Baseline and the Effects of Proposed Action(s) on Relevant Indicators with Respect to the Lower Coos River/Coos 
Rationale Used in Completing the Checklist for Documenting Environmental Baseline and the Effects of Proposed Action(s) on Relevant Indicators with Respect to the North Fork Coquille Watershed

Rationale Used in Completing the Checklist for Documenting Environmental Baseline and the Effects of Proposed Action(s) on Relevant Indicators with Respect to the Lower South Umpqua Watershed

Rationale Used in Completing the Checklist for Documenting Environmental Baseline and the Effects of Proposed Action(s) on Relevant Indicators with Respect to the Middle Main Coquille Watershed

Rationale Used in Completing the Checklist for Documenting Environmental Baseline and the Effects of Proposed Action(s) on Relevant Indicators with Respect to the Ollala-Lookingglass Watershed

List of References

\section{Appendix E1 Essential Fish Habitat Assessment}

Not Adversely Affected Assessment

Appendix F U.S. Fish and wildlife Service Endangered Species Consultation Letter of Concurrence (Not Yet Received)

Appendix G Questions and Concerns from the Public

Questions

Comments

\section{Appendix H Erosion Control Plan}

Best Management Practices (BMPs)

Active Stream Crossing Project Design Criteria (PDC)

"Bag and Flume" Construction Specifications

Project Design Criteria for Culvert Installation and Removal

Approved Materials for Use - ODOT Construction Manual

Mulching Application Specifications

\section{Appendix I Watersheds and Streams}

\section{Appendix J Construction, Operation and Maintenance Plan}

Methods

System Description

Operation Description

Maintenance Description 
Appendix K Survey and Manage Species

Appendix K1 Special-Status Species

Appendix L Glossary of Terms

Appendix M List of References 


\section{List of Tables}

Table 1: Proposed Action Segment Description $\quad 9$

Table 2: Action Alternatives Route Summary 12

Table 3: Route Summary for Proposed Action 13

Table 4: Route Summary for Hwy 42 Alternative 14

Table 5: Special-Status Fish Species in Streams Near the Proposed Action 25

Table 6: Portions of the CBW Road Affected 32

Table 7: Other Roads Affected by Pipeline 33

Table 8: Definition of Key, Direct, Indirect and Cumulative Impacts 37

Table 9: Acreage of Soil Area Impacted by Watershed in the Proposed Action 41

Table 10: Noxious Weeds in Utility Corridor 42

Table 11: PDC Cleaning List 43

Table 12: Aquatic Impact Levels $\quad 52$

Table 13: Stream Description and Crossing Type on Utility Corridor within the Lower

South Umpqua Watershed (5th field HUC)

Table 14: Stream Description and Crossing Type on Road Corridor within the

Ollala Creek/Lookingglass Creek Watershed (5th field HUC) 55

Table 15: Stream Description and Crossing Type on Utility Corridor within the

Ollala Creek/Lookingglass Creek Watershed (5th field HUC)

Table 16: Stream Description and Crossing Type on Road Corridor within the

East Fork Coquille Watershed (5th field HUC) 57

Table 17: Stream Description and Crossing Type on Utility Corridor within the

East Fork Coquille Watershed (5th field HUC)

Table 18: Stream Description and Crossing Type on Road Corridor within the

Lower Coos River/Coos Bay Watershed (5th field HUC)

Table 19: Stream Description and Crossing Type on Utility Corridor within the

Lower Coos River/Coos Bay Watershed (5th field HUC)

Table 20: Stream Description and Crossing Type on Road Corridor within the

North Fork Coquille River Watershed (5th field HUC)

Table 21: Stream Description and Crossing Type on Utility Corridor within the

North Fork Coquille River Watershed (5th field HUC)

Table 22: Stream Description and Crossing Type on Road Corridor within the

Middle Main Coquille River Watershed (5th field HUC)

Table 23: Pipeline Construction Spending for the $\$ 48$ Million Scenario

Table 24: Pipeline Construction Spending for the $\$ 34$ Million Scenario 
Table 25: Direct Impact of $\$ 48$ Million in Pipeline Construction on Coos County in Year 2000 Dollars and Person-Years of Employment

Table 26: Direct, Indirect, Induced and Total Economic Impacts on Coos County From $\$ 48$ Million in Pipeline Construction Spending in

Year 2000 Dollars and Person-Years of Employment

Table 27: Direct Impact of \$34 Million in Pipeline Construction on Coos County in Year 2000 Dollars and Person-Years of Employment

Table 28: Direct, Indirect, Induced and Total Economic Impacts on Coos County From \$34 Million in Pipeline Construction Spending

Table 29: Annual Spending on Pipeline Operations (in Year 2000 dollars)

Table 30: Annual Direct Impact of Pipeline Operations Spending on Coos County in Year 2000 Dollars and Person-Years of Employment

Table 31: Annual Direct, Indirect, Induced and Total Economic Impacts on Coos County Because of Pipeline Operations Spending in Year 2000 Dollars and Person-Years of Employment

Table 32: Comparative Population Growth Rates 1980-2000

Table 33: Propane and Heating Oil Dealers

Table 34: Impacts Summary

Table 35: Technical Consultation 82

Table 36: Pipeline Meetings

Table A-1: Survey of Foundation Soil and Rock, Coos County

Natural Gas Pipeline

Table E-1: Matrix of Factors and Indicators (All WAs \& NMFS, 1998)

Table E-2: Checklist for Documenting Environmental Baseline and Effects of Proposed Actions on Relevant Indicators (East Fork Coquille)

Table E-3: Checklist for Documenting Environmental Baseline and Effects of Proposed Actions on Relevant Indicators (Lower Coos)

Table E-4: Checklist for Documenting Environmental Baseline and Effects of Proposed Actions on Relevant Indicators (North Fork Coquille)

Table E-5: Checklist for Documenting Environmental Baseline and Effects of Proposed Actions on Relevant Indicators (Lower South Umpqua)

Table E-6: Checklist for Documenting Environmental Baseline and Effects of Proposed Actions on Relevant Indicators (Middle Main Coquille)

Table E-7: Checklist for Documenting Environmental Baseline and Effects of Proposed Actions on Relevant Indicators (Ollala-Lookingglass)

Table H-1: Fish-bearing Streams Identified for Avoiding Ground Disturbance within them

Table H-2: Specified ODOT Seed Mixture for Coast Range

Table I-1: Stream and Wetland Crossings within the Proposed Project Corridor

Table K-1: Survey and Manage Fungi, Lichens, Bryophytes and 
Table K1-1: Special-Status Fungi, Lichens, Bryophytes and Vascular Plants

K $1-2$

Table K1-2: Special-Status Fish

K $1-6$

Table K1-3: Special-Status Invertebrates

K1-6

Table K1-4: Special-Status Wildlife

K1-7

Table S-1: Permit Approval Summary

iv

Table S-2: Impacts and Route Summary 


\section{List of Figures}

Figure A-1: West-east geologic cross-section along Oregon Hwy 42

A-5

Figure A-2: View of BPA powerline on steep hillside

A-12

Figure A-3: Rise of BPA powerline, up steep 20 percent slope

A-13

Figure A-4: View along Brewster Canyon at Mile 21 on CBW Road

A-14

Figure A-5: View along Brewster Canyon at Mile 26 on CBW Road

A-15

Figure B-1: Location of the Proposed Natural Gas Pipeline

B-3

Figure B-2: Survey status and location of recommended SDP, Coos Bay to Catching Creek

B-14

Figure B-3: Survey status and location of recommended SDP, Isthmus Slough to Sitkum

B-15

Figure B-4: Survey status, location of identified cultural materials, and location of recommended SDP, Sitkum to Flournoy Valley

B-16

Figure B-5: Site Map

B-19

Figure H-1: Stream Crossing: Trenching across a flowing stream

$\mathrm{H}-5$

Figure J-1: Directional-Drill Crossing: Pilot Hole

$\mathrm{J}-4$

Figure J-2: Reaming Process

J-4

Figure J-3: Pull Back

$\mathrm{J}-4$

Figure J-4: Typical Block Valve Setting

J-8 


\title{
List of Maps
}

\author{
Map 1 - Preferred Alternative \\ Map 2 - Proposed Laterals \\ Map 3 - Alternative Routes \\ Map 4 - Preferred Alternative and Laterals \\ Map 5 - Spotted Owl and Marbled Murrelet Suitable Habitat \\ Map 6 - Spotted Owl Critical Habitat Units \\ Map 7 - Marbled Murrelet Critical Habitat Units \\ Map 8 - PDCs - Restricted Timing for Spotted Owl and Marbled Murrelet \\ Map 9 - Watersheds Impacted in Preferred Alternative \\ Geotech Soil and Geology Maps and Descriptions \\ Map 10 - Areas Designated for Archaeological and Tribal Monitoring \\ Map 11 - Restricted Season Blasting for Spotted Owl and Marbled Murrelet \\ Map 12 - Restricted Season Construction for Spotted Owls and Marbled Murrelets \\ Sheets 1-10 - 1:24,000 Maps of Proposed Action \\ Map 13 - Preferred Alternative Stream Crossings
}





\section{Chapter 1 Purpose of and Need for Action}




\section{Chapter 1 Purpose of and Need for Action}

\section{Summary of Chapters within this Document}

Chapter 1: The Environmental Impact Statement (EIS) introduction, the purpose of and need for the proposed action including a project overview and a summary of statutes, regulations and agency plans related to or affected by the proposed action.

Chapter 2: Alternatives (Including the Proposed Action).

Chapter 3: Affected Environment - includes detailed descriptions of resources (wildlife, vegetation, aquatic, cultural, etc.) existing within the study area. The resources described could sustain effects from one or more aspects of the proposed action.

Chapter 4: Environmental Consequences, which includes Mitigation and Monitoring - presents the issues which would or could cause impact to the resources listed in Chapter 3. This chapter is subdivided with respect to land ownership (Federal, Native American, State and County) to simplify the review process for each respective organization whose land is affected.

Chapter 5: Consultation and Coordination - includes information regarding persons, agencies and methods involved with scoping, consultation and research for compilation of this EIS.

This EIS includes various Appendices, which provide further information as appropriate.

Whenever possible, information is organized in East to West sequence - the direction of gas flow for the proposed action. 


\section{Background}

On May 17, 2000, Coos County, Oregon (hereafter referenced as "the County"), acting by and through its Board of Commissioners, filed application OR55754 with the U.S. Bureau of Land Management (BLM) for a perpetual or renewable (with the longest allowable initial term) right-of-way (ROW) to construct, operate and maintain a 12-inch diameter natural gas transportation pipeline across BLM-managed lands. Portions of the proposed action will be located within 3 miles of BLM rights-of-way designated for roads or utility corridors.

Application is made to establish the pipeline in accordance with: 1) The Mineral Leasing Act of 1920, Section 28, as amended (30 USC 185); and 2) regulations at 43 Code of Federal Regulation (CFR) 2800.

In August, 2000, the County filed application (Form BPA F 4300.03e) with Bonneville Power Administration (BPA) for consent to build sections of its natural gas pipeline within BPA utility corridors.

On November 10, 2000, the County filed application to the U.S. Army Corps of Engineers (COE), a cooperating federal agency, for authorization to construct the proposed pipeline across streams and wetlands along the proposed action. The U.S. Army Corps of Engineers has assigned application No. 2000-00544 to the project.

\section{Purpose and Need}

The purpose of the proposed action is to gain a right-of-way permit from the BLM for construction of a natural gas pipeline from Roseburg, OR, to Coos Bay, OR, (approximately 60 miles in length) and anticipated follow-up construction of another 28 miles of smaller-sized lateral pipelines from Fairview, OR, to Bandon, Coquille and Myrtle Point, OR. It is intended for perpetual and continuous operation to supply natural gas to consumers in Coos County. The need of the proposed action is to meet expectations of the Coos County ballot measure \#6-63 (November, 1999) authorizing funds for construction of a natural gas pipeline. Granting of the right-of-way easement would also trigger construction of a distribution facility in Coos Bay, OR, by Northwest Natural Gas (hereafter referred to as "NW Natural"), the distribution company associated with the proposed gas pipeline project. This EIS describes and analyzes the proposed action as compared to several alternatives. The analysis includes discussion of impacts from constructing, operating and maintaining the natural gas pipeline and its easement in or near private, Federal, Native American, State and County lands.

\section{Summary of scoping and significant issues of the EIS}

Scoping is required for preparation of an EIS. Its use with the proposed action was a help in determining some potential effects to assess. The formal scoping notice for preparation of the EIS was published in the Federal Register on March 29, 2001. A public scoping meeting was held in Coos Bay on April 4, 2001, and at the McKinley town hall on April 18,2001. The formal scoping period closed on April 30,2001. A total of 40 letters were received during the scoping period.

The proposed action is a result of numerous feasibility studies conducted over the course of approximately 35 years. Participants in the EIS analysis used these studies, along with additional recent studies, for the basis of information included in this EIS.

The following issues arose from the Inter-disciplinary Team (IDT) scoping process:

- Regulations affecting the proposed action;

- Impacts (effects) - (1) Impacts on aquatic and riparian habitats and water quality; (2) Impacts on air pollution and soil productivity; (3) Impacts on plants and terrestrial species and habitats, which includes Port-Orford Cedar, Noxious Weeds, Special-Status Species, Survey \& Manage Species, T\&E Species, as well as related Critical Habitat Units (CHUs); (4) Cultural resource-site protection (including Native American Religious Concerns); and (5) Economic impacts;

- under private or public (Federal, State or local) jurisdiction or ownership;

- Direct, Indirect and Cumulative effects: short and long term effects of the proposed action and its ancillary facilities;

- Agency concerns (Federal, State or local agency analysis of impacts);

- Public concerns: All public comments, questions and concerns are listed in Appendix G. 
This EIS addresses the proposed action's real or potential impacts to environmental resource components. Impacts are presented for affected land ownership. The impact analysis defines the interaction of the component(s) of the proposed action with its surrounding environment, including affected environments extending beyond the project construction boundary (the right-of-way easement).

\section{Conformance with BLM Resource Management Plan EIS}

Both the Coos Bay and Roseburg BLM District Resource Management Plans (herein referred to as 'RMP'), specifically encourage use of existing rights-of-way, such as the BPA corridor utilized in the proposed action. Both RMPs suggest that the location of new rights-of-way are placed in these existing utility corridors. Placement of a pipeline in the Coos Bay Wagon Road (CBW Road), the BPA utility corridor and the Pacific Power \& Light (owned by Pacificorp, herein referred to as PP\&L) utility corridor would be consistent with the RMP guidelines and recommendations.

\section{Authorizing Actions and Relationship to Statutes and Regulations}

The proposed action is in conformance with the following:

- Federal Land Policy and Management Act ("FLPMA") of 1976 (90 Stat. 2743, 43 U.S.C. 1701, et seq.);

- Revested Oregon and California (O\&C) Railroad and Reconveyed Coos Bay Wagon Road Grant Lands Act of 1937 (50 Stat. 874, U.S.C. 1181 a., et seq.);

- National Environmental Policy Act of 1969;

- Federal Pipeline Safety Regulations 49 CFR, parts 190-199;

- United States Environmental Protection Agency (EPA) Air and Water Quality guidelines;

- Oregon Department of Transportation (O.D.O.T.) regulations (relating to Oregon Highways);

- American Indian Religious Freedom Act (42 USC 1996). Guidelines for protecting sites;

- Northwest Forest Plan (NFP) 1994;

- Endangered Species Act (ESA) of 1973;

- Magnuson-Stevens Conservation and Management Act as amended by the Sustainable Fisheries Act of 1996;

- Section 10, Rivers and Harbors Act 1899 (33 U.S.C. 402);

- Section 404, Clean Water Act (33 U.S.C. 1344).

\section{Inter-relationship with Other Projects}

\section{Anticipated Future Gas Pipeline Projects}

Anticipated inter-relationships with future projects would likely (not automatically) take place after approval of the proposed action.

Additional (smaller) pipelines would likely be installed to the communities of North Bend, Coquille, Myrtle Point, Empire, Charleston and Bandon if these communities grant a franchise to NW Natural. These future projects would be planned based on market needs within the area they would serve, which would include determination of pipeline size. Funding for these projects, except in the case of Bandon, will be provided by NW Natural. Bandon would have the option to build their own distribution system, including a pipeline extending from the proposed action or its lateral pipelines, if they decide to have natural gas supplied to their community.

Although the final locations of the laterals are not known, it is anticipated that 28 miles of pipeline laterals would likely be constructed to Coquille, Myrtle Point and Bandon. Impacts associated with construction of the laterals are anticipated to be similar to, but of lower magnitude than, the main pipeline because the laterals would cross fewer streams and would not be adjacent to late-successional habitats. No Federal land would be impacted. 


\section{New Industrial Gas Users}

This natural gas pipeline project was proposed by Coos County and funded by county and state taxpayers for economic development. The proposed action would make natural gas available to most commercial and industrial areas of Coos County. It is hoped that the availability of natural gas will attract new manufacturing and commercial facilities to Coos County. It is also likely that existing industrial users of oil, wood and other fuels would switch to natural gas.

Natural gas is often an important factor in site selection, but other critical factors include transportation facilities (access to Interstate highways, rail, ports and airports), location relative to raw materials and markets, available work force, local wages, educational resources, quality of life and other factors. Natural gas availability alone, however, would not cause new manufacturing facilities to be built. Because no industrial commitments have yet occurred, it is not possible to quantify the potential environmental impacts of unknown future facilities and their potential locations. Future new facilities utilizing natural gas will be required to undergo their own environmental impacts analyses, within the required permitting processes for new construction.

\section{Interdependencies}

Interdependencies are projects that would likely occur upon approval of the proposed action. That is, approval of the proposed action would likely "trigger" the interdependent action.

\section{Natural Gas Distribution System}

The proposed action 12-inch mainline would end at Ocean Boulevard by the old water plant in Coos Bay. The city gate station would include a meter, a piping manifold to send gas in different directions and possibly pressure regulators to reduce pressure. NW Natural will build a gas distribution system. The design of the system will not be finalized until more marketing studies are finished to identify size and type of gas loads.

Location and construction of the distribution lines to natural gas end customers would be funded by NW Natural. Distribution lines are not expected to cross any federally managed lands. Impacts associated with the lateral lines and distribution system would be subject to regulation by the Oregon Public Utility Commission ("OPUC"). 


\section{Chapter 2 Alternatives Including the Proposed Action}




\section{Chapter 2 Alternatives Including the Proposed Action}

\section{Description of Proposed Action}

Natural gas is available near Roseburg from Williams Gas Pipeline - West, formerly Northwest Pipeline Company. The Williams pipeline system transports gas from producing wells in the Rocky Mountain region of the U.S. and Canada. The natural gas produced from the wells is stripped of corrosive elements, excess water and heavier hydrocarbons before entering the pipeline system. The natural gas is delivered via pipelines from these wells to Portland and the Willamette Valley. The Williams Grants Pass lateral extends south of Eugene, generally along Interstate-5, to Grants Pass.

In the Roseburg area, Williams has a single 10-inch steel pipeline operating at 500 to 800 pounds per square-inch (psi). The proposed action would be a 12 -inch steel pipeline connecting to the existing 10 -inch pipeline a few miles south of Roseburg.

The pipeline would be buried for its entire length. Its only above-ground components would be line markers, test stations, several bridge crossings and valve settings. It would be built and hydrostatically tested to $1,500 \mathrm{psi}$ which allows a Maximum Allowable Operating Pressure (MAOP) of 1,000 psi. It would operate at the same pressure as the Williams pipeline, which is normally 500 to 800 psi.

As noted in Chapter 1, approximately 3 miles of the preferred pipeline route would cross BLM-managed lands within the BPA power line right-of-way. The remainder of the pipeline would be located within the rights-of-way of the CBW Road and other public roads, or within PP\&L and BPA rights-of-way crossing privately owned properties.

The pipeline would terminate at Ocean Boulevard in Coos Bay where a NW Natural distribution system would be built. NW Natural has been granted the "exclusive territory" rights for gas distribution in Coos County, excluding the city of Bandon.

The straight-line distance from the Williams connection location (just south of Roseburg) to Ocean Boulevard is about 44 miles, whereas, the proposed action traverses approximately 60 miles. The proposed action within existing road and utility corridors is the shortest practical route from source to destination.

The permanent easement on BLM-managed lands would total approximately 14 acres. Additional temporary utility corridor construction right-of-way width (as necessary) is also requested. The additional utility corridor construction area of approximately 7 acres would also be completely inside the BPA utility corridor and returned to BLM control after completion of construction and site restoration.

Several delivery stations would deliver gas to end users at various locations in Coos County and Douglas County. None of these delivery stations would be located on BLM-managed lands. For safety reasons, the proposed action includes 5 block valves (see Appendix J), placed at intervals along the pipeline corridor. Placement of the valves is based upon pipeline safety regulations and operational factors, such as local distribution and lateral pipeline placement. None of these block valves would be installed on BLM-managed lands. 


\section{Location of the Proposed Action}

The corridor for the proposed action would traverse the Coast Range in Southern Oregon from the Western region of Douglas County Township 27 South, Range 6 West, Section 33 (T27S, R6W, Sec. 33) to the Western region of Coos County (T25S, R13W, Sec. 27). The terrain varies from gentle to very steep as the corridor follows 230 kilovolt (kV) transmission lines operated by BPA and PP\&L, the CBW Road, and BPA and PP\&L $115 \mathrm{kV}$ transmission lines and roads into Coos Bay. (See map following this page).

The proposed action would connect to the Williams Gas Pipeline near Happy Valley, approximately 4 miles southwest of I-5 freeway exit 124 (Harvard Avenue) in Roseburg. The pipeline route continues - as described below until it connects to its delivery facility at Ocean Boulevard.

The following is a sequential list (east to west) of section locations which contain a portion of the proposed action:

\section{Douglas County}

T27S, R6W, Sections 33, 32 and 31;

T27S, R7W, Sections 36, 35, 34, 33, 32 and 31;

T271/2S, R7W, Section 6;

T28S, R7W, Section 6;

T28S, R7 1/2W, Section 6;

T28S, R8W, Sections 1, 2, 11, 14, 15, 16, 17, 18 and 7.

\section{Coos County}

T28S, R9W, Sections 12, 13, 14, 11, 10, 9, 8 and 7;

T28S, R10W, Sections 12, 11, 10, 9, 8, 5 and 6;

T28S, R11W, Sections 12, 11, 10, 3 and 4;

T27S, R11W, Sections 33, 32, 29, 30 and 19;

T27S, R12W, Sections 24, 23, 14, 15, 16, 9, 10 and 4;

T26S, R12W, Sections 33, 32, 29, 30 and 19;

T26S, R13W, Sections 25, 24, 23, 14, 15, 10 and 3;

T25S, R13W, Sections 34 and 27. 

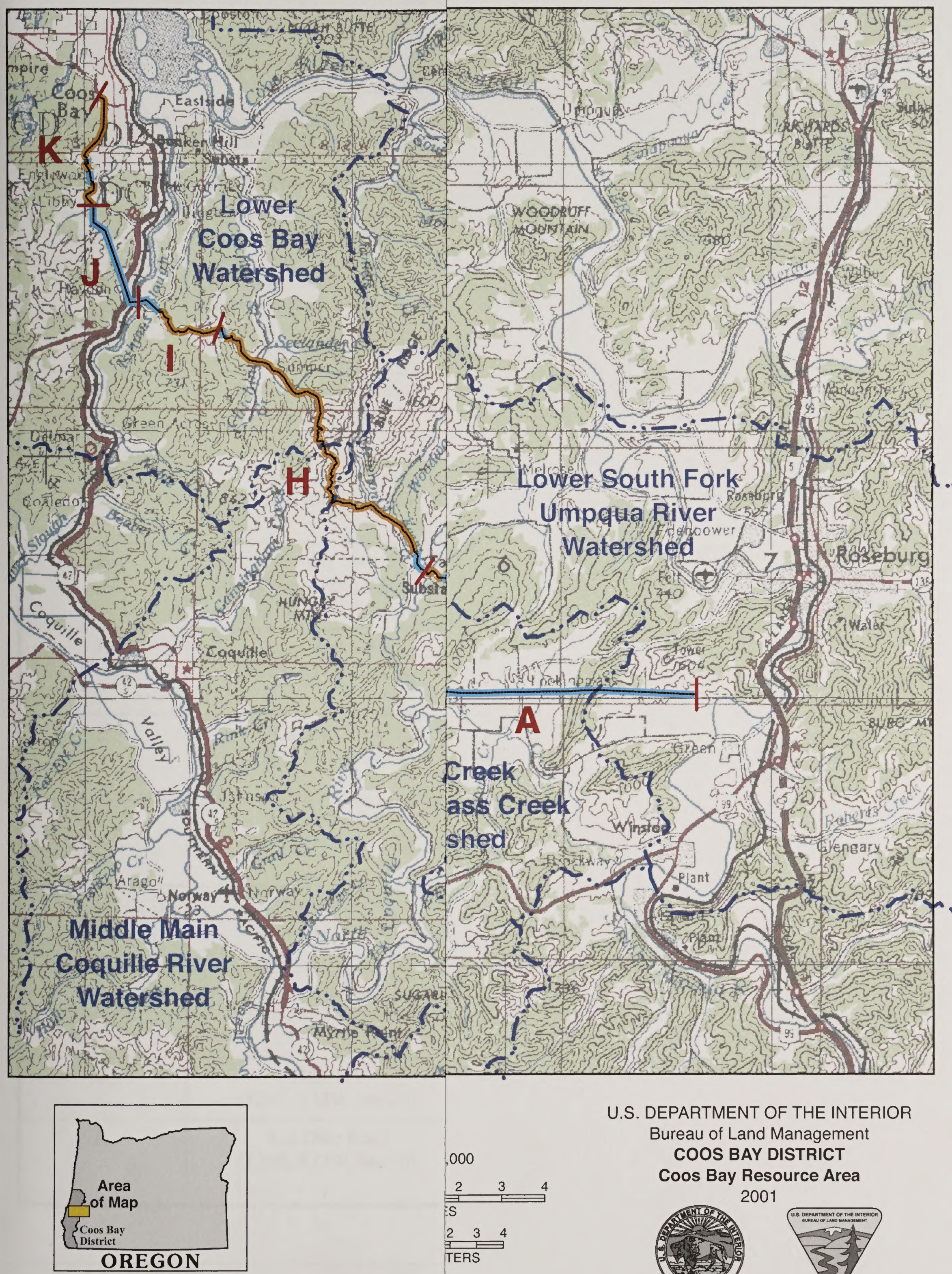

U.S. DEPARTMENT OF THE INTERIOR Bureau of Land Management COOS BAY DISTRICT

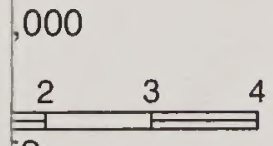
Coos Bay Resource Area $\frac{234}{2.3}$

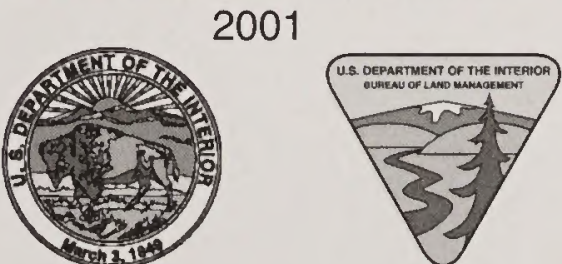




\section{Location of the Proposed Action}

The corridor for the proposed action would traverse the Coast Range in Southern Oregon from the Western region of Douglas County Township 27 South, Range 6 West, Section 33 (T27S, R6W, Sec. 33) to the Western region of Coos County (T25S, R13W, Sec. 27). The terrain varies from gentle to very steep as the corridor follows 230 kilovolt (kV) transmission lines operated by BPA and PP\&L, the CBW Road, and BPA and PP\&L $115 \mathrm{kV}$ transmission lines and roads into Coos Bay. (See map following this page).

The proposed action would connect to the Williams Gas Pipeline near Happy Valley, approximately 4 miles southwest of I-5 freeway exit 124 (Harvard Avenue) in Roseburg. The pipeline route continues - as described below until it connects to its delivery facility at Ocean Boulevard.

The following is a sequential list (east to west) of section locations which contain a portion of the proposed action:

Douglas County

T27S, R6W, Sections 33, 32 and 31;

T27S, R7W, Sections 36, 35, 34, 33, 32 and 31;

T271/2S, R7W, Section 6;

T28S, R7W, Section 6;

T28S, R7 1/2W, Section 6;

T28S, R8W, Sections 1, 2, 11, 14, 15, 16, 17, 18 and 7.

\section{Coos County}

T28S, R9W, Sections 12, 13, 14, 11, 10, 9, 8 and 7;

T28S, R10W, Sections 12, 11, 10, 9, 8, 5 and 6;

T28S, R11W, Sections 12, 11, 10, 3 and 4;

T27S, R11W, Sections 33, 32, 29, 30 and 19;

T27S, R12W, Sections 24, 23, 14, 15, 16, 9, 10 and 4;

T26S, R12W, Sections 33, 32, 29, 30 and 19;

T26S, R13W, Sections 25, 24, 23, 14, 15, 10 and 3;

T25S, R13W, Sections 34 and 27. 



\section{Description of the Proposed Action Corridor}

The proposed action corridor is delineated into Segments A through $\mathrm{K}$ (Table 1). These segments aid discussion of the proposed action by breaking it into manageable portions.

Table 1: $\quad$ Proposed Action Segment Description

\begin{tabular}{|c|c|c|c|}
\hline Segment & Begins & Ends & Distance in Miles \\
\hline $\mathbf{A}$ & $\begin{array}{l}\text { Williams Delivery Station, } \\
\text { approximately } 4 \text { miles south- } \\
\text { west of Roseburg, OR. } \\
\text { (T27S, R6W, Sec.33) }\end{array}$ & $\begin{array}{l}\text { BPA Reston Substation } \\
\text { (T27S, R7W, Sec.31) }\end{array}$ & 8.1 \\
\hline B & $\begin{array}{l}\text { BPA Reston Substation } \\
\text { (T27S, R7W, Sec.31) }\end{array}$ & $\begin{array}{l}\text { Tenmile Block Valve } \\
\text { CBW Road Mile Point } 1.7 \\
\text { (T28S, R8W, Sec.16) }\end{array}$ & 5.7 \\
\hline $\mathrm{C}$ & $\begin{array}{l}\text { Tenmile Block Valve } \\
\text { (T28S, R8W, Sec.16) }\end{array}$ & $\begin{array}{l}\text { Douglas-Coos County Line } \\
\text { Douglas County Mile Point } 6.0 \\
\text { (T28S, R9W, Sec.12) }\end{array}$ & 2.8 \\
\hline D & $\begin{array}{c}\text { County Line } \\
\text { Coos County Mile Point } 36.3 \\
\text { (T28S, R9W, Sec.12) }\end{array}$ & $\begin{array}{l}\text { Lone Pine Lane } \\
\text { CBW Road Mile Point } 17.5 \\
\text { (T28S, R11W, Sec. 10) }\end{array}$ & 18.3 \\
\hline $\mathbf{E}$ & $\begin{array}{c}\text { Lone Pine Lane } \\
\text { (T28S, R11W, Sec.10) }\end{array}$ & $\begin{array}{c}\text { Cherry Creek } \\
\text { CBW Road Mile Point } 17.9 \\
\text { (T28S, R11W, Sec.4) }\end{array}$ & 1.6 \\
\hline $\mathbf{F}$ & $\begin{array}{c}\text { Cherry Creek } \\
\text { (T28S, R11W, Sec.4) }\end{array}$ & $\begin{array}{c}\text { McKinley, OR } \\
\text { CBW Road Mile Point } 17.1 \\
\text { (T27S, R11W, Sec.32) }\end{array}$ & 0.9 \\
\hline G & $\begin{array}{c}\text { McKinley, OR } \\
\text { (T27S, R11W, Sec.32) }\end{array}$ & $\begin{array}{c}\text { Fairview, OR } \\
\text { CBW Road Mile Point } 12.5 \\
\text { (T27S, R12W, Sec.24) }\end{array}$ & 3.6 \\
\hline $\mathbf{H}$ & $\begin{array}{c}\text { Fairview, OR } \\
\text { (T27S, R12W, Sec.24) }\end{array}$ & $\begin{array}{l}\text { Sumner Lane at PP\&L } \\
\text { CBW Road Mile Point } 2.7 \\
\text { (T26S, R12W, Sec.30) }\end{array}$ & 9.9 \\
\hline I & $\begin{array}{c}\text { Sumner Lane } \\
\text { (T26S, R12W, Sec.30) }\end{array}$ & $\begin{array}{c}\text { U.S. } 101 \\
\text { CBW Road Mile Point } 0.0 \\
\text { (T26S, R13W, Sec.23) }\end{array}$ & 2.4 \\
\hline $\mathbf{J}$ & $\begin{array}{c}\text { U.S. } 101 \\
\text { (T26S, R13W, Sec.23) }\end{array}$ & $\begin{array}{l}\text { Red Dike Road CR } 183 \\
\text { (T26S, R13W, Sec.10) }\end{array}$ & 2.7 \\
\hline $\mathbf{K}$ & $\begin{array}{c}\text { Red Dike Road } \\
\text { (T26S, R13W, Sec.10) }\end{array}$ & $\begin{array}{c}\text { Coos Bay, OR } \\
\text { Off Ocean Blvd. } \\
\text { (T25S, 13W, Sec.27) }\end{array}$ & 3.1 \\
\hline
\end{tabular}




\section{Pipeline Laterals}

The Coos County 12-inch mainline would extend to the edge of the city of Coos Bay. The Coos County project would also include smaller pipeline laterals to serve Coquille, Myrtle Point and Bandon.

These lateral pipelines would be smaller in diameter than the 12-inch mainline. The projected demand in the smaller towns could be served with 6-inch and 4-inch pipelines. The laterals would be built with welded and coated steel pipe, to the same 1,000 pounds per square inch (psi) MAOP and Department of Transportation (DOT) standards as the mainline. The laterals would be operated at the same pressure as the mainline.

The routes of these lateral pipelines are not yet finalized. The pipelines would generally follow existing road, power and other rights-of-way. There is no route being considered that would impact BLM or other Federal lands (see map following this page).

\section{Lateral Routes}

The most likely lateral pipeline route would follow BPA to Bandon, OR, using the railroad grade to Coquille, OR, and Myrtle Point, OR.

\section{Fairview to Hwy 42}

Present plans would have the lateral begin at the Fairview block valve (Segment G). The lateral pipeline would likely leave the site of the block valve along an old railroad grade and follow Fairview Road (County Road [CR] 9 from Coquille) for approximately 1.6 miles.

At about 1.6 miles from the Fairview block valve, the lateral route would likely follow the BPA Fairview-Rogue 230 $\mathrm{kV}$ powerline utility corridor. This route heads southwest over the ridge at Rink Peak at 1,070 feet above sea level. The BPA corridor descends into the Coquille River valley, crossing Hwy 42 at Mile Marker (MM) 14.4. The pipeline lateral would be bored-under Hwy 42 and would follow an old Southern Pacific Railroad right-of-way adjacent to the highway corridor. Near the BPA crossing of the railroad grade, a block valve would be at the end of this 7.5-mile lateral segment. This segment would cross Lee Valley Road (CR 2B) and Hwy 42, Steele Creek, Blair Creek, Lost Creek and Aiken Creek in the Coquille watershed. This segment would be built of 6-inch or 8-inch diameter pipe.

\section{Coquille Lateral}

This lateral would likely start at the Hwy 42 block valve and travel north, following a former railroad right-of-way. The railroad from Coos Bay to Coquille still has limited traffic, but is currently under abandonment discussion. The lateral route would be in or beside the railroad grade, subject to agreement with the railroad. If such an agreement is not made, the pipeline would be installed on highway rights-of-way or on private land between the two corridors. The Coquille Lateral would then follow rail or road corridors to the south edge of Coquille. This segment would be built of 4-inch diameter pipe and approximately 2 miles long.

\section{Myrtle Point Lateral}

This lateral would likely start at the Hwy 42 block valve and travel south along a former railroad right-of-way. The anticipated route would be in the railroad right-of-way, highway or on private land. The Myrtle Point Lateral would end at the north edge of Myrtle Point near Hwy 42. This segment would cross 4 county roads. The North Fork of the Coquille River would be directionally-drilled. This segment would be built of 4 -inch diameter pipe and approximately 6 miles long.

\section{Bandon Lateral}

This lateral would likely start at the Hwy 42 block valve and travel west, following the BPA right-of-way to the east edge of Bandon. The pipeline would be directionally-drilled under the Coquille River near river mile 27. This route would follow BPA Rogue $230 \mathrm{kV}$ line to Fat Elk Road. Near Rollan Creek, the BPA Rogue corridor converges with the BPA Number 1 Fairview-Bandon $115 \mathrm{kV}$ line. The lateral would then follow a county road for a short distance. At Lampa Creek, the pipeline would follow county and/or forest roads for easier negotiation of creek crossings and elevation changes. 


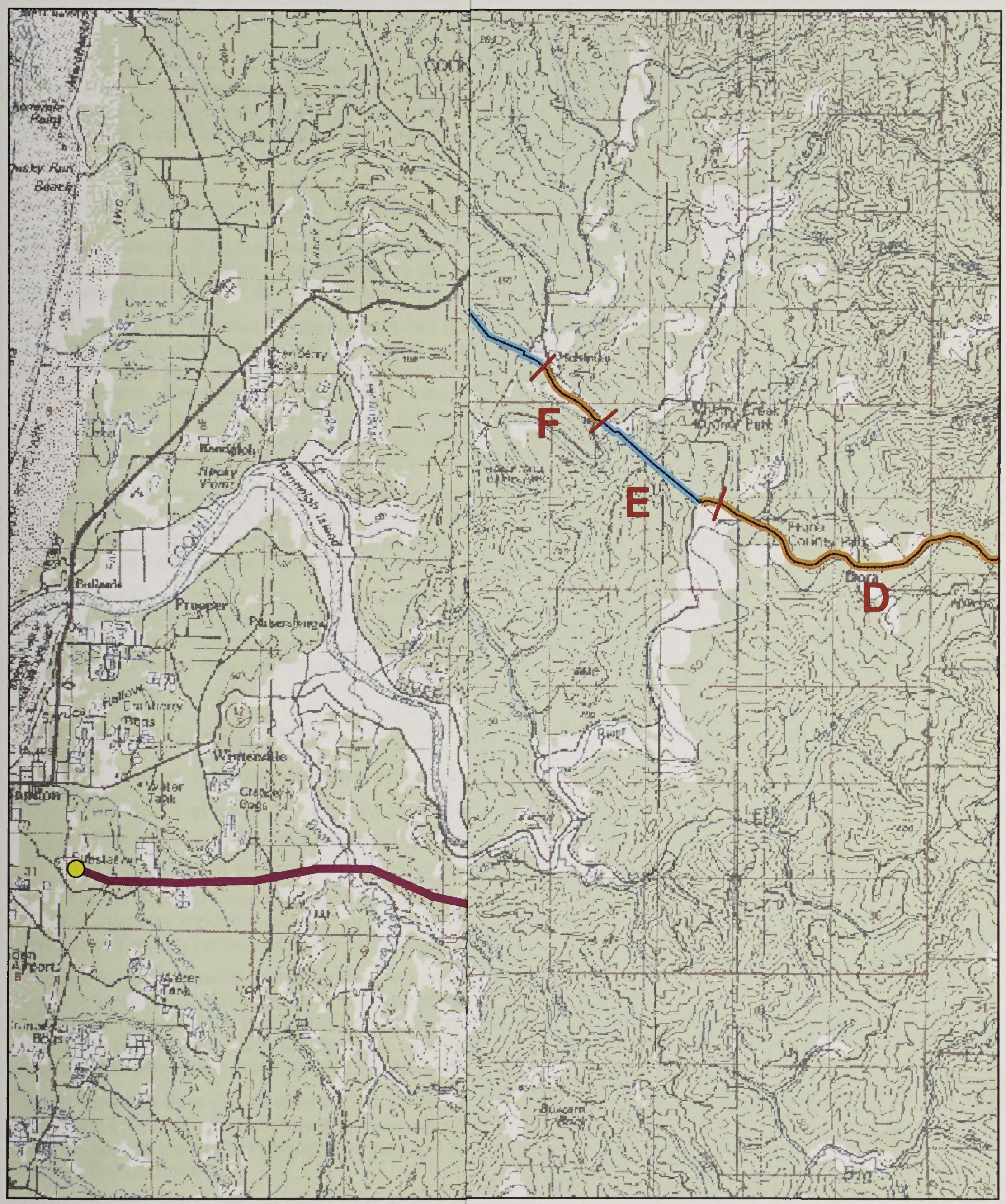

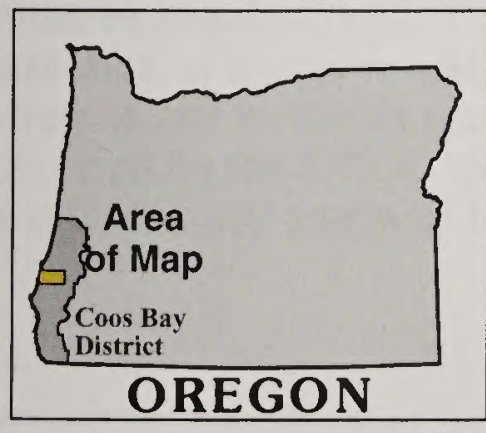

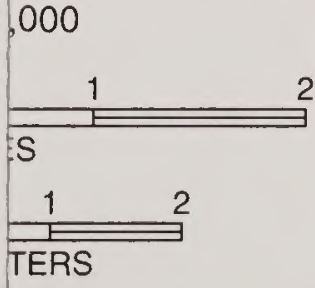

as to the accuracy,

ggregate use

sources. This

Map 2: Proposed Laterals
U.S. DEPARTMENT OF THE INTERIOR Bureau of Land Management COOS BAY DISTRICT Coos Bay Resource Area

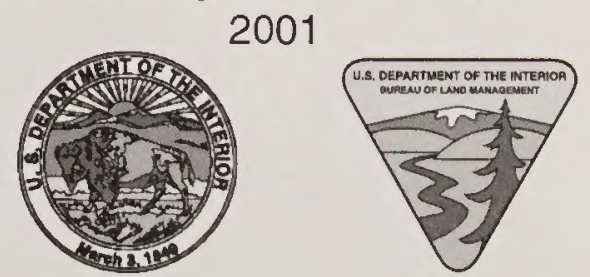

COOS COUNTY NATURAL

GAS PIPELINE PROJECT 


\section{Pipeline Laterals}

The Coos County 12-inch mainline would extend to the edge of the city of Coos Bay. The Coos County project would also include smaller pipeline laterals to serve Coquille, Myrtle Point and Bandon.

These lateral pipelines would be smaller in diameter than the 12-inch mainline. The projected demand in the smaller towns could be served with 6-inch and 4-inch pipelines. The laterals would be built with welded and coated steel pipe, to the same 1,000 pounds per square inch (psi) MAOP and Department of Transportation (DOT) standards as the mainline. The laterals would be operated at the same pressure as the mainline.

The routes of these lateral pipelines are not yet finalized. The pipelines would generally follow existing road, power and other rights-of-way. There is no route being considered that would impact BLM or other Federal lands (see map following this page).

\section{Lateral Routes}

The most likely lateral pipeline route would follow BPA to Bandon, OR, using the railroad grade to Coquille, OR, and Myrtle Point, OR.

\section{Fairview to Hwy 42}

Present plans would have the lateral begin at the Fairview block valve (Segment G). The lateral pipeline would likely leave the site of the block valve along an old railroad grade and follow Fairview Road (County Road [CR] 9 from Coquille) for approximately 1.6 miles.

At about 1.6 miles from the Fairview block valve, the lateral route would likely follow the BPA Fairview-Rogue 230 $\mathrm{kV}$ powerline utility corridor. This route heads southwest over the ridge at Rink Peak at 1,070 feet above sea level. The BPA corridor descends into the Coquille River valley, crossing Hwy 42 at Mile Marker (MM) 14.4. The pipeline lateral would be bored-under Hwy 42 and would follow an old Southern Pacific Railroad right-of-way adjacent to the highway corridor. Near the BPA crossing of the railroad grade, a block valve would be at the end of this 7.5-mile lateral segment. This segment would cross Lee Valley Road (CR 2B) and Hwy 42, Steele Creek, Blair Creek, Lost Creek and Aiken Creek in the Coquille watershed. This segment would be built of 6 -inch or 8 -inch diameter pipe.

\section{Coquille Lateral}

This lateral would likely start at the Hwy 42 block valve and travel north, following a former railroad right-of-way. The railroad from Coos Bay to Coquille still has limited traffic, but is currently under abandonment discussion. The lateral route would be in or beside the railroad grade, subject to agreement with the railroad. If such an agreement is not made, the pipeline would be installed on highway rights-of-way or on private land between the two corridors. The Coquille Lateral would then follow rail or road corridors to the south edge of Coquille. This segment would be built of 4-inch diameter pipe and approximately 2 miles long.

\section{Myrtle Point Lateral}

This lateral would likely start at the Hwy 42 block valve and travel south along a former railroad right-of-way. The anticipated route would be in the railroad right-of-way, highway or on private land. The Myrtle Point Lateral would end at the north edge of Myrtle Point near Hwy 42. This segment would cross 4 county roads. The North Fork of the Coquille River would be directionally-drilled. This segment would be built of 4 -inch diameter pipe and approximately 6 miles long.

\section{Bandon Lateral}

This lateral would likely start at the Hwy 42 block valve and travel west, following the BPA right-of-way to the east edge of Bandon. The pipeline would be directionally-drilled under the Coquille River near river mile 27. This route would follow BPA Rogue $230 \mathrm{kV}$ line to Fat Elk Road. Near Rollan Creek, the BPA Rogue corridor converges with the BPA Number 1 Fairview-Bandon $115 \mathrm{kV}$ line. The lateral would then follow a county road for a short distance. At Lampa Creek, the pipeline would follow county and/or forest roads for easier negotiation of creek crossings and elevation changes. 

This segment would cross 8 county roads. The Coquille River would be directionally-drilled. The anticipated route would cross approximately 12 named perennial streams and numerous unnamed perennial and intermittent streams. The segment would be built of 4-inch diameter pipe and approximately 12 miles long.

\section{Schedule, Sizing and Route Selection Factors}

The Coos County 12-inch mainline is scheduled for completion into Coos Bay by the end of 2002. The smaller pipeline laterals are anticipated to be finished by the end of 2003. There are several factors, including the size of lateral pipelines and selection of the lateral routes, which are not yet confirmed.

Gas distribution to Bandon is also an unknown factor. NW Natural has been authorized by the OPUC to serve all parts of Coos County with natural gas, except within the city limits of Bandon. Bandon has not yet decided whether to build its own gas distribution system, allow NW Natural a franchise, or prohibit natural gas and protect its existing electric power. The town may also wish to install or contract for a natural gas-fired generator to provide electricity. These unknown factors could result in: 1) a 4 -inch lateral constructed as envisioned now; 2) a larger lateral for greater power generation; 3) no lateral if gas distribution is not permitted; or 4) a re-route of the pipeline to accommodate a generator adjacent to the Bandon area.

The Beaver Hill area presents more unknown factors. Coos County operates a solid waste disposal plant near Beaver Hill in Section 24-T27S-R14W near U.S. 101 between Coos Bay and Bandon. This site is close to a PP\&L utility corridor, has suitable zoning and could be a potential power generation site. Pipeline access to Beaver Hill would be feasible from Fairview via Coquille or along U.S. 101 from Coos City.

No proposals have been made to Coos County. None of the likely routes to Coquille, Myrtle Point, Bandon or Beaver Hill involve BLM-managed lands. At this point in the planning process for these laterals, it is premature to formulate a detailed assessment on any of the possible lateral routes. Without BLM involvement, the U.S. Army Corps of Engineers would become the lead Federal agency for any lateral-building projects.

\section{NW Natural Gas Facilities}

NW Natural plans to install three types of gas mains:

Welded steel main lines capable of intermediate to mainline pressure (up to 1,000 psi);

Polyethylene (PE) main lines at 60 psi or less (4-inch to 8-inch diameter);

$\mathrm{PE}$ pipes down side streets at 60 psi or less (2-inch diameter).

NW Natural plans to extend service to industrial users on the North Spit. This service would likely be an 8 -inch to 12-inch diameter welded steel pipeline. Tentative plans for this line would follow Ocean Boulevard and Newmark Avenue to Empire, serving as the primary source for the Coos Bay to North Bend distribution system.

The North Spit extension would be built within 4 years of completion of the proposed action. The extension would be directionally-drilled under Coos Bay and placed within the Trans Pacific Parkway to Weyerhaeuser. Directionally-drilling under Coos Bay would require a permit from the U.S. Army Corps of Engineers. This extension will be subject to NEPA when plans are finalized. The bay crossing has been discussed as a joint venture with the local water board to upgrade water service on the North Spit.

While the main lines can be used to directly serve larger users, most customers would be serviced by a 2-inch PE main line connecting in their street or alley where a plastic tapping tee is fused onto the main line and a 1 -inch diameter PE service pipe is run through the yard to a meter at a house or building. Each customer would have a separate service line and meter.

Utility distribution mains are installed in public streets, utility easements and other existing rights-of-way. Mains must be installed with 18 to 36 inches of cover in public corridors depending on pressure rating and location. Construction of mains would be entirely in existing streets, alleys and public utility easements (PUE). Crossings of streams and wetlands usually occur in the roadway or on bridges with no impact to the off-road areas. NW Natural is certified by the OPUC to install gas distribution systems and serve all parts of Coos County with natural gas, except within the city limits of Bandon. 
Pipeline Construction Alternatives Summary

Table 2: Action Alternatives Route Summary

\begin{tabular}{|l|c|c|}
\hline & Proposed & Alt. 42 \\
\hline \hline Total length (miles) & 59.1 & 82.7 \\
\hline \hline $\begin{array}{l}\text { Total Number of Streams } \\
\text { Crossed }\end{array}$ & 188 & 209 \\
\hline $\begin{array}{l}\text { Total Number of Large Streams } \\
\text { Crossed (streams 30+ feet sum- } \\
\text { mer wetted width) }\end{array}$ & 2 & 18 \\
\hline $\begin{array}{l}\text { Total Number of Medium } \\
\text { Streams Crossed } \\
\text { (streams 15 to 30 feet summer } \\
\text { wetted width) }\end{array}$ & 6 & 12 \\
\hline \hline $\begin{array}{l}\text { Total Number of Small Streams } \\
\text { Crossed } \\
\text { (streams less than 15 feet summer } \\
\text { wetted width) }\end{array}$ & 180 & 179 \\
\hline \hline Total Number of Wetlands & 1 & 9 \\
\hline \hline $\begin{array}{l}\text { Adjacent Floodplain } \\
\text { (miles) }\end{array}$ & 2.2 & 15.3 \\
\hline \hline
\end{tabular}




\section{Proposed Action - Utility Corridors and the CBW Road}

This alternative builds a pipeline along or near the CBW Road, as described in Table 3 below.

Table 3: $\quad$ Route Summary for Proposed Action

\begin{tabular}{|c|l|c|c|}
\hline Segment & \multicolumn{1}{|c|}{ Description } & ROW Type & Distance \\
\hline \hline A & Williams to Reston Substation & PP\&L & 8.1 miles \\
\hline B & Reston to Tenmile & BPA & 5.7 miles \\
\hline C & Tenmile to County Line & BPA & 2.8 miles \\
\hline D & County Line to Lone Pine Lane & CBWR & 18.3 miles \\
\hline E & Lone Pine Lane to Cherry Creek & BPA & 1.6 miles \\
\hline F & Cherry Creek to McKinley & BPA & 3.6 miles \\
\hline G & McKinley to Fairview & CBWR & 9.9 miles \\
\hline H & Fairview to Sumner Lane & CBWR & 2.4 miles \\
\hline I & Sumner Lane to U.S. Highway 101 & BPA & 2.7 miles \\
\hline J & U.S. Highway 101 to Libby & BPA & 3.1 miles \\
\hline K & Libby to Coos Bay & & $\mathbf{5 9 . 1}$ miles \\
\hline \hline
\end{tabular}

Pipeline placement, except for certain bridges, would be entirely underground within existing roads and utility (powerline) corridors. Along the utility rights-of-way, the pipeline would be placed near the edge away from trees. The CBW Road would receive full-width repaving where the pipeline is installed under the present asphalt road surface. In addition, the gravel-surfaced road sections will be paved after construction of the pipeline. This includes 10.6 miles of Sitkum Lane east of Sitkum to the county line and 4.5 miles of Sumner Lane north of Fairview.

The proposed action is adjacent to some BLM-managed critical habitat wildlife areas. The proposed action also includes some difficult construction areas, including narrow canyon road beds and steep slopes along the utility corridors. The proposed action contains 188 stream crossings and 1 wetland crossing. Of the streams crossed, 180 are small streams (less than 0.2 cubic feet per second [cfs] of summer waterflow). The total length of 100 -year floodplains adjacent to the proposed action is 2.2 miles. The CBW Road and utility corridors rights-of-way would return to their current condition within 1 or 2 years.

Construction equipment would include bulldozers, backhoes, side-booms and other standard equipment typically used for pipeline construction. For the CBW Road segments, construction equipment would also include the typical road paving equipment necessary for full-width asphalt paving.

Operation and maintenance of the pipeline would be in accordance with all Federal, State and local regulations. (See Appendix $\mathrm{J}$ for Construction, Operation and Maintenance). Delivery of natural gas to the franchise holder (NW Natural) would generate revenue for the County, which would be applied toward the County's expenses to operate the pipeline. NW Natural anticipates to initially deliver 2 billion cubic feet of natural gas per year to customers in Coos County. The maximum potential throughput of the Coos Pipeline would be 25 billion cubic feet per year. 


\section{No Action Alternative}

For the purposes of this EIS, the "No Action Alternative" is defined as the condition in which BLM would not grant Coos County a discretionary Right-of-Way permit for construction, operation and maintenance of a natural gas pipeline on lands administered by the BLM. Affects addressed in the EIS associated with the No Action Alternative assume that the present conditions remain as they currently exist; that is, the pipeline would not be constructed.

However, if the Proposed Action as described in the EIS is denied, Coos County will proceed with plans to construct, operate and maintain the natural gas pipeline within public roads and private easements included in the Proposed Action. Federal land would be avoided, so a right-of-way permit for crossing federal lands would not be necessary.

Approximately 51.1 miles ( 86 percent) of the pipeline route described in the EIS Proposed Action would be built as described. Segments C, E and G of the described Proposed Action, which includes federal land, would be avoided by constructing the pipeline entirely in the CBW Road. The number of streams to be crossed, wildlife habitats affected and impacts to the environment would be approximately the same as described in the proposed action. However, this non-federal route would require construction of about 4 miles of additional pipeline and cost approximately $\$ 2.3$ million more. The County would be required to obtain permits from the Army Corps of Engineers (COE) and Oregon Division of State Land for crossing streams. The COE would be the lead agency for preparation of a NEPA document to address crossing of waterways and wetlands under their jurisdiction.

\section{Hwy 42 Alternative (the South Route)}

The Hwy 42 alternative (Table 4) would supply Coos Bay, North Bend and possibly other small communities within Coos and Douglas Counties with natural gas.

Table 4: $\quad$ Route Summary for Hwy 42 Alternative

\begin{tabular}{|c|l|c|c|}
\hline Segment & \multicolumn{1}{|c|}{ Description } & ROW Type & Distance \\
\hline \hline L & Winston to Tenmile & ODOT & 12.9 \\
\hline M & Tenmile to Camas Valley & ODOT & 7.5 \\
\hline N & Camas Valley to County Line & ODOT & 10.5 \\
\hline O & County Line to Powers Rd. Jct. & ODOT & 24.0 \\
\hline P & Powers Rd. Jct. to Myrtle Point & ODOT & 2.0 \\
\hline Q & Myrtle Point to Hwy 101 Jct. & ODOT & 20.0 \\
\hline R & Hwy 101 Jct. to Coos City & ODOT & 0.2 \\
\hline S & Coos City to Ocean Boulevard & BPA & 5.6 \\
\hline \hline & \multicolumn{2}{|c}{ Total Length } & $\mathbf{8 2 . 7}$ miles \\
\hline
\end{tabular}

Pipeline placement would be underground, under or beside the road beds. No trees would be removed, since the pipeline would be located within the highway right-of-way.

Relatively few private landowners would experience impact from construction activity. Construction equipment would be bulldozers, backhoes, side-mount cranes, etc., typically used for pipeline construction. Smaller equipment would be required in some portions, where the allowable working space is tighter.

This pipeline route would enter sensitive wildlife areas and difficult construction zones (including bedrock road beds) for a distance of about 7 miles. The difficulty would be further increased due to the fiber optic cables buried along either side of the road. Terrestrial and aquatic habitats would experience short-term disturbance, because not 

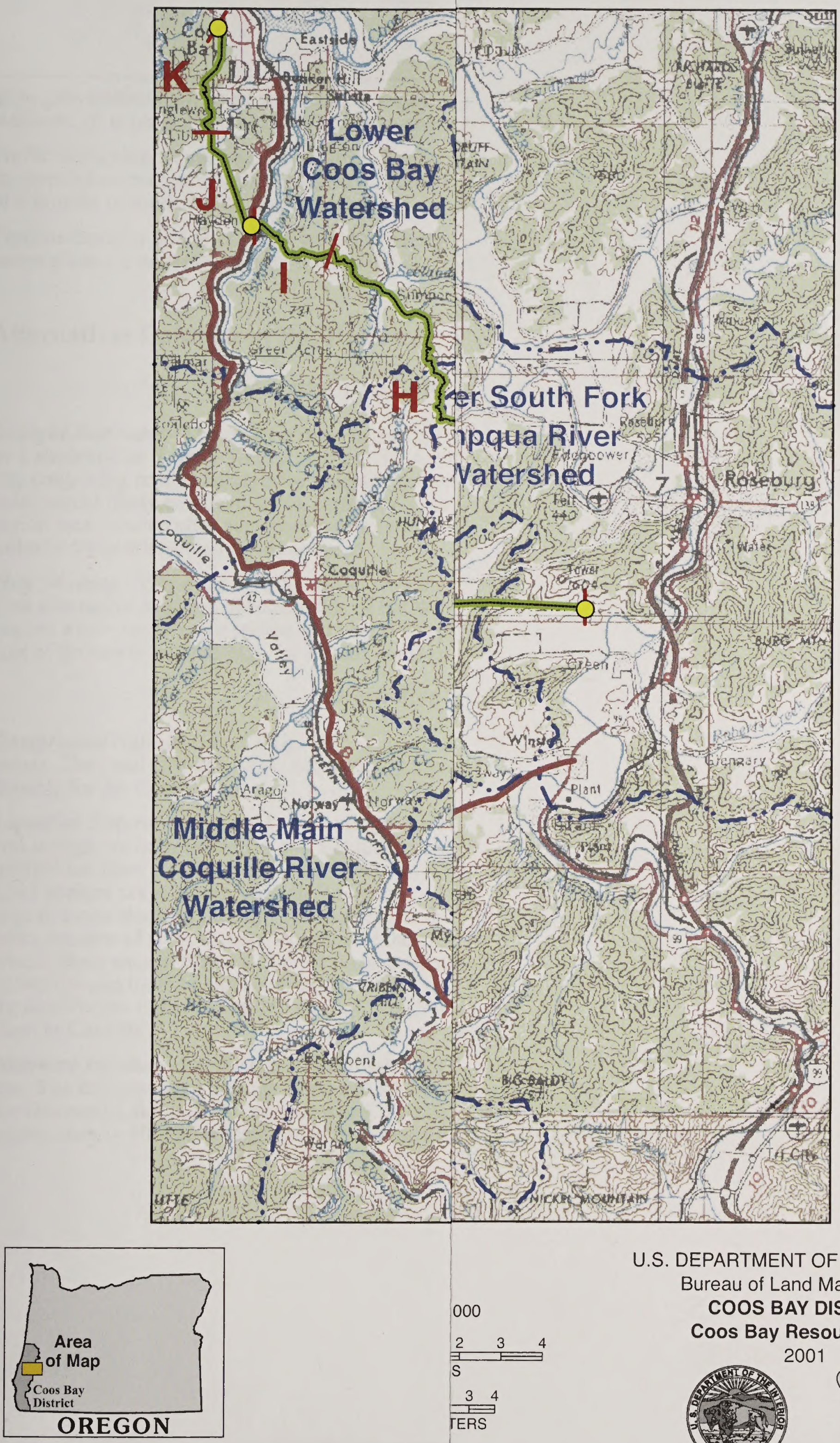

U.S. DEPARTMENT OF THE INTERIOR Bureau of Land Management COOS BAY DISTRICT

000 Coos Bay Resource Area

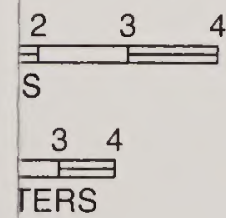

Map 3: Alternate Routes 2001

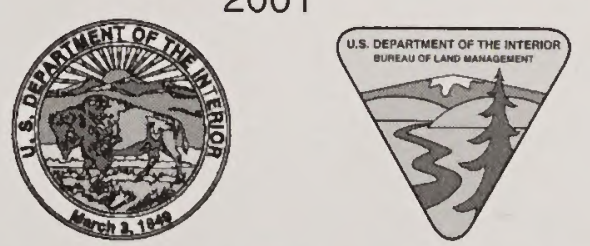




\section{No Action Alternative}

For the purposes of this EIS, the "No Action Alternative" is defined as the condition in which BLM would not grant Coos County a discretionary Right-of-Way permit for construction, operation and maintenance of a natural gas pipeline on lands administered by the BLM. Affects addressed in the EIS associated with the No Action Alternative assume that the present conditions remain as they currently exist; that is, the pipeline would not be constructed.

However, if the Proposed Action as described in the EIS is denied, Coos County will proceed with plans to construct, operate and maintain the natural gas pipeline within public roads and private easements included in the Proposed Action. Federal land would be avoided, so a right-of-way permit for crossing federal lands would not be necessary.

Approximately 51.1 miles ( 86 percent) of the pipeline route described in the EIS Proposed Action would be built as described. Segments C, E and G of the described Proposed Action, which includes federal land, would be avoided by constructing the pipeline entirely in the CBW Road. The number of streams to be crossed, wildlife habitats affected and impacts to the environment would be approximately the same as described in the proposed action. However, this non-federal route would require construction of about 4 miles of additional pipeline and cost approximately $\$ 2.3$ million more. The County would be required to obtain permits from the Army Corps of Engineers (COE) and Oregon Division of State Land for crossing streams. The COE would be the lead agency for preparation of a NEPA document to address crossing of waterways and wetlands under their jurisdiction.

\section{Hwy 42 Alternative (the South Route)}

The Hwy 42 alternative (Table 4) would supply Coos Bay, North Bend and possibly other small communities within Coos and Douglas Counties with natural gas.

Table 4: $\quad$ Route Summary for Hwy 42 Alternative

\begin{tabular}{|c|l|c|c|}
\hline Segment & \multicolumn{1}{|c|}{ Description } & ROW Type & Distance \\
\hline \hline L & Winston to Tenmile & ODOT & 12.9 \\
\hline M & Tenmile to Camas Valley & ODOT & 7.5 \\
\hline N & Camas Valley to County Line & ODOT & 10.5 \\
\hline O & County Line to Powers Rd. Jct. & ODOT & 24.0 \\
\hline P & Powers Rd. Jct. to Myrtle Point & ODOT & 2.0 \\
\hline Q & Myrtle Point to Hwy 101 Jct. & ODOT & 20.0 \\
\hline R & Hwy 101 Jct. to Coos City & ODOT & 0.2 \\
\hline S & Coos City to Ocean Boulevard & BPA & 5.6 \\
\hline \hline & \multicolumn{2}{|c}{ Total Length } & $\mathbf{8 2 . 7}$ miles \\
\hline
\end{tabular}

Pipeline placement would be underground, under or beside the road beds. No trees would be removed, since the pipeline would be located within the highway right-of-way.

Relatively few private landowners would experience impact from construction activity. Construction equipment would be bulldozers, backhoes, side-mount cranes, etc., typically used for pipeline construction. Smaller equipment would be required in some portions, where the allowable working space is tighter.

This pipeline route would enter sensitive wildlife areas and difficult construction zones (including bedrock road beds) for a distance of about 7 miles. The difficulty would be further increased due to the fiber optic cables buried along either side of the road. Terrestrial and aquatic habitats would experience short-term disturbance, because not 

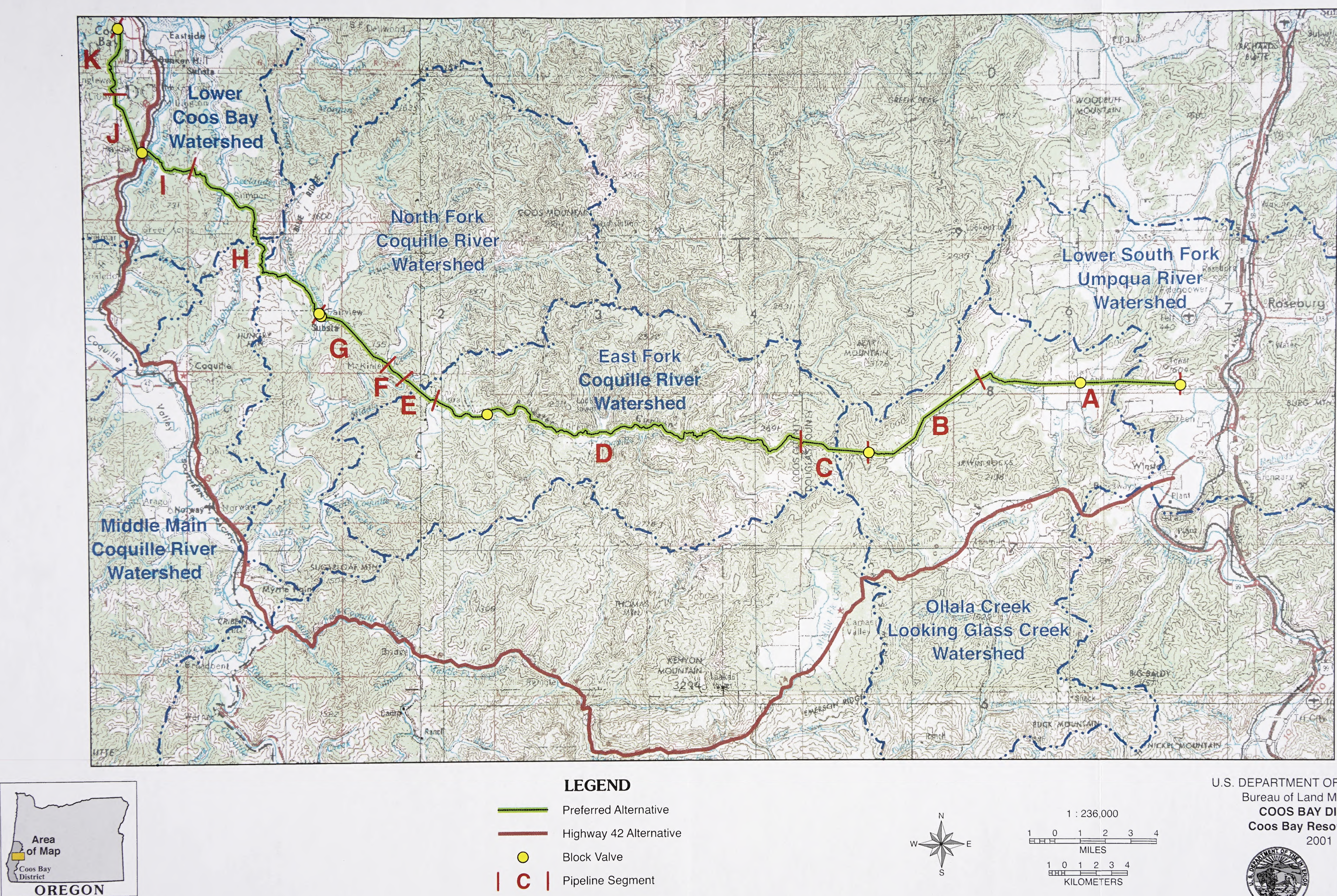

\section{LEGEND}

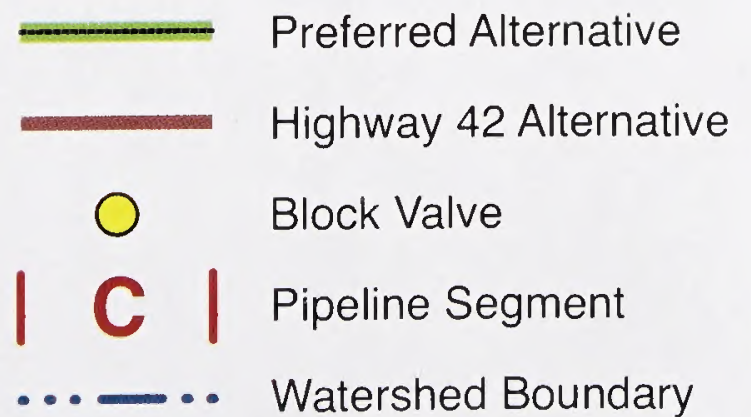

... - Watershed Boundary

Map 3: Alternate Routes

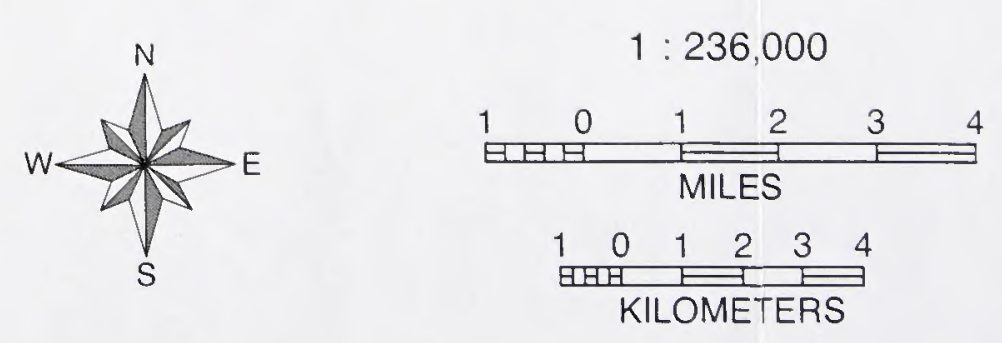

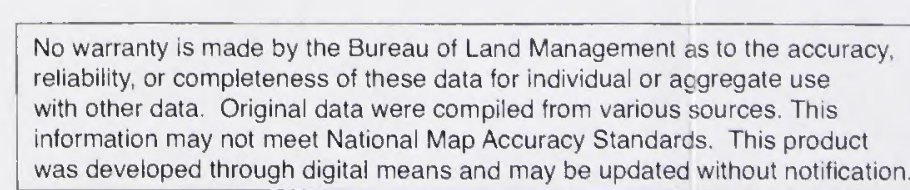

US. DEPARTMENT OF THE INTERIOR Bureau of Land Managemen Coos Bay Resource Area

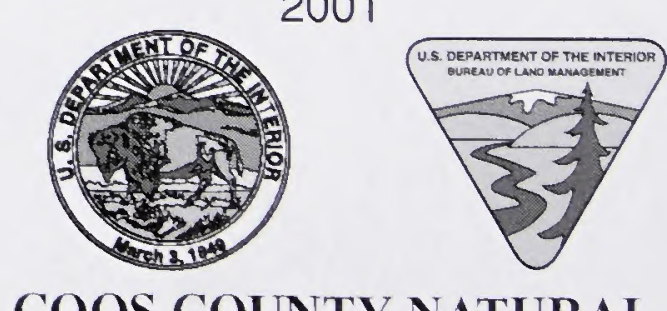
COOS COUNTY NATURAL 

all negative effects can be minimized or avoided completely. This route would encounter 209 stream crossings and 9 wetlands. It is unlikely that visual impacts would remain after construction.

Traffic disruption would be considerable. Traffic volume along this alternative is high, as it is a major truck route to the population centers of Coos and Curry Counties. It is also a major tourist route to the Coastal region. For a period of 6 months or more, traffic would be delayed.

Pipeline capacity and throughput would be nearly identical to the proposed action. Pipeline operation and maintenance plans are expected to be similar to the description given in Appendix J.

\section{Alternatives Considered But Rejected}

\section{Alternative Routes Rejected Without Intensive Studies}

Straight-line route - The shortest route to the Coos County natural gas delivery point (just south of Coos Bay), would be a straight-line traverse from Roseburg. However, a straight-line alternative would encounter very steep topography containing critical habitats for federally protected and special-status species. Significant impacts to the environment would likely be unavoidable, because no road or utility corridors exist along this straight-line route. This option was rejected after considering costs and environmental impacts. Also, a suitable corridor exists just a few miles to the south (the proposed action).

Hwy 38 route - This route would connect with the Williams pipeline near the Hwy 38 / I-5 junction near Curtin, OR. This alternative is on the upstream side of the Winchester, OR, natural gas compressor station. This route would require a new compressor station and would be approximately 20 miles longer than the proposed action. The extra cost of this route was too high for serious consideration.

\section{Alternative Sources of Natural Gas}

Compressed Natural Gas (CNG) - Natural gas can be stored and shipped via truck in high-pressure gas transport cylinders. The retail cost of CNG is substantially higher than the retail cost of propane and therefore is not economically feasible for the Coos County.

Liquefied Natural Gas ( $L N G$ ) - Natural gas can be liquefied at cryogenic temperature (-250 degrees F). Transport and storage are both expensive and technically challenging. Because of special facilities and associated costs, this method has been limited to non-industrial uses. LNG can be shipped in ocean-going tankers and barges. The nearest LNG sources are at gas production facilities in Alaska, Australia, Indonesia and the Mideast. This alternative would require a new docking facility that may require dredging of Coos Bay. The estimated cost of facilities are more than twice the cost of Coos County's portion of the estimated cost for the proposed action. LNG costs to the consumer would likely exceed the cost of most fuels presently being utilized in Coos County. NW Natural has LNG facilities in two Oregon locations and has studied LNG for various unserved communities (like Coos Bay). NW Natural owns the distribution rights for natural gas in Coos County and has determined that LNG is not economically feasible for them in Coos Bay.

Alternate Pipeline - Pacific Gas Transmission (PGT) operates an interstate pipeline system from Canada to California. The mainline runs through Bend and Klamath Falls, OR. The nearest pipeline connections would likely be at the Diamond Lake Junction northeast of Crater Lake, or at Medford, OR. A pipeline connecting to PGT would be approximately 100 miles longer than the proposed action. 


\section{Chapter 3 Affected Environment}




\section{Chapter 3 Affected Environment}

\section{Introduction}

This chapter presents the baseline environment in and around the corridor of the proposed action. Where appropriate, this chapter also includes baseline information of the southern route (Hwy 42).

\section{General Setting of the Proposed Action}

The construction corridor for the proposed action is contained within utility corridor rights-of-way or road rights-ofway (principally the CBW Road) over its entire course.

The CBW Road was established in 1872 . This road is currently maintained by Coos and Douglas Counties, with each county maintaining the segment of road within its respective jurisdiction.

The utility corridor rights-of-way include BPA and PP\&L facilities. The BPA right-of-way was established in the mid-1950's: Immediately prior to the time of its construction, the timber was removed from the 150 -foot wide utility corridor. Construction of the BPA utility corridor included access roads and towers supporting the power lines. The PP\&L right-of-way was established in 1969 in Douglas County. Its construction is similar to that of the BPA rightof-way.

The proposed action crosses both private and public lands. Each parcel of land is managed by its respective landowner or the landowner's designated land management entity.

The public lands include BLM-managed lands and county parks. BLM lands are managed in accordance with their District Resource Management Plans and the Northwest Forest Plan (NFP). Public lands in Douglas County are mostly managed by the Roseburg District BLM office. BLM lands in Coos County are managed by the Coos Bay District BLM office. The county parks are managed by their respective County Parks Departments.

The private lands are owned by timber companies, large and small business enterprises, electric power transmission facilities, small woodlot owners, ranchers and homeowners. Prior to entering the Coos Bay area, the proposed action would pass through or near the small communities of Lookingglass, Sitkum, Dora, Fairview, Sumner and old Coos City.

\section{Native American Lands}

None

\section{Physical Description of the Area, Including Visual Resources}

Numerous valleys and drainages dissect the proposed action within the Coast Range, with several steep canyons (including Brewster Canyon). The CBW Road corridor crosses farms, residential areas, rivers, streams and forests.

The Coos Bay District RMP Record of Decision, page 41, discusses Visual Resource Management (VRM) for the District. VRM Class II and Class III areas are described as follows: Representative Class II areas include lands along Hwy 101 and the Coquille Valley. Lands adjacent to most county roads in rural residential areas (such as along the CBW road) are primarily Class III. Lands along Hwy 42 are managed as VRM Class III. The majority of forest lands in the District are managed as VRM Class IV.

The CBW Road is adjacent to some BLM-managed lands classified as Visual Resource Management Class IV areas. This classification could change to VRM Class III if the CBW Road is designated as a scenic byway. None of the BLM-managed lands bordering the proposed action are VRM Class III viewsheds. See Appendix D for VRM descriptions. 
Although they are not BLM-managed lands, the following areas adjacent to the proposed action are classified as VRM Class III viewsheds: 1) Iverson Memorial Park, 2) Dave Busenbark County Park, 3) Judge Hamilton County Park, 4) Dora, 5) Frona County Park and 6) the region east of the North Fork Coquille River as viewed from Fairview.

\section{General Setting of the Hwy 42 Alternate Route}

The Hwy 42 alternative route has a general setting similar to those noted for the proposed action. This route is mostly within VRM Class IV viewsheds. Traffic on this route is considerably heavier than on the CBW Road. This highway is an important commercial and tourist travel corridor.

This alternative is a total of 82.7 miles in length. It would border approximately 2 miles of VRM Class III viewsheds, affecting approximately 340 rural residences and 15.7 miles of urban area.

\section{Environment}

\section{Climate}

The region's weather patterns have certain trends. Winter and Spring are traditionally the cooler and wetter seasons. Summer and Fall are traditionally warm and dry.

Temperature: Winter temperatures can be below freezing (especially in the higher elevations). The average winter temperature at sea-level is approximately $39^{\circ} \mathrm{F}$. Summer temperatures range from $50^{\circ} \mathrm{F}$ to $95^{\circ} \mathrm{F}$ (at Lookingglass). The mean annual temperature is $64.5^{\circ} \mathrm{F}$ at Roseburg and $67^{\circ} \mathrm{F}$ at North Bend/Coos Bay.

Precipitation: Average annual precipitation ranges from 38 inches (Lookingglass) to 70 inches (at elevations of 2,000 feet above sea level). The North Bend weather station records an average annual rainfall of 60 inches. Approximately 85 percent of the precipitation occurs as rain between October 1 and April 30.

\section{Air Quality}

The proposed action includes no special airshed management policies. However, Roseburg has been identified as a designated area under the Oregon Smoke Management Plan. This plan controls the timing for agriculture and timber lands that are burned as part of normal land-management practices.

The air quality of the proposed action corridor is typical of the rural air quality in southwest Oregon. Although no data is available regarding the current levels of noxious gases, they are assumed to be at very low levels due to the absence of heavy traffic and heavy industrial development.

Airborne particulates are at low levels in the proposed action corridor. Minor and temporary increases in dust particulate levels occur occasionally due to farming and logging operations in the area. A minor amount of smoke is common during cool weather periods near residences using wood-burning appliances.

\section{Geology}

Refer to the Geotechnical Report in Appendix A for this information. 

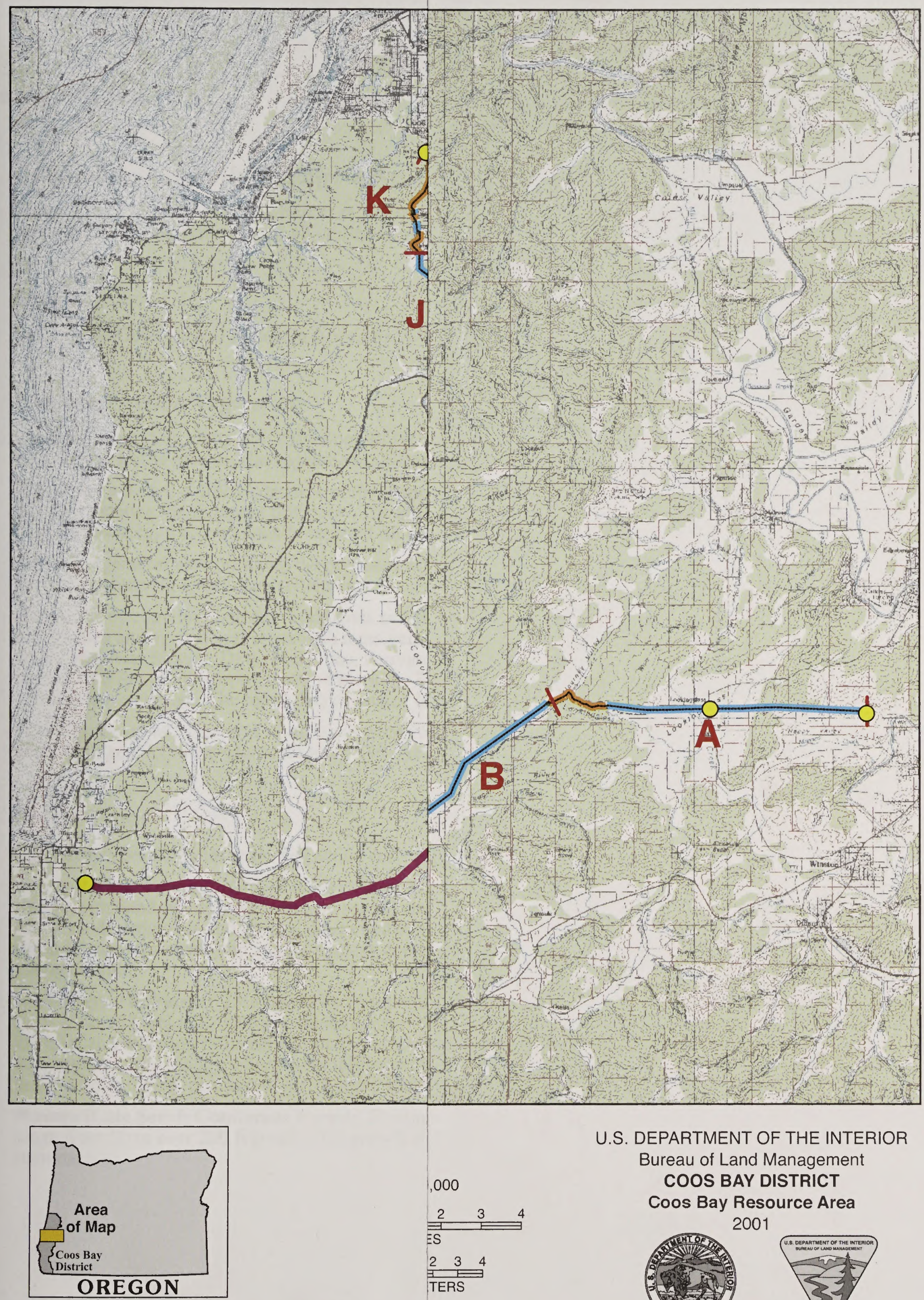

U.S. DEPARTMENT OF THE INTERIOR

Bureau of Land Management COOS BAY DISTRICT

, 000 Coos Bay Resource Area

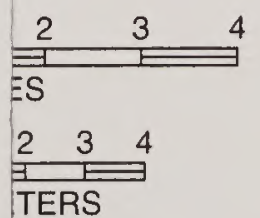
2001

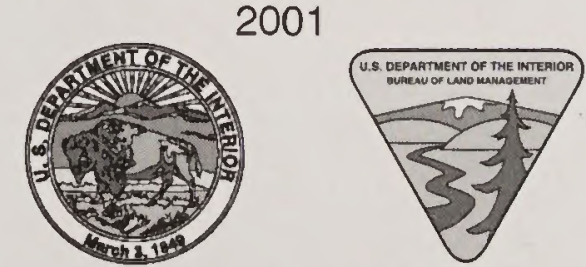


Although they are not BLM-managed lands, the following areas adjacent to the proposed action are classified as VRM Class III viewsheds: 1) Iverson Memorial Park, 2) Dave Busenbark County Park, 3) Judge Hamilton County Park, 4) Dora, 5) Frona County Park and 6) the region east of the North Fork Coquille River as viewed from Fairview.

\section{General Setting of the Hwy 42 Alternate Route}

The Hwy 42 alternative route has a general setting similar to those noted for the proposed action. This route is mostly within VRM Class IV viewsheds. Traffic on this route is considerably heavier than on the CBW Road. This highway is an important commercial and tourist travel corridor.

This alternative is a total of 82.7 miles in length. It would border approximately 2 miles of VRM Class III viewsheds, affecting approximately 340 rural residences and 15.7 miles of urban area.

\section{Environment}

\section{Climate}

The region's weather patterns have certain trends. Winter and Spring are traditionally the cooler and wetter seasons. Summer and Fall are traditionally warm and dry.

Temperature: Winter temperatures can be below freezing (especially in the higher elevations). The average winter temperature at sea-level is approximately $39^{\circ} \mathrm{F}$. Summer temperatures range from $50^{\circ} \mathrm{F}$ to $95^{\circ} \mathrm{F}$ (at Lookingglass). The mean annual temperature is $64.5^{\circ} \mathrm{F}$ at Roseburg and $67^{\circ} \mathrm{F}$ at North Bend/Coos Bay.

Precipitation: Average annual precipitation ranges from 38 inches (Lookingglass) to 70 inches (at elevations of 2,000 feet above sea level). The North Bend weather station records an average annual rainfall of 60 inches. Approximately 85 percent of the precipitation occurs as rain between October 1 and April 30.

\section{Air Quality}

The proposed action includes no special airshed management policies. However, Roseburg has been identified as a designated area under the Oregon Smoke Management Plan. This plan controls the timing for agriculture and timber lands that are burned as part of normal land-management practices.

The air quality of the proposed action corridor is typical of the rural air quality in southwest Oregon. Although no data is available regarding the current levels of noxious gases, they are assumed to be at very low levels due to the absence of heavy traffic and heavy industrial development.

Airborne particulates are at low levels in the proposed action corridor. Minor and temporary increases in dust particulate levels occur occasionally due to farming and logging operations in the area. A minor amount of smoke is common during cool weather periods near residences using wood-burning appliances.

\section{Geology}

Refer to the Geotechnical Report in Appendix A for this information. 



\section{Natural Resources}

\section{Cultural Resources (Including Native American Religious Concerns)}

Refer to the Cultural Resources Report in Appendix B for the proposed action information. The Hwy 42 alternative contains no cultural resources, as all construction would occur on highway road fill.

\section{Soils}

Refer to the Geotechnical Report in Appendix A for this information.

\section{Proposed Action Vegetation}

Roadside vegetation along the CBW Road ROW often lacks trees due to the county road maintenance practices for maintaining traffic safety. The vegetation is primarily grasses and small trees.

Vegetation within the utility corridors of the proposed action is typical of the area's vegetation, except it lacks trees due to vegetative management practices. The utility corridors support colonies of noxious weed species (from constant disturbance) that are annually targeted for control or removal by BPA and PP\&L maintenance crews.

Current vegetation patterns along the proposed action are a result of past anthropogenic management from timber harvesting, farming and human settlements.

Happy Valley contains open oak woodlands and farmland. Vegetation from Lookingglass to Reston is primarily pasture grasses and agricultural crops with interspersed oak woodlands. Small to medium parcels of agricultural land are located near Sitkum, Dora, McKinley, Fairview and old Coos City. In total, agricultural lands border approximately 10 miles of the proposed action corridor. Less than 1 percent of the landscape adjacent to the proposed action corridor is residential. The remaining vegetated lands bordering the proposed action corridor are coniferous forest.

Forest-types are as follows: 1.4 miles of young forest ( 0 - 15 years old); 38.2 miles of second-growth forest (16-79 years old); and 9.1 miles of mature forest ( $80+$ years old).

\section{Forest Types}

The forest types along the proposed action corridor are classified under three categories:

Young Forest: Young forests are areas cleared with stands established within the past 15 years. Stand structure is simple with hand-planted and naturally seeded coniferous trees 3 to 25 feet tall and are interspersed with naturally established hardwoods and shrubs. Disturbed soils and residual forest materials from logging are common. Hardwood release treatments and animal damage control measures are commonly used to accelerate development of young conifer.

Second-growth Forest: Dominated by Douglas fir, these stands are generally between 16 to 80 years old and range from 25 to 150 feet tall. Younger stands contain high stem densities, while older stands have experienced natural thinning and selection influences from wind-throw, insect or disease infestation and competition for sunlight. Openings appear in the canopy where these influences have caused tree mortalities. Silvicultural prescriptions often include tree thinning operations within these stands to reduce stem density.

Mature (Late Seral) Coniferous Forest: Dominated by Douglas fir, these stands are older than 80 years. Trees range from 80 to over 200 feet tall. Old-growth stands (200+ years) typically have multi-layered canopies and low stem density. 


\section{Vegetation of the Hwy 42 Alternative Route}

Vegetation within the Hwy 42 route is similar in nature to the vegetation within the CBW Road ROW, except the safety margin (removed trees for improved visibility) is often wider.

This route borders 29.0 miles of second-growth forest land and 4.5 miles of mature forest land. In addition, it borders 28.3 miles of agricultural lands.

\section{Farmlands, Prime and Unique}

None of the farms along the proposed action or Hwy 42 alternate route have been designated as Prime or Unique Farmland.

\section{Floodplain}

The proposed action is adjacent to 2.2 miles of 100-year floodplain located along the CBW Road near Sumner. The Hwy 42 route borders 15.3 miles of 100-year floodplain from near Myrtle Point to the coast.

\section{Water Quality, Quantity and Domestic Use}

Domestic-use (Proposed Action): Pipeline construction will disturb the top 5 feet of the soil, with 65\% of the disturbance occurring within road fill of 5 to 10 feet deep. Domestic-use water wells nearest the proposed action generally exceed 50 feet depth. No registered domestic-users of water exists in streams along the proposed action.

Domestic-use (Hwy 42 Route): Pipeline construction would be limited to disturbance within road fill areas.

Water Quality (Both): Water quality environmental baselines may be affected from pipeline construction that crosses streams ( 188 stream crossings for the proposed action and 209 stream crossings for the Hwy 42 route). See discussion below of waters along the routes; Appendix E, which contains specific water quality baseline conditions by watershed; and Appendix I, which contains a list of streams that would be crossed by the proposed action.

Water Quantity (Both): Water quantity will not be impacted by either action alternative, as any active streams crossed during pipeline construction will have water piped around the construction area back into its natural stream channel.

\section{Waters Along the Proposed Action}

Appendix I contains a listing of intermittent and perennial flowing waters within the proposed action corridor. The corridor crosses 188 natural waterways (streams, tributaries or natural drainage channels). Of these waterways, 2 are large streams (greater than 30 feet wide) and 6 of them are medium streams (15 feet to 30 feet wide). Isthmus Slough is an estuary with a width of approximately 400 feet at the crossing point.

During periods of extended rainfall, the streams in the coast range reach their high water mark. During this time, the floodplains (referenced in "Floodplain" above) become inundated with water. During the proposed pipeline's construction season (June 1 to November 1), these floodplains would lack standing water.

The proposed action crosses one wetland on private land near Coos Bay, OR. Refer to "Wetlands" (below) for further detail.

\section{Wetlands}

Regulatory documents define wetlands as:

"... areas that are inundated or saturated by surface or groundwater at a frequency and duration sufficient to support, and that under normal circumstances do support, a prevalence of vegetation typically adapted for life in saturated soil conditions." (33 [CFR] 328.3, 40 [CFR] 230.3) 


\section{Wetlands Identified Along the Proposed Action}

Information regarding the locations of wetlands along the pipeline routes was derived from on-the-ground delineation. One wetland is identified within the proposed action corridor. It will be directionally-drilled to avoid impacts. The tidal wetland in the region of Isthmus Slough will be directionally-drilled as part of the overall slough crossing and is combined as a single stream-crossing.

\section{Waters along Hwy 42 Alternative Route}

The surface waters crossed by the alternate route are similar to that of the proposed action. The Hwy 42 route would cross a total of 209 streams, 18 of which are large streams and 12 of which are medium-sized streams.

\section{Wetlands Identified Along the Hwy 42 Alternative Route}

Wetlands along the alternative route were typically associated with streams or rivers flowing parallel to the course of the roadway.

The Hwy 42 alternative route has the potential to affect 9 wetlands.

\section{Wild and Scenic Rivers}

No federally designated "Wild and Scenic Rivers" are within 10 miles of the proposed or alternate routes.

\section{Wilderness or Wilderness Study Areas}

No federally designated Wilderness or Wilderness Study Area are within 5 miles of the proposed or alternate routes.

\section{Wildlife}

The proposed action corridors lack snags and trees or other suitable breeding, feeding and sheltering habitats for federally listed, proposed, candidate or survey and manage species. No breeding or sheltering habitats for special-status species occurs in the proposed action corridor. However, the proposed action utility corridor may contain foraging habitat for a few special-status bats and birds. The Hwy 42 corridor contains no habitat for terrestrial species. In general, roadways and utility corridors have been cleared of trees and brush wherever they grow within the Hwy 42 and proposed action corridors. There is one location in the proposed action where 25 -year old trees on private ownership will be removed during pipeline construction (approximately 0.2-acre total). Overall, the action alternatives (including the proposed action) contain either no wildlife habitat (CBW Road, Hwy 101 and Hwy 42) or no suitable nesting/roosting habitat for wildlife species (utility corridors).

No part of the construction area within the proposed action corridor is managed under special habitat requirements.

However, BLM-managed lands adjacent to the proposed action corridor are managed for requirements related to special-status, threatened and endangered species, as well as overall protection of ecosystem functions. Some of these lands are designated for special management as prescribed in the NFP Record of Decision. In the vicinity of both action alternatives, Late Successional Reserves (LSR) and Riparian Reserves are included. The proposed action corridor bisects LSR \#261 and three CHUs: One spotted owl CHU (OR-60) and two marbled murrelet CHUs (OR-06-b and OR-06-d), which are delineated on maps in Appendix C.

\section{Federally Listed, Proposed or Candidate Species}

Species listed as "endangered" under the ESA are those which are in danger of extinction in all or a portion of their range. Species listed as "threatened" are under threat of endangerment. Six listed species potentially exist near the proposed alternatives.

(Because of the sensitivity of nest site data, the exact location of nests is only provided on a need-to-know basis and is therefore not included). 


\section{Northern Spotted Owl (Strix occidentalis)}

The northern spotted owl is a federally listed threatened species. Suitable habitat is adjacent to both action alternative routes. Approximately 30 percent of the proposed action is within 0.25 -mile of suitable northern spotted owl habitat. Approximately 20 percent of the Hwy 42 alternative is within 0.25 -mile of suitable northern spotted owl habitat. This habitat generally consists of late-successional forest, but mature stands with closed canopy and diverse structure are also considered suitable.

The suitable habitat within 1.5 miles of the proposed action has been surveyed for northern spotted owls. The Pacific Northwest Research Station, Ecosystem Processes Research Program, has conducted 13 years of northern spotted owl research on the BLM-managed lands, and the BLM funded a 5-year Pacific Southwest Research Station demography study. The only suitable habitat within 0.25 -mile of Hwy 42 or proposed action corridors is on federal land.

Within the general study area there is a $1,011 \mathrm{~km}^{2}$ (approximately $400 \mathrm{mi}^{2}$ ) density study area where intensive spotted owl survey and monitoring is conducted (Forsman and Anthony, 1999).

The key issue related to northern spotted owls and the proposed action is possible nest site disturbance. The U.S. Fish and Wildlife Service (USFWS) considers nest sites disturbed when activities causing moderate noise above ambient levels occur (such as pipeline construction) within 0.25 -mile of the nest site (except for blasting, which may disturb northern spotted owls up to 1.0 mile. Some segments of all the action alternatives are near suitable habitat. The most recent documentation (surveys through 2001) of northern spotted owl sites show that one pair is within 0.25 -mile of the proposed action.

\section{Marbled Murrelet (Brachyramphus marmoratus)}

The marbled murrelet is a federally listed threatened species. Suitable marbled murrelet nesting habitat, as defined by the USFWS marbled murrelet survey protocol, is present within 0.25 -mile of both action alternative routes. Habitat was confirmed using Geographical Information Systems (GIS) stand age-class data, aerial photographs and field observation. Biologists on the ground further refined and delineated suitable habitat into areas needing protocol surveys. In general, forest stands within 50 miles of the coast with nesting platforms (usually $80+$ year-old trees) are considered suitable habitat. Approximately 30 percent of the proposed action is within 0.25 -mile of suitable marbled murrelet habitat. Approximately 20 percent of the Hwy 42 alternative is within 0.25 -mile of suitable marbled murrelet habitat.

Studies in 1992 and 1997 found marbled murrelet abundance to be low in southwestern Oregon. Of 889 intensive 2hour surveys, only 17 resulted in marbled murrelet detections, and only three stands overall were considered occupied based on these surveys (USDA/USDI, 1998).

Unsurveyed suitable habitat and nest site disturbance from construction activities is the primary management concern in the proposed action.

Marbled murrelets may be disturbed up to 0.25 -mile from pipeline construction activities (except for blasting, which may disturb marbled murrelets up to 1.0 mile).

Surveys conducted on the Coos Bay BLM District indicate there are two occupied stands within 0.25-mile of the proposed action corridor.

Designated Critical Habitat for the Northern Spotted Owl and Marbled Murrelet

Critical habitats have been designated for the northern spotted owl and marbled murrelet in Oregon. The USFWS has designated CHUs for northern spotted owl and marbled murrelet on some BLM lands adjacent to all the action alternatives. CHUs are protected under the ESA and cannot be adversely modified unless impacts can be completely mitigated (see maps showing critical habitats in Appendix C). The determination of impact avoidance, minimization and mitigation for these critical habitats is conducted through the ESA and not NEPA. However, to meet the disclosure requirements for NEPA, Chapter 4 identifies the types of impacts that may occur and makes reasonable predictions as to the likelihood that impacts can be effectively avoided, minimized or mitigated.

It is also important to distinguish between designated CHUs (regulatory definition) and currently suitable habitat, which is a biological definition. CHUs are lands specifically designated by the USFWS to protect a listed species, whereas, suitable habitats are areas that provide shelter, breeding sites, foraging habitat or other elements necessary for a species' life-cycle. Because CHUs are regulatory and suitable habitat is biological, not all suitable habitat for marbled murrelets or northern spotted owls are designated critical habitat; and conversely, not all designated critical habitat is suitable habitat. 


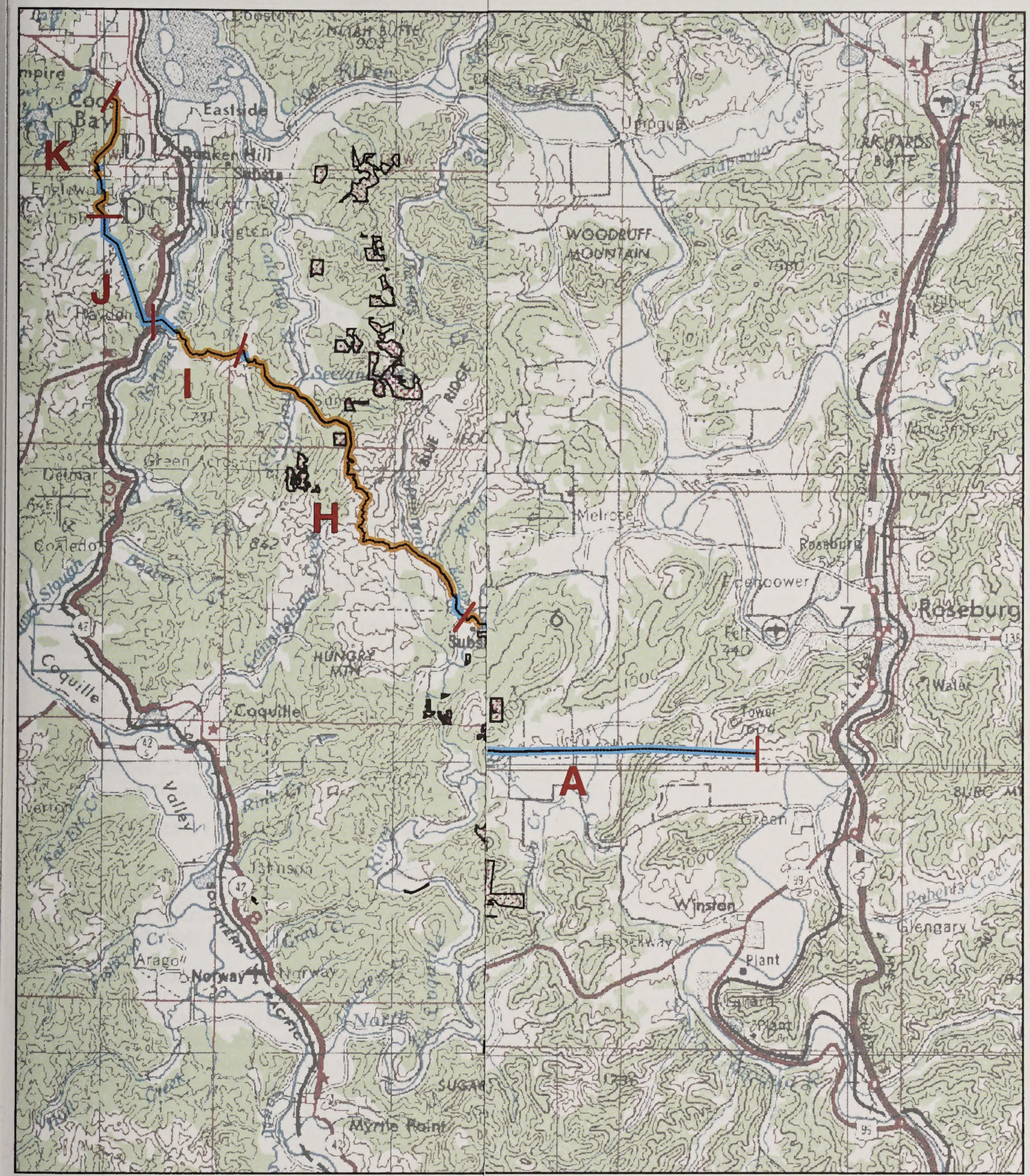

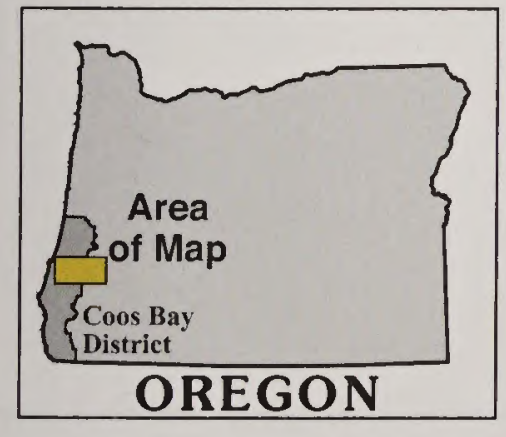

000

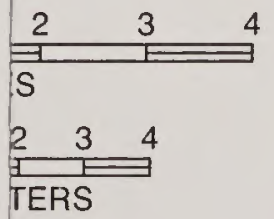

as to the accuracy,

jgregate use

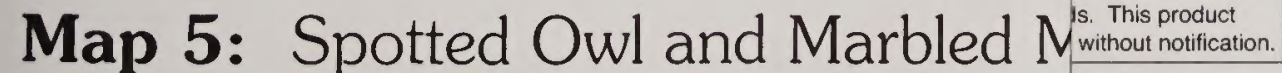

U.S. DEPARTMENT OF THE INTERIOR

Bureau of Land Management COOS BAY DISTRICT

Coos Bay Resource Area 2001
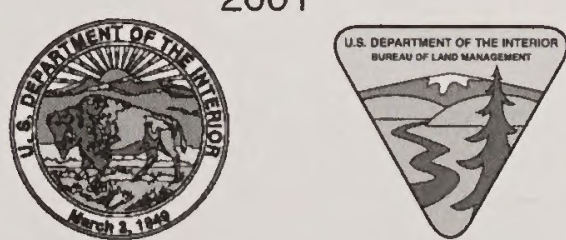

COOS COUNTY NATURAL

GAS PIPELINE PROJECT 


\section{Northern Spotted Owl (Strix occidentalis)}

The northern spotted owl is a federally listed threatened species. Suitable habitat is adjacent to both action alternative routes. Approximately 30 percent of the proposed action is within 0.25 -mile of suitable northern spotted owl habitat. Approximately 20 percent of the Hwy 42 alternative is within 0.25 -mile of suitable northern spotted owl habitat. This habitat generally consists of late-successional forest, but mature stands with closed canopy and diverse structure are also considered suitable.

The suitable habitat within 1.5 miles of the proposed action has been surveyed for northern spotted owls. The Pacific Northwest Research Station, Ecosystem Processes Research Program, has conducted 13 years of northern spotted owl research on the BLM-managed lands, and the BLM funded a 5-year Pacific Southwest Research Station demography study. The only suitable habitat within 0.25 -mile of Hwy 42 or proposed action corridors is on federal land.

Within the general study area there is a $1,011 \mathrm{~km}^{2}$ (approximately $400 \mathrm{mi}^{2}$ ) density study area where intensive spotted owl survey and monitoring is conducted (Forsman and Anthony, 1999).

The key issue related to northern spotted owls and the proposed action is possible nest site disturbance. The U.S. Fish and Wildlife Service (USFWS) considers nest sites disturbed when activities causing moderate noise above ambient levels occur (such as pipeline construction) within 0.25 -mile of the nest site (except for blasting, which may disturb northern spotted owls up to 1.0 mile. Some segments of all the action alternatives are near suitable habitat. The most recent documentation (surveys through 2001) of northern spotted owl sites show that one pair is within 0.25 -mile of the proposed action.

\section{Marbled Murrelet (Brachyramphus marmoratus)}

The marbled murrelet is a federally listed threatened species. Suitable marbled murrelet nesting habitat, as defined by the USFWS marbled murrelet survey protocol, is present within 0.25 -mile of both action alternative routes. Habitat was confirmed using Geographical Information Systems (GIS) stand age-class data, aerial photographs and field observation. Biologists on the ground further refined and delineated suitable habitat into areas needing protocol surveys. In general, forest stands within 50 miles of the coast with nesting platforms (usually 80+ year-old trees) are considered suitable habitat. Approximately 30 percent of the proposed action is within 0.25 -mile of suitable marbled murrelet habitat. Approximately 20 percent of the Hwy 42 alternative is within 0.25 -mile of suitable marbled murrelet habitat.

Studies in 1992 and 1997 found marbled murrelet abundance to be low in southwestern Oregon. Of 889 intensive 2hour surveys, only 17 resulted in marbled murrelet detections, and only three stands overall were considered occupied based on these surveys (USDA/USDI, 1998).

Unsurveyed suitable habitat and nest site disturbance from construction activities is the primary management concern in the proposed action.

Marbled murrelets may be disturbed up to 0.25 -mile from pipeline construction activities (except for blasting, which may disturb marbled murrelets up to 1.0 mile).

Surveys conducted on the Coos Bay BLM District indicate there are two occupied stands within 0.25-mile of the proposed action corridor.

\section{Designated Critical Habitat for the Northern Spotted Owl and Marbled Murrelet}

Critical habitats have been designated for the northern spotted owl and marbled murrelet in Oregon. The USFWS has designated CHUs for northern spotted owl and marbled murrelet on some BLM lands adjacent to all the action alternatives. CHUs are protected under the ESA and cannot be adversely modified unless impacts can be completely mitigated (see maps showing critical habitats in Appendix C). The determination of impact avoidance, minimization and mitigation for these critical habitats is conducted through the ESA and not NEPA. However, to meet the disclosure requirements for NEPA, Chapter 4 identifies the types of impacts that may occur and makes reasonable predictions as to the likelihood that impacts can be effectively avoided, minimized or mitigated.

It is also important to distinguish between designated CHUs (regulatory definition) and currently suitable habitat, which is a biological definition. CHUs are lands specifically designated by the USFWS to protect a listed species, whereas, suitable habitats are areas that provide shelter, breeding sites, foraging habitat or other elements necessary for a species' life-cycle. Because CHUs are regulatory and suitable habitat is biological, not all suitable habitat for marbled murrelets or northern spotted owls are designated critical habitat; and conversely, not all designated critical habitat is suitable habitat. 



\section{Bald Eagle (Haliaeetus leucocephalus)}

Currently, the bald eagle is a federally listed threatened species. Key habitats include wintering areas, nest areas, roost sites and foraging areas, such as waterfowl concentration areas and areas of abundant fish availability.

The Umpqua River is an area of high eagle concentration (Kritz pers. com.). There are 6 documented occurrences of bald eagle nests within 1.0 mile of this river. No occupied bald eagle nests are within 1.0 mile of the proposed action or Hwy 42 corridors.

\section{Columbian White-tailed Deer (Odocoileus virginianus leucurus)}

This federally listed endangered species utilizes the lowlands of the interior valley, with preference for oak woodlands and meadows with nutritious forage. The geographic range for the Roseburg population of Columbian Whitetailed deer (CWTD) is confined to Douglas County, Oregon. It was defined as follows in the 1983 CWTD Recovery Plan:
"From Oldham Creek 3 miles northeast of Oakland, south to Cow Creek, 3 miles southwest of Riddle. Morgan Creek, 1.1 miles north of its intersection with the South Umpqua River, is the southeastern-most extent of its known range, whereas the northwest boundary extends to the town of Umpqua. The eastern boundary is Fall Creek, 0.3-mile south to Little River; the western boundary is Hawkins Lake. Since 1983, the population range has expanded 5 to 10 miles in all directions, with more dispersal occurring along ripar- ian corridors." (Peterson, USFWS, pers. com.).

CWTD are likely to occur around the easternmost portion of the project area where habitat is suitable. This species is documented to exist in Cottage Grove, Callahan, Garden Valley, Nonpareil, Oak Creek Valley and Winchester United States Geological Service (USGS) quadrangles. Since the last recovery plan revision in 1983, the population has increased from 2,000-2,500 to 5,000-7,000 individuals and approximately 4,000 ha (10,000 acres) of habitat has been secured (Peterson, USFWS, pers. com.). As of this writing, the USFWS feels the Roseburg population of CWTD should be delisted and intends to publish their proposal in the Federal Register (Peterson, USFWS, pers. com.). The Oregon Department of Fish and Wildlife (ODFW) has delisted the CWTD from its previous threatened status to its current vulnerable state status.

Disturbance from construction activities is the only management concern in the Hwy 42 alternative and proposed action. There are no disturbance-related management requirements for CWTD.

\section{Brown Pelican (Pelecanus occidentalis)}

The brown pelican is a federally listed endangered species. They are documented in areas mapped on the Lakeside USGS quadrangle. Although the brown pelican may forage in and around the coastal bays during the summer, they rarely come inland. They are considered unlikely breeders north of California. No known breeding sites are within 20 miles of either the Hwy 42 alternative or proposed action.

\section{Western Snowy Plover (Charadrius alexandrinus)}

The nearest documented nesting area for this threatened species is the North Spit of Coos Bay (BLM 1994a) on the sandy beaches and dunes of the immediate coast. Western snowy plover habitat is absent from both the Hwy 42 alternative and proposed action, as NW Natural's planned natural gas distribution system from Coos Bay to the manufacturing facilities on the North Spit avoids all ACEC and western snowy plover habitat. 


\section{BLM Special-Status Species}

\section{Terrestrial Wildlife}

The BLM Special-Status Terrestrial Wildlife Species list for the project area is in Appendix K1. No suitable nesting or roosting habitats occur within the action alternatives. Field surveys found no special-status wildlife occurring within the proposed action's construction corridor. The primary issue related to special-status wildlife and the proposed action is disturbance (noise). The T\&E species disturbance issue is addressed under the Federally Listed, Proposed or Candidate Species sections in Chapters $3 \& 4$. No other special-status species in the Hwy 42 or proposed action vicinity have disturbance-related management requirements.

\section{Special-Status Birds}

No special-status bird species' roosts or nests are known to occur within or adjacent to the Hwy 42 or proposed action corridors. There is no breeding and sheltering habitat available in either action alternatives' corridors. It is possible that peregrine falcons and northern goshawks may move through and forage in the proposed action powerline corridor intermittently throughout the year, because both the Hwy 42 alternative and proposed action occurs within the range of these species. However, these two species have never been documented in the BPA or PP\&L powerline corridors. No other special-status birds are known to exist in or adjacent to either action alternative areas.

\section{Special-Status Mammals}

Bats - No special-status bat species' maternity roosts or hibernacula are known to occur within or adjacent to the Hwy 42 or proposed action corridors. Some bats such as the Townsend's big-eared bat primarily inhabit caves. Other bat species occurring in this area are found using various habitats that provide shelter and adequate temperatures for thermal regulation, including caves, mines, man-made structures and trees with cavities and/or exfoliating bark.

Suitable bat roosts are found in higher densities in older forests, because they tend to contain larger trees and snags. In general, bats utilize forest openings and water bodies for navigation and foraging. No suitable roosting or hibernacula habitat exists in or adjacent to the Hwy 42 or proposed action corridors.

Fisher - Although in the range of fisher (Maser 1998), no confirmed sighting of fisher have occurred within the Hwy 42 or proposed action project areas. Neither action alternative contains any suitable habitat for fisher, nor is it likely individuals exist adjacent to the Hwy 42 or proposed action corridors.

Disturbance from construction during foraging activity is the primary management concern for special-status mammals and the proposed action. There are no disturbance-related management requirements for foraging special-status mammals.

\section{Special-Status Amphibians}

Although considered possible on both BLM Districts, no documented sighting of special-status amphibians have occurred near the Hwy 42 or proposed action project areas. Neither action alternative contains suitable habitat for special-status amphibians.

\section{Special-Status Reptiles}

Neither action alternative contains suitable habitat for any special-status reptiles, except the western pond turtle. One documented sighting occurs within 2 miles of the proposed action corridor. The Isthmus Slough tidal marsh area and the private wetland near Coos Bay are the two places containing potential western pond turtle habitat within the proposed action. The Hwy 42 alternative crosses 9 wetlands containing potential western pond turtle habitat. No western pond turtles are known to occur in any of these potential habitat areas. All areas for both action alternatives containing potential western pond turtle habitat would be directionally-drilled to avoid aquatic system impacts, thus avoiding any potential impacts to western pond turtles.

\section{Fish}

The BLM Special-Status Fish Species list for the project area is listed below in Table 5. Suitable habitat would be crossed at Tenmile Creek during construction within the proposed action. The primary issue related to special-status fish and the proposed action is short-term increases in stream sediment and turbidity from construction soil disturbance. The soil disturbance issue is directly addressed in Appendix E. No special-status fish species have noise disturbance-related management requirements. 
Although no critical habitat streams exist in or near the proposed action corridors, Essential Fish Habitat (EFH) for all anadromous fish species was considered as part of the EIS Aquatic Ecosystem Assessment (Appendix E-1).

Table 5: $\quad$ Special-status fish species in streams near the proposed action

\begin{tabular}{|l|l|l|}
\hline \multicolumn{1}{|c|}{ Fish } & \multicolumn{1}{|c|}{ Status } & \multicolumn{1}{c|}{ Related Streams } \\
\hline \hline $\begin{array}{l}\text { Oregon Coast Coho } \\
\text { Salmon }\end{array}$ & $\begin{array}{l}\text { Federal Candidate } \\
\text { Species }\end{array}$ & $\begin{array}{l}\text { Cherry Creek, Middle Creek, E. Fork Coquille River, N. Fork Coquille } \\
\text { River, Evans Creek, Hantz Creek, Steel Creek, Catching Creek }\end{array}$ \\
\hline $\begin{array}{l}\text { Oregon Coast } \\
\text { Steelhead }\end{array}$ & $\begin{array}{l}\text { Federal Candidate } \\
\text { Species }\end{array}$ & $\begin{array}{l}\text { Tenmile Creek, Cherry Creek, Middle Creek, E. Fork Coquille River, N. } \\
\text { Fork Coquille River, Evans Creek, Hantz Creek, Steel Creek, Catching } \\
\text { Creek }\end{array}$ \\
\hline $\begin{array}{l}\text { Oregon Coast } \\
\text { Chinook Salmon }\end{array}$ & $\begin{array}{l}\text { BLM Special-Status } \\
\text { Species }\end{array}$ & E. Fork Coquille River, Steel Creek \\
\hline $\begin{array}{l}\text { Oregon Coast } \\
\text { Cutthroat Trout }\end{array}$ & $\begin{array}{l}\text { Federal Candidate } \\
\text { Species }\end{array}$ & $\begin{array}{l}\text { Cherry Creek, Middle Creek, E. Fork Coquille River, N. Fork Coquille } \\
\text { River, Evans Creek, Steel Creek }\end{array}$ \\
\hline
\end{tabular}

\section{Plants (including lichens, bryophytes and fungi)}

The BLM Special-Status Vegetation Species lists for the project area is in Appendix K1. The primary issue related to special-status vegetation and the proposed action is destruction or physical injury to individuals from soil disturbance during construction. Field surveys found no special-status vegetation occurring within the Hwy 42 alternative or proposed action construction corridors. Vegetal species have no noise disturbance-related management requirements.

\section{Invertebrates}

The BLM Special-Status Invertebrates Species list for the project area is in Appendix K1. The primary issue related to special-status invertebrates and the proposed action is destruction or physical injury to individuals from soil disturbance during construction. Field surveys found no special-status invertebrates habitats occurring within the Hwy 42 or proposed action construction corridors. Invertebrates have no noise disturbance-related management requirement.

\section{Survey and Manage Species}

Survey and Manage Species surveys are normally done when: (1) A project has the potential of being a ground-disturbing activity which may alter vegetation or other habitat elements on federally managed lands; (2) the project is within the suspected range covered by the protocol; and (3) the project must occur within suitable habitat for the species.

The BLM Districts' Survey and Manage Species list for their administration areas are in Appendix K. Field surveys revealed no suitable Survey and Manage habitats on BLM-administered lands within the proposed action and Hwy 42 construction corridors. Field surveys for Survey and Manage Species/Habitats were conducted in autumn of 2000. The primary issue related to Survey and Manage Species and the proposed action is disturbance (noise). Survey and Manage species do not have disturbance-related management requirements.

\section{Red Tree Vole}

The red tree vole (Phenacomys longicaudus) is a Northwest Forest Plan Survey and Manage species, generally found more abundant in late-successional coniferous forests containing Douglas fir. Field surveys found no individuals or suitable habitat within the proposed action or Hwy 42 corridors. However, noise disturbance during construction activities in the proposed corridor do have the potential to temporarily disturb individuals in adjacent suitable habitat. Once pipeline construction is complete, disturbance will be minimal. No mitigation for noise disturbance is needed for Survey and Manage species. 


\section{Survey and Manage Mollusks}

The Amendment to the Survey and Manage Protection Buffer and other Mitigation Measures Standards and Guidelines (USDA 2001) gives the interagency standards and guidelines for identifying species to be protected through survey and management strategies. Among those listed are terrestrial and aquatic mollusks that occur within the range of the northern spotted owl. Survey protocols were also established.

Field surveys found no Survey and Manage mollusks habitats within the proposed action alternatives.

\section{Survey and Manage Amphibians}

Only one amphibian species, the Del Norte salamander, has potential for living within any of the proposed corridors. The nearest known Del Norte salamander site is approximately 25 miles south of the Hwy 42 alternative and proposed action areas.

Field surveys revealed no findings of individuals or potential habitat for the proposed alternatives. Del Norte salamander suitable habitat is rocky outcrops and talus within forested areas, especially older and wetter stands.

\section{Survey and Manage Bryophytes, Lichens, Fungi and Vascular Plants}

Field surveys revealed no findings of habitats for the proposed action alternatives.

\section{General Wildlife Groups}

Complete lists of general wildlife occurring on the Coos Bay and Roseburg BLM Districts can be found in their respective Resource Management Plans published for each district.

\section{Raptors}

Raptors include hawks, falcons, owls, eagles and vultures. No known nest sites occur within 0.25 -mile of the proposed action corridor, other than the one spotted owl nest site (previously discussed under federally-listed species).

Daytime foraging activities from some of these species may be within the 0.25 -mile radius of construction. Disturbance from construction activities is the primary management concern for the proposed action. There are no disturbance-related management requirements for unlisted species of foraging raptors.

\section{Cavity-Nesting Birds}

Cavity-nesting birds generally nest inside tree cavities and rock crevices. Examples include woodpeckers, American kestral, western bluebird, Pacific-slope flycatcher and northern pygmy-owl. These species typically require largerdiameter trees (greater than 10 inches). Suitable trees are typically dead or dying and tend to occur more frequently in older forests. However, residual snags from logging or fire can provide suitable habitat in younger age-classes. Some species, such as the western blue bird and northern pygmy owl, prefer early-seral stands that have natural or disturbance-related openings containing suitable cavity-producing snags. The utility corridors and roadways that will be used for pipeline construction contain no cavity-related suitable habitat. The utility corridors, however, may provide foraging opportunities for some cavity-nesting species.

\section{Other Birds}

A variety of other migratory and resident birds exist within the project area. A variety of song-birds and waterfowl typically migrate from southern latitudes to breed in southwest Oregon.

Resident birds (juncos, chickadees, crows, ravens, etc.) may have seasonal movements, but tend to stay within their home-range vicinity all year. Game birds, such as quail, grouse and wild turkey, are also resident birds. Some of these species spend at least part of their life-cycle in ground-disturbed habitat, such as foraging within powerline utility corridors and agricultural lands.

\section{Deer and Elk}

Deer and elk occur throughout the project area. They provide recreational opportunities for people (i.e., hunting and wildlife observation) and are important prey species for black bears and cougars. Individuals are often seen feeding 
in forest clearings and wet meadows. Both species may use utility corridors and agricultural lands for feeding and travel/migration.

\section{Carnivorous/Omnivorous Mammals}

The project area may support populations of coyote, red fox, common gray fox, black bear, ringtail, raccoon, porcupine, opossum, river otter, bobcat and cougar. The mountain lion and black bear are game animals in Oregon, providing recreational opportunities (hunting) within the project area. Carnivorous/Omnivorous mammals may use utility corridors and roadways for travel/migration.

\section{Small Mammals}

Several species of small rodents such as shrews, rats, mice, squirrels and voles may be present within the powerline utility corridor. These species tend to prefer the early-successional habitats common in utility corridors and agricultural lands, although a few species such as the flying squirrel and white-footed vole prefer developed forests. This type of habitat is adjacent to both action alternatives.

\section{Burrowing Mammals}

Burrowing mammals such as the mole, rabbit, mountain beaver, ground squirrel and pocket gopher are known to occur throughout both of the proposed alternatives. Some of these mammals may be locally abundant and provide an important food source to predators. Because burrowing animals usually require deep, loose soil, areas containing deeper soils are the most suitable habitat for them.

\section{Reptiles}

Various non-sensitive reptiles (such as turtles, lizards and snakes) have habitat ranges within the project vicinity. Most reptiles with populations in Oregon are likely to occur in developed forests or drier environments east of the coastal mountains.

\section{Invertebrates}

Various species such as mollusks and insects are found in the project vicinity. Insects are an important source of food for some species of birds and reptiles.

\section{Amphibians}

Both action alternatives include a number of stream crossings that include trenching dry and flowing streams as part of pipeline construction. These stream crossings would include some potential habitat for amphibians during portions of their life-history cycle.

Various non-sensitive amphibian species (for example, frogs and salamanders) may be found intermittently in the project vicinity. These are a food source for mammals, fish, birds and reptiles. Amphibians use habitat features such as large down woody material, talus slopes, creeks, seeps and ponds.

\section{Fish}

The fish resources in the proposed action corridor include resident, anadromous and fluvial species. Three streams (Tenmile, Morgan and Rock Creek) to be trenched using "Bag and Flume" along the pipeline route contain enough summer waterflow $(>0.1 \mathrm{cfs})$ to contain fish during active construction. Eighteen other small drainages with very low summer waterflow $(<0.06 \mathrm{cfs})$ will be trenched in the utility corridor portions of the pipeline construction. There is no realistic potential for fish to be in the upper reaches of these 18 small streams in the area of active construction during the summer, as their flows during that time are too small for sustaining fish. The primary issue related to fish and Hwy 42 alternative/proposed action is short-term increases in stream sediment and turbidity from construction soil disturbance. This issue is directly addressed in Appendix E. Although no critical habitat streams exist in or near the proposed action corridors, Essential Fish Habitat (EFH) for fish species was considered as part of the EIS Aquatic Ecosystem Assessment (Appendix E-1). 


\section{Human Environment}

\section{Area of Critical Environmental Concern (ACEC)}

Part of the North Spit of Coos Bay (sand dunes area) has been designated as an ACEC, primarily for western snowy plover nesting habitat. Williams' plan to build a distribution system to commercial manufacturing facilities already operating on the North Spit would avoid this area completely and stay within predisturbed areas zoned for manufacturing or public roads. This distribution system would be constructed under both action alternatives.

\section{Public Health and Safety}

The primary issue of safety for the proposed action/Hwy 42 alternative is traffic on roads where pipeline construction is occurring. Accidents are possible if pedestrians or vehicles fail to heed signs and flaggers controlling traffic flow or enter active construction areas without permission. After construction is completed, the primary issue for public safety and pipeline operation would be damage from someone digging without permission with heavy equipment (such as a backhoe) or unauthorized use of explosives in the near vicinity of the pipeline.

\section{Environmental Justice}

Executive Order 12898 of February 11, 1994 requires each federal agency to identify and address any disproportionately high and adverse human health or environmental effects of its programs, policies and activities on minority populations, Native American groups and on low income populations.

There is no indication that households along either the Proposed Action or alternative Hwy 42 route are composed of a mix of minority or Native American residents which differs from elsewhere in Coos County. Therefore, analysis focused on whether a disproportionately high percentage of low income households are found along either route. This was accomplished by comparison of household income information from several geographic areas of Coos County, by reference to Census Tracts and Blocks within Census Tract. Year 2000 Census data concerning household income is not yet available, so 1990 Census data was used.

No minority or disadvantaged communities are adjacent to the proposed action or Hwy 42 alternative routes.

\section{Socio-economics in Coos County}

The economic simulation model, Impact Analysis for Planning (IMPLAN), used by ECONorthwest shows natural gas has the potential to stimulate the manufacturing sector of the local economy. The study is based upon a planning framework called IMPLAN (developed by the U.S. Forest Service), using local and national data to produce estimates of economic impact. Similar analysis of communities such as Newport, Corvallis, Albany and Grants Pass would re-affirm the significant favorable economic impacts from the introduction of natural gas to a local economy.

\section{Socio-economics within the Proposed Action}

The proposed action corridor is adjacent to the following business entities: Lookingglass Store, Northwest Hardwoods, Southport Lumber Co., Coos Country Club, Dora Store, Four Corners Grocery and the Sumner Store.

The proposed action corridor is also adjacent to 37 rural residences. Less than 2 percent of the corridor's urban settings are outside of the Coos Bay area. These urban settings are small components of the overall Coos County economy.

\section{Regional Assessment of the Natural Gas Market}

According to the ECONorthwest report, the competitive advantage of natural gas over other energy sources in general for Oregon is evident: "60 percent of Oregon's urban area homes use natural gas, while about 40 percent of the 
homes in outlying areas use natural gas" (ECONorthwest 2000). Such statistics indicate a wide-spread consumer acceptance of natural gas.

\section{Coos County General Economic Data}

Coos County 2000 Census reports it has 62,779 residents. Its economy centers around forest products and the deepwater ocean Port of Coos Bay, but the economy continues its long struggle which began in the early 1980's, when timber production diminished significantly following the impacts of several forestry-related environmental issues (Helvoigt, 2000). According to the Oregon Employment Department, the current (November, 2001) unemployment rate in the County is approximately 6.7 percent, as compared to Oregon's average unemployment rate of 6.4 percent. For further comparison, the November, 2000, national average unemployment rate was 4 percent, according to the Wall Street Journal. Historical data indicates the County's unemployment statistics are approximately double those of the national average (Coos/Curry/Douglas, 2000).

As shown in the Coos County Budget, the County's current tax structure includes real estate taxes, timber taxes and county fees. The County receives gross tax receipts for the general fund in the amount of approximately $\$ 2.96$ million per year. Payments-in-lieu-of-taxes to the County is approximately $\$ 6,752$ per year. Additional general fund revenue comes to the County from O\&C lands timber revenues and from federal lands timber revenues (from the sale of timber on BLM and U.S. Forest Service lands); in 1991, these amounted to 19 percent and 22 percent (respectively) of the County's total annual budget (Maxwell et al., 1999).

Total personal income of the County is approximately $\$ 1.1$ billion, which is an average annual per capita personal income of $\$ 19,494$; this is approximately 82 percent of the Oregon average annual per capita personal income (Coos/ Curry/Douglas, 2000).

\section{Energy Market Competition in Coos County}

Much of this information regarding energy market competition is derived from the most recent ECONorthwest report submitted for the proposed action.

Much of the electrical energy supplied to Coos Bay comes from PP\&L. This employer (and its employees) would receive no significant adverse effects from the proposed action. Natural gas can only supplement (not replace) the use of electricity. The equipment supplying the electricity would require the same amount of maintenance, regardless of the presence of a natural gas supply.

The Coos County economy currently supports propane and heating oil distributors. These supply approximately 20 percent of the heating energy needs of the cities of Coos Bay and North Bend. Small businesses transport propane and heating oil to rural residences as well as in-town businesses and residences. Businesses based outside of the County operate wholesale fuel oil and propane supply companies. Conglomerated, the nine businesses delivering fuel oil or propane to County residents and businesses (listed below) employ a total of 69 persons (ECONorthwest 2000).

The following propane dealers operate within the County: All Star Gas (North Bend), Ferrellgas (Coos Bay) and Ron's Oil Co. (Coquille).

The following heating oil dealers operate within the County: Bassett-Hyland Energy Co. (Coos Bay), Davis Oil Inc. (North Bend), Graham Oil Co. (North Bend), Tyree Oil Inc. (Coos Bay), Goddard Energy Co. (Bandon) and Hodge Distributor, Inc. (Myrtle Point).

Currently, Oregon supports an average of 1,147 residents per fuel oil or propane distributor employee. This ratio is higher than the ratio for Coos County ( 847 residents per distributor), due to the widespread availability of natural gas across most of Oregon (ECONorthwest 2000).

\section{Waste - Solid or Hazardous}

No waste sites, lagoons, landfills, transfer stations or water treatment plants exist in or near the proposed action corridor. Sewage disposal ponds are located approximately 0.5 -mile west of the proposed action corridor at Libby and the Roseburg city dump is approximately 2 miles northeast of the Williams Gas Pipeline. 
No waste sites or refuse dumping sites exist in or near the alternative route. The Myrtle Point waste water treatment plant is located approximately 1 mile from the Hwy 42 corridor and the Coquille waste water treatment plant is approximately 0.1 -mile from the Hwy 42 alternative route.

\section{Land Uses}

\section{Forestry}

The general region of the proposed action is typical in its forest products history. Since the 1850 's, timber was milled into lumber or it was used as whole logs to be sold on the market. Today, forest lands are still an important source of logs for lumber, paper and plywood mills near Roseburg, Myrtle Point, Coquille and Coos Bay. The production of timber is expected to continue as an important local economic resource.

The local forests are also an important source of firewood for residences. Many rural homes are heated with woodburning facilities (fireplaces and wood heating units). The BLM may allow wood cutting on BLM-managed lands adjacent to the proposed action corridor. The proposed action corridor includes access routes used by individuals harvesting firewood or other special forest product items within the surrounding areas.

\section{Livestock Grazing}

Farmers and ranchers in the area between Lookingglass and Coos Bay raise domestic livestock, which are the typical varieties suited to Western Oregon.

\section{Recreation along the Proposed Action}

\section{BLM-Managed Lands}

The CBW Road traverses through scattered sections of BLM public lands in the Coos Bay and Roseburg Districts. BLM public lands in the Roseburg District are part of the South River Extensive Recreation Management Area (ERMA). Public lands in the Coos Bay District are within both the Myrtlewood and the Umpqua ERMAs. Recreation uses within these ERMAs are generally characterized by dispersed types of activities that require little or no management as well as small developed recreation sites with limited facilities that support recreation uses.

The Coos Bay District RMP proposes that the CBW Road be designated as a backcountry byway. While some preliminary work was done on a backcountry byway proposal several years ago, work to complete the designation process has not been finished to date.

According to the Coos Bay District RMP (USDI 1995a), the County's BLM-managed lands are characterized as "Roaded Natural" areas. The proposed action corridor includes no BLM-managed camping or picnicking facilities.

\section{County Parks}

The parks listed below include facilities for picnicking and hiking, as well as protecting the environment and increasing the safety of facility-users. In some cases, facilities are designed and constructed to accommodate camping by conventional motorized use (car and tent, camper, truck and trailer and motor home).

Dave Busenbark County Park (Douglas County), located at T28S, R9W, Section 16.

Severt Iverson Memorial County Park (Douglas County), located at T28S, R9W, Section 16.

Judge Hamilton County Park (Coos County), located east of Sitkum at T28S, R9W, Section 7.

Frona County Park (Coos County), located west of Dora at T28S, R11W, Section 11.

Judge Hamilton County Park is undeveloped and remains in a natural state. Frona County Park has basic facilities including toilets, picnic tables and primitive camp sites with fire rings. Both parks are Congressional withdrawals (1926) of BLM public lands for the purpose of reserving these lands in Coos County as public parks and campsites, for recreational purposes and to preserve the rare groves of Myrtle trees. 


\section{Boat Ramps}

Gold Brick Boat Ramp at Dora

Frona Boat Ramp at Frona County Park

\section{Recreation along the Alternative Route}

Hwy 42 is an important access route for recreation users. This route includes several small campgrounds and picnic areas adjacent to the highway, which are used by tourists coming to and from the coastal recreational areas. This highway is also an important access route for those travelling to secondary roads.

The Coos Bay District RMP (USDI 1995a) indicates this route is used for recreation year-round. Bear Creek is a public camping area adjacent to Hwy 42 , receiving thousands of visitors each year.

\section{Transportation}

\section{Roads affected by the Proposed Action}

\section{CBW Road}

The proposed action affects approximately 1 mile of the CBW Road in Douglas County and approximately 32 miles of the CBW Road in Coos County. The length of road between Lookingglass and U.S. Hwy 101 is approximately 54 miles. A 10-mile portion of the CBW Road, between Dora and Fairview, receives a significant amount of traffic related to administrative, commercial and residential purposes. The Dora Store and Four Corners Grocery are located along these affected portions of the road.

Two dairies are located in the general region of the proposed action. The proposed action corridor is not adjacent to these dairies; however, each dairy relies on milk-transport tank trucks that use the CBW Road for milk shipments.

The 0.8-mile portion of the CBW Road (west end which joins to U.S. Hwy 101) receives high usage for access to Northwest Hardwoods, Southport Forest Products and Coos Country Club.

The 10.6-mile gravelled portion of the CBW Road between the County line and Sitkum (T28S, R10W, Sec. 10) is one of the least travelled portions of the CBW Road. The CBW Road is rarely used as a transit route from Roseburg to Coos Bay, due to the many sharp curves and gravel surface east of Sitkum.

The paved portions of the CBW Road provide access to residences, timber lands and farms. Commercial traffic on this road is mostly logging trucks and equipment and dairy tank trucks. This road is a primary access route for forest fire protection efforts, land management and law enforcement. Reston Road, Myrtle Pt.-Sitkum Road and the Coquille-Fairview Road provide access from Hwy 42 to the CBW Road. 
Table 6: $\quad$ Portions of CBW Road affected

\begin{tabular}{|c|c|c|c|}
\hline $\begin{array}{c}\text { Mile } \\
\text { marker }\end{array}$ & Description of area & $\begin{array}{l}\text { Road } \\
\text { affected } \\
\text { (miles- } \\
\text { gravel) }\end{array}$ & $\begin{array}{c}\text { Road } \\
\text { affected } \\
\text { (miles- } \\
\text { paved) }\end{array}$ \\
\hline 6.4 & CR 5, cross near Lookingglass in north edge of PP\&L & & $X$ \\
\hline 7.5 to 8.6 & CR 5, lay in road, cross Morgan Creek & & 1.1 \\
\hline 1.0 to 1.7 & CR 112, lay in road, cross Tenmile Creek & & 0.7 \\
\hline 2.3 & CR 112 , cross in north edge of BPA & & $\mathrm{X}$ \\
\hline 36.3 to 25.7 & CR 1G, lay in gravel road through Brewster Canyon & 10.6 & \\
\hline 25.7 to 17.5 & CR $1 C$ and $1 D$, in pavement through Sitkum and Dora & & 8.2 \\
\hline 17.1 to 17.9 & CR 60B, lay in road, cross Middle Creek & & 0.8 \\
\hline 13.7 & CR $60 \mathrm{~B}$, cross south of Fairview in north edge of BPA & & $\mathrm{X}$ \\
\hline 12.75 to 12.5 & CR 60B, lay in road through Fairview & & 0.3 \\
\hline 12 to 4.1 & CR 59, lay in road from north Fairview to Sumner & 4.4 & 3.5 \\
\hline 4.1 to 2.2 & CR 57, lay in road from Sumner to PP\&L & & 1.9 \\
\hline 1.7 to 0.4 & CR 57, lay in road from top of hill to Coos City & & 1.3 \\
\hline & & 15 miles & 17.7 miles \\
\hline
\end{tabular}

In total, approximately 33 miles of the CBW Road would be affected by the proposed pipeline project (Table 6). In some cases, the proposed pipeline crosses the road; in the remainder of the affected portions of the road, it would be buried beneath the roadway. 


\section{Table 7: $\quad$ Other Public Roads Affected by Pipeline}

\begin{tabular}{|c|c|c|c|}
\hline Segment & Description of area & $\begin{array}{l}\text { Road } \\
\text { affected } \\
\text { (miles- } \\
\text { gravel) }\end{array}$ & $\begin{array}{l}\text { Road } \\
\text { affected } \\
\text { (miles- } \\
\text { paved) }\end{array}$ \\
\hline A & $\begin{array}{l}\text { Lookingglass Road CR 47, cross just south of Lookingglass } \\
\text { with PP\&L }\end{array}$ & & $\mathrm{X}$ \\
\hline A & $\begin{array}{l}\text { Dairy Farm Road CR 108, cross } 1.5 \text { miles west of Lookingglass } \\
\text { with PP\&L }\end{array}$ & & $\mathrm{X}$ \\
\hline $\mathrm{E}$ & Sitkum Lane CR 1C, lay in road west of CR 60B for 2200 feet & & 0.4 \\
\hline $\mathrm{F}$ & McKinley Lane CR 13, cross at CBWR near Cherry Creek & & $\mathrm{X}$ \\
\hline $\mathrm{H}$ & Fairview Road CR 9, cross just south of Fairview & & $\mathrm{X}$ \\
\hline I & U.S. 101, cross at MM 243.4 near Coos City and Sumner Bridge & & $\mathrm{X}$ \\
\hline $\mathrm{J}$ & North Meadow Drive (not dedicated), cross gravel road & $\mathrm{X}$ & \\
\hline $\mathrm{J}$ & Red Dike Road CR 183, cross to Fruitdale Drive & & $\mathrm{X}$ \\
\hline $\mathrm{K}$ & Fruitdale Drive CR 185 , lay in road for 100 feet & & 0 \\
\hline $\mathrm{K}$ & Cooley Drive, lay in road for 1800 feet, mostly gravel & 0.3 & \\
\hline $\mathrm{K}$ & Libby Lane CR 184 , lay in road for 1200 feet & & 0.2 \\
\hline $\mathrm{K}$ & Lapping Road, lay in gravel road for 100 feet & $\mathrm{X}$ & \\
\hline $\mathrm{K}$ & 21 st Street, lay in gravel road for 2200 feet & 0.4 & \\
\hline $\mathrm{K}$ & Idaho Drive, lay in gravel road for 2200 feet & 0.4 & \\
\hline $\mathrm{K}$ & California Drive, cross in steep dirt portion & $\mathrm{X}$ & \\
\hline K & Anderson Avenue, cross in east side of PP\&L & & $\mathrm{X}$ \\
\hline & & 1.1 miles & 0.6 -mile \\
\hline
\end{tabular}

\section{Sitkum Lane (Formally Myrtle Point - Sitkum Road)}

The proposed action corridor includes approximately 0.4-mile of the Myrtle Point-Sitkum Road. The portion of affected road is between the BPA utility ROW and its intersection with the CBW Road (Table 7).

\section{Fairview Road (formerly Coquille-Fairview Road)}

The proposed action corridor includes approximately 0.1 -mile of the Coquille-Fairview Road. The portion of affected road is between the PP\&L utility ROW and the Four Corners intersection where it crosses the CBW Road. 


\section{U.S. Hwy 101}

U.S. Hwy 101 is an important commercial truck route along the coast. At the crossing location within the proposed action corridor, trucks are destined for Coos Bay, North Bend, Bandon, Langlois, Port-Orford, Coquille, Myrtle Point and small communities or farms in the surrounding areas. It is also a major commuting route for many residents in the area. The proposed action crosses Hwy 101 once. It will be directionally-drilled to avoid impacts. At the crossing, U.S. Hwy 101 is a four-lane highway with a median strip.

\section{Roads affected by the Alternate Hwy 42 Route}

\section{Oregon Hwy 42}

Oregon Highway 42 is an important commercial truck route connecting the I-5 freeway and the inland communities to the coastal communities. Truck traffic along this route is destined for Coos Bay, North Bend, Bandon, Langlois of Port-Orford, Coquille and Myrtle Point. This highway is also a commuting and access route for residents of the coast. During the summer months, it is a major tourist route. Many portions of this route include three or four lanes of traffic. Extra lanes are supplied to traffic climbing uphill grades in several locations. The portions of the highway from Myrtle Point to Coquille, and the last 7 miles (approximately) as the highway approaches U.S. Hwy 101, are four lanes of traffic with no median strip.

\section{U.S. Hwy 101}

The Hwy 42 Alternative includes portions of U.S. Hwy 101 within the proposed route. The Hwy 42 route includes a segment approximately 0.8 -mile in length, from its intersection with Hwy 42 , to the BPA utility corridor very close to the CBW Road end point. This portion of the highway includes intersections with two secondary roads leading westward.

\section{Utility Corridors}

\section{Power Lines}

The proposed action corridor begins within the PP\&L power line utility corridor. It continues within this corridor until it reaches the Flournoy Valley substation. For nearly half the distance from Flournoy Valley to Fairview, the proposed action corridor is adjacent to or within the BPA $230 \mathrm{kV}$ power line utility corridor. For approximately 0.2mile near Coos City, the pipeline is within the PP\&L $230 \mathrm{kV}$ power line utility corridor, which traverses the region parallel to the BPA utility corridor along its northward edge. A short segment of the proposed action follows a recently abandoned BPA utility corridor to the west of U.S. Hwy 101. In total, approximately 23 miles of the proposed action corridor follows power line utility corridors.

\section{Substations}

The proposed action corridor lies adjacent to several power line substation properties. These include: Co-op substation in Lookingglass Valley, the BPA Reston substation in Flournoy Valley and the Fairview substation.

\section{Power Line Utility Corridor Access Roads}

Utility crews access the power lines: 1) by working from the CBW Road or from some other county road, wherever the lines cross over the road; or 2) by working from access roads connecting to the CBW Road and other public roads.

Graveled access roads into utility corridors are constructed and maintained by the utility company. Some of these roads would be used for access to the proposed action corridor, both during pipeline construction and during maintenance procedures of the pipeline during its operation. 


\section{PP\&L and BPA Access (Douglas County)}

Access roads are spaced at approximately half-mile increments along the CBW Road between Lookingglass and Tenmile Creek. From there to the county line, four BPA access roads connect to the CBW Road.

\section{BPA Access (Fairview-Reston circuit)}

Access roads for this portion of the corridor are located as follows:

- Two access roads in T28S, R11W, Sec. 3.

- One access road in T28S, R11W, Sec. 4.

- Extensive road access in T27S, R11W, Sections 32 and 30.

- Four access roads in T27S, R12W, Sec. 24.

\section{PP\&L Access (Fairview-Isthmus circuit):}

Access road to Segment H (along the PP\&L utility corridor) is located as follows:

- One access road in T26S, R12W, Sec. 30.

\section{BPA Access (part of the Fairview-Reedsport circuit)}

Access roads to Segment J (the region west of U.S. Hwy 101) were established for BPA access. Their use for power line maintenance is no longer needed, since the power line was recently relocated. The access roads into this corridor are as follows:

- One access road coming from U.S. 101 in T26S, R12W, Sec. 23.

- One access road in T26S, R12W, Sec. 15 (again coming from U.S. 101).

- One access road in T26S, R12W, Sec. 10, coming from Shinglehouse Slough Road.

- One access road in T26S, R12W, Sec. 10, coming from North Meadow Drive.

\section{Fiber Optic Line}

Buried fiber optic line currently exists at the edge of the CBW Road and Hwy 42 over their entire lengths. This utility is buried approximately 2 feet deep at or near the edge of the roadways and is marked with plastic markers at $1 /$ 10th-mile increments. Pipeline construction on or just outside the centerline of the CBW Road would not affect the fiber optic line. At its option, Coos County may decide to install a fiber optic carrier pipe in the pipeline ditch. The carrier pipe is typically 1.25 or 2 -inch polyethylene pipe similar to gas pipe. It would be installed above the pipeline while the ditch is backfilled, with no extra excavation or site preparation required.

\section{Encumbrances}

Several timber companies have access road rights-of-way across BLM lands. These are for gaining access to timber tracts adjacent to or near the BLM tract.

The Coos Curry Electric Cooperative also has a power line right-of-way in T27S, R12W, Sec. 5.

The County is seeking permission from private land owners in the proposed action corridor to install the proposed natural gas pipeline within the already-established utility corridor crossing their land. Each land parcel requires a separate easement from the underlying owner. Most land under the utility corridors is owned by individuals, forest companies and BLM. The BPA also owns a few short segments. 


\section{Chapter 4 Environmental Consequences}




\section{Chapter 4 Environmental Consequences}

\section{Introduction}

This chapter describes aspects of the environment likely to be directly affected by the proposed action. Also described are anticipated direct and indirect effects from the proposed action under the alternatives, and the potential cumulative impacts, which form the scientific and analytical basis for the Comparison of Effects of the Alternatives.

Because the proposed action and alternatives analyzed are relatively precise in scope, the effects analysis also mirrors this precision, thus avoiding unfocused and speculative assessments. The impacts on Threatened and Endangered (T\&E) species are described and submitted for informal consultation with the USFWS.

\section{Key, Direct, Indirect and Cumulative Impacts}

Table 8: $\quad$ Definition of Key, Direct, Indirect and Cumulative Impacts

\section{Definition of Impacts Used in This Assessment}

Key Effects: Elements identified from project assessment and public comments/scoping that would likely impact the human or natural environment if the proposed action is implemented.

Direct Effects: Those foreseeable impacts that will directly result from implementation of the proposed action.

Indirect Effects: Those foreseeable impacts that are likely to indirectly occur as a result of proposed action implementation.

Cumulative Effects: Those additive impacts from the incremental effects of a proposed action when placed in context with other past, present and reasonable foreseeable future actions (CEQ regulation, 40 CFR 1508.7).

The analysis for this EIS assesses all direct, indirect and cumulative impacts for all affected lands within the scope of the proposed action, regardless of ownership. For virtually all of the terrestrial species addressed here, the interactions between the indirect effects (noise disturbance) on federally managed lands and non-federal lands where construction-induced ground disturbance occurs, are expected to be very limited, because few species' breeding and sheltering habitats occur in roads and powerline corridors. However, the aquatic ecosystem does contain some interactions between the direct effects (sediment and turbidity), ground-disturbing activities and potential impacts between federal and non-federal lands. The Aquatic Ecosystem Assessment (Appendix E) addresses these potential impacts in detail.

Categories of Key Effects: (1) Impacts on aquatic and riparian habitats and water quality; (2) Impacts on air pollution and soil productivity; (3) Impacts on terrestrial species and habitats, which includes Port-Orford Cedar, Noxious Weeds, Special-Status Species, Survey \& Manage Species, T\&E Species, as well as related CHUs; (4) Cultural resource-site protection (including Native American Religious Concerns); and (5) Economic impacts. 


\section{Proposed Action Effects Summation}

The EPA recently published a final regulation for the Total Maximum Daily Load (TMDL) program under Section 303(d) of the Clean Water Act. There are water bodies within the NFP area that have been identified as not meeting applicable water quality standards. The federal land-managing agencies have developed an Aquatic Conservation Strategy (ACS) protocol to bring the water bodies into compliance with applicable standards. Watershed analysis recommendations, if followed, can maintain or improve protection of aquatic and riparian habitats in the short-term, while promoting long-term recovery goals. The proposed actions of the preferred alternative are consistent with watershed analysis recommendations (See Appendix E).

The individual species direct, indirect and cumulative effects analyses for birds, mammals, reptiles, amphibians, fish and vegetation (including bryophytes, fungi and lichens) addresses potential adverse impacts associated with the proposed action on both federal and non-federal lands. Because the proposed actions are limited to pre-disturbed nonhabitat areas (roadways and powerlines) and use Best Management Practices (BMPs) and Project Design Criterias (PDCs) throughout the proposed action for all affected watersheds (i.e., span six 5th fields), the direct, indirect and cumulative impacts are so small as to be negligible at the 5th field Hydrologic Unit Code (HUC). These six affected watersheds are listed and analyzed in Appendix E and the Erosion Control Plan (ECP) is in Appendix H. However, at smaller scales of assessment (7th field HUC, for example), short-term sedimentation, turbidity and wildlife disturbance from construction activities may impact individuals if they are present at the construction site during the period of activity. The proposed action would provide both short and long-term beneficial impacts to the affected watersheds as well. Approximately 15 miles of gravel road would be paved, promoting long-term restoration to the sediment and turbidity baselines in 4 watersheds (Appendix E). Three culverts presently blocking fish passage in the East Fork Coquille Watershed would be replaced, providing upstream and downstream passage to anadromous fish and other aquatic wildlife, promoting immediate restoration benefits to the physical barrier baseline in the watershed.

Air quality may suffer some short-term direct localized ( 7 th field) impacts wherever pipeline construction has heavy equipment operating. The Roseburg RMP/EIS (USDI 1995a) found that effects of dust from road use by heavy equipment were both localized and transitory. The long-term direct and cumulative effect of the proposed action is a reduction in sulfurous emissions from fossil and wood fuels utilized by industries and private residences within Coos County as users switch to natural gas from alternate fuels.

Negligible impacts to soil productivity from ground disturbance are anticipated at the watershed (5th field) scale. Most of the construction (approximately 65\%) would likely occur within road fill on the CBW Road or other roads. The rest of the ground disturbance would be limited to powerline utility corridors, where normal maintenance regularly removes (disturbs) vegetation with mechanical and chemical applications. In the pipeline trench areas where soil is removed and backfilled after pipe placement, soil productivity in the utility corridors will likely be reduced permanently from compaction. In roadways, soil productivity should remain unchanged.

Cultural resource sites (including Native American Religious Concerns) have been surveyed for and identified. In construction areas where the potential for these sites exists, a certified archaeologist and tribal member will both be onsite to monitor this resource. No impacts are anticipated, because all cultural resources and Native American resource sites will be identified and avoided (See Appendix B).

The short-term and long-term direct, indirect and cumulative economic benefits of the proposed action are the primary reasons Coos County seeks to construct a natural gas pipeline.

\section{For the details of these assessments, refer to the specific effects analysis sections later in this chapter.}

\section{Northwest Forest Plan (NFP) Implementation}

Late-Successional Reserve Assessments are required before implementing actions in LSRs. Late-Successional Reserve Assessments have been developed for the BLM-Coos Bay District's LSR \#261 containing CHU OR60 (northern spotted owl), and CHUs OR06-B and OR-06-D (marbled murrelet). Because of implemented PDCs, impacts to these listed species and their designated habitats are avoided. None of the proposed actions will affect or degrade any late-successional habitats in these CHUs/LSRs, nor will they slow habitat development in these CHUs/ LSRs.

Watershed analysis is required in Key Watersheds and Riparian Reserves prior to determining how proposed management actions meet the ACS for maintaining or promoting long-term recovery. Watershed analysis was conducted within the scope of the proposed action area. All proposed management actions in the proposed action meet the ACS (Appendix E), and would not retard attainment of ACS objectives. 


\section{Environment}

\section{Air Quality}

Environmental Consequences and Comparison of Alternatives

\section{Direct Effects}

\section{No Action Alternative:}

This alternative avoids any negative short-term impacts to soil productivity and air quality.

\section{Action Alternatives:}

Under the action alternatives, the short-term air quality impacts would be transitory and localized (7th field HUC) during active construction when heavy equipment is operating. The increase in vehicle traffic from construction will have emission increases that are negligible at the watershed (5th field) scale.

\section{Indirect Effects}

\section{No Action Alternative}

Long-term negative impacts to air quality could be considerable, as the conversion to a much cleaner fuel (natural gas) would not occur and sulfur emissions could continue to increase. Soil productivity will have no impacts.

\section{Action Alternatives}

In the long-term, beneficial and measurable reductions in sulfur emissions may occur as conversion to natural gas from other more polluting fossil and wood fuels for industrial and residential use increases in those communities.

\section{Cumulative Effects}

All Alternatives: No foreseeable incremental effects. 


\section{Natural Resources}

\section{Cultural Resources (Including Native American Religious Concerns)}

\section{Background}

See Appendix B for background information regarding this resource.

Environmental Consequences and Comparison of Alternatives

\section{Direct, Indirect and Cumulative Effects}

\section{No Action Alternative}

No impacts.

\section{Proposed Action}

- Direct Impacts: Onsite monitoring by qualified archacologists and designated tribal members will be present to monitor during construction, areas that historical records and field tests have identified as having potential cultural resources (see maps in Appendix B). All identified resource areas would be avoided (go around or directionally-drill underneath the area) by construction activities for the proposed action. Therefore, there are no anticipated potential direct impacts from pipeline construction. After construction, paving of approximately 15 miles of gravel road on the CBW Road would likely occur. If this is the case, a formal Determination of Eligibility document will be prepared for the CBW Road and submitted to the State Historic Preservation Office for evaluation prior to paving. If the CBW Road is determined to be eligible for the National Register for Historic Places, then a Determination of Effect would be prepared for the proposed alterations (paving) to the gravel portions of the CBW Road.

- Indirect Impacts: None

- Cumulative Impacts: None

\section{Hwy 42 Alternative}

- Direct Impacts: No anticipated impacts, as all construction would occur on paved roads.

- Indirect Impacts: None

- Cumulative Impacts: None

\section{Soils}

\section{Background}

Refer to Appendix A for background information on soils.

Environmental Consequences and Comparison of Alternatives

\section{Direct, Indirect and Cumulative Effects}

\section{No Action Alternative}

No impacts.

\section{Proposed Action}

- Direct Impacts: The proposed action alternatives require placement of a pipeline in predisturbed road grades and/or utility corridors. Any potential short-term risk of soil loss has been minimized or eliminated by the Ero- 
sion Control Plan (Appendix H) and the PDCs for culvert placement to be so small, as to be unmeasurable (i.e., negligible) at the watershed level of assessment (5th field HUC). In areas where ground-disturbing activities occurs outside of roadways, the proposed action may negatively impact soil productivity due to compaction and backfilling with soils containing less organics than the material removed for pipe placement. The total acres of potentially reduced soil productivity under the proposed action is approximately 56 acres (Table 9).

Table 9: Acreage of soil area impacted by watershed in the proposed action.

\begin{tabular}{|c|c|c|}
\hline Watershed & Total Acres Impacted & Percent of Total Impact \\
\hline Lower South Umpqua & 5.6 & 10 \\
\hline Ollala-Lookingglass & 25.3 & 45 \\
\hline East Fork Coquille & 5.5 & 10 \\
\hline Lower Coos-Coos Bay & 6.6 & 23 \\
\hline North Fork Coquille River & 13.0 & 0 \\
\hline Middle Main Fork Coquille & 0.0 & $\mathbf{1 0 0}$ \\
\hline \hline Totals & $\mathbf{5 6 . 0}$ & 23 \\
\hline
\end{tabular}

The proposed action's watersheds listed in Appendix E are approximately 55,000 to over 100,000 acres in size. The few acres of potentially reduced soil productivity in each basin is so small that it would be unmeasurable (i.e., negligible). The Middle Main Fork Coquille Watershed has no construction area outside of roadways, therefore, there is no anticipated impact to its watershed soil productivity.

- Indirect Impacts: Potential changes in soil bulk density and drainage on the approximately 56 acres of impacted construction area.

- Cumulative Impacts: None

\section{Hwy 42 Alternative}

- Direct Impacts: No anticipated impacts, as all construction would occur on paved roads.

- Indirect Impacts: None

- Cumulative Impacts: None

\section{Vegetation}

\section{Background}

One of the goals of the management guidelines in the Roseburg RMP (USDI 1995a), Integrated Weed Control EA (USDI 1995b) and Coos Bay BLM RMP (USDI 1994) concerning noxious weeds, was to prevent the spread or infestation on BLM-managed lands. In the Port-Orford cedar (POC) Management Guidelines (USDI 1994), a primary management objective is to limit the spread of the root pathogen Phytophthora lateralis, which causes rapid mortality to POC.

Because the proposed action requires ground-disturbance in pre-disturbed utility corridors, some preventative PDCs will be implemented to avoid further spread of noxious weeds and Phytophthora lateralis within the powerline ROWs. 


\section{Vegetation, Including T\&E, Survey and Manage, Special-Status and Noxious Weeds}

The proposed action corridor was surveyed in autumn of 2000 and spring/summer of 2001 for T\&E, Special-Status, Survey and Manage and Noxious Weeds species. There is considerable man-made disturbance already occurring within it. The CBW Road sits on an average of 5 feet of fill dirt. In the powerline right-of-way, sub-climax vegetation predominates. All trees have been removed except in one draw on private property, where they will not interfere with powerlines. The powerline is serviced by access roads which are maintained by periodic bulldozing. In addition, there are dirt roads leading to the electrical towers leaving areas of exposed soil. Invasive weeds (including noxious weeds) are prevalent throughout this utility corridor. Because of the continuous intensive vegetation removal required by the County, BPA/PP\&L management plans, little change in the sub-climax/disturbed vegetal regime is anticipated. Botanical field surveys found no presence of Threatened \& Endangered, Special-Status or Survey and Manage habitats or species (including bryophytes, lichens and fungi) in the pipeline construction corridor. Some noxious weeds, however, were found:

Table 10: Noxious Weeds in Utility Corridor

\begin{tabular}{|c|c|}
\hline Common & Scientific \\
\hline \hline Himalayan Blackberry & Rubis discolor \\
\hline Gorse & Ulex europaeus \\
\hline Pennyroyal & Mentha pulegium \\
\hline Scotch Broom & Cytisus scoparius \\
\hline Tansey Ragwort & Senecio jacobaea \\
\hline Canada Thistle & Circium arvense \\
\hline St. Johns Wort & Hypericum perforatum \\
\hline Bull Thistle & Cirsium vulgare \\
\hline
\end{tabular}

Himalayan blackberry, Scotch Broom, St. Johns Wort and Bull thistle occur throughout the utility corridor, varying in abundance from dense to scattered. Gorse was found on private land adjacent to BLM (T28S, R11W Sect. 10, NW 1/ 4 NE 1/4). Tansy ragwort and Canada thistle occur in an adjacent riparian area on Reston Ridge, and Pennyroyal is common in adjacent moist meadows, especially where ponding occurs in the spring and winter, giving it a competitive edge over less water tolerant plants.

The nearest plant of concern was the Western Lily (Lilium occidentale) located along the coastal strand which extends 4 miles inland near Bandon. Site surveys made for Oregon Natural Heritage tracking species in the vicinity of the proposed action corridor, listed only Cusick's Checker Mallow (Sidalcea cusickii), which was found in the Umpqua and Coquille Valleys in moist habitat. 


\section{Noxious Weeds/Port-Orford Cedar Project Design Criteria}

Implementation of the PDCs listed below (before entering and after exiting BLM-managed powerline utility corridors), avoids potential impacts from the spread of noxious weeds and the root pathogen Phytophthora lateralis.

- Conduct pre-project surveys, risk assessment and weed treatment(s) prior to ground disturbing activities. This has been completed.

- Minimize the removal of vegetation during construction, reconstruction and maintenance wherever possible.

- Re-establish vegetation on all disturbed ground to minimize potential noxious weed spread. Seed all disturbed soil resulting from pipe construction within 7 days of the final disturbance. Use native plant seeds and/or approved BLM seed list for re-vegetation.

- Post project monitoring of ground-disturbed construction areas to determine the efficacy of minimization PDCs. Treat any noxious weeds to prevent new infestations from becoming established in the ground-disturbed areas.

- High-pressure water cleaning at a designated cleaning station, to remove all clumps of soil and organic material from construction equipment and vehicles.

- The designated cleaning station must be off-site and away from the construction corridor.

Table 11: $\quad$ PDC - Cleaning List

\begin{tabular}{|c|c|}
\hline RUBBER-TIRED VEHICLES & TRACK-LAYING VEHICLES \\
\hline \hline TIRES & TRACKS \\
WHEEL RIMS & ROAD WHEELS \\
AXLES & DENDERS \\
& TRALLER FRAME \\
& TRALES \& IDLERS \\
\hline EQUIPMENT AS APPROPRIATE \\
FRAME Or UNDERCARRIAGE \\
DOZER BLADE/BUCKET/ARMS \\
BELLY PANS \\
RIPPER \\
STABILIZERS \\
BRUSH RAKES \\
GRAPPLE AND ARMS \\
WINCH AND SHEAR HEADS \\
\hline
\end{tabular}


Environmental Consequences and Comparison of Alternatives

\section{No Action Alternative}

- Direct Impacts: This alternative would have no direct impacts on the plant community in the proposed action area. No ground disturbance would occur under this alternative.

- Indirect Impacts: This alternative would have no indirect effects on the plant community in the proposed action area. No ground disturbance would occur under this alternative.

- Cumulative Impacts: This alternative would have no cumulative effects on the plant community in the proposed action area. No ground disturbance would occur under this alternative.

\section{Proposed Action}

- Direct Impacts: Because field surveys found no T\&E, Special Status or Survey and Manage species (including bryophytes, lichens and fungi) or habitats in the proposed action area, the project would have no direct impact to these species.

- Bare soil would be temporarily exposed to possible invasion of noxious weeds. After ground disturbing activities, the bare soil areas on BLM property will be seeded and mulched with approved BLM-seed mixtures to enhance propagation of desirable plant species and minimize potential for weed encroachment. Private land areas would receive the same post-construction treatment, except that a state-approved seed mix for the Oregon Coast Range (See Table H. 2. in Appendix H) will be used on those ownerships. The noxious weed/PortOrford Cedar PDCs for the construction areas in the utility corridor are specifically designed to eliminate/minimize the spread of undesirable plant species' propagates. However, these invasive species may still spread in some areas due to the ground-disturbing activities. Prior to ground-disturbing activities, construction areas with noxious weeds that have not been sprayed as part of the County's CBW Road or BPA/PP\&L corridor maintenance plans, will be treated mechanically. Post-construction treatment (mechanical or herbicides) of disturbed areas for noxious weeds will occur the following year in areas where noxious weeds have invaded disturbed ground from pipeline construction.

- Because of the treatments for noxious weeds and the ongoing disturbance in the CBW Road and utility corridors, no measurable direct impacts from noxious weeds is anticipated from the proposed action

- Temporary removal of grasses, weeds and small shrubs would occur in the proposed action from ground-disturbing activities. Until the vegetation regrows, the seeded plants will temporarily replace the sub-climax grasses, weeds and small shrubs now present in the 56 acres to be disturbed within the utility corridors.

- Indirect Impacts: Indirect effects would include the potential for long-term increased spread of noxious weeds in the project area which may displace native plant species habitats. There would be no indirect effects for T\&E, Special-Status or Survey and Manage species (including bryophytes, lichens and fungi), since none exist in the proposed action area.

- Cumulative Impacts: The cumulative effects would include the potential increase of noxious weeds in the powerline utility corridor area. There would be a temporary reduction in the amount of vegetation which protects the soil in the existing powerline right-of-way, thus increasing the risk of weed invasion. There would be no cumulative impacts for T\&E, Special-Status or Survey and Manage species (including bryophytes, lichens and fungi), since none exist within the proposed action area.

\section{Hwy 42 Alternative}

- Direct Impacts: This alternative would have no anticipated direct impact on the plant communities in the proposed action area, as ground disturbance would be limited to roadways.

- Indirect Impacts: This alternative would have no indirect effect on the plant communities in the proposed action area, as no ground disturbance outside of roadways were anticipated.

- Cumulative Impacts: This alternative would have no cumulative effect on the plant community in the proposed action area. 


\section{Floodplains}

\section{Direct, Indirect and Cumulative Effects}

\section{No Action Alternative}

No impact.

\section{Action Alternatives}

Both corridors are adjacent to 100-year floodplains. Each corridor's adjacent area (2.2 miles for proposed action and 15.3 miles for Hwy 42 alternative) to the floodplain are on roadways that sit well above the floodplain on 5 - 10 feet of road fill. No anticipated impacts.

\section{Wild and Scenic Rivers}

\section{All Alternatives}

No Wild and Scenic Rivers exist in any alternative. No effect.

\section{Wildlife}

\section{Federally Listed, Proposed or Candidate Species}

This section discusses the potential effects to species listed as threatened or endangered, or proposed for listing, under the Endangered Species Act of 1973, as amended. It only discusses in detail those listed terrestrial species that have the potential to be affected by the proposed actions. Other listed, candidate and proposed species will not be affected by the proposed actions. The BLM request for a USFWS Letter of Concurrence is being developed.

\section{Northern Spotted Owl}

\section{Background}

The management and recovery of northern spotted owls was an important consideration and received extensive attention to the Northwest Forest Plan Final Supplemental Environmental Impact Statement (FSEIS) (USDA, USDI 1994a, pp. 3\&4; 211 through 245 and Appendices G, J1, J3). Late-Successional Reserve Assessments have been developed for the BLM-Coos Bay District's LSR \#261 containing CHU OR60 (northern spotted owl), and CHUs OR06-B and OR-06-D (marbled murrelet). Because of implemented PDCs, impacts to these designated species and habitats are avoided. None of the proposed actions will affect or degrade any late-successional habitats in these CHUs/LSRs, nor will they slow habitat development in these CHUs/LSRs.

Detailed accounts of the taxonomy, ecology and reproductive characteristics of the spotted owl are found in the Status Reviews produced by the USFWS (USDI 1987, 1990a); the 1989 Status Review Supplement (USDI 1989); the Interagency Scientific Report (Thomas et al. 1990); and the final rule designating the spotted owl as a threatened species (USDI 1990b). There are approximately 5,608 pairs of northern spotted owls and resident singles (activity centers) and approximately 8.1 million acres of suitable habitat currently estimated across the range of the species (Holzman, USFWS, pers. com. 1995). Recent demographic studies (Burnham et al. 1994) indicate that the population is declining. While such a decline is expected to continue as spotted owl sites with severely degraded habitat conditions become inactive, implementation of the NFP is expected to abate the decline by protecting all spotted owl sites within LSRs. The NFP will provide for the conservation of the species by allowing non-suitable, but capable habitat to regenerate within the LSRs to allow the population to increase and stabilize across its range. Preliminary results from a more recent (Dec 1998) meta-analysis of available demographic data for the period 1985-1998, though, found no evidence of a decline in reproduction or in the overall annual survival probability during the period of study (Forsman and Anthony 1999). 
The 1990 Spotted Owl Status Review Committee stated that population size is primarily a function of the amount and distribution of available habitat (USDI 1990a). In developing a conservation strategy for late-successional and oldgrowth forest-associated species, the Departments of Interior and Agriculture developed a network of late-successional and old-growth habitat reserves across the Pacific Northwest. This network of Late-Successional Reserves is designed to conserve forest species closely associated with late-successional and old-growth forest habitat where habitat conditions are relatively intact and also provide for the regeneration of late-successional forest habitat where habitat is extremely limited and the reliant plant and wildlife populations are low.

On the Coos Bay District BLM, the early nesting season is considered March 1 through June 30 . The intent in selecting 30 June is to insure that nearly all young northern spotted owls will have left the nest tree and be somewhat mobile by this date. We reviewed over 700 nesting status records for 1990-1994 on the District; 0.1 percent of the records indicated young owls were still in the nest tree by June 30 suggesting that this date is reasonable.

\section{Environmental Consequences and Comparison of Alternatives}

\section{Direct and Cumulative Effects}

\section{No Action Alternative}

No anticipated impacts.

\section{Action Alternatives}

Both action alternatives contain no direct or cumulative impacts on the northern spotted owl, because neither remove or degrade any suitable habitat for this species.

\section{Indirect Effects}

\section{No Action Alternative}

No anticipated impacts.

\section{Action Alternatives}

The potential indirect impacts due to disturbance from equipment noise are avoided in the PDCs (listed below), which provide both seasonal and daily timing restrictions that would eliminate most, if not all, potential short-term (1-7 days) adverse indirect effects.

\section{Habitat or Individuals}

(I) No habitat would be removed from proposed actions.

\section{Disturbance}

(I) Work activities such as trenching, pipe-laying and re-paving, would not take place within 0.25 -mile of any nest site or activity center of known pairs and resident singles between March 1st and June 30th.

(II) This PDC may be waived in a particular year by the USFWS, if nesting or reproductive success surveys conducted according to the USFWS-endorsed survey guidelines reveal that northern spotted owls are non-nesting or that no young-of-the-year are present. Waivers are only valid until March 1st of the following year. Previously known sites and activity centers are assumed occupied unless surveys indicate otherwise.

(III) No helicopter activities will occur.

(IV) Blasting would not occur within 1 mile of suitable habitat March 1st to June 30th.

(V) Blasting would not occur within 1 mile of known nest sites March 1st to September 30th. 


\title{
$\underline{\text { Marbled Murrelet }}$
}

\section{Background}

The management and recovery of marbled murrelets was an important consideration and received extensive attention to the Northwest Forest Plan Final SEIS (USDA, USDI 1994a, pp. 3\&4; 245 through 249 and Appendices G and J2). Late-Successional Reserve Assessments have been developed for the BLM-Coos Bay District's LSR \#261 containing CHU OR60 (northern spotted owl), and CHUs OR06-B and OR-06-D (marbled murrelet). Because of implemented PDCs, direct and cumulative impacts to these designated species and habitats are avoided. None of the proposed actions will affect or degrade any late-successional habitats in these CHUs/LSRs, nor will they slow habitat development in these CHUs/LSRs.

An account of the taxonomy, ecology and reproductive characteristics of the marbled murrelet is found in Marshall 1988, USDI 1992b, USDI 1996, USDI 1994, USDA USDI 1994b and USDI 1997. The U.S. Forest Service has published the Ecology and Conservation of the Marbled Murrelet, an up-to-date and comprehensive summary of the status of the species, which was peer reviewed by representatives of numerous wildlife and ecological societies (Ralph et al. 1995). This document makes several key points regarding the status of the marbled murrelet. Population trends are clearly downward. Ralph et al. (1995) and USDI (1997) suggested possible reasons for the decline include the species' dependence on older forests for nesting (forests which are now scarce and highly fragmented); its low reproductive rate; and adult mortality due to predation, capture in gill nets and encounters with oil spills. The amount and distribution of the remaining suitable habitat is considered to be the most important determinant of the long-term population trend and further loss may severely hamper the stabilization and recovery of the species.

Most population estimates for marbled murrelets have been conducted using at-sea surveys and are subject to many sources of error, such as the methods of counting flying birds, environmental conditions and observer ability (Ralph et al. 1995). These sources of error may also change with the season and location of the surveys.

Population estimates for the marbled murrelet in Oregon vary substantially. For example, Varoujean and Williams (1995) used aerial surveys conducted along the entire Oregon Coast in August and September 1993 to estimate that 6,600 marbled murrelets occur in Oregon. In a different study, Strong et al. (1995) used boat surveys to estimate that 15-20,000 marbled murrelets occur in Oregon; they caution that large numbers of non-breeding adults and low numbers of fledglings on the water may be due to a lack of suitable nesting habitat.

Population estimates for Washington and California are less variable. Spiech and Wahl (1995) concluded that marbled murrelet populations in Puget Sound are lower now than they were at the beginning of this century, and total estimates for Washington are about 5,500 marbled murrelets (Ralph et al. 1995). Ralph and Miller (1995) estimated the California population to be approximately 6,500 birds.

Beissinger (1995) constructed a demographic model of the marbled murrelet and concluded that the population may be declining at rates of 4-6 percent per year; but this estimate is limited by the possibility that the age-ratio data used in the model are reflective of a relatively temporary decline due to unusual ocean conditions (Ralph et al. 1995). Ralph et al. (1995) summarized some of the reasons for population estimate variability among researchers, including differences in methodology, assumptions, spatial coverage and survey and model errors. Nevertheless, both Ralph et al. (1995) and USDI (1997) have concluded that the listed population appears to be in a long-term downward trend.

There are approximately 979 known marbled murrelet occupied sites within Washington, Oregon, and California (Holzman, USFWS, pers. com. 1995). Total number of suitable habitat acres in these three states is unknown. Ralph et al. (1995) estimated there are 2,561,500 acres of suitable habitat for the marbled murrelet on Federal lands in the listed range of this species.

\section{Environmental Consequences and Comparison of Alternatives}

\author{
Direct and Cumulative Effects
}

\section{No Action Alternative}

No anticipated impacts. 


\section{Action Alternatives}

Both action alternatives contain no direct or cumulative impacts on the marbled murrelet, because neither remove or degrade any suitable habitat for this species.

\section{Indirect Effects}

\section{No Action Alternative}

No anticipated impacts.

\section{Action Alternatives}

The potential indirect impacts due to disturbance from equipment noise are addressed in the PDCs (listed below), which provide both seasonal and daily timing restrictions that would eliminate most, if not all, potential short-term (1-7 days) adverse indirect effects.

\section{Disturbance}

(I) Daily timing of the project's "Moderately above ambient noise levels for less than 1 week" and related activities occurring within 0.25 -mile of unsurveyed suitable habitat, shall be no earlier than 2 hours after sunrise and no later than 2 hours before sunset from April 1st to September 15th.

(II) Daily timing of the project's "Moderately above ambient noise levels for less than 1 week" and related activities occurring within 0.25-mile of occupied habitat, shall be seasonally restricted from April 1 st to August 5th.

(III) Daily timing of the project's "Moderately above ambient noise levels for less than 1 week" and related activities occurring within 0.25 -mile of occupied habitat, shall be no earlier than 2 hours after sunrise and no later than 2 hours before sunset from August 6th to September 15th.

(IV) No blasting will occur within 1 mile of occupied or unsurveyed suitable habitat April 1st to September 15th.

(V) No helicopter activities will occur.

\section{Bald Eagle}

\section{Background}

Breeding and wintering populations of the bald eagle occur throughout Southwest Oregon. Recovery efforts for bald eagles have allowed populations to increase to the extent that the species is now proposed for delisting in the lower 48 states (USFWS 1999).

Recovery efforts for bald eagles have allowed populations to increase to the extent that the species is now proposed for delisting in the lower 48 states (USFWS 1999). The population in Oregon is listed as threatened. Its present status is a result of past and present destruction of habitat, a declining food base, environmental contaminants, disturbance, electrocution and illegal harassment including, but not limited to shooting and poisoning. Currently the primary threats to bald eagles are habitat degradation and, in some areas, environmental contaminants.

In the Pacific Northwest, bald eagles typically nest in multi-layered, coniferous stands with old-growth trees located within a mile of large bodies of water (USDI 1986). Availability of suitable trees for nesting and perching is critical for maintaining bald eagle populations. The Pacific Northwest is a key area for wintering bald eagles and supports over 25 percent of the wintering bald eagles in the lower 48 states (USDI 1986). Wintering sites are typically in the vicinity of concentrated food sources such as anadromous fish runs and high concentrations of waterfowl or mammalian carrion.

A number of habitat features are desirable. Eagles need perch trees for hunting and resting. These trees typically provide an unobstructed view of the surrounding area and are usually near nests or feeding areas such as large rivers. 
Environmental Consequences and Comparison of Alternatives

\section{Direct and Cumulative Effects}

\section{No Action Alternative}

No anticipated impacts.

\section{Action Alternatives}

Both action alternatives would have no direct or cumulative effect on bald eagles or bald eagle habitat management. No suitable habitat would be removed.

\section{Indirect Effects}

\section{No Action Alternative}

No anticipated impacts.

\section{Proposed Action}

No anticipated impacts, as no known active bald eagle sites are within 2 miles of the proposed action corridor.

\section{Hwy 42 Alternative}

The potential indirect impacts due to disturbance of resident bald eagle nests along these corridors from equipment noise are addressed in the PDCs (listed below), which provide both seasonal and daily timing restrictions that would eliminate most, if not all, potential adverse effects.

\section{Disturbance}

(I) Work activities that cause disturbance would not take place within 1312 feet of active nests and roosts, or within 2625 feet line-of-sight from nests and roosts during periods of eagle use unless field surveys demonstrate that the nest or roosts are not being used during the normal season of use. For nests, the period of eagle use is January 1 st to August 31 st (or two weeks post-fledging). For roosts, the period of eagle use is November 15 th to March 15th.

(II) No helicopter activities will occur.

\section{BLM Special-Status Species}

\section{Background}

According to the definition in the BLM 6840 policy, a special-status designation includes species that could easily become endangered or extinct in state. They are either restricted in range or have natural or human-caused threats to survival. Special-status species are not listed, proposed or candidate species, but are eligible for federal or state listing or candidate status. BLM special-status species are designated by the BLM State Director. BLM 6840 policy requires that any BLM action will not contribute to the need to list any of these species. (A list of these species is found in Appendix K1.) Noise disturbance is assessed out to 0.25 -mile from all construction-related activities. 
Environmental Consequences and Comparison of Alternatives

\section{Direct and Cumulative Effects}

\section{No Action Alternative}

No anticipated impacts.

\section{Action Alternatives}

Both action alternatives would have no direct or cumulative effect on Special-Status Species. No individuals or suitable habitat would be removed due to the proposed or Hwy 42 alternative actions.

\section{Indirect Effects}

\section{No Action Alternative}

No anticipated impacts.

\section{Action Alternatives}

Vertebrates spending part of their life-history cycle adjacent to the proposed action corridor during active construction may be disturbed by short-term (1-7 days) ambient noise from heavy equipment used to lay pipe. There are no management requirements or PDCs for any special-status species. Although no documented locations of special-status vertebrates are known adjacent to the pipeline corridor, some minor disturbance potential is assumed, because adjacent suitable habitat has not been surveyed for special-status species.

Some special-status bats and birds that use the utility corridors for diurnal and nocturnal foraging, may be disturbed away from those areas where construction is active, to alternate foraging areas further from construction noise. The number of special-status species individuals utilizing the powerline corridor for foraging has not been documented and is unknown. Because construction is short-term (1-7 days) with moderate noise above ambient background levels, any indirect impacts to special-status species from indirect noise effects would be negligible.

\section{Survey and Manage Species}

Survey and Manage species represent flora and fauna in the NFP area that are believed to be locally rare, with a limited habitat range requiring late-successional forests; some are endemic to western forests in southwestern Oregon. See Appendix K for list of these species. Noise disturbance is assessed out to 0.25 -mile from all construction-related activities.

\section{Environmental Consequences and Comparison of Alternatives}

\section{No Action Alternative}

No anticipated Direct, Indirect or Cumulative Impacts.

\section{Action Alternatives}

- Direct Impacts: The proposed action would have no direct effects on Survey and Manage Species habitats or individuals.

-Indirect Impacts: Except for the possibility of noise disturbance affecting individual red tree voles in adjacent suitable habitat areas, the proposed action would have no other anticipated indirect impacts on Survey and Manage Species in the proposed action areas, as no ground-disturbing activities occur within their habitats. The number of red tree vole individuals utilizing habitat adjacent to the pipeline corridor for breeding, feeding and sheltering has not been documented and is unknown. Because construction is short-term (1-7) with moderate noise above ambient background levels during the daytime only, any indirect impacts to nocturnal red tree 
voles from indirect noise effects would be negligible.

- Cumulative Impacts: None

\section{Other Wildlife}

Note: Noise disturbance is assessed out to 0.25 -mile from all construction-related activities.

Environmental Consequences and Comparison of Alternatives

\section{No Action Alternative}

No anticipated Direct, Indirect or Cumulative Impacts.

\section{Proposed Action}

- Direct Impacts: Birds that utilize small shrubs as part of their life-history cycle may temporarily lose some potential shrub habitat in the utility corridor in areas of ground disturbance from construction. Approximately 0.2 -acre of conifer plantation trees on private land would be removed in the utility corridor (under the powerlines that span two hillsides). Although these trees are immature ( 25 years old) and densely packed ( 300 trees per acre), they do offer perches for flycatchers and other avian insect foragers that may use the powerline/utility corridor for feeding. Habitat loss from tree and shrub removal would be long-term impacts.

- Indirect Impacts: Short-term (1-7 days) noise disturbance from heavy equipment in the proposed action corridor during the active construction period may briefly impact individual diurnal mammals, herptofauna and birds that utilize powerline corridors or adjacent habitats for travel or foraging. Nocturnal use of the powerline ROWs (by owls, bats, etc.) would remain relatively unchanged and undisturbed, as no nighttime construction activity is anticipated.

- Cumulative Impacts: None

\section{Hwy 42 Alternative}

- Direct Impacts: None are anticipated, as no individuals or habitat would be removed.

- Indirect Impacts: Noise disturbance from heavy equipment in the Hwy 42 corridor during the active construction period may briefly impact individual mammals, herptofauna and birds that utilize habitats adjacent to the highway. However, construction noise should not be measurably greater (i.e., negligible) than normal levels caused by highway traffic and should not add any measurable impacts.

- Cumulative Impacts: None

\section{Aquatic Ecosystem}

\section{Background}

The ACS is a habitat-based approach for restoration and maintenance of watersheds and the aquatic ecosystems contained within them on federally managed lands (USDA, USDI 1994a and USDA, USDI 1994b). When assessing discretionary federal actions (as in this document), analyses must include effects on the non-federal lands contained in the proposed actions. This is exactly what occurred. In fact, the emphasis of this document's assessment is on nonfederal lands in the proposed action, because BLM-managed lands represent only 3.5 percent of the proposed action corridor. The foundation principle for maintaining and restoring aquatic habitats within the NFP area was avoidance of species-specific strategies in the ACS objectives. The NFP Record of Decision emphasized this foundation strategy by stating:

\footnotetext{
"Any species-specific strategy aimed at defining explicit standards for habitat elements would be insufficient for protecting even the targeted species. The Aquatic Conservation Strategy must strive to maintain and restore ecosystem health at watershed and landscape scales to protect habitat for fish and other riparian-
} 
dependent species and resources and restore currently degraded habitats." (USDA, USDI 1994b, p. B-9)

The components of the proposed action aquatic management plan (watershed analysis and watershed protection/restoration), provide the fundamental building blocks for protecting aquatic and riparian-dependent flora and fauna. Coupled with watershed analysis (Appendix E), other elements of the aquatic management plan (Appendix $\mathrm{H}$ ) within the proposed action are designed to protect in the short-term and enhance in the long-term, water quality and aquatic/ riparian habitats for those aquatic/riparian-dependent species throughout all federal and non-federal landholdings within the scope of the proposed action. The Coos Bay and Roseburg Districts' Watershed Analyses (containing the Hwy 42 and the proposed action's affected areas) give watershed baseline conditions that are used to assess impacts of the proposed actions on the aquatic ecosystem. Impacts (Table 12) to all aquatic plant and animal species are viewed under the umbrella of these assessments.

\section{Table 12: $\quad$ Aquatic Impact Levels}

\section{Definition of Impacts (As Used in This Analysis)}

Adverse Impact: Mechanisms to streams exist adjacent to ground disturbance areas and cause long-term effects (greater than 30 days) from pipeline construction that measurably reduce baseline conditions.

Negligible Impact: Mechanisms to streams exist adjacent to ground disturbance areas and cause short-term effects (less than 30 days) from pipeline construction that cannot be measured from baseline conditions.

No Impact: Causes no change in baseline conditions from pipeline construction.

Beneficial Impact: Provides mechanisms to streams for improving baseline conditions from pipeline construction.

\section{Environmental Consequences and Comparison of Alternatives}

Following the ACS provides significant protection for aquatic and riparian-dependent flora and fauna, regardless of the alternative selected. All of the alternatives in this EIS are consistent with the ACS objectives (Appendix E), and the action alternatives contain specific measures to minimize risk to aquatic and riparian-dependent flora and fauna.

\section{No Action Alternative}

Under this alternative, there would be no impacts (including no potential beneficial impacts).

\section{Hwy 42 Alternative}

The Hwy 42 action alternative would contain the same protective measures for building a natural gas pipeline as the proposed action, which successfully minimizes potential adverse impacts to the aquatic ecosystem. The differences occur mainly in corridor length (the proposed action is the shortest) and in the number of streams/wetlands crossed (the proposed action has the least). (See Action Alternatives Route Summaries: Table 2, Chapter 2) Also, the Hwy 42 alternate route lacks the beneficial mitigation measures (adding cross-drains and paving) contained in the proposed action for enhancing the sedimentation and turbidity baseline habitat elements.

\section{HABITAT ELEMENT}

Sedimentation

Turbidity

Physical Barriers

NEGATIVE IMPACT
Negligible ( $<30$ days)
Negligible ( $<30$ days)
None

NEGATIVE IMPACT

None

\section{BENEFICIAL IMPACT}

None

None

Immediate

Improvement in the physical barrier baseline would be achieved by replacing at least 2 deteriorating culverts that presently block fish passage. 


\section{Proposed Action}

After assessing potential impacts in all six watershed analyses, the proposed action effects on baseline conditions of two habitat elements were identified for their potential short-term negative impacts to the aquatic ecosystem. These two elements are sedimentation and turbidity. (Appendix E contains the specific assessments by watershed for each habitat element identified in their pertinent watershed analysis area.) The protective measures (Appendix $\mathrm{H}$ ) contained in the proposed action's overall ECP, are specifically designed to avoid most adverse impacts to the two habitat elements (sedimentation and turbidity) identified as potentially impacted by pipeline construction. Furthermore, specific mitigation has been identified to restore the sedimentation, turbidity and physical barrier (fish passage) baselines. That is, the proposed action is designed to avoid adverse impacts to the aquatic ecosystem while providing substantive beneficial impacts.

\section{HABITAT ELEMENT}

Sedimentation

Turbidity

Physical Barriers

\author{
NEGATIVE IMPACT \\ Negligible (<30 days) \\ Negligible (<30 days) \\ None
}

\author{
BENEFICIAL IMPACT \\ Long-term ( $>30$ days) \\ Long-term (>30 days) \\ Immediate (2 un-named streams and \\ Knapper Creek)
}

Improvement in the sedimentation and turbidity baselines would be achieved through paving approximately 15 miles of the CBW Road that is presently a gravel-dirt surface. This paving would be spread across 4 watersheds: East Fork Coquille - 10.3 miles, Middle Main Coquille - 1.9 miles, North Fork Coquille - 1.0 mile and Lower Coos/Coos Bay 1.9 miles. Gravel-dirt roads have been identified as the major source of sediment and turbidity, and the paving of approximately 15 miles would provide long-term benefits to these watersheds.

Improvement in the physical barrier baseline would be achieved by replacing 3 deteriorating culverts that presently block anadromous fish passage within the East Fork Coquille Watershed. 


\section{Summary of the Lower South Umpqua Watershed Stream Crossings}

A total of 8 intermittent streams within the Lower South Umpqua Watershed would be affected by the proposed action (Table 13). All of the construction in this watershed would occur in the powerline utility corridor and when these intermittent streams are dry within the utility ROWs.

Table 13: $\quad$ Stream Description and Crossing Type on Utility Corridor within the Lower South Umpqua Watershed (5th field HUC)

\begin{tabular}{|c|c|c|c|c|c|c|}
\hline Slope & $\begin{array}{c}\text { Stream } \\
\text { Width } \\
\text { (feet) }\end{array}$ & $\begin{array}{c}\text { Dry } \\
\text { Streams }\end{array}$ & $\begin{array}{l}\text { Bag \& } \\
\text { Flume }\end{array}$ & $\begin{array}{c}\text { Directionally } \\
\text { Drilled }\end{array}$ & $\begin{array}{c}\text { Hang on } \\
\text { Bridge }\end{array}$ & $\begin{array}{l}\text { Above } \\
\text { Stream (in } \\
\text { road fill) }\end{array}$ \\
\hline \multirow{3}{*}{$\begin{array}{c}\text { Gentle } \\
\text { Perennial } \\
(<2 \% \text { rise })\end{array}$} & $0-15$ & 0 & 0 & 0 & 0 & 0 \\
\hline & $15-30$ & 0 & 0 & 0 & 0 & 0 \\
\hline & $>30$ & 0 & 0 & 0 & 0 & 0 \\
\hline \multirow{3}{*}{$\begin{array}{c}\text { Moderate } \\
\text { Perennial } \\
(2-4 \% \text { rise })\end{array}$} & $0-15$ & 0 & 0 & 0 & 0 & 0 \\
\hline & $15-30$ & 0 & 0 & 0 & 0 & 0 \\
\hline & $>30$ & 0 & 0 & 0 & 0 & 0 \\
\hline \multirow{3}{*}{$\begin{array}{c}\text { Steep } \\
\text { Perennial } \\
(>4 \% \text { rise })\end{array}$} & $0-15$ & 0 & 0 & 0 & 0 & 0 \\
\hline & $15-30$ & 0 & 0 & 0 & 0 & 0 \\
\hline & $>30$ & 0 & 0 & 0 & 0 & 0 \\
\hline \multirow{3}{*}{$\begin{array}{c}\text { Gentle } \\
\text { Intermittent } \\
(<2 \% \text { rise })\end{array}$} & $0-15$ & 0 & 0 & 0 & 0 & 0 \\
\hline & $15-30$ & 0 & 0 & 0 & 0 & 0 \\
\hline & $>30$ & 0 & 0 & 0 & 0 & 0 \\
\hline \multirow{3}{*}{$\begin{array}{c}\text { Moderate } \\
\text { Intermittent } \\
(2-4 \% \text { rise })\end{array}$} & $0-15$ & 1 & 0 & 0 & 0 & 0 \\
\hline & $15-30$ & 4 & 0 & 0 & 0 & 0 \\
\hline & $>30$ & 0 & 0 & 0 & 0 & 0 \\
\hline \multirow{3}{*}{$\begin{array}{c}\text { Steep } \\
\text { Intermittent } \\
(>4 \% \text { rise })\end{array}$} & $0-15$ & 1 & 0 & 0 & 0 & 0 \\
\hline & $15-30$ & 2 & 0 & 0 & 0 & 0 \\
\hline & $>30$ & 0 & 0 & 0 & 0 & 0 \\
\hline \multicolumn{2}{|l|}{ TOTAL } & 8 & 0 & 0 & 0 & 0 \\
\hline
\end{tabular}




\section{Summary of the Olalla Creek/Lookingglass Creek Watershed Road Corridor Stream Crossings}

A total of 10 streams within the Olalla Creek/Lookingglass Creek Watershed would be affected by the proposed action in the CBW Road. Eight crossings occur above the streams within the roadbed of existing public roads and two perennial streams would be crossed using the bag and flume method (Table 14).

Table 14: Stream Description and Crossing Type on Road Corridor within the Olalla Creek/ Lookingglass Creek Watershed (5th field HUC)

\begin{tabular}{|c|c|c|c|c|c|c|}
\hline Slope & $\begin{array}{l}\text { Stream } \\
\text { Width } \\
\text { (feet) }\end{array}$ & $\begin{array}{c}\text { Dry } \\
\text { Streams }\end{array}$ & $\begin{array}{l}\text { Bag \& } \\
\text { Flume }\end{array}$ & $\begin{array}{c}\text { Directionally } \\
\text { Drilled }\end{array}$ & $\begin{array}{c}\text { Hang on } \\
\text { Bridge }\end{array}$ & $\begin{array}{c}\text { Above } \\
\text { Stream (in } \\
\text { road fill) }\end{array}$ \\
\hline \multirow{3}{*}{$\begin{array}{c}\text { Gentle } \\
\text { Perennial } \\
(<2 \% \text { rise })\end{array}$} & $0-15$ & 0 & 1 & 0 & 0 & 1 \\
\hline & $15-30$ & 0 & 0 & 0 & 0 & 0 \\
\hline & $>30$ & 0 & 0 & 0 & 0 & 0 \\
\hline \multirow{3}{*}{$\begin{array}{c}\text { Moderate } \\
\text { Perennial } \\
(2-4 \% \text { rise })\end{array}$} & $0-15$ & 0 & 0 & 0 & 0 & 2 \\
\hline & $15-30$ & 0 & 0 & 0 & 0 & 0 \\
\hline & $>30$ & 0 & 0 & 0 & 0 & 0 \\
\hline \multirow{3}{*}{$\begin{array}{c}\text { Steep } \\
\text { Perennial } \\
(>4 \% \text { rise })\end{array}$} & $0-15$ & 0 & 1 & 0 & 0 & 1 \\
\hline & $15-30$ & 0 & 0 & 0 & 0 & 0 \\
\hline & $>30$ & 0 & 0 & 0 & 0 & 0 \\
\hline \multirow{3}{*}{$\begin{array}{c}\text { Gentle } \\
\text { Intermittent } \\
(<2 \% \text { rise })\end{array}$} & $0-15$ & 0 & 0 & 0 & 0 & 2 \\
\hline & $15-30$ & 0 & 0 & 0 & 0 & 0 \\
\hline & $>30$ & 0 & 0 & 0 & 0 & 0 \\
\hline \multirow{3}{*}{$\begin{array}{c}\text { Moderate } \\
\text { Intermittent } \\
(2-4 \% \text { rise })\end{array}$} & $0-15$ & 0 & 0 & 0 & 0 & 1 \\
\hline & $15-30$ & 0 & 0 & 0 & 0 & 0 \\
\hline & $>30$ & 0 & 0 & 0 & 0 & 0 \\
\hline \multirow{3}{*}{$\begin{array}{c}\text { Steep } \\
\text { Intermittent } \\
(>4 \% \text { rise })\end{array}$} & $0-15$ & 0 & 0 & 0 & 0 & 1 \\
\hline & $15-30$ & 0 & 0 & 0 & 0 & 0 \\
\hline & $>30$ & 0 & 0 & 0 & 0 & 0 \\
\hline TOTAL & & 0 & 2 & 0 & 0 & 8 \\
\hline
\end{tabular}




\section{Summary of the Olalla Creek/Lookingglass Creek Watershed Utility Corridor Stream Crossings}

A total of 38 streams within the Olalla Creek/Lookingglass Creek watershed would be crossed within existing utility corridors (Table 15). Thirty streams would crossed by the dry trench method and eight streams would be crossed by the bag and flume method.

Table 15: Stream Description and Crossing Type on Utility Corridor within the Olalla Creek/ Lookingglass Creek Watershed (5th field HUC)

\begin{tabular}{|c|c|c|c|c|c|c|}
\hline Slope & $\begin{array}{c}\text { Stream } \\
\text { Width } \\
\text { (feet) }\end{array}$ & $\begin{array}{c}\text { Dry } \\
\text { Streams }\end{array}$ & $\begin{array}{l}\text { Bag \& } \\
\text { Flume }\end{array}$ & $\begin{array}{c}\text { Directionally } \\
\text { Drilled }\end{array}$ & $\begin{array}{c}\text { Hang on } \\
\text { Bridge }\end{array}$ & $\begin{array}{l}\text { Above } \\
\text { Stream (in } \\
\text { road fill) }\end{array}$ \\
\hline \multirow{3}{*}{$\begin{array}{c}\text { Gentle } \\
\text { Perennial } \\
(<2 \% \text { rise })\end{array}$} & $0-15$ & 0 & 3 & 0 & 0 & 0 \\
\hline & $15-30$ & 0 & 0 & 0 & 0 & 0 \\
\hline & $>30$ & 0 & 0 & 0 & 0 & 0 \\
\hline \multirow{3}{*}{$\begin{array}{c}\text { Moderate } \\
\text { Perennial } \\
(2-4 \% \text { rise })\end{array}$} & $0-15$ & 0 & 2 & 0 & 0 & 0 \\
\hline & $15-30$ & 0 & 0 & 0 & 0 & 0 \\
\hline & $>30$ & 0 & 0 & 0 & 0 & 0 \\
\hline \multirow{3}{*}{$\begin{array}{c}\text { Steep } \\
\text { Perennial } \\
(>4 \% \text { rise })\end{array}$} & $0-15$ & 0 & 3 & 0 & 0 & 0 \\
\hline & $15-30$ & 0 & 0 & 0 & 0 & 0 \\
\hline & $>30$ & 0 & 0 & 0 & 0 & 0 \\
\hline \multirow{3}{*}{$\begin{array}{c}\text { Gentle } \\
\text { Intermittent } \\
(<2 \% \text { rise })\end{array}$} & $0-15$ & 6 & 0 & 0 & 0 & 0 \\
\hline & $15-30$ & 0 & 0 & 0 & 0 & 0 \\
\hline & $>30$ & 0 & 0 & 0 & 0 & 0 \\
\hline \multirow{3}{*}{$\begin{array}{c}\text { Moderate } \\
\text { Intermittent } \\
(2-4 \% \text { rise })\end{array}$} & $0-15$ & 1 & 0 & 0 & 0 & 0 \\
\hline & $15-30$ & 0 & 0 & 0 & 0 & 0 \\
\hline & $>30$ & 0 & 0 & 0 & 0 & 0 \\
\hline \multirow{3}{*}{$\begin{array}{c}\text { Steep } \\
\text { Intermittent } \\
(>4 \% \text { rise })\end{array}$} & $0-15$ & 23 & 0 & 0 & 0 & 0 \\
\hline & $15-30$ & 0 & 0 & 0 & 0 & 0 \\
\hline & $>30$ & 0 & 0 & 0 & 0 & 0 \\
\hline \multicolumn{2}{|l|}{ TOTAL } & 30 & 8 & 0 & 0 & 0 \\
\hline
\end{tabular}


Summary of the East Fork Coquille Watershed Road Corridor Stream Crossings

A total of 55 streams along the CBW Road in the East Fork Coquille Watershed would be affected by the proposed action (Table 16). Fifty-one crossings would occur above the streams within the roadbed; three crossings would be hung on bridges; and one crossing would be directionally-drilled below the stream.

Table 16: Stream Description and Crossing Type on Road Corridor within the East Fork Coquille Watershed (5th field HUC)

\begin{tabular}{|c|c|c|c|c|c|c|}
\hline Slope & $\begin{array}{l}\text { Stream } \\
\text { Width } \\
\text { (feet) }\end{array}$ & $\begin{array}{c}\text { Dry } \\
\text { Streams }\end{array}$ & $\begin{array}{l}\text { Bag \& } \\
\text { Flume }\end{array}$ & $\begin{array}{l}\text { Directionally } \\
\text { Drilled }\end{array}$ & $\begin{array}{c}\text { Hang on } \\
\text { Bridge }\end{array}$ & $\begin{array}{l}\text { Above } \\
\text { Stream (in } \\
\text { road fill) }\end{array}$ \\
\hline \multirow{3}{*}{$\begin{array}{c}\text { Gentle } \\
\text { Perennial } \\
(<2 \% \text { rise })\end{array}$} & $0-15$ & 0 & 0 & 0 & 1 & 2 \\
\hline & $15-30$ & 0 & 0 & 0 & 0 & 0 \\
\hline & $>30$ & 0 & 0 & 0 & 0 & 0 \\
\hline \multirow{3}{*}{$\begin{array}{c}\text { Moderate } \\
\text { Perennial } \\
(2-4 \% \text { rise })\end{array}$} & $0-15$ & 0 & 0 & 1 & 0 & 3 \\
\hline & $15-30$ & 0 & 0 & 0 & 0 & 0 \\
\hline & $>30$ & 0 & 0 & 0 & 0 & 0 \\
\hline \multirow{3}{*}{$\begin{array}{c}\text { Steep } \\
\text { Perennial } \\
(>4 \% \text { rise })\end{array}$} & $0-15$ & 0 & 0 & 0 & 0 & 14 \\
\hline & $15-30$ & 0 & 0 & 0 & 2 & 0 \\
\hline & $>30$ & 0 & 0 & 0 & 0 & 0 \\
\hline \multirow{3}{*}{$\begin{array}{c}\text { Gentle } \\
\text { Intermittent } \\
(<2 \% \text { rise })\end{array}$} & $0-15$ & 0 & 0 & 0 & 0 & 3 \\
\hline & $15-30$ & 0 & 0 & 0 & 0 & 0 \\
\hline & $>30$ & 0 & 0 & 0 & 0 & 0 \\
\hline \multirow{3}{*}{$\begin{array}{c}\text { Moderate } \\
\text { Intermittent } \\
(2-4 \% \text { rise })\end{array}$} & $0-15$ & 0 & 0 & 0 & 0 & 3 \\
\hline & $15-30$ & 0 & 0 & 0 & 0 & 0 \\
\hline & $>30$ & 0 & 0 & 0 & 0 & 0 \\
\hline \multirow{3}{*}{$\begin{array}{c}\text { Steep } \\
\text { Intermittent } \\
(>4 \% \text { rise })\end{array}$} & $0-15$ & 0 & 0 & 0 & 0 & 26 \\
\hline & $15-30$ & 0 & 0 & 0 & 0 & 0 \\
\hline & $>30$ & 0 & 0 & 0 & 0 & 0 \\
\hline \multicolumn{2}{|l|}{ TOTAL } & 0 & 0 & 1 & 3 & 51 \\
\hline
\end{tabular}




\section{Summary of the East Fork Coquille Watershed Utility Corridor Stream Crossings}

Only 2 streams would be crossed by the proposed action within the East Fork Coquille Watershed within utility ROW (Table 17). One intermittent stream would be crossed by the dry trench method and one small perennial stream would be crossed by the bag and flume method.

Table 17: Stream Description and Crossing Type on Utility Corridor within the East Fork Coquille Watershed (5th field HUC)

\begin{tabular}{|c|c|c|c|c|c|c|}
\hline Slope & $\begin{array}{l}\text { Stream } \\
\text { Width } \\
\text { (feet) }\end{array}$ & $\begin{array}{c}\text { Dry } \\
\text { Streams }\end{array}$ & $\begin{array}{l}\text { Bag \& } \\
\text { Flume }\end{array}$ & $\begin{array}{c}\text { Directionally } \\
\text { Drilled }\end{array}$ & $\begin{array}{c}\text { Hang on } \\
\text { Bridge }\end{array}$ & $\begin{array}{l}\text { Above } \\
\text { Stream (in } \\
\text { road fill) }\end{array}$ \\
\hline \multirow{3}{*}{$\begin{array}{c}\text { Gentle } \\
\text { Perennial } \\
(<2 \% \text { rise })\end{array}$} & $0-15$ & 0 & 0 & 0 & 0 & 0 \\
\hline & $15-30$ & 0 & 0 & 0 & 0 & 0 \\
\hline & $>30$ & 0 & 0 & 0 & 0 & 0 \\
\hline \multirow{3}{*}{$\begin{array}{c}\text { Moderate } \\
\text { Perennial } \\
(2-4 \% \text { rise })\end{array}$} & $0-15$ & 0 & 0 & 0 & 0 & 0 \\
\hline & $15-30$ & 0 & 0 & 0 & 0 & 0 \\
\hline & $>30$ & 0 & 0 & 0 & 0 & 0 \\
\hline \multirow{3}{*}{$\begin{array}{c}\text { Steep } \\
\text { Perennial } \\
(>4 \% \text { rise })\end{array}$} & $0-15$ & 0 & 1 & 0 & 0 & 0 \\
\hline & $15-30$ & 0 & 0 & 0 & 0 & 0 \\
\hline & $>30$ & 0 & 0 & 0 & 0 & 0 \\
\hline \multirow{3}{*}{$\begin{array}{c}\text { Gentle } \\
\text { Intermittent } \\
(<2 \% \text { rise })\end{array}$} & $0-15$ & 0 & 0 & 0 & 0 & 0 \\
\hline & $15-30$ & 0 & 0 & 0 & 0 & 0 \\
\hline & $>30$ & 0 & 0 & 0 & 0 & 0 \\
\hline \multirow{3}{*}{$\begin{array}{c}\text { Moderate } \\
\text { Intermittent } \\
(2-4 \% \text { rise })\end{array}$} & $0-15$ & 0 & 0 & 0 & 0 & 0 \\
\hline & $15-30$ & 0 & 0 & 0 & 0 & 0 \\
\hline & $>30$ & 0 & 0 & 0 & 0 & 0 \\
\hline \multirow{3}{*}{$\begin{array}{c}\text { Steep } \\
\text { Intermittent } \\
(>4 \% \text { rise })\end{array}$} & $0-15$ & 1 & 0 & 0 & 0 & 0 \\
\hline & $15-30$ & 0 & 0 & 0 & 0 & 0 \\
\hline & $>30$ & 0 & 0 & 0 & 0 & 0 \\
\hline \multicolumn{2}{|l|}{ TOTAL } & 1 & 1 & 0 & 0 & 0 \\
\hline
\end{tabular}


Summary of the Lower Coos River/Coos Bay Watershed Road Corridor Stream Crossings

A total of 29 streams within the CBW Road in the Lower Coos River/Lower Coos Bay Watershed would be affected by the proposed action. All 29 crossings occur above the streams within the roadbed of the CBW Road (Table 18).

Table 18: $\quad$ Stream Description and Crossing Type on Road Corridor within the Lower Coos River/ Coos Bay Watershed (5th field HUC)

\begin{tabular}{|c|c|c|c|c|c|c|}
\hline Slope & $\begin{array}{l}\text { Stream } \\
\text { Width } \\
\text { (feet) }\end{array}$ & $\begin{array}{c}\text { Dry } \\
\text { Streams }\end{array}$ & $\begin{array}{l}\text { Bag \& } \\
\text { Flume }\end{array}$ & $\begin{array}{l}\text { Directionally } \\
\text { Drilled }\end{array}$ & $\begin{array}{l}\text { Hang on } \\
\text { Bridge }\end{array}$ & $\begin{array}{l}\text { Above } \\
\text { Stream (in } \\
\text { road fill) }\end{array}$ \\
\hline \multirow{3}{*}{$\begin{array}{c}\text { Gentle } \\
\text { Perennial } \\
(<2 \% \text { rise })\end{array}$} & $0-15$ & 0 & 0 & 0 & 0 & 15 \\
\hline & $15-30$ & 0 & 0 & 0 & 0 & 0 \\
\hline & $>30$ & 0 & 0 & 0 & 0 & 0 \\
\hline \multirow{3}{*}{$\begin{array}{c}\text { Moderate } \\
\text { Perennial } \\
(2-4 \% \text { rise })\end{array}$} & $0-15$ & 0 & 0 & 0 & 0 & 0 \\
\hline & $15-30$ & 0 & 0 & 0 & 0 & 0 \\
\hline & $>30$ & 0 & 0 & 0 & 0 & 0 \\
\hline \multirow{3}{*}{$\begin{array}{c}\text { Steep } \\
\text { Perennial } \\
(>4 \% \text { rise })\end{array}$} & $0-15$ & 0 & 0 & 0 & 0 & 2 \\
\hline & $15-30$ & 0 & 0 & 0 & 0 & 0 \\
\hline & $>30$ & 0 & 0 & 0 & 0 & 0 \\
\hline \multirow{3}{*}{$\begin{array}{c}\text { Gentle } \\
\text { Intermittent } \\
(<2 \% \text { rise })\end{array}$} & $0-15$ & 0 & 0 & 0 & 0 & 10 \\
\hline & $15-30$ & 0 & 0 & 0 & 0 & 0 \\
\hline & $>30$ & 0 & 0 & 0 & 0 & 0 \\
\hline \multirow{3}{*}{$\begin{array}{c}\text { Moderate } \\
\text { Intermittent } \\
(2-4 \% \text { rise })\end{array}$} & $0-15$ & 0 & 0 & 0 & 0 & 1 \\
\hline & $15-30$ & 0 & 0 & 0 & 0 & 0 \\
\hline & $>30$ & 0 & 0 & 0 & 0 & 0 \\
\hline \multirow{3}{*}{$\begin{array}{c}\text { Steep } \\
\text { Intermittent } \\
(>4 \% \text { rise })\end{array}$} & $0-15$ & 0 & 0 & 0 & 0 & 1 \\
\hline & $15-30$ & 0 & 0 & 0 & 0 & 0 \\
\hline & $>30$ & 0 & 0 & 0 & 0 & 0 \\
\hline \multicolumn{2}{|l|}{ TOTAL } & 0 & 0 & 0 & 0 & 29 \\
\hline
\end{tabular}




\section{Summary of the Lower Coos River/Coos Bay Watershed Utility Corridor Stream Crossings}

Thirteen crossings within the Lower Coos River/Coos Bay Watershed would occur on existing utility ROW (Table 19). Seven streams would be crossed using the dry trench method; four streams would be crossed using the bag and flume method; and two crossings would be directionally-drilled below the stream.

Table 19: Stream Description and Crossing Type on Utility Corridor within the Lower Coos River/ Coos Bay Watershed (5th field HUC)

\begin{tabular}{|c|c|c|c|c|c|c|}
\hline Slope & $\begin{array}{l}\text { Stream } \\
\text { Width } \\
\text { (feet) }\end{array}$ & $\begin{array}{c}\text { Dry } \\
\text { Streams }\end{array}$ & $\begin{array}{l}\text { Bag \& } \\
\text { Flume }\end{array}$ & $\begin{array}{c}\text { Directionally } \\
\text { Drilled }\end{array}$ & $\begin{array}{l}\text { Hang on } \\
\text { Bridge }\end{array}$ & $\begin{array}{l}\text { Above } \\
\text { Stream (in } \\
\text { road fill) }\end{array}$ \\
\hline \multirow{3}{*}{$\begin{array}{c}\text { Gentle } \\
\text { Perennial } \\
(<2 \% \text { rise })\end{array}$} & $0-15$ & 0 & 0 & 0 & 0 & 0 \\
\hline & $15-30$ & 0 & 0 & 0 & 0 & 0 \\
\hline & $>30$ & 0 & 0 & 1 & 0 & 0 \\
\hline \multirow{3}{*}{$\begin{array}{c}\text { Moderate } \\
\text { Perennial } \\
(2-4 \% \text { rise })\end{array}$} & $0-15$ & 0 & 2 & 0 & 0 & 0 \\
\hline & $15-30$ & 0 & 0 & 0 & 0 & 0 \\
\hline & $>30$ & 0 & 0 & 0 & 0 & 0 \\
\hline \multirow{3}{*}{$\begin{array}{c}\text { Steep } \\
\text { Perennial } \\
(>4 \% \text { rise })\end{array}$} & $0-15$ & 0 & 2 & 0 & 0 & 0 \\
\hline & $15-30$ & 0 & 0 & 0 & 0 & 0 \\
\hline & $>30$ & 0 & 0 & 0 & 0 & 0 \\
\hline \multirow{3}{*}{$\begin{array}{c}\text { Gentle } \\
\text { Intermittent } \\
(<2 \% \text { rise })\end{array}$} & $0-15$ & 2 & 0 & 0 & 0 & 0 \\
\hline & $15-30$ & 0 & 0 & 0 & 0 & 0 \\
\hline & $>30$ & 0 & 0 & 0 & 0 & 0 \\
\hline \multirow{3}{*}{$\begin{array}{c}\text { Moderate } \\
\text { Intermittent } \\
(2-4 \% \text { rise })\end{array}$} & $0-15$ & 1 & 0 & 0 & 0 & 0 \\
\hline & $15-30$ & 0 & 0 & 0 & 0 & 0 \\
\hline & $>30$ & 0 & 0 & 0 & 0 & 0 \\
\hline \multirow{3}{*}{$\begin{array}{c}\text { Steep } \\
\text { Intermittent } \\
(>4 \% \text { rise })\end{array}$} & $0-15$ & 4 & 0 & 1 & 0 & 0 \\
\hline & $15-30$ & 0 & 0 & 0 & 0 & 0 \\
\hline & $>30$ & 0 & 0 & 0 & 0 & 0 \\
\hline \multicolumn{2}{|l|}{ TOTAL } & 7 & 4 & 2 & 0 & 0 \\
\hline
\end{tabular}




\section{Summary of the North Fork Coquille Watershed Road Corridor Stream Crossings}

A total of 5 streams within the CBW Road in the North Fork Coquille Watershed would be affected by the proposed action. All 5 crossings occur above the streams within the roadbed of existing public roads (Table 20).

Table 20: $\quad$ Stream Description and Crossing Type on Road Corridor within the North Fork Coquille Watershed (5th field HUC)

\begin{tabular}{|c|c|c|c|c|c|c|}
\hline Slope & $\begin{array}{l}\text { Stream } \\
\text { Width } \\
\text { (feet) }\end{array}$ & $\begin{array}{c}\text { Dry } \\
\text { Streams }\end{array}$ & $\begin{array}{l}\text { Bag \& } \\
\text { Flume }\end{array}$ & $\begin{array}{l}\text { Directionally } \\
\text { Drilled }\end{array}$ & $\begin{array}{c}\text { Hang on } \\
\text { Bridge }\end{array}$ & $\begin{array}{l}\text { Above } \\
\text { Stream (in } \\
\text { road fill) }\end{array}$ \\
\hline \multirow{3}{*}{$\begin{array}{c}\text { Gentle } \\
\text { Perennial } \\
(<2 \% \text { rise })\end{array}$} & $0-15$ & 0 & 0 & 0 & 0 & 1 \\
\hline & $15-30$ & 0 & 0 & 0 & 0 & 0 \\
\hline & $>30$ & 0 & 0 & 0 & 0 & 0 \\
\hline \multirow{3}{*}{$\begin{array}{c}\text { Moderate } \\
\text { Perennial } \\
(2-4 \% \text { rise })\end{array}$} & $0-15$ & 0 & 0 & 0 & 0 & 0 \\
\hline & $15-30$ & 0 & 0 & 0 & 0 & 0 \\
\hline & $>30$ & 0 & 0 & 0 & 0 & 0 \\
\hline \multirow{3}{*}{$\begin{array}{c}\text { Steep } \\
\text { Perennial } \\
(>4 \% \text { rise })\end{array}$} & $0-15$ & 0 & 0 & 0 & 0 & 0 \\
\hline & $15-30$ & 0 & 0 & 0 & 0 & 0 \\
\hline & $>30$ & 0 & 0 & 0 & 0 & 0 \\
\hline \multirow{3}{*}{$\begin{array}{c}\text { Gentle } \\
\text { Intermittent } \\
(<2 \% \text { rise })\end{array}$} & $0-15$ & 0 & 0 & 0 & 0 & 4 \\
\hline & $15-30$ & 0 & 0 & 0 & 0 & 0 \\
\hline & $>30$ & 0 & 0 & 0 & 0 & 0 \\
\hline \multirow{3}{*}{$\begin{array}{c}\text { Moderate } \\
\text { Intermittent } \\
(2-4 \% \text { rise })\end{array}$} & $0-15$ & 0 & 0 & 0 & 0 & 0 \\
\hline & $15-30$ & 0 & 0 & 0 & 0 & 0 \\
\hline & $>30$ & 0 & 0 & 0 & 0 & 0 \\
\hline \multirow{3}{*}{$\begin{array}{c}\text { Steep } \\
\text { Intermittent } \\
(>4 \% \text { rise })\end{array}$} & $0-15$ & 0 & 0 & 0 & 0 & 0 \\
\hline & $15-30$ & 0 & 0 & 0 & 0 & 0 \\
\hline & $>30$ & 0 & 0 & 0 & 0 & 0 \\
\hline \multicolumn{2}{|l|}{ TOTAL } & 0 & 0 & 0 & 0 & 5 \\
\hline
\end{tabular}




\section{Summary of the North Fork Coquille Watershed Utility Corridor Stream Crossings}

Eleven stream crossings would occur within the utility ROW (Table 21). One stream would be crossed by the dry trench method; six streams would be crossed by the bag and flume method; and four stream crossings would be directionally-drilled.

Table 21: Stream Description and Crossing Type on Utility Corridor within the North Fork Coquille Watershed (5th field HUC)

\begin{tabular}{|c|c|c|c|c|c|c|}
\hline Slope & $\begin{array}{c}\text { Stream } \\
\text { Width } \\
\text { (feet) }\end{array}$ & $\begin{array}{c}\text { Dry } \\
\text { Streams }\end{array}$ & $\begin{array}{l}\text { Bag \& } \\
\text { Flume }\end{array}$ & $\begin{array}{l}\text { Directionally } \\
\text { Drilled }\end{array}$ & $\begin{array}{c}\text { Hang on } \\
\text { Bridge }\end{array}$ & $\begin{array}{l}\text { Above } \\
\text { Stream (in } \\
\text { road fill) }\end{array}$ \\
\hline \multirow{3}{*}{$\begin{array}{c}\text { Gentle } \\
\text { Perennial } \\
(<2 \% \text { rise })\end{array}$} & $0-15$ & 0 & 0 & 0 & 0 & 0 \\
\hline & $15-30$ & 0 & 1 & 1 & 0 & 0 \\
\hline & $>30$ & 0 & 0 & 1 & 0 & 0 \\
\hline \multirow{3}{*}{$\begin{array}{c}\text { Moderate } \\
\text { Perennial } \\
(2-4 \% \text { rise })\end{array}$} & $0-15$ & 0 & 1 & 0 & 0 & 0 \\
\hline & $15-30$ & 0 & 0 & 0 & 0 & 0 \\
\hline & $>30$ & 0 & 0 & 0 & 0 & 0 \\
\hline \multirow{3}{*}{$\begin{array}{c}\text { Steep } \\
\text { Perennial } \\
(>4 \% \text { rise })\end{array}$} & $0-15$ & 0 & 4 & 0 & 0 & 0 \\
\hline & $15-30$ & 0 & 0 & 0 & 0 & 0 \\
\hline & $>30$ & 0 & 0 & 0 & 0 & 0 \\
\hline \multirow{3}{*}{$\begin{array}{c}\text { Gentle } \\
\text { Intermittent } \\
(<2 \% \text { rise })\end{array}$} & $0-15$ & 0 & 0 & 2 & 0 & 0 \\
\hline & $15-30$ & 0 & 0 & 0 & 0 & 0 \\
\hline & $>30$ & 0 & 0 & 0 & 0 & 0 \\
\hline \multirow{3}{*}{$\begin{array}{c}\text { Moderate } \\
\text { Intermittent } \\
(2-4 \% \text { rise })\end{array}$} & $0-15$ & 0 & 0 & 0 & 0 & 0 \\
\hline & $15-30$ & 0 & 0 & 0 & 0 & 0 \\
\hline & $>30$ & 0 & 0 & 0 & 0 & 0 \\
\hline \multirow{3}{*}{$\begin{array}{c}\text { Steep } \\
\text { Intermittent } \\
(>4 \% \text { rise })\end{array}$} & $0-15$ & 1 & 0 & 0 & 0 & 0 \\
\hline & $15-30$ & 0 & 0 & 0 & 0 & 0 \\
\hline & $>30$ & 0 & 0 & 0 & 0 & 0 \\
\hline \multicolumn{2}{|l|}{ TOTAL } & 1 & 6 & 4 & 0 & 0 \\
\hline
\end{tabular}




\section{Summary of the Middle Main Coquille Watershed Road Corridor Stream Crossings}

A total of 17 streams within the Middle Main Coquille Watershed would be affected by the proposed action. All of these crossings would occur above the stream in road fill within existing public road rights-of-way (Table 22).

Table 22: $\quad$ Stream Description and Crossing Type on Road Corridor within the Middle Main Coquille Watershed (5th field HUC)

\begin{tabular}{|c|c|c|c|c|c|c|}
\hline Slope & $\begin{array}{l}\text { Stream } \\
\text { Width } \\
\text { (feet) }\end{array}$ & $\begin{array}{c}\text { Dry } \\
\text { Streams }\end{array}$ & $\begin{array}{l}\text { Bag \& } \\
\text { Flume }\end{array}$ & $\begin{array}{l}\text { Directionally } \\
\text { Drilled }\end{array}$ & $\begin{array}{c}\text { Hang on } \\
\text { Bridge }\end{array}$ & $\begin{array}{l}\text { Above } \\
\text { Stream (in } \\
\text { road fill) }\end{array}$ \\
\hline \multirow{3}{*}{$\begin{array}{c}\text { Gentle } \\
\text { Perennial } \\
(<2 \% \text { rise })\end{array}$} & $0-15$ & 0 & 0 & 0 & 0 & 11 \\
\hline & $15-30$ & 0 & 0 & 0 & 0 & 0 \\
\hline & $>30$ & 0 & 0 & 0 & 0 & 0 \\
\hline \multirow{3}{*}{$\begin{array}{c}\text { Moderate } \\
\text { Perennial } \\
(2-4 \% \text { rise })\end{array}$} & $0-15$ & 0 & 0 & 0 & 0 & 0 \\
\hline & $15-30$ & 0 & 0 & 0 & 0 & 0 \\
\hline & $>30$ & 0 & 0 & 0 & 0 & 0 \\
\hline \multirow{3}{*}{$\begin{array}{c}\text { Steep } \\
\text { Perennial } \\
(>4 \% \text { rise })\end{array}$} & $0-15$ & 0 & 0 & 0 & 0 & 0 \\
\hline & $15-30$ & 0 & 0 & 0 & 0 & 0 \\
\hline & $>30$ & 0 & 0 & 0 & 0 & 0 \\
\hline \multirow{3}{*}{$\begin{array}{c}\text { Gentle } \\
\text { Intermittent } \\
(<2 \% \text { rise })\end{array}$} & $0-15$ & 0 & 0 & 0 & 0 & 6 \\
\hline & $15-30$ & 0 & 0 & 0 & 0 & 0 \\
\hline & $>30$ & 0 & 0 & 0 & 0 & 0 \\
\hline \multirow{3}{*}{$\begin{array}{c}\text { Moderate } \\
\text { Intermittent } \\
(2-4 \% \text { rise })\end{array}$} & $0-15$ & 0 & 0 & 0 & 0 & 0 \\
\hline & $15-30$ & 0 & 0 & 0 & 0 & 0 \\
\hline & $>30$ & 0 & 0 & 0 & 0 & 0 \\
\hline \multirow{3}{*}{$\begin{array}{c}\text { Steep } \\
\text { Intermittent } \\
(>4 \% \text { rise })\end{array}$} & $0-15$ & 0 & 0 & 0 & 0 & 0 \\
\hline & $15-30$ & 0 & 0 & 0 & 0 & 0 \\
\hline & $>30$ & 0 & 0 & 0 & 0 & 0 \\
\hline \multicolumn{2}{|l|}{ TOTAL } & 0 & 0 & 0 & 0 & 17 \\
\hline
\end{tabular}




\section{$\underline{\text { Reasonably Foreseeable Future Actions }}$}

Laterals to Coquille, Myrtle Point and Bandon, OR, would likely be constructed in the future. These proposed laterals would start near the Fairview block valve, and likely be placed within the roads or utility corridors to those cities from the CBW Road. Decisions relating to timing and placement of the laterals have not been finalized. Although construction and placement are not finalized, the anticipated design would still follow the protective measures contained in the construction plans for the proposed action. The amount of disturbance from in-stream work and culvert placement would be determined by whether the laterals are placed in utility corridors or on road fill. The proposed laterals would be approximately 28 miles in total length. The present plans include construction and placement of 6inch and 4-inch pipe. The amount of ground disturbance would be less than the mainline (proposed action), because smaller construction equipment and less ground area would be necessary.

NW Natural has announced plans to extend service to industrial users on the North Spit of Coos Bay. An 8 to 12 -inch pipe would be placed under the road from Ocean Boulevard to Newmark Avenue to Empire. From there, the extension would be directionally-drilled under Coos Bay to a paved road on the North Spit. This distribution pipeline would likely be built concurrently with the Coos County Pipeline. Impacts to aquatic habitats will be avoided, as construction will be limited to paved areas in Coos Bay, and directionally-drilled under the bay itself. Portions of the North Spit are designated as an ACEC. All construction plans identified by NW Natural keep the North Spit Extension on utility corridors or road ROW, thus avoiding all potential impacts to the ACEC area.

\section{Summary of Direct, Indirect and Cumulative Effects for the Alternatives}

Both the Hwy 42 and proposed action alternatives include measures to minimize the risk of potential short-term sedimentation from construction, which can affect water quality and water-dependent flora and fauna at the site scale. Short-term potential sedimentation impacts have been anticipated and adequate protective measures are utilized to minimize these potential impacts (i.e., make negligible). None of the alternatives would affect the analysis or planned outcomes as developed in the NFP Final SEIS and as implemented through its Record of Decision (USDA, USDA 1994b). See Appendix E for all watershed baselines and the specific rationale behind the effects determinations. See Appendix H and the ODOT Erosion Control and Sediment Manual for specific aquatic system protection measures for the proposed action.

\section{Direct Effects}

1. No Action Alternative: No negative or beneficial impacts anticipated.

2. Proposed Action: Negligible negative impacts from pipeline construction in each watershed (5th field HUC) may occur. Normal background sedimentation and turbidity present in the watersheds will receive no measurable impacts at the 5th field level. At the 7th field HUC (sub-subwatershed level), small, localized and transitory increases to sedimentation and turbidity will likely occur during active trenching of small perennial streams, and during the first significant autumn precipitation event. Beneficial impacts from placement of new stream and cross-drain culverts and paving approximately 15 miles of gravel-dirt road (on the CBW Road), will likely improve watershed baseline conditions in the long-term for sedimentation and turbidity, with immediate improvement in the baseline for physical barriers (fish passage).

3. Hwy 42 Alternative: Negligible negative impacts from pipeline construction in each watershed (5th field HUC) may occur. Normal background sedimentation and turbidity present in the watersheds will receive no measurable impacts at the 5th field level. At the 7th field HUC (sub-subwatershed level), small, localized and transitory increases to sedimentation and turbidity will likely occur during active trenching of live streams, and during the first significant autumn precipitation event. Immediate beneficial impacts are anticipated for physical barriers. 


\section{Indirect Effects}

1. No Action Alternative: None.

2. Proposed Action: Negligible negative impacts to sedimentation and turbidity baselines and beneficial impacts to physical barrier baseline. Short-term (1-8 hours) disturbance potential for individual aquatic vertebrates at the perennial stream crossing sites when construction occurs.

3. Hwy 42 Alternative: Negligible negative impacts to sedimentation and turbidity baselines and beneficial impacts to physical barrier baseline. Short-term (1-8 hours) disturbance potential for individual aquatic vertebrates at the perennial stream crossing sites when construction occurs.

\section{Cumulative Effects}

1. No Action Alternative: No foreseeable incremental effects.

2. Proposed Action: Beneficial incremental effects anticipated for the aquatic ecosystem from reduced sedimentation from the CBW Road and improved access to habitat for fish.

3. Hwy 42 Alternative: Beneficial incremental effects anticipated for habitat access for fish.

\section{Human Environment}

\section{Areas of Critical Environmental Concern (ACEC)}

The North Spit of Coos Bay contains the only ACEC near the action alternatives. Both the Hwy 42 alternative and the proposed action would trigger NW Natural to develop a distribution system to the manufacturing facilities presently located on the North Spit. NW Natural's distribution system would be built under paved roads within Coos Bay and the North Spit. To access the North Spit manufacturing area, NW Natural would cross under the bay using the directionally-drill method (shown in Appendix J).

Environmental Consequences and Comparison of Alternatives

\section{Direct, Indirect and Cumulative Effects}

\section{All Alternatives, including No Action}

None of the alternatives would affect the North Spit ACEC, as that area would be avoided. No impacts.

\section{Socio-economics}

\section{Background}

In February 1999, ECONorthwest published a study forecasting the economic impacts of a new pipeline. This study also measured the impacts of the distribution system, the long-term benefits to manufacturing employment and the effects the distribution system would have on government revenues. The report was prepared for Northwest Natural and distributed to the public. The 1999 study itself was a revision of an earlier report by ECONorthwest completed in 1997 for Northwest Natural Gas and Carbon Energy International. It discussed the impacts of a natural gas distribution system confined to the County's two largest cities - North Bend and Coos Bay. 
Both the 1997 and the 1999 studies relied on rough cost estimates for the pipeline. The route, timing and dimensions of the pipeline had not been determined at the time the impact studies were completed.

In this report, cost estimates provided by Coos County are used. As such, it is ECONorthwest's understanding that the pipeline construction cost estimates are more precise than those used in the 1999 and 1997 studies. Two scenarios suggested that the pipeline would cost approximately $\$ 34$ million (proposed action) or \$48 million (Hwy 42 alternative) depending on which route is chosen. Furthermore, these cost estimates reflected dollar values for the 2000 fiscal year.

This report shows the results of a model estimating the economic impacts on Coos County from the construction and operation of a natural gas pipeline. The economic impact model reports values in year 2000 dollars. IMPLAN expresses employment in terms of person-years of employment. A person-year equals enough hours of work to keep one person fully employed for one year. In actuality, two or more people may share those hours. An employment impact is a mixture of new jobs, some additional part time work and added hours of work for people who are already employed.

\section{Environmental Consequences and Comparison of Alternatives}

\section{No Action Alternative}

The anticipated beneficial impacts from the proposed action would not occur.

\section{Action Alternatives}

There are three kinds of economic impacts. They are direct, indirect and induced. A direct impact occurs when a person who builds or operates a pipeline: 1) Buys local goods and services and 2) hires local labor. The money they use to do this is a direct impact. Their spending, in turn, causes indirect impacts because those who supply goods and services to the gas pipeline will make some purchases in Coos County. Total employment and income in the County goes up. That puts more purchasing power in the hands of Coos County citizens. They then will increase their local spending and savings. This causes an additional stimulus to the County's economy called an induced (i.e., cumulative) impact. Money spent locally by pipeline workers is included as an induced impact.

The economic modeling framework which best captures these direct, indirect and induced effects is called Input-Output Modeling. Input-Output Models are mathematical representations of the economy which incorporate how different parts (or sectors) of the economy are linked. With an Input-Output Model, one can trace the effects of a change in one sector through the rest of the economy.

Because Input-Output Models generally are not available for state and regional economies, special techniques have been developed to estimate the necessary relationships using national data and county-level measures of economic activity. This planning framework is called IMPLAN (for IMpact Analysis for PLANing). ECONorthwest used the most current version, IMPLAN Professional 2.0, to estimate the impacts of the natural gas pipeline on Coos County.

IMPLAN was developed by the Forest Service of the US Department of Agriculture in cooperation with the Federal Emergency Management Agency and the Bureau of Land Management of the US Department of the Interior to assist federal agencies in their land and resource management planning.

\section{Pipeline Construction}

ECONorthwest built an Input-Output Model for Coos County to estimate the economic impacts of the construction and operation of the natural gas pipeline on the County. This model was used to estimate economic impacts under two scenarios of construction costs. They are: 1) A \$48 million proposal, which would follow, in part, a railroad right-of-way; and 2) a more direct path, which would result in a lower construction cost of $\$ 34$ million.

\section{Construction Cost Estimates}

ECONorthwest estimated the cost breakdown of the pipeline construction along three major categories: Materials, labor and contractors, and right-of-way. In addition, those expenditures were divided according to where those dollars would likely be spent. Table 23 shows the construction spending estimates for a $\$ 48$ million construction cost pipeline project. 
Table 23: $\quad$ Pipeline Construction Spending for the $\$ 48$ Million Scenario (in 2000 Dollars)

\begin{tabular}{|l|r|r|r|r|}
\hline & Materials & $\begin{array}{c}\text { Labor and } \\
\text { Contractors }\end{array}$ & \multicolumn{1}{|c|}{ Right-of-Way } & \multicolumn{1}{|c|}{ Total } \\
\hline \hline Coos County & $\$ 1,436,000$ & $\$ 14,361,200$ & $\$ 9,800$ & $\$ 15,807,000$ \\
\hline Elsewhere & $5,744,500$ & $26,328,800$ & 119,700 & $32,193,000$ \\
\hline \hline Total & $\$ 7,180,500$ & $\$ 40,690,000$ & $\$ 129,500$ & $\$ 48,000,000$ \\
\hline
\end{tabular}

Table 24 provides the estimate for the direct pipeline route. Under this scenario the cost of building the pipeline is expected to total $\$ 34$ million (proposed action estimate is closest to this).

Table 24: Pipeline Construction Spending for the \$34 Million Scenario (in 2000 Dollars)

\begin{tabular}{|l|r|r|r|r|}
\hline & Materials & $\begin{array}{c}\text { Labor and } \\
\text { Contractors }\end{array}$ & Right-of-Way & \multicolumn{1}{|c|}{ Total } \\
\hline \hline Coos County & $\$ 1,017,200$ & $\$ 10,172,500$ & $\$ 6,900$ & $\$ 11,196,600$ \\
\hline Elsewhere & $4,069,000$ & $18,649,600$ & 84,800 & $22,803,400$ \\
\hline \hline Total & $\$ 5,086,200$ & $\$ 28,822,100$ & $\$ 91,700$ & $\$ 34,000,000$ \\
\hline
\end{tabular}

The pipeline construction project would have the greatest effect on the local economy if all of the expenditures were made in Coos County. However, Coos County lacks some of the resources needed for the specialized undertaking of constructing a natural gas pipeline. Consequently, a significant portion of the expenditures will go to contractors, labor and manufacturers based outside of Coos County.

Parts of the project that use general skills will likely rely on local workers. Local contractors, for example, may perform the construction, restoration and replanting of the pipeline right-of-way. Specialized work unique to pipeline construction will use non-local labor. However, this also can have a positive impact on the local economy. Consumption spending by these workers, many of whom will come from out-of-state, will benefit the Coos County economy. These non-local workers can be expected to spend a significant fraction of their pay (including their per diems) on consumption items within the Coos County, in addition to special lodging, food and drink and other services associated with their temporary residence.

As shown in Table 23 and Table 24, ECONorthwest isolated spending that will occur wholly outside the County, and accordingly, they assumed this spending would generate no impacts on Coos County. For example, the purchases of pipe manufacture in California, or accounting services in Portland, OR, are not included in the estimate of direct spending, as these expenditures affect activity outside Coos County.

\section{Economic Impact of the $\$ 48$ Million Construction Scenario}

The direct impacts of a $\$ 48$ million natural gas pipeline construction project are shown in Table 25 . These are divided into five categories, and these categories are used throughout this report. 
Table 25: Direct Impact of $\$ 48$ Million in Pipeline Construction on Coos County in Year 2000 Dollars and Person-Years of Employment

\begin{tabular}{|l|r|}
\hline \multicolumn{2}{|c|}{ Direct Impact } \\
\hline \hline Output & $\$ 15,184,300$ \\
\hline Employees' Income & $\$ 2,300,800$ \\
\hline Proprietor's Income & $\$ 387,300$ \\
\hline Other Income & $\$ 1,574,100$ \\
\hline Employment & 114.3 \\
\hline
\end{tabular}

The first category, output, is the value of increased business activity in Coos County due to the construction. The IMPLAN model calculated that the construction of a $\$ 48$ million pipeline would directly contribute nearly $\$ 15.2$ million to the Coos County economy.

The next three categories measure the gains in local incomes. They are employees income, income going to proprietors (such as an independent construction contractor), and other property-type income such as rents received on properties, royalties from contracts and corporate profits. ECONorthwest forecasts that the $\$ 48$ million project will have the direct impact of adding $\$ 4,262,200$ in income to Coos County.

The last impact category on Table 25 is employment. The construction project is projected to support directly over 114 person-years of employment for county residents.

Table 26 shows the total impact of the $\$ 48$ million project on Coos County. Even though most of the materials and workforce necessary to complete the project will originate from outside the county, the project will still have an impressive positive impact on the economy. It will boost output in Coos County by $\$ 18,679,600$ and support the equivalent of over 162 jobs for local residents.

Table 26: Direct, Indirect, Induced and Total Economic Impacts on Coos County from \$48 Million in Pipeline Construction Spending in Year 2000 Dollars and Person-Years of Employment

\begin{tabular}{|c|r|r|r|r|r|r|}
\hline Impact & Output & \multicolumn{1}{|c|}{$\begin{array}{c}\text { Employee's } \\
\text { Income }\end{array}$} & $\begin{array}{c}\text { Proprietor's } \\
\text { Income }\end{array}$ & \multicolumn{1}{c|}{$\begin{array}{c}\text { Other } \\
\text { Income }\end{array}$} & Jobs & $\begin{array}{c}\text { Average } \\
\text { Annual } \\
\text { Wage }\end{array}$ \\
\hline \hline Direct & $\$ 15,184,300$ & $\$ 2,300,800$ & $\$ 387,300$ & $\$ 1,574,100$ & 114.3 & $\$ 23,500$ \\
\hline Indirect & $\$ 1,602,600$ & $\$ 424,200$ & $\$ 119,900$ & $\$ 272,300$ & 20.5 & $\$ 26,600$ \\
\hline Induced & $\$ 1,892,700$ & $\$ 565,900$ & $\$ 104,000$ & $\$ 397,100$ & 28.2 & $\$ 23,700$ \\
\hline \hline Total & $\$ 18,679,600$ & $\$ 3,290,900$ & $\$ 611,200$ & $\$ 2,243,500$ & 162.9 & $\$ 23,900$ \\
\hline
\end{tabular}

\section{Economic Impact of the \$34 Million Construction Scenario}

Table 27 shows the direct impacts of a $\$ 34$ million natural gas pipeline construction project. The project would contribute nearly $\$ 10.8$ million directly to the Coos County economy and over $\$ 3,019,000$ in higher incomes to its residents. The project would be able to support the equivalent of over 80 full-time jobs for local workers. 
Table 27: Direct Impact of \$34 Million in Pipeline Construction on Coos County in Year 2000 Dollars and Person-Years of Employment

\begin{tabular}{|l|r|}
\hline \multicolumn{2}{|c|}{ Direct Impact } \\
\hline \hline Output & $\$ 10,755,500$ \\
\hline Employees' Income & $\$ 1,629,700$ \\
\hline Proprietor's Income & $\$ 274,300$ \\
\hline Other Income & $\$ 1,115,000$ \\
\hline Employment & 80.9 \\
\hline
\end{tabular}

Table 28: Direct, Indirect, Induced and Total Economic Impacts on Coos County from \$34 Million in Pipeline Construction Spending

\begin{tabular}{|r|r|r|r|r|r|r|}
\hline Impact & Output & $\begin{array}{c}\text { Employee's } \\
\text { Income }\end{array}$ & $\begin{array}{c}\text { Proprietor's } \\
\text { Income }\end{array}$ & $\begin{array}{c}\text { Other } \\
\text { Income }\end{array}$ & Jobs & $\begin{array}{c}\text { Average } \\
\text { Annual } \\
\text { Wage }\end{array}$ \\
\hline Direct & $\$ 10,755,500$ & $\$ 1,029,700$ & $\$ 274,300$ & $\$ 1,115,000$ & 80.9 & $\$ 23,500$ \\
\hline Indirect & $\$ 1,135,200$ & $\$ 300,500$ & $\$ 84,900$ & $\$ 192,900$ & 14.5 & $\$ 26,600$ \\
\hline Induced & $\$ 1,340,700$ & $\$ 400,800$ & $\$ 73,700$ & $\$ 281,300$ & 20.0 & $\$ 23,700$ \\
\hline \hline Total & $\$ 13,231,400$ & $\$ 2,331,000$ & $\$ 432,900$ & $\$ 1,589,200$ & 115.4 & $\$ 23,900$ \\
\hline
\end{tabular}

\section{Pipeline Operations}

ECONorthwest used the IMPLAN model to estimate the annual economic impact on Coos County attributable to pipeline operating expenses. The expenses include the costs of on-site monitoring, inspection, maintenance and repairs of the pipeline. Costs related to the distribution of gas, that is the delivery of natural gas from the pipeline to individual customers, are considered local utility functions and are not included in this analysis.

\section{A). Operating Cost Estimate}

The annual operating costs for modern natural gas transmission pipelines of the length and capacity needed for Coos County are low relative to the amounts of money needed for their construction. Unlike the construction phase, however, the economic impact of operating the pipeline will be a reoccurring benefit. Such benefits will continue for the life of the pipeline. A well maintained natural gas transmission pipeline could theoretically last indefinitely.

ECONorthwest estimates that the Coos County pipeline will require six, predominantly full-time equivalent workers. Employees of natural gas transmission pipeline systems are generally highly skilled and well compensated. The labor cost estimate, which appears in Table 29, is based on the Oregon statewide average for workers in the gas transmission industry. Most of their work must be done on-site; thus, approximately 75 percent of the spending on labor will accrue to Coos County. ECONorthwest estimates annual expenses for equipment and materials are expected to total $\$ 60,000$, with 20 percent coming from within the county. However, actual annual expenses are expected to be $\$ 20,000$ (pers. com. Coos County Commissioners). 
Table 29: Annual Spending on Pipeline Operations (in 2000 Dollars)

\begin{tabular}{|l|r|r|r|}
\hline & $\begin{array}{c}\text { Equipment \& } \\
\text { Materials }\end{array}$ & Labor \& Contractors & \multicolumn{1}{c|}{ Total } \\
\hline \hline Coos County & $\$ 12,000$ & $\$ 371,254$ & $\$ 383,254$ \\
\hline Elsewhere & 48,000 & 123,751 & 171,751 \\
\hline \hline Total & $\$ 60,000$ & $\$ 495,005$ & $\$ 555,005$ \\
\hline
\end{tabular}

Annual spending for pipeline operations will total $\$ 550,005$ a year. ECONorthwest anticipates $\$ 383,254$ of the total will be spent within Coos County each year.

\section{B). Economic Impact of the Pipeline Operations}

The economic impacts from operating a well-run and properly maintained natural gas pipeline are relatively modest. Pipelines normally do not require extensive equipment replacements, nor further construction work. ECONorthwest estimated, through its use of a Coos County IMPLAN model, that $\$ 378,100$ in direct economic output for the local economy would result every year that the pipeline operates. Table 30 is a list of the annual direct impacts. Much of it will be in the form of compensation for the estimated six employees who will be needed in Coos County to operate the pipeline.

Table 30: Annual Direct Impact of Pipeline Operations Spending on Coos County in Year 2000 Dollars and Person-Years of Employment

\begin{tabular}{|l|r|}
\hline \multicolumn{2}{|c|}{ Direct Impact } \\
\hline \hline Output & $\$ 378,100$ \\
\hline Employees' Income & $\$ 372,200$ \\
\hline Proprietor's Income & $\$ 9,600$ \\
\hline Other Income & $\$ 40,200$ \\
\hline Employment & 6.0 \\
\hline
\end{tabular}

The indirect and induced impacts from the pipelines operation will be largely due to the personal spending of the pipeline employees. In total, these "downstream" impacts will contribute $\$ 87,000$ to total output, and that would be sufficient to support less than two more jobs in the County. Aggregate income in Coos County will be $\$ 468,800$ higher every year throughout the operating life of the pipeline.

\section{C). Economic Impacts of the Distribution System}

Ultimately, most of the benefits to Coos County that will arise because of the pipeline's construction will come about from the operations of a distribution system (Table 31). A distribution system takes gas from the pipeline and delivers it to industrial, commercial and residential consumers. An economic impact analysis of a distribution system is outside the scope of work for this report. Nonetheless, it is necessary to address the economic impacts such a system would have on the Coos County area, as distribution is an essential element in the overall plan to build a pipeline. 
Table 31: Annual Direct, Indirect, Induced and Total Economic Impacts on Coos County Because of Pipeline Operations Spending In Year 2000 Dollars and Person-Years of Employment

\begin{tabular}{|r|r|r|r|r|r|r|}
\hline \multicolumn{1}{|r|}{ Impact } & Output & \multicolumn{1}{|c|}{$\begin{array}{c}\text { Employee's } \\
\text { Income }\end{array}$} & $\begin{array}{c}\text { Proprietor's } \\
\text { Income }\end{array}$ & $\begin{array}{c}\text { Other } \\
\text { Income }\end{array}$ & Jobs & $\begin{array}{c}\text { Average } \\
\text { Annual } \\
\text { Wage }\end{array}$ \\
\hline Direct & $\$ 378,100$ & $\$ 372,200$ & $\$ 9,600$ & $\$ 40,200$ & 6.0 & $\$ 63,100$ \\
\hline Indirect & $\$ 39,800$ & $\$ 10,500$ & $\$ 3,000$ & $\$ 6,800$ & 0.5 & $\$ 26,800$ \\
\hline Induced & $\$ 47,200$ & $\$ 14,100$ & $\$ 2,500$ & $\$ 9,900$ & 0.7 & $\$ 23,600$ \\
\hline \hline Total & $\$ 465,100$ & $\$ 396,800$ & $\$ 15,100$ & $\$ 56,900$ & 7.2 & $\$ 56,800$ \\
\hline
\end{tabular}

D). Static and Dynamic Efficiency Effects

A distribution system will stimulate the economy over the long run through what economist call static and dynamic efficiency effects.

Static efficiency occurs when a development (in this case distributing a low cost fuel to Coos County consumers) reduces the costs of living and doing business. By simply spending less money on their utility bills, local people and businesses will have more money to spend on other goods and services. The savings created by the introduction of natural gas will give residents, schools, businesses and others more disposable income. They will spend much of that extra income locally, stimulating the economy.

Lacking natural gas, the Coos Bay area currently depends on electricity, heating oil, propane and wood for its fuel needs. In many circumstances, natural gas is more efficient and less expensive than electric, oil, or propane. For example, about half of all the households in the county use electric heating. A typical single family home would save $\$ 410$ in annual utility bills by switching from electric to natural gas heat. The competitive advantage of natural gas is evident in Oregon communities where it is available. In urban areas about 60 percent of the homes use natural gas while in outlying areas about 40 percent utilize it.

Residents, commercial businesses and small industrial businesses in the Coos Bay area will save increasing amounts of money each year as the distribution system is built out and as new consumers convert to natural gas. ECONorthwest estimates that by the tenth year, consumers will save over $\$ 6.7$ million a year. The static efficiency effect of these savings is sufficient to support nearly 50 jobs and nearly $\$ 1.9$ million in additional personal, business and other income within Coos County.

Dynamic efficiency effects are caused by a change that allows the local economy to expand in ways that would otherwise be impossible or unlikely without the change. Economists often use the term "production possibilities frontier" to describe the limits of what can be done given what is available locally.

For example, the introduction of natural gas may make it possible, or at minimum more practical, to build a metal fabricating plant or ammonia fertilizer factory in Coos County. New businesses, who otherwise would avoid Coos County because of the lack of natural gas, would now consider locating there. Existing businesses that currently depend on expensive propane fuel may be able to compete more effectively once they can switch to lower cost natural gas. This would allow them to expand their sales and payrolls. These are examples of dynamic efficiency. The frontier of what businesses can do in Coos County expands.

Forecasting the dynamic efficiency effect is problematic. While the economic development impact of natural gas would be great, determining the timing and extent of the impact is extremely difficult. ECONorthwest previously estimated that dynamic efficiencies would lead to over 1,500 new manufacturing jobs after ten years. This was based on a comparison between parts of Oregon with natural gas and those without. There is a strong relationship between the availability of natural gas and manufacturing employment. In turn, manufacturing jobs stimulate employment in other local economic sectors. Through the use of the IMPLAN model, ECONorthwest estimates that because of the dynamic efficiency effect, total employment in the Coos Bay area would be over 2,900 jobs higher ten years after natural gas is introduced.

It is instructive to compare the Coos Bay area with Newport, Oregon-a coastal city that shares many of the 
same characteristics as Coos Bay, except that it has natural gas. Table 32 shows the population growth rates from 1980 to 2000 for the Zip codes comprising the Coos Bay and Newport areas. While the Coos Bay area population has experienced decline or little growth, Newport and its neighboring community of Toledo have seen substantial population gains. The availability of natural gas was one of the reasons for this difference, although other factors also played major roles.

Table 32: $\quad$ Comparative Population Growth Rates 1980 - 2000

\begin{tabular}{|c|l|c|c|c|}
\hline Zip Code & \multicolumn{1}{|c|}{ City Name } & $\begin{array}{c}1980 \\
\text { Population }\end{array}$ & $\begin{array}{c}\text { 2000 } \\
\text { Population }\end{array}$ & $\begin{array}{c}\text { Percent } \\
\text { Change }\end{array}$ \\
\hline \hline Coos Bay Area: & 6,275 & 6,329 & $0.9 \%$ \\
\hline 97411 & Bandon & 24,476 & 23,679 & $-3.3 \%$ \\
\hline 97420 & Coos Bay & 8,061 & 7,443 & $-7.7 \%$ \\
\hline 97423 & Coquille & 5,845 & 5,506 & $-5.8 \%$ \\
\hline 97458 & Myrtle Point & 16,021 & 15,489 & $-3.3 \%$ \\
\hline 97459 & North Bend & 60,678 & 58,446 & $-3.7 \%$ \\
\hline \hline \multicolumn{2}{|c|}{ Coos Bay Area Total } & 8,624 & 10,956 & $27.0 \%$ \\
\hline Newport Area: & Newport & 5,969 & 6,286 & $5.3 \%$ \\
\hline 97365 & Toledo & 14,593 & 17,242 & $18.2 \%$ \\
\hline \multicolumn{2}{|c|}{ Newport Area Total } & & & \\
\hline \hline
\end{tabular}

\section{E). Adversely Affected Businesses}

While Coos County businesses and consumers will benefit from the availability of natural gas, there is one segment of the local economy that will sustain setbacks large enough to have a notable effect on employment. That segment consists of propane and heating oil distributors. They will likely experience declining market shares and will reduce their employee counts as a result.

Consumers who now use propane for heating, drying, fireplaces and cooking, in most cases will be able to readily switch to natural gas. Pricing and convenience advantages give natural gas a strong competitive advantage over propane. Heating oil, too, will lose customers to natural gas. However, the rate of substitution will be much slower because conversion costs are high and price advantages are less.

Other sectors that compete with natural gas will be adversely affected; however, the impact on employment will be far less consequential. There will be negative up and down stream effects caused by revenue and employment losses by propane and heating oil distributors. There will be revenue losses for businesses that transport and wholesale propane, heating oil and residual fuel oil. If any such business is heavily dependent on these fuels and local workers, the revenue loss could lead to job losses. Electricity demand will be affected as natural gas gradually replaces electric based heating, cooking and clothes drying. Natural gas, though, can only supplement and not replace electricity. Thus, its impact on electric utility employment will be negligible.

ECONorthwest expects that local propane and heating oil distributors will sustain the only marked reduction in employment over the long run. Table 33 is a list of the distributors who will be affected by the new natural gas distribution system. The list is from the American Business Directory database for the year 2000. The directory assigns an employment range for each listing. ECONorthwest averaged these ranges and arrived at an estimate that the nine propane and heating oil distributors employ 69 individuals. 
Table 33: Propane and Heating Oil Distributors

\begin{tabular}{|l|l|l|c|}
\hline \multicolumn{1}{|c|}{ Company } & \multicolumn{1}{c|}{ Address } & \multicolumn{1}{c|}{ City } & \multicolumn{1}{c|}{ Fuel } \\
\hline \hline All Star Gas Inc. & 425 Virginia Ave & North Bend & Propane \\
\hline Bassett-Hyland Energy Co & 425 W Lockhart Ave & Coos Bay & Heating Oil \\
\hline Davis Oil Inc. & 280 Newmark St. & North Bend & Heating Oil \\
\hline Ferrellgas & 1165 Newmark Ave \# D & Coos Bay & Propane \\
\hline Goddard Energy Co & 2nd \& Elmira & Bandon & Heating Oil \\
\hline Graham Oil Co & 1765 Sheridan Ave & North Bend & Heating Oil \\
\hline Rons Oil Co & 580 N Central St. & Coquille & Propane \\
\hline Tyree Oil Inc. & 2395 N Bayshore Dr. & Coos Bay & Heating Oil \\
\hline Hodge Distributing Inc. & 1893 Roseburg Rd. & Myrtle Point & Heating Oil \\
\hline
\end{tabular}

According to the 2000 Census data, Coos County has a population of 62,779 . There are approximately 850 residents for each of the 69 propane and heating oil distributor employees. In the state of Oregon, using Claritas and American Business Directory data, ECONorthwest determined that the ratio is approximately 1,150 residents per distributor employee. The statewide ratio is higher because natural gas is widely available and distribution systems have been long in-place throughout most of Oregon. Therefore, propane and heating oil distributors need a higher population base to draw upon so that they may generate enough sales to support an employee.

ECONorthwest estimates that if the Coos County area were to mirror the highly competitive market characteristic of the rest of the state, it too would be able to only support one propane and heating oil distributor employee for every 1,150 residents. Given that statewide ratio and applying it to an approximate population base of 60,000 , ECONorthwest estimates that the affected area would be able to sustain 51 propane and heating oil distributor employees over the long run. Thus, there is a projected eventual loss of 18 jobs in this sector.

\section{Summary of Direct, Indirect and Cumulative Economic Effects for Action Alternatives}

Construction of a natural gas pipeline will have a simulative impact on the Coos County economy of between $\$ 13.2$ and $\$ 18.7$ million depending on the route taken. The construction project will support the equivalent of 115 to 163 full-time jobs for local residents. From then on, pipeline operations spending will have an annual economic impact of $\$ 465,100$ to Coos County. This is sufficient to sustain over seven full-time jobs with an average wage rate of $\$ 56,800$.

The pipeline will deliver natural gas to a distribution system that will supply gas to homes and businesses. The economic impact of the distribution system will be great.

Clearly the area to be served with natural gas from the pipeline would be better off over the long run with natural gas than without. No one could easily argue that other areas of Oregon with natural gas and similar populations, such as Grants Pass, Albany, or Corvallis, would be better off without natural gas. If gas were taken away from those cities, one would expect businesses to move, factories to close, and jobs to be lost. Conversely, one can expect the major economic benefits over time once natural gas becomes available to Coos County.

ECONorthwest believes that there will be static efficiency benefits to the local economy that will steadily grow as natural gas consumption increases. These will be partly offset by losses in businesses that will find it difficult to compete against natural gas. The net impact, however, will be positive because consumers will enjoy much greater benefits in the form of lower energy costs. They will spend much of their savings locally.

Long-term, one expects to see dynamic efficiency effects that will lead to substantial increases in manufacturing employment. This will then stimulate employment in other sectors of the local economy. Predicting the net impact is 
difficult and requires some level of speculation. However, within ten years employment could increase by over 2,900 in the region because of the availability of natural gas.

\section{Environmental Justice}

\section{Direct, Indirect and Cumulative Effects}

\section{All Alternatives, including No Action}

Household Income (Variable 80) in Census Database C90STF3A was examined for each of ten geographic areas within Coos County, and cumulative frequency plots were constructed for the 25 income levels as compared to other portions of mid-Coquille basin, and just slightly lower than average income levels as compared to other geographic areas within Coos County.

Pipeline construction activities will have a similar affect upon all households residing in the vicinity of the construction zone. As documented elsewhere, construction activities may result in inconvenient travel delays or equipment noise. However, this analysis shows that low income populations will not be disproportionately affected because of the route choice. Therefore, Environmental Justice concerns will not be created by pipeline construction activities.

No minority or disadvantaged groups or communities are within or adjacent to the proposed action or Hwy 42 Alternative. No impact.

\section{Public Health and Safety}

\section{Direct Effects}

\section{No Action Alternative}

No anticipated impacts.

\section{Proposed Action}

Approximately 40 miles of pipeline construction would occur in roadways, creating short-term (1-7 days) delays for traffic. If individual vehicles, bicyclists, pedestrians, etc. fail to yield to flaggers and other warning signs and enter active construction areas without supervision, injury potential from heavy equipment or falling into the pipeline ditch would occur. Spill containment kits on site of active construction will be required.

\section{Hwy 42 Alternative}

Approximately 80 miles of pipeline construction would occur in roadways, creating long-term ( 6 months) delays for traffic. If individual vehicles, bicyclists, pedestrians, etc. fail to yield to flaggers and other warning signs and enter active construction areas without supervision, injury potential from heavy equipment or falling into the pipeline ditch would occur. Spill containment kits on site of active construction will be required.

\section{Indirect Effects}

\section{No Action Alternative}

No anticipated impacts.

\section{Action Alternatives}

Illegal use of explosives within or digging-up of soil containing the operational natural gas pipeline with heavy equipment such as a backhoe, could lead to physical injury to the participants in these activities. 


\section{Cumulative Effects}

All Alternatives, including No Action

None

Waste - Solid or Hazardous

\section{Direct, Indirect and Cumulative Effects}

No Action Alternative

No anticipated impacts.

\section{Action Alternatives}

No hazardous waste would be created by either action alternative. Each contractor will prepare and implement as necessary Spill Prevention and Control Countermeasure Plans (40 C.F.R. 112) for applicable equipment and their supplies. All solid waste from construction and/or construction crews will be removed offsite for disposal. Copies of the above will be maintained and made available on request by the pipeline construction contractor. Spill containment kits will be kept on site. No anticipated impacts.

\section{Land Uses}

\section{Forestry}

\section{Direct, Indirect and Cumulative Effects}

\section{All Alternatives, including No Action}

No impact.

\section{Livestock Grazing}

\section{Direct, Indirect and Cumulative Effects}

\section{All Alternatives, including No Action}

No impact.

\section{Recreation}

\section{Direct and Cumulative Effects}

\section{All Alternatives, including No Action}

No anticipated impacts. 


\section{Indirect Effects}

\section{No Action Alternative}

No anticipated impacts.

\section{Proposed Action}

No anticipated impacts.

\section{Hwy 42 Alternative}

Long-term (6 months) delays of traffic may influence recreationists' activities and other optional travel to other areas within driving distance containing similar recreational opportunities.

\section{Transportation}

\section{Direct Effects}

\section{No Action Alternative}

No anticipated impacts.

\section{Proposed Action}

Approximately 40 miles of pipeline construction would occur in roadways, creating short-term (1-7 days) delays for local traffic in those construction areas. Approximately 40 houses are adjacent to the portions of the CBW Road in the proposed action. Some residents may also experience the temporary inconvenience of traffic interference, including reduced speeds and stopped traffic in construction zones, due to pipeline installation and repaving activities.

\section{Hwy 42 Alternative}

Approximately 80 miles of pipeline construction would occur in roadways, creating long-term (6 months) delays in a number of locations simultaneously for a U.S. highway with high traffic volumes. The urban areas of Coquille and Myrtle Point, as well as approximately 200 houses in rural areas, boarder this route. Since Hwy 42 is a major access route, highway upgrades (including relocation, widening and straightening) are very likely. The risk of contractorinduced damage to the pipeline, as well as pipeline relocation, is also a possibility.

\section{Indirect Effects}

\section{No Action Alternative}

No anticipated impacts.

\section{Proposed Action}

No anticipated impacts.

\section{Hwy 42 Alternative}

Long-term (6 months) delays of traffic may influence tourist activity and other optional travel to the Coos Bay North Bend area for travelers whose only realistic travel option is the Hwy 42 corridor.

\section{Cumulative Effects}

\section{All Alternatives, including No Action}

No anticipated impacts. 


\section{Utility Corridors}

\section{Direct, Indirect and Cumulative Effects}

\section{All Alternatives, including No Action}

Current utility corridor management, management plans, activities and uses would continue unchanged. No impact.

\section{Conflicts with Other Plans}

The Council on Environmental Quality (CEQ) regulations (40 CFR 1502.16) require a discussion of "possible conflicts between the proposed action and the objectives of federal, regional, state and local (and in the case of a reservation, Indian tribe) land use plans, policies and controls for the area concerned."

The proposed action contains no known conflicts with any other plans, policies and controls. 


\section{IMPACTS SUMMARY TABLE}

\section{Table 34: Impacts Summary}

\begin{tabular}{|c|c|c|c|}
\hline & No Action Alternatives & Proposed Action & Hwy 42 Alternative \\
\hline $\begin{array}{c}\text { Aquatic } \\
\text { Ecosystems }\end{array}$ & $\begin{array}{l}\text { No beneficial impacts to sedi- } \\
\text { mentation, turbidity or physical } \\
\text { barriers (fish passage). }\end{array}$ & $\begin{array}{l}\text { Negligible short-term } \\
\text { impacts to sedimentation and } \\
\text { turbidity baselines. } \\
\text { Beneficial long-term impacts } \\
\text { to sedimentation and turbid- } \\
\text { ity baselines. Immediate } \\
\text { beneficial impacts to physi- } \\
\text { cal barriers (fish passage). }\end{array}$ & $\begin{array}{l}\text { Negligible short-term } \\
\text { impacts to sedimentation and } \\
\text { turbidity baselines. } \\
\text { Immediate beneficial } \\
\text { impacts to physical barriers } \\
\text { (fish passage). }\end{array}$ \\
\hline Air Quality & $\begin{array}{l}\text { No negative impacts. } \\
\text { No beneficial impacts from } \\
\text { reduced fossil fuel pollution. }\end{array}$ & $\begin{array}{l}\text { Negligible transitory, local- } \\
\text { ized, short-term impacts in } \\
\text { construction areas. } \\
\text { Beneficial long-term impacts } \\
\text { from reduced fossil fuel } \\
\text { pollution. }\end{array}$ & $\begin{array}{l}\text { Negligible transitory, local- } \\
\text { ized, short-term impacts in } \\
\text { construction areas. } \\
\text { Beneficial long-term impacts } \\
\text { from reduced fossil fuel } \\
\text { pollution. }\end{array}$ \\
\hline $\begin{array}{c}\text { Soil } \\
\text { Productivity }\end{array}$ & No negative impacts. & $\begin{array}{l}\text { Approximately } 56 \text { acres of } \\
\text { reduced soil productivity. }\end{array}$ & No negative impacts. \\
\hline T\&E Plants & No Effect. & No Effect. & No Effect. \\
\hline $\begin{array}{l}\text { Special-Status } \\
\text { Species }\end{array}$ & No Effect. & $\begin{array}{c}\text { Short-term disturbance of } \\
\text { individuals that utilize pow- } \\
\text { erline corridor or adjacent } \\
\text { habitats. }\end{array}$ & $\begin{array}{l}\text { Short-term disturbance of } \\
\text { individuals that utilize } \\
\text { adjacent habitats. }\end{array}$ \\
\hline $\begin{array}{c}\text { Survey \& } \\
\text { Manage Species }\end{array}$ & No anticipated impacts. & $\begin{array}{l}\text { Short-term disturbance to } \\
\text { red tree vole individuals that } \\
\text { utilize adjacent habitats. }\end{array}$ & $\begin{array}{l}\text { Short-term disturbance to } \\
\text { red tree vole individuals that } \\
\text { utilize adjacent habitats. }\end{array}$ \\
\hline Other Wildlife & No anticipated impacts. & $\begin{array}{l}\text { Short-term disturbance of } \\
\text { individuals that utilize pow- } \\
\text { erline corridor or adjacent } \\
\text { habitats. }\end{array}$ & $\begin{array}{l}\text { Short-term indirect effects } \\
\text { (disturbance) of individuals } \\
\text { that utilize adjacent habitats. } \\
\text { Direct effects on utility cor- } \\
\text { ridor species' habitats. } \\
\text { (shrubs, weeds and grasses } \\
\text { utilized by birds and rodents) }\end{array}$ \\
\hline \multicolumn{4}{|l|}{ T\&E Species: } \\
\hline Spotted Owl & No Effect. & $\begin{array}{l}\text { Disturbance impacts avoided } \\
\text { from timing restrictions. }\end{array}$ & $\begin{array}{l}\text { Disturbance impacts avoided } \\
\text { from timing restrictions. }\end{array}$ \\
\hline
\end{tabular}


Table 34: Impacts Summary

\begin{tabular}{|c|c|c|c|}
\hline & No Action Alternatives & Proposed Action & Hwy 42 Alternative \\
\hline $\begin{array}{l}\text { Marbled } \\
\text { Murrelet }\end{array}$ & No Effect. & $\begin{array}{l}\text { Disturbance impacts avoided } \\
\text { from timing restrictions. }\end{array}$ & $\begin{array}{l}\text { Disturbance impacts avoided } \\
\text { from timing restrictions. }\end{array}$ \\
\hline $\begin{array}{l}\text { Bald Eagle, } \\
\text { Columbian } \\
\text { White-tailed } \\
\text { deer, Western } \\
\text { Snowy Plover, } \\
\text { Brown Pelican }\end{array}$ & No Effect. & No Effect. & No Effect. \\
\hline Floodplains & No impact. & No impact. & No impact. \\
\hline $\begin{array}{l}\text { Waste (Solid or } \\
\text { Hazardous) }\end{array}$ & No impact. & No anticipated impacts. & No anticipated impacts. \\
\hline Traffic Safety & No impact. & $\begin{array}{c}\text { Short-term (1-7 days) } \\
\text { impacts in low-traffic CBW } \\
\text { Road. }\end{array}$ & $\begin{array}{l}\text { Long-term (6 months) } \\
\text { impacts in high-traffic Hwy } \\
42 .\end{array}$ \\
\hline Traffic Delays & No impact. & $\begin{array}{c}\text { Short-term (1-7 days) } \\
\text { impacts in low-traffic CBW } \\
\text { Road. }\end{array}$ & $\begin{array}{l}\text { Long-term (6 months) } \\
\text { impacts in high-traffic Hwy } \\
42 .\end{array}$ \\
\hline Financial Costs & No impact. & Approximately $\$ 34$ million. & Approximately $\$ 48$ million. \\
\hline $\begin{array}{c}\text { Economic } \\
\text { Benefits }\end{array}$ & $\begin{array}{l}\text { Loss of direct, indirect and } \\
\text { induced short and long-term } \\
\text { beneficial impacts. } \\
\text { Long-term increase in commer- } \\
\text { cial and residential fuel costs. } \\
\text { No increase in property tax } \\
\text { assessments to fund pipeline } \\
\text { construction bond. }\end{array}$ & $\begin{array}{c}\text { Approximately } \$ 13 \text { million } \\
\text { direct, indirect and induced } \\
\text { benefit from short-term } \\
\text { investment (pipeline con- } \\
\text { struction). } \\
\text { Long-term increase in jobs } \\
\text { available in Coos County } \\
\text { after pipeline construction. } \\
\text { Long-term reduction in com- } \\
\text { mercial and residential fuel } \\
\text { costs. } \\
\text { Property tax increase averag- } \\
\text { ing } \$ 19 \text { per county resident. }\end{array}$ & $\begin{array}{l}\text { Approximately } \$ 18 \text { million } \\
\text { direct, indirect and induced } \\
\text { benefit from short-term } \\
\text { investment (pipeline con- } \\
\text { struction). } \\
\text { Long-term increase in jobs } \\
\text { available in Coos County } \\
\text { after pipeline construction. } \\
\text { Long-term reduction in com- } \\
\text { mercial and residential fuel } \\
\text { costs. } \\
\text { Property tax increase averag- } \\
\text { ing } \$ 62 \text { per county resident. }\end{array}$ \\
\hline
\end{tabular}




\section{Chapter 5}

\section{Consultation and Coordination}




\section{Chapter 5}

\section{Consultation and Coordination}

Initial scoping of this project was administered by the BLM management team following the County Commissioner's initial meeting with BLM on April 28,2000. The scoping identified environmental issues and alternatives appropriate for inclusion in this Environmental Impact Statement. All concerns received from the various meetings (listed below) were evaluated. This resulted in the list of specific impact topics for detailed analysis in this EIS.

Public scoping was accomplished by inviting the public to the various meetings listed below. The public comments or questions were taken into consideration for the EIS assessment. The general issues received from the public were concerning socio-economic impacts of the proposed action, fish and wildlife concerns, and future impacts of the proposed action in regard to potential industrial growth within the County. Public comments and questions are presented in Appendix G. No comments received by the public varied from issues already identified in the initial scoping process with the BLM management team and Coos County. All public concerns regarding potential human/environment impacts are addressed in this EIS.

\section{List of Contributors}

Albert Oetting

Cultural Resources

Education: Ph.D Anthropology, University of Oregon

M.A. Anthropology, San Diego State University

B.A. Anthropology, University of California, Berkeley

Experience: 25 years

Robert Whelan

Socio-Economics

Education: B.S. Geology, Adelphi University

M.S. Mineral Economics, Pennsylvania State University

Post Graduate Courses, Economics, Columbia University

Experience: 22 years

Dave Leonard

Geotech and Soils

Education: B.S. Environmental Engineering, Southern Illinois University

M.B.A. Business Administration, University of Illinois

Experience: 29 years

Brian Cox

Plants, Fish, Wildlife and NEPA

Education: B.S. Wildlife Biology, University of Montana

M.S. Range Ecology, Texas A\&M University

Experience: 13 years 
Melanie Little

Fish, Wildlife and NEPA

Education: B.S. Wildlife and Fishery Science, University of Tennessee

Experience: 10 years

Ted Schattenkerk

Botany

Education: B.S. Range Science, Oregon State University

Experience: 30 years

Steve Shute

Pipeline Construction, Public Scoping

Education: B.S. Electrical Engineering, Kansas State University

Experience: 25 years

\section{Steve Oxford}

Pipeline Construction, Public Scoping

Education: B.S. Petroleum Engineering, Louisiana State University

Experience: 22 years

Technical matters related to this EIS (construction requirements, for example) were resolved with the help of specialists and consultants as listed in Table 35.

Table 35: Technical Consultation

\begin{tabular}{|l|l|}
\hline \multicolumn{1}{|c|}{ Consultant } & \multicolumn{1}{c|}{ Contribution Role } \\
\hline $\begin{array}{l}\text { Industrial Gas Services, Inc. } \\
\text { Pipeline Solutions, Inc. }\end{array}$ & $\begin{array}{l}\text { Project advisors; technical, permitting and construction require- } \\
\text { ments }\end{array}$ \\
\hline ECONorthwest & Economic analysis \\
\hline Dave Leonard & Geotechnical report \\
\hline Heritage Research Associates, Inc. & Cultural Resources study of the proposed action \\
\hline Biological Information Specialists, Inc. & EIS document and BAs \\
\hline
\end{tabular}




\section{Organizations Consulted}

BLM-Roseburg

BLM-Coos Bay

Coos County Commission

National Marine Fisheries Service

Oregon Dept. of Fish \& Wildlife

U.S.Fish \& Wildlife Service

Cow Creek Band of the Umpqua

Coquille Indian Tribe

Confederated Tribe of the Coos

Army Corps of Engineers

Oregon Public Utilities Commission

Bonneville Power Administration

NW Natural Gas

PacifiCorp (Pacific Power \& Light)

Oregon National Historic Preservation Administration

Table 36: Pipeline Meetings

\begin{tabular}{|l|l|}
\hline \multicolumn{1}{|c|}{ Date } & \multicolumn{1}{c|}{ Meeting } \\
\hline \hline January 7, 1999 & Work session - Natural Gas Pipeline - Commissioners' Courtroom, Coquille Courthouse \\
\hline January 25, 1999 & Chamber of Commerce Economic Development Committee \\
\hline February 22,1999 & Chamber of Commerce Economic Development Committee \\
\hline March 29,1999 & Chamber of Commerce Economic Development Committee \\
\hline April 21, 1999 & Economic Forum on Natural Gas \\
\hline April 26, 1999 & Chamber of Commerce Economic Development Committee \\
\hline May 19, 1999 & Work session - Natural Gas Pipeline - Commissioners' Courtroom, Coquille Courthouse \\
\hline June 2, 1999 & $\begin{array}{l}\text { Work session - Tim Bishop Re: Pipeline Project - Commissioners' Courtroom, Coquille Court- } \\
\text { house }\end{array}$ \\
\hline June 21, 1999 & Review of RFQ's - Commissioners' Courtroom, Coquille Courthouse \\
\hline June 28, 1999 & Chamber of Commerce Economic Development Committee \\
\hline July 13, 1999 & Radio Interviews KWRO \\
\hline July 26, 1999 & Chamber of Commerce Economic Development Committee \\
\hline July 26, 1999 & Democratic Central Committee \\
\hline July 28, 1999 & $\begin{array}{l}\text { Work session - Timing Issues Re Bond Measure for November Ballot - } \\
\text { Commissioners' Courtroom, Coquille Courthouse }\end{array}$ \\
\hline July 29, 1999 & Rental Owners Association \\
\hline August 19, 1999 & Board of Realtors \\
\hline
\end{tabular}




\section{Table 36: Pipeline Meetings}

\begin{tabular}{|c|c|}
\hline Date & Meeting \\
\hline September 1, 1999 & Hearing - Bond Measure - Coquille Annex Planning Conference Room \\
\hline October 1,1999 & McKinley Grange \\
\hline October 5, 1999 & Bay Broadcasting \\
\hline October 5, 1999 & Rotary - Natural Gas \\
\hline October 12, 1999 & Rotary - Natural Gas \\
\hline October 13, 1999 & FONSI Rally - North Bend Community Center \\
\hline November 4, 1999 & Economic Development -- SWOCC \\
\hline November 17,1999 & Economic Development Forum \\
\hline November 22, 1999 & Chamber of Commerce Economic Development Committee \\
\hline December 8, 1999 & $\begin{array}{l}\text { Hearing - Supplemental Budget (To include bond funds and give authority to spend funds received } \\
\text { for pipeline) }\end{array}$ \\
\hline March 8, 2000 & Commissioners interview Project Advisors, Courthouse. \\
\hline April 12,2000 & Work session with Industrial Gas Solutions, Inc. and Pipeline Solutions, Inc. \\
\hline April 12,2000 & OPUC hearing on NW Natural case - Coquille community center \\
\hline April 28, 2000 & * BLM staff meeting - North Bend BLM office \\
\hline May 17,2000 & $\begin{array}{l}\text { Open House - Pipeline - Coquille Annex Conference Room } \\
\text { Public meeting on pipeline, Courthouse basement. }\end{array}$ \\
\hline June 7,2000 & *Fed / State agency meeting, Coquille "War Room" \\
\hline July 12,2000 & Pipeline Town Hall Meeting - Courthouse Conference Room \\
\hline August 23, 2000 & Pipeline Meeting - Courthouse Conference Room \\
\hline October 3, 2000 & OPUC staff meeting - Salem OPUC offices \\
\hline October 23,2000 & * BLM Specialists Management Team - BLM offices, North Bend \\
\hline November 29,2000 & Pipeline Update Meeting - Coos Bay Council Chambers \\
\hline December 14,2000 & Work session - EA Public Comment Period - Commissioners' Courtroom, Courthouse, Coquille \\
\hline January 30,2001 & * Oregon Department of Fish and Wildlife \\
\hline April 4, 2001 & Public Scoping meeting for EIS - Coos Bay Library \\
\hline April 10, 2001 & Public Scoping meeting for EIS - Courthouse Conference Room \\
\hline April 18, 2001 & Public Scoping meeting for EIS - McKinley Grange \\
\hline
\end{tabular}

* Unless otherwise indicated by an asterisk, the meetings listed in Table 36 were open for public attendance. 


\section{Distribution List and Document Availability on the Internet}

This Draft Environmental Impact Statement is being sent to the following individuals, groups and organizations.

In addition, the draft EIS will be available on the internet at: the BLM web site (www.or.blm.gov/coosbay) and the Coos County web site (http://www.co.coos.or.us).

\section{Elected Officials}

Honorable Gordon Smith

Honorable Ron Wyden

Honorable Peter DeFazio

Governor's Office

Coos County Board of Commissioners

Douglas County Board of Commissioners

Curry County Board of Commissioners

\section{Federal Agencies}

USDI-Natural Resources Library

Director USDI BLM

Bureau of Mines

Fish and Wildlife Service

Mineral Management Service

National Park Service

Environmental Protection Agency

Office of Environmental Compliance

Department of Transportation

U.S. Geological Survey

USDI-BLM Library

Federal Energy Regulatory Commission

NW Power Planning Council

USDI-BLM State Director

Army Corps of Engineers

Bonneville Power Administration

National Marine Fisheries Service

Regional Environmental Officer, Office of the Secretary, DOI

Bureau of Indian Affairs

BLM Eugene District 
BLM Coos Bay District

BLM Roseburg District

BLM Medford District

\section{State, County and Local Governments}

Oregon Department of Fish \& Wildlife

Oregon Department of Environmental Quality

Oregon Department of Geology \& Mineral Industries

Fish and Wildlife Service

Oregon Water Resources Department

Oregon Public Utilities Commission

Oregon Department of Economic Development

Oregon Department of Energy

Oregon Department of Transportation

Oregon Division of State Lands

Historic Preservation Office

Parks and Recreation Department

Oregon Department of Land Conservation \& Development

Bandon Public Library

Coos Bay Public Library

City of Coos Bay

City of North Bend

Coos County Library Service District - Extended Services Office

Southwestern Oregon Community College Library

Coquille Public Library

Lakeside Pubic Library

Dora Public Library

Flora M. Laird Memorial Library

North Bend Public Library

Douglas County Library System

\section{American Indian Tribes and Nations}

Confederated Tribes of Coos, Lower Umpqua and Siuslaw Indians

Coquille Indian Tribe

Cow Creek Band of Umpqua 


\section{Businesses, Organizations and Individuals}

Association of O\&C Counties

Association of Oregon Counties

PacifiCorp

Coast Range Association

Industrial Gas Services Inc.

Richard D. Robertson

Pipeline Solutions Inc.

Pat \& John Simpson

Roberta Stewart

Robert and Carol Doty

Don Schoonmaker

Stephen Brown

Gary Montesano

Jolly Hibbits

B.I.S., Inc.

Bay Area Chamber of Commerce

Keith E. Vrell

Leo Taconi

Laura Hughes

Les Lemke, The Watch Report

Jason Reed

John and Jennifer Shank

Bob Gunther

Jaye Bell

Charlie Vincent

George and Eulia Johnson

Ronnie Herne

Mrs. Ruth Randall

Jim Brown

John and Peggy Swindle

Lester Barkley

Larry D. Tams

Hal K. Graham

Ron Sadler

Dana Gabb

Peter Ryan 
Christina Alexander

Bill and Pat Titus

Kalmiopsis Audubon Society

Douglas Timber Operators

Umpqua Watersheds, Inc.

Ronald S. Yockim

Pinnacle Engineering

Native Plant Society of Oregon

Klamath-Siskiyou Wildland Center 


\section{Appendices}

\section{List of Appendices:}

Appendix A. Geotechnical Engineering Report

Appendix B. Cultural Resources

Appendix C. Maps

Appendix D. Agency Management Plans for Resources Adjacent to the Proposed Action Corridor

Appendix E. Aquatic Ecosystem Assessment

Appendix E1. Essential Fish Habitat

Appendix F. U.S. Fish and Wildlife Service Endangered Species Consultation Letter of Concurrence

Appendix G. Questions and Concerns from the Public

Appendix H. Erosion Control Plan

Appendix I. Watersheds and Streams

Appendix J. Construction, Operation and Maintenance Plan

Appendix K. Survey and Manage Species

Appendix K1. Special-Status Species

Appendix L. Glossary of Terms

Appendix M. List of References 



\section{Appendix A. Geotechnical Engineering Report}

Site Reconnaissance and Construction Recommendations

for the Coos County Natural Gas Pipeline

Project

Prepared by:

Pinnacle Engineering, Inc.

3329 NE Stephens St.

Roseburg, OR 97470

Project \# 20517.2 


\section{GEOTECHNICAL ENGINEERING REPORT}

Roule Reconnaissance and Construetion Recommendations for the Copos County Natural Gas Pipeline P'roject

FOR:

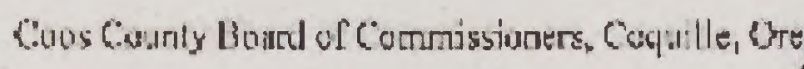

DATE: Novemhetr 28, 2001

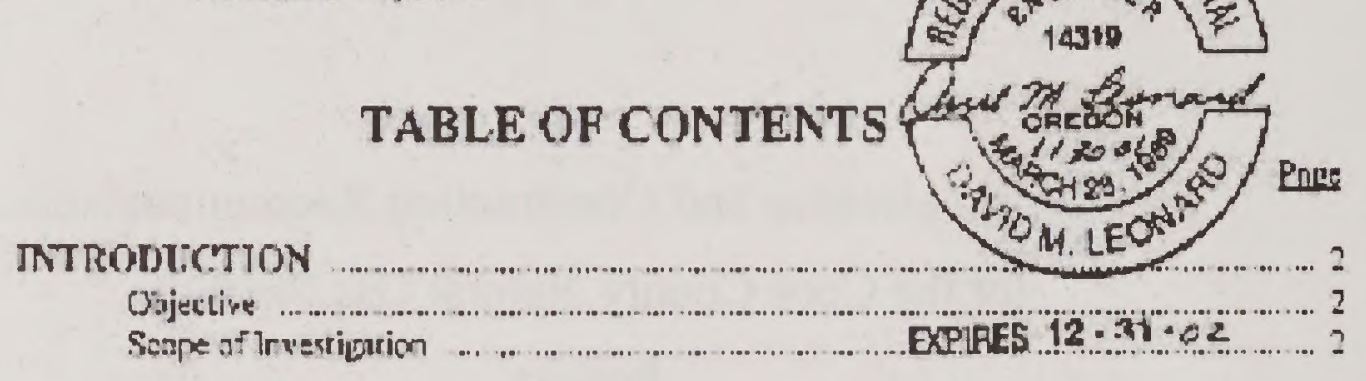

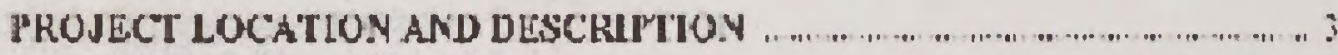

Site [ocation ard Desipiption .................................................................................... j

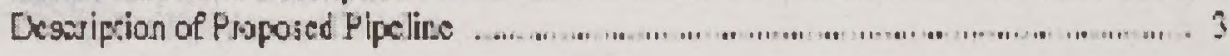

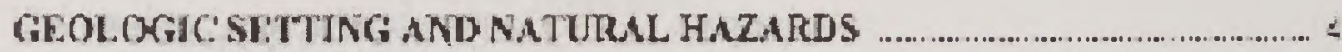

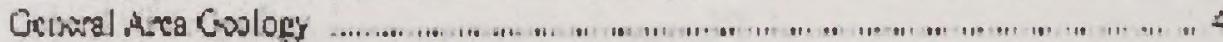

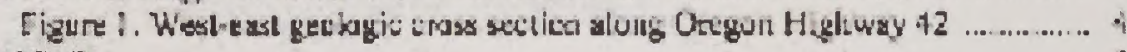

Surticial Soils .............................................................................................................. S

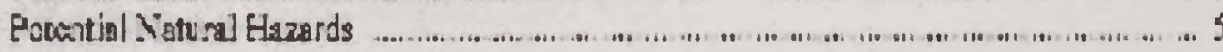

OBSERYATIONS AYD RECOMMEYDATIONS ............................

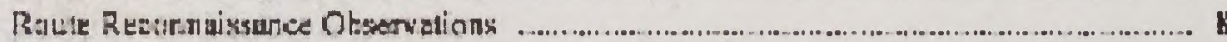

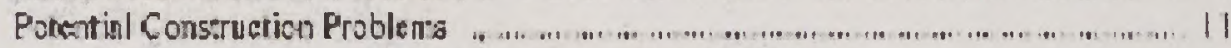

Figure 2. View of BPA power line an slexp lillside ....................................... 12

Fisure 3. Rias of BPA ponyar line up steep, 20 per eent, slspe ................... 12

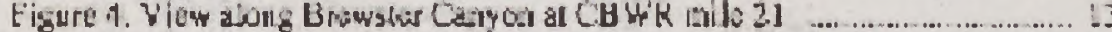

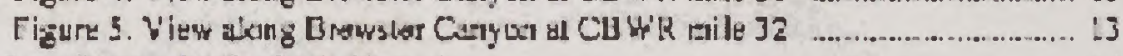

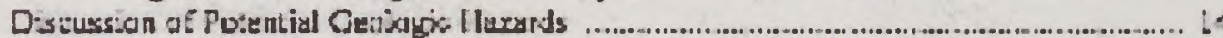

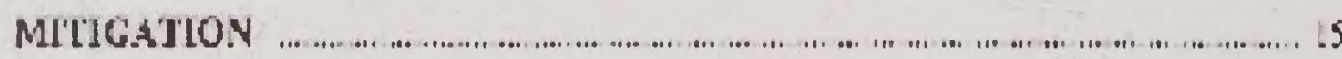

RECOMME.YDATIUYS HOK FUTLRE WOKK ................................... Is

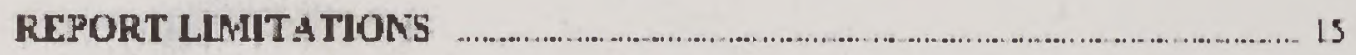

TABLL ], Sarrey of Foundation Soil and Rock, Coos County Naturn Gas Pipeline Projest . 17

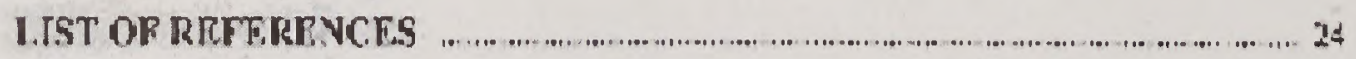

APPENDIX A - TOPOCRAPHIC M.APS OE PHOPOSED ALICNMENT ......... 20

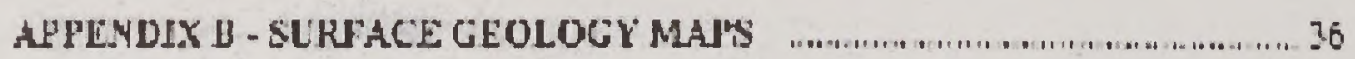




\section{Introduction}

\section{Objective}

The Coos County Natural Gas Pipeline ("the pipeline") is proposed for construction between Roseburg and Coos Bay, Oregon, along the route depicted in Appendix A. The route will utilize the rights-of-way of the Coos Bay Wagon Road (CBW Road) and the Bonneville Power Administration (BPA) power line and will pass through or near the communities of Lookingglass, Reston, Sitkum, Dora, McKinley, Fairview and Sumner, ending near Coos Bay.

Engineering design and construction of the pipeline will be directly affected by:

- geologic features,

- the type and thickness of soil deposits,

- depth to rock,

- gradient of soil and rock slopes within the construction limits,

- width of working space available,

- watercourses and stream crossings,

- natural and man-made obstacles.

This report presents the results of a geotechnical engineering reconnaissance survey of the proposed route. The observations and opinions presented herein are focused on constructability of the pipeline from a surface soils, i.e., geotechnical engineering, standpoint.

The original report was prepared by S. Joseph Spigolon, Ph. D., P.E. for the Coos County Board of Commissioners and Biological Information Specialists, Inc. Subsequent to preparation of the draft report and while agency review was being conducted, Dr. Spigolon succumbed to a sudden illness. Pinnacle Engineering, Inc. was then engaged to review Dr. Spigolon's report and agency review comments and to issue a final report, including responses to agency comments.

Also while agency review was being conducted, portions of the route alignment were changed from, that evaluated by Dr. Spigolon. Accordingly, geotechnical review and opinion of the revised route is also contained herein. The scope of services performed by Pinnacle for the route change were identical to those conducted for the original report.

Data presented in Dr. Spigolon's report [21] have been reviewed to the extent practical and, where appropriate, relied upon in this revised report.

\section{Scope of Investigation}

The level of investigation for this study was limited to reviewing appropriate geotechnical and geological literature and conducting a site observation and reconnaissance of the proposed pipeline route. The literature review searched for relevant information about project soils and surficial rock contained in published and unpublished geological and Soil Survey documents. Reconnaissance of the entire proposed pipeline route was conducted to observe soil and rock outcrops. morphology, limitations to construction access and evidence of existing or potential natural hazards. 


\section{Project Location and Description}

\section{Site Location and Description}

The proposed natural gas pipeline will start at the Williams Gas Pipeline metering facility southwest of Roseburg and end near Coos Bay. At Coos Bay, the pipeline will connect with proposed Northwest Natural Gas (NW Natural) distribution facilities to service the surrounding communities and possibly the industrial properties on the North Spit. All of the sixty mile route is to be located within existing rights-of-way of either the CBW Road and other public roads or within existing power line corridors. The pipeline route (maps) is depicted fully in Appendix C of this EIS.

Virtually the entire length of the proposed pipeline route is within the Coast Range, a long narrow band of moderately high mountains that ends in coastal headlands at Coos Bay. The Coast Range in Oregon extends from the Columbia River to the Middle Fork of the Coquille River at the southern limits of Coos County [1] ${ }^{1}$. The Coast Range is about fifty miles wide at the project location and the terrain, consisting of steep hills and sharp crests, ranges in height from sea level to crests at about 3,000 feet above sea level.

The Coast Range is mainly formed of weakly consolidated sandstone and siltstone and is easily weathered and eroded. The major streams in the area west of the Coast Range, including the East Fork of the Coquille River, flow westward toward the ocean or, in the Coos Bay area, north toward the bay. East of the Coast Range, the major streams flow easterly to the South Umpqua River, then north and west toward the ocean at Reedsport. The terrain is formed of a succession of ridges and small valleys. The heavily dissected erosion gullies are typically oriented northsouth. Many of the valleys have differences in elevation along the BPA power line route of 1,000 feet or more between ridge crest and valley bottom.

In the eastern 75 percent of Coos County and the western part of Douglas County, the soils along the proposed pipeline route are mostly well drained and loamy or clayey and are well suited to timber production [2] except in Brewster Canyon. Some of the land adjoining the route has been clear-cut by timbering operations. The rights-of-way of both the CBW Road and the BPA power line have been cleared as a result of prior construction activity.

\section{Description of Proposed Pipeline}

The main line of the Coos County Natural Gas Pipeline will consist of a 12.75-inch outside diameter, 0.25 inch wall thickness, welded steel pipe having a design pressure of 2,039 pounds per square inch gauge (psig). The maximum allowable operating pressure will be 1,000 psig. The pipe will be coated and packaged magnesium anodes will be attached at approximate 1,000 feet intervals to limit corrosion. Where the pipeline is constructed within the power line corridor, additional measures may be taken to mitigate potential hazards due to induced current.

A number of block valves will be included in the project. Mitigation of potential geologic and geotechnical impacts along the route will be accomplished by installation of an assortment of additional automatic and/or remote control valves at strategic locations to be selected during final design. Automatic or remote control valve locations will be selected during final design. Preliminary locations are recommended in subsequent sections of this report.

Pipeline construction will best be accomplished using a working space of 25 to 30 feet, which may require a total width of up to 60 feet in steep side slope areas. Where sufficient width is not available, short sections of the project may be constructed in a more restricted width.

The pipe will be installed with 36 inches of cover where practical. In areas with less than 3 feet depth to consolidated rock, a minimum of 24 inches of cover is allowed. The existing rights-of-way will be restored to current or better condition as construction is completed.

\section{Geologic Setting and Natural Hazards}

The following discussion of surface geology and natural hazards near or affecting the project route is based on published and unpublished information from the following sources:

1. Number in brackets [ ] refer to documents included in the List of References at the end of this report. 
- various bulletins and geologic maps published by the Oregon Department of Geology and Mineral Industries,

- reference texts discussing the geology of the project route,

- unpublished air photos and pedologic soil descriptions from the Douglas County Area Office of the Natural Resources Conservation Service, Roseburg,

- the Soil Survey of Coos County [2] published by the Natural Resources Conservation Service and

- various documents published by the USGS, including the Geologic Map and Database of the Roseburg Quadrangle.

\section{General Area Geology}

The bedrock forming the Coast Range consists of materials that were deposited in the ocean and later uplifted by tectonic action. Layers of basalt were deposited under water by volcanic activity and subsequently covered by sand and silt sediments eroded from the Klamath Mountains. Much later, after the sand and silt became sandstone and siltstone, the mass of rock was raised and crumpled into folds by the slow landward movement of the Pacific Ocean floor [3]. The present day outcrops of the rock show a sequence of north-south exposures consisting of a few relatively narrow bands of basalt interspersed with large, wide expanses of the sandstone and siltstone of several formations. The soils resulting from weathering of the underlying bedrock reflect the mineralogy of the parent rock. A west-east cross section of the route along U. S. Highway 42 [3, p. 106], south of and roughly parallel to the CBWR, is shown in Figure 1 as an illustration of the typical geologic section along the pipeline route.

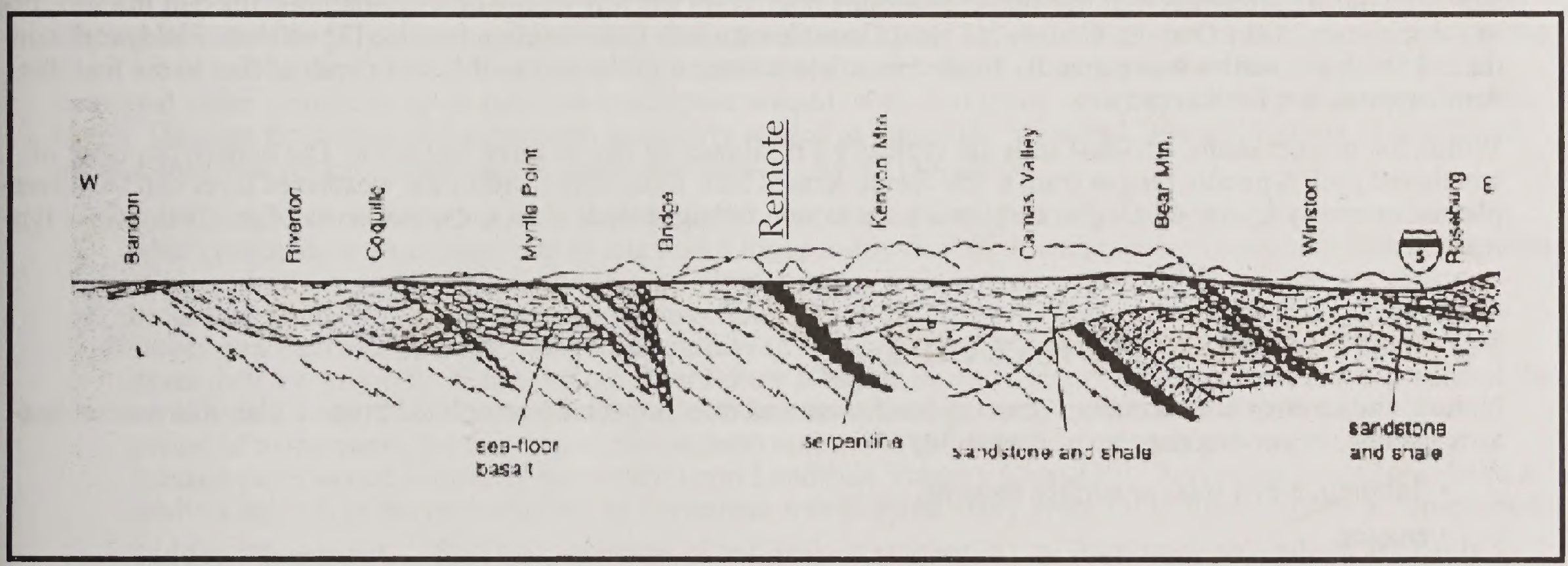

Figure A-1. West-east geologic cross-section along Oregon Highway 42, south of and parallel to the CBW Road, showing compression and tilting of strata.

The folding of the rocks illustrated in Figure A-1 resulted in a series of lineaments or fault lines, more or less oriented perpendicular to the direction of push $[4,5]$. These are ancient lines of movement and are not active fault lines.

Starting at the eastern end of the project, the bedrock underlying much of the city of Roseburg, and extending westward to the west slope of the hills immediately east of Lookingglass, is a layer of basalt. This is the Roseburg Formation, the basal member of the Umpqua Formation [6].

As the route enters Lookingglass Valley, the underlying bedrock is a rhythmically bedded sandstone and siltstone of the Lookingglass Formation. Near the western edge of the Lookingglass Valley, the pipeline route crosses the inactive Reston-Bonanza Fault. Between Lookingglass and Reston the terrain is underlain by the mudstone, siltstone and fine grained sandstone of the Flournoy Formation. 
West of Reston the route enters the outcropping of the Tyee Formation, an arkosic sandstone with siltstone interbeds. Arkosic sandstone is described in the geologic literature [7] as a light pink sandstone predominantly of feldspar and quartz, coarse grained, porous and easily eroded. Brewster Valley and the surrounding heavily eroded ridge and valley terrain are underlain by the Tyee Formation.

West of Dora the route enters a short north-south outcrop of the Lookingglass Formation, as described above [6].

Northwest of Dora, the area encompassing the communities of McKinley and Fairview is underlain by the Roseburg Formation. In this area, the bedrock is a rhythmically bedded sandstone and siltstone with localized, thin interbeds of basalt.

At the western end of the proposed pipeline, between Fairview and Coos Bay, the route is underlain by the sandstone and interbedded siltstone of the Coaledo Formation.

Surface geology along the route is depicted with maps at the end of this report.

\section{Surficial Soils}

Construction of the pipeline will be affected by the properties and thickness of surface and near-surface soils and the depth from the ground surface to underlying rock. Generally, the surface soils were derived from mechanical and chemical weathering of the underlying parent rock. Most of the soils within project limits are residual in nature, although significant expanses of transported soils, i.e., colluvial and alluvial material exist, especially in the western section.

Research during preparation of this report depended heavily on the soil profile descriptions contained in the soil survey documents of the Douglas County [11] and Coos County Soil Conservation Service [2] offices. Field work conducted for those studies was generally limited to a determination of the soil profile to a depth of five to six feet, the depth appropriate for this project.

Within the project limits, residual soils are typically a minimum of two to three feet thick. The underlying layer of weathered rock typically ranges from a few feet to tens of feet. Excavation within the weathered layer can be accomplished normally by use of a high energy track excavator. Along steeper slopes, the thickness of residual soils is typically less.

\section{POTENTIAL NATURAL HAZARDS}

Natural site hazards are naturally occurring conditions that may impact the completed project. Credible natural hazards include, in varying degrees of probability;

- flooding, either tidal or surface streams,

- erosion,

- mass soil movement, either creep or landslides,

- seismic activity, i.e., earthquakes, liquefaction and tsunamis,

- general land subsidence.

Of these potential natural hazards, only stream flooding, erosion, mass soil movement and seismic activity are considered credible potential natural hazards for the project.

\section{Stream Flooding}

Except in the alluvial floodplains around the several communities along the route and in Brewster Canyon, the proposed pipeline route is within the BPA power line right-of-way in the hillsides, well above stream levels and stream flooding is not a credible hazard. Stream flooding in the alluvial floodplains and in Brewster Canyon, however, is likely to occur during the design life of the project, but would only be significant to the extent that it affected integrity or operability of the completed pipeline. 
Integrity of the pipeline would not be affected by inundation, as the pipeline will be buried, air-tight and under internal pressure. Further;

- there is no record of past flooding of rivers and major streams to a degree that would compromise integrity of the proposed pipeline.

- the CBWR in Brewster Canyon, along the East Fork of the Coquille River, is rarely flooded above roadway level.

Operability of the pipeline, specifically certain of the valves, could be affected by flooding. Potential impacts to operability can be mitigated by location of critical valves above flood elevations or by incorporating design features that would allow valve operation regardless of flood conditions.

\section{Erosion}

Since the proposed gas pipeline is anticipated to be bored beneath major stream crossings, damaging erosion will be effectively mitigated by vertical separation. Minor erosion is possible at crossings of intermittent streams, but damage to the pipeline from such erosion is not credible.

\section{Mass Soil Movement}

Slopes are susceptible to mass movement any time the weight of the soil mass acting along the slope travel angle exceeds the soil shear strength available to resist the movement. Slope movement can occur even at a very gradual slope gradient. Naturally occurring landslides, those not caused by the action of man such as loading of the top of the slope or removal of soil at the bottom, invariably result from a decrease in shear strength of the soil mass due to increased water content or by an increase in effective weight of the soil mass, such as would occur during a seismic event. Damage from mass soil movement is directly related to Landslide Velocity Class and volume of mobilized mass. Landslide Velocity Class ranges from unnoticeable (creep) to sudden.

- Soil Creep. Soil creep is a very slow downhill movement of soil that is typically a continuous movement which proceeds at an average rate of less than a foot per decade [20]. It occurs more commonly in deep deposits of high plasticity soils on moderate slopes. Shrinkage cracks may form in the soil during the dry season, becoming partially filled with drier soil particles. During the following wet season, moisture content of the clayey soil increases, usually more at the surface than below. The moisture increase decreases the shear strength to a nearly critical state where shear failure is imminent and a slight movement can occur, greater at the surface than at depth. This combination of effects usually leads to very slow downhill movement. Over a period of many years, the movement can become noticeable and significant damage can occur. Severity of damage experienced is directly dependent upon Landslide Velocity Class [20]. Soil creep is not considered a credible hazard, as the probable rate of movement would allow many years for mitigation to be accomplished.

- Sudden Movement. Sudden movement of soil masses ranging in size from small to medium are likely to occur at several locations within the project limits during its design life. Locations of most concern are described in subsequent sections of this report, as are recommended mitigation measures.

\section{Earthquake}

Earthquakes are the result of a sudden differential displacement of a portion of the earth along a fault plane. The movement releases elastic energy that causes violent shaking of the earth's surface in both the horizontal and vertical directions. Such shaking can induce mass soil movement. As noted above, the historical record of earthquakes in Oregon only extends back to 1833 [15].

Earthquakes in Oregon originate from one of three different source areas [13, 14, 22]:

- Crustal earthquakes, that occur along relatively short and shallow faults that exist within the upper 6 to 12 miles of the surface. These are faults, such as those illustrated in Figure A-1, that are sometimes, but not always, visible at the surface and, therefore, may not create horizontal displacements at the ground surface. The resulting earthquake can reach a magnitude as large as 6.5 to 7 . The March 1993 Scotts Mills earthquake, magnitude 5.6, and the September 1993 Klamath Falls main shocks, magnitude 5.9 and 6.0, were crustal earth- 
quakes.

Intraplate earthquakes occur within the remains of the ocean floor, the San Juan de Fuca Plate, that has been subducted under the North American Plate. These are deep movements, occurring at depths of 25 to 37 miles below the ground surface, that can reach a magnitude as large as 7 to 7.5. The Puget Sound earthquakes of 1949 and 1965 were intraplate earthquakes.

- Cascadia Subduction Zone (CSZ) slippage. Great subduction zone earthquakes occur around the world when tectonic plates collide. The dipping interface between the two plates is the origin of some of the most powerful earthquakes ever recorded, often having magnitudes of 8 to 9 [22]. In the northwest, the Cascadia Subduction Zone has been recognized for many years, but no earthquakes have occurred during our 200 year recorded history. In the CSZ, the San Juan de Fuca Plate is slowly moving under the North American Plate along a line about 40 to 50 miles offshore extending from British Columbia to northern California. Sliding friction between the two plates is believed to be causing the edge of the North American Plate, in the region of the coastal area of the Coast Range, to bow upward. Periodically, the friction is believed to be overcome along a section of the CSZ, allowing that portion to drop a short distance and cause violent shaking.

Although no CSZ earthquakes have occurred in the past 200 years, there is widespread evidence that very large earthquakes have occurred repeatedly in the past, most recently about 300 years ago. The best available evidence indicates that CSZ earthquakes occur on average about every 500 to 540 years, with an interval between individual events ranging from $100-300$ years to about 1,000 years.

Discussion. Crustal earthquakes of low magnitude are common in northern and eastern Oregon, but not in the Coos-Douglas County area. Jacobson [16] plotted the Oregon earthquake database record on a map of Oregon and showed that there have been no earthquakes recorded within 50 miles of the proposed pipeline route except for a magnitude 3.0 quake in central Douglas County. Geologic evidence of fault movement has been summarized in the map by Madin and Mabey [17]. They showed that there has been no known fault movement within the past $1,600,000$ years along the route of the proposed pipeline. There are, however, a few faults that have moved within the past 10,000 years south of Coos Bay.

The major earthquake concern along the southern Oregon region is the potential for a CSZ displacement and the damage that would result. Geolcgic evidence of such events [18] indicates that at least five such earthquakes have occurred within the past 300 to 3,500 years, each occurring along a limited, 150 to 300 miles, length of the coast in the region between Vancouver, B.C. and northern California. It is estimated that the most recent event occurred about 300 years ago.

Estimates of coastal subsidence [18] for a subduction zone event are on the order of a maximum of 1.5 to 3 feet. This will create a ground acceleration of about $0.4 \mathrm{~g}$ (gravity) along the coast at Coos Bay [19] if that part of the coast is included in the CSZ slippage zone. The acceleration rate is attenuated by distance from the slippage so that acceleration of the bedrock at Roseburg would be reduced to about $0.2 \mathrm{~g}$ from the same event. A similar attenuation will occur at Coos Bay if the slippage occurs at some distance north or south along the length of the subduction zone.

The most severe damage due to earthquakes is commonly localized and generally caused by one or more of the following;

- Amplification of ground shaking by a soft soil column.

- Liquefaction of water-saturated sand, silt or gravel, creating areas of "quicksand".

- Landslides triggered by shaking, even on relatively gentle slopes.

- Amplification is not deemed a credible risk, as;

- The depth of soft soil and properties conducive to amplification do not generally exist along the alignment.

- Damage from amplification is most critical to above ground structures, where the fundamental site period and first period of vibration of the structure are similar.

Liquefaction can occur in deep, saturated deposits of loose, clean sand, gravel or silt if shaking causes the grain structure of the soil to lose inter-particle friction and collapse, i.e., a temporary loss of shear strength. When liquefied, the soil deposit behaves like a viscous liquid. Since deposits subject to liquefaction are not likely to exist along the proposed pipeline route, liquefaction is not considered a credible risk to the project.

Landslides triggered by shaking, although low probability, are deemed the most likely seismically induced hazard that could affect the project. Mitigation measures for seismically induced landslides are identical to those recommended for landslides induced by increased moisture and are described in subsequent sections of this report. 


\section{Observations and Recommendations}

\section{Route Reconnaissance Observations}

Six visual reconnaissance trips [21] along the proposed route of pipeline were made for this report, four by vehicle on the Coos Bay Wagon Road and one each by helicopter and airplane along the BPA power line route. The objective of each reconnaissance trip was to observe soil and rock outcrops, slopes, width available for construction, and to discover evidence of existing or potential natural hazards. In addition, several segments of the BPA right of way, where potentially significant problem areas were noted by aerial or photo reconnaissance, were observed on foot.

A tabulated summary of the near-surface soils along the route is contained in Table A-1, Survey of Foundation Soil and Rock, Coos County Natural Gas Pipeline, included subsequently in this report. The information and observations contained in Table 1 were derived from a combination of;

- field and office interpretations of geologic features along the route,

- field and office interpretations of the Douglas County and Coos County Soil Survey data cited above and

- field observations made during the six reconnaissance trips.

The proposed route of the Coos County Natural Gas Pipeline, consists of six distinct sections:

a) from the connection to the Williams pipeline south of Roseburg to about the Coos County line, west of Reston, it will follow the Pacificorp/ BPA rights-of-way.

b) at the Coos/Douglas County line, the pipeline will follow the right-of-way of the CBWR through Brewster Canyon to three miles west of Dora.

c) from three miles west of Dora to the Lone Pine Bridge, it will follow the BPA right of way.

d) from the Lone Pine Bridge to McKinley, it will follow the CBWR.

e) from McKinley to Fairview it will first follow the power line right of way, then from Fairview to the Coos City Bridge, it will follow the CBWR.

f) the final segment will rejoin the BPA right-of-way and continue to the end of the pipeline near Coos Bay.

Physical conditions along the pipeline route are generally described as;

1. Section from Williams Pipeline to Lookingglass. This five-mile section of the project passes through a hill of basalt with an overlying layer of high plasticity clay soil. Slopes along the roadway and the Pacificorp power line are typically less than 10 percent, although a short section of between 20 and 40 percent slope exist as the route descends into the Lookingglass Valley.

The soil is estimated to be over five feet thick along the power line. There are two rock quarries at ground level near the alignment, indicating a possible thin soil overburden at isolated locations. The soil in Lookingglass Valley is quaternary alluvium, typically firm, with depth to rock greater than five feet.

Between the Williams sub-station and Lookingglass, the pipeline will cross a small remnant of an ancient landslide and a localized seepage area along the east slope of Powderhouse Canyon. Neither of these features are likely to impact project integrity or constructability.

2. Section from Lookingglass to Reston. At the Lookingglass Valley, bedrock is sandstone and siltstone of the Flournoy Formation and the residual soils are sandy clay and silty clay of low plasticity. Because of low resistance to erosion, the rocks in this region and the remainder of the route are at an increased slope gradient and the valleys are deeper. Both the CBWR and the power line sometimes follow hillsides. Slopes along the paved roadway and the BPA power line are typically less than 10 percent, although short sections exist where the slope is between 20 and 45 per- 
cent. Soil thickness over rock is generally greater than five feet along both the CBWR and power line routes. The roadway is a full two lanes wide in this section of the project.

West of Lookingglass, as the pipeline joins the road, a hummocky area was noted on the south side of the road. At Reston, a short stretch of recent slumps were noted. Neither of these features are likely to impact project integrity or constructability, however, the slumps should be further investigated during final design and mitigated conventionally.

3. Section from Reston to Sitkum. West of Reston the CBWR enters hillier terrain, the most rugged along the proposed route. Bedrock is soft sandstone and siltstone of the Tyee Formation and is heavily eroded. Residual soils over the rock are either sandy or silty clay of low to moderate plasticity. Depth of soil along the steep hillside route of the BPA power line is generally more than five feet.

Hillside slopes along the power line are typically greater than 20 percent and reach as much as 33 percent. Short stretches exist that are steeper. Ridges can be as much as 1,000 and more feet apart with 1,000 feet of elevation change from ridge top to valley bottom.

The power line route crosses a small slump and a large hummocky area before descending to join the CBWR. At the junction of the power line right of way and the CBWR, the alignment passes longitudinally through an ancient landslide. None of these features are likely to affect project integrity or constructability, although landslide mitigation measures discussed more fully herein should be incorporated.

The CBWR enters Brewster Canyon near the Coos County line. Between the Coos County line and Sitkum, the Brewster Valley route of the CBWR is in a deep valley created by the East Fork of the Coquille River. The roadway is unpaved and is at the bottom of a series of steep, nearly vertical, rock cliffs. The width of the roadway varies from one lane to barely two lanes and the width from cliff face to river drop-off is occasionally less than 30 feet. The road generally follows very close to the river which is typically at some depth below roadway level. The river bottom is exposed and appears to be unweathered rock. The depth of soil along the roadway is unknown but is probably less than five feet except, perhaps, at the edge away from the cliff face. The roadway generally is at a gentle grade and crosses the Coquille River twice over bridges. Sitkum is at the entrance to the Brummit Creek valley.

Except for short sections where competent rock may be within three feet of surface, there are no features of geotechnical concern in the CBWR segment.

4. Section from Sitkum to Dora. This section of the CBWR also follows Brewster Canyon and the Tyee Formation, but is slightly less rugged. Roadway widths continue to be narrow and rock cliffs still form one side of the unpaved roadway. Soil depth along the roadway is still probably less than five feet. Slopes along the BPA power line remain steep, often reaching 26 percent to 28 percent, with long distances between ridge lines. Depth to fractured sandstone in the hillside soils is occasionally less than five feet.

A geologic map [5] of the area indicates that there are small sections, each between 100 and 3,000 feet long, along either the CBWR or the East Fork of the Coquille River, that consist of landslide deposits of geologically recent (Holocene and Pleistocene epochs, i.e., within the past 1,600,000 years) age. These deposits are described as "fragments of bedrock mixed with gravel, sand, silt or clay." Observations of these "landslide" areas concluded that they are mainly characterized by more gentle slopes than the surrounding hills and large, over 15 feet wide, boulders scattered about. This is typical of the debris at the lower part of a slide in the soft sandstone and siltstone bedrock. The slides are ancient, as demonstrated by formation of the Coquille River floodplain at several areas at the bases of the slides and weathering of the exposed surface of the boulders. These slides appear to be stable and are not likely to impact project integrity or constructability.

5. Section from Dora to McKinley and Fairview. At Dora the CBWR and the BPA power line leave the valley of the East Fork of the Coquille River and Brewster Canyon and turn northwest. Bedrock is the Roseburg Formation consisting of sandstone and siltstone with localized, thin interbeds of basalt. The residual soils are a sandy or silty clay of low to moderate plasticity. Soil depths appear to be greater than five feet. The terrain is less rugged than along the Brewster Canyon segment, although hillside slopes along the BPA power line route can reach as much as 15 percent to 20 percent. The roadway becomes two-lane and paved at McKinley and remains paved to just beyond Fairview. 
One mile west of Dora, an ancient landslide similar to that described above is located north of the CBWR. A recent rockfall was noted clear of the route, south of the CBWR about 1.1 miles northwest of McKinley. Neither of these features are likely to impact project integrity or constructability.

6. Section from Fairview to Sumner. At Fairview, the pipeline continues along the CBWR, which is unpaved for several miles but is at least two lanes wide. The terrain continues to be more gentle than that to the east, with hillside slopes ranging from 5 percent to 12 percent. Short sections of steeper topography exist. Soil depths are expected to be greater than five feet.

There are no features of geotechnical concern which would impact project constructability or integrity in this segment.

7. Section from Sumner to near Coos Bay. After passing South Slough Road, the BPA power line and the proposed pipeline route leave the CBWR and continue along the Coos-Sumner Road, finally reaching and crossing Isthmus Slough and U. S. Highway 101. West of the highway the BPA power line turns north to the end of the proposed pipeline near Coos Bay. Bedrock is Coaledo Formation sandstone and siltstone and continues to be less rugged, with much more gentle slopes.

There are no features of geotechnical concern which would impact project constructability or integrity in this segment, although the horizontal bore beneath Isthmus Slough will require typical scrutiny during final design.

\section{POTENTIAL CONSTRUCTION PROBLEMS}

There are no particularly unusual or difficult construction problems anticipated for the proposed pipeline project. Soils over most of the route will be deep enough and firm enough to stand open without bracing the three to four foot deep trench necessary for construction and will not be below the groundwater level, except at isolated locations. Where the pipeline is located within the roadway, short sections may be encountered where depth to competent rock is less than five feet. We anticipate, however, that most of these areas can be excavated to a satisfactory depth using a high energy track hoe.

Final design is expected to be typical for the size, type and location of the proposed project. Of normal concern are;

1. Sideslope Construction. Along several locations, the BPA power line was constructed on relatively steep sideslopes, illustrated by Figure A-2. Since pipeline construction equipment will require a reasonably level working space of 25 to 30 feet wide, as much as 60 feet in width will be required to allow excavation and leveling of the work area. Except for minor impacts on schedule, this feature does not present unusual complexity.

2. Steepness of Slopes. The heavily eroded ridge and valley ground surface along the route from Reston to Dora has resulted in very steep slopes with large elevation differences between the ridge top and valley bottom. Steep slopes reaching, and occasionally exceeding, 20 percent grade exist along the sections of the pipeline originally proposed to be placed in the BPA power line right-of-way. This is illustrated in Figure A-3. 


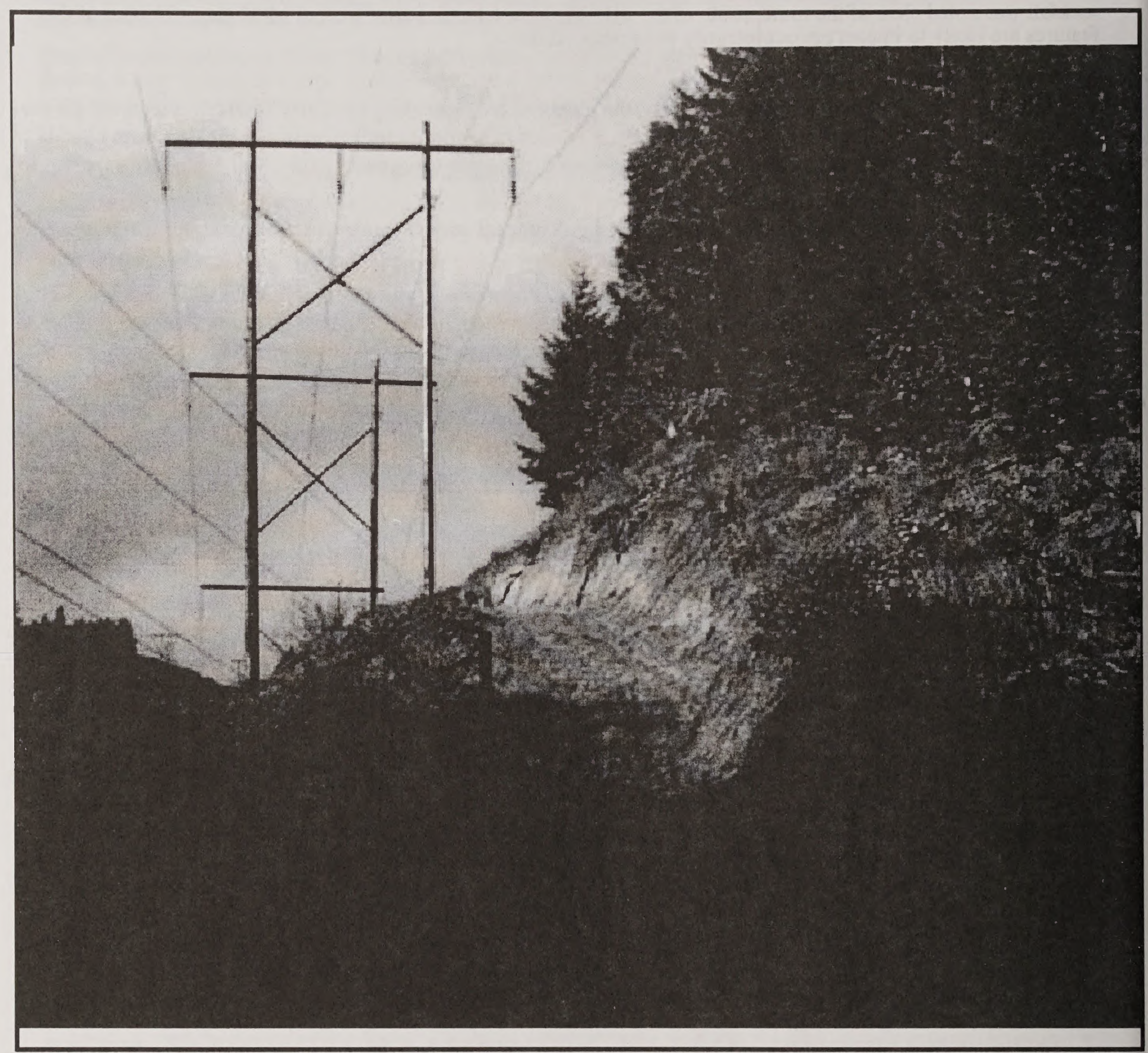

Figure A-2. View of BPA powerline on steep hillside at Mile 10 on CBW Road. 


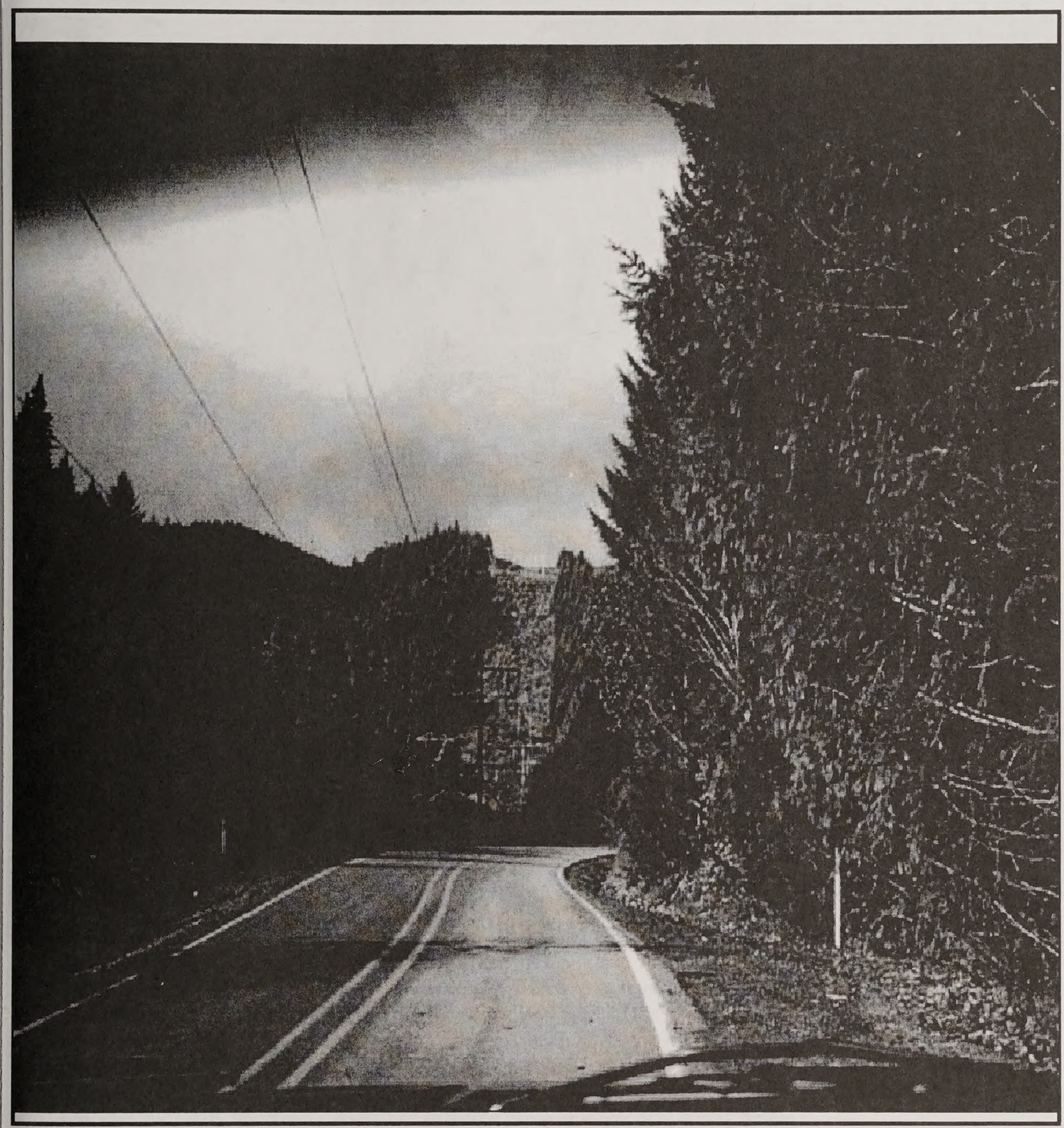

Figure A-3. Rise of BPA powerline up steep 20 percent slope at Mile 13 on CBW Road 
Figure A-4. View along Brewster Canyon at Mile 21 on CBW Road. Left side of road leads down at steep angle to the East Fork of the Coquille River

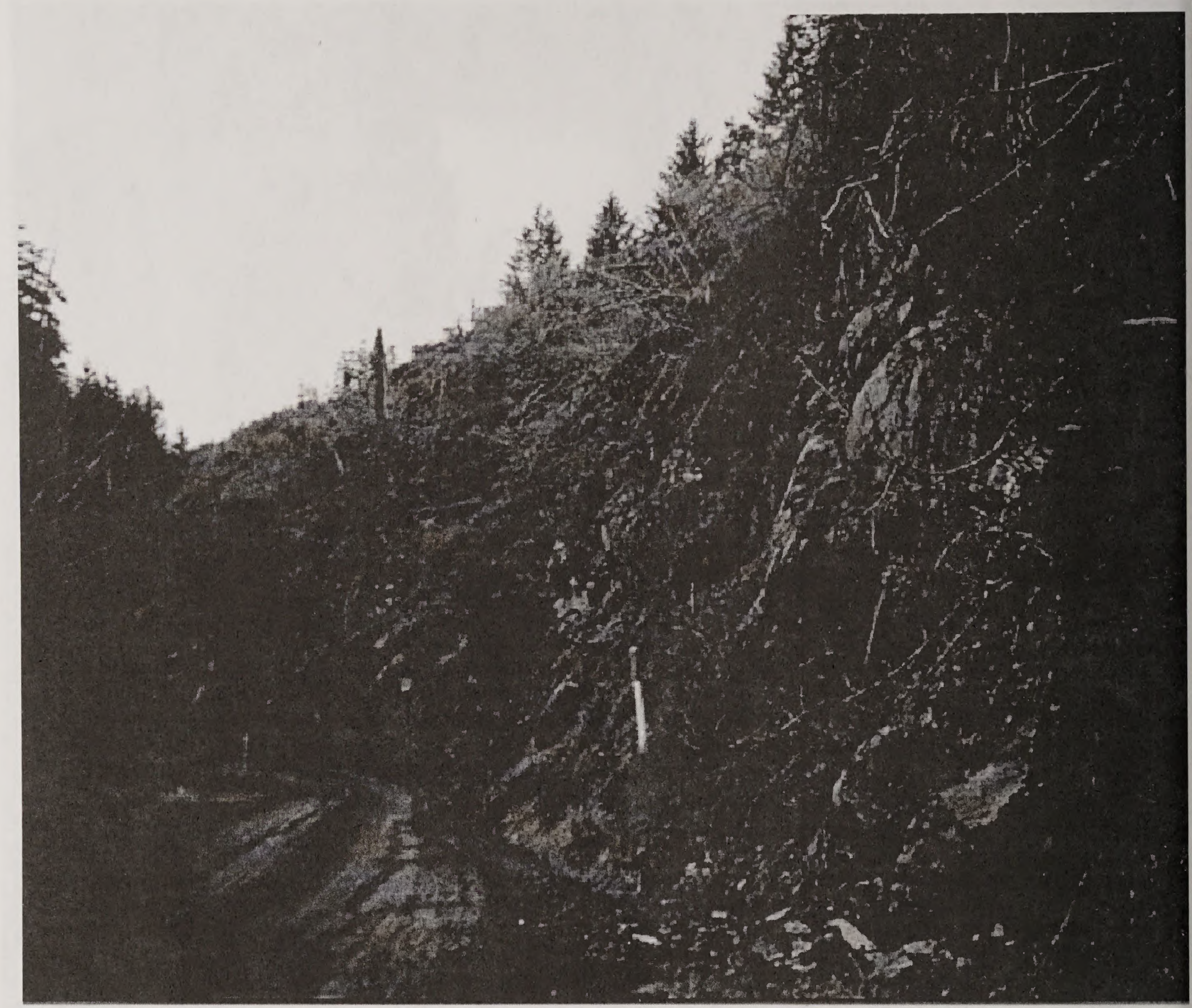


Figure A-5: View Along Brewster Canyon on CBW Road.

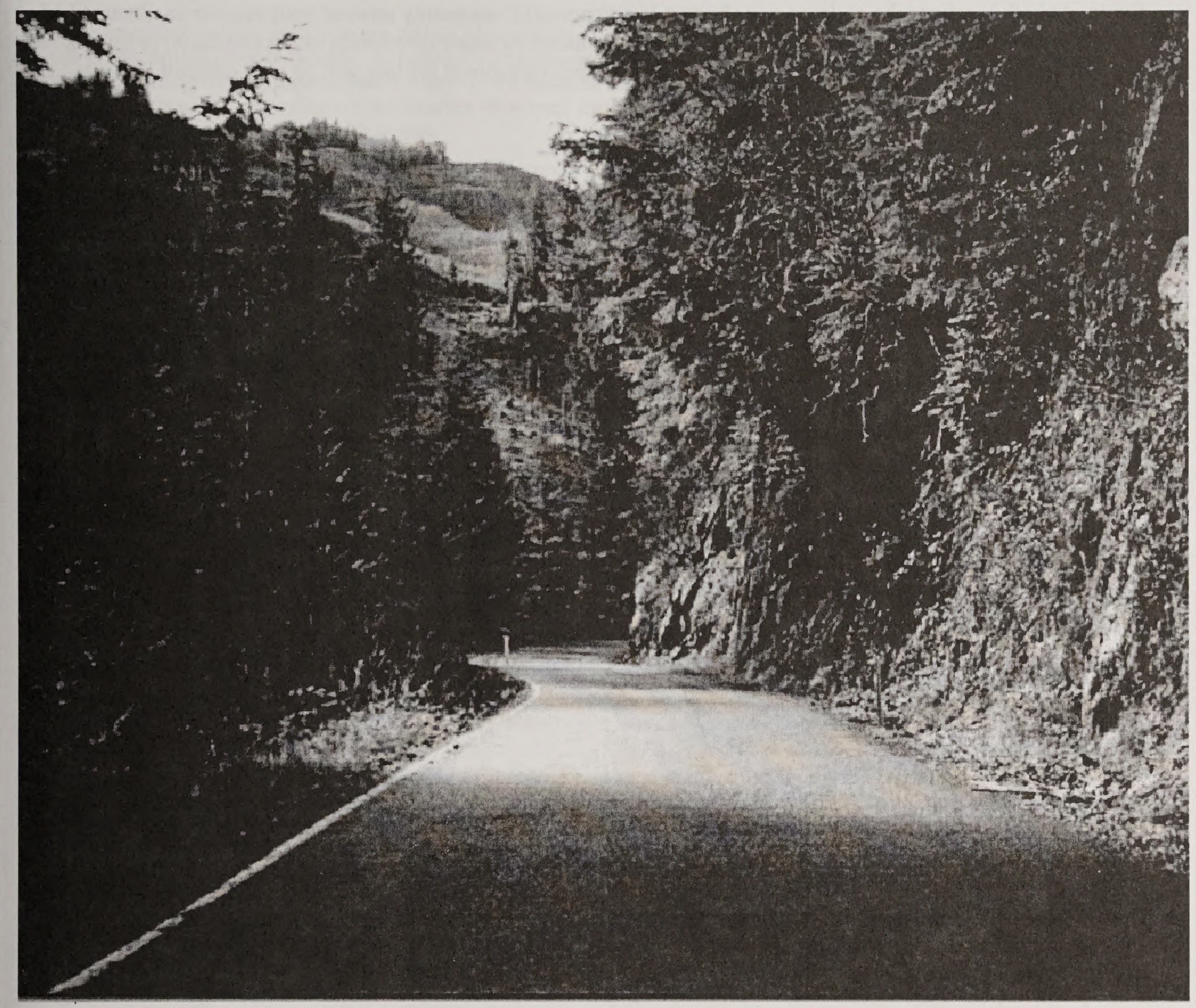

3. Shallow Depth to Rock. At a few locations along the Coos Bay Wagon Road, especially in Brewster Canyon, the depth to rock along the centerline of the roadway may require isolated use of air tools to achieve the desired three feet of cover. Sections of the CBWR that may have rock very close to the roadway surface are illustrated in Figure 3 and 4 and are more fully delineated in Table A-1. Since depth of competent rock has not been verified by field test, inferred instead from the appearance of rock along the side of the road at roadway level and from the probable method of construction used during the 1870 's, locations determined to be especially problematic or to pose unacceptable budgetary uncertainty should be explored using an auger drill during design.

Considering the recent experience gained during construction of a separate underground utility project, for which a trencher was used with little difficulty to excavate a three to four feet deep trench, we anticipate that rock excavation requirements will not be unusually difficult. 
4. Rock in Coquille River. At two locations in Brewster Canyon, the CBWR crosses the East Fork of the Coquille River. At both locations the exposed river bottom is composed of apparently unweathered sandstone-siltstone bedrock. We recommend that these two crossings be accomplished by either direct excavation and burial or by suspending the pipeline from the two existing bridge structures, since directional drilling will be very difficult.

\section{Discussion of Potential Geologic Hazards}

The steel, continuously welded and buried pipeline is similar to a long elastic string and can sustain some general lateral and/or vertical movement or direct tension. The potential causes of rupture of the pipeline along the proposed route are either shearing movement of the supporting soil, in which there is an abrupt lateral and/or vertical displacement of soil and pipeline, or a tensile failure resulting from the pipeline being "stretched" as it resists a sliding soil mass. Shear or tensile forces are most likely to result from landslides.

\section{Seismic Activity}

Earthquake shaking of the ground causes general ground movement but does not normally cause surface shearing movements. The principal source of earthquake induced shear displacement at the surface is landslides, which can be triggered by a seismic acceleration of the soil mass.

The probability of an earthquake-induced landslide resulting in shearing of the pipeline is dependent on earthquake recurrence interval. As noted in preceding sections of this report, the principal seismic concern is a CSZ event originating along a line about 40 to 50 miles off the coast of Oregon, resulting in lateral accelerations between 0.2 and 0.4 g. Although the probability of a CSZ event occurring during the design life of the project is highly speculative, if one does occur, it is more probable than not that landslides will result. Accordingly, mitigation of potential landslide impacts should be incorporated into the design.

\section{Moisture Induced Landslides}

Moisture induced landslides is deemed no more likely along the proposed route than in any other route that would logically serve the project. Considering the high ductility of the pipe material and the considerable tensile strength of the completed pipeline, along with the probable size of conceivable instabilities, we believe that landslide induced failure of the pipeline is of low probability.

Although landslide induced failure of the pipeline is of low probability, several past instabilities were noted during project reconnaissance, as more fully described in the preceding Route Reconnaissance Observations. Mitigation measures are recommended subsequently herein.

The effect of recent timbering clear cuts on the inducement or probability of landslides along the route cannot be assessed adequately with the limited information available for this study. Generally, however, we anticipate that timber activities will have no impact on stability of the pipeline.

\section{Erosion}

The potential for erosion exists along the pipeline alignment at virtually any of the stream crossings. Considering the very short sections of pipe at most crossings, along with the pipe's ductility, few of the crossings should require special attention during design. At most locations, if permit conditions allow, we recommend that the pipeline should be buried beneath the stream bottom using conventional excavation instead of boring.

Several of the crossings under more substantial streams should be bored. Preliminarily, the recommended boring locations include;

- Brummit Creek

- Cherry Creek

- Middle Creek

- North Fork of the Coquille

- Isthmus Slough

- Blossom Gulch Creek 


\section{MITIGATION}

The proposed project is of average or less complexity. There is little risk of impact to constructability or integrity due to geotechnical considerations. Seismically induced impacts are of low probability. To the extent that short term pipeline integrity is compromised by any of the hazards noted herein, however, mitigation is recommended. All potential impacts, regardless of probability or source can best be mitigated by installation of automatic or remotely controlled valves at strategic locations.

Although the final location, type and special features, if any, of the valves are best addressed during final design, we recommend that automatic or remote control valves be considered at the following locations;

- Williams sub-station connection

- east side of Douglas County Road 52

- Reston

- Dora

- Isthmus Slough at Ross Slough Road

\section{RECOMMENDATIONS FOR FUTURE WORK}

As a result of this reconnaissance level study, we are satisfied that no additional geotechnical work is necessary for the current phase. During final design, a number of other efforts, including site specific geotechnical exploration, will be beneficial.

\section{REPORT LIMITATIONS}

Exclusivity of Report. This report has been prepared for the exclusive use of the Coos County Board of Commissioners and Coquille, Oregon, and/or their designees for specific application to the proposed Coos Bay Natural Gas Pipeline, Coos-Douglas Counties, Oregon. No other use is authorized without the written permission of Pinnacle Engineering, Inc., Roseburg, Oregon.

Report Limited to Scopes of Service. The observations and conclusions described in this report are based solely on the scope of service described in and implemented pursuant to the Agreement of August 27, 2000, between Biological Information Specialists, Camas Valley, Oregon, and Dr. S. Joseph Spigolon, P.E. as supplemented by contract dated October 17, 2001, between Pinnacle Engineering, Inc. and Coos County, Oregon. Neither Spigolon nor Pinnacle have performed any observation, investigation, study or testing that is not specifically listed in the scope of service and, therefore, shall not be liable for failing to discover any condition whose discovery required the performance of services not authorized by the Agreement.

Conceptual-level Study. The visual reconnaissance and evaluative approaches used in this limited, preliminary study are believed to be consistent with those normally used in geotechnical engineering practice for preparation of environmental documents. The scope of our effort was intentionally less than that required for design purposes, but is deemed are sufficient for developing preliminary design guidelines. When design concepts have been better defined, soil/rock sampling and testing, and additional evaluation should be considered for use in final design. 
Table A-1. Survey of Foundation Soil and Rock, Coos County Natural Gas Pipeline

\begin{tabular}{|c|c|c|c|c|}
\hline $\begin{array}{l}\text { CBW } \\
\text { Road } \\
\text { miles }\end{array}$ & $\begin{array}{l}\text { Power line } \\
\text { miles } \\
\text { (approx.) }\end{array}$ & Route Features & $\begin{array}{c}\text { CBW Road Soils/Rock and } \\
\text { Comments }\end{array}$ & $\begin{array}{l}\text { BPA Power line Soils/Rock } \\
\text { and Comments }\end{array}$ \\
\hline \multirow[t]{2}{*}{0.0} & 0.0 & $\begin{array}{l}\text { William's Northwest } \\
\text { Pipeline; start of Coos } \\
\text { County pipeline. } \\
\text { Enter Section } 28 .\end{array}$ & $\begin{array}{l}\text { Dark brown clay; high plasticity; } \\
\text { residuum derived from basalt bed- } \\
\text { rock; depth to rock }<5 \mathrm{ft} \text {. No evi- } \\
\text { dence of soil creep - trees are } \\
\text { vertical. Road is paved in Dou- } \\
\text { glas County. }\end{array}$ & $\begin{array}{l}\text { Pacificorp transmission line. Same } \\
\text { as CBW Road; average } 10 \text { percent } \\
\text { slopes. }\end{array}$ \\
\hline & 1.2 & Powderhouse Canyon. & Same as above. & $\begin{array}{l}\text { Same as above; slopes about } 6 \text { per- } \\
\text { cent. }\end{array}$ \\
\hline \multirow[t]{2}{*}{1.9} & & Basalt rock quarry. & $\begin{array}{l}\text { Rock at or very near road sur- } \\
\text { face. Slopes about } 6 \text { percent. }\end{array}$ & \\
\hline & 1.7 & $\begin{array}{l}\text { Tributary of Marsters } \\
\text { Creek. }\end{array}$ & & $\begin{array}{l}\text { Black clay; alluvium from weathered } \\
\text { basalt; high plasticity; depth }>5 \mathrm{ft} \text {. }\end{array}$ \\
\hline 3.0 & 2.8 & $\begin{array}{l}\text { Slope down to enter } \\
\text { Lookingglass Valley. }\end{array}$ & $\begin{array}{l}\text { Gray brown gravelly silty clay; } \\
\text { moderate plasticity; alluvium } \\
\text { from sandstone; flat; depth }>5 \mathrm{ft} \text {. }\end{array}$ & $\begin{array}{l}\text { Same as CBW Road; slopes average } \\
10 \text { percent. }\end{array}$ \\
\hline \multirow[t]{2}{*}{3.2} & 3.1 & $\begin{array}{l}\text { Tributary of Looking- } \\
\text { glass Creek; in valley. }\end{array}$ & $\begin{array}{l}\text { Brown sandy clay; moderate to } \\
\text { high plasticity; mixed alluvium; } \\
\text { flat; depth }>5 \mathrm{ft} \text {. }\end{array}$ & $\begin{array}{l}\text { Same as CBW Road; flat grade; } \\
\text { depth }>5 \mathrm{ft} \text {. }\end{array}$ \\
\hline & 3.6 & $\begin{array}{l}\text { Tributary of Looking- } \\
\text { glass Creek; in valley. }\end{array}$ & $\begin{array}{l}\text { Brown clay; moderate plasticity; } \\
\text { alluvium; flat; depth }>5 \mathrm{ft} \text {. }\end{array}$ & $\begin{array}{l}\text { Same as CBW Road; flat grade; } \\
\text { depth }>5 \mathrm{ft} \text {. }\end{array}$ \\
\hline 4.5 & 3.9 & $\begin{array}{l}\text { Downtown Looking- } \\
\text { glass; intersection of } \\
\text { Lookingglass Road } \\
\text { and CBW Road; CBW } \\
\text { Road turns west; enter } \\
\text { Sec. } 35 \text {. }\end{array}$ & $\begin{array}{l}\text { Brown clay; moderate to high } \\
\text { plasticity; mixed alluvium; flat; } \\
\text { depth }>5 \mathrm{ft} \text {. }\end{array}$ & $\begin{array}{l}\text { Same as CBW Road; flat grade; } \\
\text { depth }>5 \mathrm{ft} \text {. }\end{array}$ \\
\hline 4.6 to 5.1 & 4.0 to 4.5 & $\begin{array}{l}\text { Three tributaries of } \\
\text { Lookingglass Creek; } \\
\text { valley. }\end{array}$ & $\begin{array}{l}\text { Brown clay; moderate to high } \\
\text { plasticity; mixed alluvium; flat; } \\
\text { depth }>5 \mathrm{ft} \text {. }\end{array}$ & $\begin{array}{l}\text { Same as CBW Road; flat grade; } \\
\text { depth }>5 \mathrm{ft} \text {. }\end{array}$ \\
\hline 5.9 & 5.4 & $\begin{array}{l}\text { Power line crosses } \\
\text { road; substation. }\end{array}$ & $\begin{array}{l}\text { Brown silty clay; moderate to } \\
\text { high plasticity; colluvium; road in } \\
\text { hillside several feet above flood- } \\
\text { plain level; depth }>5 \mathrm{ft} \text {. }\end{array}$ & $\begin{array}{l}\text { Same as CBW Road; on hillside } \\
\text { above roadway; depth }>5 \mathrm{ft} \text {. }\end{array}$ \\
\hline & & & & (Sheet 1 of 8 ) \\
\hline
\end{tabular}


Table A-1. Survey of Foundation Soil and Rock, Coos County Natural Gas Pipeline

\begin{tabular}{|c|c|c|c|c|}
\hline $\begin{array}{l}\text { CBW } \\
\text { Road } \\
\text { miles }\end{array}$ & $\begin{array}{l}\text { Power line } \\
\text { miles } \\
\text { (approx.) }\end{array}$ & Route Features & $\begin{array}{c}\text { CBW Road Soils/Rock and } \\
\text { Comments }\end{array}$ & $\begin{array}{l}\text { BPA Power line Soils/Rock } \\
\text { and Comments }\end{array}$ \\
\hline 7.2 & 6.6 & $\begin{array}{l}\text { Power line goes up } \\
\text { and down hills. Minor } \\
\text { gullies. }\end{array}$ & $\begin{array}{l}\text { Brown silty clay; moderate to } \\
\text { high plasticity; colluvium; road } \\
\text { starts vertical curves; several rock } \\
\text { outcrops at side of road; depth }>5 \\
\text { ft. }\end{array}$ & $\begin{array}{l}\text { Same as CBW Road. On hillside } \\
\text { above roadway; depth }>5 \mathrm{ft} \text {. }\end{array}$ \\
\hline 8.2 & 7.5 & Cross Rock Creek. & $\begin{array}{l}\text { Gravelly sand; alluvium; non- } \\
\text { plastic; depth }>5 \mathrm{ft} \text {. }\end{array}$ & Same as CBW Road. \\
\hline 8.3 & 7.6 & $\begin{array}{l}\text { Power line crosses } \\
\text { road. }\end{array}$ & $\begin{array}{l}\text { Brown gravelly silty clay; resid- } \\
\text { uum from siltstone; moderate } \\
\text { plasticity; no rocks showing in } \\
\text { road cuts; depth }>5 \mathrm{ft} \text {. }\end{array}$ & Same as CBW Road. \\
\hline 8.6 & & $\begin{array}{l}\text { Tributary of Rock } \\
\text { Creek. }\end{array}$ & $\begin{array}{l}\text { Dk. red silty clay; residuum from } \\
\text { siltstone; hillside; moderate plas- } \\
\text { ticity; depth to rock }=5 \mathrm{ft} \text {. }\end{array}$ & \\
\hline \multirow[t]{2}{*}{8.7} & 8.0 & $\begin{array}{l}\text { Reston substation; } \\
\text { start BPA power lines. }\end{array}$ & $\begin{array}{l}\text { Dk. red silty clay; residuum from } \\
\text { siltstone; hillside; moderate plas- } \\
\text { ticity; depth to rock } 5 \mathrm{ft} \text {. }\end{array}$ & $\begin{array}{l}\text { Brown gravelly sand; alluvium of } \\
\text { Flournoy Valley; non-plastic; depth }> \\
5 \mathrm{ft} \text {. }\end{array}$ \\
\hline & 8.8 & $\begin{array}{l}\text { Tributary of Rock } \\
\text { Creek. }\end{array}$ & & $\begin{array}{l}\text { Dk. brown clay; alluvium; high plas- } \\
\text { ticity; depth }>5 \mathrm{ft} \text {. }\end{array}$ \\
\hline \multirow[t]{2}{*}{10.2} & & Rock Creek. & $\begin{array}{l}\text { Gravelly sandy clay; colluvium } \\
\text { from sandstone; none to low plas- } \\
\text { ticity; depth }>5 \mathrm{ft} \text {. }\end{array}$ & $\begin{array}{l}\text { Ridge and steep valley terrain; } 12 \\
\text { percent slope. }\end{array}$ \\
\hline & 10.1 & Rock Creek. & $\begin{array}{l}\text { Sandstone showing in steep road } \\
\text { cut on south side of CBW Road. }\end{array}$ & $\begin{array}{l}\text { Dk. red silty clay; residuum from silt- } \\
\text { stone; hillside; moderate plasticity; } \\
\text { depth to rock = } 5 \mathrm{ft} \text {. }\end{array}$ \\
\hline 12.0 & 11.1 & $\begin{array}{l}\text { Hillside; downgrade } \\
\text { toward Reston. }\end{array}$ & $\begin{array}{l}\text { Sandstone-siltstone rock in road } \\
\text { cuts on side of roadway. }\end{array}$ & Hillsides reach 10 percent grade. \\
\hline 12.8 & 12.0 & $\begin{array}{l}\text { Intersection with } \\
\text { Reston Road. Substa- } \\
\text { tion. }\end{array}$ & $\begin{array}{l}\text { Sandy clay; alluvium; depth }>5 \\
\text { ft.; hills; no rock. }\end{array}$ & Power line close to road; gentle. \\
\hline \multirow[t]{2}{*}{13.8} & 12.8 & $\begin{array}{l}\text { Power line crosses } \\
\text { road. Tenmile Creek } \\
\text { crossing. }\end{array}$ & $\begin{array}{l}\text { Dk. red silty clay; residuum from } \\
\text { siltstone; hillside; moderate plas- } \\
\text { ticity; depth to rock }=5 \mathrm{ft} \text {. }\end{array}$ & Same as CBW Road; 8 percent grade. \\
\hline & 13.2 & $\begin{array}{l}\text { Tributary of Tenmile } \\
\text { Creek. }\end{array}$ & $\begin{array}{l}\text { Pass Iverson County Park; curvy } \\
\text { road. }\end{array}$ & $\begin{array}{l}\text { Dk. red silty clay; residuum from silt- } \\
\text { stone; hillside; moderate plasticity; } \\
\text { depth to rock }=5 \mathrm{ft} \text {. }\end{array}$ \\
\hline
\end{tabular}


Table A-1. Survey of Foundation Soil and Rock, Coos County Natural Gas Pipeline

\begin{tabular}{|c|c|c|c|c|}
\hline $\begin{array}{l}\text { CBW } \\
\text { Road } \\
\text { miles }\end{array}$ & $\begin{array}{l}\text { Power line } \\
\text { miles } \\
\text { (approx.) }\end{array}$ & Route Features & $\begin{array}{c}\text { CBW Road Soils/Rock and } \\
\text { Comments }\end{array}$ & $\begin{array}{l}\text { BPA Power line Soils/Rock } \\
\text { and Comments }\end{array}$ \\
\hline 15.0 & 13.8 & $\begin{array}{l}\text { Power line crosses } \\
\text { road. Roadway very } \\
\text { curvy. }\end{array}$ & $\begin{array}{l}\text { Dk. red silty clay; residuum from } \\
\text { siltstone; hillside; moderate plas- } \\
\text { ticity; depth to rock }=5 \mathrm{ft} \text {. }\end{array}$ & Same as CBW Road. \\
\hline 15.1 & 13.9 & Steep hill. & $\begin{array}{l}\text { Same as above; road grade } \\
\text { reaches } 15 \text { percent. }\end{array}$ & $\begin{array}{l}\text { Same as CBW Road; slopes reach } 18 \\
\text { percent to } 20 \text { percent. }\end{array}$ \\
\hline $\begin{array}{c}17.5 \& \\
17.9\end{array}$ & & $\begin{array}{l}\text { Cross East Fork of } \\
\text { Coquille River. }\end{array}$ & $\begin{array}{l}\text { Brown sandy clay; low plasticity; } \\
\text { colluvium and residuum over } \\
\text { sandstone; depth }>5 \mathrm{ft} \text {. }\end{array}$ & $\begin{array}{l}\text { Gravelly sandy clay; colluvium from } \\
\text { sandstone; depth }=3-4 \mathrm{ft} \text {. over frac- } \\
\text { tured sandstone; slopes of } 10 \text { percent } \\
\text { to } 22 \text { percent. }\end{array}$ \\
\hline 18.1 & 15.3 & $\begin{array}{l}\text { Tributary of Coquille } \\
\text { River. }\end{array}$ & $\begin{array}{l}\text { Brown sandy clay; low plasticity; } \\
\text { colluvium and residuum over } \\
\text { sandstone; depth }>5 \mathrm{ft} \text {. }\end{array}$ & $\begin{array}{l}\text { Same as CBW Road; slopes range } 14 \\
\text { percent to } 18 \text { percent. }\end{array}$ \\
\hline 19.0 & 16.3 & $\begin{array}{l}\text { Coos County Line; } \\
\text { road is no longer } \\
\text { paved. Enter Brewster } \\
\text { Canyon. }\end{array}$ & $\begin{array}{l}\text { Same as above; steep canyon wall } \\
\text { on north side; depth to rock is } \\
\text { shallow. }\end{array}$ & $\begin{array}{l}\text { Same as CBW Road; slopes range } \\
\text { from } 27 \text { percent to } 32 \text { percent in } \\
\text { crossing East Fork of Coquille River. }\end{array}$ \\
\hline 19.5 & 16.6 & Cross Knapper Creek. & $\begin{array}{l}\text { Soil in roadway unknown; narrow } \\
\text { roadway - about } 15 \text { - } 20 \mathrm{ft} \text {. wide; } \\
\text { steep side wall; exposed rock to } \\
\text { road bed; depth to rock is very } \\
\text { shallow; East Fork of Coquille } \\
\text { River on south side. }\end{array}$ & $\begin{array}{l}\text { Brown sandy clay; low plasticity; } \\
\text { colluvium and residuum over sand- } \\
\text { stone; depth }>5 \mathrm{ft} \text {. }\end{array}$ \\
\hline 20.1 & & Milepost 35 & Same as above & Same as above \\
\hline 21.1 & 17.7 & $\begin{array}{l}\text { Power line crosses } \\
\text { road. }\end{array}$ & $\begin{array}{l}\text { Same as above; small slide in road } \\
\text { south toward river; sandstone in } \\
\text { the vertical, north-side wall. }\end{array}$ & $\begin{array}{l}\text { Sandy clay; colluvium and residuum } \\
\text { from sandstone; low plasticity; soil } \\
\text { depth = } 3 \text { to } 6 \mathrm{ft} \text {. }\end{array}$ \\
\hline 22.4 & 18.8 & Cross small stream. & $\begin{array}{l}\text { Same as above, except no slide; } \\
\text { about } 30 \mathrm{ft} \text {. above river and steep } \\
\text { slope to river. }\end{array}$ & Same as above. \\
\hline 23.0 & 19.5 & $\begin{array}{l}\text { Milepost } 32 \text {. Bridge; } \\
\text { cross East Fork of } \\
\text { Coquille River. }\end{array}$ & $\begin{array}{l}\text { Sandstone-siltstone rock exposed } \\
\text { in river bottom and river banks; } \\
\text { no soil. }\end{array}$ & Same as above. \\
\hline 23.5 & & $\begin{array}{l}\text { Lost Creek enters river } \\
\text { from the north. }\end{array}$ & $\begin{array}{l}\text { Soil in roadway unknown; narrow } \\
\text { roadway - about } 15 \text { - } 20 \mathrm{ft} \text {. wide; } \\
\text { steep side wall; exposed rock to } \\
\text { road bed; depth to rock is very } \\
\text { shallow; East Fork of Coquille } \\
\text { River on north side. }\end{array}$ & $\begin{array}{l}\text { Same as above; slopes reach } 27 \text { per- } \\
\text { cent to } 33 \text { percent. }\end{array}$ \\
\hline
\end{tabular}


Table A-1. Survey of Foundation Soil and Rock, Coos County Natural Gas Pipeline

\begin{tabular}{|c|c|c|c|c|}
\hline $\begin{array}{l}\text { CBW } \\
\text { Road } \\
\text { miles }\end{array}$ & $\begin{array}{l}\text { Power line } \\
\text { miles } \\
\text { (approx.) }\end{array}$ & Route Features & $\begin{array}{c}\text { CBW Road Soils/Rock and } \\
\text { Comments }\end{array}$ & $\begin{array}{l}\text { BPA Power line Soils/Rock } \\
\text { and Comments }\end{array}$ \\
\hline 24.3 & $20.1 \& 20.3$ & $\begin{array}{l}\text { Tributary to Coquille } \\
\text { River. }\end{array}$ & Same as above. & Same as above; rock depth is $<3 \mathrm{ft}$. \\
\hline 25.2 & & $\begin{array}{l}\text { Dead Horse Creek } \\
\text { enters river from } \\
\text { north. }\end{array}$ & Same as above. & Same as above. \\
\hline 25.5 & $20.9 \& 21.4$ & $\begin{array}{l}\text { Tributary to Coquille } \\
\text { River. }\end{array}$ & Same as above. & Same as above. \\
\hline 25.7 & & $\begin{array}{l}\text { Bridge; cross East } \\
\text { Fork of Coquille } \\
\text { River. }\end{array}$ & $\begin{array}{l}\text { Same as above. River on south } \\
\text { side of road. }\end{array}$ & Same as above. \\
\hline 26.7 & & Hamilton County Park & Same as above. & Same as above. Rock depth varies. \\
\hline \multirow[t]{2}{*}{27.5} & 22.8 & $\begin{array}{l}\text { Cross Camas Creek; } \\
\text { roadway paved. }\end{array}$ & $\begin{array}{l}\text { Enter broad valley. Road on hill- } \\
\text { side; sandy clay and fine sand; } \\
\text { alluvium; low plasticity; depth }>5 \\
\text { ft. }\end{array}$ & Same as above. \\
\hline & 23.3 & Enter Brewster Valley. & Same as above. & $\begin{array}{l}\text { Enter broad valley. Sandy clay and } \\
\text { fine sand; alluvium; low plasticity; } \\
\text { depth }>5 \mathrm{ft} \text {. }\end{array}$ \\
\hline \multirow[t]{2}{*}{29.4} & & $\begin{array}{l}\text { Cross Brummit Creek. } \\
\text { Enter Sitkum. }\end{array}$ & $\begin{array}{l}\text { Sandy clay and fine sand; allu- } \\
\text { vium; low plasticity; depth }>5 \mathrm{ft} \text {; } \\
\text { road at base of hill, } 10 \mathrm{ft} \text {. above } \\
\text { plain. }\end{array}$ & Same as above. \\
\hline & 25.4 & Cross Coquille River. & $\begin{array}{l}\text { Brown silty clay; hillside; resid- } \\
\text { uum from siltstone; depth to rock } \\
\text { varies from } 4 \mathrm{ft} \text {. and more. }\end{array}$ & Same as above. \\
\hline 31.5 & 26.1 & $\begin{array}{l}\text { Road re-enters Brew- } \\
\text { ster Canyon. }\end{array}$ & $\begin{array}{l}\text { Same as above; one lane road; } \\
\text { hillside; depth }>5 \mathrm{ft} \text {. }\end{array}$ & Same as above. \\
\hline 32.9 & 27.6 & Milepost 22 & $\begin{array}{l}\text { Gravelly sandy clay; colluvium } \\
\text { derived from sandstone; rock in } \\
\text { road cut at road level; depth to } \\
\text { rock about } 3 \mathrm{ft} \text {. in hillside. }\end{array}$ & Same as CBW Road. \\
\hline 34.1 & 28.5 & $\begin{array}{l}\text { Tributary of Coquille } \\
\text { River. }\end{array}$ & $\begin{array}{l}\text { Soil in roadway unknown; narrow } \\
\text { roadway - about } 15 \text { - } 20 \mathrm{ft} \text {. wide; } \\
\text { steep side wall; exposed rock to } \\
\text { road bed; depth to rock is very } \\
\text { shallow. East Fork of Coquille } \\
\text { River on south side. }\end{array}$ & $\begin{array}{l}\text { Brown silty clay; residuum and collu- } \\
\text { vium derived from sandstone; slopes } \\
\text { reach } 26 \text { percent to } 28 \text { percent; soil } \\
\text { depth }>5 \mathrm{ft} \text {. }\end{array}$ \\
\hline
\end{tabular}


Table A-1. Survey of Foundation Soil and Rock, Coos County Natural Gas Pipeline

\begin{tabular}{|c|c|c|c|c|}
\hline $\begin{array}{l}\text { CBW } \\
\text { Road } \\
\text { miles }\end{array}$ & $\begin{array}{l}\text { Power line } \\
\text { miles } \\
\text { (approx.) }\end{array}$ & Route Features & $\begin{array}{c}\text { CBW Road Soils/Rock and } \\
\text { Comments }\end{array}$ & $\begin{array}{l}\text { BPA Power line Soils/Rock } \\
\text { and Comments }\end{array}$ \\
\hline 34.9 & 30.2 & $\begin{array}{l}\text { Enter broad Flood- } \\
\text { plains at Dora. }\end{array}$ & $\begin{array}{l}\text { Brown fine sandy clay; mixed } \\
\text { alluvium; soil depth }>5 \mathrm{ft} \text {. }\end{array}$ & Same as CBW Road. \\
\hline 37.2 & 32.3 & $\begin{array}{l}\text { Pass Frona County } \\
\text { Park; Power line cross } \\
\text { road. }\end{array}$ & $\begin{array}{l}\text { Brown silty clay; hillside; resid- } \\
\text { uum from siltstone; depth to rock } \\
>5 \mathrm{ft} \text {. }\end{array}$ & $\begin{array}{l}\text { Same as CBW Road; slopes reach } 15 \\
\text { percent to } 20 .\end{array}$ \\
\hline 39.2 & 33.1 & $\begin{array}{l}\text { Road crosses Cherry } \\
\text { Creek and Cherry } \\
\text { Creek Road; power } \\
\text { line crosses upper } \\
\text { reach of E. F. Coquille } \\
\text { River. }\end{array}$ & $\begin{array}{l}\text { Brown silty clay; mixed alluvium; } \\
\text { soil depth }>5 \mathrm{ft} \text {. }\end{array}$ & $\begin{array}{l}\text { Brown gravelly sandy clay; residuum } \\
\text { from sandstone; depth to fractured } \\
\text { rock }<5 \mathrm{ft} \text {. }\end{array}$ \\
\hline 40.2 & 34.1 & $\begin{array}{l}\text { Power line crosses } \\
\text { road. }\end{array}$ & $\begin{array}{l}\text { Brown silty clay; mixed alluvium; } \\
\text { soil depth }>5 \mathrm{ft} \text {. }\end{array}$ & $\begin{array}{l}\text { Same as CBW Road. Power line in } \\
\text { hillside; sandy clay from sandstone; } \\
\text { low plasticity; depth }>5 \mathrm{ft} \text {. }\end{array}$ \\
\hline 41.5 & 35.0 & $\begin{array}{l}\text { Power line crosses } \\
\text { road; road crosses } \\
\text { Middle Creek. }\end{array}$ & $\begin{array}{l}\text { Brown silty clay; mixed alluvium; } \\
\text { soil depth }>5 \mathrm{ft} \text {. }\end{array}$ & $\begin{array}{l}\text { Same as CBW Road. Power line } \\
\text { starts up steep hill with } 15 \text { percent to } \\
19 \text { percent slope. }\end{array}$ \\
\hline $\begin{array}{l}41.5 \text { to } \\
44.3\end{array}$ & 35.0 to 37.5 & Hilly terrain. & $\begin{array}{l}\text { Brown silty clay; hillside; resid- } \\
\text { uum from siltstone; depth to rock } \\
>5 \mathrm{ft} \text {. Slopes reach } 8 \text { percent to } \\
10 \text { percent. }\end{array}$ & $\begin{array}{l}\text { Same as CBW Road. Slopes reach } \\
15 \text { percent to } 20 \text { percent. }\end{array}$ \\
\hline 44.3 & 37.5 & $\begin{array}{l}\text { Power line crosses } \\
\text { road. Steep hill down } \\
\text { to Bolton Prairie. }\end{array}$ & $\begin{array}{l}\text { Dk. red silty clay; residuum from } \\
\text { siltstone; hillside; moderate plas- } \\
\text { ticity }(\mathrm{PI}=20-30) \text {; depth to rock = } \\
5 \mathrm{ft} . \text { Slope about } 11 \text { percent. }\end{array}$ & $\begin{array}{l}\text { Same as CBW Road. Slope about } 11 \\
\text { percent. }\end{array}$ \\
\hline 45.4 & 38.0 & $\begin{array}{l}\text { Cross bridge; North } \\
\text { Fork of Coquille } \\
\text { River. }\end{array}$ & $\begin{array}{l}\text { Brown silty clay; mixed alluvium; } \\
\text { low plasticity; depth }>5 \mathrm{ft} \text {. }\end{array}$ & Same as CBW Road. \\
\hline 45.7 & 38.3 & $\begin{array}{l}\text { Cross Fairview Road; } \\
\text { enter Fairview; power } \\
\text { line crosses road. }\end{array}$ & Same as above. & Same as above. \\
\hline 46.0 & & $\begin{array}{l}\text { Rejoin CBW Road, } \\
\text { parallel Evans Creek } \\
\text { on right. }\end{array}$ & $\begin{array}{l}\text { Dark brown silty clay; mixed, } \\
\text { alluvium; low plasticity; organic; } \\
\text { slopes } 3 \text { percent; depth to rock. } 5 \\
\text { ft. }\end{array}$ & \\
\hline 46.1 & & $\begin{array}{l}\text { Continue northwest- } \\
\text { erly parallel Evans } \\
\text { Creek. }\end{array}$ & $\begin{array}{l}\text { Dark gray silty clay; mixed allu- } \\
\text { vium; moderate plasticity; slopes } \\
<8 \text { percent; depth to rock }>5 \mathrm{ft} \text {. }\end{array}$ & \\
\hline \multicolumn{5}{|r|}{ (Sheet 5 of 8 ) } \\
\hline
\end{tabular}


Table A-1. Survey of Foundation Soil and Rock, Coos County Natural Gas Pipeline

\begin{tabular}{|c|c|c|c|c|}
\hline $\begin{array}{l}\text { CBW } \\
\text { Road } \\
\text { miles }\end{array}$ & $\begin{array}{l}\text { Power line } \\
\text { miles } \\
\text { (approx.) }\end{array}$ & Route Features & $\begin{array}{c}\text { CBW Road Soils/Rock and } \\
\text { Comments }\end{array}$ & $\begin{array}{l}\text { BPA Power line Soils/Rock } \\
\text { and Comments }\end{array}$ \\
\hline 46.4 & & $\begin{array}{l}\text { Continue parallel to } \\
\text { Evans Creek. }\end{array}$ & $\begin{array}{l}\text { Dark brown silty clay; mixed allu- } \\
\text { vium; low plasticity; organic; } \\
\text { slopes }<3 \text { percent; depth to rock }> \\
5 \mathrm{ft} \text {.; some areas more organic. }\end{array}$ & \\
\hline 46.5 & & $\begin{array}{l}\text { Begin parallel to. } \\
\text { Steinman Creek }\end{array}$ & $\begin{array}{l}\text { Dark gray silty clay; mixed allu- } \\
\text { vium; moderate plasticity; slopes } \\
<8 \text { percent; depth to rock }>5 \mathrm{ft} \text {. }\end{array}$ & \\
\hline 46.6 & & $\begin{array}{l}\text { Continue parallel to } \\
\text { Steinman Creek. }\end{array}$ & $\begin{array}{l}\text { Reddish brown organic silty clay; } \\
\text { mixed colluvium; slopes } 3 \text { to } 30 \\
\text { percent; generally non-plastic; } \\
\text { depth to rock }>5 \mathrm{ft} \text {. }\end{array}$ & \\
\hline 47.0 & & $\begin{array}{l}\text { Continue parallel to } \\
\text { Steinman Creek. }\end{array}$ & $\begin{array}{l}\text { Dark gray silty clay; mixed allu- } \\
\text { vium; moderate plasticity; slopes } \\
<8 \text { percent; depth to rock }>5 \mathrm{ft} \text {. }\end{array}$ & \\
\hline 47.5 & & $\begin{array}{l}\text { Pass confluence of } \\
\text { west fork of Steinman } \\
\text { Creek parallel west } \\
\text { fork. }\end{array}$ & $\begin{array}{l}\text { Reddish brown organic silty clay; } \\
\text { mixed colluvium; slopes } 3 \text { to } 30 \\
\text { percent; generally non-plastic; } \\
\text { depth to rock }>5 \mathrm{ft} \text {. }\end{array}$ & \\
\hline 48.1 & & $\begin{array}{l}\text { Leave west fork of } \\
\text { Steinman Creek, begin } \\
\text { climbing to north. }\end{array}$ & $\begin{array}{l}\text { Reddish brown organic silty clay; } \\
\text { occasional mixed alluvium; slopes } \\
3 \text { to } 30 \text { percent (occasional } 30 \text { to } \\
50 \text { percent); generally non-plastic; } \\
\text { depth to rock }>5 \mathrm{ft} \text {. }\end{array}$ & \\
\hline 48.4 & & Continue & $\begin{array}{l}\text { Reddish brown organic silty clay; } \\
\text { mixed colluvium, becoming dark } \\
\text { red clay; moderately plastic; depth } \\
\text { to rock }>5 \mathrm{ft} \text {. }\end{array}$ & \\
\hline 48.5 & & Continue & $\begin{array}{l}\text { Reddish brown organic silty clay; } \\
\text { mixed colluvium; slopes } 3 \text { to } 30 \\
\text { percent; generally non-plastic; } \\
\text { depth to rock }>5 \mathrm{ft} \text {. }\end{array}$ & \\
\hline $\begin{array}{c}48.8 \text { to } \\
49.0\end{array}$ & & Continue & $\begin{array}{l}\text { Reddish brown organic silty clay; } \\
\text { mixed colluvium, becoming dark } \\
\text { red clay; moderately plastic; depth } \\
\text { to rock }>5 \mathrm{ft} \text {. Occasional rock }<5 \\
\text { ft. }\end{array}$ & \\
\hline & & & & (Sheet 6 of 8 ) \\
\hline
\end{tabular}


Table A-1. Survey of Foundation Soil and Rock, Coos County Natural Gas Pipeline

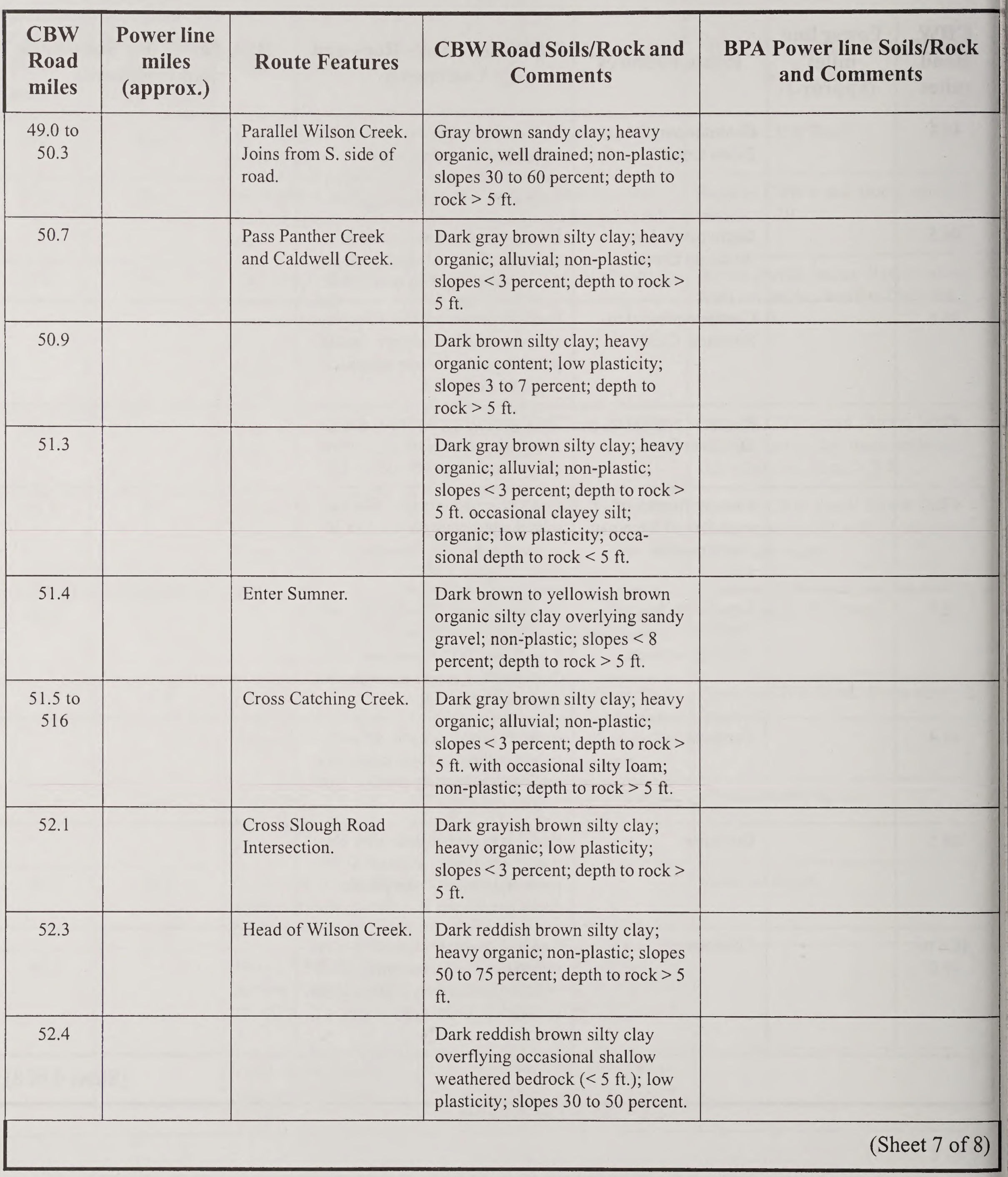


Table A-1. Survey of Foundation Soil and Rock, Coos County Natural Gas Pipeline

\begin{tabular}{|c|c|c|c|c|}
\hline $\begin{array}{l}\text { CBW } \\
\text { Road } \\
\text { miles }\end{array}$ & $\begin{array}{l}\text { Power line } \\
\text { miles } \\
\text { (approx.) }\end{array}$ & Route Features & $\begin{array}{c}\text { CBW Road Soils/Rock and } \\
\text { Comments }\end{array}$ & $\begin{array}{c}\text { BPA Power line Soils/Rock } \\
\text { and Comments }\end{array}$ \\
\hline 52.6 & & & $\begin{array}{l}\text { Dark reddish brown silty clay; } \\
\text { heavy organic; non-plastic; slopes } \\
50 \text { to } 75 \text { percent; depth to rock }>5 \\
\text { ft. }\end{array}$ & \\
\hline 52.7 & & & $\begin{array}{l}\text { Dark reddish brown silt; heavy } \\
\text { organics; generally low plasticity; } \\
\text { slopes } 12 \text { to } 30 \text { percent; depth to } \\
\text { weathered rock }=5 \mathrm{ft} \text {. }\end{array}$ & \\
\hline 52.7 & & $\begin{array}{l}\text { Cross Cardwell Creek; } \\
\text { CBW Road pavement } \\
\text { starts. }\end{array}$ & Same as above. & Same as CBW Road. \\
\hline 53.5 & & Sumner. & $\begin{array}{l}\text { Brown silty clay; mixed alluvium; } \\
\text { soil depth }>5 \mathrm{ft} \text {. }\end{array}$ & \\
\hline 55.2 & 46.3 & $\begin{array}{l}\text { Power line crosses } \\
\text { road. }\end{array}$ & $\begin{array}{l}\text { Brown silty clay; residuum from } \\
\text { sandstone; low plasticity; slopes } \\
\text { range } 5 \text { percent to } 12 \text { percent. }\end{array}$ & Same as CBW Road. \\
\hline 56.7 & 47.8 & $\begin{array}{l}\text { Cross Ross Slough } \\
\text { Road. }\end{array}$ & Same as above. & Same as above. \\
\hline 57.7 & 48.1 & Cross Isthmus Slough. & $\begin{array}{l}\text { Gravelly sandy clay; alluvium; } \\
\text { depth }>5 \mathrm{ft} \text {. }\end{array}$ & Same as at left. \\
\hline \multirow[t]{3}{*}{57.8} & 48.2 & Cross Hwy 101. & Same as above. & Same as at left. \\
\hline & 49.5 & $\begin{array}{l}\text { Cross Shinglehouse. } \\
\text { Slough. }\end{array}$ & 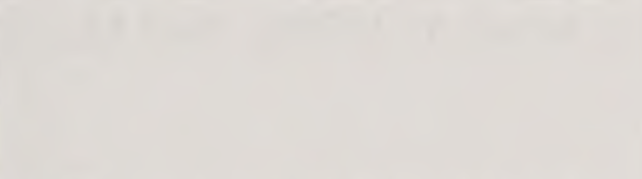 & $\begin{array}{l}\text { Brown silty clay; residuum from } \\
\text { sandstone; low plasticity; slopes }<5 \\
\text { percent. }\end{array}$ \\
\hline & 60.1 & $\begin{array}{l}\text { Reach Coos Bay area. } \\
\text { End of Coos County } \\
\text { Natural Gas Pipeline. }\end{array}$ & $\begin{array}{l}\text { Same as above until reach Coos } \\
\text { Bay area; then enter sandy clay } \\
\text { alluvium of Coalbank Slough. }\end{array}$ & \\
\hline
\end{tabular}




\section{LIST OF REFERENCES}

1. Orr, E. L. and Orr, W. N. (1999). Geology of Oregon, Fifth Edition, Kendall/Hunt Publishing Co., Dubuque, Iowa.

2. Haagen, J. T. (1989). Soil Survey of Coos County, Oregon, USDA Soil Conservation Service (renamed Natural Resources Conservation Service), Portland, Oregon.

3. Alt, D. D. and Hyndman, D. W. (1978). Roadside Geology of Oregon, Mountain Press Publishing Co., Missoula, Montana.

4. Black, G. L. (1990). "Geologic Map of the Reston Quadrangle, Douglas County, Oregon," Geological Map Series GMS-68, Oregon Department of Geology and Mineral Resources, Portland.

5. Wiley, T. J. (1995). "Reconnaissance Geologic Map of the Dora and Sitkum Quadrangles, Coos County, Oregon," Geological Map Series GMS-98, Oregon Department of Geology and Mineral Resources, Portland.

6. Baldwin, E.M. and Beaulieu, J. D. (1973). "Geology and Mineral Resources of Coos County, Oregon," Bulletin 80, Oregon Department of Geology and Mineral Industries. Portland.

7. Goodman, R. E. (1993). Engineering Geology, John Wiley and Sons, New York.

8. Spigolon, S. J. (1993). "Geotechnical Site Investigation Strategy for Dredging Projects," Report 2 of "Geotechnical Factors in the Dredgeability of Sediments." Contract Report DRP-93-3, U.S. Army Engineer Waterways Experiment Station, Vicksburg, MS, October.

9. Terzaghi, K., Peck, R. B., and Mesri, G. (1996). Soil Mechanics in Engineering Practice, Third Edition, John Wiley \& Sons, New York.

10. Sowers, G. F. (1979). Introductory Soil Mechanics and Foundations.- Geotechnical Engineering, Fourth edition, Macmillan Publishing, New York.

11. Douglas County Area Office of the Natural Resources Conservation Service. Unpublished soil survey data sheets, Roseburg, Oregon.

12. Deere, D. U. and Patton, F. D. (1971). "Slope Stability in Residual Soils." Fourth Pan-American Conference on Soil Mechanics and Foundation Engineering, American Society of Civil Engineers, New York.

13. Madin, I. P. and Mabey, M. A. (1996). "Earthquake Hazard Maps for Oregon," Geological Map Series GMS100, Oregon Department of Geology and Mineral Resources. Portland.

14. Building Codes Structures Board, State of Oregon. (1998). "Seismic Zonation for the Oregon Coast." Final Report to the State of Oregon Building Codes Structures Board, Salem, Oregon. February 12. 
15. Johnson, A.G., Scofield, D.H., and Madin, I. P. (1994). "Earthquake Database for Oregon, 1833 through October 25, 1993." Open File Report OFR 94-04, Oregon Department of Geology and Mineral Industries, Portland.

16. Jacobson, R. S. (1986). "Map of Oregon Seismicity, 1841-1986," Geological Map Series GMS-49, Oregon Department of Geology and Mineral Resources, Portland.

17. Madin, I. P. and Mabey, M. A. (1996). "Earthquake Hazard Maps for Oregon," Geological Map Series GMS100, Oregon Department of Geology and Mineral Resources, Portland.

18. Peterson, C. D., Barnett, E. T., Briggs, G. C., Carver, G. A.,. Clague, J. J., and Darienzo, M. E. (1997). "Estimates of Coastal Subsidence from Great Earthquakes in the Cascadia Subduction Zone, Vancouver Island. B.C. Washington, Oregon. and Northernmost California," Open File Report 0-97-5, Oregon Department of Geology and Mineral Resources, Portland.

19. Wang, Y. (1998). "Earthquake Damage and Loss Estimate for Oregon," Open File Report O-98-3, Oregon Department of Geology and Mineral Resources, Portland.

20. Transportation Research Board, National Research Council. (1996). "Landslides - Investigation and Mitigation.", National Academy Press, Washington, D.C.

21. Spigolon, S. Joseph, Ph D., Route Reconnaissance and Construction Recommendations for the Coos County Natural Gas Pipeline Project Coos and Douglas Counties, Oregon, February, 2001.

22. Madin, I. P. and Wang, Z. (1999. "Relative Earthquake Hazard Maps for selected urban areas in western Oregon," Geological Map Series IMS- 9, Oregon Department of Geology and Mineral Resources, Portland.

Numbers in brackets [ ] refer to documents included in the List of References at the end of this report 



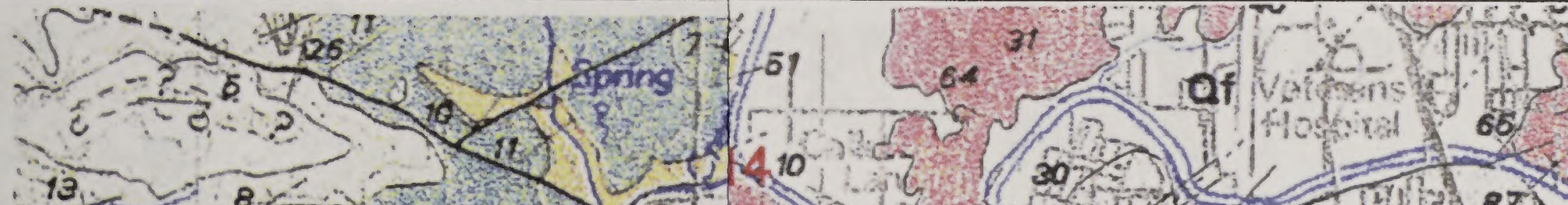

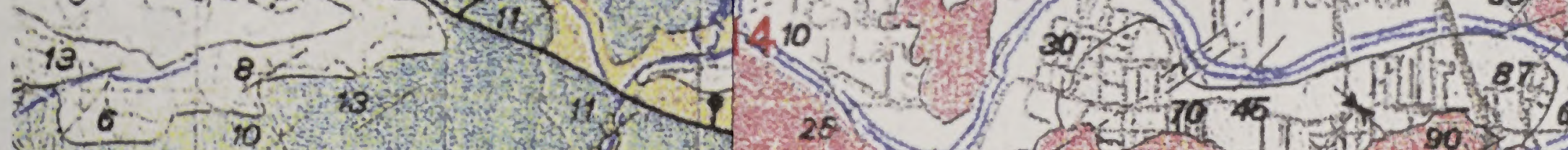

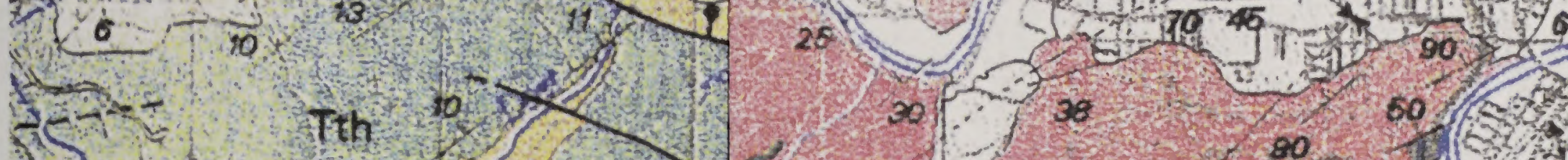

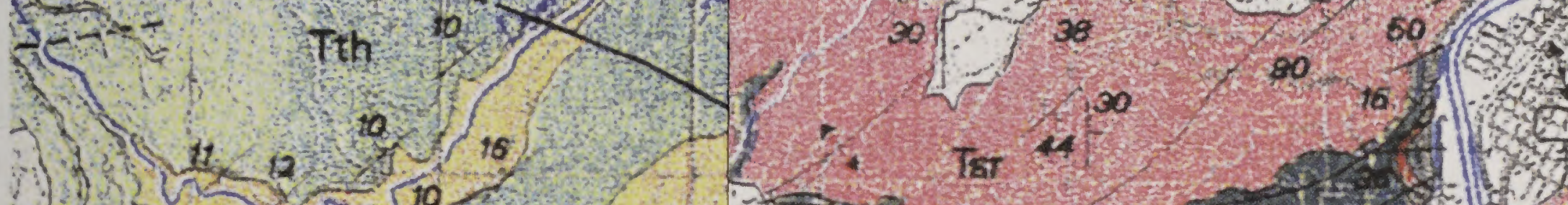

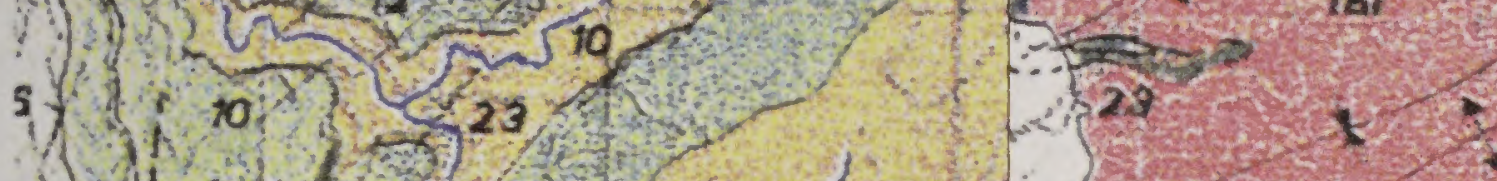

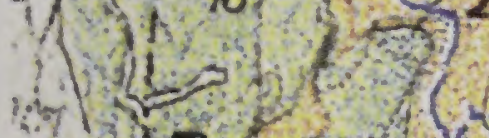

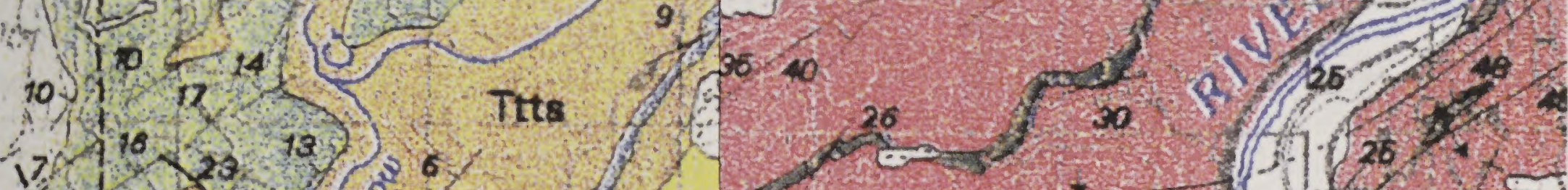

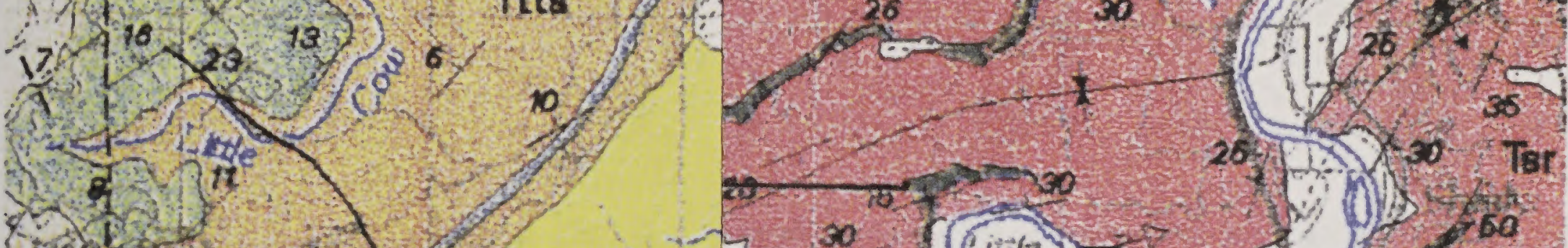

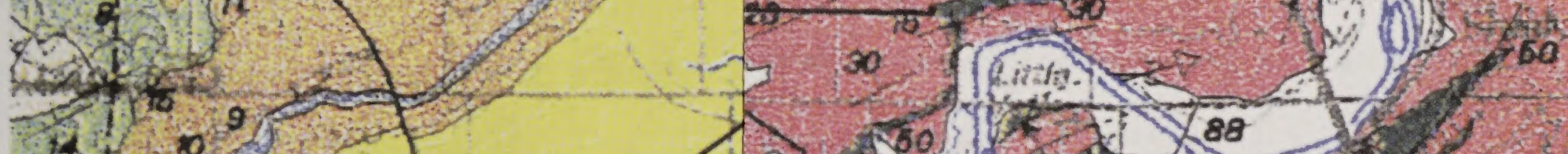

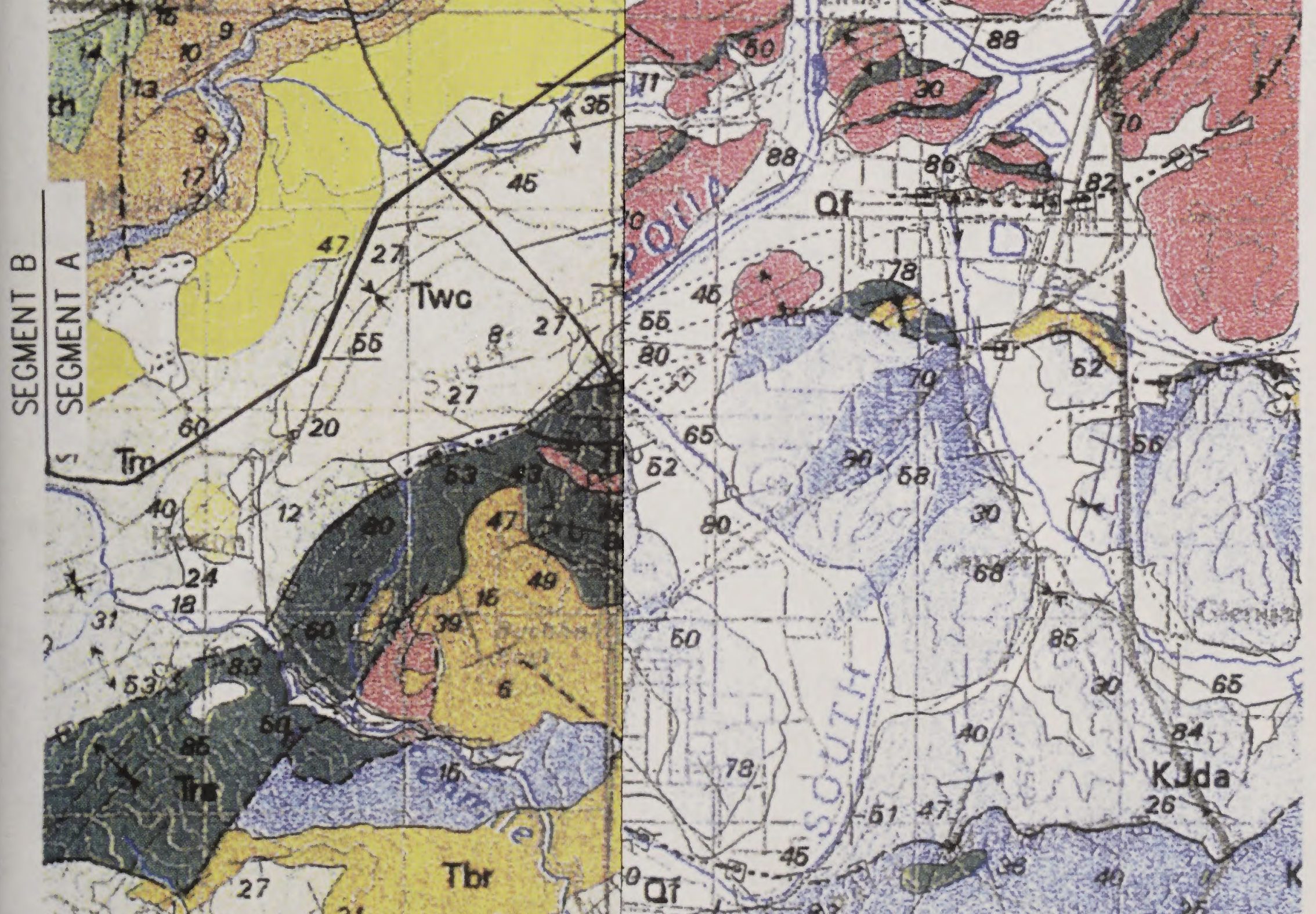

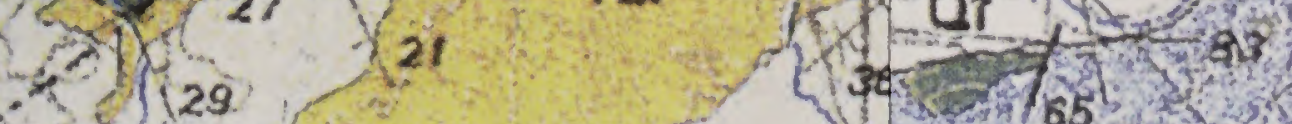

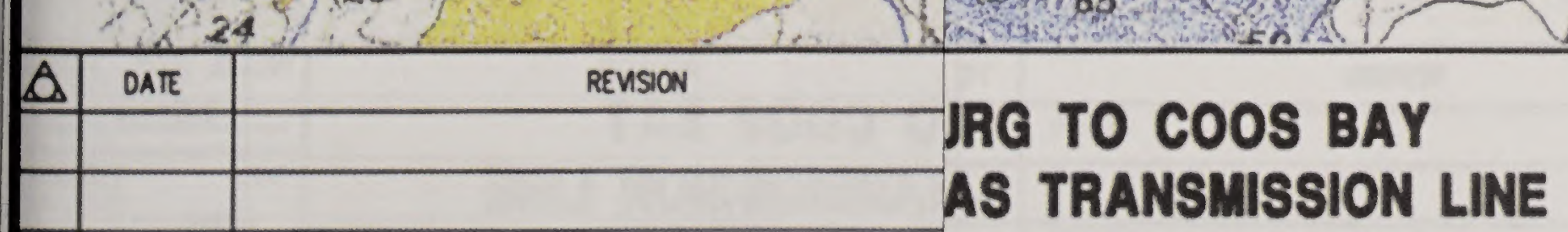

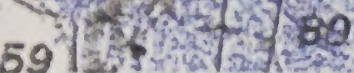





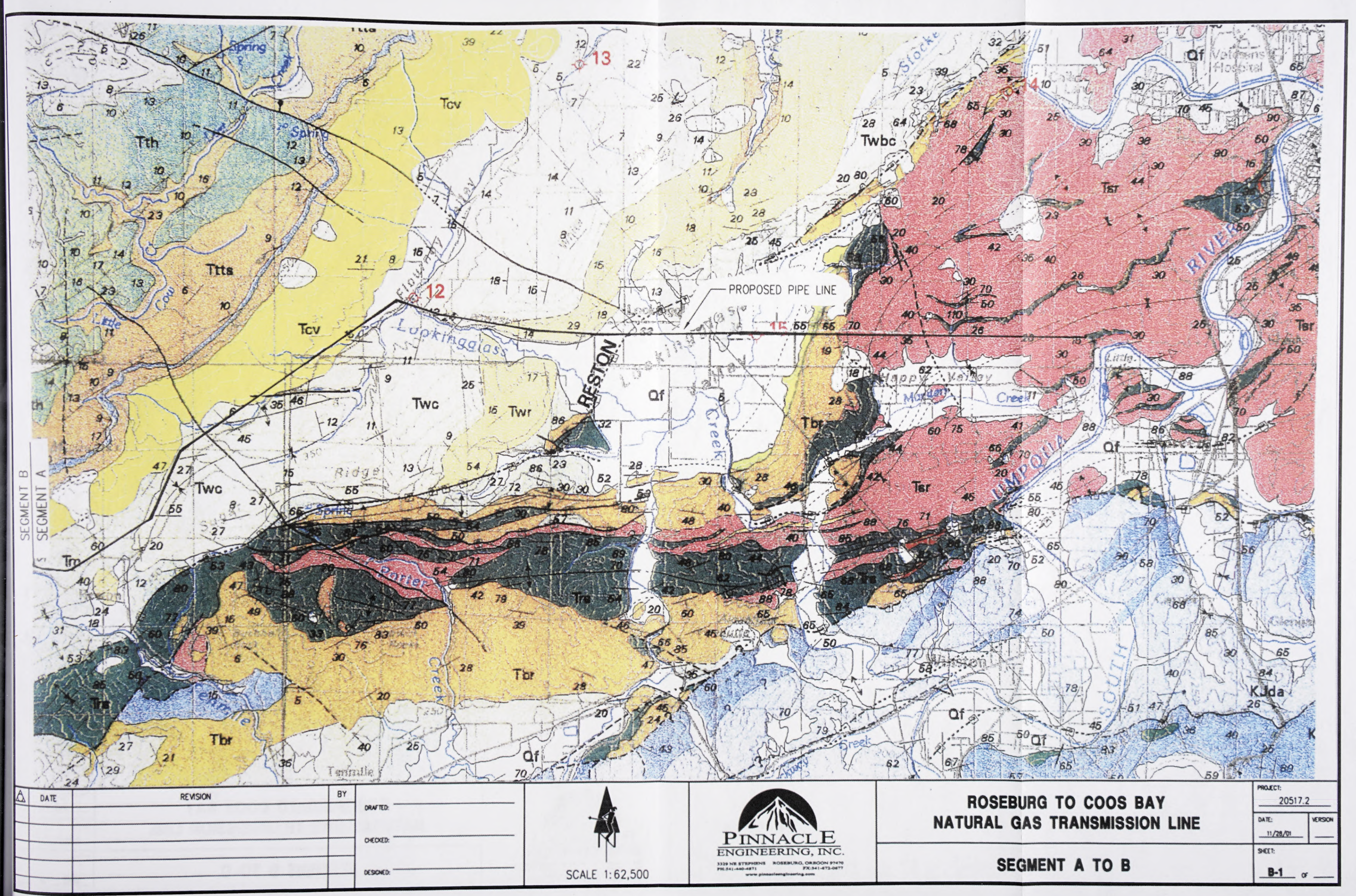




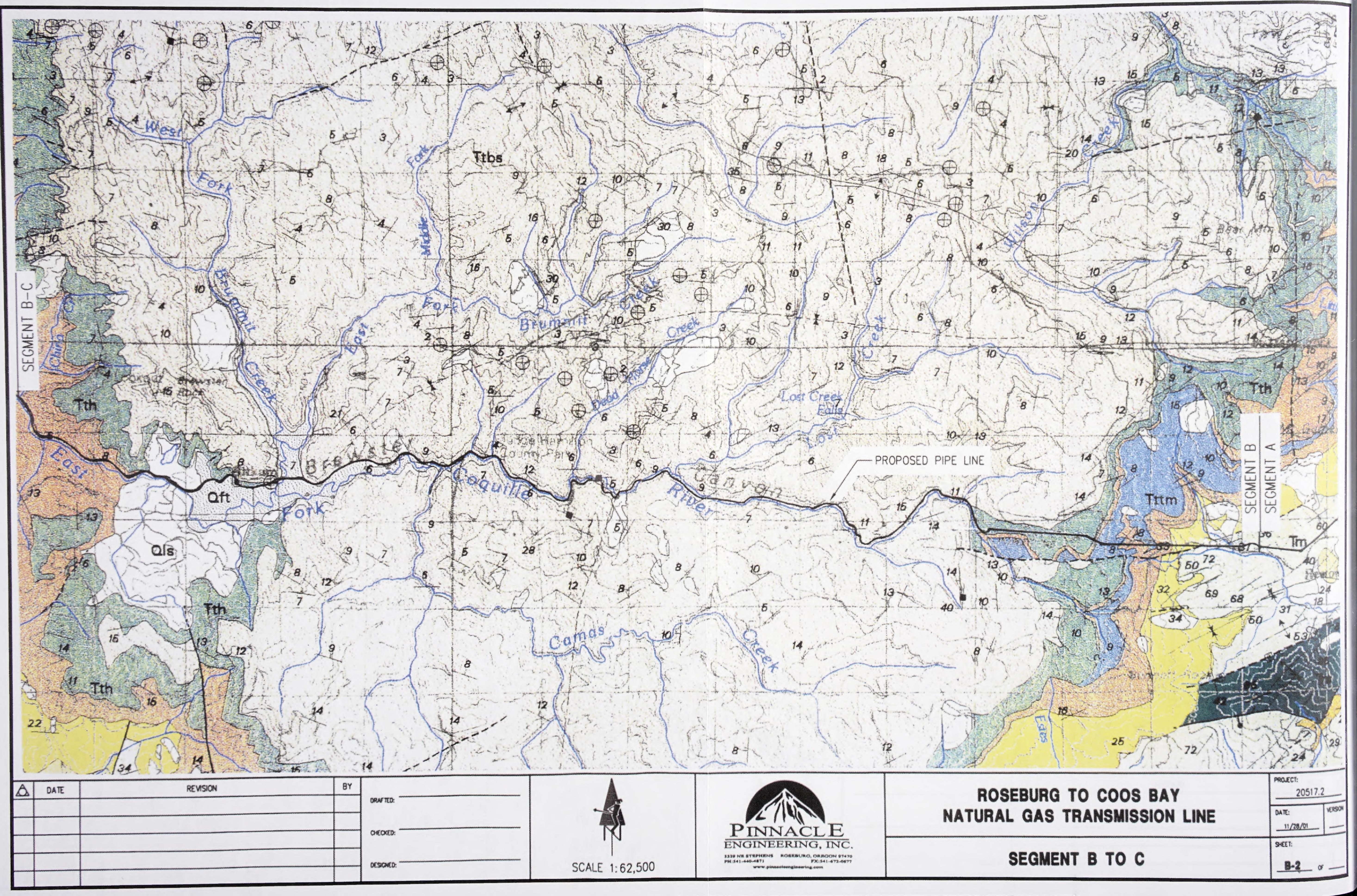




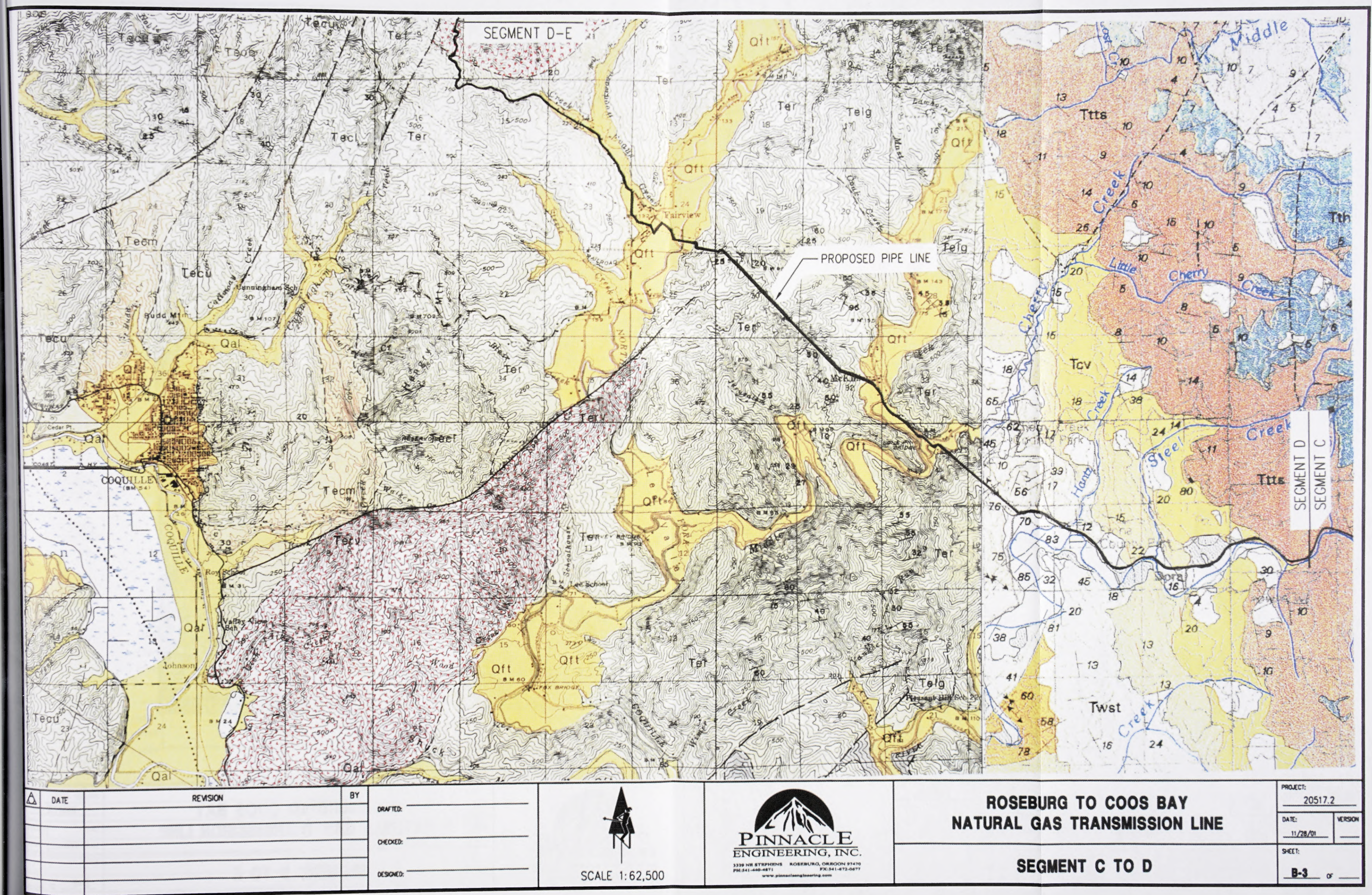


to provide

small strucndorff Formation (late Eocene and early Oligocene): Thinly includes sdded shale and siltstone confined to the South Slough, Isthmus differentiabugh and Catching Creeh areas; mantled by silty loam and silty thick estuasy loam; very low permeability and ground-water potential.

SS stable sand: is. protected

vegetation,do Formation - middle member (late Eocene): Thinly bedded thinner sotstone with minor sandstone interbeds: mantled by silly loam and include strily clay loam: very low permeability and ground-water polential: overwithdrzards include eroston, slow headland erosion, and local mass elevations; puement. with other

do Formation - undifferentiated (late Eocene): Parts of the

unstable dunediffermention - undifferentiated (late Eocene): Parts of the large duntstone content: lithology and hazands simllar to those of the thickness, ddle member of the coaledo formatlon: prectse distribution stable sandermined by on-site inspection.

excevation

or other am Formation (middle Eocene): Thinly bedded slltstone with nor sandstone interbeds: mantled with silty loam and sllty clay deflation plaim; very low permeability and gnound-woter polential; hazards grained sanlude erosion and mass movement. dune field to those shallow desalt of Tertiary Aze

bility and

dependent urg Formation - basalt (early Eocene): Marine basalt of veriable ology including plllow basalt, basaltlc breccla and intrusive lidal tlat: Undall: hardness, jolnting, alteration, and potential use varioble: idal tlat: Ung gespread low-grade alteration; interfingers with sedimentery rock estuaries al the Roseburg Formation: mantled by silly clay loam and silty of seismle $m$ a few inches to several tens of leet in thichness: hazards dune sands. lude rapid erosion and mass movement.

marsh and peaks of Pre-Tertiary Age

estuarine of

vegetction, iR Mountain Conglomerate (early Cretaceous): Small exposure of foundattonded conglomerate and sandstone.

be present

sands.

pint Formation (Jurassic): A tectonically sheared assemblage of is including pervasively sheared sedimentary rocks (Jop) nou Quaternary allie to regional mass movement and subordinate omounts of mud in thered to intact voleanic rock (Jov), isolated blocks of thiniy siltstone taded lightly folded chert (Jc). exposures of serpentinite (Jsp) upper reac isolated blocks of resistant blueschist (Js). a medium-grade grain size damorphic rock. Soil types, thicknesses, and properties highly maderate; able: major hazands include mass movement, slope erosion. hazards incm-bank erosion, and variable bearing strength. flooding, si

Formation (Jurassic): Limited exposures of volcanic rock and Quaternary Uded siltstone.

dated flat.

present str

present leu

of estuarin

Quaternary

Quaterno

stream-ben

Qmt Quaternary m

dated llat-l

sravel local

little as 2

hundred fe

ground-wat

headland

deep cuts,

mantled by

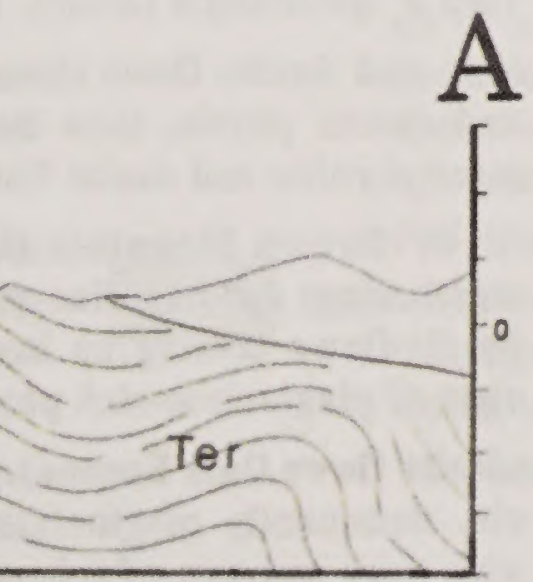

\begin{tabular}{|c|c|c|c|c|c|}
\hline $\bar{\Delta}$ & DATE & REUSION & \multirow{3}{*}{$\begin{array}{l}\text { JRG TO COOS BAY } \\
\text { AS TRANSMISSION LINE }\end{array}$} & \multirow{2}{*}{\multicolumn{2}{|c|}{\begin{tabular}{|l} 
mascer: \\
$\quad 20517.2$ \\
\end{tabular}}} \\
\hline & & & & & \\
\hline & & & & our: & nesom \\
\hline & & & & & \\
\hline & & & ECTION A'-A' & & \\
\hline
\end{tabular}




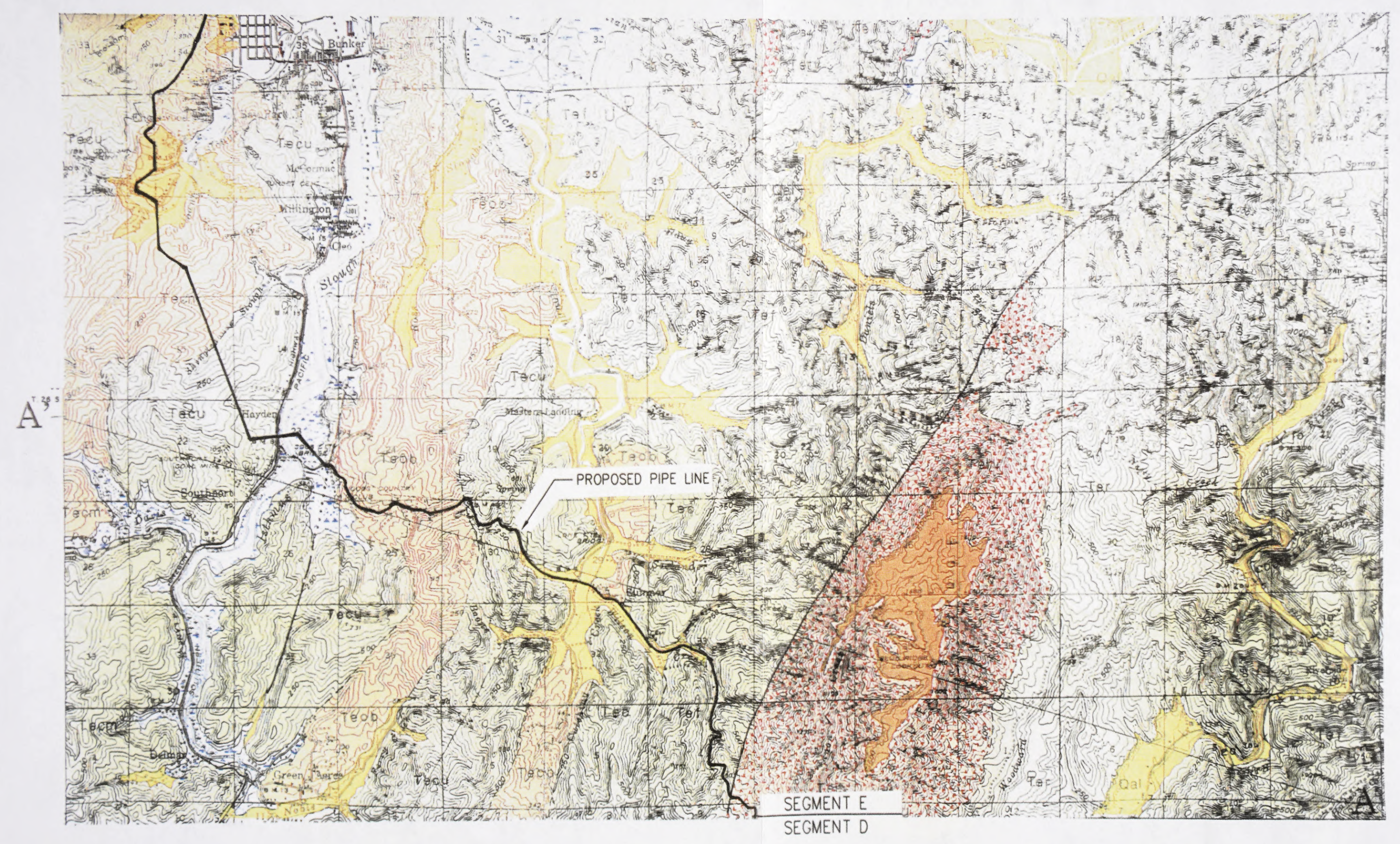

\begin{tabular}{|c|c|c|c|c|c|c|c|c|}
\hline$\Delta$ & DATE & REUSON & 8r & oesina & A & & & masch: \\
\hline & & & & (n) & & & NATURAL GAS TRANSMISSION LINE & 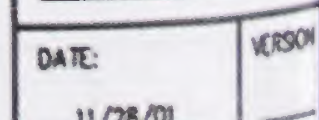 \\
\hline & & & & assoce. - & SCALE $1: 62,500$ & 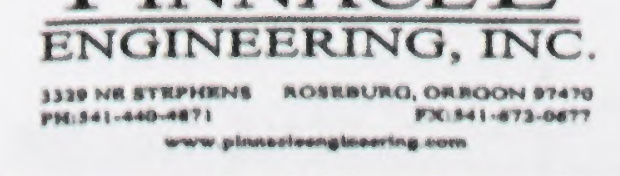 & SEGMENT D TO E & $\begin{array}{ll}\text { sere: } \\
B-4 \quad a\end{array}$ \\
\hline
\end{tabular}




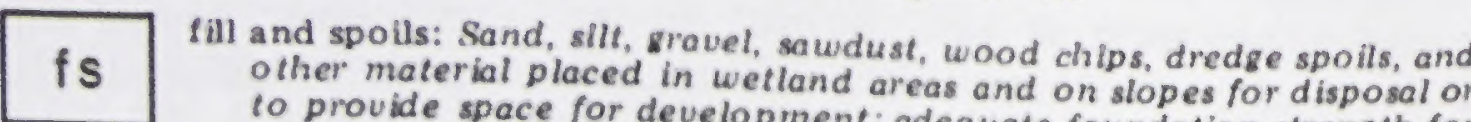
small structures if properly phent: adequate foundation strens th for

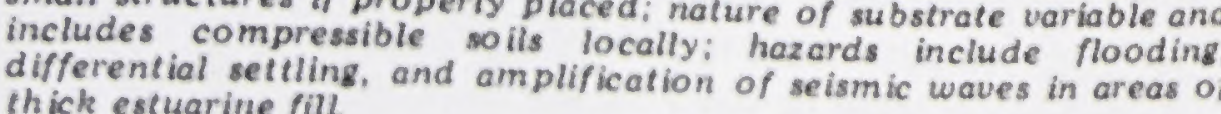

ss

Sle sand: Unconsolidated fine. to medium-rrained dune sand
protected from wind erosion by notural or artulically introduced thinner south of Bandon; ground.water production hields, mu

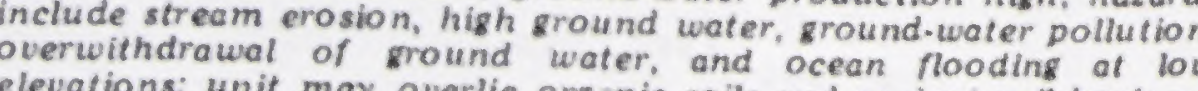

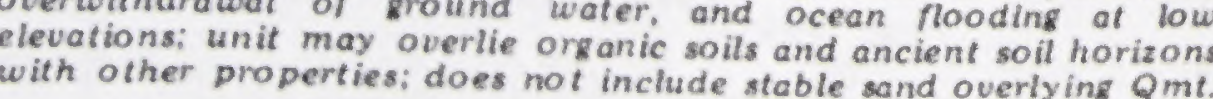

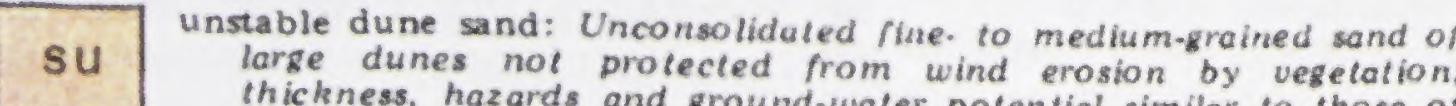

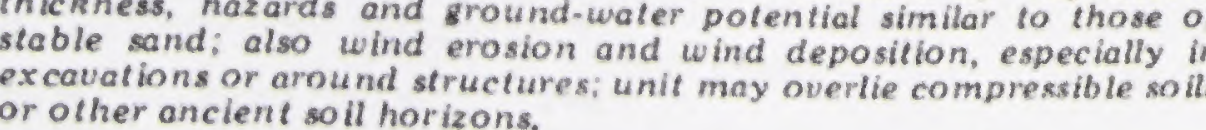

SdpD deflation plain and beach sand: Unconsolidated fine, to medium the

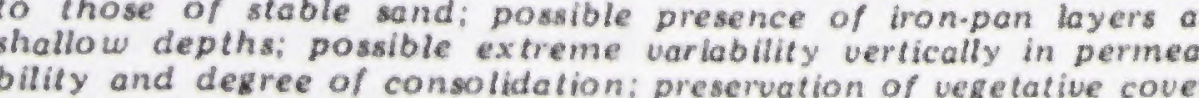
bility and desree of con
dependent on water table.

11 tidal flat: Unconsolidated mud, sith, clay, and sand in the tidal zone of

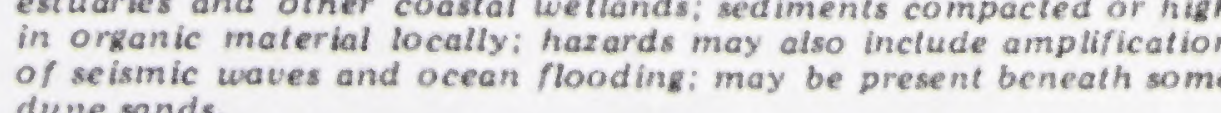

mpt marsh and peat: Unconsolidated organic soils of silt, cloy, and sand in

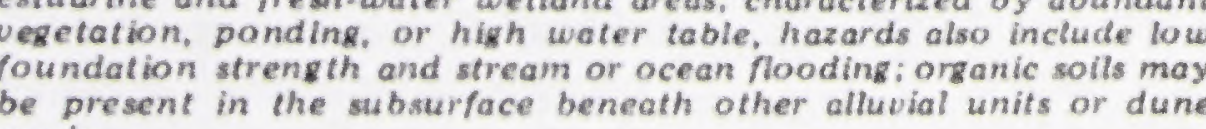
sands

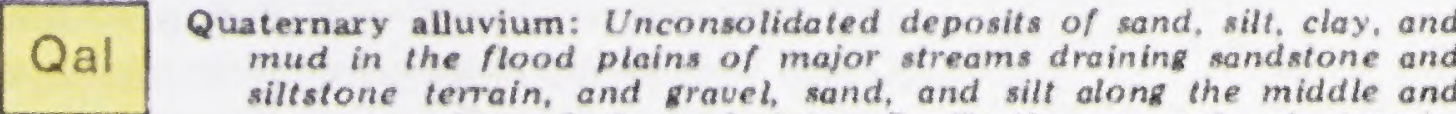
upper reaches of rivers dratining

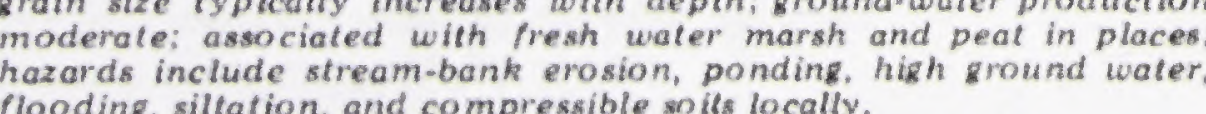

Qft

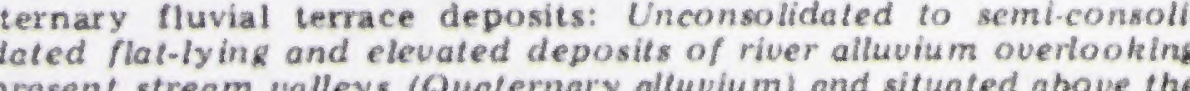
present levels of hooding, also includes hine-gratied terrace deposita

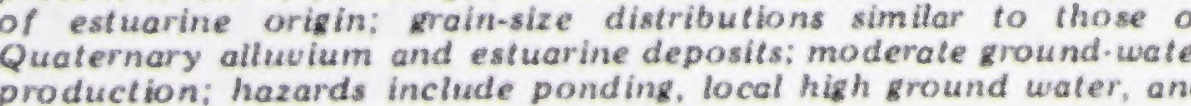
atream-bank erosion,

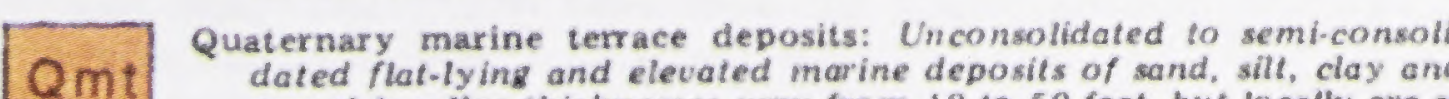

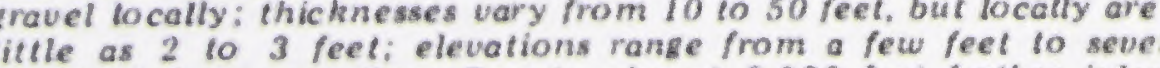

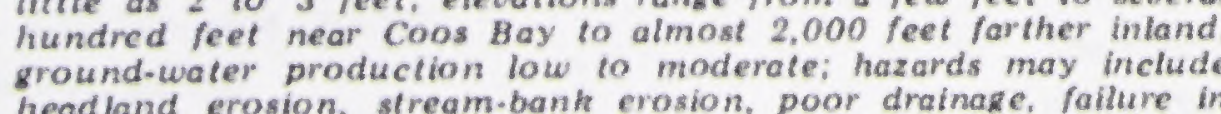

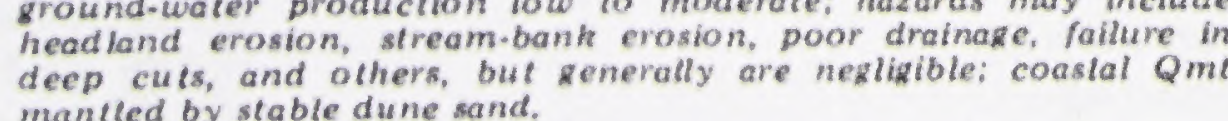

Bedrock Geologic Units

Sand stone of Tertiary $\mathrm{Ag}$

Tpe $\begin{gathered}\text { Empire Formation (Plilocene): Thickly bedded, hard, marine sandston } \\ \text { with minor thin interbeds of silstone; impermeable, fin }\end{gathered}$ hazards include rocklfall in coostat cliffs and variable erosion an

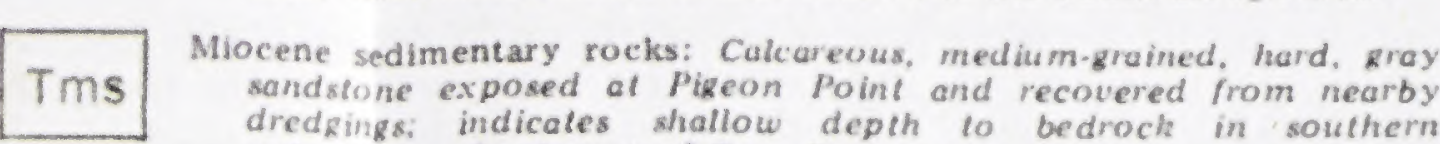

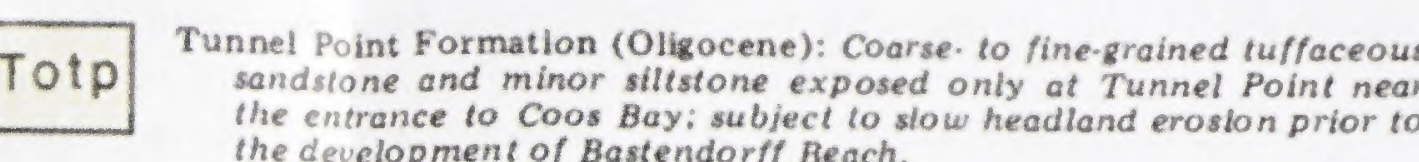

TACU Coaledo Formation, upper and lower members (late Eocene): Coarse

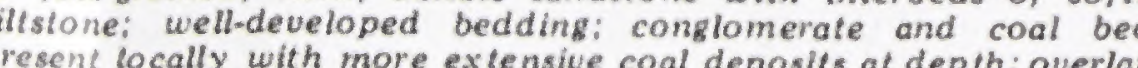

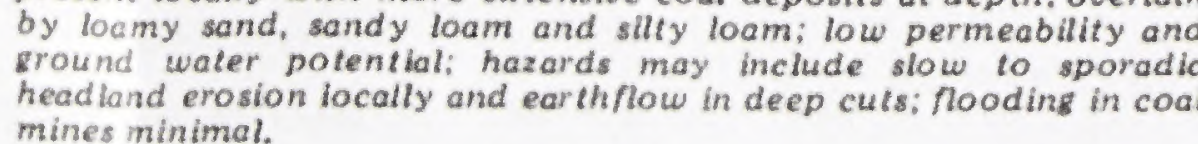

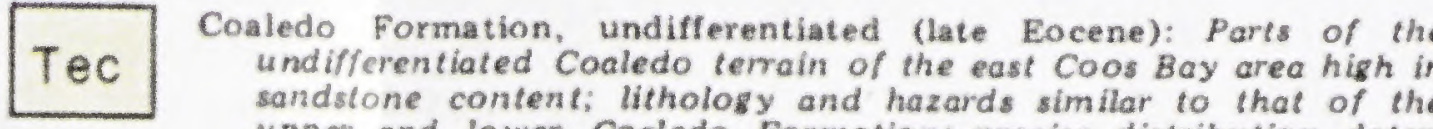

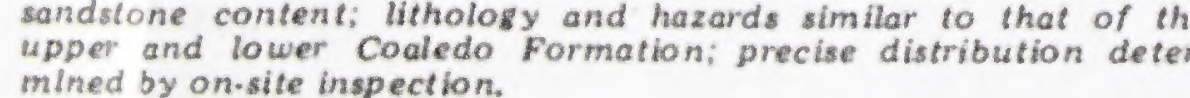

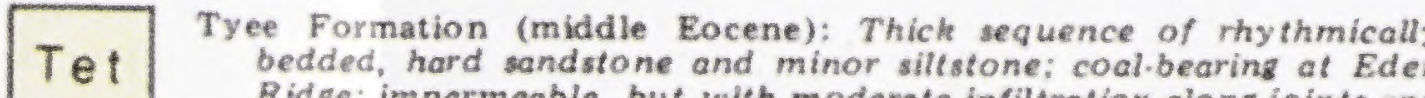

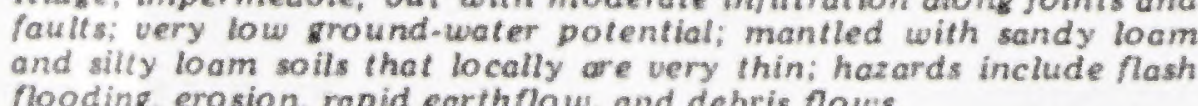

Tef Flournoy Formation (mlddie Eocene): Lithology and soils similar to

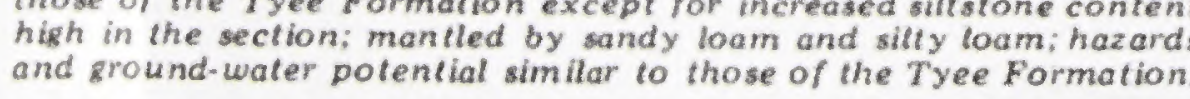

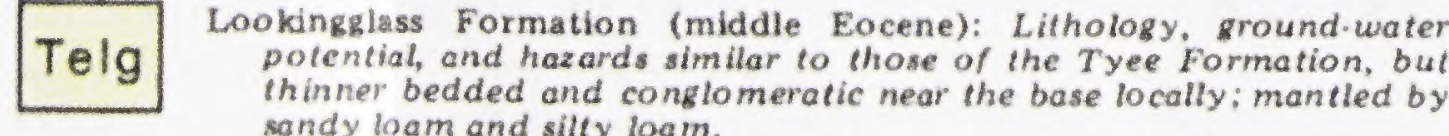

Ter Roseburg Formation- Sedimentary rocks (lower Eocene and older)

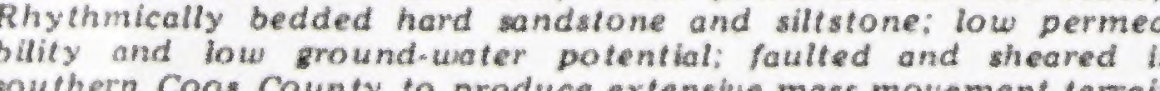

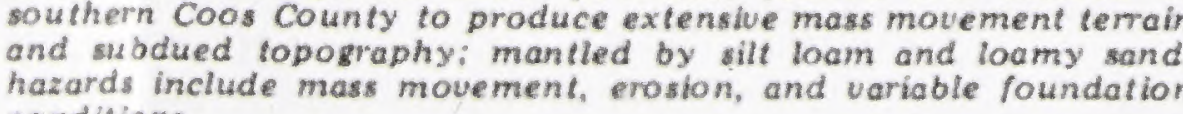

Geologic Cross Section
Siltstone of Tertiary Ag

Bastendorff Formation (late Eocene and early Oligocene): Thin Stough shale and siltstone confined to the South Slough, Isthmus
Slough Catching Creek areass mantled by silty loam and silty clay lomi very low permeability and ground- woter potential:
hozards include erosion, slow mass movement, and fallures in deep

Tecm Coaledo Formation - middile member (late Eocene): Thinly bedded ally clay loam; very low permeability and dround water poletential
hazards include erosion, slow headland erosion, and local mass Caledo Formation - undifferentiated (late Eocene): Parts of the

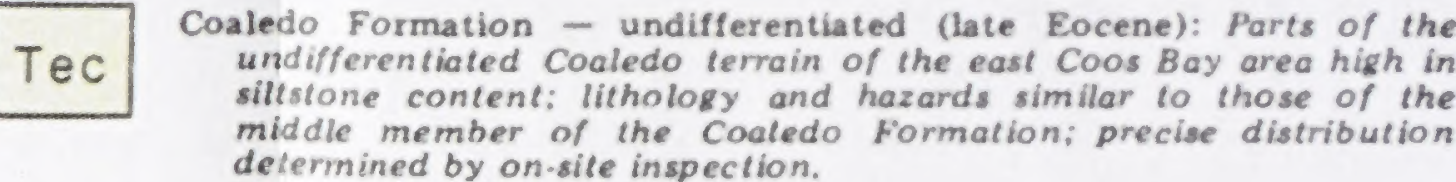

Tee Elkton Formation (middle Eocene): Thinly bedded siltstone with
minor sandstone interbeds: mantled with silty loam and silty clay

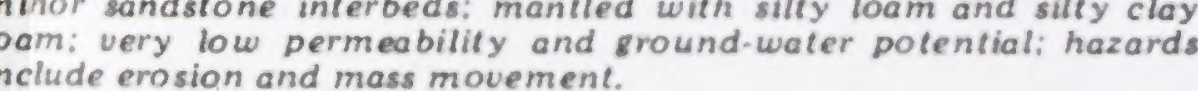
Baselt of Tertiary Aze

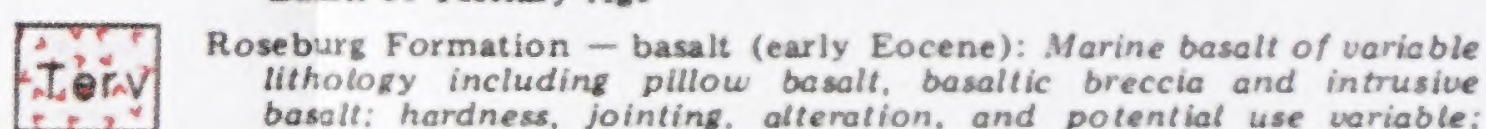

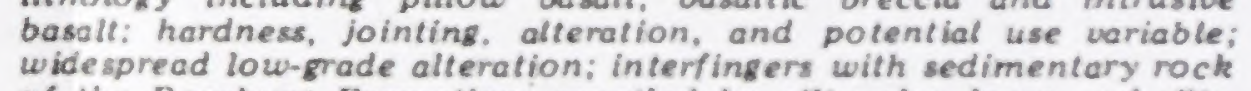

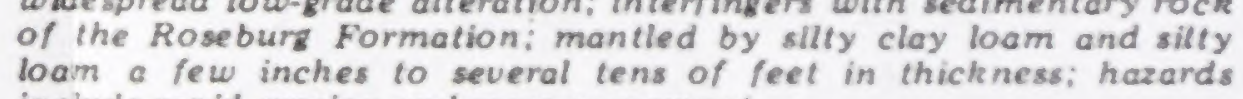

nocks of Pre-Tertiary Age

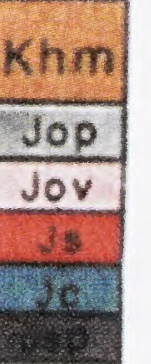
mbur Mountain Conglomerate (early
bedded conglomerale and sandstone. 作 er Point Formation (Jurassic): A tectonically sheared assemblage of
rochs including pervasively sheared sedimentary rochs (Jop) nou

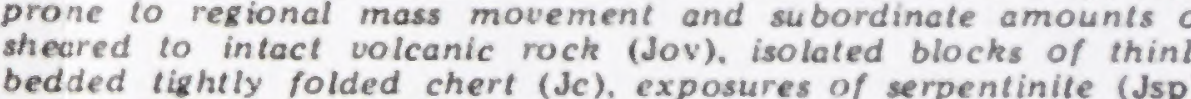
bedded tightly folded chert (Jc), exposures of serpentinite (Jsp)
and isolated blocks of resistant blueschist (Js). a medium-krade

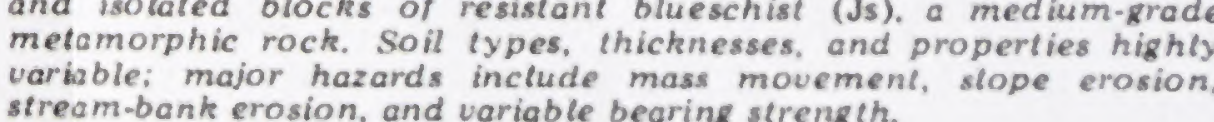

Galice Formation (J
bedded siltstone,

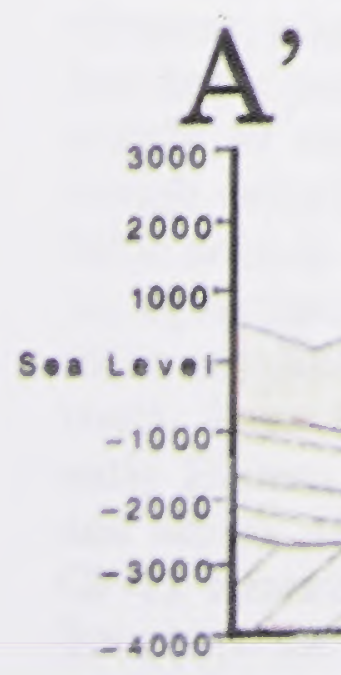

\begin{tabular}{|l|l|l|l|l|}
\hline$\Delta$ & OATE & REVSION & BY & \\
\hline & & & \\
\hline & & \\
\hline & & \\
\hline & & \\
\hline
\end{tabular}
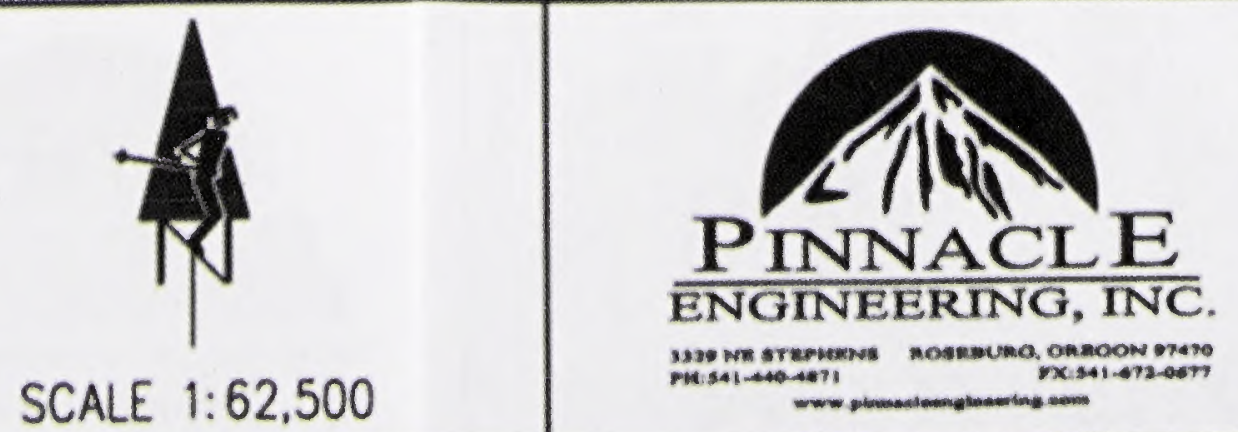

ROSEBURG TO COOS BAY NATURAL GAS TRANSMISSION LINE

SECTION A'-A'

A 
te, and laharic breccia (late Eocanic sandstone, silt and conglomerate 11t, and silicic clasts: interbedded with locally consisting of chaotic blocks of lows and silicic tuff breccia

edimentary and volcaniclastic rocks. tary unit consisting of boulder, cobble ind tuffaceous sandstone, pale whitish rounded to subangular clasts of $\mathrm{Kla}$ graywacke, pebble conglomerate of ons, porphyritic volcanic rocks, chert. tone with little or no mica, and grittynbles disarticulated, deeply weathered supported, conglomerate clasts comand at one locality in the Lane Mounone with well-developed groove casts ely 300 to 400 meters thick

middle Eocene) -Dominantly glomporphyritic diabase and basalt sills $\mathrm{nt}$ and basal Tertiary section; may be ountain; some dikes cut tuff of Bond c rocks developed around largest indepth in the Mobil well east of Su4 and $36.8 \pm 3.6 \mathrm{Ma}$ (Ryu and others,

d middle Eocene)-Dominantly fine dikes and sills within Remote Memnation. May be feeders for flows in

dle Eocene) - Platy to blocky jointnely crystalline andesite intruding ansedimentary rocks of unit Tvs

\section{BASIN}

Eocene) $-120 \mathrm{~m}$ of friable, fine- to ed, thick- to very thick-bedded, micanated sandstone with a few coal beds 1-deltaic; some shallow-marine mole unit as late Eocene (Hoover, 1963;

Eocene) $-750 \mathrm{~m}$ of fine- to coarsebedded to ripple and parallel laminat. arkosic sandstone; minor overbank and bioturbated sandstone with a few 991); composed of many thickeningted delta. Unit caps high ridges; in ion

middle Eocene) - Thin to thick bedritic mudstone; interfingers with $\mathrm{Ba}$ of outcrop area
Elkton Formation mudstone (middle Eocene) $-450 \mathrm{~m}$ of laminated, medium to dark gray foram-bearing (bathyal) micaceous mudstone; upper slope to basinal; contains some nested channel sequences of medium- to thick-bedded, amalgamated, graded micaceous arkosic turbidite sandstone and thin mudstone beds; a few thickening-upward beds of shallow-marine, molluskbearing, laminated to hummocky bedded, micaceous arkosic sandstone in lower part. Formation is middle Eocene (upper Ulatisian-lower Narizian foraminiferal stage according to Bird, 1967; equivalent to A-1 stage of Almgren and others, 1988, and coccolith subzone $\mathrm{CP} 12 \mathrm{~b}$. Interfingers with the Baughman Member (Ttbs) of the Tyee Formation

Tyee Formation (middle and early Eocene)-Divided into:

Ttbs Baughman Member (middle Eocene)-300 to $600 \mathrm{~m}$ of zeolite-cemented, iron-stained, coarse-grained, thick- to very thick-bedded, micaceous, lithic arkosic sandstone; cliff-former; some large-scale cross-bedded pebbly sandstone and polymict conglomerate lenses; represents fluvial to wave-dominated delta. Delta plain facies includes massive, green to carbo. naceous-micaceous overbank mudstone and sub-bituminous coal beds; delta front facies contains oyster-bearing estuarine deposits, paralic coal, and thickening-upward delta front parasequences of hummocky bedded, bioturbated to ripple-laminated sandstone. In southern part of map, local unconformity at base with fluvial mudstone chip conglomerate incised into underlying deep-marine Hubbard Creek mudstone; conformable contact toward northern part of the map. Molluscan fossils indicate middle Eocene age (Ryu and others, 1992)

Ttbm Baughman Member mudstone (middle and early Eocene)-Massive, gray green to carbonaceous-micaceous overbank mudstone

Th Hubbard Creek Member (middle and early Eocene) -120 to $300 \mathrm{~m}$ of micaceous laminated to massive deep-marine mudstone (lower to upper slope); minor fine-grained, micaceous arkosic, graded, thin- to thick-bedded turbidite sandstone and thin mudstone in nested channel sequence (Tths) with slump structures and mudstone chip conglomerates. Uppermost part of unit is bioturbated shelfal-upper slope mudstone (Ryu and others, 1992). Benthic foraminifers are referrable to middle Eocene (A-1 to G-1 stages of Almgren and others, 1988, according to Ryu and others, 1992). Unit conformably overlies and interfingers with Tyee Mountain Member mudstone (Tttm) and locally disconformably overlies Camas Valley Formation in the southern part of the map area (Black, 1990, 1993)

Hubbard Creek Member sandstone (middle Eocene)-Fine-grained, micaceous arkosic, graded, thin- to thick-bedded turbidite sandstone and thin mudstone in nested channel sequences

\begin{tabular}{|c|c|c|c|}
\hline \multirow{3}{*}{$\begin{array}{l}\text { PINNACLE } \\
\text { ENGINEERNG, INC. } \\
\text { ENGINEERNG }\end{array}$} & \multirow{2}{*}{$\begin{array}{l}\text { ROSEBURG TO COOS BAY } \\
\text { NATURAL GAS TRANSMISSION LINE }\end{array}$} & \multicolumn{2}{|c|}{$\begin{array}{ll}\text { masce: } \\
20517.2 \\
\end{array}$} \\
\hline & & ane: & (6800 \\
\hline & LEGEND OF GEOLOGIC DESCRIPTIONS & Bet: & \\
\hline
\end{tabular}


Tyee Mountain Member (middle and eaCreek Member (early Eocene)-More than $150 \mathrm{~m}$ of well-indu. rhythmically bedded, thick- to very thelta front, hummocky to cross-bedded and bioturbated, mollusk indurated, clay-cemented, light gray, bebbly lithic arkosic sandstone with minor mudstone and thin pol stone (graywacke) and subordinate throngomerate beds; many thickening-upward delta front parasequen mudstone (sandstone to mudstone rationdstone is fine- to medium-grained, medium gray (fresh) to yellow. abe and ae turbidite divisions common(weathered) and thick- to very thick-bedded or amalgamated. Peb. groove marks, and load casts. Graded se chert, quartz, metamorphic, and intermediate to mafic volcanic grained and generally structureless bu:r conformably interfingers with underlying mudstone of Tenmile tional upper contacts. Very coarse flakion. Molluscan fauna and coccolith flora indicate an early Eocene tinctive of this unit. Some thick slope ciccolith biozone CP-11; D. Bukry, written commmunication, 1994; stones (20 to $75 \mathrm{~m}$ thick) with slumpedrs and others, 1995; Moore, 1991, in Ryu and others, 1992)

erates. Inner and middle submarine famed siltstone member (early Eocene)-Massive to thin-bedded maproximal ramp facies of Heller and Dihdstone underlying sandstone of Whitetail Ridge in southwest corner medium-bedded outer fan turbidite sairangle; unconformable on folded turbidites of Tenmile Formation; micaceous mudstone ( $T \mathrm{ttm})$. Mudstone to be deeper marine facies of Whitetail Ridge Formation incised into underlying Camas Valley $\mathrm{F}$ map, but turbidite unit thickens rapid Formation (early Eocene)-includes:

plain facies turbidites of the Tenmile lle Formation, undivided (early Eocene) - Up to $1,000 \mathrm{~m}$ of masreferrable to the Ulatisian stage, and cowell-bedded, very thick sequences of deep-marine, well-indurated, zone (middle and early Eocene: Bukry edium gray, rhythmically bedded, thin. graded, medium- to very 1992; Brouwers and others, 1995) grained lithic turbidites (Bouma abed and bed divisions common)

Tyee Mountain Member mudstone (mi laminated micaceous mudstone dark gray mudstone interstratified with thick bathyal foraminifera. upper to lower slope and basinal, dark gray laminated to massive ne; minor medium- to thick-bedded, very coarse-grained, lithic tur-

Umpqua Group (early Eocene and late $\mathrm{Pa}$ some thick lenses and channels of massive, pebbly lithic sandstone

Camas Valley Formation (early Eocene-ganized and organized polymict pebble-cobble conglomerate. Thin slope, medium dark gray, laminated mk-bearing, upper slope-outer shelf mudstone in upper part of unit $100 \mathrm{~m}$ contain some calcareous concrend others. 1992). Tenmile Formation strata conformably overlie Unit forms broad gentle sloping valleyll Rock Formation. Foraminiferal and coccolith assemblages indioverlies undivided White Tail Ridge (Tmation is early Eocene (Penutian foraminiferal stage; Thoms, 1965; (Twre) and locally unconformably over1977; and CP10 and 11 coccolith stages: D. Bukry, written commuluscan assemblages as well as benthils, 1991-96; Brouwers and others, 1995). Lower part of the unit semblages indicate a late-early Eocer to foraminiferal stages C and B-4 to B-1 of Laiming (as described Almgren and others, 1988) (Miles, 18ren and others, 1988; McKeel, 1991 in Ryu and others, 1992) written communication in Ryu and othudstone (early Eocene)-Dark gray slope mudstone with mediequate to CP.11 zone of Bukry and Snay, thin-bedded lithic turbidite sandstone filling cross-cutting nested

White Tail Ridge Formation (early Eoos; lenticular sandstone beds, slumped and prolapsed bedding, flame White Tail Ridge Formation, undivi d structures. Some massive upper slope-outer shelf, massive, dark $\mathrm{m}$ of moderately to well-indurated, rids oturbated mollusk-bearing delta front-1

thick- to thick-bedded lithic arkosic site sandstone and mudstone (early Eocene)-Thin- to mediummudstone; some paralic subbituminous(?), lenticular lithic sandstone and dark gray mudstone; grades lat. sandstone, tidal flat accretionary bank pto unit Tmcs submarine turbidite channel deposits; possible inner siltstone; many coarsening- and thickere deposit

and upper part of the formation. In the erately to well-indurated delta plain trough cross-bedded, coarse- to very a lithic arkosic sandstone, some polymic ate (quartzite, chert, metamorphic, an thick, massive, green, root-mottled ove coals. Some fining- and thinning-upw early Eocene (planktonic foraminifera and others, 1992, Penutian-lower Ulat CP-11 coccolith stage, Bukry and Sna Brouwers and others, 1995; D. Bukry,

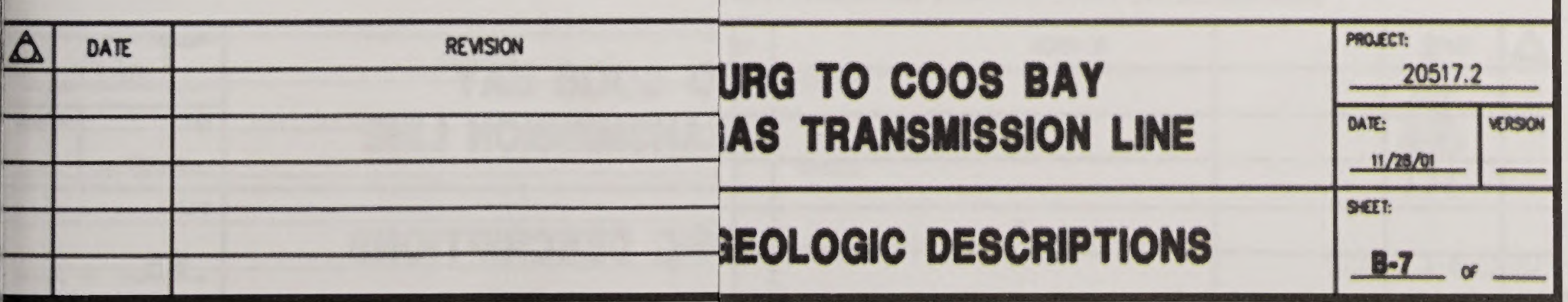


DESCRIPTION OF MAP UNITS

SURFICIAL DEPOSITS

af Fluvial deposits (Holocene)- Unconsolidated or poorly consolidated river de posits consisting of moderately sorted, sub-angular to well-rounded boulders, gravel, sand, and silt: locally may include older river deposits on poorly defined lower terraces

Ocl Colluvium (Holocene and Pleistocene)-Unconsolidated or poorly consolida ed slope deposits consisting of moderately sorted, sub-angular to angular boulders, gravel, sand, and silt; locally may include older river deposits on poorly defined lower terraces

Qls Landslide deposits (Holocene and Pleistocene)-Chaotic, angular fragments of weathered and fresh bedrock and colluvium, as clast-supported or mud matrix supported diamict derived from upslope. Includes areas of hummocky topography inferred to be underlain by landslide deposits

Qtt Fluvial terrace deposits (Pleistocene)-Moderately sorted, well-rounded to sub-rounded, semi-consolidated stratified gravel, sand, and silt on elevated

Older Fluvial terrace deposits (Pleistocene) - Moderately sorted, we rounded to sub-rounded, stratified gravel, sand, and silt on highest elevalconsolidated than lower terrace deposits

Volcanic, intrusive and sedimentary rock

Upper dacite (late Eocene)-Pyroxene dacite flows, platy, flow foliated, light gray where fresh, weathers red-brown

Tuff of Bond Creek (late Eocene)-Divided into:

Upper unit (late Eocene)-Moderately to poorly welded rhyolitic ash flow partially resorbed quartz, plagioclase and sanidine(?) with minor biotite. sphene, disseminated opaques and trace amounts of very fine grained eubedral amphibole, epidote and tourmaline that may be vapor phase crystallization. Includes rare xenoliths of mica schist; approximately 120 to 150 meters thick

Toci Lower unit (late Eocene)-Moderately to poorly welded rhyolitic as flow tuff; white to pale grey weathering, quartz and plagioclase phyric, crystal rich, trace white mica and epidote, rare rounded and resorbed botite, abundant opaques, mafic minerals strongly altered,, approximately 120 meters thick; interpreted to be lower cooling unit of Tuff of Bond Creek. K-Ar age of $34.9 \mathrm{Ma}$ determined from outcrops in adjacent Med-

Tsf Rhyolite and dacite flows (late Eocene)-Light gray to white, plagioclase and quartz phyric, flow banded to massive, locally hydrothermally altered rhyolite and dacite flow

Basalt of Brown Mountain (late Eocene)-Dark gray to black, brown weathering, aphyric, fine grained to aphanitic, columnar jointed to platy basall nows making up Brown Mounh. Upper part of sequento sists of plagiolase-rich phyric basall hin. Ups alor piate top

Andesite flows (late Eocene)-Andesitic flows and amygdaloidal flow breccia, dominantly plagioclase and plagioclase-clinopyroxene porphyritic. with trace amounts of sphene and apatile, massive, locally columnar joined; locally overlain by dacitic plagioclase phyir to 180 meters thick

\begin{tabular}{|c|c|c|c|c|}
\hline$\theta$ & DATE & REUSON & $B Y$ & \multirow{5}{*}{ 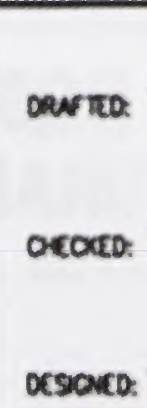 } \\
\hline & & & & \\
\hline & & & & \\
\hline & & & & \\
\hline & & & & \\
\hline
\end{tabular}

Volcanolithic sandstone, conglomerate, and laharic breccia (late Eocene)-Greenish gray, indurated volcanic sandstone, silt and conglomerate containing porphyrtic andesite, basalt, and silicic clasts, interbedded with sedimentary rock, and rare andesite flows and silicic tuff breccia

To Colestin Formation (late Eocene?)-Sedimentary and volcaniclastic rocks, Fluvial and shallow marine sedimentary unit consisting of boulder, cobble and pebble conglomerate sandstone and tuffaceous sandstone, pale whitish orange and ochre weathering, well-rounded to subangular clasts of Klamath lithologies, including schistose graywacke, pebble conglomerate of the Days Creek and Riddle Formation, porphyritic volcanic rocks, cher. Plut lanic derived sandstone that reseme diorite, poorly consolidated, matrix supported, conglomerate clasts commonly imbricated; marine fossils found at one locality in the Lane Mountain Quadrangle, massive red sandstone with well-developed groove casis observed at one locality; approximately 300 to 400 meters thick

$$
\text { Intrusive Rocks }
$$

Diabase and basalt intrusions (late and middle Eocene) - Dominantly glomero-porphyritic augite + plagioclase porphyritic diabase and basalt sills feeder dikes to basalt of Brown Mountain; some dikes cut tuff of Bond Creek; contact aureoles in Mesozoic rocks developed around largest intrusive bodies. Sills at 10,000 foot depth in the Mobil well east of $S u$ therlin give K-Ar ages of $33.9 \pm 3.4$ and $36.8 \pm 3.6 \mathrm{Ma}$ (Ryu and others, 1992)

Rhyolite and dacite intrusions (late and middle Eocene)-Dominantly fine
grained, aphyric, light gray to white dikes and sills within Remote Member (Twr) of White Tail Ridge Formation. May be feeders for flows in unit Tsf.

Andesite dikes and sills (late and middle Eocene)-Platy to blocky jointed, aphyric to plagioclase phyric, finely crystalline andesite intruding

$$
\text { ROCKS OF THE TYEE BASIN }
$$

Spencer Formation (late and middle Eocene)-120 $\mathrm{m}$ of friable, fine- to very coarse-grained moderately sorted, thick- to very thick-bedded, mica-
ceous, arkosic cross-bedded to laminated sandstone with a few coal bed and carbonaceous mudstone; fluvial-deltaic; some shallow-marine mollusks and carbonized leaves date the unit as late Eocene (Hoover. 1963; Sanborn, 1937)

Tab Bateman Formation (late and middle Eocene) $-750 \mathrm{~m}$ of fine- to coarsegrained, moderately indurated, cross-bedded to ripple and parallel laminated to hummocky bedded, micaceous arkosic sandstone; minor overbank mudstone; some sub-bituminous coal and bioturbated sandstone with a few shells of Venericardia (Weatherby, 1991); composed of many thickening. upward parasequences; wave-dominated delta. Unit caps high ridges; in part age-equivalent to Spencer Formation

Tebm Bateman Formation mudstone (late and middle Eocene) - Thin to thick bedded, locally fossiliferous pro-delta-neritic mudstone; interfingers with Bateman sandstone unit in southern part of outcrop area
Toe Elkton Formation mudstone (middle Eocene) $450 \mathrm{~m}$ of laminated, medium to dark gray foram-bearing (bathyal) micaceous mudstone; upper slope to ded, aralgames graded micaceous arkosic turbidite sandstone and thin mudstone beds: a few thickening-upward beds of shallow-marine, mollusk. bearing, laminated to hummocky bedded, micaceous arkosic sandstone in lower part. Formation is middle Eocene (upper Ulatisian-lower Narizian foraminiferal stage according to Bird, 1967; equivalent to A-1 stage of Almgren and others, 1988, and coccolith subzone CP12b. Interfingers with the Baughman Member (Ttbs) of the Tyee Formation

Tyee Formation (middle and early Eocene)-Divided into:

Ttbs Baughman Member (middle Eocene)- 300 to $600 \mathrm{~m}$ of zeolite-cement. ed, iron-stained, coarse-grained, thick- to very thick-bedded, micaceous, lity arkosic sandstone, cliff-former, some large-scale cross-bedded pebWe wave-dominated delta. Delta plain facies inclues massive, green to carbota front facies contains oyster-bearing estuarine deposits, paralic coal, and thickening-upward delta front parasequences of hummocky bedded, bioturbated to ripple-laminated sandstone. In southern part of map, local unconformity at base with fluvial mudstone chip conglomerate incised into underlying deep-marine Hubbard Creek mudstone: conformable contact toward northern part of the map. Molluscan fossils indicate middle Eocene age (Ryu and others, 1992)

Baughman Member mudstone (middle and early Eocene)-Massive, gray green to carbonaceous-micaceous overbank mudstone

Hubbard Creek Member (middle and early Eocene) - 120 to 300 mof slope); minor fine-grained, micaceous arkosic, graded, thin- to thick-bed ded turbidite sandstone and thin mudstone in nested channel sequence (T ths) with slump structures and muds tone chip conglomerates. Uppermost part of unit is bioturbated shelfal-upper slope mudstone (Ryu and others 1992). Benthic foraminifers are referrable to middle Eocene (A-1 to G-1 stages of Almgren and others, 1988, according to Ryu and others, 1992. Unit conformably overlies and interfingers with Tyee Mountain Member mudstone (Ttm) and locally disconformably overlies Camas Valley For mation in the southern part of the map area (Black, 1990, 1993)

Hubbard Creek Member sandstone (middle Eocene)-Fine-grained, micaceous arkosic, graded, thin- to thick-bedded turbidite sandstone and thin mudstone in nested channel sequences

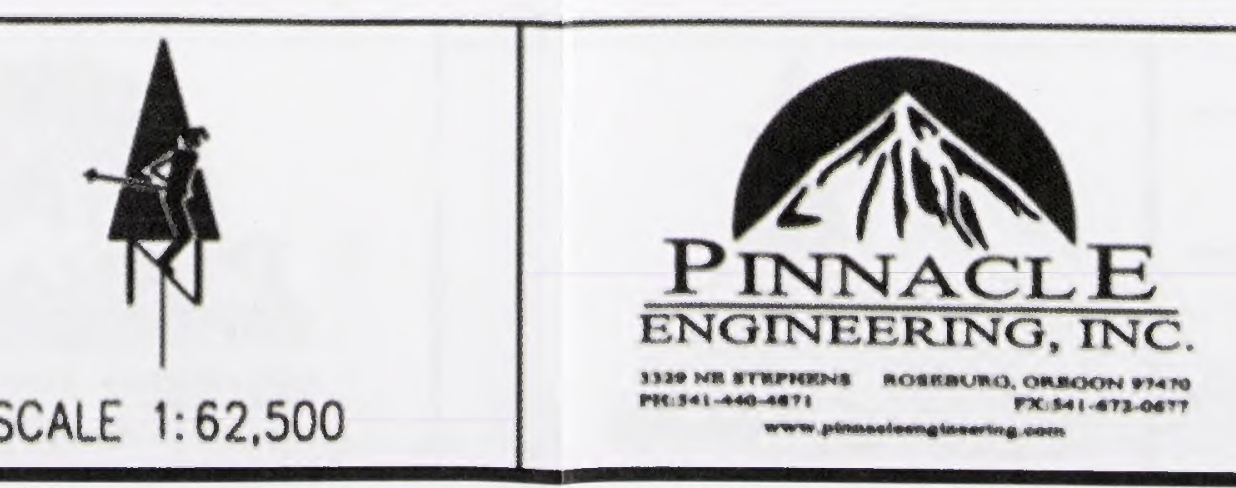

ROSEBURG TO COOS BAY NATURAL GAS TRANSMISSION LINE LEGEND OF GEOLOGIC DESCRIPTIONS marce: on:
on: भeft: 
Ttts Tyee Mountain Member (middle and early Eocene) $-1,500$ to $1,800 \mathrm{~m}$ of rhythmically bedded, thick - to very thick-bedded to amalgamated, wellstone (graywacke) and subordinate thin beds of deep-feldspathic sandmudstone (sandstone to mudstone ratio ranges from $5: 1$ to $30: 1$ ). Brk gray abe and ae turbidite divisions common; with mudstone rip-ups, flute and groove marks, and load casts. Graded sandstone beds are medium to fine. grained and generally structureless but display sharp bottom and gradational upper contacts. Very coarse flakes of muscovite and biotite are distinctive of this unit. Some thick slope channel amalgamated turbidite sandstones ( 20 to $75 \mathrm{~m}$ thick) with slumped beds and mudstone-chip conglomerates. Inner and middle submarine fan facies of Chan and Dott (1983) or proximal ramp facies of Heller and Dickinson (1985). Near base, thin- to medium-bedded outer fan turbidite sandstone with some thick laminated micaceous mudstone (Ttim). Mudstone-chip channel turbidite sandstones incised into underlying Camas Valley Formation in the southern part of the plain facies referrable to the Ulatisian stage, and coccoliths are referrable to the CP. 12 zone (middle and early Eocene; Bukry and Snavely, 1988; Ryu and others, 1992; Brouwers and others, 1995)

作 laminated micaceous mudstone

Umpqua Group (early Eocene and late Paleocene)-Consists of:

Tov Camas Valley Formation (early Eocene) $-600 \mathrm{~m}$ of outer shelf and upper slope, medium dark gray, laminated mudstone; massive, micaceous; upper $100 \mathrm{~m}$ contain some calcareous concretions and shallow-marine mollusks. Unit forms broad gentle sloping valleys. Formation interfingers with an (Twre) and locally unconformably overlies Tenmile Formation $(\mathrm{Tm}$ ). Molluscan assemblages as well as benthic and planktonic foraminiferal assemblages indicate a late-early Eocene age (B-1 foraminiferal stage of Almgren and others, 1988) (Miles, 1977; Moore, 1991; McKeel, 1991 written communication in Ryu and others, 1992). Coccolith assemblages equate to CP-11 zone of Bukry and Snavely, 1988

White Tail Ridge Formation (early Eocene)-Includes:

White Tail Ridge Formation, undivided (early Eocene) -425 to 1425 $\mathrm{m}$ of moderately to well-indurated, ridge-forming hummocky bedded to bioturbated mollusk-bearing delta front-shoreline, fine- to medium-grained, thick- to thick-bedded lithic arkosic sandstone and thin subordinate gray mudstone; some paralic subbituminous coal beds, estuarine oyster-bearing siltstone; many coarsening-and thickening-upward parasequences in lower and upper part of the formation. In the middle part of the formation, mod erately to well-indurated delta plain and haval, planar and large-scale trough cross-bedded, coarse- some polymict boulder-cobble-pebble conglomer-

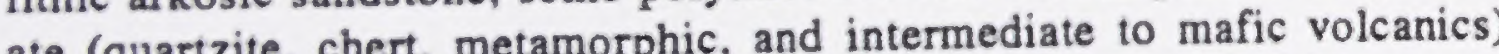
thick massive, green, root-mottled overbank mudstone, and subbituminous coals. Some fining-and thinning-upward fluvial sequences. Formation is early Eocene (planktonic foraminiferal zone PlO McKeel, 1991, in Ry and others, 1992, Penutian-lower Ulatisian benthonic foraminiferal stage: CP-11 coccolith stage, Bukry and Snavely, 1988, Ryu and others,
Brouwers and others, 1995; D. Bukry, written communication, 1993)
Twro Rasler Creek tongue (early Eocene) - $150 \mathrm{~m}$ of moderately to well-indurated, delta front or shoreline lithic arkosic sandstone; bioturbated to hummocky bedded; a few subbituminous coal and thin gray mudstone in terbeds; thickening- and coarsening-upward parasequences; sandstone is conformable tongue that extends into and pinches out northward into mud stone of the Camas Valley Formation (unit Tev). Unit grades laterally into thick Tw south of the map area. Tongue is lower Eocene (Ryu and others, thick Tw2

Twc Coquille River Member (early Eocene) $-300 \mathrm{~m}$ of moderately indurated and sorted, shell-bearing fine- to medium-grained, bioturbated to hum mocky bedded, lithic-arkosic delta front sandstone with thin subordinate gray mudstone interbeds; coarsening- and thickening-upward parasequences common; some lower delta plain, thick, massive, overbank carbonaceous mudstone interbeds, several subbituminous coal beds $(0.5$ to $2 \mathrm{~m})$, and estuarine, oyster-bearing to shallow-marine bioturbated, mollusk-bearing fine- to medium-grained sandstone (Ryu and others, 1992). Member pinches out to the north and northeast. Basal contact of the member interfingers with underlying Remole Me Ber and locally overties massive

Twr Remote Member (early Eocene) $-650 \mathrm{~m}$ of ridge-forming, multiple fining and thinning upward sequences ( 6 to $60 \mathrm{~m}$ thick) of coarse- to very coarse-grained pebbly quartzose-lithic-arkosic fluvial (meandering river) to delta plain sandstone, subordinate thick, root-mottled, overbank deposits; massive light gray-green mudstone, dark gray carbonaceous siltstone,
and thin coals (Kugler, 1979). Poorly sorted sandstone beds in lower part of member are channelized, lenticular, contain lenses of pebbles in largescale planar to trough cross-beds with some overlying ripple- and parallellaminated thinner sandstone which contains carbonized tree limbs and molds of logs. In the southern part of the map area and in the adjacen 1:100,000 sheet, unit is very thick pebble-cobble-boulder polymict fluvia conglomerate suggestive of a braided stream deposit (Ryu and others. 1992). Minor delta front interbeds of bioturbated shelf shallow-marine sandstone that contain fossil mollusks, including Venericardia and Turrichert, graywacke, quartzite, mafic and intermediate volcanic rocks, mudstone rip-ups, and fine pebble chert-quartz conglomerate derived from Mesozoic Klamath Mountains terranes (Koler, 1979; Kugler, 1979; Ryberg, 1984). The thick pebble-cobble-boulder conglomerate incised valley fill in lower part of member is organized imbricated and disorganized matrix-supported debris flow-braided stream deposits that rapidly thin and pinch out northward into typical Remote Member delta plain-meandering river sandstone, mudstone, and coal. The incised valley fill overlies a loCreek Member (unit Twbc; Kyu and others, 19y2); locally divided into:

Twrm Mudstone (early Eocene) - Subordinate thick, root-mottled, overbank massive light gray-green mudstone, dark gray carbonaceous siltstone, an thin coals (Kugler, 1979)
Berry Creek Member (eariy Eocene)-More than 150 mof w bearing, pebbly, hummocky to cross-bedded and bioturbated, mollusk ymict congomerate beds: many thickening-upward delta front parasequen ces. Sandstone is fine- to medium-grained, medium gray (fresh) to yellow. brown (weathered) and thick- to very thick-bedded or amalgamated. Peb. bles are chert, quartz metamorphic, and intermediate to mafic volcanic Menber conformably interfingers with underlying mudstone of Tenmile Formation. Molluscan fauna and coccolith flora indicate an early Eocene age (coccolith biozone CP-11: D. Bukry, withen conmmenication, 1994: Brouwers and others, 1995; Moore, 1991, in Ryu and others, 1992

Twst Unnamed siltstone member (early Eocene)-Massive to thin-bedded marine mudstone underlying sandstone of Whitetail Ridge in southwest corner of quadrangle; unconformable on folded turbidites of Tenmile Formation inferred to be deeper marine facies of Whitetail Ridge Formation

Tenmile Formation (early Eocene)-Includes:

$\mathrm{Tm}$ Tenmile Formation, undivided (early Eocene)-Up to $1,000 \mathrm{~m}$ of massive to well-bedded, very thick sequences of deep-marine, well-indurated, dark medium gray, rhythmically bedded, thin, graded, medium - to very coarse-grained lithic turbidites (Bouma abcd and bed divisions common) and thin dark gray mudstone interstratified with thick bathyal foraminiferabearing. upper to lower slope and basinal, dark gray laminated to massive
mudstone; minor medium- to thick-bedded, very coarse-grained, lithic turbidites: some thick lenses and channels of massive, pebbly lithic sandstone to disorganized and organized polymict pebble-cobble conglomerate. Thin mollusk-bearing, upper slope-outer shelf mudstone in upper part of unit (Ryu and others, 1992). Tenmile Formation strata conformably overlie Bushnell Rock Formation. Foraminiferal and coccolith assemblages indicate formation is early Eocene (Penutian foraminiferal stage: Thoms, 1965; Miles, 1977; and CP10 and 11 coccolith stages: D. Bukry, written communications, 1991-96; Brouwers and others, 1995). Lower part of the unit equates to foraminiferal stages C and B-4 to B-1 of Laiming (as describect
by Almgren and others, 1988; McKeel, 1991 in Ryu and others, 1992)

Slope mudstone (early Eocene) - Dark gray slope mudstone with medium gray, thin-bedded lithic turbidite sandstone filling cross-cutting nested channels; lenticular sandstone beds, slumped and prolapsed bedding, flame and load structures. Some massive upper slope-outer shelf, massive, dark gray, mollusk-bearing mudstone in upper part; unit overlies basin plain

Tmsm Turbidite sandstone and mudstone (early Eocene)-Thin- to mediumGedded(?). lenticular lithic sandstone and dark gray mudstone; grades latfan levee deposit
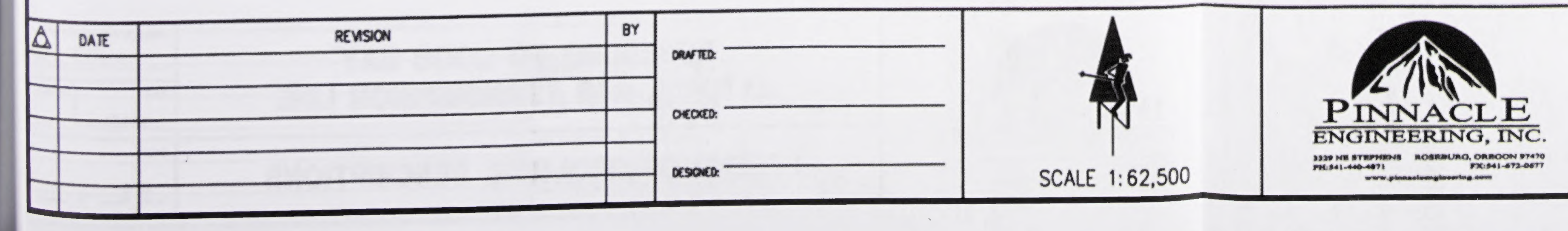

ROSEBURG TO COOS BAY 
omerate (early Eocene)- Unit cone channel deposits - up to $500 \mathrm{~m}$ thick ne, medium gray, pebble-cobble-bouldy quartz, volcanic, and metamorphic , framework-supported, graded and re-rounded; some dehris flow deposits of ers and cobbles (unit Tbrm) and pebbly, , lithic sandstone; minor bathyal fora minated mudstone interbeds and minor cies represents deep-marine submarine submarine fan valley sequences (Ryu thofacies - locally underlies submarine sists of up to $730 \mathrm{~m}$ of ridge- and cliff. t fanglomerate, debris flow deposits, le conglomerate, and braided river deframework-supported conglomeratic. yu and others, 1992). Clasts are domi. vein quartz, quartzite, phyllite, greenate to mafic volcanic rocks. Minor mas. nated, fine-grained lithic sandstone in. of formation consists of $75 \mathrm{~m}$ of neared, moderately sorted, pebbly, mediumpolymict conglomerate lenses become this lithofacies. Formation locally conils and sparse benthic foraminifers of rly Penutian foraminiferal stages: Mc2; Brouwers and others, 1995) and coc0 (D. Bukry, written communication. both the Mesozoic Klamath Mountains cene Siletz. River Volcanics, bus is synthrusting. Between Winston and Dixon- marine facies ( $\mathrm{Tbr}$ ) is interbedded with River Volcanics and is intruded by corade laterally northward into lower part oup of Ryu and others, 1992, 1996)

cene) - Very poorly sorted polymict b- angular boulders up to $4 \mathrm{~m}$ in diame. chert, and basalt in a matrix of basaltic in lenses of turbidite sandstone and sili.

and late Paleocene) - Submarine pillow bedded volcaniclastic and sedimeniary

nd late Paleocene) - Sedimentary units 1 pillow basalt in the Roseburg Formais resiricted to the sedimentary units.
Turbidite sandstone and mudstone (early Eocene and late Palecene)-Indurated, rhythmically bedded, thin- to very thick-bedded, medium gray, graded lithic sandstone and subordinate thin to medium beds of dark gray foraminifer-bearing mudstone interbedded with pillow lava and submarine basaltic breccia of Siletz River Volcanics (Tsr). Sandstone beds contain Bouma abcde and bede divisions. flute clasts, grooves, burrows, load casts, and mudstone rip-ups characterisitc of deep-marine environment. Sandstones derived from Mesozoic Klamath Mountains terranes and locally from basaltic source terrane; lithologically similar to younger Tenmile lithofacies. Unit forms interbeds $1010100 \mathrm{~m}$ thick between flows and becomes the dominant lithofacies to the southwest. Mudstone contains sparse late Paleocene to lower Eocene foraminifers and coccoliths (CP 8 to 10. Ryu and others, 1992; Brouwers and others, 1995; D. Bukry, written communication, 1996).

Tre Conglomerate (early Eocene) - Thick- to very thick-bedded, deep-marine, framework-supported, polymici poorly sorted pebble-cobble-boulder conglomerate interbedded with pillow basalt of Siletz River Volcanics and locally enclosed within pillows ; contains sub-rounded to rounded clasts of basalt, quartz, chert, metagreywacke, limestone, and metavolcanic rocks derived from Mesozoic terranes south of Wildlife Safari faulı; unit is poorly to moderately sorted, reverse and normally graded, amalgamated to mas. sive, lenticular to channelized beds

Basaltic sandstone (early Eocene)-Dark brownish black to greenish brown. well-cemented basaltic sandstone; massive to thick-bedded, medium- to very coarse-grained, moderately to poorly sorted; locally pebbly and conglomeritic, with zeolite-filled vesicles in clasts: contains broken molluscan and echinoid fossils; interbedded with pillow basalt and locally overlying subaerial basalt; formed as shallow-marine and pocket beach deposits around subsiding oceanic island headlands and basaltic sea stacks of the underlying Siletz River Volcanics

\begin{tabular}{|c|c|c|}
\hline \multirow{3}{*}{ 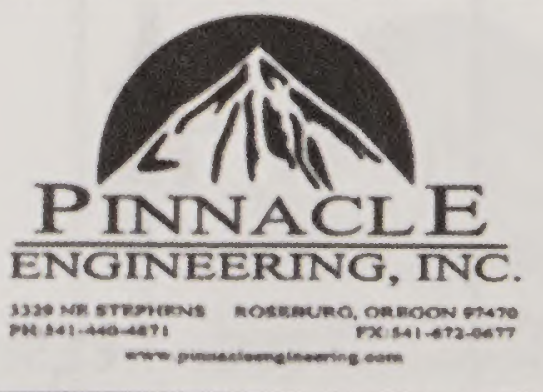 } & \multirow{2}{*}{$\begin{array}{l}\text { ROSEBURG TO COOS BAY } \\
\text { NATURAL GAS TRANSMISSION LINE }\end{array}$} & $\begin{array}{l}\text { masct: } \\
20517.2 \\
\end{array}$ \\
\hline & & \begin{tabular}{l|l} 
ant: & hersom \\
\end{tabular} \\
\hline & LEGEND OF GEOLOGIC DESCRIPTIONS & B-8 $\circ$ \\
\hline
\end{tabular}


Submarine basalt flows ly aphyric to plagiocla lava, columnar jointed tens of meters thick: b: vesicle and fracture f quartz, and zeolite: ce contacts poorly defined tic tuffaceous siltstone mudflow breccia. Flow km thick in Roseburg a and basaltic breccia en. sicular, amygdaloidal. of 13.177 feet. Upper I nell Rock Formation: clasis of Mesozoic ros cene (CP.8) to lower E ry, written communica others, 1995). Along $t$ T26 S.. R.4 W.), a m contains a foraminifer: or D stage of Alingren Whole rock $\mathrm{K}$-Ar date: and in the Coquille-M Roseburg quadrangle (Duncan, 1982). K-Ar by Mobil Oil Corporat ta, courtesy of Bill See Jack Creek-Dickinson the bottom of Mobil's Ma (Duncan, 1982), cl salt in Mobil's Sutherli (unpublished data, cor sites in the Roseburg are all magnetically re $X)$, suggesting eruptid 27 to $23(62.5-51.8 \mathrm{M}$ )

Subaerial basalt flows umnar-jointed aphyric ered and oxidized floy dark red oxidized silts Turkey Hill-Dickensol salt and are in turn ove

\begin{tabular}{|c|c|c|c|c|}
\hline DATE & REUSION & \multirow{3}{*}{$\begin{array}{l}\text { TRG TO COOS BAY } \\
\text { AS TRANSMISSION LINE }\end{array}$} & \multicolumn{2}{|c|}{$\begin{array}{l}\text { prascet: } \\
\quad 20517.2 \\
\end{array}$} \\
\hline & & & & Versom \\
\hline & & & in/28/01 & \\
\hline & & EOLOGIC DESCRIPTIONS & & \\
\hline
\end{tabular}


Turbidite sandstone (early Eocene) - 45 to $150 \mathrm{~m}$ of well-indurated, bidite lithic sandstone, rhythmically bedded, wilh subordinate thinner, dark gray, even-bellod mudstone, sandstone to mudstone ratio ranges from $2: 1$ to 5:1; some thinning-and fining-upward as well as thickening-and coarsening-upward sequences, includes a few very thick-bedded amalgamated. massive, medium-grained lithic sandstone with thin discontinuous mud

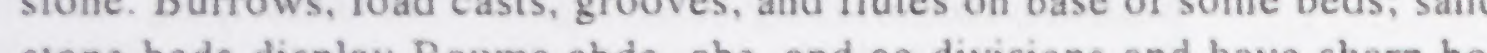
stone beds display Bowna abde, abe, and ac divisions and have sharp boups. $\mathrm{Pidge}$ forne (1972) representing submarine mid fan lobes and clunnels (Ryberg. 198 Tmms, and Tmsm

Basin plain mudstone (early Eocene) - Up $101225 \mathrm{~m}$ of foraminiferbearing, chippy weathering basinal mudstone, dark medium gray, laminat to thin-bedded, fine-grained lithic turbidite sandstone and mudsıne; forms condensed secion $(<40 \mathrm{~m}$ thick) where unit onlaps subaerial paleohighs of Sileiz River volcanics that include a basal dark brown, well-cemented basaltic sandstone (up to $35 \mathrm{~m}$ thick) shallow-marine and pocket beach deposits

Mudstone and turbidite sandstone (early Eocene)-Thick, even-bedded sequences of well-indurated, deep-marine (bathyal) rhythmically bedded, thin to very thin, graded beds of medium gray, fine- to medium-grained turbidite lintic sandstone and dark gray mudstone; sandsione to mudstone ratio ranges from 1.1 to 1.4, some beds contain flute casts, grooves and burrows and Bouma bede, abede, and cde divisions, turbitite facies D of Mutti and Ricei Lucelii (1972); Outer submarine fan to basinal facies (Ryberg, 1984; Ryu and others, 192 is interbedded with unit Tms

Submarine fan channel sandstone (early Eocene) $-230 \mathrm{~m}$ of well cemented, very thick-bedded, amalgamaled, massive to graded, ridge-forming, pebbiy, coarse-grained, decp-marinc, lenticular, hithic sandstone (with Bouma aa and ahe disions)

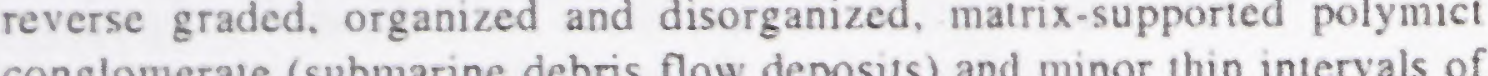
derk simmped bedding Sandstone is locally bleached white io buff near faulis by hydrothermal fluids associated with mercury mineralization (Wells and Waters, 1934). Conglomerate is very poorly sorted and is composed of rounded to sub-rounded clasts of Klamath Mounlains Mesozolc melamorphic, sedimentary, and volcanic rocks. Inner fan and mid fan and lower slope channel and inner fan valley (Ryd and onters. unit Tmss and grades to the sovivesing slope turbidie mudstones of

Bushnell Rock Formation (early Eocene) - Divided into:

Slater Creek Member (early Eocene) - $640 \mathrm{~m}$ of well-indurated, shallow-marine, fine-grained, thick- to very thick-bedded, massive to faintly laminated, gray-green, lithic feldspathic sandstone at the top of the Bushnell Rock Formation. Contains minor dark gray mudstonc partings and polymicr conglomorace lenses: broken fos cor sils locally abundant in hiourbated fine sandstone are referrable to the early Eocene and indeate a nertuc environument (I) Marincovich, wrillen communication, 1993: Brounwers and others, 1995
Bushnell Rock Formation conglomerate (early Eocene) - Unit consits - up $10500 \mathrm{~m}$ thick consist of well-indurated deep-marine, medium gray, pebble-cobble-boulda polymict conglomerate (mainly quartz, volcanic, and metamorplic thasts, thick- 10 very thick-bedded, framework-supported, graded and re gerseded clasts rounded to sub-rounded; some debris flow deposits of sandy elay matrix-supported boulders and cobbles (unit Tbrm) and pebbly. porny soned, very coarse-grained, lithic sandstone, minor bathyal for

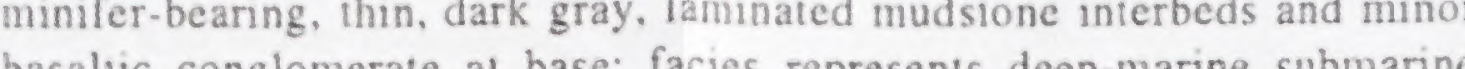

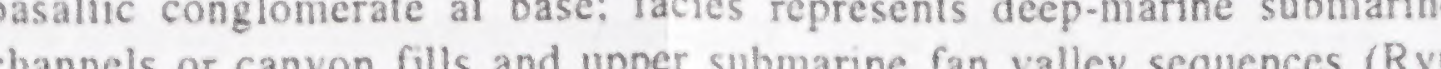

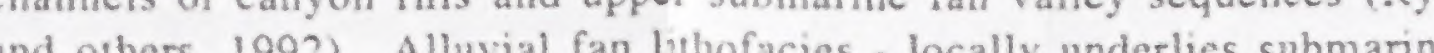

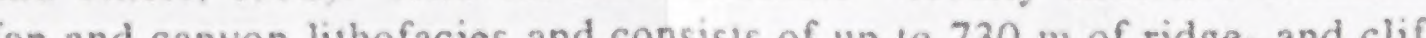
forming, reddish brown polymict fanglomerate, debris flow deposis, poorly sorted boulder-cobble-pebble conglomerate, and braided river deposits of cross-bedded to massive framework-supporied conglomeratic. coarse-grained lithic sandstone (Ryu and others, 1992). Clasts are domnantly graywacke, cherl, quartz, vein quartz, quartzite, phyllite, greensione, graniluc rocks, and intermediate to mafic volcanic rocks. Minor massive maroon mudstone, ripple-laminated, fine-grained linhic sandstone in terbeds. A fan delia facies at top of formation consists of $75 \mathrm{~m}$ of nearshore, mollusk-bearing, cross-bedded, moderately sorled, pebbly, mediumto coarse-grained linic sandstone, polymict conglomerate lenses become

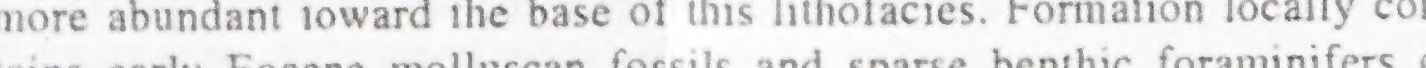

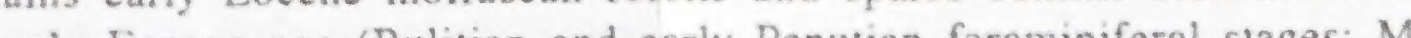
Keel 1991 in Ryy and others, 1992. Brouwers and others, 1995) and coccoliths referrable to biozone CP10 (D) Bukry, written communication. 1996). Unit is unconformable on both the Mesozoic Klamath Mountains terranes and Paleocene to early Eocene Silezz River Volcanics, but is syntectonic and in places involved in thrusting. Between Winston and Dixonville, the basal Bushnell Rock deep-marine facies (Tbr) is interbedded wi submarine pillow lavas of Siletz River Volcanics and is intruded by comagmatic diabase sills. Unil may grade lacerally nonthard ino lower par

Debris flow deposits (early Eocene)-Very poorly sorted polymic boulder conglomerate containing sub-angular boulders up $104 \mathrm{~m}$ in diantelaharic breccia, interbedded with thin lenses of turbidite sandstone and sibt. stone

Siletz River Yolcanics (early Eocene and late Paleocene)-Submarine pillow basalt, subaerial bast

Roseburg Member (early Eocene and late Paleocene) - Sedimentary units that were previously included with pillow basalt in the Roseburg Forn tion of Baldwin (1974); usage here is restricted to the sedimentary units.
Turbidite sandstone and mudstone (early Eocene and late Palecene-Indurated, rhythmically bedded, thin- to very thick-bedded, me um gray, graded lithic sandstone and subordinate thin to medium beds of dark gray foraminifer-bearing mudstone interbedded with pillown submanne basaltic breccia of Sile dizisions, flute clasts, grooves, burrovs, load casts, and mudsione rip-ups characterisitc of deep-marnne enviran ment. Sandstones derived from Mesozoic Klamath Mounains terranes and locally from basalitic source ierranc, hithologically sithiar io younger Ten.

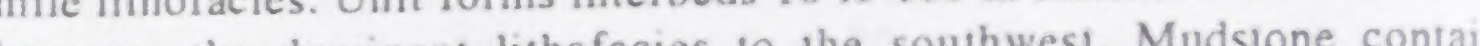
becomes the dominant lithofacies to the soun parse late Palecens. 1992: Brouwers and others. 1995: D. Bukry, written (0, Ryu and oncrs,

.

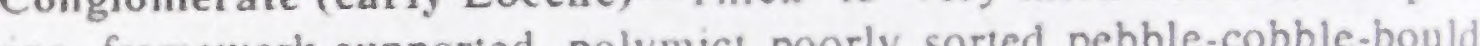
rine, framework-supported, polymict poorty sorted pebiver Volcanics an locally enclosed within pillows; contains sub-rounded to rounded clasts of basalt, quartz, cher1, metagreywacke, limestone, and metavolcanic rock derived from Mesozoic terranes south of Wildlife Safari fault; unit is poor. y to moderately sorted, reverse and

sive, lenticular to channelized beds

Basaltic sandstone (early Eocene) Dark brownish black to greenish brown, well-cemented basaltic sandstone: massive to thick-bedded, mec-

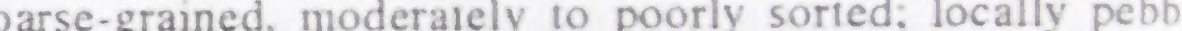
and conglomeritic, with zeolite-filled vesicles in clasis; contains brokc moltuscan and echinoid fossils; interbedded wilh pillow basalt and focanty perying subaerial basali; formed as shallow-marine and pocket beach the underlying Siletz River Volcanics

\section{\begin{tabular}{|l}
\hline \\
\hline
\end{tabular}}

REVSion
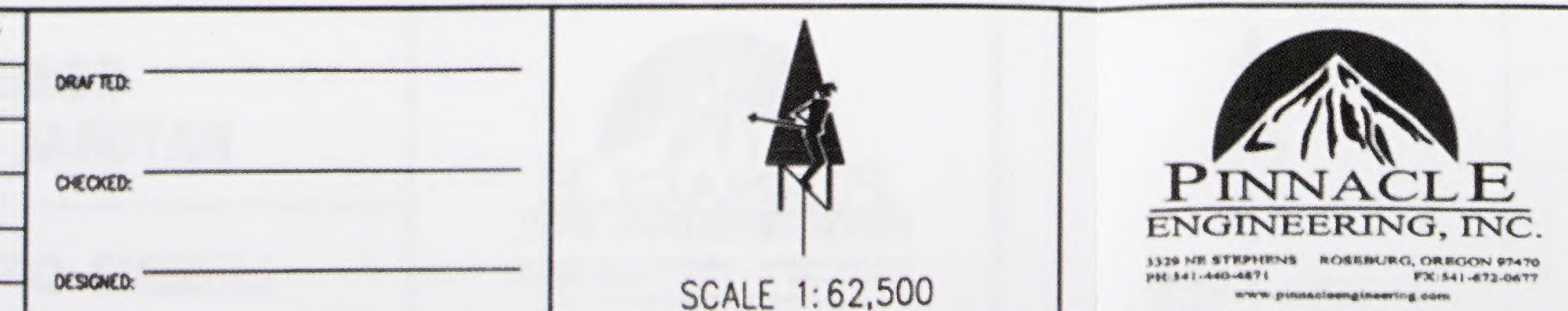

ROSEBURG TO COOS BAY NATURAL GAS TRANSMISSION LINE

20517.2

SCALE $1: 62,500$

LEGEND OF GEOLOGIC DESCRIPTIONS 
Tsr:- Submarine basalt flows (early Eocene and late Paleocene) - Dominantdy aphyric to plagioctase phytic tholenitic basalt; as closely packed pillow

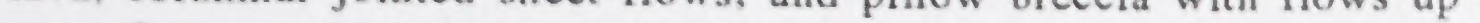
tens of meters thick. basalt is in places amygdalordal and tectonized, with resicle and fractire filhngs or greenish brown smectitic clay, calcite. quartz, and zeolite, com tocally massive and tic tuffaceous silstone, surbidite sandsone, polywict cor mudflow breccia. Flows are steeply dipping, tightly folded, and at least 6 $\mathrm{km}$ thick in Roseburg anticlinorium, with base not exposed: 8900' f basal and basaltic breccia encountered in Sutherlin Mobil well: basalt is very vescular, amygdaloidal, and oxidized (subaerial?) near bottom of well at TD of 13.177 feet. Upper part of unit interfingers with conglomerate of Bushnell Rock Formation; pillows locally surround and enclose well rounded clasts of Mesozoic rocks. Mudstone interbeds contain sparse late Paleocene (CP-8) to tower Eocene (CP10) foraminifers and coccoliths (D. Buky. written communication, 1990-96. Ryu and others. 1992; Brouwers and T26 S. R 4 W A ang the North Umpqua River near Glide (secs.17 and 18 126 S.. R.4 W.). a thadstone interbed near he rop of he pillow basals or D stage of Almgren and others, 1988: McKeel, 1990, written commun). Whole rock K-Ar dates for the Siletz River Volcanics from the Drain are and in the Coquite-Myrtle Point-Remore arez just north and west of the Roseburg quadrangle range in age from $62.1+1.0 \mathrm{Ma}$ to $59.2+2.8 \mathrm{M}$ (Duncan, 1982). K-Ar dates of surface samples from these areas analyzed by Mobil Oil Corporation range from 47.2 Ma to 56.5 Ma (unpublished data. courtesy of Bill Seeley), with the youngest dates clustered in the Drain-

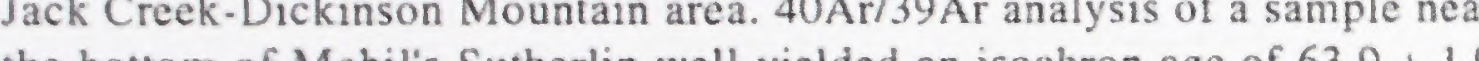
the bottom of Mob2) salt in Mobil's Sutherin well at dephs of 11,340 to $11.350 \mathrm{fh}$, respectively (unpublished data, courtesy of Bill Seeley). Paleomagnetic data from 19 sites in the Roseburg anticlinorium. Turkey Hill, and Coquille River area are all magnetically reversed (Wells and others, 1985 and this paper, Table $X)$, suggesting eruption sometime during predominantly reversed Chrons 27 to 23 (62.5-51.8 Ma, timescale of Berggren and others. 1995).

Subaerial basalt flows (early Eocene and late Paleocene)-- Crudely columnar-jointed aphyric and augite and plagioclase phyric flows with weathered and oxidized flow tops, locally with zeohite-filled vesicles and minor

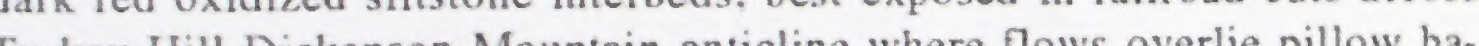
salt and are in
Basait tuff (early Eocene) - Massive to blocky and conchoidally fracturing, light gray, white to buff weathering basaltic aquagene tuff; locally dis. plays bedding, with very fine laminations, scour and fill, and graded bedding: some outcrops contain beds of vesicular, altered basaltic glass lapilit and basaltic mudflow breccia. Interbedded with pillow basalt hows and Mesozoic clasis. Interpreted to be submarine tuffs deposited on the flanks of growing oceanic islands in close proximity to the continen Intrusive Rocks

Diabase (early Eocene) -Massive, blocky, to crudely columnar-jointed aphy. ric to plagioclase phyric, amygdaloidal, plagioclase-augite diabase and baSalt: vesicles filled with greenish-brown smectitic clay, zeolite, and and overlying Bushnell Rock Formation: locally hydrothermally altere along Bonanza fault zone; inferred to be co-magmatic with Silciz River Volcanics

\begin{tabular}{|c|c|c|c|c|c|c|c|c|}
\hline DATE & REUSION & Br & \multirow{3}{*}{ 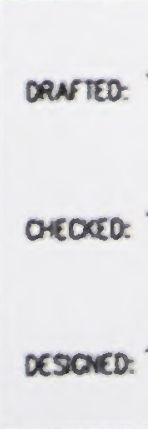 } & & & \multirow{2}{*}{$\begin{array}{l}\text { ROSEBURG TO COOS BAY } \\
\text { NATURAL GAS TRANSMISSION LINE }\end{array}$} & \multicolumn{2}{|c|}{$\begin{array}{l}\text { pracect: } \\
\quad 20517.2 \\
\end{array}$} \\
\hline & & & & & PINNACLE & & $\begin{array}{l}\text { onT: } \\
\text { 11/28/01 } \\
\end{array}$ & Eessom \\
\hline & & & & SCALE $1: 62,500$ & 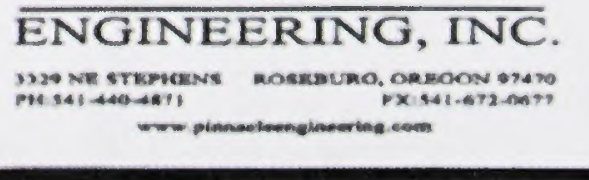 & LEGEND OF GEOLOGIC DESCRIPTIONS & Beहf: & \\
\hline
\end{tabular}





\title{
Appendix B. Cultural Resources
}

CULTURAL RESOURCES INVENTORY FOR A PROPOSED NATURAL GAS PIPELINE BETWEEN COOS BAY AND ROSEBURG, COOS AND DOUGLAS COUNTIES, OREGON

\author{
Prepared for: \\ B.I.S., Inc. \\ Camas Valley, Oregon \\ Prepared by: \\ Albert C. Oetting \\ Heritage Research Associates, Inc. \\ 1997 Garden Avenue \\ Eugene, Oregon 97403 \\ October 1, 2001
}

Heritage Research Associates Report No. 239 


\title{
Appendix B Cultural Resources
}

\author{
CULTURAL RESOURCES INVENTORY FOR A PROPOSED NATURAL GAS \\ PIPELINE BETWEEN COOS BAY AND ROSEBURG, COOS AND DOUGLAS \\ COUNTIES, OREGON
}

\section{Introduction}

A cultural resources surface inventory survey has been conducted by Heritage Research Associates, Inc. for portions of an underground natural gas pipeline route in western Oregon from Coos Bay, Coos County, to Happy Valley near Roseburg, Douglas County. This project was conducted under contract to B.I.S., Inc. For the most part, the proposed route follows existing transmission lines or roads. Portions of the route have been previously surveyed for cultural resources; these were not re-examined for this project.

From the western end in Coos Bay (Table B-1), the proposed route first follows a new right-of-way (ROW) corridor in the hills above the city of Coos Bay, then follows a Bonneville Power Administration (BPA) transmission line to Isthmus Slough. The proposed route then alternates between the CBW Road and a BPA transmission line ROW to cross the mountainous Coast Range. Near Reston, on the east edge of the mountains, the route returns to the BPA transmission line ROW and continues through the southern portion of Flournoy Valley, across Lookingglass Valley, and across the northern margin of Happy Valley to the eastern terminus at an existing natural gas pipeline near the South Umpqua River. The overall route is approximately 60 miles. The route portions surveyed for the current project included the new ROW section at the western end of the route, transmission line sections southeast of Cherry Creek and between McKinley and Fairview, and all of the transmission line route from the eastern terminus to the CBW Road west of Reston. All of the CBW Road sections of the proposed route were surveyed for cultural resources in 1999 (Oetting 1999), and the transmission line from the Coos City Bridge to the Libby district in Coos Bay was also surveyed in 1999 (Boersema and Minor 1999). These sections were not re-surveyed.

A background literature search conducted at the Oregon State Historic Preservation Office revealed nine previously recorded prehistoric archaeological sites located within two miles of the proposed route, and that one of these prehistoric sites is within the proposed route. Several historic buildings and properties border the route, but none will be affected by the construction or operation of the gas pipeline. With permission of landowners or the appropriate federal agencies, those portions of the proposed route not previously surveyed were inspected by one or two archaeologists in January and August, 2001. The previously recorded site within the proposed route was relocated in the field, and one new prehistoric site was found and recorded. One isolated find location was also identified. Several other areas along the proposed route were considered to have a high probability for containing prehistoric or historic cultural materials, although no surface artifacts were identified during the survey.

It is recommended that the two prehistoric archaeological sites in the proposed route (35DO819 and 35DO879) be avoided by the pipeline construction. If avoidance is not feasible, it is recommended subsurface site evaluation test excavations be undertaken to determine the significance of these two sites in terms of eligibility to the National Register of Historic Places. It is also recommended subsurface site discovery probes be excavated in eight specific areas along the route, seven where the route crosses streams or rivers, and at one location where an isolated surface artifact was observed. It is recommended a qualified archaeologist monitor the pipeline construction activities in areas along the route where archaeological sites are likely to occur, to be determined when the site discovery probes are completed. Finally, if future realignments of the route include segments that have not been examined for cultural resources, it is recommended such route segments be inspected in a manner consistent with the present project.

This survey was conducted through B.I.S., Inc. The field survey was directed by Robert Musil with the assistance of Richard Bland, Julie Ricks, and Laura White. This report has been prepared by Albert Oetting. Brian Cox, B.I.S., Inc., contributed pertinent maps and other data for the successful completion of this project. 
Figure B-1: Location of the Proposed Natural Gas Pipeline

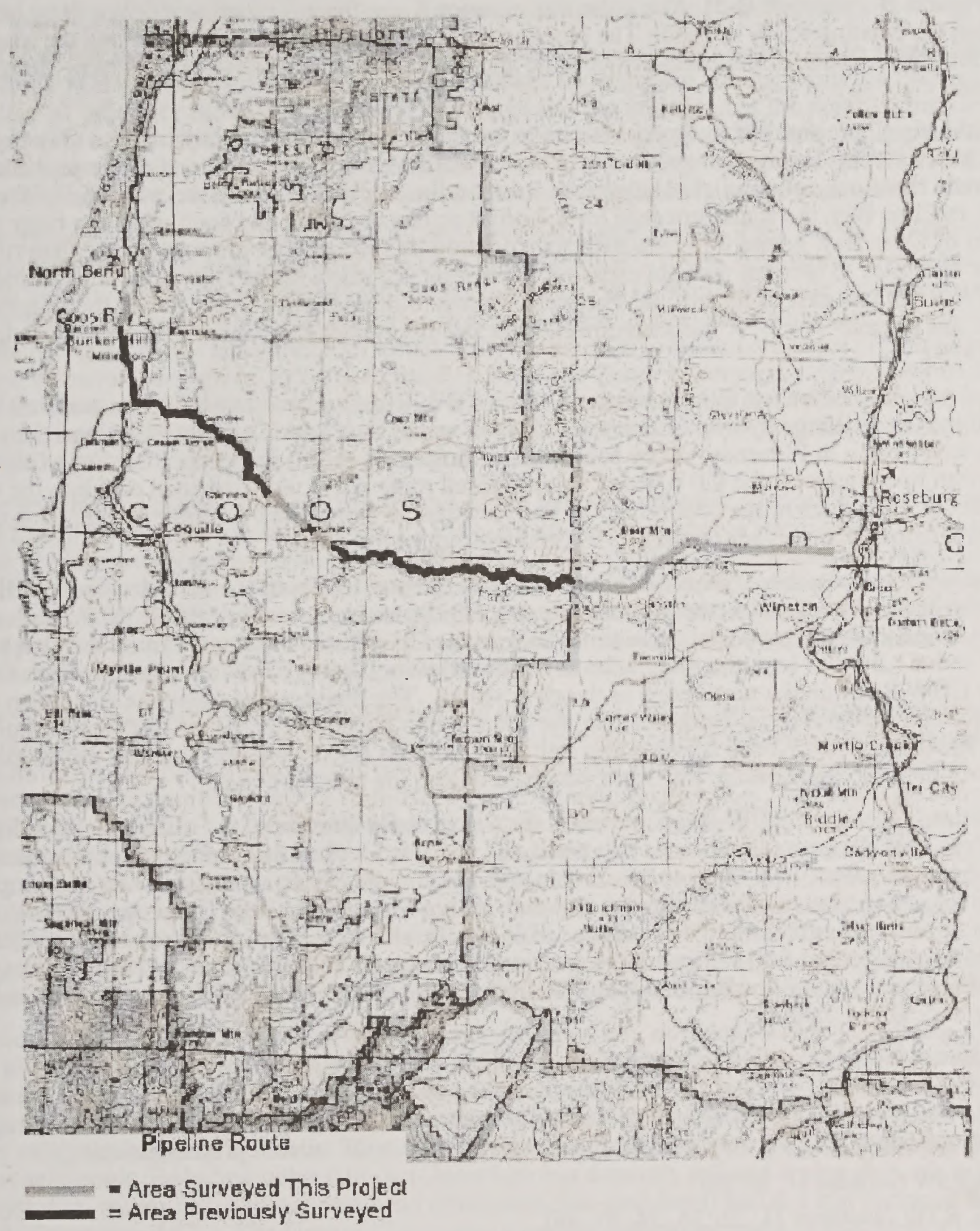




\section{Project Location and Setting}

The planned route for the underground natural gas pipeline generally follows segments of BPA transmission lines and portions of the CBW Road through the central areas of Coos and Douglas counties in western Oregon (Figure B1, see also Figures B-2 through B-5). Along the transmission lines, the gas pipeline ROW will be beneath the power lines or within the existing ROW corridor. The pipeline will be buried in the roadbed or along the road shoulder in the sections on the CBW Road. Underground fiber optic and other utility lines are already present along portions of this proposed route.

The proposed natural gas pipeline route runs between a western terminus in the city of Coos Bay to an existing natural gas pipeline in Happy Valley, just southwest of the city of Roseburg. The west end of the pipeline is the only portion of the route that does not parallel existing transmission lines or a road. From the west end of the pipeline near Ocean Blvd. in Coos Bay, the route proceeds for 1.7 miles southeast, south and southwest to a ridge above the Englewood section of Coos Bay, where it joins a BPA transmission line ROW. The proposed route then runs south and southeast for 4.5 miles to Isthmus Slough, crossing the slough just north of the Coos City Bridge and intersecting with the CBW Road just east of the bridge. The westernmost route section, before joining the transmission line, was surveyed for this project. The BPA transmission line has been previously surveyed for cultural resources (Boersema and Minor 1999).

The proposed pipeline route then follows sections of the CBW Road and another BPA transmission line through the mountains of the Coast Range by way of Brewster Canyon on the East Fork Coquille River, and then it descends into the Umpqua River basin in Flournoy Valley southwest of Roseburg. From just east of the Coos City Bridge, where the transmission line intersects the CBW Road, the proposed route will follow the road east into the Coast Range uplands for about 11.7 miles to the community of Fairview on the North Fork Coquille River. This CBW Road section has been previously surveyed (Oetting 1999) and was not re-inspected.

The proposed route follows the CBW road southeast from Fairview for about 0.4-mile, to where a BPA transmission line crosses the road. At this point, the proposed route joins the transmission line ROW for 3.1 miles southeast to McKinley. At McKinley the proposed route shifts back to the CBW Road for about 1 mile, then back to the transmission line for about 1.2 miles over the mountainous divide between Cherry Creek and the East Fork Coquille River, rejoining the CBW Road on the north edge of the river valley. The proposed gas pipeline route then parallels the CBW Road for about 20 miles, up Brewster Canyon and through the communities of Dora and Sitkum. This portion of the CBW Road has already been surveyed for cultural resources (Oetting 1999) and was not re-examined. The two segments along the transmission line were surveyed during the present project.

The proposed route along the CBW Road intersects the transmission line about 9.7 miles east of Sitkum, just west of the crest of the Coast Range mountains. At this point, the proposed route shifts back to the transmission line ROW and follows it east for about 16.4 miles to the eastern end of the route. The transmission line and proposed route first crosses the divide, then turns northeast toward the south end of Flournoy Valley. The proposed route and transmission line then turns to the east along the south base of White Tail Ridge and crosses Lookingglass Valley south of the community of Lookingglass. Still following the transmission line, the route ascends the ridge dividing Lookingglass and Happy valleys and crosses the lower slope of the hills on the north side of Happy Valley to the eastern terminus at an existing natural gas pipeline.

Overall, this linear route is approximately 60 miles long, but about 37.6 miles have been surveyed in the recent past (Boersema and Minor 1999; Oetting 1999). Therefore, the portion of the route surveyed during the current project was about 22.4 miles in length. The surveyed route segments pass through portions of seven townships. These townships and sections containing portions of the route surveyed during the current project include:

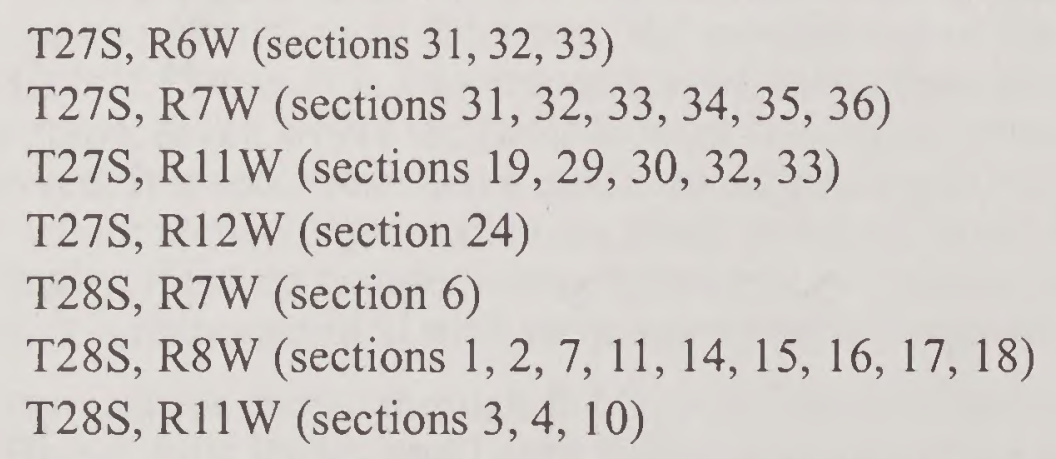

The proposed natural gas pipeline route passes through two prominent physiographic areas of southwest Oregon--the Coast Range and the Umpqua River basin. High precipitation and incisive water erosion have carved the Coast Range foothills and mountains into a rugged terrain of steep and densely forested slopes, deep narrow river and 
stream canyons and long sinuous ridgetops that insulate the interior basins from the Pacific Ocean (Orr et al. 1992; Welcher and Greenspan 1992). The Umpqua River basin is comprised of large and small tributary stream valleys separated from one another by rolling hills and ridges. The North and South Umpqua rivers have their headwaters in the Western Cascades Mountains and have created valleys with fertile bottomlands above and below their confluence. The lower Umpqua River cuts through the Coast Range and drains into the Pacific Ocean.

The Coast Range has a mild, marine-influenced climate with high precipitation during the winter and moderate yearround temperatures. This north-south mountain range catches the moisture coming from the Pacific Ocean and creates a rain shadow effect for the eastern slopes of this range and the drainages of the neighboring Umpqua River basin. Precipitation ranges from 60 to 90 inches along the coast to as much as 200 inches along the crest of the Coast Range, but declines to only 20-40 inches in the eastern foothills and valleys (Loy et al. 1976). The Umpqua River basin has a relatively mild climate characterized by wet cool winters and warm dry summers.

The mild, wet climate of the Coast Range fosters extensive and dense stands of the Pacific Northwest temperate coniferous forests. The northwest end of the proposed pipeline route is in the Sitka Spruce (Picea sitchensis) forest zone of these widespread western forests (Franklin and Dyrness 1973), while the route crossing the Coast Range mountains is within the western hemlock-Douglas fir (Tsuga heterophylla) vegetation zone. The principal overstory species of the Picea sitchensis zone are Sitka spruce (Picea sitchensis), western red cedar (Thuja plicata), Douglas fir (Pseudotsuga menziesii) and grand fir (Abies grandis), while the Tsuga heterophylla zone is dominated by Douglas fir and western hemlock (Tsuga heterophylla), with a variety of other conifers and deciduous trees such as bigleaf maple (Acer macrophyllum) and alder (Alnus rubra). A dense understory of many different trees, shrubs, ferns, grasses and forbs generally covers the floor of these forest zones.

The warmer and drier climates of the interior valleys of the Umpqua drainage support distinctive vegetation communities. Prior to agriculture and fire suppression by Euro-American emigrants in the nineteenth century, these inland valleys were predominantly open prairie grasslands. These grassy prairies were created and maintained through fires regularly set by Native Americans to promote the growth and harvest of certain plants, especially seed-bearing species, and to control the movement and concentration of game animals for more productive hunting. Scattered oaks dotted these prairies, creating oak savannahs and oak-conifer woodlands covered the hills bordering the valleys. Rivers and streams were bordered with riparian gallery forests.

These native grasslands were extensively disturbed and altered by Euro-American introduction of agriculture and livestock grazing, but they were probably similar to the bunchgrass-needlegrass communities found in the interior valleys of California and can be generally divided into moist or dry habitats (Franklin and Dyrness 1973; Habeck 1961). These habitats supported a variety of forbs and seed-bearing grasses (e.g., danthonia [Danthonia californica], sunflower [Eriophyllum lanatum], fescue [Festuca spp.], strawberry [Fragaria spp.], needlegrass [Stipa spp.]), and the moist areas also supported marsh and wet meadow species such as camas (Camassia quamash) and sedges (Carex spp., Eleocharis spp.). The oak woodlands and savannahs of the valley floors were predominantly Oregon white oak (Quercus garryana) with some California black oak (Quercus kellogii). The oak-conifer woodlands of the foothills included elements of the upland conifer forests such as Douglas fir, grand fir and western red cedar, along with the oaks and other deciduous species. The bottomland gallery forests consisted of Oregon white ash (Fraxinus oregana), black cottonwood (Populus trichocarpa), Douglas fir, bigleaf maple and a variety of understory species.

These upland and lowland environmental settings supported a variety of fauna (Bailey 1936). Black-tailed and whitetailed deer (Odocoileus columbianus columbianus, O. virginianus leucurus) frequented lowland valleys as well as upland settings, along with Roosevelt elk (Cervus canadensis roosevelti), black bear (Euarctos americanus altifrontalis) and many smaller species of mammals. Waterfowl and terrestrial birds, both residential and migratory, were common in valley streams and wetlands. The Umpqua River and its tributaries provide spawning grounds for many anadromous salmonids, including coho salmon (Oncorhynchus kisutch), fall and spring chinook salmon (Oncorhynchus tshawytscha), winter and summer steelhead (Oncorhynchus gairdneri) and sea-run cutthroat trout (Oncorhynchus clarki) (Greenspan 1992). The Umpqua basin also supports substantial resident fish populations. 


\section{Cultural Setting}

Productive archaeological research has been conducted for several years by projects in the Umpqua River basin and on the Oregon coastal margin, through federally-mandated projects to identify and protect significant cultural properties and through research projects sponsored by regional universities. Cultural chronologies and models of settlement-subsistence adaptations have been developed for these regions. However, very little is known about the prehistory of the Coast Range. Very few sites have been found in the many archaeological surveys conducted on federal land in these rugged mountains and while some sites are known in the canyon bottoms, very few have been investigated since they are in private ownership. The archaeological background presented below blends data from overviews and research for the Oregon coast (Minor 1998; Moss and Erlandson 1998), the Umpqua River basin (Minor and Beckham 1992; O'Neill 1989) and the Coast Range (Toepel and Oetting 1992 [see also Aikens 1993]).

The proposed natural gas pipeline route crosses several discrete physiographic areas, which were home to several different Native American groups when European and American trappers and explorers first entered western Oregon. The Coos Indians resided in the vicinity of Coos Bay, the Upper Coquille Indians lived along the Coquille River, including the East Fork Coquille River which the pipeline route follows into the Coast Range. The Upper Umpqua Indians occupied the lowland areas of the upper and middle Umpqua River basin. In general, these groups followed similar seasonal rounds that incorporated lowland winter villages, with shifts to smaller, more mobile task groups in the warmer months that moved about to obtain food resources, visit with relatives and acquaintances, and trade with other groups. The following brief sketches of Native American lifeways, focusing on settlement, subsistence and group mobility, are abstracted from Beckham (1992), Miller and Seaburg (1990), Toepel and Beckham (1981, 1992), Toepel (1987) and Zenk (1976, 1990).

Histories detailing Euro-American settlement and development of the region are available for the counties crossed by the route (Beckham 1986; Peterson and Powers 1952) and for some of the federal lands bordering the route (Minor and Beckham 1992). More complete discussions of regional archaeology, ethnography and history may be found in the sources mentioned above.

\section{$\underline{\text { Archaeology }}$}

Models of settlement-subsistence and cultural chronologies have been developed for the Oregon coast (Minor 1998; Moss and Erlandson 1998) and for the Umpqua River basin (O'Neill 1989; Minor and Beckham 1992). These chronologies are general, using relatively broad time periods and outlining basic settlement-subsistence adaptations. Temporal periods have been defined using radiocarbon ages obtained from specific sites, combined with typological cross-dating of projectile points from a wider range of sites. The age spans are based on uncorrected radiocarbon years before present (RCYBP). The age spans for various projectile point styles have been developed using data from throughout western Oregon.

Proposed settlement and subsistence models for each region and period are based on data excavated at a small number of sites, analogies to ethnographic groups in the region, and parallels seen with prehistoric periods elsewhere in Oregon and western North America. Finally, nearly all of the sites currently recorded west of the Coast Range are right along the coast or in the coastal river valleys. Very few sites are known for the forested areas inland from the coast or in the rugged Coast Range uplands. Therefore, the coastal chronology focuses on evidence from coastal sites and the development of coastal settlement-subsistence adaptations, while the interior chronology relies on material from valley settings and the Western Cascade Mountains in discussing settlement and subsistence strategies.

\section{Oregon Coast}

Paleo-Indian: Isolated finds of fluted points in western Oregon attest to the presence of people in the Pacific Northwest prior to $10,000 \mathrm{BP}$, but none have been identified along the modern coastline. It is likely that artifacts and other evidence of early occupation have been drowned by rising sea levels during the last 10,000 years (Minor 1998).

Early Archaic: At present, the earliest evidence for occupation of the Oregon coast occurs in the Early Archaic period (10,000-5,500 BP [Before Present]). Radiocarbon ages of 6,500 RCYBP to 9,000 RCYBP have been obtained at three sites on the central and southern coast, and similarities in point types and artifact assemblages suggest that several other sites have Early Archaic occupations (Minor 1998). However, the lifeways of these early groups are unclear. Many of the Early Archaic sites lack associated shell middens, leading some researchers to suggest that these earliest inhabitants pursued a "pre-marine" or "pre-littoral" subsistence strategy using terrestrial resources (e.g., 
Lyman 1991). However, early radiocarbon ages are associated with marine vertebrate faunal species or shellfish at the Tahkenitch Landing site and the Indian Sands site. These suggest some use of marine resources during this period, but it is perhaps too early to clearly characterize Early Archaic adaptive strategies (Lyman 1997; Minor 1997; Moss and Erlandson 1998).

Middle Archaic: Marine-oriented subsistence strategies were clearly in use during the Middle Archaic period (5,500-3,000 BP). Numerous sites along the Oregon coast have large shell middens which have yielded Middle Archaic radiocarbon ages and artifacts (Minor 1998). Several of the larger sites are thought to have been villages (Minor 1991). Faunal material indicate Middle Archaic groups were using a variety of intertidal shellfish, coastal birds and mammals (terrestrial and marine). Off-shore fishing may also be indicated by fish remains at the Tahkenitch Landing site. Sites are located on coastal headlands and bluffs, as well as on estuaries and rivers near the coast.

Late Archaic: Economies focused on intensive use of marine resources were present throughout the southern Northwest Coast region by the Late Archaic (3,000-1,500 BP) (Minor 1998). Sites generally contain substantial middens with many varieties of shellfish, fish, birds and mammals. Some changes in settlement patterning are apparent, as Late Archaic sites often do not have preceding Middle Archaic occupations, and many continued to be inhabited into more recent periods (Minor 1991). A number of these sites are large and appear to have been villages. The earliest evidence on the Oregon coast for the rectangular plank houses and bone/antler artwork typical of Northwest Coast late prehistoric and ethnographic societies is found during this period at the Palmrose site on the north coast. These changes may reflect the origins and early development of the complex societies of the succeeding Formative Period and the ethnographic groups of the Oregon coast.

Formative: The Formative Period (1,500-200 BP) encompassed the full emergence of ethnographic Northwest Coast culture patterns along the Oregon coast (Minor 1998). These cultural patterns are characterized by large villages containing plank houses, ranked societies and distinctive modes of artistic elaboration. Formative period sites often have underlying Late Archaic components and are found all along the Oregon coast. The final 200 years of this period is subdivided as the Protohistoric era (Minor 1998), when non-native artifacts entered sites along the northern Oregon coast. These artifacts, such as beeswax and East Asian ceramics, probably came from shipwrecks of one or more Spanish Manila galleons between about Anno Domini (AD) 1550 and 1650. The epidemic diseases that accompanied Europeans to North America apparently resulted in a rapid decline in the coastal Formative population and had a disastrous impact on their cultural and economic lifeways. The complexity of these late prehistoric societies is not clearly reflected in the limited ethnographic data available from surviving coastal groups.

\section{Interior Southwest Oregon}

Paleo-Indian: The presence of a Paleo-Indian period, dating prior to $10,000 \mathrm{BP}$, is based on the isolated occurrence of fluted points in the region. Solitary fluted points have been found in the Eugene and Cottage Grove areas of the southern Willamette Valley (Allely 1975; Connolly 1994; Minor 1985) and along the North Umpqua River and lower Cascade Mountains in the Umpqua River basin (O'Neill 1989; Ozbun and Fagan 1996). No sites dating to this period are known for the region. These artifacts are thought to be equivalent in age with the well-dated 11,500 BP to 10,000 BP fluted point complexes in the Great Plains and Southwest. Whether these fluted points are indicative of a local lifeway of nomadic big game hunting, as suggested elsewhere in North America, remains to be determined.

Early Archaic: This period, 10,000 to 6,000 BP, is viewed as a time of adaptation to the developing Holocene environment of western Oregon (Minor and Toepel 1981). The leaf-shaped "Cascade" projectile point is diagnostic of this period. These points were common in the early levels of Cascadia Cave in the Western Cascade mountains above the central Willamette Valley, and are found in the lower levels of sites elsewhere in Oregon. A variety of plant and animal resources were exploited during this period, but primary emphasis seems to have been on hunting.

The earliest radiocarbon-dated evidence for occupation in the Umpqua region comes from pre-Mazama components at the Dry Creek Site (O'Neill 1992) in the North Umpqua River basin and the Tiller Site (Bevill et al. 1994) in the South Umpqua drainage, as well as post-Mazama levels at the Narrows site on the North Umpqua (O'Neill 1989). The pre-Mazama occupations range in age between 7,130 and 6,500 RCYBP, while the post-Mazama component is 6,270 RCYBP. Undated pre-Mazama occupations have also been identified at Susan Creek Campground (Musil 1994) and the Medicine Creek Site (Snyder 1981). These pre-Mazama occupations are characterized by the presence of broad-stemmed and foliate points, and the use of andesite for the manufacture of large bifaces.

Middle Archaic: Middle Archaic period sites, dating to between 6,000 and 2,000 BP, are found throughout western Oregon (Minor and Toepel 1981). The number of sites and their diverse settings in the Umpqua basin suggest that populations were growing and that a wide range of resources was being used. Ground stone tools are common in sites 
of this period and the frequency of bowl mortars, hopper mortar bases and pestles attests to the increased importance of plant resources to regional subsistence. Leaf-shaped projectile points continue in use during this period, but the most common points are broad-necked stemmed and notched forms.

Umpqua basin sites with Middle Archaic components are found primarily in the foothills of the Western Cascades Mountains. The earliest radiocarbon dated evidence for a Middle Archaic occupation in the region is at the Narrows Site on the North Umpqua River, where charcoal from a small firepit yielded an age of 5,090 RCYBP (O'Neill 1989). Other North Umpqua sites with Middle Archaic occupations include a burial pit at the Island Campground Site (Tasa 1992), the middle component at Susan Creek Campground (Musil 1994), and the middle component at the Apple Creek Site (O'Neill 1991). In the South Umpqua region, Middle Archaic levels are found at rockshelters such as Times Square Rockshelter (Minor and Connolly 1987; Spencer 1989) and the Upper Shelter at South Umpqua Falls (Minor 1987).

Late Archaic: The Late Archaic, from 2,000 BP to Euro-American contact, witnessed the continued development and refinement of preceding Middle Archaic cultural patterns (Minor and Toepel 1981). Populations expanded and inter-regional contacts increased. The settlement and subsistence practices characteristic of the Upper Umpqua and other ethnographic groups became clearly established during this time. A broad range of resources was being exploited by this period. Plant resources were the primary foodstuffs, but hunting remained an important activity. Small, narrow-necked projectile points dominate Late Archaic artifact assemblages, considered to signal the introduction and use of the bow and arrow.

Late Archaic settlement patterns reflect those of the Middle Archaic in much of western Oregon, with Late Archaic cultural components often overlying Middle Archaic components at the same sites. Archaeological evidence in the Umpqua basin indicates that populations were increasing and that settlement and subsistence patterns focused on lowland villages, with seasonal movements to foraging camps in the surrounding uplands (Minor and Beckham 1992). Sites with Late Archaic point types and radiocarbon ages are found throughout both the North and South Umpqua drainages.

Historic: The epidemic diseases which accompanied Euro-Americans to the western hemisphere disrupted and decimated the indigenous people of the Pacific Northwest, including those of the Umpqua region. Here as elsewhere, various diseases resulted in population declines and disrupted traditional social and economic lifeways. The brief Historic period encompasses initial Euro-American contact in the region, around AD 1750, to the signing of the Dayton Treaty in AD 1855 and the removal of surviving Indian populations from their homelands to reservations (Minor and Toepel 1981). Very few sites are known in the Umpqua basin for this period, identified by the presence of EuroAmerican manufactured items. The small number of known sites may reflect the short duration of the period, but may also reflect the drastic decline of the native population due to disease.

\section{Ethnography}

The Indian groups inhabiting the regions crossed by the proposed pipeline route when European and American trappers and explorers first began entering western Oregon include the Coos Indians around Coos Bay, the Upper Coquille Indians in the Coquille River basin west of the Coast Range, and the Upper Umpqua Indians in the Umpqua River basin. These people interacted with one another and shared general cultural patterns, but differed from one another in language and specific cultural expressions.

Oregon Indians were hard hit by the European epidemic diseases that swept the Americas. A series of epidemics resulted in dramatic population losses, abandonment and relocation in some areas, coalition of formerly autonomous groups, and serious disruption of traditional social and economic lifeways. These disruptions had already occurred to a significant degree when ethnographic and ethnohistoric records were beginning to be made, thus these information sources may not accurately reflect the traditional lifeways of the native groups.

Coos: The Coos people resided in the region from the Coquille River on the south to Ten Mile Lake on the north. The Coos spoke two related languages--Hanis and Miluk. Hanis was spoken around Coos Bay and the northern area, while Miluk was spoken around South Slough and in the coastal area around the mouth of the Coquille River. Each tribal group consisted of a group of villages speaking the same language and a common territory with certain rights of access to resources (Zenk 1990). The largest political entity was the winter village group (of one or more villages and hamlets), generally consisting of family groups of paternally related males and their families.

The lifeways of the Coos and other Oregon coast groups were similar in most ways to their more well-known neighbors elsewhere in the Northwest Coast culture area (Toepel and Beckham 1992). People resided in permanent winter 
villages on the shores of estuaries and river mouths, as well as along the lower reaches of the many coastal rivers. They lived in large semi-subterranean, rectangular cedar plank houses. Their economic pursuits were varied, focusing on fish, shellfish, sea mammals and other water-related resources, but also including a variety of terrestrial plant and animal resources. Families or task groups made seasonal trips to obtain particular resources.

Each village group had a chief, usually hereditary, who wielded advisory and judicial powers. The chief was the supervisor for communal activities, moderated quarrels and group discussions, and was expected to look after the welfare of the people, but had little coercive authority. As with other people in the Northwest Coast cultural area, Coosan society operated through a status system based on social rank (generally hereditary) and wealth. Chiefs, their relatives and other wealthy families formed the upper rank of society, the majority of the population formed a socially respectable middle rank, while exceptionally poor people and a few slaves formed the two lower ranks. Wealth was inherited and could also be acquired through trade and exchange between and within groups. Chiefs redistributed some of this wealth through feasting and gift-giving, which enhanced their influence as well as contributing to the well-being of the community. Social and religious ceremonies and rituals constituted important aspects of Coosan life.

Upper Coquille: Historically, the Upper Coquille people resided in the interior watershed of the Coquille River and its primary tributary forks, including the vicinity of the western part of the proposed pipeline route along the East Fork Coquille River. The Miluk Coos lived at the mouth of the river and along the neighboring coastal fringe. The Upper Coquille spoke a dialect of Tututni, an Athapaskan language. Information on the Upper Coquille is limited, but they shared similar cultural traits with other groups in southwest Oregon, and with their more well-known neighbors elsewhere in the Northwest Coast culture area (Toepel and Beckham 1992).

Each tribal group consisted of a group of villages speaking the same language and a common territory with certain rights of access to resources (Zenk 1990). The winter village group was politically autonomous, the population generally consisting of family groups of paternally related males with wives and children. The primary Upper Coquille winter villages were located on the mainstem Coquille River and along the lower reaches of the principal forks. Winter dwellings were large semi-subterranean, rectangular cedar plank houses, although house size varied according to the wealth and status of the family. Economic pursuits were varied, but, as an inland group, they focused on fall salmon runs. Other river-dwelling fish were also taken, along with many kinds of roots, berries and other terrestrial plant and animal resources. Families or task groups made seasonal trips to obtain particular resources.

Typical of the Northwest Coast cultural area, Upper Coquille society operated through a system based on wealth and hereditary social rank, although these social ranks seemed less rigid than those on the northern Northwest Coast (Miller and Seaburg 1990). Chiefs, their relatives, and other wealthy families formed an upper rank of society, with those of moderate wealth and the poor also being distinguished as middle and lower ranks. Among the Upper Coquille, slaves were attached to a chief's household, regardless of actual ownership. After a period of servitude, slaves "got to be a person, not a slave anymore" (Miller and Seaburg 1990:583), and the division between slave and commoner was generally not too rigid. Wealth was inherited and could also be acquired through trade and exchange between and within groups. Each village group had a chief, usually hereditary, who wielded advisory and judicial powers. The chief was the supervisor for communal activities, moderated quarrels and group discussions, and was expected to look after the welfare of the people, but had little coercive authority. Chiefs redistributed some of their wealth through feasting and gift-giving. Social and religious ceremonies and rituals were also important aspects of Upper Coquille life.

Upper Umpqua: The Athapaskan-speaking Upper Umpqua shared linguistic and cultural affiliations with other Athapaskan groups in interior southwestern Oregon and along the coast of southern Oregon and northwestern California (Miller and Seaburg 1990). As with the neighboring Upper Coquille, information on the traditional lifeways of the Upper Umpqua is also very sparse. They resided in the river valleys and foothills of the mainstem Umpqua River and the lower reaches of the primary tributaries to the Umpqua, including both the North Umpqua and the South Umpqua rivers.

The Upper Umpqua generally resided in autonomous villages situated in lowland valleys near rivers during the winter, with small groups moving to various temporary camps between spring and fall to take advantage of various seasonal food resources (O'Neill 1989). Cedar plank houses were built and occupied in the winter, while less substantial brush structures and windbreaks were used during warmer seasons. There were no formal political or economic organizations beyond the level of the village, although inter-village marriages and trading promoted informal alliances between groups. Acquisition of wealth, as well as its redistribution, was considered a virtue and social distinctions were based on wealth (Miller and Seaburg 1990). 
The Upper Umpqua followed an annual cycle of resource procurement, moving as needed to obtain and process foods and goods. Roots, seeds and berries were gathered in the spring and summer, as they ripened in various areas. Fishing for anadromous and resident species was probably a primary activity pursued from spring through fall. Large mammals such as deer, elk and bear were plentiful in the region and were important resources (O'Neill 1989). Mountain upland areas were visited during the summer, and probably early fall, to acquire a variety of vegetal resources, such as berries, seeds and nuts, and to hunt terrestrial game.

\section{History}

European and American trappers and traders began exploring the valleys and mountains of western Oregon in the early nineteenth century AD, trapping in the Willamette Valley in and after 1812, and crossing into the Umpqua basin between 1819 and 1821 (Beckham 1986). In 1826-1827, Alexander McLeod led a party of Hudson's Bay Company trappers and botanist David Douglas on an expedition that included the Willamette Valley, the lower Umpqua River drainage to the coast, and a return through the Coast Range on the North Fork Coquille River and through the middle Umpqua River basin back to the Willamette Valley (Davies and Johnson 1961; Peterson and Powers 1952). This party probably followed existing Indian trails for much of their journey. Trappers continued to work this region, and from 1836 to 1854, Fort Umpqua trading station was maintained by Hudson's Bay Company.

Overland exploration, travel, and then trade in the 1830s and 1840s linked the trading posts of Oregon with the towns of California via the Oregon-California Trail, again probably following older Indian routes through the Umpqua and Willamette valleys. By the 1840s, the moderate climate and rich soil of the Willamette Valley was well known, and emigrants from the United States began arriving over the Oregon Trail. In 1846, a party led by Jesse and Lindsey Applegate passed through the Umpqua region in an effort to establish a new emigrant trail into the Willamette Valley, which became known as the Southern Emigrant Route, or Applegate Trail (Beckham 1986). At the same time, these explorers saw the potential for settlement and agriculture in the Umpqua River basin. Within a few years, settlers began staking lands in the northern stream valleys of the Umpqua basin. With passage of the Donation Land Claim Act in 1850 and with the increasing density of settlement in the Willamette Valley, more emigrants began moving to the Umpqua River basin, and some homesteaded the fertile river valleys of the coastal rivers. The discovery of gold in California, and then in southwest Oregon, provided markets for western Oregon agriculture and timber, as well as bringing prospectors and other speculators to the region in search of mineral wealth.

Tensions between the native population and these emigrants boiled over into hostilities in southwest Oregon in 1855 and 1856. A treaty was signed, but not ratified, and most of the native peoples of southwest Oregon were removed to reservations in the central or northern Coast Range by 1860 . Since then, the Indians of the region have struggled to regain recognition and their rights as Native American groups. The Cow Creek Band of Umpqua Tribe of Indians regained federal recognition in 1982. Most Coosans and Siuslawans joined together to form the Confederated Tribes of Coos, Lower Umpqua, and Siuslaw Indians, which regained federal recognition in 1984. The Coquille Tribe, recognized in 1989, consists of Miluk Coos and Upper Coquille Athapaskan people.

Euro-American population and economic growth continued slowly through the latter half of the nineteenth century and into the twentieth century. The Oregon and California Railroad connected Roseburg to Portland in 1872. Financial troubles stopped the railroad at this point, but this proved to be a boon for Roseburg as it became the transportation hub for commerce throughout interior southwest Oregon. Construction of a military wagon road connecting Coos Bay with Roseburg began in 1870, and the CBW Road was open to traffic in 1872, providing Roseburg with a transportation link to the Pacific coast, and providing Coos Bay with a connection to the interior valleys.

Economic development in the river valleys and larger coastal estuaries has focused on agriculture and stock raising, while the dense forests and rugged terrain of the Coast Range and Western Cascades mountains fostered industrial enterprises such as logging and mining. Logging became a cornerstone of western Oregon industry in the twentieth century, but the economic importance of the timber industry has recently declined with dwindling forest reserves and increasing environmental concerns and regulations. 


\section{Previous Cultural Resources Research In The Project Vicinity}

The archaeological site files and maps maintained by the State Historic Preservation Office (SHPO) in Salem, Oregon, were consulted to locate previously recorded sites in or near the project area, as well as previous investigations that have been conducted in the vicinity. In addition, the district archaeologists for the Coos Bay and Roseburg BLM districts were consulted to obtain information for the project vicinity. Finally, the Coquille Tribe provided information on areas where archaeological cultural materials have been reported in the past.

The proposed underground natural gas pipeline route is approximately 60 miles long and crosses a total of 12 townships between its endpoints near Coos Bay and Roseburg. Due to its length, the route passes near several archaeological sites, historic properties, and areas of previous cultural resources investigations, yet because of its narrow width, the present project actually crosses very few of these recorded sites or previous projects. Overall, nine prehistoric archaeological sites recorded at the SHPO are within two miles of the proposed route. Of this total, one (35DO819) is crossed by the proposed pipeline route, one is mapped adjacent to but not within the route near Fairview, four others are within two miles in the North Fork Coquille River valley near Fairview, one is in the hills east of the Coast Range near Reston, and two are within two miles near the eastern end of the route in Happy Valley.

The probable locations of seven unrecorded archaeological sites on the East Fork Coquille River near Dora and Sitkum have been plotted on the Coos Bay BLM District cultural resources maps. These correspond closely with areas of concern noted by the Coquille Tribe. None of these appear to be intersected by the proposed route (along the CBW Road in this area), but all are located within one mile of this road.

Portions of the proposed pipeline route parallel the historic CBW Road. A historical study of this road has recently been conducted (Beckham 1997). The road, completed in 1872, was dirt for much of its length, but about 20 miles on the western end was planked. The route probably followed older Indian trails. Use of the road declined over the years, as a competing road through Camas Valley (now State Highway 42) and other routes were developed and improved. The road was little used in the 1920s and 1930s. With the rise of truck transportation for logging in the late 1930 s and after World War II, industrial use of the road increased. Comparison of the route shown on the General Land Office township cadastral plats with the current road indicates that the route has changed somewhat, probably reconstructed over the years to accommodate the logging traffic. Sections of the road are paved, with the remaining portions being graded and graveled. The study concluded that the CBW Road retained much of its historical landscape but that the associated historic properties generally had poor integrity and that the road was an "equivocal candidate for nomination to the National Register" (Beckham 1997:76). Furthermore, while improvements to road condition and safety would make this historical landscape more accessible, they might also compromise the historical character of the road. The CBW Road has not been formally evaluated for National Register eligibility by the Oregon SHPO.

Given the age of this road, it is not surprising that several historic properties (50 years old or older) are found along the route. One property, the Abernethy House in the community of Dora, is currently listed on the National Register of Historic Places. However, no historic structures or districts are within the right-of-way that will be affected by construction associated with the proposed pipeline route.

Several cultural resources investigations on file at the SHPO have been conducted within 2 miles of the proposed route. Most have been surveys associated with federal timber sales on the eastern slopes of the Coast Range above the proposed route. Three studies have included portions of the proposed pipeline route, including the CBW Road historical study discussed above. A survey of a BPA transmission line in the Coos Bay area included a segment of the currently proposed route (Boersema and Minor 1999). No cultural resources were found along the route, although site discovery probes were recommended at the Isthmus Slough crossing if ground disturbing construction was undertaken in this area. As mentioned in discussions above, portions of the current route along the CBW Road were included in a survey for a fiber optic line that also included the CBW Road (Oetting 1999). The archaeological site (35DO819) that is within the current project route was recorded during this survey. This site was avoided during the fiber optic line construction by boring beneath the site. Several sections along the CBW Road were monitored during this construction, but no cultural resources were encountered (Oetting 2000).

General Land Office (GLO) survey plats for the 12 townships crossed by the proposed pipeline route were also examined. The cadastral plats for townships in the Coos Bay and Roseburg areas were surveyed in the 1850s, while those crossing the Coast Range were platted in the 1870s. In general, a few cultural features such as houses and land claims were found near the current proposed route near Roseburg-two houses and Donation Land Claims in Lookingglass Valley and one Donation Land Claim with a house in Happy Valley. The CBW Road is depicted on the appropriate Coast Range township plats, and a few houses are identified, but none of the towns along this road had been developed when the plats were surveyed in the mid-1870s. 


\section{Inventory Methods}

An intensive pedestrian survey was undertaken to determine if surface evidence of prehistoric or historic sites or artifacts was present along the portions of the proposed pipeline route where landowner permission had been obtained and that had not been previously surveyed. Four segments of the proposed route were surveyed during the current study, one in the hills above Coos Bay and three within BPA transmission line ROWs.

The proposed route segment in Coos Bay generally followed the route of one lane dirt roads up the ridges on either side of Blossom Gulch. These ridges have been logged in the past and are now covered with second growth shrubs, small trees and brush. The route across Blossom Gulch passes through densley vegetated wet bottomland. The vegetation in this segment limited ground visibility and made walking through the area extrememly difficult. In addition, the wet bottomland ground made the Blossom Gulch area impassable. Survey along this route corridor therefore, was limited to the existing dirt roads and their shoulders. Two archaeologists surveyed this segment, either as a team on either side of the road, or independently surveying along one side of the road in one direction and returning on the opposite side of the road.

The other surveyed sections were within BPA transmission line ROWs. These surveyed segments included 3.1 miles between Fairview and McKinley, 1.2 miles between Cherry Creek (southeast of McKinley) and the East Fork Coquille River valley (west of Dora), and 16.4 miles from the CBW Road at the Douglas County line to the eastern terminus of the pipeline route. In each segment, the transmission line corridor was inspected by two archaeologists, one walking beneath each of the overhead transmission line arms, or by one archaeologist walking one direction under one line arm and returning under the other line arm. If a service road was present within the corridor, at least one archaeologist inspected the road, since it generally provided the greatest mineral soil visibility. Although large trees have been removed from the transmission line corridor, much of the ROW corridor is covered with grass and understory brush. In some areas, trees and brush have been cut but not removed, making passage difficult and further limiting ground surface visibility. Ground surface visibility was generally limited by thick surface vegetation along most of the surveyed route. The routes of each surveyor varied to maximize surface visibility within the transmission line corridor.

Both prehistoric and historic artifacts were searched for during the field inventory. "Historic" items were defined, in accordance with National Register eligibility criteria, as artifacts or features that were at least 50 years old. In addition, the field crew noted landforms, such as stream terraces; where archaeological sites were likely to occur and where site discovery probes should be recommended.

When cultural materials were located, the surveyor halted and examined the find locale to determine if the specimen was isolated or could be identified as part of a larger population of artifacts--a site. The location was flagged in the field and was returned to by the entire field crew to examine the area more closely and, if necessary, record the site. Archaeological sites were designated pragmatically, using several criteria. These criteria include the number and kind of cultural items observed, the site setting, and the conditions of observation. In general, locations with 10 or more artifacts found within a $10 \mathrm{~m}$ diameter area were recorded as sites. In areas where specific landforms created discrete surfaces (such as small benches), the presence of 10 or more items on that surface would be sufficient for designation as a site. Finds of cultural materials which were not classified as sites were also noted and mapped as isolated finds. All prehistoric and demonstrably historic materials encountered within the project limits during the survey were documented. The location of each archaeological site and isolated find was placed on the appropriate USGS 7.5' topographic maps.

Locations determined to be archaeological sites were recorded in the field and these data were subsequently transferred to SHPO Site Record forms. At each site, physical setting, primary vegetation, water source, site size, artifact density and diversity, occurrence of cultural features, and relationships to other sites were examined and recorded. The types of artifacts observed and counts or estimates of their frequency were recorded, along with brief descriptions of the exposed cultural materials. No artifacts were collected during this survey. Photographs were taken at each site to illustrate the site area and local environmental setting. 


\section{Inventory Results}

The transmission line segments were surveyed in January, 2001, and the westernmost segment above Coos Bay was surveyed in August, 2001. The pedestrian survey of each section was accomplished by a field crew of one or two archaeologists, examining the transmission line corridor as described above. Survey conditions and ground surface visibility varied along the route due to terrain and surface vegetation.

The proposed route in the hills above Coos Bay crossed steep ridge slopes and wet bottomland. Survey was limited to the mineral soil visible in the existing dirt roads and road shoulders, as ground visibility away from these areas was less than 10 percent. No cultural materials, prehistoric or historic, were found in this segment. Given the difficult topography of this proposed route segment, the probability for cultural resource sites here is low.

The two short transmission line segments on the west side of the Coast Range also crossed steep, hilly terrain and contained dense vegetation. Ground surface visibility was no more than 10 percent, with mineral soil visible only in the transmission line service road. No cultural resources were noted in these sections, but two streamside areas likely to contain archaeological sites were noted. One location is along the banks of the North Fork Coquille River just southeast of Fairview (T27S, R12W, section 24). The other high probability area is along the banks of Cherry Creek, about one mile southeast of McKinley (T28S, R11W, section 4).

The long eastern transmission line survey segment, 16.4 miles between the Douglas County line and the eastern terminus of the proposed pipeline, contained varied terrain and vegetation. The Coast Range divide was very steep, with dense vegetation. North of Reston, the route crosses rolling hills and side slopes, then descends into Flournoy Valley. The route then turns east, skirts the base of White Tail Ridge and crosses Lookingglass Valley. The transmission line then crosses a steep ridge dividing Lookingglass Valley from Happy Valley and then crosses the side slopes on the northern edge of Happy Valley to the east end of the proposed route. The valleys were pasturelands covered with grass. The side slopes contained mixtures of grasslands and woodlands. The steeper terrain was forested. Ground visibility was again about 10-15 percent, with the mineral ground surface generally visible only in disturbed areas such as dirt roads, road shoulders, rodent burrow backdirt and other animal disturbances.

One previously recorded prehistoric archaeological site (35DO819) was observed along this segment, and one new prehistoric site (BIS-1) and one isolated prehistoric artifact (35DO879) were also discovered and recorded on this segment of the proposed pipeline route. Several areas with a high probability for archaeological sites were also noted.

ISO-1: The isolated find is a chert biface tip fragment found in the disturbed soil of a road cut near a creek just northwest of Reston (T28S, R8W, section 15). The area was carefully searched for additional artifacts, but no other items were located. This area is near a creek, an area with a high likelihood to contain archaeological sites.

Site 35D0819: This site was recorded in 1999 (Oetting 1999). It is a thin lithic scatter of chert flakes on a low rise between Rock Creek and an unnamed stream at the southwest end of Flournoy Valley (T27S, R7W, section 32). The transmission line passes over this rise, paralleling the CBW Road which bisects the rise. Twenty chert flakes were found in the cutbanks and drainage ditches bordering the road when the site was first recorded, 19 on the west side of the road nearest the transmission line. No tools or other artifacts were observed in the site area. The flakes occur for about $100 \mathrm{~m}$ ( 330 feet) along the road. This site area should be avoided by construction activities by altering the pipeline route or construction methods. If the site cannot be avoided, site evaluation test excavations should be conducted, to determine whether the site is eligible to the National Register of Historic Places.

Site 35DO879 (BIS-1): This small lithic scatter site was found during the current survey. It is about 1 mile west of the eastern end of the proposed pipeline route, on the top and east flank of a flat-topped knoll overlooking a small creek (T27S, R6W, section 33). Ten chert flakes, two basalt flakes, and one chert biface tip fragment were found in a $10 \times 25 \mathrm{~m}$ area. All of the artifacts were found in a road cut. Several of the flakes and the biface fragment were found down the eastern slope. They may have been pushed down this slope by road construction or by natural erosion. This site area should be avoided by construction activities by altering the pipeline route or construction methods. If the site cannot be avoided, site evaluation test excavations should be conducted, to determine whether the site is eligible to the National Register of Historic Places.

High Probability Areas: Several areas likely to contain archaeological sites were noted, but visibility was poor and no cultural materials were observed during the survey. Site discovery probe excavations should be conducted in these areas to better determine whether archaeological sites are present. These areas include an elevated bench above a creek northeast of Reston (T28S, R8W, section 11), stream banks near the head of Flournoy Valley (T27S, R7W, section 31), the valley floor just southwest of site 35DO819 (T27S, R7W, section 32), and two canyon bottom creek banks-in Powderhouse Canyon and in the next drainage to the west of Powerhouse Canyon (both in T27S, R6W, section 32). 
Figure B-2: Survey status and location of recommended site discovery probes (SDP), Coos Bay to Catching Creek

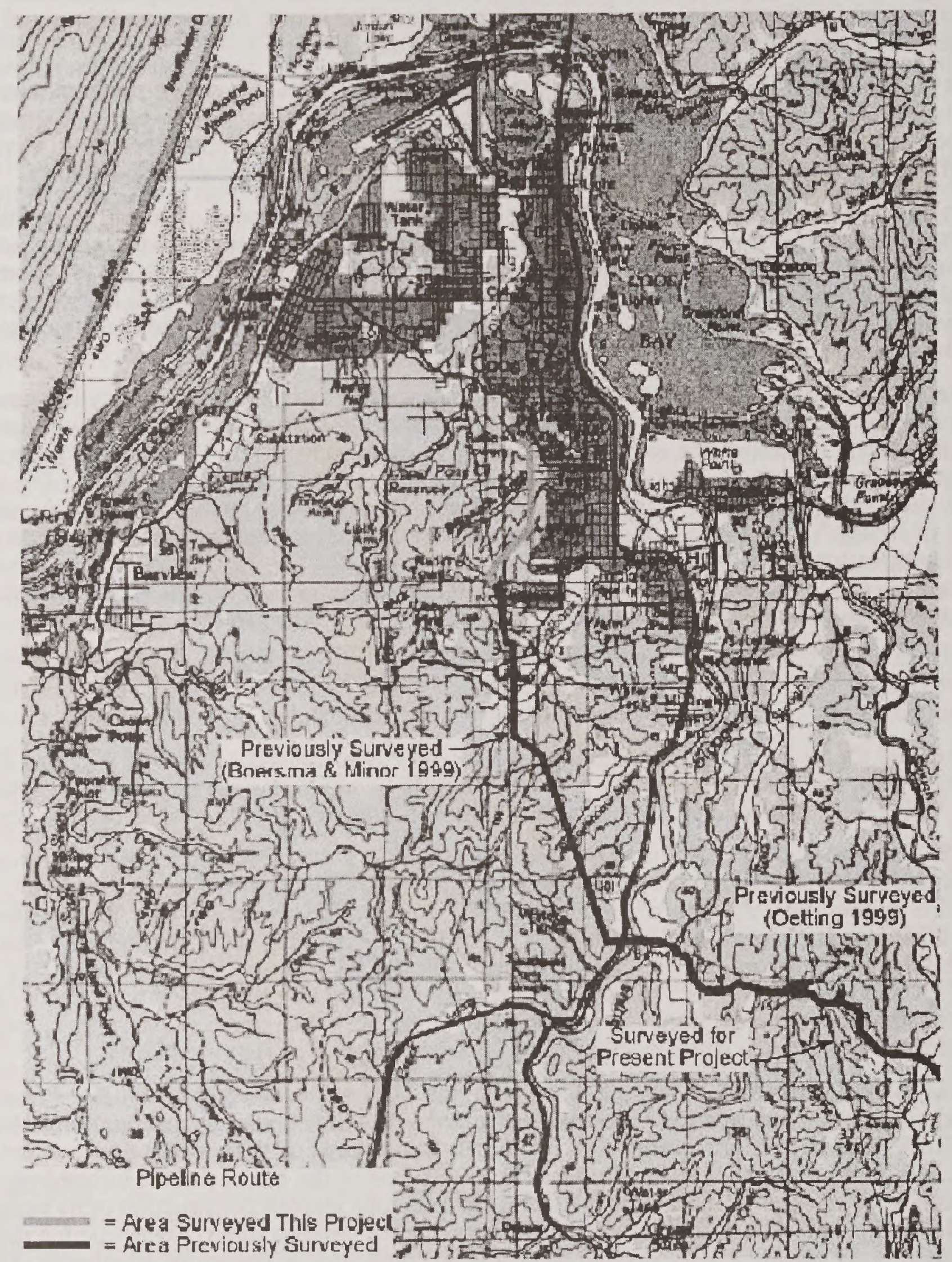


Figure B-3: Survey status an location of recommended site discovery probes (SDP), Isthmus Slough to Sitkum

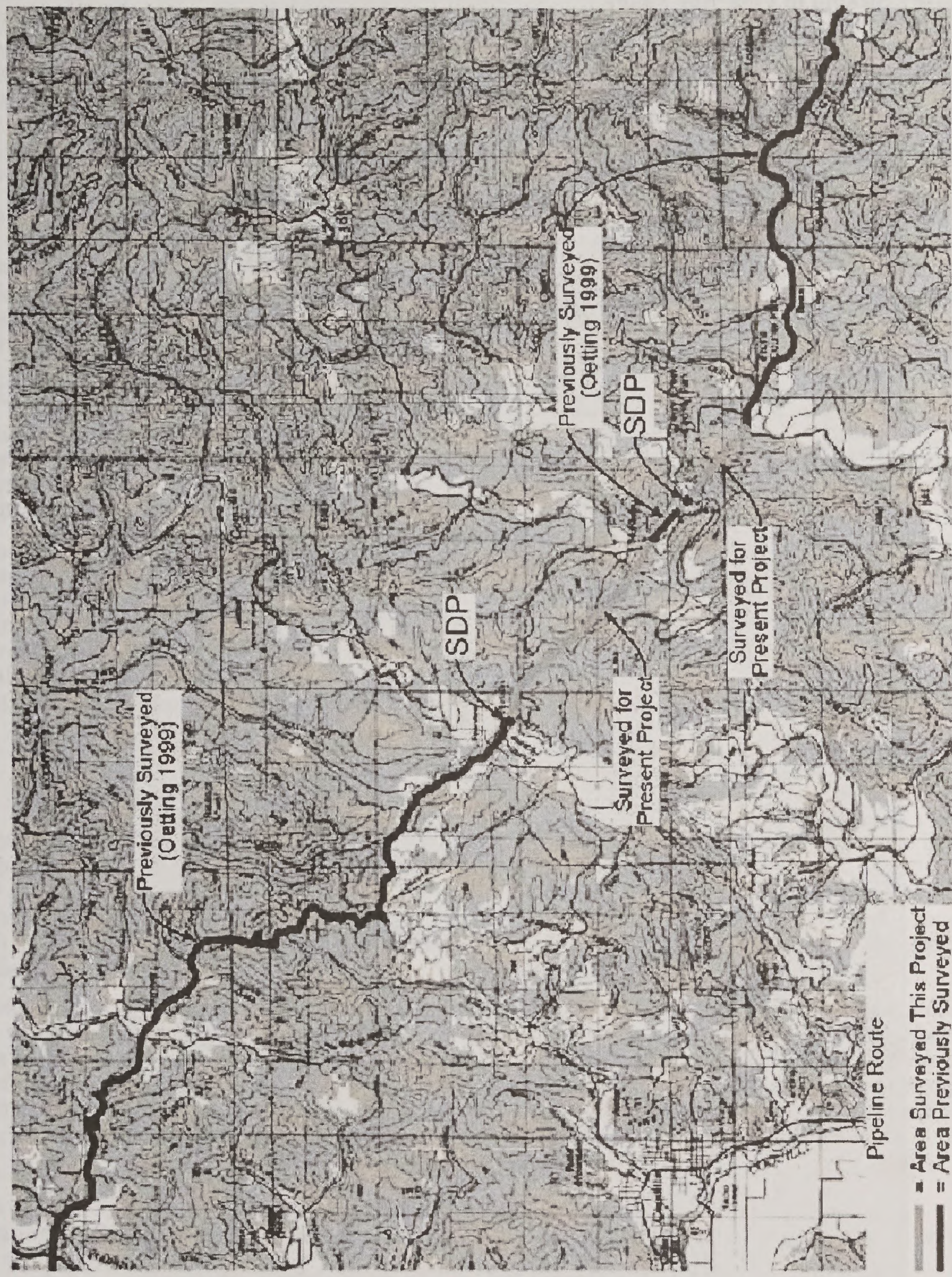


Figure B-4: Survey status, location of identified cultural materials, and location of recommended site discovery probes (SDP), Sitkum to Flournoy Valley

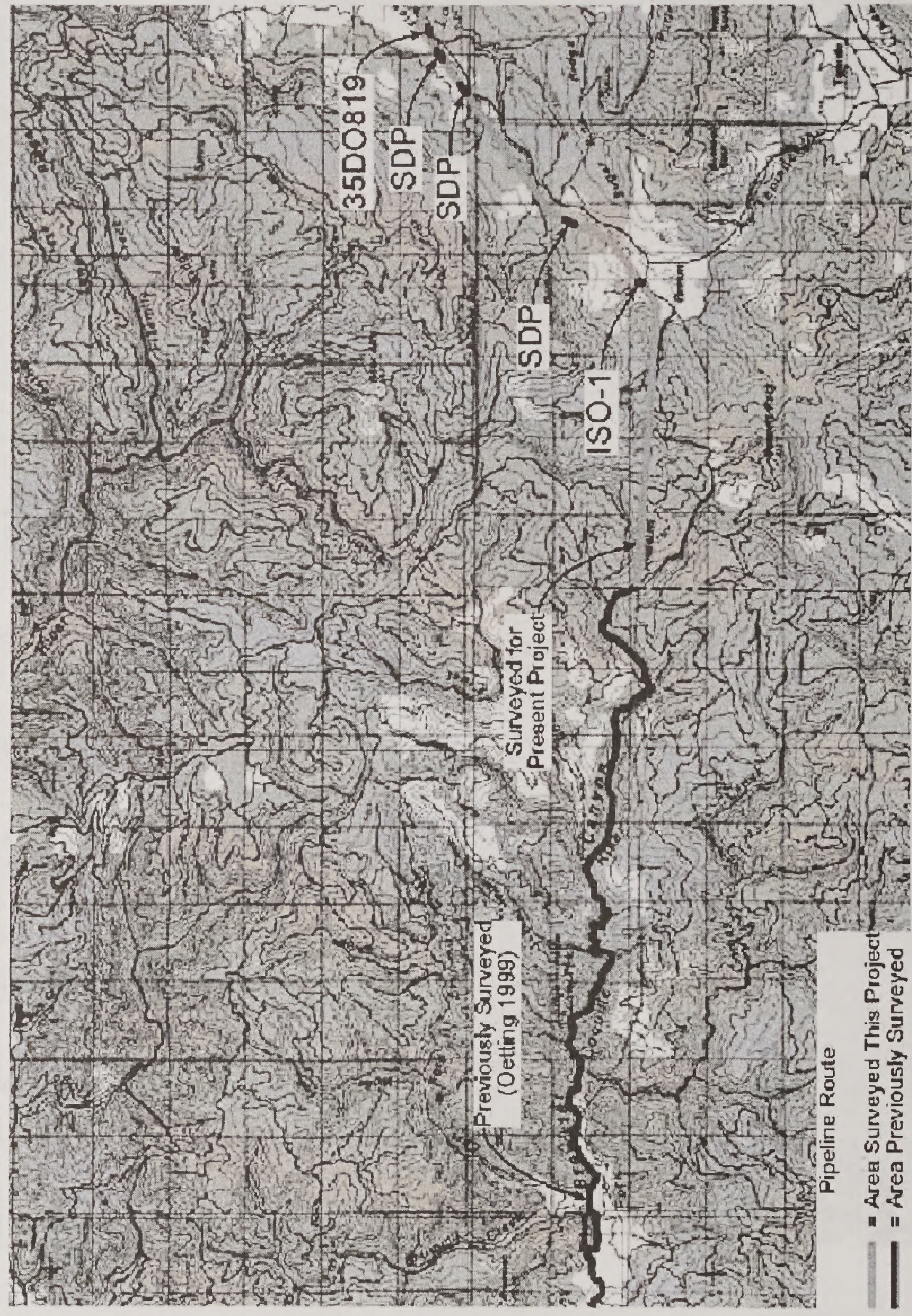




\section{Summary And Recommendations}

A review of background literature and other data found that 16 prehistoric sites have been recorded within 2 miles of the proposed underground natural gas pipeline route, and that one of these recorded prehistoric sites is within the proposed route where it passes through the head of Flournoy Valley, northeast of Reston. This total includes nine sites recorded at the Oregon SHPO and seven unrecorded prehistoric sites near the CBW Road mapped by the Coos Bay BLM District. Some historic structures are present near the CBW Road and the route passes by several Donation Land Claims in Lookingglass and Happy valleys, but no known historic structures are located in areas that will be affected by the proposed pipeline route.

The proposed pipeline route is approximately 60 miles long, but about 37.6 miles were recently surveyed for cultural resources (Boersema and Minor 1999; Oetting 1999) and were not re-examined during this project. The portions of the route surveyed for the current project were about 22.4 miles in length. A systematic pedestrian survey was undertaken to determine if surface evidence of prehistoric or historic sites or artifacts was present along these portions of the proposed pipeline route. One route segment was 1.7 miles long in the hills above Coos Bay. The other three segments were within BPA transmission line ROWs, including 3.1 miles between Fairview and McKinley, 1.2 miles between Cherry Creek southeast of McKinley and the East Fork Coquille River valley west of Dora, and 16.4 miles from the CBW Road at the Douglas County line to the eastern terminus of the pipeline route.

The archaeologists relocated the one previously recorded prehistoric archaeological site (35DO819) that was within the proposed route, and identified one new prehistoric site (35DO879) and one isolated prehistoric artifact (ISO-1). Several areas with a high probability for archaeological sites were also noted. These locations are shown on the appropriate maps in Figures B-2 through B-5.

The proposed route passes near the reported locations of several archaeological sites near Dora and Sitkum on the CBW Road, but this portion of the route had already been surveyed and no cultural materials were noted within the road corridor in these areas during that survey (Oetting 1999). The CBW Road is a historic road, but its significance and National Register eligibility have not been formally evaluated by the Oregon SHPO. The physical elements of the road (road grade, road bed, surfacing, etc.) have been maintained, repaired, rebuilt and realigned as needed in the past, but altering current road conditions could affect the historic character of the road. The natural gas pipeline route should not affect this historic transportation route if the road is returned to current conditions after pipeline construction.

\section{$\underline{\text { Recommendations }}$}

The two prehistoric archaeological sites identified along the project route have not been evaluated to determine whether they are eligible for listing in the National Register of Historic Places (NRHP). These are lithic scatter sites $35 \mathrm{DO} 819$ and 35D0879, respectively located in T27S, R7W, section 32, and T27S, R6W, section 33. If feasible, it is recommended that these site areas be avoided by any project-related construction activity. If these sites cannot be avoided, it is recommended that subsurface site evaluation test excavations be undertaken to determine the significance of these two sites in terms of eligibility to the NRHP.

The pipeline crosses many landforms, especially stream banks, that are likely locations to find archaeological sites. However, vegetation in many of these areas limited surface visibility. It is recommended that subsurface site discovery probes be excavated in eight specific areas along the route where the route crosses streams or rivers, and at the location of ISO-1, an isolated flaked stone tool found on the surface. It may be prudent to monitor pipeline construction activities in some of the high probability areas. Site discovery probes should be excavated at the following locations (from west to east along the route):

1. the banks of the North Fork Coquille River just southeast of Fairview in T27S, R12W, section 24;

2. the banks of Cherry Creek, about 1 mile southeast of McKinley, in T28S, R11W, section 4;

3. at the location of ISO-1, a chert biface tip, found in the disturbed soil of a road cut near a creek just northwest of Reston in T28S, R8W, section 15;

4. an elevated bench above a creek northeast of Reston in T28S, R8W, section 11;

5. stream banks near the head of Flournoy Valley in T27S, R7W, section 31;

6. the Flournoy Valley floor in the transmission line corridor just southwest of site 35DO819 T27S, R7W, section 32;

7. the creek banks in the canyon bottom directly west of Powderhouse Canyon, in T27S, R6W, section 32; and

8. the creek banks in the bottom of Powderhouse Canyon, also in T27S, R6W, section 32. 
The CBW Road has been recognized as a historic transportation route, but it has not been formally evaluated for significance by the Oregon SHPO. The pipeline is to be buried beneath the road or road shoulder along several portions of the road. Modifications to the road may affect the historic character of this transportation route,. Therefore, it is recommended that any alteration to the existing road surface/shoulders in the planned route be avoided, by returning these sections to their existing conditions after pipeline construction.

If modifications (such as paving graveled sections to help protect the pipeline) are required, formal review and evaluation by the SHPO will be necessary prior to construction. If this is the case, it is recommended that a formal Determination of Eligibility (DOE) document be prepared for the road and submitted to the SHPO for evaluation. If the road is determined eligible for the NRHP, then a Determination of Effect (Section 106 Finding of Effect) must be prepared for the proposed alterations.

To briefly summarize, recommendations are as follows:

a) Known archaeological sites should be avoided during pipeline construction.

b) If known sites cannot be avoided, they should be tested to determine the extent and nature of the cultural deposits within the project right-of-way.

c) Site discovery probes should be excavated at eight specific locations delineated above where archaeological sites are especially likely to occur. If sites are discovered, the above recommendations apply.

d) If the pipeline route is re-aligned to include alignments that have not been examined for cultural resources, it is recommended that these routes be inspected in a manner consistent with the investigations conducted for the current project. In addition, portions of the route not yet surveyed pending owner permission should also be examined for cultural resources.

e) A qualified archaeologist should be present to monitor pipeline construction activities in the vicinity of defined sites and areas with a high probability for archaeological sites. These monitoring areas will be specifically defined upon the completion of the site discovery probes recommended above. The tribes and agencies should be consulted in the development and implementation of the monitoring plan.

f) The portions of the CBW Road affected by pipeline construction should be returned to the same conditions existing before construction.

g) If portions of the CBW Road must be altered, it is recommended that a formal Determination of Eligibility (DOE) document be prepared and submitted for SHPO evaluation. If determined eligible, a Determination of Effect (Section 106 Finding of Effect) will be needed for the proposed changes to the road.

There is always the possibility that buried or obscured prehistoric or historic cultural resources may be present along the chosen natural gas pipeline route. Archaeological sites and, in particular, Indian burials are protected under Oregon state law (ORS 97.745 and 358.920) and by Federal regulations where federal lands, funds, or permits are involved (e.g., 36 CFR part 800). Disturbance of graves is specifically prohibited, even through accidental discovery. If cultural resources are inadvertently encountered during the course of construction along the route, earth-disturbing activities in the vicinity of the find should be suspended immediately, in accordance with applicable laws, and a qualified archaeologist should be called in to evaluate the discovery and recommend subsequent courses of action. 


\section{Figure B-5: Site Map}

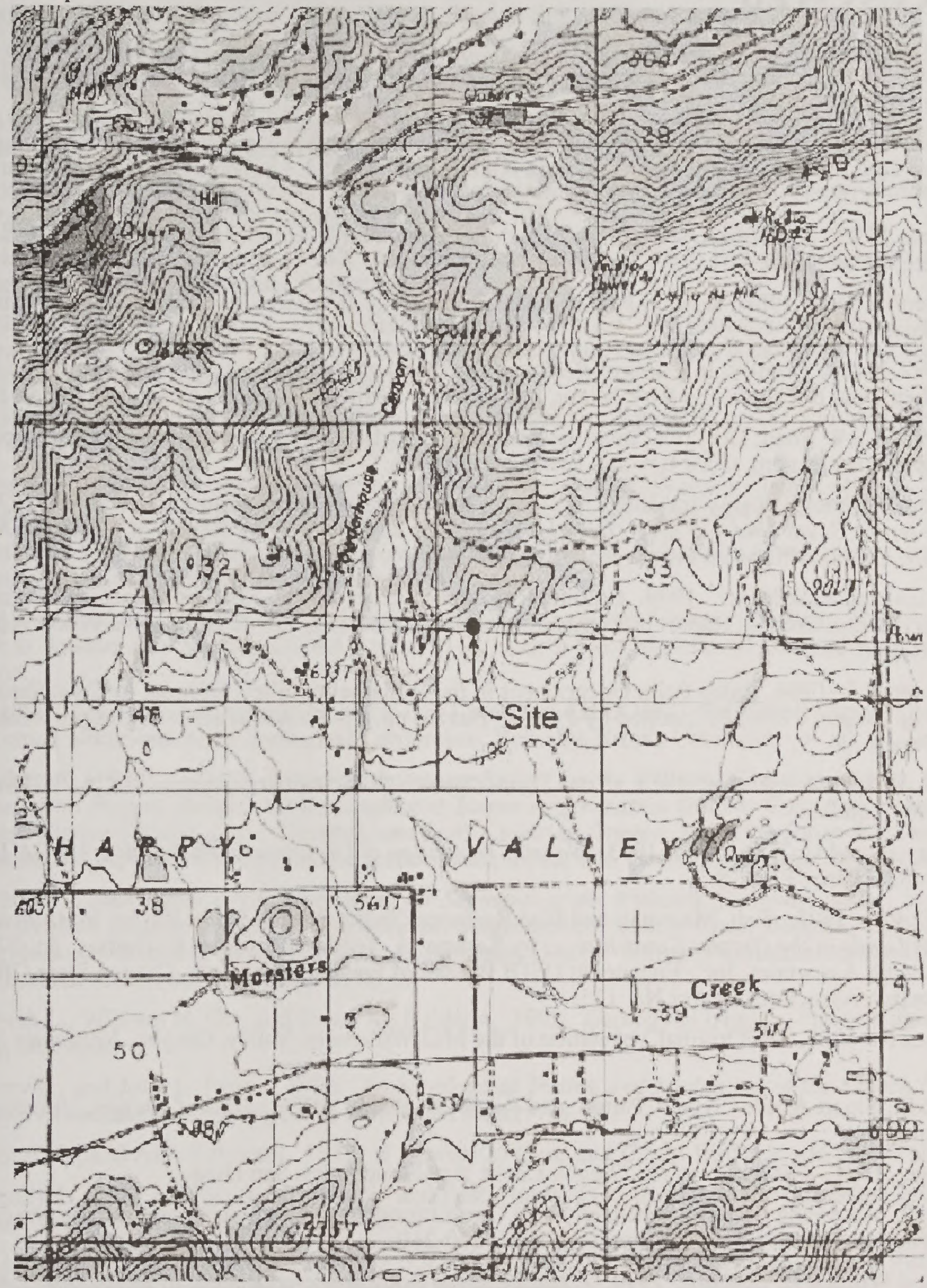




\section{REFERENCES CITED}

Aikens, C. Melvin. 1993. The Archaeology of Oregon. U. S. Department of Interior, Bureau of Land Management, Oregon State Office, Portland.

Allely, Steven. 1975. A Clovis Point from the Mohawk River Valley, Western Oregon. In Archaeological Studies in the Willamette Valley, Oregon, edited by C. Melvin Aikens, pp. 549-552. University of Oregon Anthropological Papers 8.

Bailey, Vernon. 1936. The Mammals and Life Zones of Oregon. North American Fauna No. 55, U. S. Government Printing Office, Washington, D. C.

Beckham, Stephen Dow. 1986. Land of the Umpqua: A History of Douglas County, Oregon. Douglas County Commissioners, Roseburg.

--------. 1992. Native Peoples. In Cultural Resource Overview of the Umpqua National Forest, Southwestern Oregon, by Stephen Dow Beckham and Rick Minor, pp. 101-124. Heritage Research Associates Report No. 125.

-.---.-.. 1997. CBW Road: Historical Investigations and Identification of Interpretive Options. Report to the USDI Bureau of Land Management, Coos Bay and Roseburg Districts.

Bevill, Russell, Michael S. Kelly, and Elena Nilsson. 1994. Archaeological Data Recovery at 35DO37, A PreMazama Site on the South Umpqua River, Douglas County, Southwest Oregon. Report of Mountain Anthropological Research to the Umpqua National Forest, Roseburg, Oregon.

Boersema, Jana, and Rick Minor. 1999. Cultural Resources Survey for the Reedsport-Fairview Transmission Project, Coos County, Oregon. Report by Heritage Research Associates, Inc. to Bonneville Power Administration. HRA Letter Report 99-5.

Connolly, Thomas J. 1994. Paleo Point Occurrences in the Willamette Valley, Oregon. In Contributions to the Archaeology of Oregon 1989-1994, edited by Paul W. Baxter, pp. 81-88. Association of Oregon Archaeologists, Occasional Papers No. 5.

Davies, K. G., and A. M. Johnson. 1961. Peter Skene Ogden's Snake Country Journal, 1826-27. The Hudson's Bay Record Society, London.

Franklin, Jerry F., and C. T. Dyrness. 1973. Natural Vegetation of Oregon and Washington. USDA Forest Service General Technical Paper PNW-8.

Greenspan, Ruth L. 1992. Fish, Mammal, and Bird Resources in the Oregon Coast Range. In An Inventory Strategy Plan for BLM Lands in the Oregon Coast Range, by Kathryn A. Toepel and Albert C. Oetting, pp. 37-65. Report by Heritage Research Associates, Inc., Eugene, to USDI Bureau of Land Management, Oregon State Office, Portland. Heritage Research Associates Report No. 135.

Habeck, James R. 1961. The Original Vegetation of the Mid-Willamette Valley, Oregon. Northwest Science 35(2):65-77.

Loy, William G., Stuart Allan, Clyde P. Patton, and Robert D. Plank. 1976. Atlas of Oregon. University of Oregon Books, Eugene.

Lyman, R. Lee. 1991. Prehistory of the Oregon Coast. Academic Press, San Diego.

--------. 1997. Assessing a Reassessment of Early "Pre-Littoral" Radiocarbon Dates from the Oregon Coast. Journal of California and Great Basin Anthropology 19(2):260-269.

Miller, Jay, and William R. Seaburg. 1990. Athapaskans of Southwestern Oregon. In Handbook of North American Indians, Volume 7: Northwest Coast, edited by Wayne Suttles, pp. 580-588. Smithsonian Institution, Washington, D.C.

Minor, Rick. 1985. Paleo-Indians in Western Oregon: A Description of Two Fluted Projectile Points. Northwest Anthropological Research Notes 19(1):33-40.

--------. 1987. Archaeology of the South Umpqua Falls Rockshelters, Douglas County, Oregon. Report to Umpqua National Forest, Roseburg. Heritage Research Associates Report No. 64. 
--------. 1991. Yaquina Head: A Middle Archaic Settlement on the North-Central Oregon Coast. USDI Bureau of Land Management, Cultural Resources Series No. 6. Oregon State Office, Portland.

1997. Pre-Littoral or Early Archaic? Conceptualizing Early Adaptations on the Southern Northwest Coast. Journal of California and Great Basin Anthropology 19(2):269-280.

1998. Southern Northwest Coast. In Archaeology of Prehistoric Native America, An Encyclopedia, edited by Guy Gibbon, pp. 791-793. Garland Publishing, Inc., New York and London.

Minor, Rick and Stephan Dow Beckham. 1992. Cultural Resource Overview of the Umpqua National Forest, Southwestern Oregon. Heritage Research Associates Report No. 125.

Minor, Rick and Thomas J. Connolly. 1987. Archaeological Testing at Times Square Rockshelter, Douglas County, Oregon. Heritage Research Associates Report No. 55.

Minor, Rick, and Kathryn A. Toepel. 1981. Archaeological Overview. In Prehistory and History of BLM Lands in West-Central Oregon: A Cultural Resource Overview, by Stephen D. Beckham, Rick Minor, and Kathryn A. Toepel, pp.117-183. University of Oregon Anthropological Papers 25.

Moss, Madonna L., and Jon M. Erlandson. 1998. Early Holocene Adaptations on the Southern Northwest Coast. Journal of California and Great Basin Anthropology 20(1):13-25.

Musil, Robert R. 1994. The Archaeology of Susan Creek Campground, Douglas County, Oregon. Report to Bureau of Land Management, Roseburg District, Roseburg. Heritage Research Associates Report No. 162.

O'Neill, Brian L. 1989. Archaeological Investigations at the Narrows and Martin Creek Sites, Douglas County, Oregon. Bureau of Land Management Cultural Resource Series No. 4.

--------. 1991. Evaluation of Six Archaeological Sites Along the North Umpqua Highway, Douglas County: Steamboat Creek to Boulder Flat Section. OSMA Report 91-1. Oregon State Museum of Anthropology, University of Oregon, Eugene.

--------. 1992. Pre-Mazama Occupation of the Dry Creek Site (35DO401), Southwest Oregon. Paper presented at the 45th Annual Northwest Anthropological Conference, Burnaby, British Columbia.

Oetting, Albert C. 1999. Cultural Resources Inventory Report for the Williams Communications, Inc. Fiber Optic Cable Installation Project, Bandon Cable Landing to Jasper Regeneration Station: Coos Bay Wagon Road to Jasper Regeneration Station Section, Coos, Douglas, and Lane Counties, Oregon. Report to Jones \& Stokes Associates,

Inc., Sacramento, CA, for Williams Communications Inc., Tulsa, OK. Heritage Research Associates Report No. 222.

---------. 2000. Cultural Resources Monitoring for Segments of the Williams Communications, Inc. Fiber Optic Installation Project, Bandon Cable Landing to Jasper Regeneration Station, Coos, Douglas, and Lane County, Oregon. Report to Jones \& Stokes Associates, Inc., Sacramento, CA, for Williams Communications Inc., Tulsa, OK. Heritage Research Associates Letter Report 00-6.

Orr, Elizabeth L., William N. Orr, and Ewart M. Baldwin. 1992. Geology of Oregon. Fourth Edition. Kendall Hunt Publishing, Dubuque.

Ozbun, Terry L., and John L. Fagan. 1996. Archaeological Testing and Evaluation of the Seneca Clovis Site (35D0634). Archaeological Investigations Northwest Report No. 102.

Peterson, Emil R., and Alfred Powers. 1952. A Century of Coos and Curry. Binfords and Mort Publishing, Portland.

Snyder, Sandra L. 1981. Medicine Creek: Pre- and Post-Mazama Occupation in the Cascades. Tebiwa, Miscellaneous Papers in Regional Anthropology No. 23.

Spencer, Lee. 1989. Times Square Rockshelter, 35DO212: A Stratified Dry Rockshelter in the Western Cascades, Douglas County, Oregon. Lee Spencer Archeology Paper 1989-4.

Tasa, Guy L. 1992. Human Cremation from the Island Campground Site (34DO422), Douglas County, Oregon. OSMA Report 92-1. Oregon State Museum of Anthropology, University of Oregon, Eugene.

Toepel. Kathryn A. 1987. Ethnographic Background. In Cultural Resource Overview of the Willamette National Forest: A 10-Year Update, by Rick Minor, pp.7-31. Heritage Research Associates Report No. 60. Report to Willamette National Forest, Eugene, Oregon. 
Toepel, Kathryn A., and Stephen D. Beckham. 1981. Ethnographic Overview. In Prehistory and History of BLM Lands in West-Central Oregon: A Cultural Resource Overview, by Stephen D. Beckham, Rick Minor, and Kathryn A. Toepel, pp.41-114. University of Oregon Anthropological Papers 25.

--------. 1992. Ethnography, Prehistory, and History of the Coast Range. In An Inventory Strategy Plan for BLM Lands in the Oregon Coast Range, by Kathryn A. Toepel and Albert C. Oetting, pp. 67-78. Report by Heritage Research Associates, Inc., Eugene, to USDI Bureau of Land Management, Oregon State Office, Portland. Heritage Research Associates Report No. 135.

Toepel, Kathryn A., and Albert C. Oetting. 1992. An Inventory Strategy Plan for BLM Lands in the Oregon Coast Range. Report by Heritage Research Associates, Inc., Eugene, to USDI Bureau of Land Management, Oregon State Office, Portland. Heritage Research Associates Report No. 135.

Welcher, Karin, and Ruth L. Greenspan. 1992. Physical Environment. In An Inventory Strategy Plan for BLM Lands in the Oregon Coast Range, by Kathryn A. Toepel and Albert C. Oetting, pp. 5-17. Report by Heritage Research Associates, Inc., Eugene, to USDI Bureau of Land Management, Oregon State Office, Portland. Heritage Research Associates Report No. 135.

Zenk, Henry B. 1976. Contributions to Tualatin Ethnography: Subsistence and Ethnobiology. Unpublished Master's thesis, Department of Anthropology, Portland State University.

--------. 1990. Siuslawans and Coosans. In Handbook of North American Indians, Volume 7: Northwest Coast, edited by Wayne Suttles, pp. 572-579. Smithsonian Institution, Washington, D.C. 


\section{Appendix C. Maps}




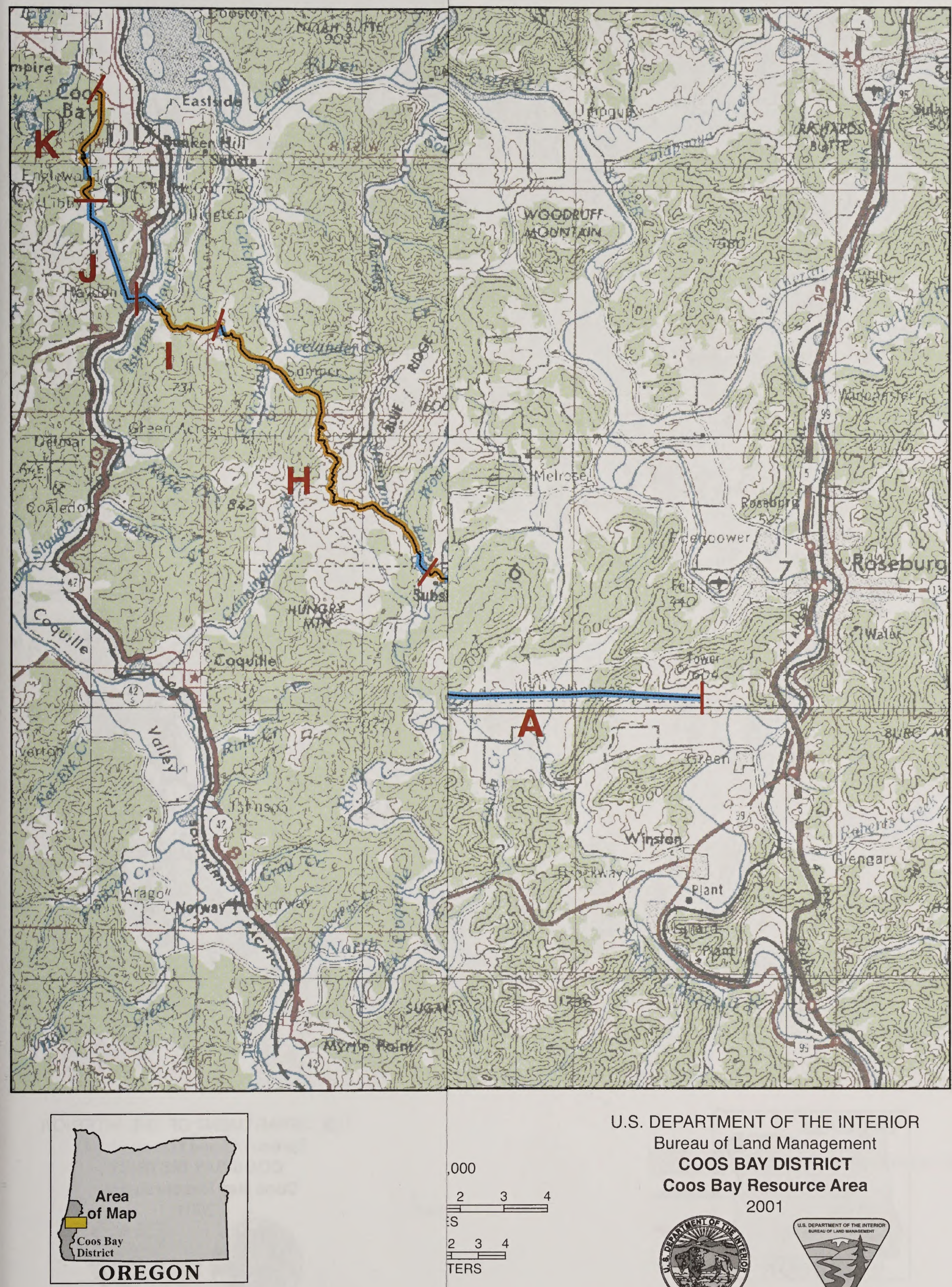

U.S. DEPARTMENT OF THE INTERIOR

Bureau of Land Management

, 000

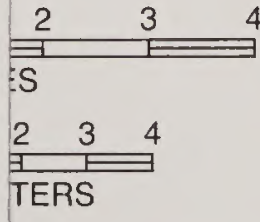

as to the accuracy

ggregate use

sources. This

Map 6: Spotted Owl Critical Habita winhou notiticalion.
COOS BAY DISTRICT

Coos Bay Resource Area

2001

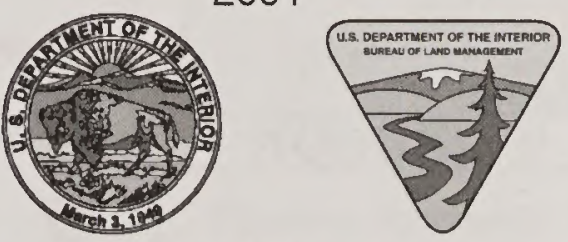

COOS COUNTY NATURAL

GAS PIPELINE PROJECT 



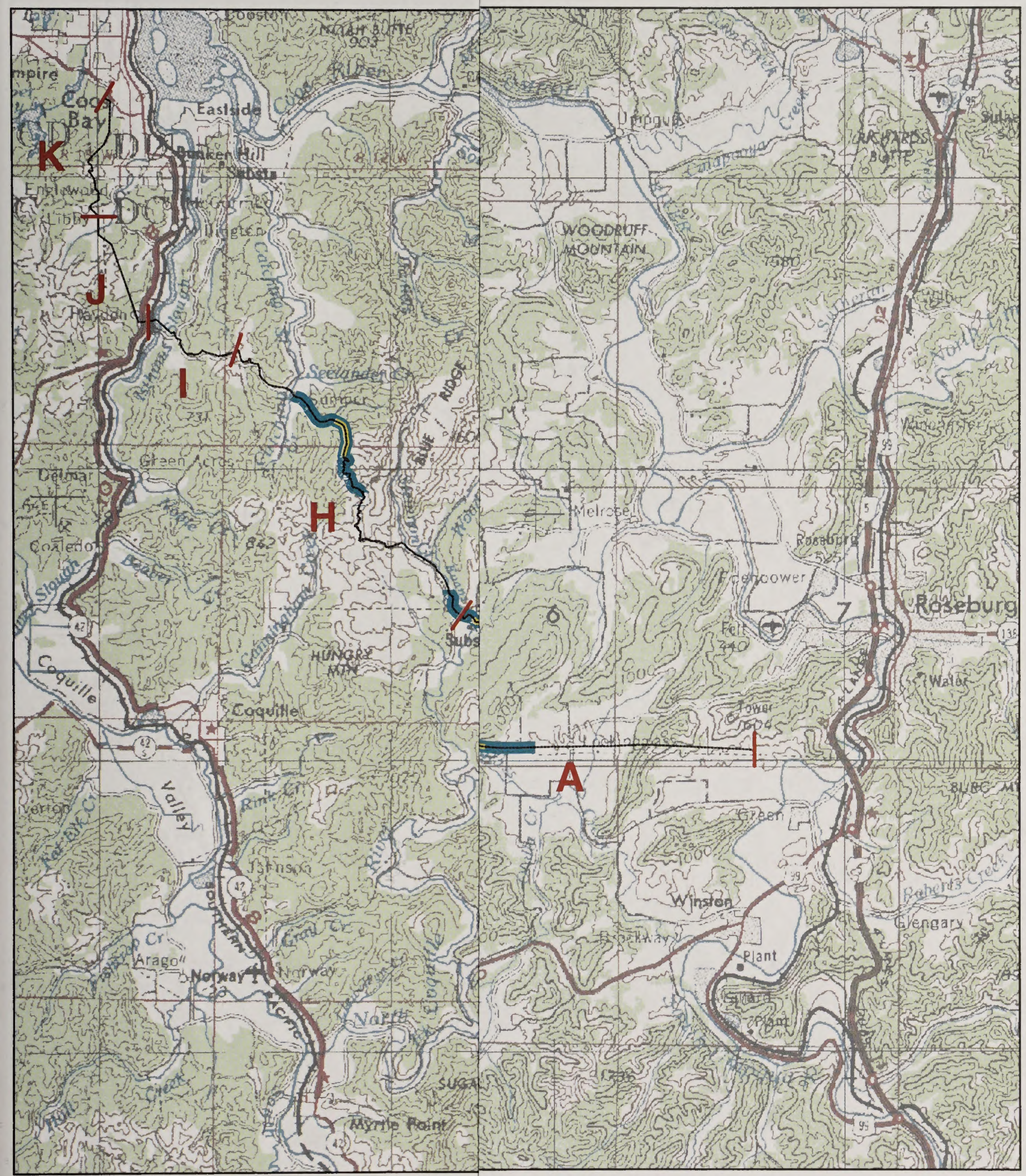

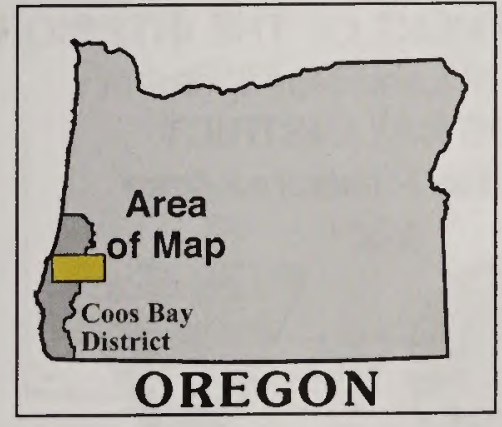

, 000

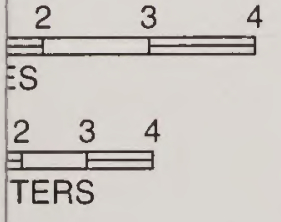

as to the accuracy,

ggregate use

Map 8: PDCs - Restricted Timing

without notification.
U.S. DEPARTMENT OF THE INTERIOR

Bureau of Land Management

COOS BAY DISTRICT

Coos Bay Resource Area

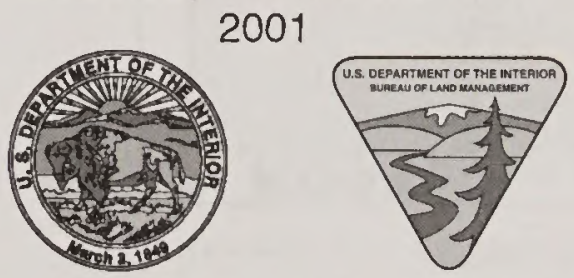

COOS COUNTY NATURAL

GAS PIPELINE PROJECT 


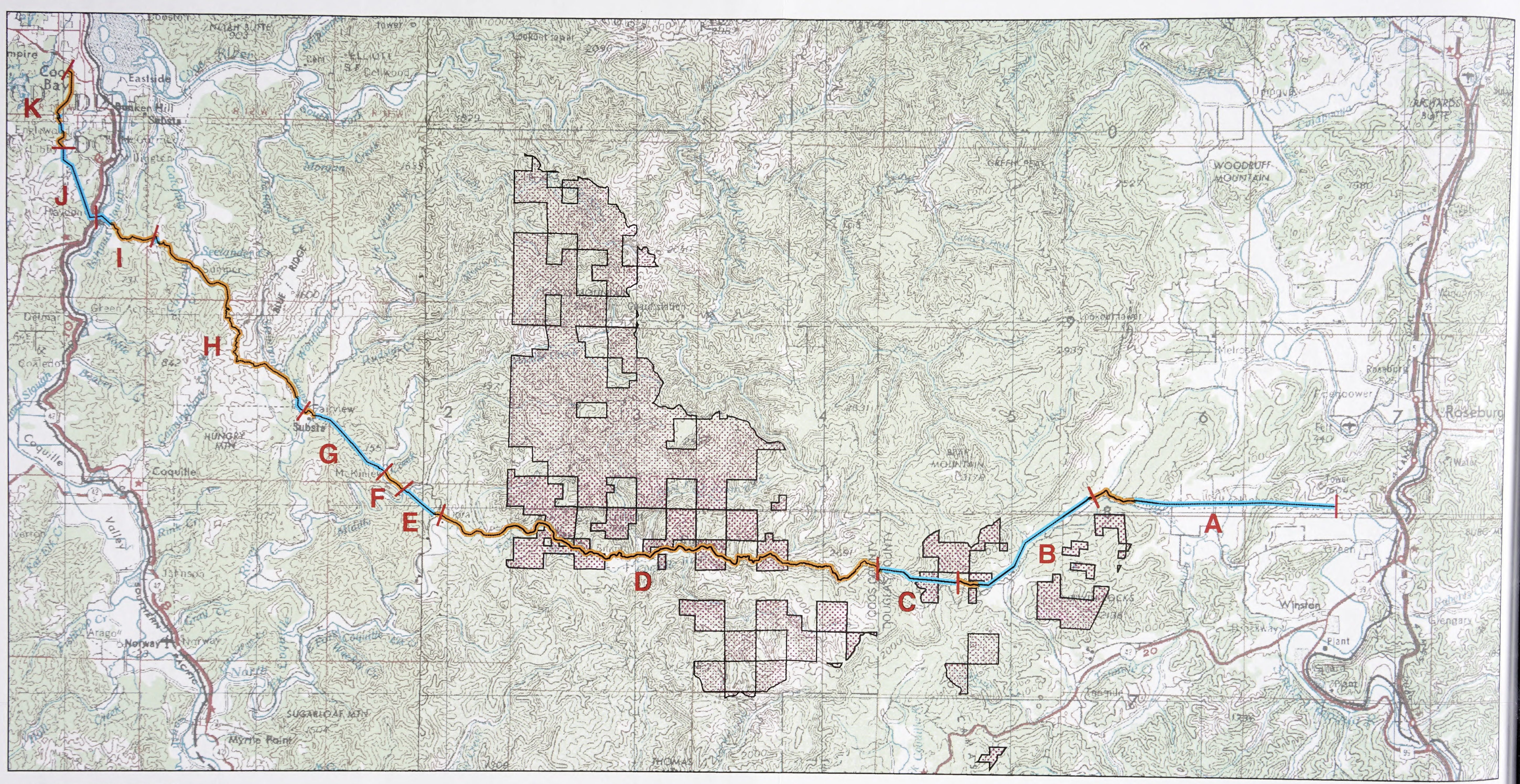

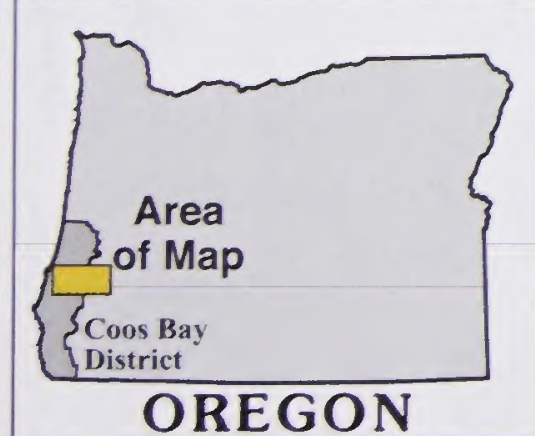

OREGON

Map 7: Marbled Murrelet Critical Habitat Units

\section{LEGEND}

Marbled Murrelet Critical Habitat Unit

Power Line

Wagon Road

I C I Pipeline Segment

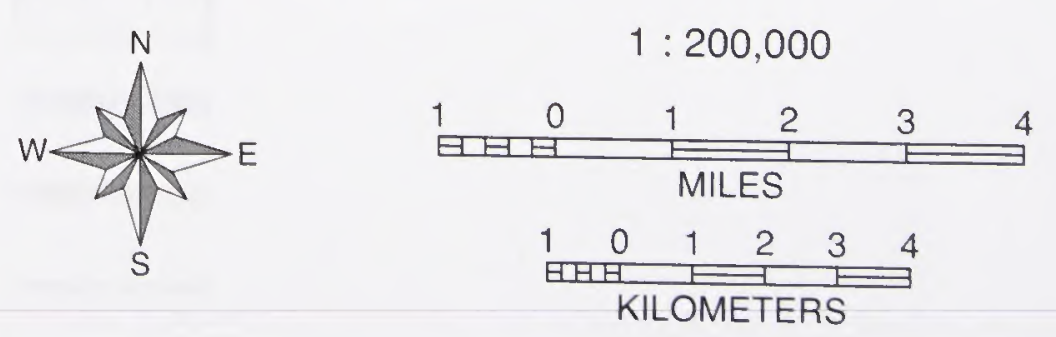

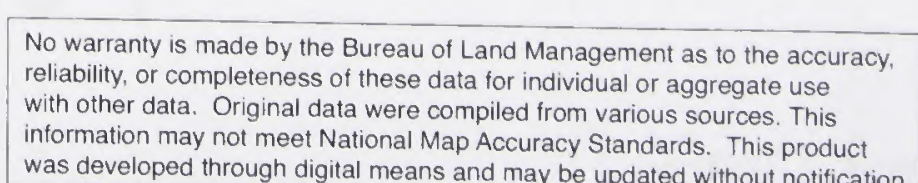

US. DEPARTMENT OF THE INTERIOR Bureau of Land Managemen Coos Bay Resource Area
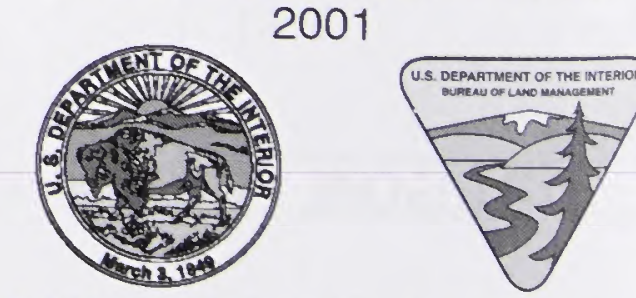


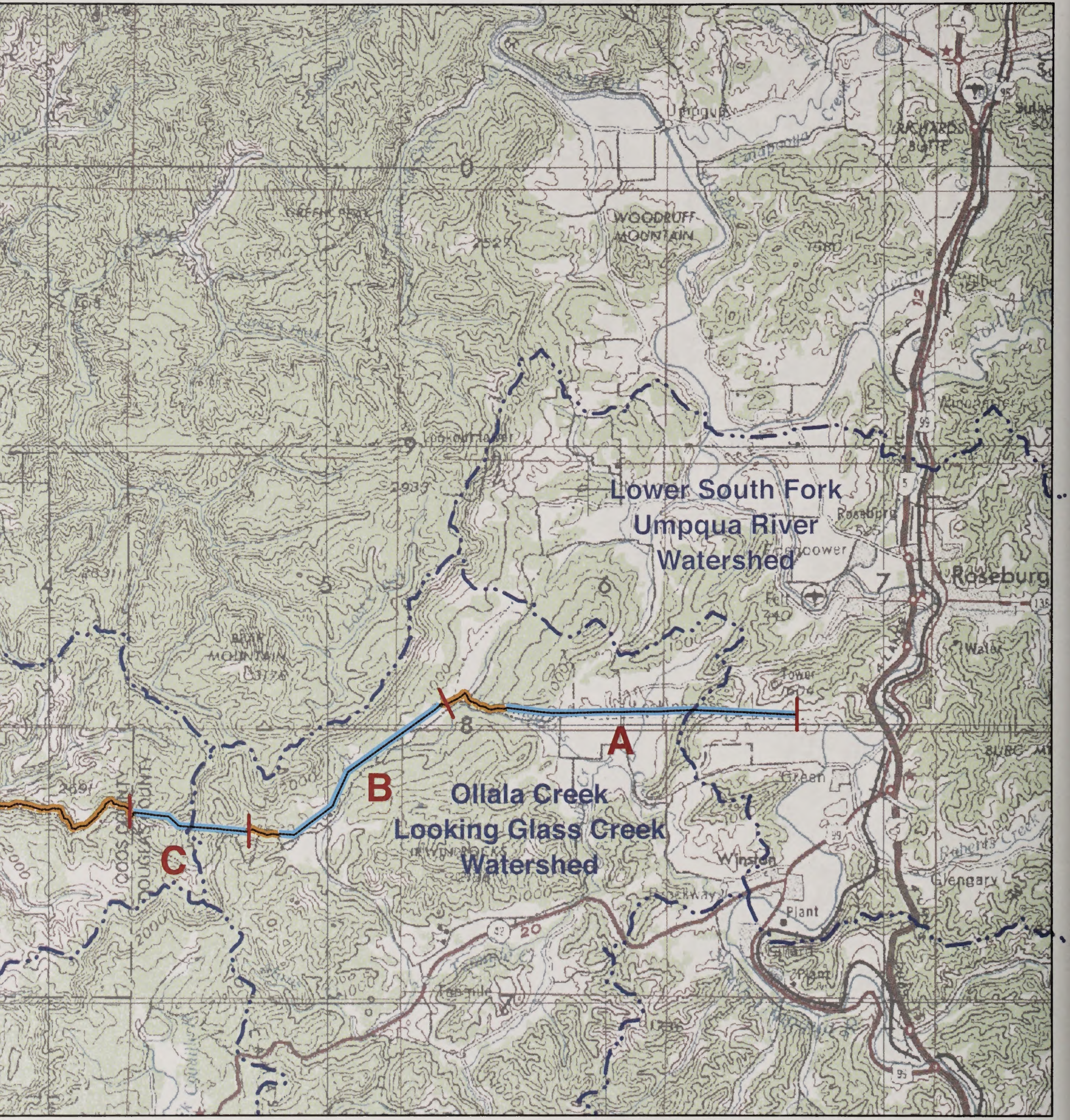

U.S. DEPARTMENT OF THE INTERIOR Bureau of Land Management COOS BAY DISTRICT

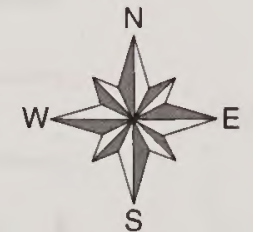

$1: 200,000$ Coos Bay Resource Area

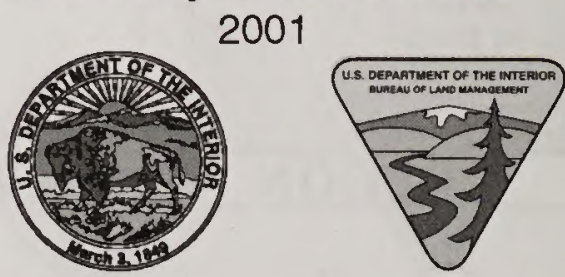



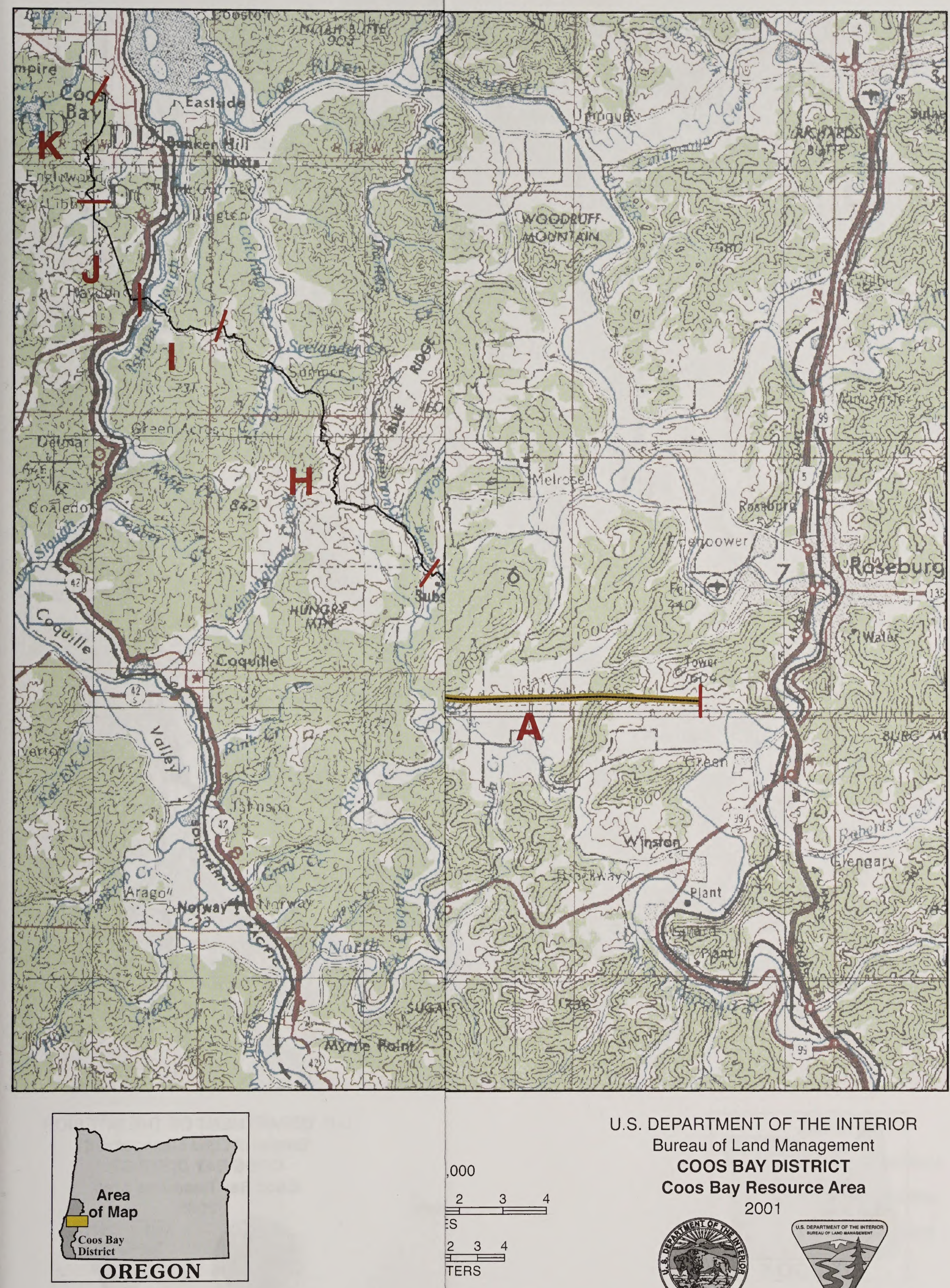

U.S. DEPARTMENT OF THE INTERIOR Bureau of Land Management

.000

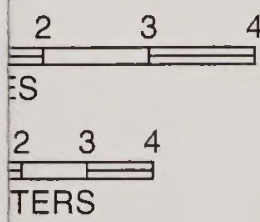

as to the accuracy,

ggregate use

sources. This

Map 10: Areas Designated for Arcls stiser poduct
COOS BAY DISTRICT

Coos Bay Resource Area

2001
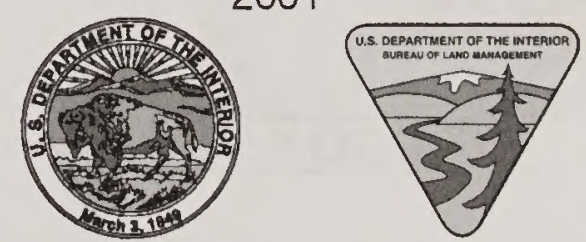

COOS COUN'TY NATURAL

GAS PIPELINE PROJECT 


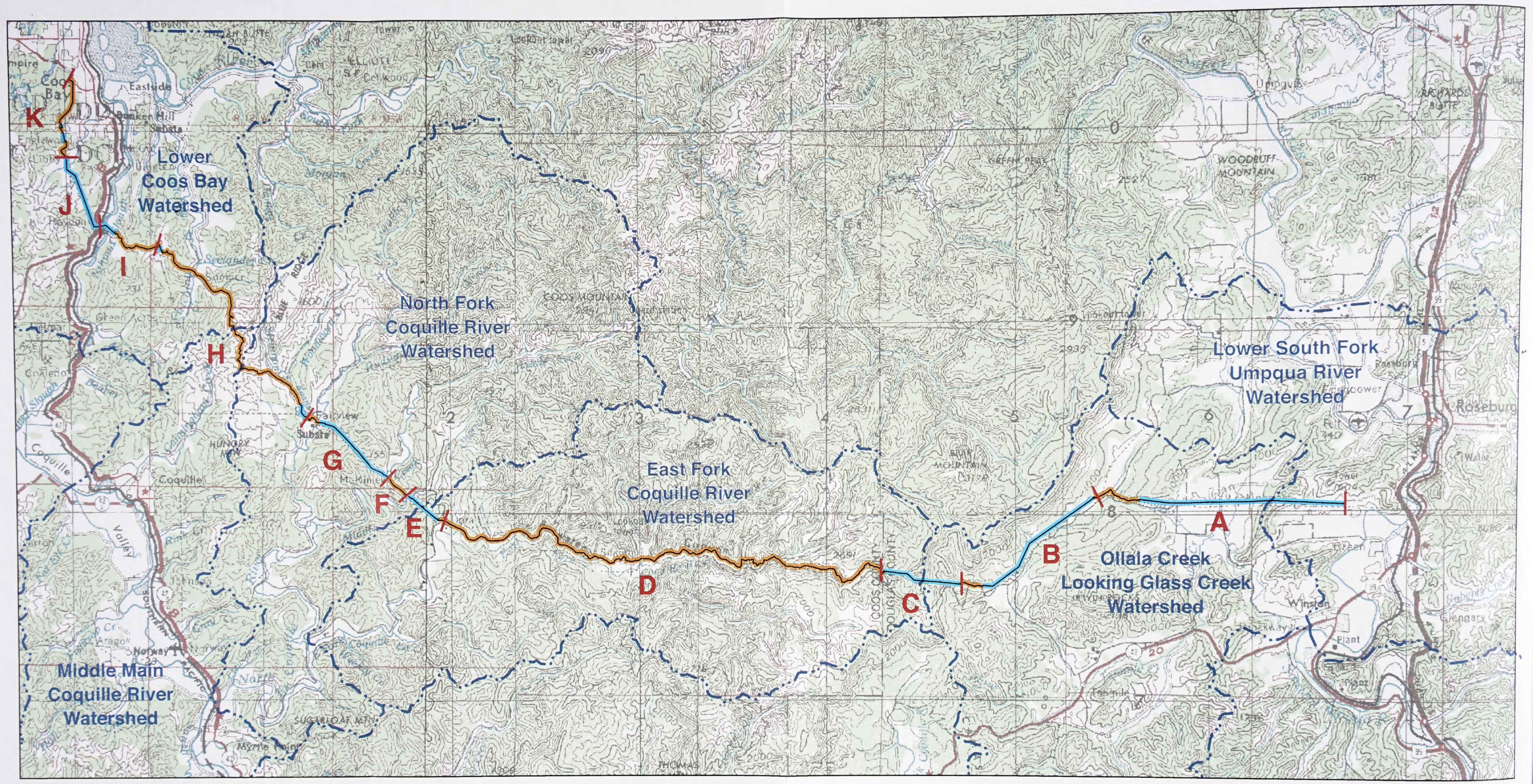

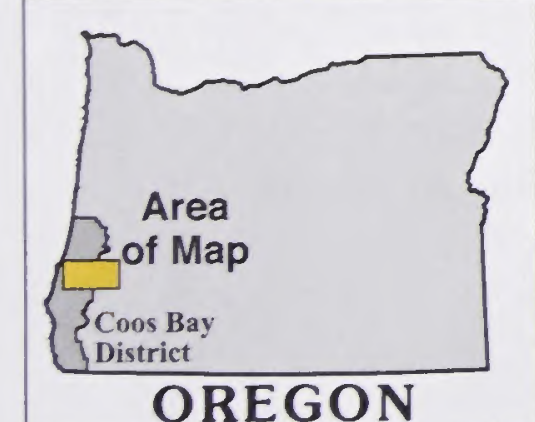

Map 9: Watersheds Impacted in Preferred Alternative

\section{LEGEND}

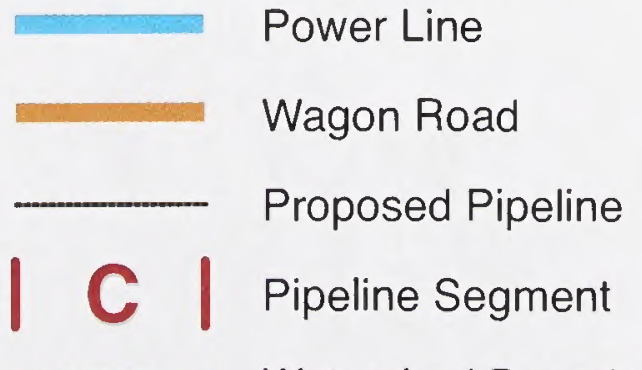

.... Watershed Boundary $\left.\right|_{s} ^{N}$

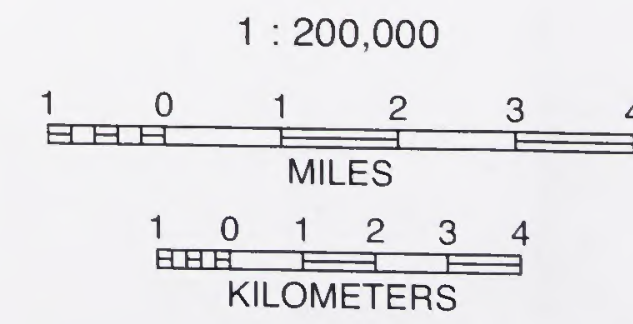

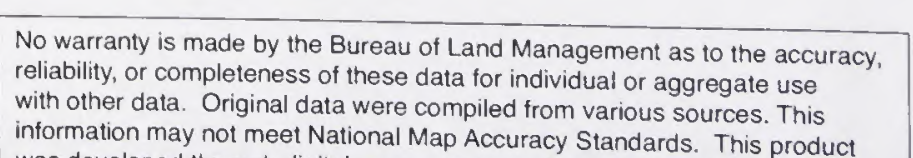

U.S. DEPARTMENT OF THE INTERIOR Bureau of Land Management Coos Bay Resource Area

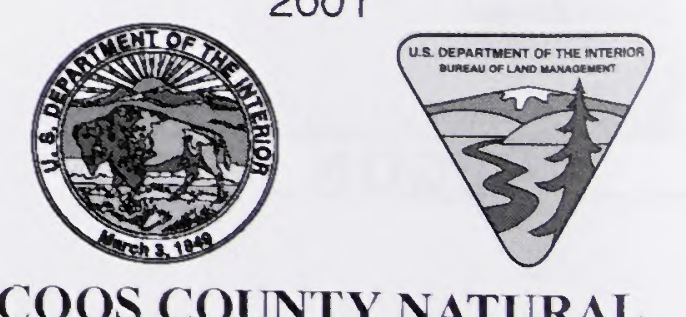

COOS COUNTY NATURAL GAS PIPELINE PROJECT 


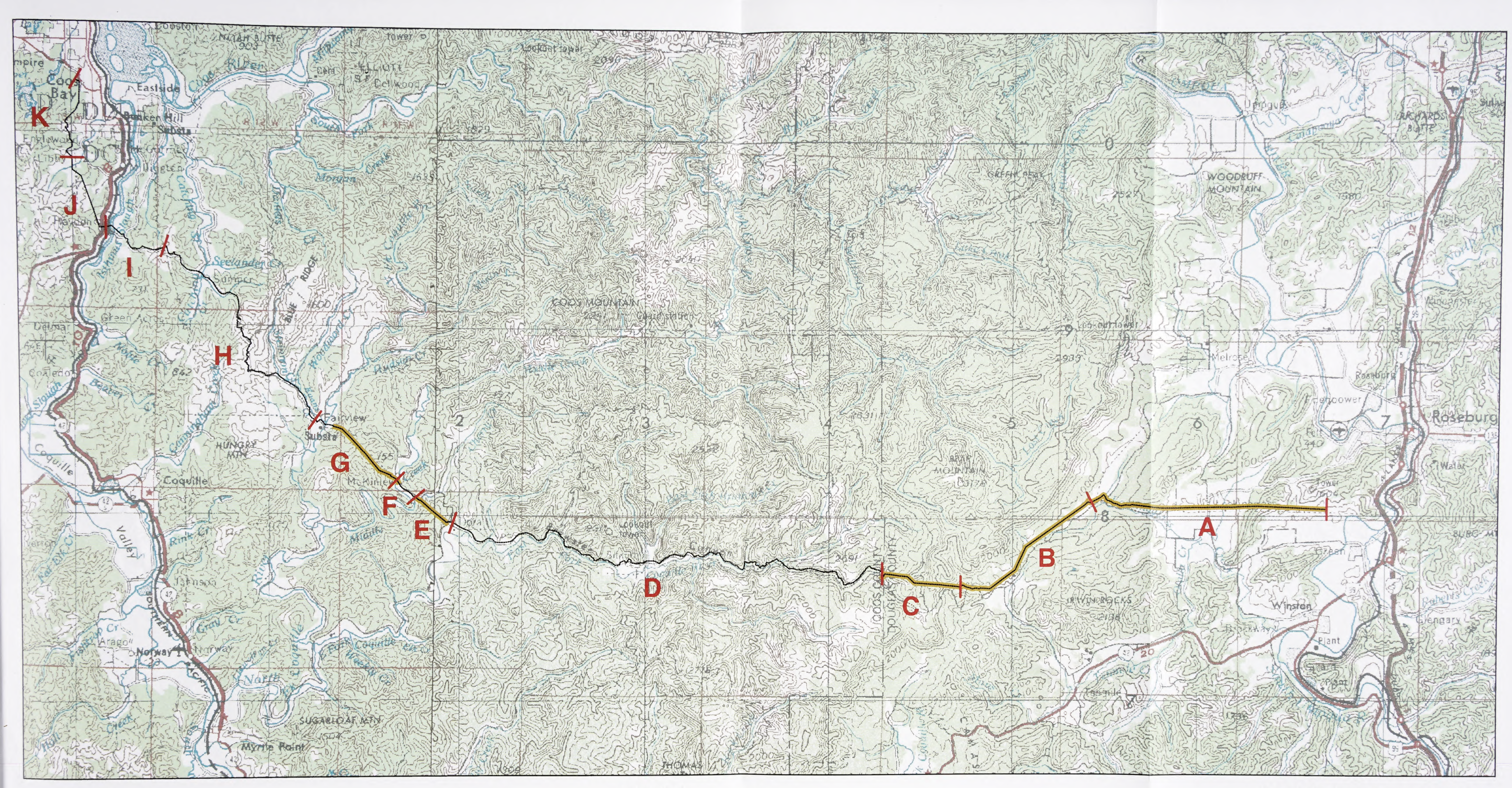

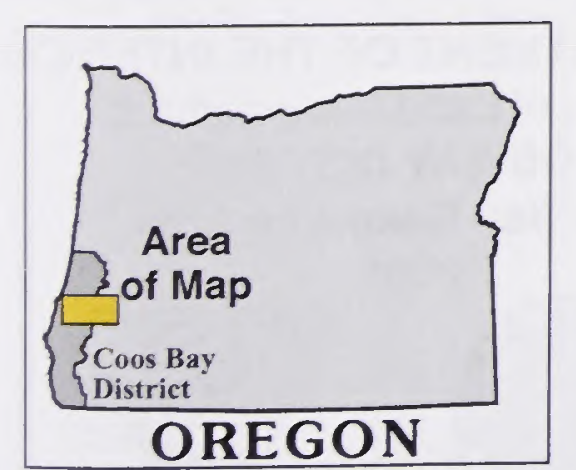

Map 10: Areas Designated for Archaeological and Tribal Monitoring

\section{LEGEND}

\begin{tabular}{ll} 
& Archaeology Monitoring Area \\
\hline I C I Proposed Pipeline \\
\hline Pipeline Segment
\end{tabular}

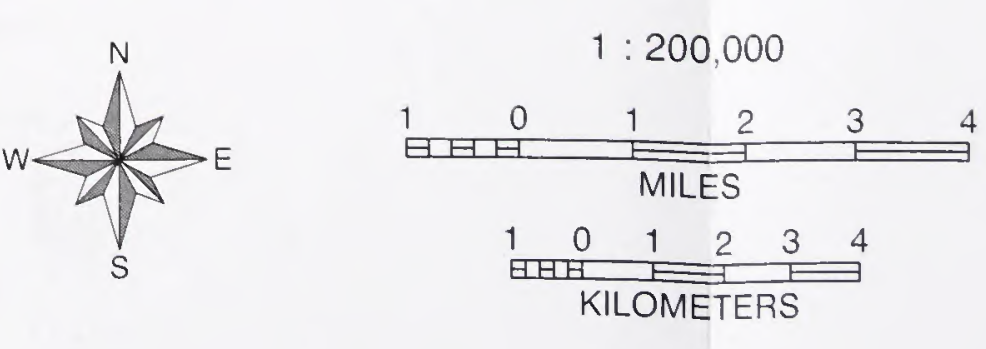

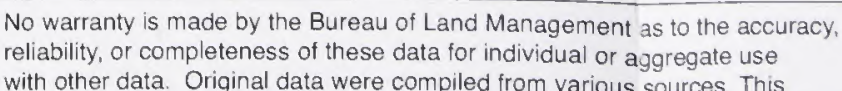

U.S. DEPARTMENT OF THE INTERIOR Bureau of Land Management Coos Bay Resource Area

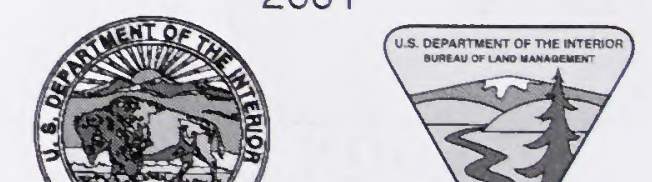




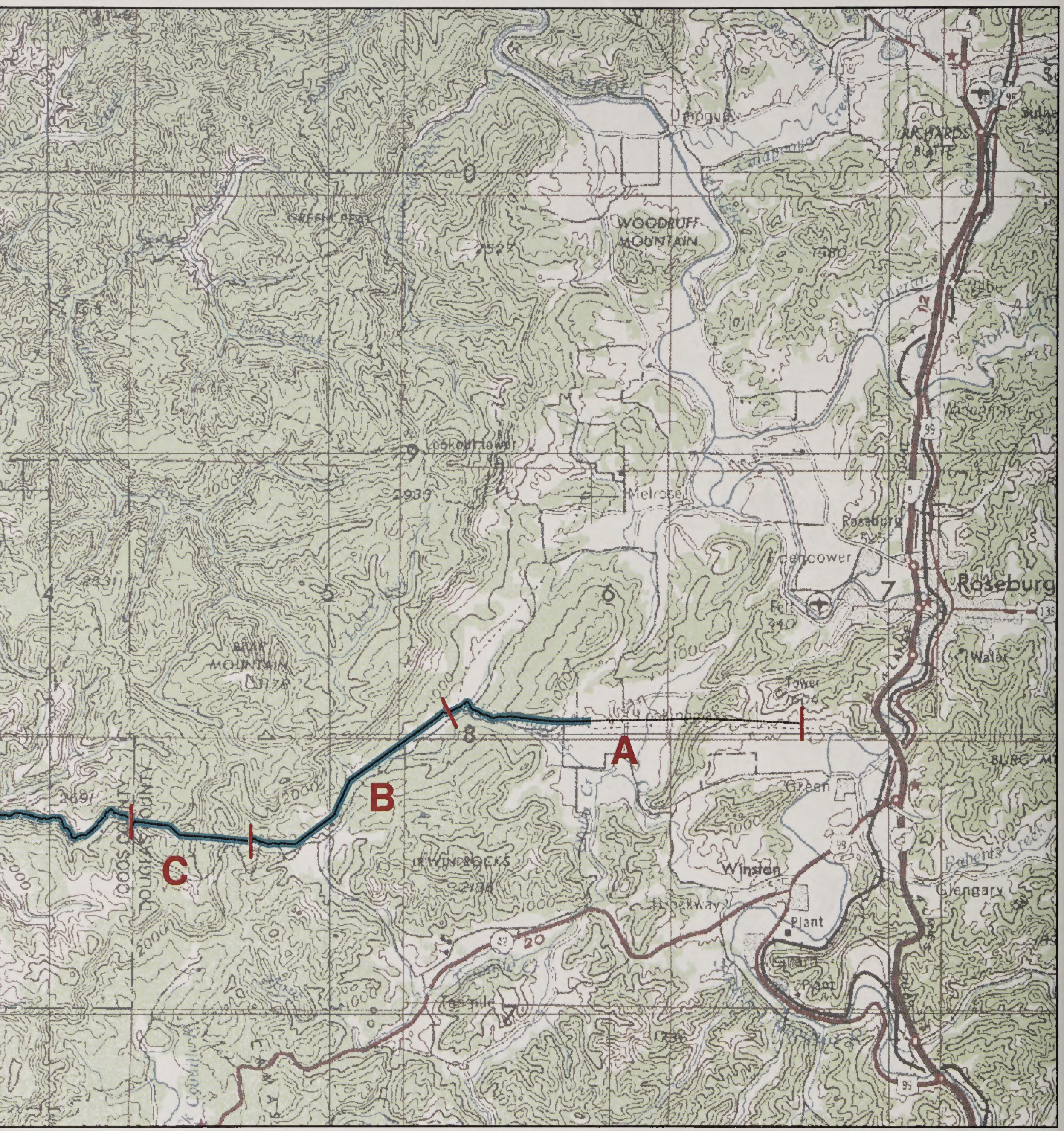



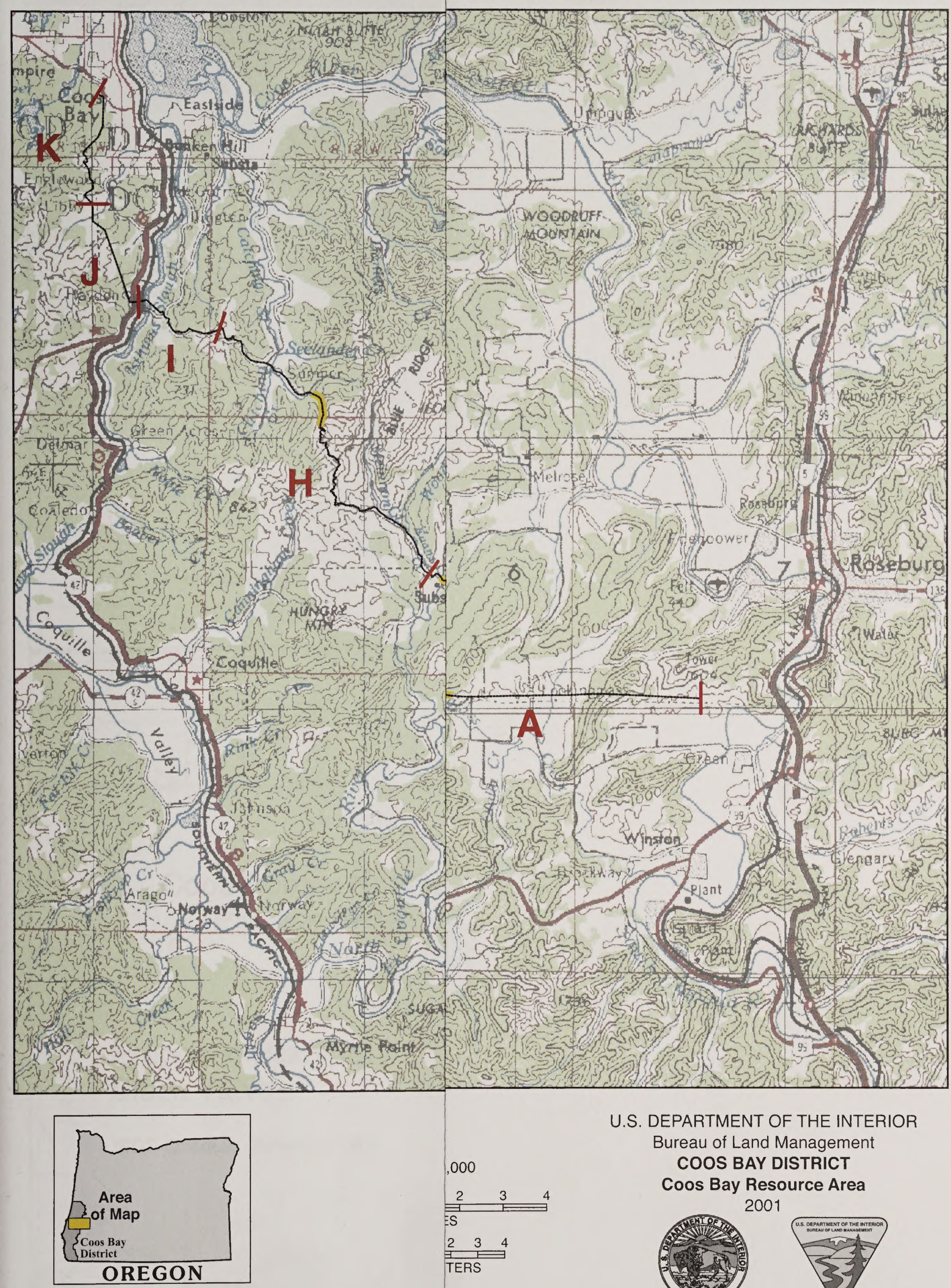

U.S. DEPARTMENT OF THE INTERIOR Bureau of Land Management

, 000

\begin{tabular}{|c|c|c|}
\hline 2 & . & 3 \\
\hline$E$ & & \\
\hline 2 & 3 & 4 \\
\hline
\end{tabular}

as to the accuracy,

ggregate use

sources. This

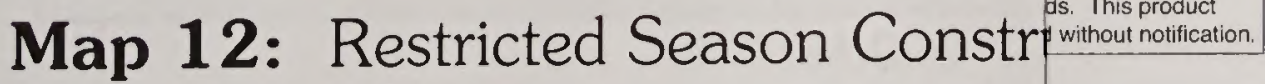

COOS BAY DISTRICT

Coos Bay Resource Area 2001

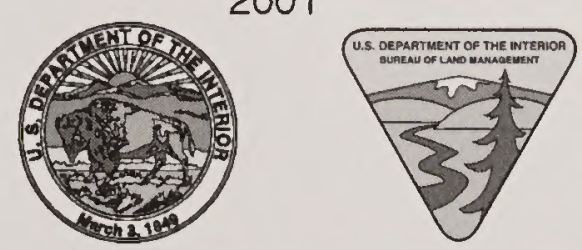

COOS COUNTY NATURAL

GAS PIPELINE PROJECT 

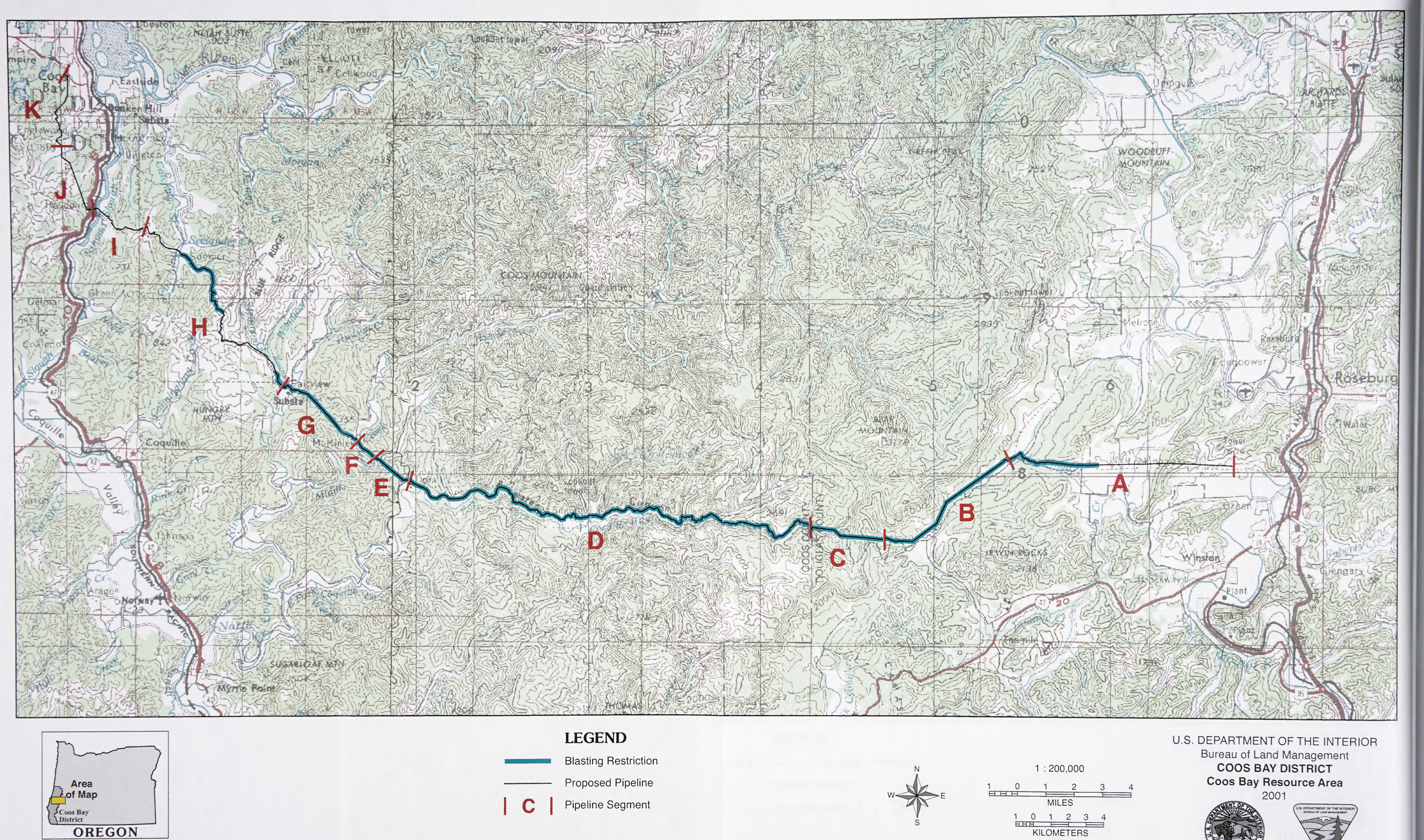

\section{LEGEND}

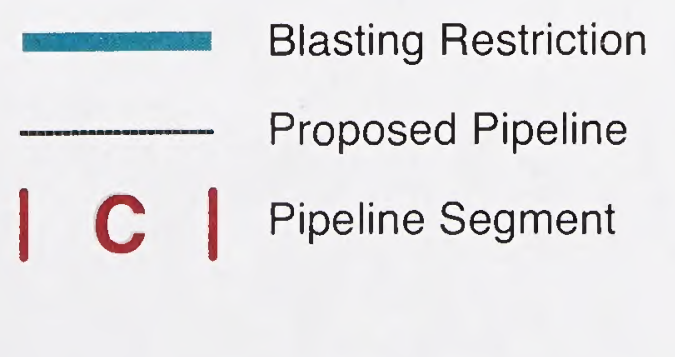

Map 11: Restricted Season Blasting - Spotted Owls and Marbled Murrelets

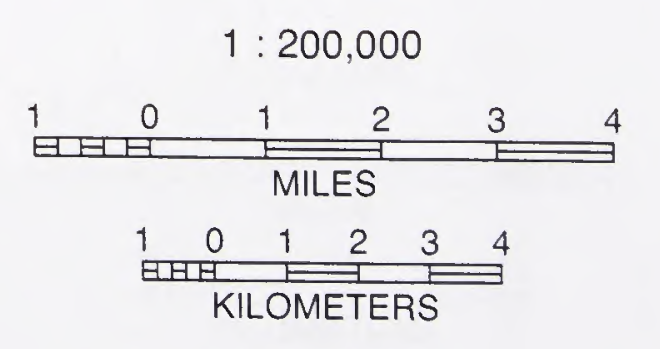

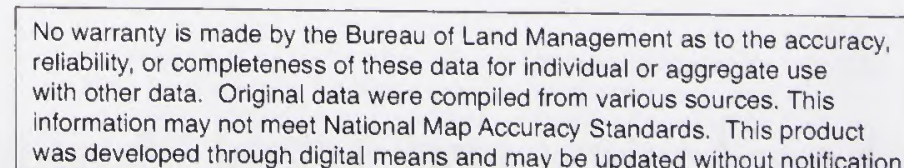

U.S. DEPARTMENT OF THE INTERIOR COOS BAY DISTRICT Coos Bay Resource Area

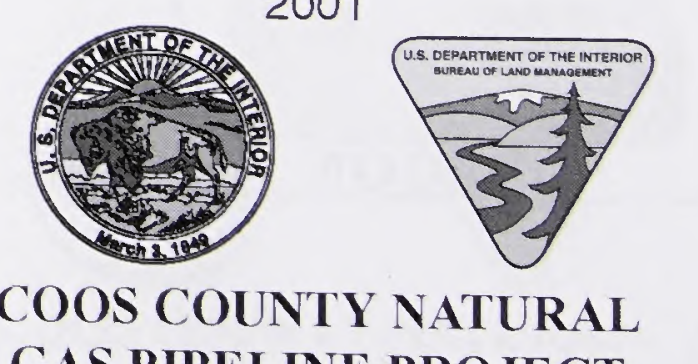

COOS COUNTY NATURAL 


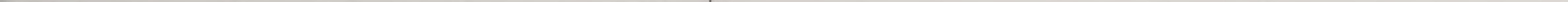



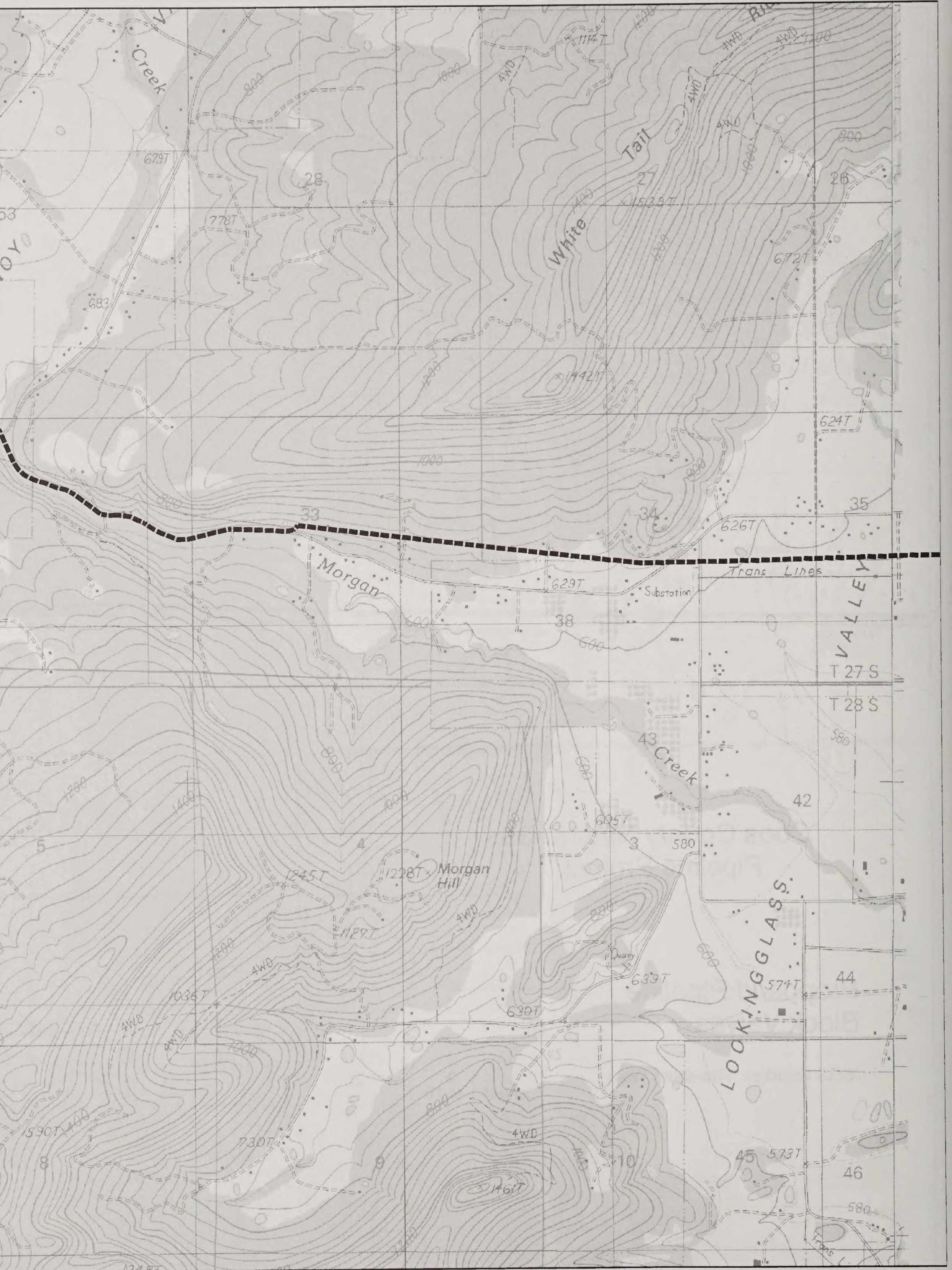




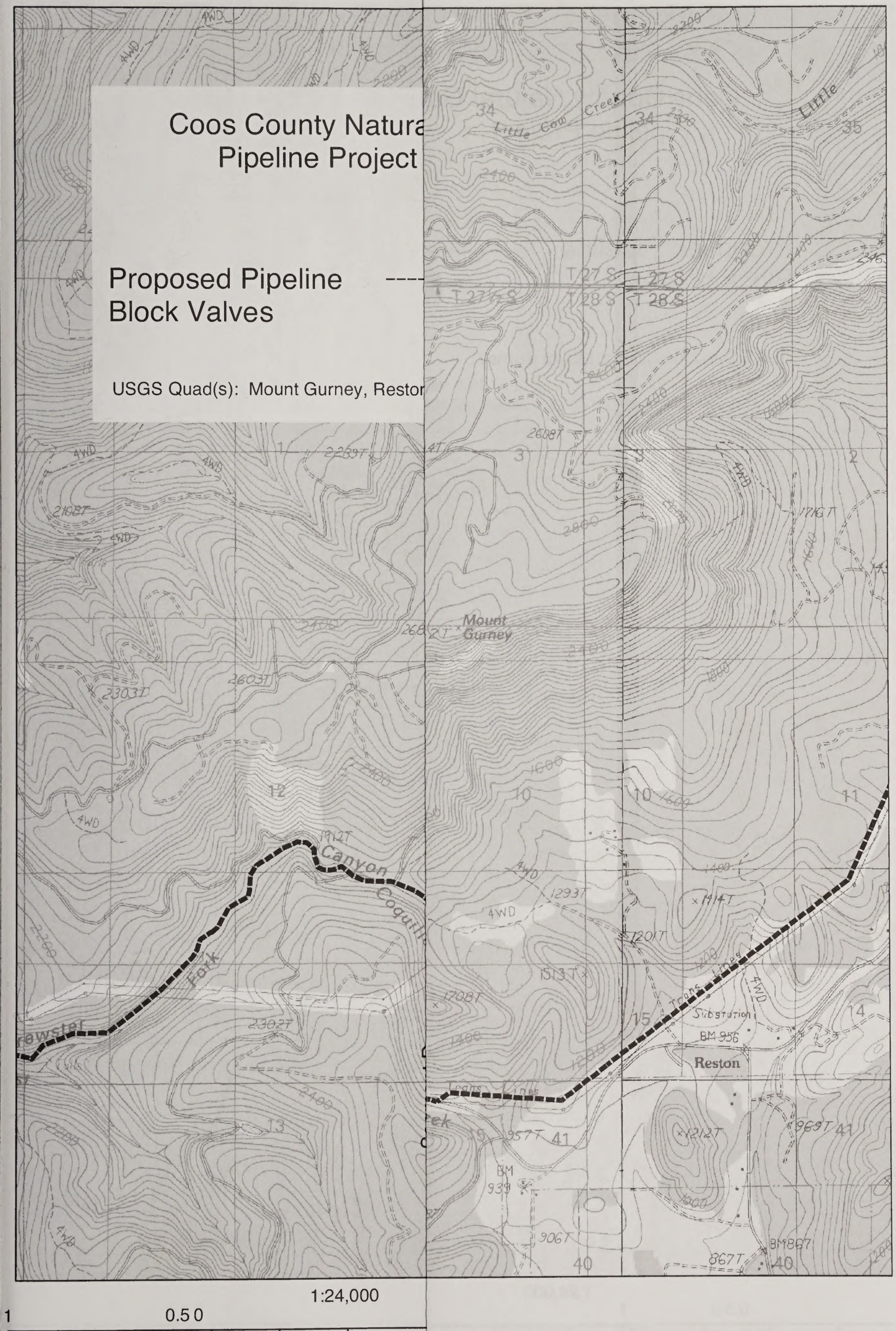


Coos County Natural Gas Pipeline Project

Proposed Pipeline Block Valves

USGS Quad(s): Reston

sheet 2 of 10

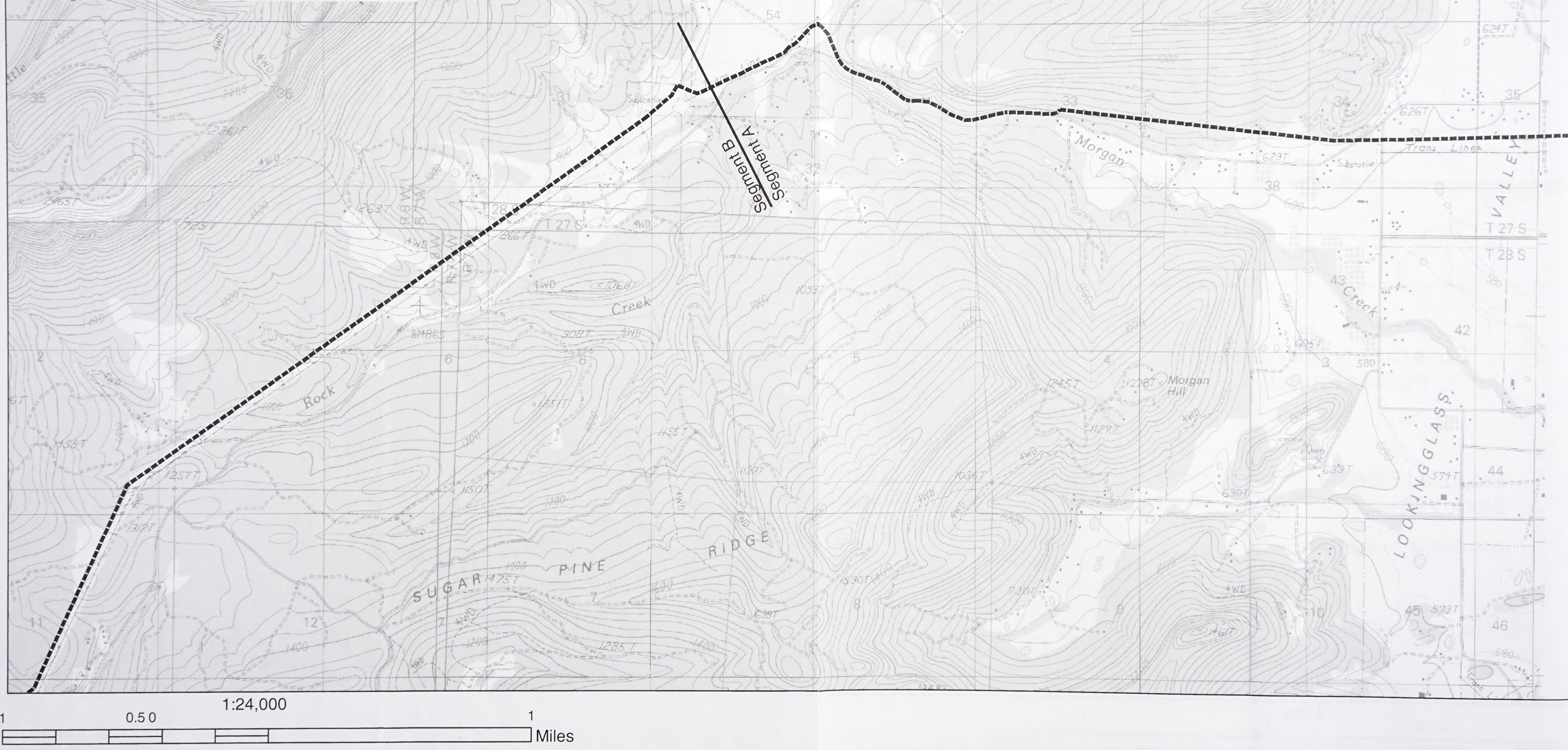


Coos County Natural Gas Pipeline Project

Proposed Pipeline

Block Valves

USGS Quad(s): Mount Gurney, Reston

sheet 3 of 10

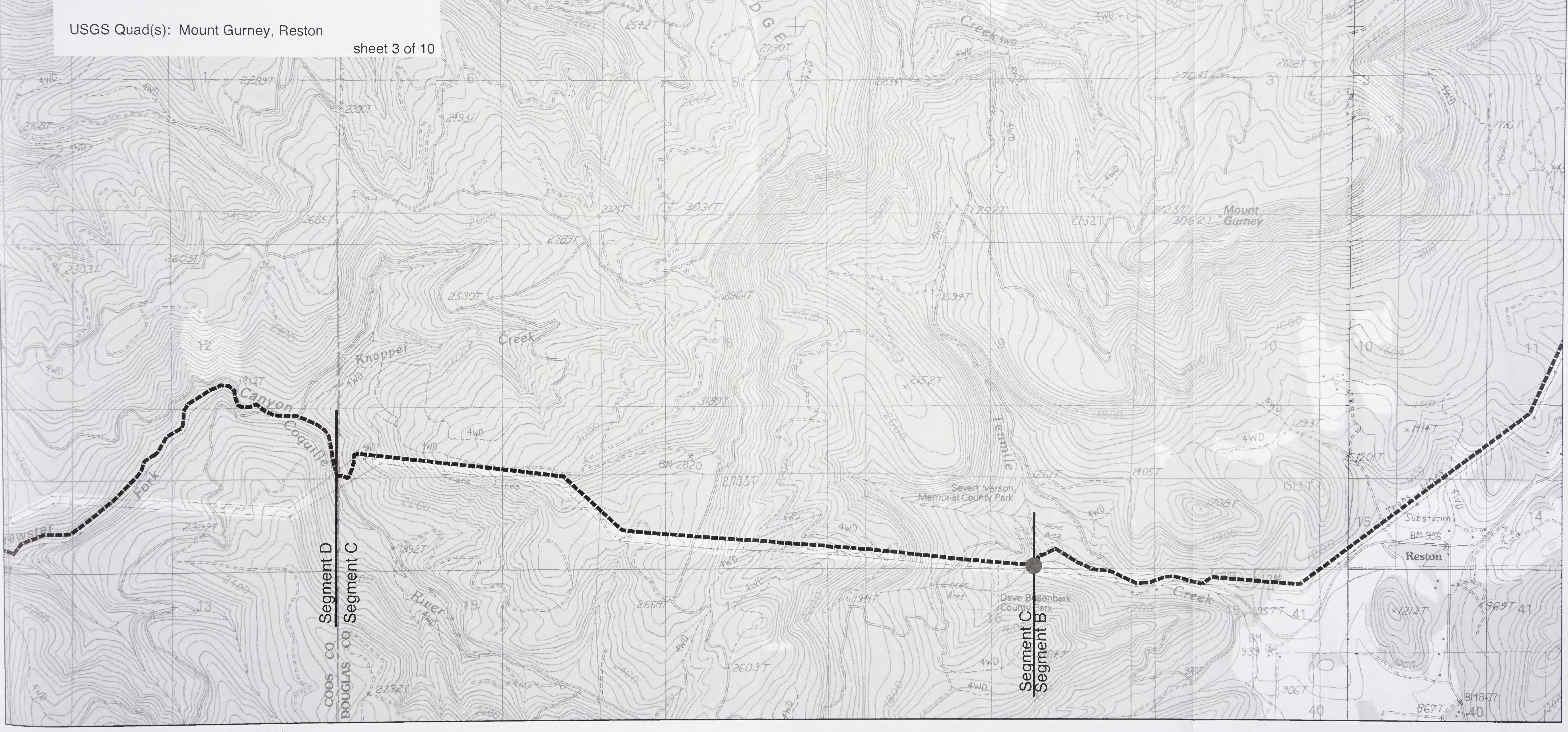

0.50 

Coos County Natural Gas Pipeline Project

Proposed Pipeline

Block Valves

USGS Quad(s): Sitkum, Mount Gurney

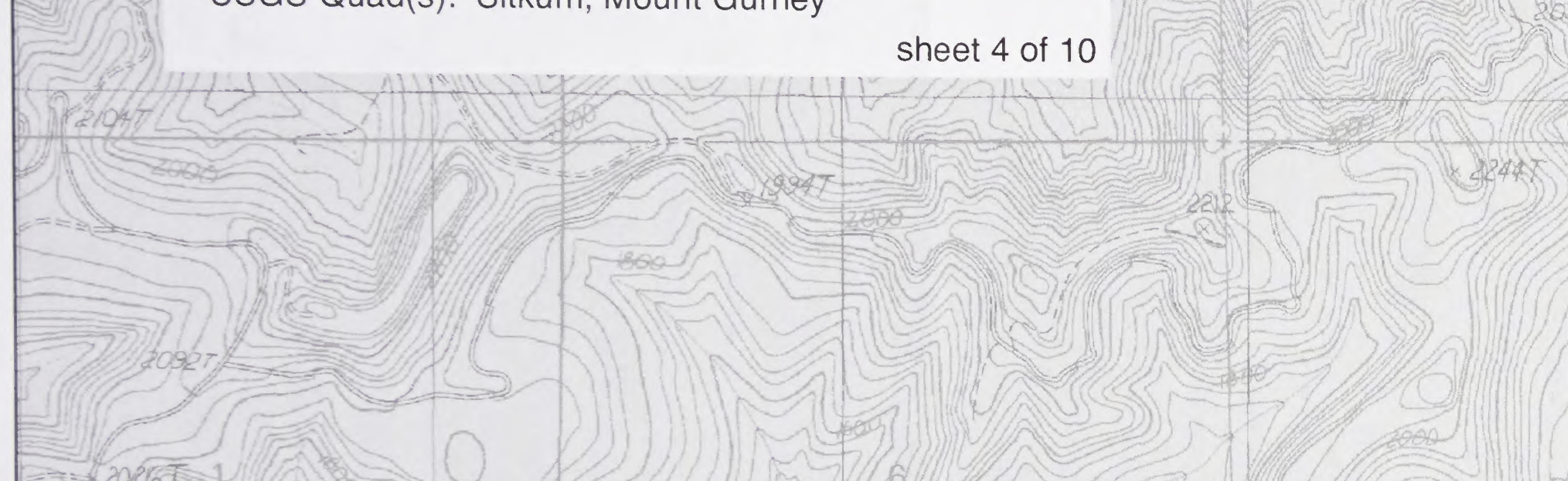

Ex 20261
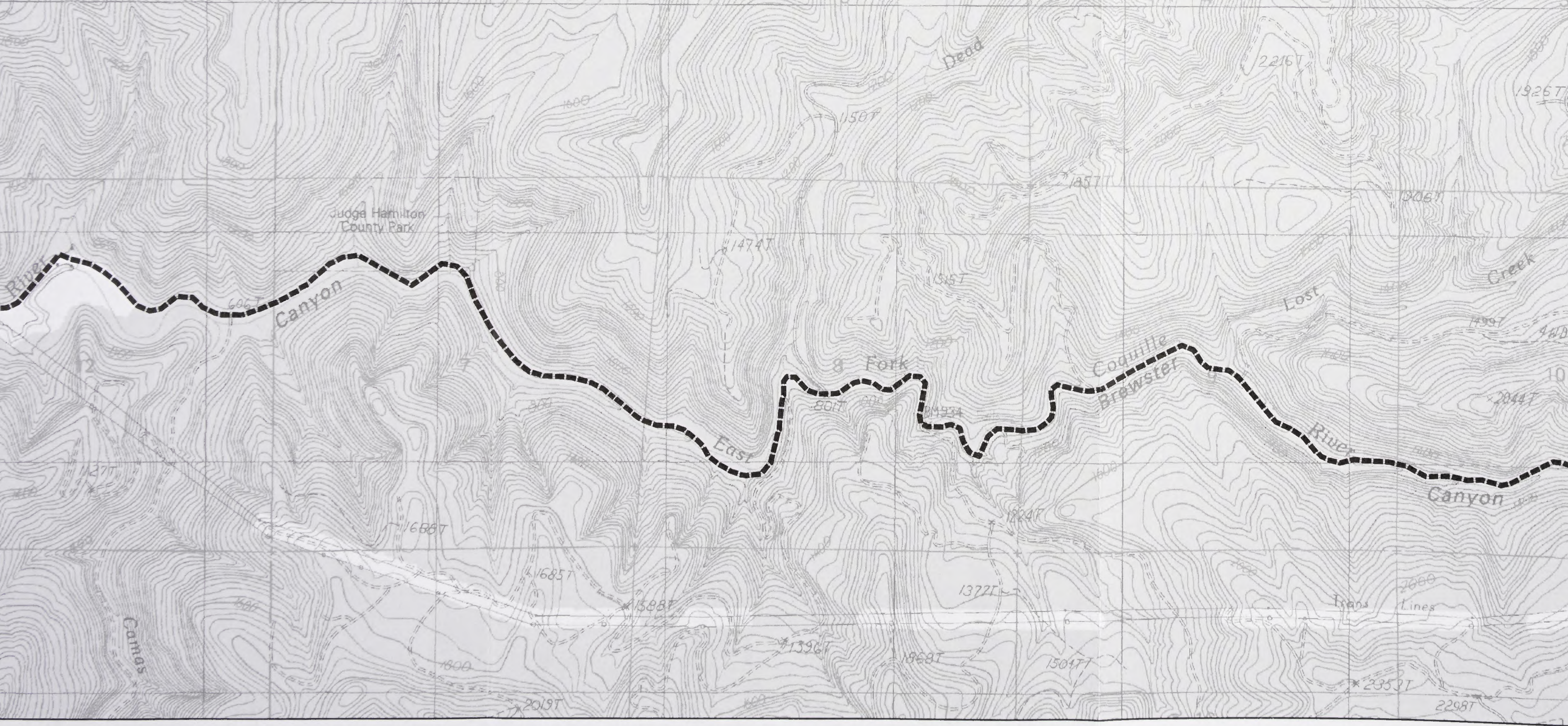

0.50 


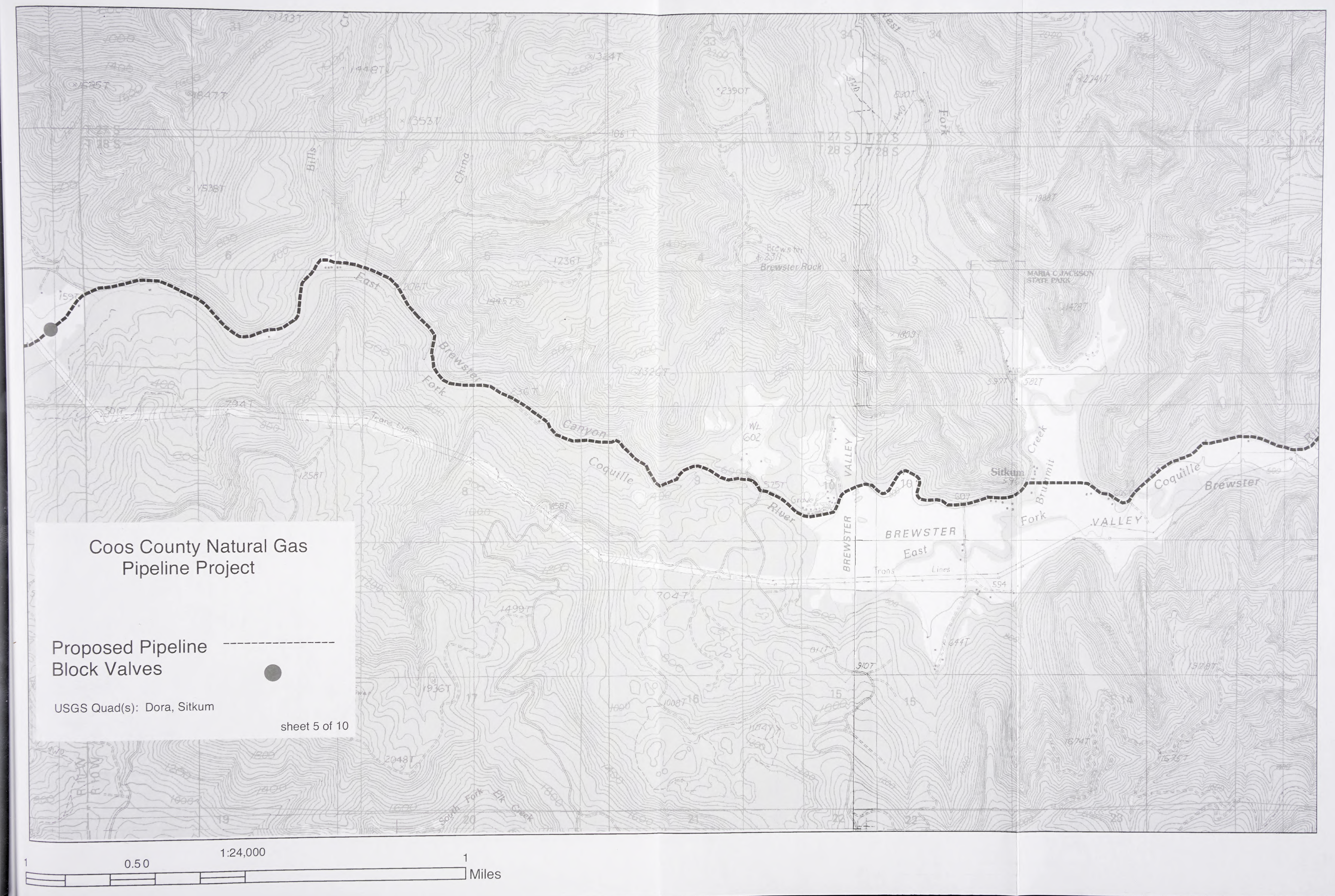




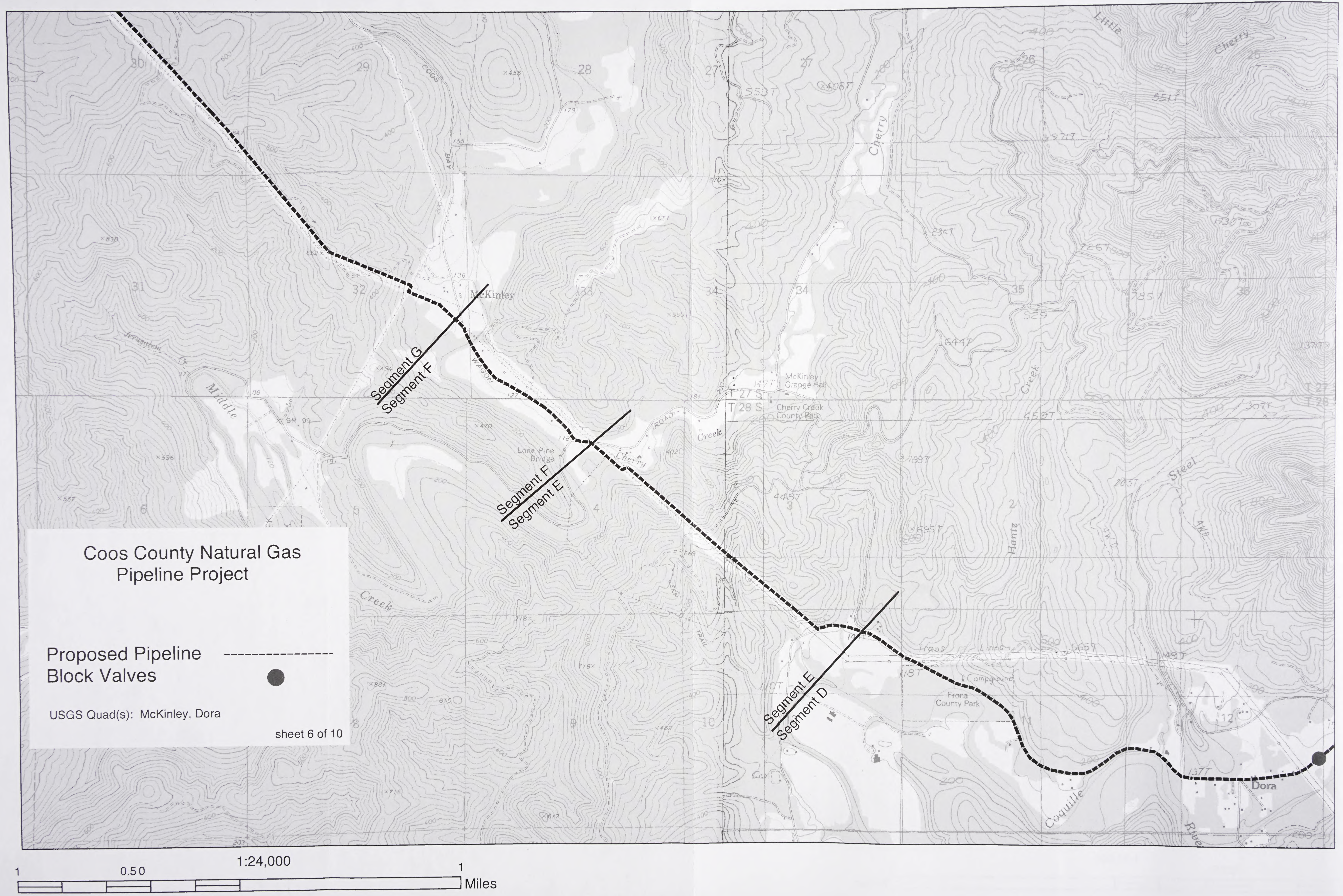




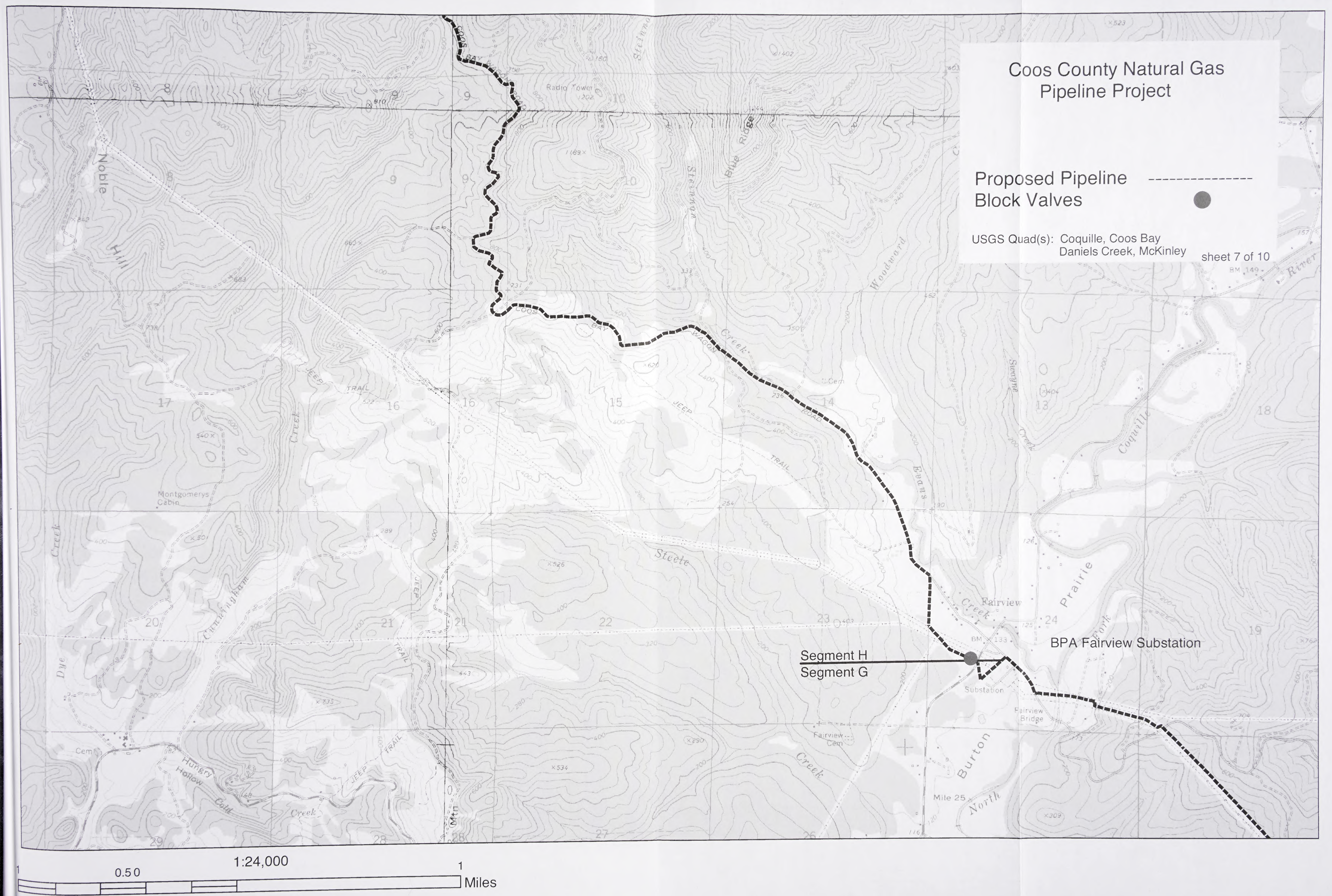



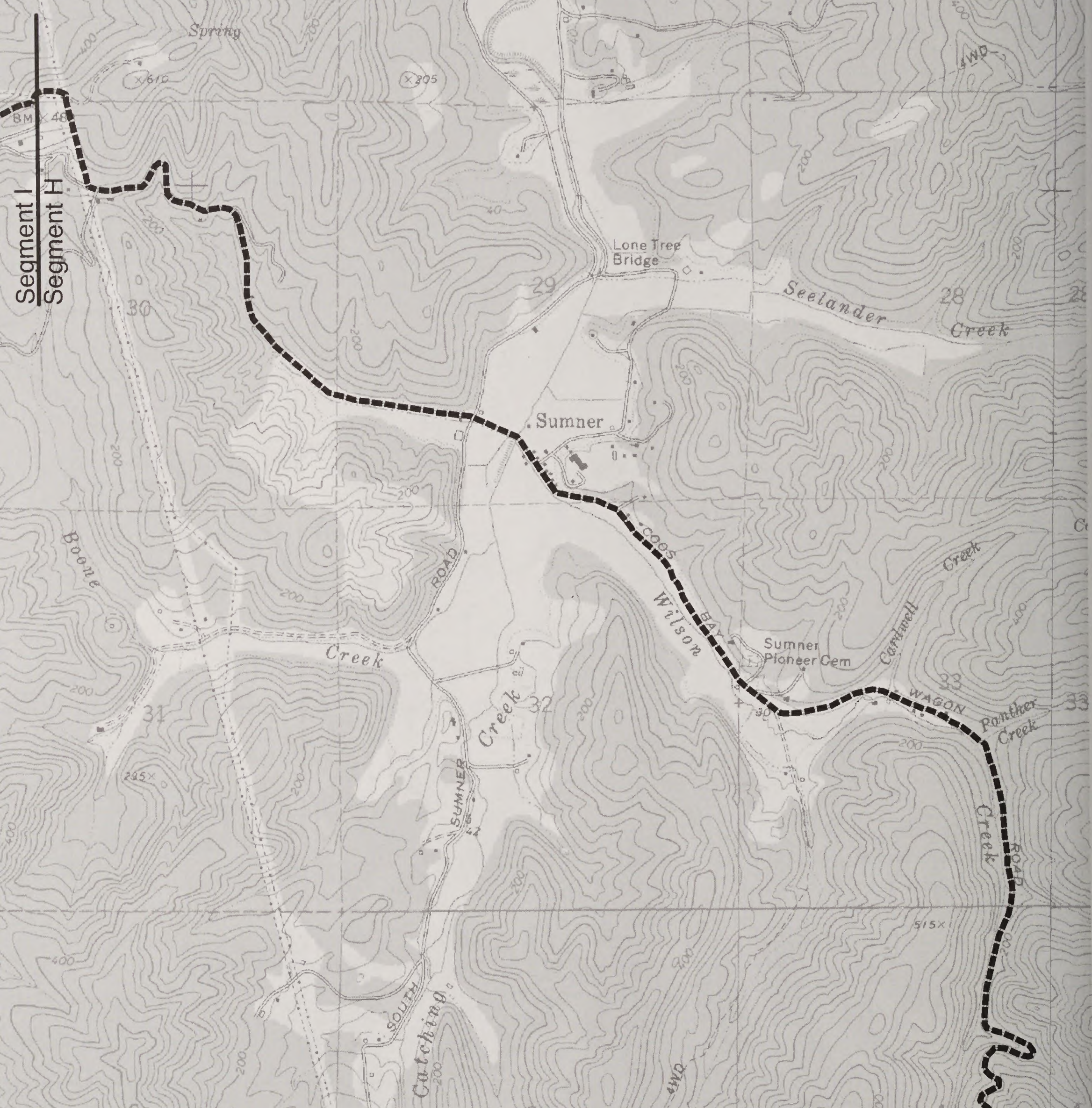

s 


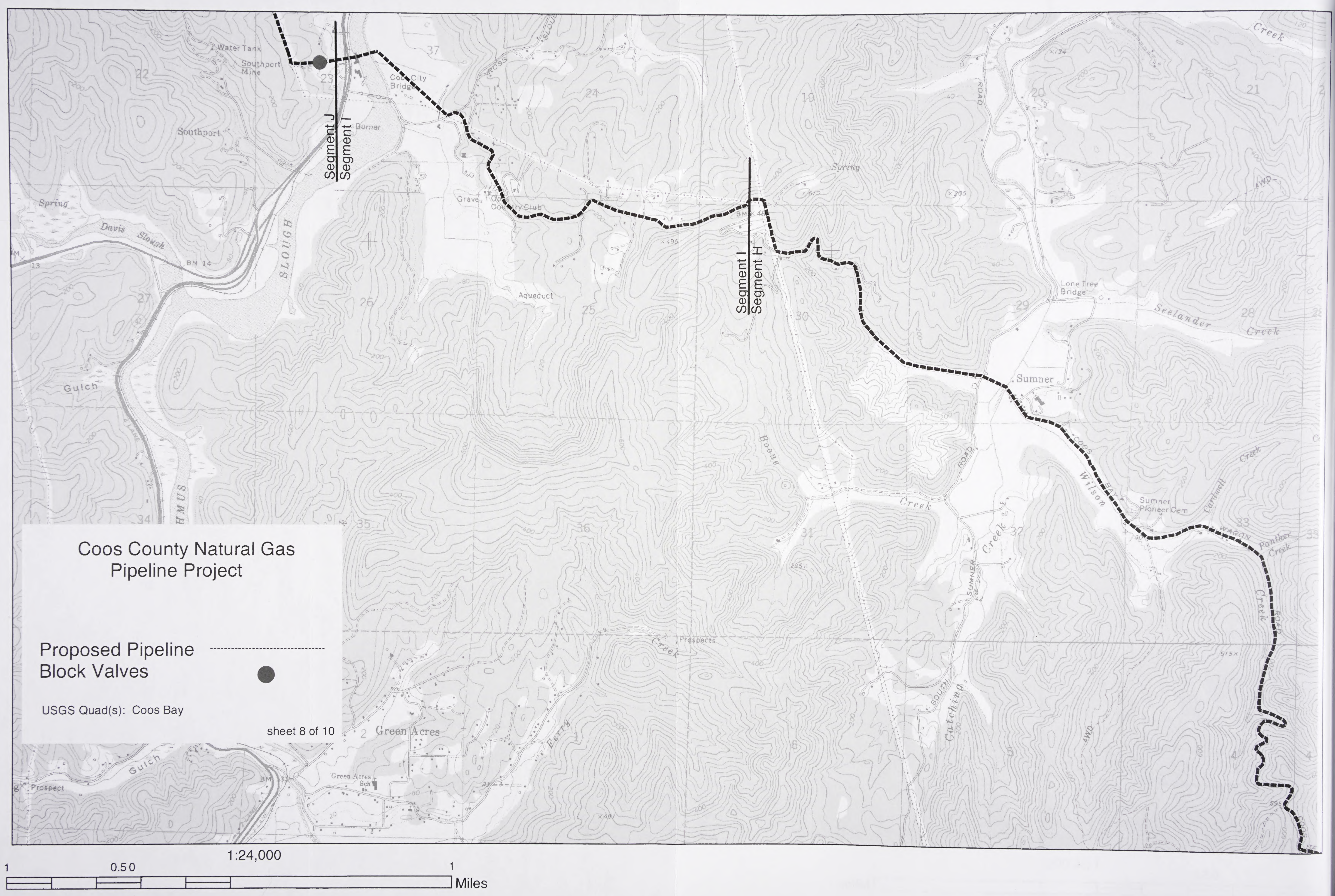




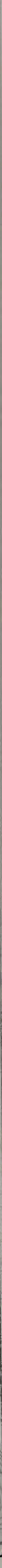




\title{
Appendix D.
}

\section{Agency Management Plans for Resources Adjacent to the Proposed Action}

\author{
Prepared By: \\ Brian T. Cox \\ Biological Information Specialists, Inc. \\ P.O. Box 27 \\ Camas Valley, OR 97416 \\ October 1, 2001
}




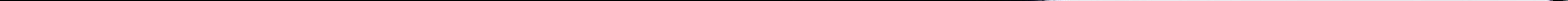




\title{
Appendix D.
}

\section{Agency Management Plans for Resources Adjacent to the Proposed Action}

\author{
Prepared By: \\ Brian T. Cox
}

Biological Information Specialists, Inc.

P.O. Box 27

Camas Valley, OR 97416

October 1, 2001 


\section{Appendix D}

The BLM Resource Management Plan includes management classifications and criteria for a wide variety of aspects throughout the forest ecosystem. Below is a listing of such classifications and criteria pertinent to the proposed action.

\section{Visual Resource Management}

The visual resource management (VRM) classes and objectives for BLM lands within the proposed action corridor are as follows:

Class I - Objective of this class is to provide for natural ecological changes in VRM I areas. Some very limited management activities may occur in these areas. The level of change to the characteristic landscape should be very low and must not attract attention. Changes should repeat the basic elements of form, line, color, texture and scale found in the predominant natural features of the characteristic landscape.

Class II - Objective of this class is to manage lands for low levels of change to the characteristic landscape. Management activities may be seen but should not attract the attention of the casual observer. Changes should repeat the basic elements of form, line, color, texture and scale found in the predominant natural features of the characteristic landscape.

Class III - Objective of this class is to provide for management activities for moderate levels of change to the characteristic landscape. Management activities may attract attention but should not dominate the view of the casual observer. Changes should repeat the basic elements of form, line, color, texture and scale found in the predominant natural features of the characteristic landscape.

Class IV - Objective of this class is to provide for management activities which may dominate the view and be the major focus of the viewer's attention. Every attempt should be made to minimize the impact of these activities through careful pipeline location, minimum disturbance and repetition of the basic elements of form, line, color and texture.

Descriptions of other VRM classes and objectives are in the Coos Bay BLM District RMP EIS (1995).

\section{Riparian Reserve and Aquatic Conservation Strategy Management}

Overall objective: Restore and maintain the ecological health of watersheds.

Other objectives:

a. Provide a scientific basis for protecting aquatic ecosystem using Riparian Reserve Scenarios and Watershed Analysis.

b. Enable planning for sustainable resource management (watershed restoration).

c. Conserve at-risk species through Key Watershed Management and through Riparian Reserve Management. 


\section{Watershed Management Plans}

- Conduct Watershed Analysis to meet ACS objectives.

- Identify Key Watersheds needing restoration efforts which provide the requisites of at-risk species.

\section{BLM Land-Use Allocations}

The land-use allocation areas listed below are located adjacent to or near the alternative routes (including the proposed action). For further information about these, refer to the Coos Bay or Roseburg RMPs.

\section{Late-Succession Forest Reserve (LSR)}

The proposed action corridor is adjacent to approximately 4.5 miles of LSR. The Hwy 42 alternative is adjacent to approximately 3 miles of LSR.

\section{Area of Critical Environmental Concern (ACEC)}

Part of the North Spit of Coos Bay is designated as an ACEC. Depending on where NW Natural decides to extend its distribution network in Coos Bay, it may cross under a portion of the North Spit ACEC. However, all ground disturbance in the North Spit would occur in road or utility rights-of-way.

The proposed action and Hwy 42 alternative would not cross any ACEC on other designated special areas.

\section{Research Natural Areas}

No Research Natural Areas exist within or near the proposed action corridor. The Cherry Creek Instant Study Area is located just over 3 miles north of Dora and the CBW Road. This area is set aside for protection of its special-status plant and animal habitats, and recreational development is precluded from this area.

\section{Coquille Forest Special Management Areas}

None of the alternative routes (including the proposed action) enter the Coquille Forests.

\section{Native American Religious Concerns}

No known Native American religious sites exist within or adjacent to the proposed action corridor or the other alternative routes. Also see Appendix B. 



\section{Appendix E. Aquatic Ecosystem Assessment}

AQUATIC ECOSYSTEM ASSESSMENT for the COOS COUNTY PIPELINE,

COOS BAY DISTRICT, BUREAU OF LAND MANAGEMENT,

COOS COUNTY

Prepared By:

Brian T. Cox

Biological Information Specialists, Inc.

P.O. Box 27

Camas Valley, OR 97416

October 1, 2001 


\section{Evaluation of Consistency With Watershed Analysis (WA)}

\section{Pipeline Construction Treatments}

After pipeline construction is finished, there are no plans for management actions other than normal pipeline monitoring and light maintenance.

\section{Road Treatments}

Roads can affect the quality of the ecosystem at both localized and landscape levels. Roads allow increased human disturbance which may disrupt local ecosystem function on a temporal basis. Roads reduce the area for vegetation growth at an approximate rate of five acres per road-mile. Hydrologic function, landslide rates, sedimentation and pollution from dumping or spills are all potential local and landscape effects of roads. Roads may increase/decrease the utility of interior habitats for certain wildlife species. Roads may create movement barriers for certain species. Extensive riparian road networks may encroach on streams, extend channels, re-route sediment and disconnect streams from floodplains. All of the Watershed Analyses recommended that no new road construction occur within interior habitats or on erosive/unstable soils.

No new road treatments are planned for the proposed action. Only existing road networks will be used in the proposed action. Graveled portions of the CBW Road will be paved after pipeline construction to reduce sediment production. Deteriorating stream and cross-drain culverts will be replaced. Extra cross-drain culverts will be added to reduce ditchline sediment production. These treatments are consistent with the WA recommendations.

\section{Riparian Reserve Reduction}

The proposed action contains no Riparian Reserve reductions or treatments. There are no proposed federal foreststand treatments in this project. These treatments are consistent with the WA recommendations.

\section{Transient Snow Zone}

The pipeline corridor does not occur within a transient snow zone, and no impacts to overstory forest vegetation occur from the proposed action or its interrelated actions. These treatments are consistent with the WA recommendations.

\section{ACS Consistency}

ACS consistency is determined at the 5th field HUC watershed level. 


\section{Evaluation Of Consistency With National Marine Fishery Service's (NMFS) March 18, 1997 Land Resource Management Plan-Level Biological Opinion (LRMP BO):}

\section{Conservation Recommendations}

Four of the WAs included assessments of the aquatic ecosystem, which addressed salmonid conservation as a main issue. This meets LRMP BO Conservation Recommendation 3. The East Fork Coquille and North Fork Coquille Watershed Analyses included recommendations for restoration projects, including projects that promote long-term recovery. This is consistent with LRMP BO Conservation Recommendations 5 and 6 . As part of the watershed analysis, Transportation Management Plans were completed. This meets Conservation Recommendation 11. No other Conservation Recommendations specifically apply to this proposed action.

\section{Reasonable and Prudent Measures}

During the WA process, the interdisciplinary team used applicable criteria in the Northwest Forest Plan ROD to ensure that proposed actions are fully consistent with applicable standards and guidelines and ACS objectives. This is consistent with Reasonable and Prudent Measure 1. The NMFS is currently reviewing the proposed actions. This is consistent with Reasonable and Prudent Measure 2. Based on the ACS Evaluation, proposed actions would not detract from long-term ecosystem recovery. This is consistent with Reasonable and Prudent Measure 4. All related roadwork would be completed during the dry season and utilize BMPs. This is consistent with Reasonable and Prudent Measures 5 and 6 . No other Conservation Recommendations specifically apply to this proposed action.

\section{Terms and Conditions}

No other terms and conditions specifically apply to this proposed action.

\section{LRMP BO Consistency}

LRMP BO consistency is determined at the 5th field HUC watershed level. 


\section{Table E-1. MATRIX OF FACTORS AND INDICATORS (ALL WAs \& NMFS, 1998)}

\begin{tabular}{|c|c|c|c|c|}
\hline PATHWAYS & INDICATORS & $\begin{array}{c}\text { PROPERLY } \\
\text { FUNCTIONING (PF) }\end{array}$ & $\begin{array}{l}\text { AT RISK (All situations not } \\
\text { described as PF or NPF) }\end{array}$ & $\begin{array}{c}\text { NOT PROPERLY FUNC- } \\
\text { TIONING (NPF) }\end{array}$ \\
\hline \multirow[t]{3}{*}{ Water Quality: } & $\begin{array}{l}\text { Maximum } \\
\text { Temperature }\end{array}$ & $<60^{\circ} \mathrm{F}$ & $60-68^{\circ} \mathrm{F}$ & $>68^{\circ} \mathrm{F}$ \\
\hline & Turbidity & $\begin{array}{l}\text { Similar frequency and duration } \\
\text { relative to unimpacted streams in } \\
\text { basin. }\end{array}$ & $\begin{array}{l}\text { Moderately higher frequency and } \\
\text { duration relative to unimpacted } \\
\text { streams in basin. }\end{array}$ & $\begin{array}{l}\text { Higher frequency and duration } \\
\text { relative to unimpacted streams in } \\
\text { basin. }\end{array}$ \\
\hline & $\begin{array}{c}\text { Chemical } \\
\text { Concentration/Nutri- } \\
\text { ents }\end{array}$ & $\begin{array}{l}\text { No biological evidence of con- } \\
\text { tamination. }\end{array}$ & & $\begin{array}{l}\text { Obvious biological evidence of } \\
\text { contamination (e.g., fish kills, } \\
\text { algal blooms, deformities.) }\end{array}$ \\
\hline Habitat Access: & Physical Barriers & $\begin{array}{l}\text { No man-made barriers in water- } \\
\text { shed that prevent upstream and } \\
\text { downstream passage of any age } \\
\text { of salmonids. }\end{array}$ & & $\begin{array}{l}\text { Any man-made barriers in water- } \\
\text { shed prevent upstream or down- } \\
\text { stream passage of any age of } \\
\text { salmonids. }\end{array}$ \\
\hline \multirow[t]{7}{*}{$\begin{array}{l}\text { Habitat } \\
\text { Elements: }\end{array}$} & Substrate/Sediment & $\begin{array}{l}50 \% \text { of riffle habitat is gravel } \\
\text { dominated, with very little } \\
\text { embeddeness. }>5 \% \text { of riffles are } \\
\text { dominated by fines - or- In low } \\
\text { gradient riffle, }<10 \% \text { of substrate } \\
\text { is sand or silt. }\end{array}$ & $\begin{array}{l}\text { Gravel and cobble is subdomi- } \\
\text { nant, or if dominant, embedded- } \\
\text { ness } 20-30 \% \text {. }\end{array}$ & $\begin{array}{l}<20 \% \text { of riffle habitat is gravel } \\
\text { dominated or gravel/cobble with } \\
\text { large degree of embeddedness. } \\
>10 \% \text { of riffles are dominated by } \\
\text { fines - or- Low gradient riffle has } \\
>25 \% \text { sand or silt. }\end{array}$ \\
\hline & $\begin{array}{l}\text { Large Woody Debris } \\
\text { (LWD) }\end{array}$ & $\begin{array}{l}>80 \text { Pieces/mile, }>24 \text { " diameter, } \\
>50 \text { ' length. Little or no evidence } \\
\text { of stream clean-out or manage- } \\
\text { ment related debris flows. }\end{array}$ & $\begin{array}{l}30-80 \text { pieces/mile, }>24 \text { " in diam- } \\
\text { eter, }>50 \text { 'length. Some evidence } \\
\text { of stream clean-out and/or man- } \\
\text { agement related debris flow. }\end{array}$ & $\begin{array}{l}<30 \text { pieces/mile, } 24 \text { " in diameter, } \\
>50 \text { ' length. Evidence of stream } \\
\text { clean-out and/or management } \\
\text { related debris flows is wide- } \\
\text { spread. }\end{array}$ \\
\hline & Pool Area & Basaltic Headlands: $>35 \%$ & Basaltic Headlands: $20-35 \%$ & Basaltic Headlands: $<20 \%$ \\
\hline & & Rest of Province: $>50 \%$ & Rest of Province: $30-50 \%$ & Rest of Province: $<30 \%$ \\
\hline & Pool Quality & $\begin{array}{c}>20 \% \text { pool habitat by area is }>1 \\
\text { meter deep. }\end{array}$ & $\begin{array}{c}10-20 \% \text { pool habitat by area is }>1 \\
\text { meter deep. }\end{array}$ & $\begin{array}{c}<10 \% \text { pool habitat by area is }>1 \\
\text { meter deep. }\end{array}$ \\
\hline & Pool Frequency & $<8$ channel widths between pools. & $\begin{array}{l}\text { 8-19 channel widths between } \\
\text { pools. }\end{array}$ & $\begin{array}{l}>20 \text { channel widths between } \\
\text { pools. }\end{array}$ \\
\hline & $\begin{array}{l}\text { Off-Channel } \\
\text { Habitat }\end{array}$ & $\begin{array}{l}\text { Frequent backwaters w/cover, \& } \\
\text { low-energy channel areas (ponds, } \\
\text { oxbows) are }>10 \% \text { of total area. }\end{array}$ & $\begin{array}{l}\text { Less frequent backwaters w/ } \\
\text { cover, \& low-energy channel } \\
\text { areas (ponds, oxbows) are 5-10\% } \\
\text { of total area. }\end{array}$ & $\begin{array}{l}\text { Infrequent backwaters w/cover, \& } \\
\text { low-energy channel areas (ponds, } \\
\text { oxbows) are }<10 \% \text { of total area. }\end{array}$ \\
\hline $\begin{array}{l}\text { Channel } \\
\text { Condition and } \\
\text { Dynamics: }\end{array}$ & $\begin{array}{l}\text { Width/Depth Ratio } \\
\text { and Channel Type }\end{array}$ & $\begin{array}{l}\text { W/D ratios and channel types are } \\
\text { well within historic ranges and } \\
\text { site potential in watershed. } \\
\begin{array}{cc}\text { Rosgen Type } & \frac{\text { W/D Ratio }}{\text { A,E,G }} \\
\text { B,C,F } & 12-30 \\
\text { D } & >40\end{array}\end{array}$ & $\begin{array}{l}\text { W/D ratios and/or channel types } \\
\text { in portions of watershed are out- } \\
\text { side historic ranges and/or site } \\
\text { potentials. }\end{array}$ & $\begin{array}{l}\text { W/D ratios and channel types } \\
\text { throughout the watershed are well } \\
\text { outside of historic ranges and/or } \\
\text { site potential. }\end{array}$ \\
\hline
\end{tabular}




\begin{tabular}{|c|c|c|c|c|}
\hline & $\begin{array}{l}\text { Stream Bank } \\
\text { Condition }\end{array}$ & $\begin{array}{l}\text { Relatively stable banks, few or no } \\
\text { areas of additive erosion. }\end{array}$ & $\begin{array}{l}\text { Moderately stable banks, few } \\
\text { areas of additive erosion. }\end{array}$ & $\begin{array}{l}\text { Highly unstable banks. Many } \\
\text { areas of exposed soil and stream- } \\
\text { bank cutting. }\end{array}$ \\
\hline & $\begin{array}{l}\text { Floodplain } \\
\text { Connectivity }\end{array}$ & $\begin{array}{l}\text { Logjams and other features create } \\
\text { pools \& secondary channels, } \\
\text { which trap debris and food and } \\
\text { maintain a high water table that } \\
\text { provides cooled late-season } \\
\text { flows. Floodplain is well-vege- } \\
\text { tated. }\end{array}$ & $\begin{array}{l}\text { Logjams and other features create } \\
\text { some pools \& secondary chan- } \\
\text { nels, which trap debris and food } \\
\text { and maintains enough water table } \\
\text { to provide some cooled late-sea- } \\
\text { son flows. Floodplain is mostly } \\
\text { well-vegetated. }\end{array}$ & $\begin{array}{l}\text { Secondary channels lacking. } \\
\text { Unconstrained main channel } \\
\text { often downcut to bedrock and rel- } \\
\text { atively short, lacking pools, } \\
\text { meanders and collections of food } \\
\text { and debris. Warm, low, late-sea- } \\
\text { son flows. }\end{array}$ \\
\hline \multirow[t]{2}{*}{$\begin{array}{c}\text { Flow/ } \\
\text { Hydrology }\end{array}$} & $\begin{array}{c}\text { Change Peak/Base } \\
\text { Flows }\end{array}$ & $\begin{array}{l}\text { Timber harvest and roading his- } \\
\text { tory is such that little or no } \\
\text { change to the natural flow regime } \\
\text { has occurred. }\end{array}$ & $\begin{array}{l}\text { Moderate amounts of timber har- } \\
\text { vest and roading have likely } \\
\text { altered the flow regime to some } \\
\text { extent. }\end{array}$ & $\begin{array}{l}\text { Relatively high levels of timber } \\
\text { harvest and roads have likely had } \\
\text { a large effect on the flow regime. }\end{array}$ \\
\hline & Drainage Network & $\begin{array}{l}\text { Zero or minimum increase in } \\
\text { drainage network density due to } \\
\text { roads. }\end{array}$ & $\begin{array}{l}\text { Moderate increases in drainage } \\
\text { network due to roads. }\end{array}$ & $\begin{array}{l}\text { Significant increases in drainage } \\
\text { network density due to roads. }\end{array}$ \\
\hline \multirow[t]{5}{*}{$\begin{array}{l}\text { Watershed } \\
\text { Condition: }\end{array}$} & $\begin{array}{l}\text { Road Density and } \\
\text { Location/Drainage } \\
\text { Network }\end{array}$ & $\begin{array}{l}\text { Road density }<2 \text { miles per square } \\
\text { mile; with no valley bottom } \\
\text { roads. If unstable areas exist, no } \\
\text { midslope roads. }\end{array}$ & $\begin{array}{c}\text { Road density } 2-3 \text { miles per square } \\
\text { mile; with few valley bottom } \\
\text { roads. }\end{array}$ & $\begin{array}{l}\text { Road density }>3 \text { miles per mile, } \\
\text { with valley bottom roads. }\end{array}$ \\
\hline & Disturbance History & $\begin{array}{l}<5 \% \text { ECA/decade (entire water- } \\
\text { shed) with no concentration of } \\
\text { disturbance in unstable or poten- } \\
\text { tially unstable areas, and/or } \\
\text { Riparian Reserves; and for NFP } \\
\text { area (except AMAs) }>15 \% \text { reten- } \\
\text { tion of LSOG in watershed. }\end{array}$ & $\begin{array}{c}<5 \% \text { ECA/decade (entire water- } \\
\text { shed) but disturbance concentra- } \\
\text { tion in unstable or potentially } \\
\text { unstable areas, and/or Riparian } \\
\text { Reserves; and for NFP area } \\
\text { (except AMAs) }>15 \% \text { retention } \\
\text { of LSOG in watershed. }\end{array}$ & $\begin{array}{c}<5 \% \mathrm{ECA} / \text { decade (entire water- } \\
\text { shed) and disturbance concentra- } \\
\text { tion in unstable or potentially } \\
\text { unstable areas, and/or Riparian } \\
\text { Reserves; does not meet NFP } \\
\text { standard for LSOG in watershed. }\end{array}$ \\
\hline & Riparian Reserves & $\begin{array}{c}\text { Terrestrial vegetation conditions } \\
\text { show that the watershed is rela- } \\
\text { tively intact. }\end{array}$ & & $\begin{array}{c}\text { Watershed is fragmented and } \\
\text { highly impacted. }\end{array}$ \\
\hline & Landslide Rates & $\begin{array}{l}\text { Within } 10-20 \% \text { of historic, natu- } \\
\text { ral rates. Stream conditions not } \\
\text { evidently altered due to manage- } \\
\text { ment caused landslides. }\end{array}$ & $\begin{array}{l}\text { Some subdrainages with }>20 \% \text { of } \\
\text { landslides related land manage- } \\
\text { ment activities. Some stream con- } \\
\text { ditions evidently altered by } \\
\text { management related landslides. }\end{array}$ & $\begin{array}{l}\text { Many subdrainages with }>25 \% \text { of } \\
\text { landslides related to land manage- } \\
\text { ment activities. Stream conditions } \\
\text { obviously and/or dramatically } \\
\text { altered by management related } \\
\text { landslides. }\end{array}$ \\
\hline & Refugia & $\begin{array}{l}\text { Habitat refugia exist and are ade- } \\
\text { quately buffered. Existing refu- } \\
\text { gia are sufficient in size, number, } \\
\text { and connectivity to maintain via- } \\
\text { ble populations or } \\
\text { subpopulations. }\end{array}$ & $\begin{array}{l}\text { Habitat refugia exist, but some } \\
\text { are not adequately buffered. } \\
\text { Existing refugia may be insuffi- } \\
\text { cient in size, number, and connec- } \\
\text { tivity to maintain viable sub- } \\
\text { populations. }\end{array}$ & $\begin{array}{l}\text { Adequate habitat refugia do not } \\
\text { exist to maintain viable fish popu- } \\
\text { lations. }\end{array}$ \\
\hline
\end{tabular}




\section{Table E-2. CHECKLIST FOR DOCUMENTING ENVIRONMENTAL BASELINE AND EFFECTS OF PROPOSED ACTIONS ON RELEVANT INDICATORS.}

Name and location: Coos Bay District - BLM

Basin: $5^{\text {th }}$ field: East Fork Coquille River

\begin{tabular}{|c|c|c|c|c|c|c|}
\hline \multirow{2}{*}{$\frac{\text { Pathways }}{\text { Indicators }}$} & \multicolumn{3}{|c|}{ Environmental Baseline $^{1}$} & \multicolumn{3}{|c|}{ Effects of the Actions ${ }^{2}$} \\
\hline & $\begin{array}{c}\text { Properly } \\
\text { Functioning }\end{array}$ & At Risk ${ }^{3}$ & $\begin{array}{l}\text { Not Properly } \\
\text { Functioning }\end{array}$ & Restore $^{4}$ & Maintain ${ }^{4}$ & Degrade $^{4}$ \\
\hline$\frac{\text { Water Quality }}{\text { Temperature }}$ & & & WA, MON & & PJ & \\
\hline Turbidity & & & WA & Long-term & & Short-term \\
\hline $\begin{array}{c}\text { Chemical Concentration/ Nutri- } \\
\text { ents }\end{array}$ & & & PJ & & PJ & \\
\hline $\begin{array}{c}\text { Access } \\
\text { Physical Barriers }\end{array}$ & & & WA & PJ & & \\
\hline $\begin{array}{l}\text { Habitat Elements } \\
\text { Substrate/Sediment }\end{array}$ & & & WA & Long-term & & Short-term \\
\hline Large Wood & & & WA & & PJ & \\
\hline Pool Area & & WA & & & PJ & \\
\hline Pool Quality & & WA & & & PJ & \\
\hline Off-Channel Habitat & & & WA & & PJ & \\
\hline$\frac{\text { Channel Condition \& Dynamics }}{\text { Width/Depth Ratio }}$ & & & PJ, WA & & PJ & \\
\hline Streambank Condition & & & PJ, WA & & PJ & \\
\hline Floodplain Connectivity & & & PJ, WA & & PJ & \\
\hline $\begin{array}{l}\text { Watershed Conditions } \\
\text { Road Density and Location }\end{array}$ & & & PJ, WA & & PJ & \\
\hline Human Disturbance History & & & PJ, WA & & PJ & \\
\hline Landslide Rates & & & WA & & PJ & \\
\hline Riparian Reserves & & & PJ, WA & & PJ & \\
\hline
\end{tabular}

1. Environmental Baseline conditions are derived from BLM stream survey data and synthesis of watershed analysis findings: MON-Monitoring; WA- East Fork Coquille Water shed Analyses; SS- Stream Surveys; PJ- Professional Judgment.

2. Effects of the Actions are derived from this document and description of proposed actions.

3. These three categories of function ("properly functioning", "at risk", or "not properly functioning") are defined for each indicator in the "Matrix of Pathways and Indicators" (Table E-1).

4. For the purposes of this Table E-2 checklist, "restore" means to change the function of an "at risk" indicator to "properly functioning", "not properly functioning" to "at risk" and "properly functioning" moving towards recovery. "Short-term" effects, for the purposes of this checklist, are defined as: intermittent or inconsistently occurring effects (i.e., hauling more than 10 loads per day during heavy-rain events) that are brief in duration (i.e., days). "Long-term" effects, for the purposes of this checklist, are defined as consistently occurring effects (i.e., new permanent road construction) that are lengthy in duration (i.e., months/years). 

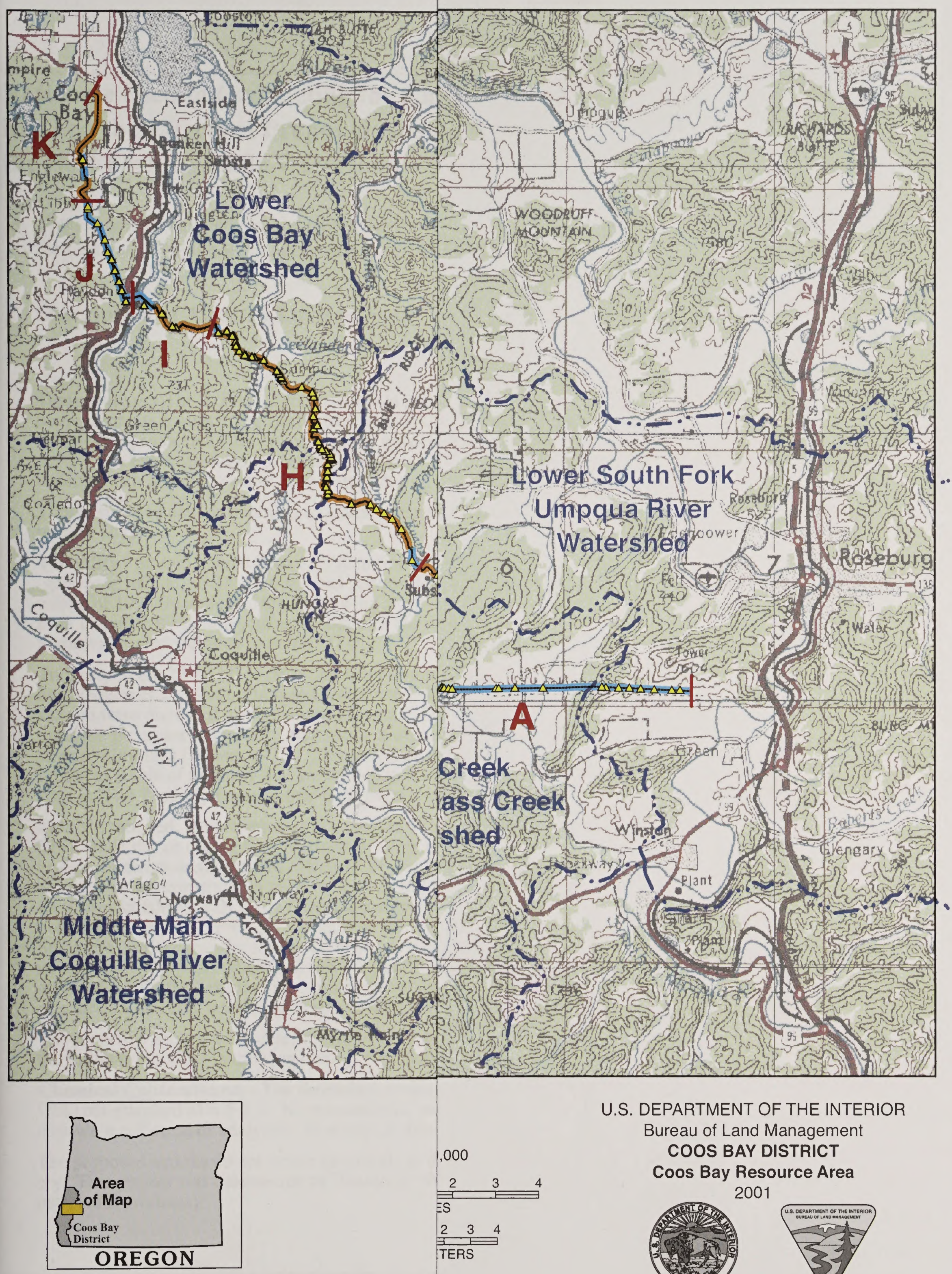

U.S. DEPARTMENT OF THE INTERIOR Bureau of Land Management

, 000 COOS BAY DISTRICT Coos Bay Resource Area

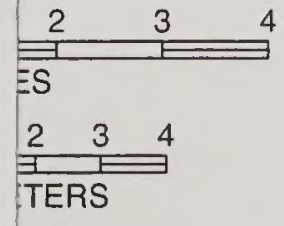

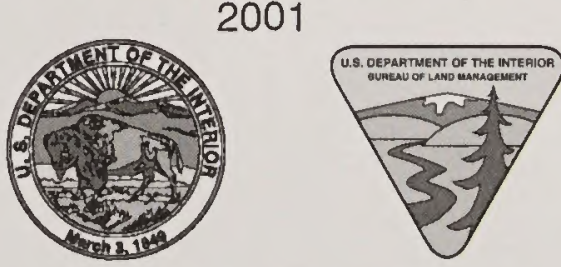

Map 13: Preferred Alternative Stre 


\section{Table E-2. CHECKLIST FOR DOCUMENTING ENVIRONMENTAL BASELINE AND EFFECTS OF PROPOSED ACTIONS ON RELEVANT INDICATORS.}

Name and location: Coos Bay District - BLM

Basin: $5^{\text {th }}$ field: East Fork Coquille River

\begin{tabular}{|c|c|c|c|c|c|c|}
\hline \multirow{2}{*}{$\begin{array}{l}\text { Pathways } \\
\text { Indicators }\end{array}$} & \multicolumn{3}{|c|}{ Environmental Baseline ${ }^{1}$} & \multicolumn{3}{|c|}{ Effects of the Actions ${ }^{2}$} \\
\hline & $\begin{array}{c}\text { Properly } \\
\text { Functioning }\end{array}$ & At Risk ${ }^{3}$ & $\begin{array}{l}\text { Not Properly } \\
\text { Functioning }^{3}\end{array}$ & Restore $^{4}$ & Maintain $^{4}$ & Degrade $^{4}$ \\
\hline$\frac{\text { Water Ouality }}{\text { Temperature }}$ & & & WA, MON & & PJ & \\
\hline Turbidity & & & WA & Long-term & & Short-term \\
\hline $\begin{array}{c}\text { Chemical Concentration/ Nutri- } \\
\text { ents }\end{array}$ & & & PJ & & PJ & \\
\hline $\begin{array}{c}\frac{\text { Access }}{\text { Physical Barriers }} \\
\end{array}$ & & & WA & PJ & & \\
\hline $\begin{array}{l}\underline{\text { Habitat Elements }} \\
\text { Substrate/Sediment }\end{array}$ & & & WA & Long-term & & Short-term \\
\hline Large Wood & & & WA & & PJ & \\
\hline Pool Area & & WA & & & PJ & \\
\hline Pool Quality & & WA & & & $\mathrm{PJ}$ & \\
\hline Off-Channel Habitat & & & WA & & PJ & \\
\hline$\frac{\text { Channel Condition \& Dynamics }}{\text { Width/Depth Ratio }}$ & & & PJ, WA & & PJ & \\
\hline Streambank Condition & & & PJ, WA & & PJ & \\
\hline Floodplain Connectivity & & & PJ, WA & & PJ & \\
\hline $\begin{array}{l}\text { Watershed Conditions } \\
\text { Road Density and Location }\end{array}$ & & & PJ, WA & & PJ & \\
\hline Human Disturbance History & & & PJ, WA & & PJ & \\
\hline Landslide Rates & & & WA & & $\mathrm{PJ}$ & \\
\hline Riparian Reserves & & & PJ, WA & & PJ & \\
\hline
\end{tabular}

1. Environmental Baseline conditions are derived from BLM stream survey data and synthesis of watershed analysis findings: MON-Monitoring; WA- East Fork Coquille Water shed Analyses; SS- Stream Surveys; PJ- Professional Judgment.

2. Effects of the Actions are derived from this document and description of proposed actions.

3. These three categories of function ("properly functioning", "at risk", or "not properly functioning") are defined for each indicator in the "Matrix of Pathways and Indicators" (Table E-1)

4. For the purposes of this Table E-2 checklist, "restore" means to change the function of an "at risk" indicator to "properly functioning", "not properly functioning" to "at risk" and "properly functioning" moving towards recovery. "Short-term" effects, for the purposes of this checklist, are defined as: intermittent or inconsistently occurring effects (i.e., hauling more than 10 loads per day during heavy-rain events) that are brief in duration (i.e., days). "Long-term" effects, for the purposes of this checklist, are defined as consistently occurring effects (i.e., new permanent road construction) that are lengthy in duration (i.e., months/years). 



\section{Rationale Used in Completing the Checklist for Documenting Environmental Base- line and the Effects of Proposed Action(s) on Relevant Indicators with Respect to the East Fork Coquille Watershed}

Note: Unless cited otherwise, the information source used for accessing the environmental baseline is contained in the East Fork Coquille Watershed Analysis (4/14/99). The size of the East Fork Coquille watershed is $130 \mathrm{mi}^{2}$.

\section{Description of Affected Environment:}

\section{Water Quality}

Temperature - The E. Fork Coquille River is included in the Oregon DEQ's 303(d) list of temperature-limited water bodies from its mouth to the confluence of Lost Creek. Water temperature monitoring data for the E. Fork Coquille (1994-1996) indicated 7-day average daily maximums of $73.6^{\circ} \mathrm{F}$ at the mouth to $64.4^{\circ} \mathrm{F}$ at $\mathrm{RM} 23.2$; the standard $\left(64^{\circ} \mathrm{F}\right)$ was exceeded for up to 94 days per year. The watershed was therefore determined to be "Not Properly Functioning" with respect to water temperature during the migrating and rearing period.

These proposed actions contain no riparian overstory tree removal and were determined to "Maintain" the temperature baseline.

Turbidity - Stream habitat inventory data from 1992-1997 documented greater than 17 percent fines in riffles (spawning habitat) in 21 of 56 reaches surveyed in the E. Fork Coquille Sub-basin. BLM data collected during the winter of 1995/96 indicated that, following storm events, turbidity levels at several sampling stations in the Lower E. Fork Coquille River and adjacent tributaries consistently exceeded 50 Nephelometric Turbidity Units (NTU). The highest recorded turbidity was 164 NTU.

Turbidity in the 25-50 NTU range has been implicated in the reduction of growth in young coho salmon and steelhead (Sigler et al. 1984). Berg and Northcote (1985) reported that feeding and territorial behavior of juvenile coho salmon were disrupted by short-term exposures (2.5-4.5 days) to turbid water up to 60 NTUs. Furthermore, sudden, dramatic increases in turbidity may result in elimination of benthic macro invertebrates, the primary food source of stream salmonids (Waters 1972). Turbidity data collected on the E. Fork Coquille indicates that the stream regularly produces levels of turbidity that are known to adversely affect fish behavior and growth, suggesting that the watershed is "Not Properly Functioning" with respect to turbidity.

In this watershed, the proposed action crosses 57 intermittent and small perennial streams (see Appendix I of the EIS), when dry or during the low flows of summer. Of these 57 streams, 55 would be crossed over top on road fill, bridges or directionally-drilled (Table 16 of this EIS). Small amounts of increased transitory turbidity may occur during pipeline construction prior to seeding and mulching of ground-disturbed areas of the other 2 streams. However, project BMPs, PDCs and ODOT Erosion and Sediment Control Manual elements will minimize sedimentation potential to very low levels for a brief time (see Appendix H and the ODOT Erosion and Sediment Control Manual). Sediment barriers and site revegetation are required throughout the construction project corridor to eliminate continuous turbidity impacts where delivery mechanisms to streams exist. Larger streams will be directionally-drilled or attached to bridges, avoiding all construction-induced turbidity at those crossings. Beneficial project actions include new stream culverts, new cross-drains in the CBW Road and paving 10.3 miles of gravel road.

The proposed actions were determined to "Degrade" the turbidity baseline in the short-term ( 3 weeks) and "Restore" the turbidity baseline in the long-term (4+ weeks).

Chemical Contaminants - The watershed analysis indicates that some $\mathrm{pH}$-measurements collected exceeded the DEQ pH-standard of 6.5-8.5. No assessments, measurements or duration criteria of "management-related inputs" data were collected or analyzed. However, it does suggest meeting the criteria for "Not Properly Functioning."

The proposed actions do not utilize chemicals in the construction process other than products for running the machinery. This project was determined to "Maintain" the chemical contaminant baseline (barring accidental release of petroleum products). 


\section{Habitat Access}

Physical Barriers - BLM data and culvert inventories by the Coquille Watershed Association document several instances of culverts that present barriers to fish passage at a range of flows, resulting in a "Not Properly Functioning" designation in this category.

Three new stream culverts (Knapper Creek and two unnamed perennial streams) will replace the deteriorating culverts where fish passage is blocked in the CBW Road. Therefore, it was determined to "Restore" the physical barrier baseline.

\section{Habitat Elements}

Substrate/Sediment - Data from 1992-1997 stream habitat inventories of tributaries to the E. Fork Coquille River indicate that gravels/cobbles are the dominant substrates in approximately 60 percent of the streams surveyed. Embeddedness was not directly measured during these surveys. However, silt, sand and organics in riffles substantially exceeded the ODFW benchmark standard of 10 percent in over half of the surveyed reaches. (Refer to tables in Appendix $\mathrm{H}$ in the E. Fork Coquille WA.) As a result, the watershed was determined to be "Not Properly Functioning" with respect to substrate and sediments.

In this watershed, the proposed action crosses 57 intermittent and small perennial streams (see Appendix I of the EIS), when dry or during the low flows of summer. Of these 57 streams, 55 would be crossed over top on road fill, bridges or directionally-drilled (Table 16 of this EIS). Small amounts of increased transitory turbidity may occur during pipeline construction prior to seeding and mulching of ground-disturbed areas of the other 2 streams. However, project BMPs, PDCs and ODOT Erosion and Sediment Control Manual elements will minimize sedimentation potential to very low levels for a brief time (see Appendix H and the ODOT Erosion and Sediment Control Manual). Sediment barriers and site revegetation are required throughout the construction project corridor to eliminate continuous turbidity impacts where delivery mechanisms to streams exist. Larger streams will be directionally-drilled or attached to bridges, avoiding all construction-induced turbidity at those crossings. Beneficial project actions include new stream culverts, new cross-drains in the CBW Road and paving 10.3 miles of gravel road.

The proposed actions were determined to "Degrade" the substrate/sediment baseline in the short-term ( 3 weeks) and "Restore" the substrate/sediment baseline in the long-term (4+ weeks).

Large Wood Debris (LWD) - According to Wolniakowski et. al. (1990) and Farnell (1979) splash dams and stream cleaning occurred on the main stem of the E. Fork Coquille River and two major tributaries (Steel Creek and Elk Creek). Stream habitat inventory data from 1992-1997 (Appendix H of the WA) clearly demonstrates poor LWD loading and/or pool complexity in substantial portions of nearly every surveyed tributary. Furthermore, the main stem of the E. Fork Coquille River below Brewster Gorge is practically devoid of any wood (personal observation). This is probably due to salvage logging, stream cleaning and lack of recruitment from the riparian area. As a result, the watershed was determined to be "Not Properly Functioning" with respect to LWD.

No tree removal occurs within 200 feet of any stream in this watershed. Proposed actions are limited to powerline utility corridors and the CBW Road. Hence, the proposed actions were determined to "Maintain" the baseline for LWD.

Pool Character and Quality - According to 1992-1997 Stream Habitat Inventory data on E. Fork Coquille tributaries, pool frequency (pools/mile) is below the benchmark set forth in the Matrix of Pathways and Indicators in 40 out of the 56 surveyed reaches. However, the criteria for this benchmark were derived for the Upper Columbia River Basin and may not readily apply to Southwest Oregon Coast Range streams. It should be noted that only 10 of the 56 surveyed reaches rated "poor" against the ODFW Habitat Benchmarks (1997) for pool area and/or pool frequency (channel widths/pool). Stream habitat inventory data from the Oregon Coast Range was used in the formulation of the ODFW Benchmark criteria.

The 1992-1997 Stream Habitat Inventory data also indicates that pools $>1$ meter deep are uncommon on most surveyed tributaries. Furthermore, over half of the stream reaches surveyed rated poorly with respect to pool habitat complexity. The previously mentioned water temperature problems in the E. Fork Coquille River also compromise the overall quality of the available pool habitat. Reduction of pool volume due to fine sediments has not been demonstrated within the E. Fork Coquille Sub-basin. The watershed was therefore determined to be "At Risk" with respect to pool area and quality.

Proposed actions are limited to powerline ROWs and the CBW Road. Hence, the proposed actions were determined to "Maintain" the baseline for pool character and quality. 
Off-channel Habitat - Due to its proximity to roads and a history of stream cleaning and splash dams, any segments of the E. Fork Coquille are severely downcut and isolated from the natural floodplain. As a result, few, if any, backwaters pools, alcoves or other off-channel areas exist.

Many of the tributaries are constrained by hillslopes and are not likely to contain off-channel areas. Because of these conditions in the E. Fork Coquille River, the watershed is determined to be "Not Properly Functioning" with respect to this criteria.

Proposed actions are limited to powerline ROWs and the CBW Road. Hence, the proposed actions were determined to "Maintain" the baseline for off-channel habitat.

\section{Channel Conditions and Dynamics}

Width-Depth Ratio - Current information on riffle width and depth is lacking for the main stem of the E. Fork Coquille River, but has been collected for several tributaries in the basin. Reaches in Steel Creek have W/D ratios of 40.5 and 34.2; the Camas Creek W/D ratio is 26.0. Therefore, the watershed was determined to be "Not Properly Functioning" with respect to this baseline.

Proposed actions are limited to powerline ROWs and the CBW Road. Therefore, the proposed actions were determined to "Maintain" the baseline for width-depth ratio.

Streambank Condition - Streambank condition is good for many of the tributaries of the E. Fork Coquille; however, many areas along the E. Fork Coquille are highly unstable and actively eroding (pers. com. B. Hudson and M.

Kellett, Coos Bay BLM). The watershed was therefore determined to be "Not Properly Functioning" with respect to streambank condition.

Proposed actions have adequate preventive measures (Appendix $H$ ) to maintain streambank integrity during and after construction in the riparian areas of the two streams that would be trenched in this watershed. Thus, the proposed actions were determined to "Maintain" the baseline for streambank condition.

Floodplain Connectivity - Due to its proximity to roads and a history of stream cleaning and splash dams, many segments of the E. Fork Coquille are severely downicut. Few, if any, aggregations of large wood remain to create large pools, secondary channels and maintain a high water table. Where the river is unconstrained by hillslopes or terraces, floodplain vegetation is primarily agricultural or residential. The watershed is therefore determined to be "Not Properly Functioning" with respect to floodplain connectivity.

There are no activities in the 100-year floodplain within this watershed. Hence, the proposed actions were determined to "Maintain" the baseline for floodplain connectivity.

\section{Watershed Condition}

Road Density \& Location/Drainage Network - Road densities throughout the E. Fork Coquille Watershed are high (average of 4.4 miles of road per square mile). Additionally, most of the wider valley bottoms contain roads and many of the larger tributaries of the E. Fork Coquille River have roads along much of their length. The watershed is therefore determined to be "Not Properly Functioning" with respect to this baseline.

Proposed actions are limited to powerline ROWs and the CBW Road. Thus, the proposed actions were determined to "Maintain" the baseline for road density and location/drainage network.

Disturbance History - The watershed contains greater than 15 percent Late Successional-Old-Growth (LSOG). However, disturbance activities such as road building, stream cleaning and splash dams have been concentrated in riparian areas. Furthermore, the high percentage of hardwoods in riparian areas documented in stream surveys along several tributaries of the E. Fork Coquille River (W. Fork Brummet, Peevey, Camas and Steel Cr.) show a high level of disturbance. Lane (1987) indicates a high rate of mass movements in some road and logged areas. Therefore, the watershed was determined to be "Not Properly Functioning" with respect to disturbance history.

Proposed actions are limited to human-disturbed sites (utility corridors and roadways). Therefore, the proposed actions were determined to "Maintain" the baseline for disturbance history.

Landslide Rates - In the Relations Between Geology and Mass Movement Features in a part of the East Fork Coquille River Watershed, Southern Coast Range, Oregon, Lane (1987) indicates that a disproportionately high percentage (47 percent) of debris avalanches in the watershed are concentrated in road and logged areas which made up 
only 13 percent of the landscape. As a result, the watershed was determined to be "Not Properly Functioning" for landslide rates.

Appendix A of this EIS (Geotechnical Report) assesses potential landslide areas for pipeline construction. The report determined there would be no effect from construction on landslide rates within the watershed. Hence, the proposed actions were determined to "Maintain" the baseline for landslide rates.

Riparian Reserves - Federal ownership in the E. Fork Coquille River watershed follows a "checkerboard" pattern and, as a result, the riparian reserve system is highly fragmented. Additionally, high water temperatures in the E. Fork Coquille River indicate that riparian zones throughout the watershed may not be providing adequate shade. The watershed is therefore determined to be "Not Properly Functioning" with respect to riparian reserves.

The proposed actions will not impact any overstory riparian vegetation. Therefore, the proposed actions were determined to "Maintain" the baseline for Riparian Reserves. 
Table E-3. Checklist for Documenting Environmental Baseline and Effects of Proposed Actions on Relevant Indicators.

Name and location: Coos Bay District - BLM

Basin: $5^{\text {th }}$ field: Lower Coos River

\begin{tabular}{|c|c|c|c|c|c|c|}
\hline \multirow{2}{*}{$\begin{array}{l}\text { Pathways } \\
\text { Indicators }\end{array}$} & \multicolumn{3}{|c|}{ Environmental Baseline ${ }^{1}$} & \multicolumn{3}{|c|}{ Effects of the Actions ${ }^{2}$} \\
\hline & $\begin{array}{c}\text { Properly } \\
\text { Functioning }^{3}\end{array}$ & At Risk ${ }^{3}$ & $\begin{array}{l}\text { Not Properly } \\
\text { Functioning }^{3}\end{array}$ & Restore $^{4}$ & Maintain $^{4}$ & Degrade $^{4}$ \\
\hline$\frac{\text { Water Quality }}{\text { Temperature }}$ & & PJ, DEQ & & & PJ & \\
\hline Turbidity & & & PJ & Long-term & & Short-term \\
\hline $\begin{array}{c}\text { Chemical Concentration/ Nutri- } \\
\text { ents }\end{array}$ & & & PJ, DEQ & & PJ & \\
\hline$\frac{\underline{A c c e s s}}{\text { Physical Barriers }}$ & & & DS & & PJ & \\
\hline $\begin{array}{c}\text { Habitat Elements } \\
\text { Substrate/Sediment }\end{array}$ & & PJ & & Long-term & & Short-term \\
\hline Large Wood & & & PJ & & PJ & \\
\hline Pool Area (\%) & & & PJ & & PJ & \\
\hline Pool Quality & & & PJ & & PJ & \\
\hline Off-Channel Habitat & & PJ & & & PJ & \\
\hline$\frac{\text { Channel Condition \& Dynamics }}{\text { Width/Depth Ratio }}$ & & & PJ & & PJ & \\
\hline Streambank Condition & $x=$ & PJ & & & PJ & \\
\hline Floodplain Connectivity & & PJ & & & $\mathrm{PJ}$ & \\
\hline $\begin{array}{c}\text { Watershed Conditions } \\
\text { Road Density and Location }\end{array}$ & & & $\mathrm{PJ}$ & & PJ & \\
\hline Human Disturbance History & & & PJ & & $\mathrm{PJ}$ & \\
\hline Landslide Rates & & PJ & & & PJ & \\
\hline Riparian Reserves & & & PJ & & PJ & \\
\hline
\end{tabular}

1. Environmental Baseline conditions are derived from BLM stream survey data and synthesis of watershed analysis findings: DEQ - Oregon DEQ; DS - Data from surveys; PJProfessional Judgment.

2. Effects of the Actions are derived from this document and description of proposed actions.

3. These three catcgories of function ("properly functioning", "at risk", or "not properly functioning") are defined for each indicator in the "Matrix of Pathways and lndicators" (Table E-1).

4. For the purposes of this checklist (Table E-3), "restore" means to change the function of an "at risk" indicator to "properly functioning", "not properly functioning" to "at risk" and "properly functioning" moving towards recovery. "Short-term" effects, for the purposes of this checklist, are defined as: intermittent or inconsistently occurring effects (i.e., hauling more than 10 loads per day during heavy-rain events) that are brief in duration (i.e., days). "Long-term" effects, for the purposes of this checklist, are defined as consistently occurring effects (i.e., new permanent road construction) that are lengthy in duration (i.e., months/years). 


\section{Rationale Used in Completing the Checklist for Documenting Environmental Base- line and the Effects of Proposed Action(s) on Relevant Indicators With Respect to the Lower Coos River/Coos Bay Watershed}

Note: BLM has not completed a watershed analysis for this 5 th field watershed because of the minimal amount of BLM-administered lands within the watershed. The BLM IDT lacks data on the habitat conditions across the watershed, and much of the evaluation of baseline conditions is based on their professional judgment and personal knowledge of various fish-bearing streams across the watershed.

\section{Description of Affected Environment:}

\section{Water Quality}

Temperature - An assessment by Oregon DEQ and the professional judgment of BLM fisheries biologists indicate this watershed to be "At Risk" with respect to temperature.

The proposed actions contain no riparian overstory tree removal and were determined to "Maintain" the temperature baseline.

Turbidity - The professional judgment of BLM fisheries biologists indicate this watershed to be "Not Properly Functioning" with respect to turbidity.

In this watershed, the proposed action would cross 42 intermittent and small perennial streams (see Appendix I of this EIS) in the Lower Coos River/Coos Bay Watershed, when intermittent streams are dry and during perennial streams' summer low flows. Of these 42 streams, 29 will be crossed over top on road fill and 2 would be directionally-drilled (Tables 18 and 19 of this EIS). Of the 11 streams to be trenched, 7 would be dry during the period of construction, and 4 would be trenched using the "bag and flume" method. Small amounts of increased transitory turbidity may occur during pipeline construction prior to seeding and mulching of ground-disturbed areas. However, the BMPs, PDCs and the ECP will minimize sedimentation potential to very low levels for a brief time (Appendix $\mathrm{H})$. Sediment barriers and site revegetation are required throughout the construction project corridor to eliminate continuous turbidity impacts where delivery mechanisms to streams exist. Larger streams will be directionallydrilled to avoid all construction-induced turbidity at those crossings. Beneficial project actions include new crossdrains in the CBW Road and paving 1.9 miles of gravel road.

The proposed actions were determined to "Degrade" the turbidity baseline in the short-term (3 weeks) and "Restore" the turbidity baseline in the long-term (4+ weeks).

Chemical Contaminants and Nutrients - An assessment by Oregon DEQ and the professional judgment of BLM fisheries biologists indicate this watershed to be "Not Properly Functioning" with respect to chemical contaminants and nutrients.

The proposed actions do not utilize chemicals in the construction process other than products for running the machinery. This project was determined to "Maintain" the chemical contaminant baseline (barring accidental release of petroleum products).

\section{Habitat Access}

Physical Barriers - Data provided from state field surveys show that more than 3 culverts block fish passage in this watershed, meeting the criteria for "Not Properly Functioning" with respect to physical barriers.

The proposed actions contain no new permanent in-stream structures. Hence, the proposed actions were determined to "Maintain" the baseline for physical barriers.

\section{Habitat Elements}

Substrate/Sediment - The professional judgment of BLM fisheries biologists indicate this watershed to be "At Risk" with respect to substrate and sediment factors. 
In this watershed, the proposed action would cross 42 intermittent and small perennial streams (see Appendix I of this EIS) in the Lower Coos River/Coos Bay Watershed, when intermittent streams are dry and during perennial streams' summer low flows. Of these 42 streams, 29 will be crossed over top on road fill and 2 would be directionally-drilled (Tables 18 and 19 of this EIS). Of the 11 streams to be trenched, 7 would be dry during the period of construction, and 4 would be trenched using the "bag and flume" method. Small amounts of increased transitory turbidity may occur during pipeline construction prior to seeding and mulching of ground-disturbed areas. However, the BMPs, PDCs and the ECP will minimize sedimentation potential to very low levels for a brief time (Appendix $\mathrm{H})$. Sediment barriers and site revegetation are required throughout the construction project corridor to eliminate continuous turbidity impacts where delivery mechanisms to streams exist. Larger streams will be directionallydrilled to avoid all construction-induced turbidity at those crossings. Beneficial project actions include new crossdrains in the CBW Road and paving 1.9 miles of gravel road.

The proposed actions were determined to "Degrade" the substrate/sediment baseline in the short-term ( 3 weeks) and "Restore" the substrate/sediment baseline in the long-term (4+ weeks).

Large Woody Debris (LWD) - The professional judgment of BLM fisheries biologists indicate this watershed meets the criteria for "Not Properly Functioning" with respect to LWD.

No tree removal occurs within the watershed. Proposed actions are limited to powerline utility corridors and the CBW Road. Hence, the proposed actions were determined to "Maintain" the baseline for LWD.

Pool Area/ Pool Quality - The professional judgment of BLM fisheries biologists indicate this watershed to be "Not Properly Functioning" with respect to percent pool area/quality.

Proposed actions are limited to powerline ROWs and the CBW Road. Hence, the proposed actions were determined to "Maintain" the baseline for pool character and quality.

Off-Channel Habitat - The professional judgment of BLM fisheries biologists indicate this watershed meets the criteria for "At Risk" with respect to off-channel habitat.

Proposed actions are limited to powerline ROWs and the CBW Road. Hence, the proposed actions were determined to "Maintain" the baseline for off-channel habitat.

\section{Channel Condition and Dynamics}

Width/Depth Ratio - The professional judgment of BLM fisheries biologists indicate this watershed to be "Not Properly Functioning" with respect to width/depth ratio.

Proposed actions are limited to powerline ROWs and the CBW Road. Therefore, the proposed actions were determined to "Maintain" the baseline for width-depth ratio.

Streambank Condition - The professional judgment of BLM fisheries biologists indicate this watershed meets the criteria for "At Risk" with respect to streambank condition.

Proposed actions have adequate ECP measures (Appendix H) to maintain streambank integrity during and after construction. Thus, the proposed actions were determined to "Maintain" the baseline for streambank condition.

Floodplain Connectivity - The professional judgment of BLM fisheries biologists indicate this watershed meets the criteria for "At Risk" with respect to floodplain connectivity.

Proposed actions are adjacent to 0.9 -mile of floodplain in the watershed. Activities in this area are limited to the CBW Road, which sits on 5 feet of fill dirt. Hence, the proposed actions were determined to "Maintain" the baseline for floodplain connectivity.

\section{Watershed Condition}

Road Density/Location - The professional judgment of BLM fisheries biologists indicate this watershed to be "Not Properly Functioning" with respect to road densities and location.

Proposed actions are limited to powerline ROWs and the CBW Road. Thus, the proposed actions were determined to "Maintain" the baseline for road density and location/drainage network.

Disturbance History - The professional judgment of BLM fisheries biologists indicate this watershed meets the criteria for "Not Properly Functioning" with respect to disturbance history. 
Proposed actions are limited to human-disturbed sites (utility corridors and roadways). Therefore, the proposed actions were determined to "Maintain" the baseline for disturbance history.

Landslide Rates - The professional judgment of BLM fish biologists indicate this watershed meets the criteria for "At Risk" with respect to landslide rates.

Appendix A of this EIS (Geotechnical Report) assesses potential landslide areas for pipeline construction. The report determined there would be no effect on landslide rates from construction within the CBW Road or the utility corridor. Hence, the proposed actions were determined to "Maintain" the baseline for landslide rates.

Riparian Reserves - The professional judgment of BLM fisheries biologists indicate this watershed meets the criteria for "Not Properly Functioning" with respect to riparian reserves.

The proposed actions will not impact any overstory riparian vegetation. Therefore, the proposed actions were determined to "Maintain" the baseline for Riparian Reserves. 
Table E-4. Checklist for Documenting Environmental Baseline and Effects of Proposed Actions on Relevant Indicators.

Name and location: Coos Bay District - BLM

Basin: $5^{\text {th }}$ field: North Fork Coquille

\begin{tabular}{|c|c|c|c|c|c|c|}
\hline \multirow{2}{*}{$\frac{\text { Pathways }}{\text { Indicators }}$} & \multicolumn{3}{|c|}{ Environmental Baseline $^{1}$} & \multicolumn{3}{|c|}{ Effects of the Actions ${ }^{2}$} \\
\hline & $\begin{array}{c}\text { Properly } \\
\text { Functioning }\end{array}$ & At Risk ${ }^{3}$ & $\begin{array}{l}\text { Not Properly } \\
\text { Functioning }\end{array}$ & Restore $^{4}$ & Maintain ${ }^{4}$ & Degrade $^{4}$ \\
\hline$\frac{\text { Water Quality }}{\text { Temperature }}$ & & & DEQ & & PJ & \\
\hline Turbidity & & & PJ, WA & Long-term & & Short-term \\
\hline $\begin{array}{c}\text { Chemical Concentration/ } \\
\text { Nutrients }\end{array}$ & & & DEQ & $\because$ & PJ & \\
\hline $\begin{array}{l}\quad \frac{\text { Access }}{\text { Physical Barriers }} \\
\text { Pal }\end{array}$ & & & WA & & PJ & \\
\hline $\begin{array}{l}\text { Habitat Elements } \\
\text { Substrate/Sediment }\end{array}$ & & PJ, WA & & Long-term & & Short-term \\
\hline Large Wood & & & WA & & PJ & \\
\hline Pool Area (\%) & & PJ, WA & & & PJ & \\
\hline Pool Quality & & & PJ & & $\mathrm{PJ}$ & \\
\hline Off-Channel Habitat & & PJ, WA & & & PJ & \\
\hline $\begin{array}{c}\text { Channel Condition \& Dynamics } \\
\text { Width/Depth Ratio }\end{array}$ & & & PJ, WA & & PJ & \\
\hline Streambank Condition & & PJ, WA & & & PJ & \\
\hline Floodplain Connectivity & & & PJ, WA & & PJ & \\
\hline$\frac{\text { Watershed Conditions }}{\text { Road Density }}$ & & & PJ, WA & & PJ & \\
\hline Human Disturbance History & & PJ, WA & & & PJ & \\
\hline Landslide Rates & & & PJ, WA & & PJ & \\
\hline Riparian Reserves & & & PJ, WA & & PJ & \\
\hline
\end{tabular}

1. Environmental Baseline conditions are derived from BLM stream survey data and synthesis of watershed analysis findings: WA-North Fork Coquille Watershed Analyses; PJProfessional Judgment; DEQ - Oregon DEQ.

2. Effects of the Actions are derived from this document and description of proposed actions.

3. These three categories of function ("properly functioning", "at risk", or "not properly functioning") are defined for each indicator in "Matrix of Pathways and Indicators" (Table E-1).

4. For the purposes of this checklist (Table E-4), "restore" means to change the function of an "at risk" indicator to "properly functioning", "not properly functioning" to "at risk" and "properly functioning" moving towards recovery. "Short-term" effects, for the purposes of this checklist, are defined as: intermittent or inconsistently occurring effects (i.e., hauling more than 10 loads per day during heavy-rain events) that are brief in duration (i.e., days). "Long-term" effects, for the purposes of this checklist, are defined as consistently occurring effects (i.e., new permanent road construction) that are lengthy in duration (i.e., months/years). 


\section{Rationale Used in Completing the Checklist for Documenting Environmental Base- line and the Effects of Proposed Action(s) on Relevant Indicators With Respect to the North Fork Coquille Watershed}

Note: Unless cited otherwise, the information source used for accessing the environmental baseline is contained in the North Fork Coquille Watershed Analysis in preparation by the Coos Bay District Umpqua Resource Area (07/20/ 2001). The watershed covers approximately 98,467 acres.

\section{Description of Affected Environment:}

\section{Water Quality}

Temperature - The N. Fork Coquille River is included in the Oregon DEQ 303(d) list of temperature-limited water bodies from its mouth to the confluence of Lost Creek. Water temperature monitoring data for the N. Fork Coquille (1986-1994) indicate 7-day average daily maximums of $69.9^{\circ} \mathrm{F}$ between the mouth to Middle Creek and Middle Creek to Little N. Fork; the standard $\left(64^{\circ} \mathrm{F}\right)$ was exceeded for up to 96 days per year. The watershed was therefore determined to be "Not Properly Functioning" with respect to water temperature during the migrating/rearing period.

These proposed actions contain no riparian overstory tree removal and "Maintain" the temperature baseline.

Turbidity - No direct quantitative analysis of turbidity occurred in the WA. However, page 30 of chapter 8 documents that the headwaters of Woodward Creek are down cutting through a clay deposit which enters into suspension and imparts a milky turbidity to the creek. The watershed was therefore determined to be "Not Properly Functioning" with respect to water turbidity.

In this watershed, the proposed action would cross 5 intermittent and 11 perennial streams (see Appendix I of the EIS) when dry or during summer low flows. Of these 16 streams, 5 will be crossed over top on road fill and 4 would be directionally-drilled (Tables 20 and 21 of this EIS). Of the 7 streams to be trenched, 1 would be dry during the period of construction, and 6 would be trenched using the "bag and flume" method. Small amounts of increased transitory turbidity may occur during pipeline construction, prior to seeding and mulching of ground-disturbed areas. However, the BMPs, PDCs and ECP will minimize sedimentation potential to very low levels for a brief time (Appendix H). Sediment barriers and site revegetation are required throughout the construction project corridor to eliminate continuous turbidity impacts where delivery mechanisms to streams exist. Larger streams will be directionally-drilled to avoid all construction-induced turbidity at those crossings. Beneficial project actions include new cross-drains in the CBW Road and paving 1.0 mile of gravel road.

The proposed actions were determined to "Degrade" the turbidity baseline in the short-term (3 weeks) and "Restore" the turbidity baseline in the long-term (4+ weeks).

Chemical Contaminants - The Oregon DEQ identified the Coquille River as potentially water limited as early as 1973 and confirmed it as a "Waterbody of Concern" in the 1988 Water Quality Report. Furthermore, Table WQ-11 lists the N. Fork Coquille River from the Mouth to Middle Creek exceeding fecal coliform FWS standard values, thus meeting the criteria for "Not Properly Functioning."

The proposed actions do not utilize chemicals in the construction process other than products for running the machinery. This project was determined to "Maintain" the chemical contaminant baseline (barring accidental release of petroleum products).

\section{Habitat Access}

Physical Barriers - Page 5 in chapter 8 of the WA states, "...many culverts in the subwatershed partially or entirely block fish and amphibian passage." Additionally, page 19 of chapter 8 discusses anadromous fish having been eliminated from some former suitable habitat by blockages created by impassable culverts in this watershed, thus meeting the criteria for "Not Properly Functioning" with respect to physical barriers.

The proposed actions contain no new permanent in-stream structures. Hence, the proposed actions were determined to "Maintain" the baseline for physical barriers. 


\section{Habitat Elements}

Substrate/Sediment - Page 17 in chapter 7 of the WA states that sediment from road failure was considered the greatest water quality problem, and erosion of soils exposed by severe slash burning on steep slopes was often the principle cause of surface erosion.

The watershed was therefore determined to be "At Risk" with respect to water substrate and sediment.

In this watershed, the proposed action would cross 5 intermittent and 11 perennial streams (see Appendix I of the EIS) when dry or during summer low flows. Of these 16 streams, 5 will be crossed over top on road fill and 4 would be directionally-drilled (Tables 20 and 21 of this EIS). Of the 7 streams to be trenched, 1 would be dry during the period of construction, and 6 would be trenched using the "bag and flume" method. Small amounts of increased transitory turbidity may occur during pipeline construction, prior to seeding and mulching of ground-disturbed areas. However, the BMPs, PDCs and ECP will minimize sedimentation potential to very low levels for a brief time (Appendix $\mathrm{H}$ ). Sediment barriers and site revegetation are required throughout the construction project corridor to eliminate continuous turbidity impacts where delivery mechanisms to streams exist. Larger streams will be directionally-drilled to avoid all construction-induced turbidity at those crossings. Beneficial project actions include new cross-drains in the CBW Road and paving 1.0 mile of gravel road.

The proposed actions were determined to "Degrade" the substrate/sediment baseline in the short-term ( 3 weeks) and "Restore" the substrate/sediment baseline in the long-term (4+ weeks).

Large Wood Debris (LWD) - During the early 1900s, stream "improvements" including eliminating vegetation along the river banks, blasting channel boulders and removing large woody debris and snags from the river channel occurred on the main stem of the N. Fork Coquille. Much of this "improvement and maintenance" was in association with splash damming. Page 15 in chapter 8 of the WA reveals that stream cleaning was required on BLM timber sales conducted from 1965 through 1991. Furthermore, stated on page 28 in chapter 8 of the WA, "While stream cleaning and salvaging from streams and riparian areas has been stopped, the legacy of the cleaning process remains. It will be many years before the in-stream habitat improvement options of the State water protection rules will be applied to sections of the North Fork Coquille River, if they ever will be." As a result, the watershed was determined to be "Not Properly Functioning" with respect to LWD.

No tree removal occurs within this watershed. Proposed actions are limited to powerline utility corridors and the CBW Road. Hence, the proposed actions were determined to "Maintain" the baseline for LWD.

Pool Area (\%) - Page 5 in chapter 8 of the WA reports only 2 pools with a maximum depth of $>3$ feet were documented along 2 miles of stream inventoried. The percent pool area was rated fair for the 4th order reaches, and poor in 0.2 -mile of 3 rd-order channels. The watershed was therefore determined to be "At Risk" with respect to pool area.

Proposed actions are limited to powerline ROWs and the CBW Road. Hence, the proposed actions were determined to "Maintain" the baseline for pool area.

Pool Quality - The professional judgment of a BLM fisheries biologists indicate this watershed to be "Not Properly Functioning" with respect to percent pool area/quality.

Proposed actions are limited to powerline ROWs and the CBW Road. Hence, the proposed actions were determined to "Maintain" the baseline for pool character and quality.

Off-channel Habitat - Due to its proximity to roads and a history of stream cleaning and splash dams, many segments of the N. Fork Coquille River are severely downcut and isolated from the natural floodplain. As a result, few, if any, backwaters pools, alcoves or other off-channel areas exist.

Many of the tributaries are constrained by hillslopes and are not likely to contain off-channel areas. However, because of the condition of the N. Fork Coquille River, the watershed is determined to be "At Risk" with respect to this criteria.

Proposed actions are limited to powerline ROWs and the CBW Road. Hence, the proposed actions were determined to "Maintain" the baseline for off-channel habitat. 


\section{Channel Conditions and Dynamics}

Width-Depth Ratio - Current information on riffle width and depth is lacking for the main stem of the N. Fork Coquille River but has been summarized for the 1997 Middle Main Coquille-North Coquille Mouth-Catching Creek Watershed Analysis. It is revealed on page 6 of chapter 9 of the WA that many channels have become wider with a corresponding reduction in stream depth. Thus, this watershed was determined to be "Not Properly Functioning" due to the degraded aquatic habitat caused by past logging and past and current agricultural practices.

Proposed actions are limited to powerline ROWs and the CBW Road. Therefore, the proposed actions were determined to "Maintain" the baseline for width-depth ratio.

Streambank Condition - Page 5 of chapter 8 discusses some of the primary reasons for the degraded conditions, including stream-bank damage from livestock, down-cutting of streams due to the removal of stream-side vegetation and in-stream structure, as well as the confinement of stream channels. The watershed was therefore determined to be "At Risk" with respect to streambank condition.

Proposed actions have adequate measures (Appendix $\mathrm{H}$ ) to maintain streambank integrity during and after construction. Thus, the proposed actions were determined to "Maintain" the baseline for streambank condition.

Floodplain Connectivity - Page 6 of chapter 5 states, "Large areas of floodplain have been cleared and drained for development. The loss of vegetation maintained stream bank stability resulted in increased stream bank erosion. The loss of wood recruitment to the channel, along with loss of stream bank vegetation, reduced channel roughness. This in turn resulted in higher stream velocities that contribute to increased stream bank erosion, downcutting and the loss and/or simplification of habitat, especially aquatic habitat that is critical during high flows. The watershed is therefore determined to be "Not Properly Functioning" with respect to floodplain connectivity.

In the floodplain area of this watershed, the proposed action is limited to the CBW Road, which sits on 5 feet of fill dirt. Hence, the proposed actions were determined to "Maintain" the baseline for floodplain connectivity.

\section{Watershed Condition}

Road Density - Table Intro-4, page 5 in chapter 1 of the WA, gives an estimate of total roads in the WA as 751.3 miles. Table Intro-1, page 3 in chapter 1, lists total area in the WA as 98,476 acres, which translates to 639 square miles. These numbers can be expressed as 1.2 miles of road per square mile within the WA. Although this is a relatively low road density, the location of roads and effects to drainage network are discussed on page 5 in chapter 8 of the WA, where it is stated, "Roads paralleling streams and crossing tributaries restrict interactions between the aquatic and riparian areas" and further stated, "Road construction along streams has resulted in the establishment of alders next to the stream channels, thus reducing the future recruitment of large, durable conifers." Thus, this watershed was determined to be "Not Properly Functioning" with respect to road density \& location/drainage network.

Proposed actions are limited to existing powerline ROWs and the CBW Road. Thus, the proposed actions were determined to "Maintain" the baseline for road density.

Disturbance History - Page 5 in chapter 8 of the WA discusses the combined impacts of agricultural practices, past timber practices and the associated land management activities. Some of the disturbance effects included harvesting of large conifers next to streams, the removal of LWD through stream cleaning and salvage practices, poorly constructed culverts and poorly located and/or constructed roads. The watershed was therefore determined to be "At Risk" with respect to disturbance history.

Proposed actions are limited to human-disturbed sites (utility corridors and roadways). Therefore, the proposed actions were determined to "Maintain" the baseline for disturbance history.

Landslide Rates - Page 11 in the WA Erosion Process Appendix discusses landslides and debris avalanches and states "In the Late 1950s through the mid-1970s, human-related soil/slope failures dominated as road construction and clearcutting reached the middle and upper parts of the subwatershed. In this period, there were 106 humanrelated landslides, 64 of which were directly related to road construction." As a result, the watershed was determined to be "Not Properly Functioning" for landslide rates.

Appendix A of this EIS (Geotechnical Report) assessed potential landslide areas for pipeline construction. The report determined there would be no effect from construction on landslide rates within the CBW Road or utility corridor. Hence, the proposed actions were determined to "Maintain" the baseline for landslide rates. 
Riparian Reserves - Chapter 5 of the WA discusses the current condition and pattern of vegetation within the watershed. Stated on page 3 in chapter 5, "Current vegetation patterns are a result of past management actions, harvest practices and associated road building, land ownership, fires, human settlements, agriculture and farming. Early or mid-seral stands occupy most of the private forest land in the watershed. Approximately 9,358 acres are agricultural and rural residential lands." The watershed is therefore determined to be "Not Properly Functioning" with respect to riparian reserves.

The proposed actions in this watershed will not impact any overstory riparian vegetation. Therefore, the proposed actions were determined to "Maintain" the baseline for Riparian Reserves. 
Table E-5. Checklist for Documenting Environmental Baseline and Effects of Proposed Actions on Relevant Indicators.

Name and location: Roseburg District South River Resource Area - BLM

Basin: $5^{\text {th }}$ field: Lower South Umpqua

\begin{tabular}{|c|c|c|c|c|c|c|}
\hline \multirow{2}{*}{$\frac{\text { Pathways }}{\text { Indicators }}$} & \multicolumn{3}{|c|}{ Environmental Baseline $^{1}$} & \multicolumn{3}{|c|}{ Effects of the Actions ${ }^{2}$} \\
\hline & $\begin{array}{c}\text { Properly } \\
\text { Functioning }\end{array}$ & At Risk ${ }^{3}$ & $\begin{array}{l}\text { Not Properly } \\
\text { Functioning }\end{array}$ & Restore $^{4}$ & Maintain ${ }^{4}$ & Degrade $^{4}$ \\
\hline$\frac{\text { Water Quality }}{\text { Temperature }}$ & & & WA & & PJ & \\
\hline Sediment and Turbidity & & & WA, PJ & & Long-term & Short-term \\
\hline $\begin{array}{c}\frac{\text { Access }}{\text { Physical Barriers }} \\
\end{array}$ & & WA, PJ & & & PJ & \\
\hline$\frac{\text { Habitat Elements }}{\text { Large Wood }}$ & & WA & & & PJ & \\
\hline Substrate & & WA & & & Long-term & Short-term \\
\hline Pool Characteristics & & WA & & & PJ & \\
\hline Off-Channel Habitat & & WA, PJ & & & PJ & \\
\hline$\frac{\text { Channel Conditions and Dynamics }}{\text { Width/Depth Ratio }}$ & & WA, PJ & & & PJ & \\
\hline Streambank Condition & & WA, PJ & & & PJ & \\
\hline Floodplain Connectivity & & WA & & & PJ & \\
\hline $\begin{array}{c}\text { Flow/Hydrology } \\
\text { Change in Peak/Base Flows }\end{array}$ & & & WA, PJ & & $\mathrm{PJ}$ & \\
\hline Drainage Network & & & WA & & PJ & \\
\hline $\begin{array}{l}\text { Watershed Conditions } \\
\text { Road Density and Location }\end{array}$ & & & WA & & PJ & \\
\hline Disturbance History & & & WA & & PJ & \\
\hline Riparian Reserves & & & WA & & PJ & \\
\hline Landslide Rates & & WA & & & PJ & \\
\hline Refugia & & PJ & & & PJ & \\
\hline
\end{tabular}

1. Environmental Baseline conditions are derived from BLM stream survey data and synthesis of watershed analysis findings: WA- Lower South Umpqua Watershed Analyses; PJ. Professional Judgment.

2. Effects of the Actions are derived from this document and description of proposed actions.

3. These three categories of function ("properly functioning", "at risk", or "not properly functioning") are defined for each indicator in the "Matrix of Pathways and Indicators" (Table E-1).

4. For the purposes of this checklist (Table E-5), "restore" means to change the function of an "at risk" indicator to "properly functioning", "not properly functioning" to "at risk" and "properly functioning" moving towards recovery. "Short-term" effects, for the purposes of this checklist, are defined as: intermittent or inconsistently occurring effects (i.e., hauling more than 10 loads per day during heavy-rain events) that are brief in duration (i.e., days). "Long-term" effects, for the purposes of this checklist, are defined as consistently occurring effects (i.e., new permanent road construction) that are lengthy in duration (i.e., months/years). 


\section{Rationale Used in Completing the Checklist for Documenting Environmental Base- line and the Effects of Proposed Action(s) on Relevant Indicators With Respect to the Lower South Umpqua Watershed}

Note: Unless cited otherwise, the information source used for accessing the environmental baseline is contained in the Lower South Umpqua Watershed Analysis prepared by the Roseburg District South River Resource Area (05/30/ 2000). The WA covers approximately 110,419 acres.

\section{Description of Affected Environment:}

\section{Water Quality}

Maximum Temperature - Table C-2, found in appendix C of the WA, rates the watershed as "Poor" (temperatures = $70^{\circ} \mathrm{F}$ ), thereby meeting the criteria for "Not Properly Functioning."

These proposed actions contain no riparian overstory tree removal and were determined to "Maintain" the temperature baseline.

Sediment/Turbidity - No direct quantitative analysis of turbidity occurred in the WA. However, a definition is given on page 82: "Turbidity is a function of suspended sediments and algal growth in a stream." Also stated in this section, "Roads have the potential to affect the sediment regime. Erosional effects can occur when culverts become plugged or cannot handle peak flows, diverting streams out of their original channel, flowing down the road and entering another stream channel." Page 84 of the WA states "Many roads within the WAU have not been maintained on a regular schedule. The lack of routine road maintenance may lead to increased sedimentation from the road surfaces, landslides from road failures and an increased risk of culvert problems." Page 83 discusses the increased sedimentation to the WAU caused by human-related activities (e.g., agriculture, urbanization and road construction).

Assessments, inferred from these data, suggest that sediment/turbidity in this watershed is of higher frequency and duration relative to unimpacted streams in the basin. This meets the criteria for "Not Properly Functioning" with respect to sediment and turbidity.

In this watershed, the proposed action would cross 8 intermittent streams (Table 13 of the EIS) when dry. Small amounts of increased transitory turbidity may occur during precipitation events after pipeline construction and prior to seeding and mulching of ground-disturbed areas. However, the ECP elements will minimize sedimentation potential to very low levels for a brief time (Appendix H). Sediment barriers and site revegetation are required throughout the construction project corridor to eliminate continuous turbidity impacts where delivery mechanisms to streams exist.

The proposed actions were determined to "Degrade" the turbidity baseline in the short-term ( 3 weeks) and "Maintain" the turbidity baseline in the long-term (4+ weeks).

\section{Habitat Access}

Physical Barriers - Fish migration barriers are considered a data gap for the Lower South Umpqua WA and were not specifically quantified. However, high road densities (WA page 77, Table 25) and numerous stream crossings (WA page 73), 57 percent of which are within 100 feet of a stream, indicate this watershed to be "At Risk" with respect to physical barriers.

The proposed actions contain no new permanent in-stream structures. Hence, the proposed actions were determined to "Maintain" the baseline for physical barriers.

\section{Habitat Elements}

Large Woody Debris (LWD) - Page 93 of the WA states, "Recent ODFW Aquatic Habitat Inventory data indicates well-distributed or frequently occurring LWD is lacking in the survey stream reaches." Large woody debris frequency (Table C-3) in this watershed averages 35 pieces/mile, thus meeting the criteria for "At Risk." 
No tree removal occurs within this watershed. Proposed actions are limited to powerline utility corridors. Hence, the proposed actions were determined to "Maintain" the baseline for LWD.

Substrate - Table C-2 (in Appendix C of the WA) lists the dominant substrate as gravel with a subdominant substrate of cobble and embeddedness is rated as "Fair" (26-49 percent), meeting the criteria for "At Risk" with respect to substrate.

In this watershed, the proposed action would cross 8 intermittent streams (Table 13 of the EIS) when dry. Small amounts of increased transitory turbidity may occur during precipitation events after pipeline construction and prior to seeding and mulching of ground-disturbed areas. However, the ECP elements will minimize sedimentation potential to very low levels for a brief time (Appendix H). Sediment barriers and site revegetation are required throughout the construction project corridor to eliminate continuous turbidity impacts where delivery mechanisms to streams exist.

The proposed actions were determined to "Degrade" the substrate baseline in the short-term ( 3 weeks) and "Maintain" the substrate baseline in the long-term (4+ weeks).

Pool Characteristics - Table C-2 in Appendix C of the WA rates percent pool area as "Fair" (16-29 percent) meeting the criteria for "At Risk" (less than 30 percent pool habitat).

In this watershed, the proposed actions are limited to the powerline ROWs. Hence, the proposed actions were determined to "Maintain" the baseline for pool characteristics.

Off-Channel Habitat - No data quantified this indicator in the WA. However, page 84 of the WA describes the watershed as having less complex stream channels, degraded substrate and poor fish habitat in some areas of the watershed. This is attributed to the removal of LWD from the stream channels (a key component for creating offchannel habitat), cutting trees along many streams (off-channel shading) and road construction (primary constituent for channelization) in and adjacent to riparian areas. Based on this impacts list of factors in the WA, it was determined to be "At Risk" with respect to off-channel habitat.

In this watershed, the proposed actions are limited to the powerline ROWs. Hence, the proposed actions were determined to "Maintain" the baseline for off-channel habitat.

\section{Channel Condition and Dynamics}

Width/Depth Ratio - Although current width to depth ratios given in table C-2 of the WA are rated as "Good", page 85 discusses the significant changes in historical stream width occurring within the South Umpqua River Basin stating, "Thirteen of the 14 stream reaches located in areas where timber harvesting occurred were significantly wider than in 1937." Also, lack of LWD within the basin projects poor recruitment for continuation of a high width/depth ratio rating, creating conditions where the present rating of "Good" in table C-2 may not be sustained. Thus, with respect to width/depth ratio, this watershed meets the criteria for "At Risk."

In this watershed, the proposed actions are limited to the powerline ROWs. Therefore, the proposed actions were determined to "Maintain" the baseline for width-depth ratio.

Streambank Condition - There is no direct mention of this indicator in the WA. However, inferences from the WA can be made. Page 70 states, "Many low gradient stream channels in the watershed have been eroded down to bedrock, probably due to increased peak flows as a result of timber harvesting, road construction, channel downcutting due to over grazing on streambanks, and the lack of LWD due to stream cleaning practices." This indicates consistent levels of human disturbance both historically and ongoing, leaving some of the streams within the watershed with unstable banks. Thus, based on inferences from the data, streambank condition meets the criteria for "At Risk."

Proposed action has adequate measures (Appendix H) to maintain streambank integrity during and after construction. Thus, the proposed actions were determined to "Maintain" the baseline for streambank condition.

Floodplain Connectivity - No direct mention of this indicator occurred in the WA. However, page 83 of the WA discusses the negative impacts to streams and stream flow due to removing water for irrigation and riparian vegetation. Some areas of wetlands and floodplains within the watershed are blocked by human development (such as roads and agricultural development) during summer low flows, which reduce linkages and degrade the wetland/riparian vegetation ecological functions. Also, there is a high density of roads and stream crossings throughout the basin. Inferences from these factors indicate floodplain connectivity to be "At Risk."

There are no activities in the 100-year floodplain within this watershed. Hence, the proposed actions were determined to "Maintain" the baseline for floodplain connectivity. 


\section{Flow/Hydrology}

Change in Peak/Base Flow - Page 79 of the WA discusses drainages in the watershed with high road densities, high stream crossing densities, previously harvested and/or in the transient snow zone areas as being susceptible to increased peak flows. Additionally, it is stated on page 79, "The majority of roads within the watershed were constructed with ditches and/or insloped road surfaces designed to carry water off of the road surface. Once the water is in the ditch, much of it may reach the stream faster than in an unroaded area. In fact, some ditchlines effectively function as stream channels extending the actual length of flowing streams during rain storms. Increased drainage density due to road construction may increase peak flows and mean annual floods." Based on these observations, it was determined to be "Not Properly Functioning" with respect to peak/base flow.

The proposed actions contain no new road construction or timber harvest within the basin, therefore, it was determined to "Maintain" the change in peak/base flow.

Drainage Network - High road densities (WA, Table 23) and the resulting increase in drainage density (discussed on page 79 of the WA) indicate this watershed meets the criteria for "Not Properly Functioning" with respect to drainage network.

In this watershed, the proposed actions are limited to the powerline ROWs. Therefore, the proposed actions will "Maintain" the baseline with respect to drainage network.

\section{Watershed Condition}

Road Density/Location - Road densities in the Lower South Umpqua WAU average $5.66 \mathrm{miles} / \mathrm{mi}^{2}$ (Table 23, WA) meeting the criteria for "Not Properly Functioning."

In this watershed, the proposed actions are limited to the powerline ROWs. Thus, the proposed actions were determined to "Maintain" the baseline for road density and location/drainage network.

Disturbance History - Pages 10-13 of the WA list past and current human land uses in the Lower South Umpqua River watershed as agriculture/grazing, timber harvesting, collection of special forest products and recreation (including ATV and motorcycle use). Additionally, the WA states, "The city of Roseburg is located in the WAU and provides food, gas, and other essentials for tourists, commercial travelers and local residents. Roseburg is the center of commerce for the local area." High levels of human activity in conjunction with the high road densities in this watershed meet the criteria for "Not Properly Functioning" with respect to disturbance history.

In this watershed, the proposed actions are limited to the powerline ROWs (human-disturbed sites). Therefore, the proposed actions were determined to "Maintain" the baseline for disturbance history.

Riparian Reserves - Table 9 in the WA lists the current riparian reserve age class distribution for this watershed, demonstrating approximately 34 percent (less than the 60 percent criteria) of the forested areas are in late seral successional stages. This meets the criteria for "Not Properly Functioning" with respect to riparian reserves.

The proposed actions will not impact any overstory riparian vegetation. Therefore, the proposed actions were determined to "Maintain" the baseline for Riparian Reserves.

Landslide Rates - Page 84 of the WA discusses the increased risk of landslides and road failures due to timber harvesting and improper maintenance of existing roads. Therefore, with respect to landslide rates, this watershed meets the criteria for "At Risk."

Appendix A of this EIS (Geotechnical Report) assesses potential landslide areas for pipeline construction. The report determined there would be no effect from construction within the utility corridor. Hence, the proposed actions were determined to "Maintain" the baseline for landslide rates.

Refugia - Channelization from high road densities, lack of LWD recruitment and poor off-channel habitat conditions throughout the basin and sub-basin are direct indicators of available refugia within the watershed. From these assessments, it was inferred to meet the criteria for "At Risk."

In this watershed, the proposed actions are limited to the powerline ROWs. Thus, the proposed actions were determined to "Maintain" the baseline for refugia. 


\section{Table E-6. Checklist for Documenting Environmental Baseline and Effects of Proposed Actions on Relevant Indicators.}

Name and location: Coos Bay District - BLM

Basin: $5^{\text {th }}$ field: Middle Main Coquille

\begin{tabular}{|c|c|c|c|c|c|c|}
\hline \multirow{2}{*}{$\frac{\text { Pathways }}{\text { Indicators }}$} & \multicolumn{3}{|c|}{ Environmental Baseline ${ }^{1}$} & \multicolumn{3}{|c|}{ Effects of the Actions ${ }^{2}$} \\
\hline & $\begin{array}{c}\text { Properly } \\
\text { Functioning }^{3}\end{array}$ & At Risk $^{3}$ & $\begin{array}{l}\text { Not Properly } \\
\text { Functioning }^{3}\end{array}$ & Restore $^{4}$ & Maintain 4 & Degrade $^{4}$ \\
\hline $\begin{array}{l}\text { Water Ouality } \\
\text { Temperature }\end{array}$ & & & WA, PJ & & PJ & \\
\hline Turbidity & & WA, PJ & & Long-term & & Short-term \\
\hline $\begin{array}{c}\text { Chemical Contamination/ } \\
\text { Nutrients }\end{array}$ & & WA & & & PJ & \\
\hline$\frac{\underline{A c c e s s}}{\text { Physical Barriers }}$ & . & & WA & & PJ & \\
\hline $\begin{array}{l}\text { Habitat Elements } \\
\text { Substrate/Sediment }\end{array}$ & & & WA, PJ & Long-term & & Short-term \\
\hline Large Wood & & & WA, PJ & & PJ & \\
\hline Pool Area \% & & WA & & & PJ & \\
\hline Pool Quality & & WA, PJ & & & PJ & \\
\hline Off-Channel Habitat & & WA & & & PJ & \\
\hline$\frac{\text { Channel Conditions and Dynamics }}{\text { Width/Depth Ratio }}$ & & WA, PJ & & & PJ & \\
\hline Streambank Condition & & WA & & & PJ & \\
\hline Floodplain Connectivity & & & WA & & PJ & \\
\hline $\begin{array}{l}\text { Watershed Conditions } \\
\text { Road Density and Location }\end{array}$ & & & WA & & PJ & \\
\hline Disturbance History & & & WA, PJ & & PJ & \\
\hline Riparian Reserves & & & WA, PJ & & PJ & \\
\hline Landslide Rates & & & WA & & PJ & \\
\hline
\end{tabular}

1. Environmental Baseline conditions are derived from BLM stream survey data and synthesis of watershed analysis findings: WA-Middle Main Coquille North Coquille Mouth Catching Creek Watershed Analyses; PJ- Professional Judgment.

2. Effects of the Actions are derived from this document and description of proposed actions.

3. These three categories of function ("properly functioning", "at risk", or "not properly functioning") are defined for each indicator in the "Matrix of Pathways and Indicators" (Table E-1).

4. For the purposes of this checklist (Table E-6), "restore" means to change the function of an "at risk" indicator to "properly functioning", "not properly functioning" to "at risk" and "properly functioning" moving towards recovery. "Short-term" effects, for the purposes of this checklist, are defined as: intermittent or inconsistently occurring effects (i.e., hauling more than 10 loads per day during heavy-rain events) that are brief in duration (i.e., days). "Long-term" effects, for the purposes of this checklist, are defined as consistently occurring effects (i.e., new permanent road construction) that are lengthy in duration (i.e., months/years). 


\section{Rationale Used in Completing the Checklist for Documenting Environmental Base- line and the Effects of Proposed Action(s) on Relevant Indicators With Respect to the Middle Main Coquille Watershed}

Note: Unless cited otherwise, the information source used for accessing the environmental baseline is contained in the Middle Main Coquille Watershed Analysis prepared by the Umpqua Resource Area, Coos Bay District Bureau of Land Management (09/30/1997). The WA includes 3 subwatersheds: North Coquille Mouth, Middle Main Coquille and Catching Creek. North Coquille Mouth Subwatershed I is part of the North Fork Coquille 5th field watershed. Middle Main Coquille and Catching Creek Subwatersheds together make up the Middle Main Coquille 5th field watershed. The watershed covers approximately 55,728 acres.

\section{Description of Affected Environment:}

\section{Water Quality}

Temperature - The Little North Fork Coquille and Catching Creek are listed on Oregon's 303 (d) list as water quality limited due to temperature and the South, North and Middle Forks, as well as the main stem of the Coquille River, are also warmer than optimum (WA, page 19). John's Creek, however, is considered to be properly functioning (WA, table FISH-3). There is little other mention of water temperature in the watershed analysis and no mention of 7-day maximum averages. Riparian vegetation on BLM land is said to be in good condition (WA, page 25) and riparian vegetation is said to be partially responsible for the lack of change from historic conditions of type A and B channels (WA, page 18). It appears that upper reaches of the watershed are receiving adequate shading. Lower portions of the watershed that have been converted to farmland and grazing do not have intact riparian corridors (WA, page 18), therefore, any heating of the water due to lack of shading would likely be occurring in the lower portions of the watershed. Based on these data and observations, it was determined to be "Not Properly Functioning" with respect to temperature.

These proposed actions contain no riparian overstory tree removal and were determined to "Maintain" the temperature baseline.

Turbidity - Roughly 12 percent of the watershed is located on soils that generally yield silt and clay sediments (WA, pg. 5), which tend to remain suspended longer (WA, pg. 10). Whereas larger particles, such as sand and gravel, tend to settle out of the water column sooner. Because of this assessment, it was determined to be "At Risk" with regards to turbidity.

In this watershed, the proposed action would cross over top 17 intermittent and small perennial streams (Table 22 of the EIS) on road fill when streams are dry or during summer low flows. Small amounts of increased transitory turbidity may occur during pipeline construction, prior to repaving of the CBW Road. However, the ECP measures will minimize sedimentation potential to very low levels for a brief time (Appendix H). Sediment barriers are required throughout the construction project corridor, eliminating continuous turbidity impacts where delivery mechanisms to streams exist. In this watershed, no vegetation removal will occur as construction is limited to the CBW Road. Beneficial project actions include new cross-drains in the CBW Road and paving 1.9 miles of gravel road.

The proposed actions were determined to "Degrade" the turbidity baseline in the short-term ( 3 weeks) and "Restore" the turbidity baseline in the long-term (4+ weeks).

Chemical Contamination/Nutrients - In the 1986 Water Quality Report the Oregon DEQ listed the Coquille River as a "Waterbody of Concern." In 1991, it specifically identified wastewater treatment plants in Myrtle Point and Coquille for producing nutrient and coliform bacteria and toxic substances as areas of concern for the Coquille River. However, no record of fish kills or other biological evidence of serious or chronic contamination exist. Therefore, with respect to chemical contamination/nutrients, it was determined to be "At Risk."

The proposed actions do not utilize chemicals in the construction process other than products for running the machinery. This project was determined to "Maintain" the chemical contaminant baseline (barring accidental release of petroleum products). 


\section{Habitat Access}

Physical Barriers - On pages 21 to 26 of the WA, culverts acting as artificial barriers to salmonid passage are discussed. This meets the criteria to be classified as "Not Properly Functioning" with respect to physical barriers.

The proposed actions contain no new permanent in-stream structures. Hence, the proposed actions were determined to "Maintain" the baseline for physical barriers.

\section{Habitat Elements}

Substrate/Sediment - The only analysis area for which substrate was sampled (as percent gravel in the riffles) is John's Creek, which was rated as "Good" with regard to gravel and "Fair" with regard to silt/sand/organics (WA, Table FISH-1). Pages 18 \& 19 of the WA state, "However, the substrate composition... [sic] has changed in response to man's activities..." and, "Many larger channels have scoured to bedrock or migrated laterally, and have difficulty retaining substrate. The systems that could retain substrate may have difficulty recruiting it because streamside and mid-slope roads function as terraces that trap material that would otherwise proceed downhill to the channel." Based on these references, it was inferred to be "Not Properly Functioning" with respect to substrate/sediment.

The proposed actions contain no new road construction. Sediment barriers will be placed along the entire pipeline corridor in areas where delivery mechanisms to streams exist, as well as all stream crossings. In this watershed, the pipeline would cross over top on road fill 6 intermittent and 11 small perennial streams, when dry or during summer low flows (Table 22 of the EIS). Small amounts of transitory sediment may enter the streams after construction during the first precipitation prior to repaving. Sediment barriers are required throughout the construction project corridor to eliminate sedimentation impacts. In this watershed, no vegetation removal will occur as construction is limited to the CBW Road. Beneficial project actions include paving 1.9 miles of gravel road.

The proposed actions were determined to "Degrade" the substrate/sediment baseline in the short-term (3 weeks) and "Restore" the substrate/sediment baseline in the long-term (4+ weeks).

Large Woody Debris (LWD) - The only place where the WA specifically addresses large woody debris in terms of pieces/mile is table FISH-1 which only covers John's Creek. The table lists the number as 20 pieces/mile and classifies it as "Fair." Table FISH- 3, however, gives large woody debris as "Unknown" for John's Creek and "Not Properly Functioning" for Wimer Creek.

Pages 18 and 20 of the WA indicate that much large woody debris has been removed from the channels, and page 20 also indicates that future recruitment of large woody debris will be limited (at least in the near-term) by historical management actions in the basin. Based on this information, the watershed was determined to be "Not Properly Functioning" in relation to LWD.

No vegetation removal would occur in this watershed from the pipeline project, as the proposed actions are limited to the CBW Road. Hence, the proposed actions were determined to "Maintain" the baseline for LWD.

Pool Area (\%) - Pool area is listed as 17 percent (average) for John's Creek in table FISH-1 of the WA and is considered "Not Properly Functioning" in table FISH-3. The other indication of pool area for the watershed is the statement, "...beaver populations are probably much lower currently than historically, and that beaver dams have decreased proportionately" (WA, pages $24 \& 25$ ). Pool area would be expected to be less in upper reaches of a watershed (such as John's Creek) where the slopes are steeper than lower down in the watershed. Based on these observations and current trends, it was given a rating of "At Risk" with respect to pool area.

In this watershed, proposed actions are limited to the CBW Road. Hence, the proposed actions were determined to "Maintain" the baseline for pool area.

Pool Quality - Table FISH-3 in the WA rates pool quality as "Not Properly Functioning" for John's Creek and Wimer Creek; while, table FISH-l rates it as "Good" for John's Creek. It is assumed that as stream order increases, pool depth will increase as well. Based on these inferences and the decrease in beaver activity in the watershed, which can be a prime source of deep, high quality pools (WA, pages $24 \& 25$ ), the watershed appears to be "At Risk" with regard to pool quality.

Proposed actions are limited to the CBW Road in this watershed. Hence, the proposed actions were determined to "Maintain" the baseline for pool quality. 


\section{Channel Condition and Dynamics}

Off-Channel Habitat - Off-channel habitat is considered to be "At Risk" in both John's Creek and Wimer Creek (see table FISH-3). Throughout the rest of the WA, the only mention is on page 18 where it states, "The floodplains have been cleared and drained for development resulting in the loss or simplification of habitat; especially, aquatic habitat that is critical during high flows." Based on these references, it was determined that the watershed is "At Risk" with respect to off-channel habitat.

Proposed actions are limited to the CBW Road in this watershed. Hence, the proposed actions were determined to "Maintain" the baseline for off-channel habitat.

Width/Depth Ratio - Page 23 of the WA states concerning John's Creek, "The width/depth ratio of riffles was fair for all stream reaches." Increased erosion and sedimentation resulting from logging, road building and agricultural activities (WA, page 5), have altered the substrate composition of the watershed (WA, page 18). Increased sedimentation also directly acts to increase width/depth ratios. The watershed, therefore, was rated "At Risk" regarding width/depth ratios.

Proposed actions are limited to the CBW Road in this watershed. Hence, the proposed actions were determined to "Maintain" the baseline for width/depth ratios.

Streambank Condition - Page 17 of the WA states, "Most of the assessment area has a dendritic drainage pattern and is steep, water-cut, deeply dissected, and forested." This portion would be classified under the Rosgen Stream Types as A and B type channels which are relatively stable. Page 18 indicates that $C$ type channels in the watershed have decreased bank stability due to human manipulations. Because of anticipated ongoing human impacts, it was determined to be "At Risk" with respect to streambank condition.

Proposed actions are limited to the CBW Road in this watershed. Thus, the proposed actions were determined to "Maintain" the baseline for streambank condition.

Floodplain Connectivity - Floodplain connectivity is discussed on page 18 of the WA; it states, "Removal of vegetation, ditching and draining, and construction of flood control structures has... [sic]... significantly altered the channels and their interaction with the floodplain." Also, "The floodplains have been cleared and drained for

development." Table FISH-3 assesses John's Creek and Wimer Creek as both being "At Risk" regarding floodplain connectivity. However, most of the floodplain occurs lower down in the drainage system, where heavy disconnecting of floodplains from road construction exists. Therefore, with respect to floodplain connectivity, the watershed was determined to be "Not Properly Functioning."

There are no activities in the 100-year floodplain within this watershed. Hence, the proposed actions were determined to "Maintain" the baseline for floodplain connectivity.

\section{Watershed Conditions}

Road Density \& Location/Drainage Network - While there is insufficient data to estimate road densities in nonBLM land in the watershed (WA, page 2), it is listed for John's Creek and Wimer Creek both as being "Not Properly Functioning" (table FISH-3). Page 49 of the WA gives the road density on BLM administered lands as 3.92 miles per square mile (table EROD-3 gives the road density for BLM administered lands as 3.82 miles per square mile), and page 23 indicates that some roads were constructed along streams. Map EROD-6 shows many intersections of roads and streams. Combined, these indicate that the watershed is "Not Properly Functioning" with regard to road density and location/drainage network.

Proposed actions are limited to the CBW Road in this watershed. Thus, the proposed actions were determined to "Maintain" the baseline for road density location network.

Disturbance History - Page 23 of the WA says, "The combined impacts of agricultural practices, past timber harvest practices, and the associated land management activities have degraded stream habitat conditions in the Area (watershed)." Table Veg-3 (WA, page 14) indicates that although a high percentage of BLM-managed land is currently in mid-to late-seral stages; it is a small percentage of the entire land base. WA pages 40 \& 41 highlight historic splash damming in the watershed causing bank erosion and stream scouring. These references illustrate that the watershed is "Not Properly Functioning" with respect to disturbance history.

Proposed actions are limited to human-disturbed sites (CBW Road). Therefore, the proposed actions were determined to "Maintain" the baseline for disturbance history. 
Landslide Rates - Page 6 of the WA indicates that of the 182 known slides in the watershed, 63 percent were associated with recent timber-yarding; while, 16 percent were associated with roads. These data meet the criteria for "Not Properly Functioning" with regard to landslide rates.

Appendix A (Geotechnical Report) of this EIS assesses potential landslide areas and pipeline construction. The report determined there would be no effect on landslide rates from construction within the CBW Road. Hence, the proposed actions were determined to "Maintain" the baseline for landslide rates.

Riparian Reserves - Page 25 of the WA states that riparian buffers on BLM-managed lands are intact and that future recruitment of large wood "appears to be good." For the watershed as a whole, however, page 18 indicates that $\mathrm{C}$ type channels have had considerable disturbance of stream-side vegetation, and page 23 indicates that considerable areas on private land do not have the potential to provide large wood to the streams. Because of the riparian management on private land in the basin, the watershed was determined to be "Not Properly Functioning" with respect to Riparian Reserves.

The proposed actions will not impact any overstory riparian vegetation. Therefore, the proposed actions were determined to "Maintain" the baseline for Riparian Reserves. 
Table E-7. Checklist for Documenting Environmental Baseline and Effects of Proposed Actions on Relevant Indicators.

Name and location: Coos Bay District - BLM

Basin: $5^{\text {th }}$ field: Olalla-Lookingglass

\begin{tabular}{|c|c|c|c|c|c|c|}
\hline \multirow{2}{*}{$\begin{array}{l}\text { Pathways } \\
\text { Indicators }\end{array}$} & \multicolumn{3}{|c|}{ Environmental Baseline ${ }^{1}$} & \multicolumn{3}{|c|}{ Effects of the Actions ${ }^{2}$} \\
\hline & $\begin{array}{c}\text { Properly } \\
\text { Functioning }\end{array}$ & At Risk $^{3}$ & $\begin{array}{l}\text { Not Properly } \\
\text { Functioning }\end{array}$ & Restore $^{4}$ & Maintain $^{4}$ & Degrade $^{4}$ \\
\hline$\frac{\text { Water Quality }}{\text { Temperature }}$ & & & WA & & PJ & \\
\hline Turbidity & & WA, PJ & & & Long-term & Short-term \\
\hline $\begin{array}{l}\text { Chemical Contaminants and } \\
\text { Nutrients }\end{array}$ & & DEQ & & & PJ & \\
\hline$\frac{\text { Access }}{\text { Physical Barriers }}$ & & WA, PJ & & & PJ & \\
\hline$\frac{\text { Habitat Elements }}{\text { Substrate/Sediment }}$ & & WA & & & Long-term & Short-term \\
\hline Large Woody Debris & WA & & & & PJ & \\
\hline Pool Area and Pool Quality & & WA & & & PJ & \\
\hline Off-Channel Habitat & & & WA, PJ & & PJ & \\
\hline$\frac{\text { Channel Conditions and Dynamics }}{\text { Width/Depth Ratio }}$ & & & WA & & PJ & \\
\hline Streambank Condition & & & WA, PJ & & PJ & \\
\hline Floodplain Connectivity & & WA, PJ & & & PJ & \\
\hline $\begin{array}{c}\text { Watershed Conditions } \\
\text { Road Density and Location }\end{array}$ & & & WA & & PJ & \\
\hline Disturbance History & & & WA, PJ & & PJ & \\
\hline Landslide Rates & & WA, PJ & & & PJ & \\
\hline Riparian Reserves & & & WA & & PJ & \\
\hline
\end{tabular}

1. Environmental Baseline conditions are derived from BLM stream survey data and synthesis of watershed analysis findings: WA-Olalla-Lookingglass Creek Watershed Analyses; PJ- Professional Judgment; DEQ - Oregon DEQ.

2. Effects of the Actions are derived from this document and description of proposed actions.

3. These three categories of function ("properly functioning", "at risk", or "not properly functioning") are defined for each indicator in the "Matrix of Pathways and Indicators" (Table E-7).

4. For the purposes of this checklist (Table E-7), "restore" means to change the function of an "at risk" indicator to "properly functioning", "not properly functioning" to "at risk" and "properly functioning" moving towards recovery. "Short-term" effects, for the purposes of this checklist, are defined as: intermittent or inconsistently occurring effects (i.e., hauling more than 10 loads per day during heavy-rain events) that are brief in duration (i.e., days). "Long-term" effects, for the purposes of this checklist, are defined as consistently occurring effects (i.e., new permanent road construction) that are lengthy in duration (i.e., months/years). 


\section{Rationale Used in Completing the Checklist for Documenting Environmental Base- line and the Effects of Proposed Action(s) on Relevant Indicators With Respect to the Olalla-Lookingglass Watershed}

Note: Unless documented otherwise, the information source used for accessing the environmental baseline is contained in the Olalla-Lookingglass Watershed Analysis prepared by the Roseburg District South River Resource Area (04/02/1998). The watershed covers approximately 103,109 acres.

\section{Description of Affected Environment:}

\section{Water Quality}

Temperature - Pages 72 and 73 from Olalla-Lookingglass Watershed Analysis (WA) indicate that the 7-day maximum water temperature of Olalla Creek exceeds $68^{\circ} \mathrm{F}$, thus meeting the criteria for "Not Properly Functioning" with respect to temperature.

These proposed actions contain no riparian overstory tree removal and were determined to "Maintain" the temperature baseline.

Turbidity - Pages 71 and 75 of the WA report that problems with turbidity were identified by DEQ on Thompson Creek within the Olalla-Lookingglass WAU. A weighted average of "Fair" was derived from ODFW habitat surveys (table C-6 in WA) of percent area covered in silt/sand in the watershed. From this data, it was inferred to be "At Risk" with respect to turbidity.

The proposed action would cross 48 intermittent and small perennial streams (Appendix I) in this watershed when dry or during summer low flows. Of these 48 stream crossings, 30 would be trenched dry during summer construction and 8 would be over top on road fill (Tables 14 and 15 of this EIS). Ten small (less than $0.1 \mathrm{cfs}$ ) perennial streams would be trenched using the "bag and flume" method during low flows (Tables 14 and 15 of this EIS). Small amounts of increased transitory turbidity may occur during pipeline construction prior to seeding and mulching of ground-disturbed areas. However, the BMPs, PDCs and ECP minimize sedimentation potential to very low levels for a brief time (Appendix H). Sediment barriers and site revegetation are required throughout the construction project corridor, to eliminate continuous turbidity impacts where delivery mechanisms to streams exist. Beneficial project actions include new cross-drains in the CBW Road.

The proposed actions were determined to "Degrade" the turbidity baseline in the short-term (3 weeks) and "Maintain" the turbidity baseline in the long-term (4+ weeks).

Contaminants and Nutrients - Pages 72 and 75 state that one pH measurement collected in 1996 was 8.0, which was within the standards set by DEQ of 6.5-8.5. No assessments, measurements or duration criteria of managementrelated inputs data were collected or analyzed. Table C-6 rated organics as fair for the watershed. However, due to continued impacts from human development (residences, agriculture, logging, etc.), there is potential for future increases in contaminants. Because of this potential increase, it was determined to be "At Risk" with respect to contaminants and nutrients.

The proposed actions do not utilize chemicals in the construction process other than products for running the machinery. This project was determined to "Maintain" the chemical contaminant baseline (barring accidental release of petroleum products).

\section{Habitat Access}

Physical Barriers - Pages 63- 68 and Appendix C of the WA discuss the high road densities (greater than 3 miles of road per square mile of area) and their impacts within the Olalla-Lookingglass watershed. There are roughly 2 stream crossings per stream mile within the watershed. Some culverts in the watershed likely inhibit fish passage during high or low flows. Based on these data, it was determined to be "At Risk" with respect to physical barriers.

The proposed actions contain no new permanent in-stream structures. Hence, the proposed actions were determined to "Maintain" the baseline for physical barriers. 


\section{Habitat Elements}

Substrate/Sediment - Pages 63 - 68 and Appendix C of the WA discuss the impacts of high road densities ( $>3 \mathrm{mi} /$ $\mathrm{mi}^{2}$ area) and their ability to increase sedimentation. Although road-related surface erosion was not quantified for this WA, pages $71 \& 75$ indicate that problems with sedimentation were specifically identified by DEQ within the Olalla-Lookingglass watershed. Table C-6 gives embeddedness as $26-49$ percent with cobble as the dominant substrate. This indicates that the watershed is "At Risk" with respect to substrate/sediment.

The proposed action would cross 48 intermittent and small perennial streams (Appendix I) in this watershed when dry or during summer low flows. Of these 48 stream crossings, 30 would be trenched dry during summer construction and 8 would be over top on road fill (Tables 14 and 15 of this EIS). Ten small (less than $0.1 \mathrm{cfs}$ ) perennial streams would be trenched using the "bag and flume" method during low flows (Tables 14 and 15 of this EIS). Small amounts of increased transitory turbidity may occur during pipeline construction prior to seeding and mulching of ground-disturbed areas. However, the BMPs, PDCs and ECP minimize sedimentation potential to very low levels for a brief time (Appendix H). Sediment barriers and site revegetation are required throughout the construction project corridor, to eliminate continuous turbidity impacts where delivery mechanisms to streams exist. Beneficial project actions include new cross-drains in the CBW Road.

The proposed actions were determined to "Degrade" the substrate/sediment baseline in the short-term ( 3 weeks) and "Maintain" the substrate/sediment baseline in the long-term (4+ weeks).

Large Woody Debris (LWD) - Pages 68 and 69 state that LWD is lacking in many stream channels within the watershed because of previous stream cleaning practices. However, aquatic inventory data in Appendix $C$ of the WA reports an average of 220.2 pieces of LWD per mile of stream, which is well above the criteria of greater than 80 pieces required for a "Properly Functioning" classification.

No tree removal occurs within this watershed from the proposed action. Proposed actions are limited to powerline utility corridors and the CBW Road. Hence, the proposed actions were determined to "Maintain" the baseline for LWD.

Pool Area and Pool Quality -Table C-6 gives a weighted average of "Fair" (16 - 29 percent) for the watershed as a whole with respect to pool area. According to the WA, this corresponds with the NMFS designation of "At Risk."

Proposed actions are limited to powerline ROWs and the CBW Road. Hence, the proposed actions were determined to "Maintain" the baseline for pool quality.

Off-Channel Habitat - No quantification of this indicator occurred in the WA. However, due to its high density of roads and a history of stream cleaning, severe downcutting has occurred, thus isolating the natural floodplain. From this, it was inferred to be "Not Properly Functioning" with respect to off-channel habitat.

Proposed actions are limited to powerline ROWs and the CBW Road. Hence, the proposed actions were determined to "Maintain" the baseline for off-channel habitat.

\section{Channel Condition \& Dynamics}

Width/Depth Ratio - Page 69 and table C-6 in Appendix C from the WA indicate that the width/depth ratio exceeds 12, thus meeting the criteria for "Not Properly Functioning."

Proposed actions are limited to powerline ROWs and the CBW Road. Hence, the proposed actions were determined to "Maintain" the baseline for width/depth ratio.

Streambank Condition - Page 68 from the WA discusses field surveys which found that stream channels are downcutting and causing accelerated bank erosion. It was inferred from these observations that streambank condition could meet the criteria for "Not Properly Functioning."

Proposed actions have adequate measures (Appendix $\mathrm{H}$ ) to maintain streambank integrity during and after construction. Thus, the proposed actions were determined to "Maintain" the baseline for streambank condition.

Floodplain Connectivity - This indicator was indirectly assessed as overall hydrologic flows through out the watershed (WA, pages 59-68). Page 58 states that, "...increased drainage densities, due to road construction, may increase peak flows and mean annual floods." Based on these comments in the context of high road densities prevalent within the watershed, it was determined to be "At Risk" with respect to floodplain connectivity. 
There are no activities in the 100-year floodplain within this watershed. Hence, the proposed actions were determined to "Maintain" the baseline for floodplain connectivity.

\section{Watershed Condition}

Road Density and Location/Drainage Network - Appendix C, page 63, as well as pages 66-68 from the WA, indicate that the road density/drainage network exceeds 3 road miles per square mile with an average of 4.49 miles of road per square mile. Also, many of the wider valley bottoms contain roads and many of the larger tributaries within the watershed have roads along much of their length. The watershed was determined to be "Not Properly Functioning" with respect to road density and location/drainage network.

Proposed project actions are limited to powerline ROWs and the CBW Road. Thus, the proposed actions were determined to "Maintain" the baseline for road density location network.

Disturbance History - Pages 15-29 of the WA discuss the disturbance history of the watershed. Vegetation data from 1936, when compared with vegetation data from 1997, reveals a shift in the watershed to a higher proportion of early seral vegetation. Therefore, stem exclusion conditions are over-represented within the landscape, fragmenting the forest matrix with early seral patches (age 0-30). Also, the proportion of the landscape classified as nonforested has grown significantly, because of urban and agricultural land uses, each of which display a high intensity disturbance regime. Historically, natural disturbances such as slides, fire, storm events, etc., played a significant role in defining the landscape of the watershed (WA pages 15-29). However, landscape changes from 1936-1997 were primarily attributed to human-induced influences. Based on this information, it was determined to be "Not Properly Functioning" with respect to disturbance history.

Proposed project actions are limited to human-disturbed sites (utility corridors and roadways). Therefore, the proposed actions were determined to "Maintain" the baseline for disturbance history.

Landslide Rates - Page 53 of the WA indicates that landslide rates can be increased by human activity, such as road building. There was no quantified measure of landslide rates in the WA. However, since human impacts (such as road densities) throughout the Olalla-Lookingglass Watershed are high, it seems likely that landslide rates are above historical levels. Based on these inferences, the watershed was determined to be "At Risk" with respect to landslide rates.

Appendix A of this EIS (Geotechnical Report) assessed potential landslide areas for pipeline construction. The report determined there would be no effect on landslide rates from construction within the CBW Road or the utility corridor. Hence, the proposed actions were determined to "Maintain" the baseline for landslide rates.

Riparian Reserves - Riparian reserves within the Olalla-Lookingglass basin are highly impacted and fragmented from human activities as a result of the "checkerboard" federal ownership pattern that exists within the watershed. Table C-2 shows that the Lookingglass Creek subwatershed is less than 70 percent intact. This meets the criteria for "Not Properly Functioning" with respect to Riparian Reserves.

The proposed project actions will not impact any overstory riparian vegetation. Therefore, the proposed actions were determined to "Maintain" the baseline for Riparian Reserves. 


\section{List of References}

Coos Bay District, Bureau of Land Management. September 30, 1999. East Fork Coquille River Watershed Analysis. North Bend, Oregon.

Coos Bay District, Bureau of Land Management. July 20, 2001. North Fork Coquille Watershed Analysis. North Bend, Oregon.

Coos Bay District, Bureau of Land Management. September 30, 1997. Middle Main Coquille Watershed Analysis. North Bend, Oregon.

Oregon Department of Fish and Wildlife. 2000. Oregon Guidelines for Timing of In-Stream Work to Protect Fish and Wildlife Resources.

Oregon Department of Transportation. December, 1999. Erosion and Sediment Control Manual.

Porior, Don. January, 2000. Designing For Stream Simulation At Road Crossings.

Roseburg District, Bureau of Land Management. April 2, 1998. Olalla-Lookingglass Watershed Analysis. Roseburg, Oregon.

Roseburg District, Bureau of Land Management. May 30, 2000. Lower South Umpqua Watershed Analysis. Roseburg, Oregon.

USDA and USDI. 1994. Standards and Guidelines for Management of Habitat for Late-Successional and OldGrowth Forest Related Species Within the Range of the Northern Spotted Owl ROD.

USDA and USDI. 2001. Record of Decision (ROD) and Standards and Guidelines for Amendments to the Survey and Manage, Protection Buffer, and other Mitigation Measures Standards and Guidelines. Portland, Oregon.

USDA Forest Service. 1991. Road Construction and Maintenance In: Influences of Forest and Rangeland Management On Salmonid Fishes and Their Habitats. W.R. Meehan, editor. pages 297-323.

USDA Forest Service and US Department of Transportation. November 1990. Fish Passage Through Culverts. $67 \mathrm{pp}$.

USDA Forest Service. 1973. Protecting Fish Habitat During Forest Road Development.

USDI Bureau of Land Management. 1986. Northwest Area Noxious Weed Control Program Record of Decision (ROD). Portland, Oregon.

USDI Bureau of Land Management. 1987. Supplement to the Northwest Area Noxious Weed Control Program Record of Decision (ROD). Portland, Oregon.

USDI Bureau of Land Management. 1995a. Record of Decision (ROD) and Resource Management Plan. Coos Bay Oregon and Roseburg, Oregon. 



\section{Appendix E1. Essential Fish Habitat Assessment}




\section{Appendix E1. Essential Fish Habitat Assessment}

ESSENTIAL FISH HABITAT ASSESSMENT for the COOS COUNTY NATURAL GAS PIPLINE, COOS BAY DISTRICT, BUREAU OF LAND MANAGEMENT, COOS COUNTY, OREGON

Prepared By: Brian T. Cox

Biological Information Specialists, Inc.

P.O. Box 27

Camas Valley, OR 97416

November 1, 2001 


\section{INTRODUCTION}

Coos County proposes to construct a natural gas pipeline from Roseburg, Oregon, to Coos Bay, Oregon. This pipeline is approximately 60 miles in length and crosses approximately 3 miles of land managed by the Bureau of Land Management (BLM), Coos Bay District.

\section{PUPRPOSE}

An Essential Fish Habitat (EFH) assessment is required to ensure BLM actions and/or proposed actions on BLM lands are compliant with the Magnuson-Stevens Fishery Conservation and Management Act. EFH is defined as those waters and substrate necessary to fish for spawning, breeding, feeding or growth to maturity.

\section{BACKGROUND}

The act was originally passed in 1976 and provided the NMFS legislative authority for fisheries regulation in the United States offshore areas. The 1996 amendments to the Act require the identification of EFH for federally managed fish species and implementation of measures to conserve and enhance this habitat as described in federal fishery management plans. Essential Fish Habitat designated by the Pacific Fisheries Management Council includes freshwater habitats in BLM administered lands in California, Oregon, Washington and Idaho.

The Act requires all federal agencies to consult with National Marine Fisheries Service (NMFS) on all new federal actions that have been determined to adversely affect EFH.

Consultation is not required for existing actions, nor for actions determined not likely to adversely affect EFH.

\section{POLICY/ACTION}

I. For any project within designated EFH areas, the project-level National Environmental Policy Act (NEPA) analysis must assess potential effects to EFH, and the results of that analysis must be documented in the Environmental Impact Statement (EIS) or Environmental Assessment (EA) for the project.

II. If the EFH effects analysis supports a conclusion that EFH will not be adversely affected, no EFH consultation with NMFS is required.

III. If the EFH analysis results in a conclusion that adverse effects to EFH may result from the action, EFH consultation with NMFS is required.

\section{CONCLUSIONS}

The Aquatic Ecosystem Assessment (Appendix E of this EIS) evaluates impacts of the proposed action as compared to baseline conditions for each watershed occurring within the proposed action area with respect to "Matrix of Factors and Indicators" (NMFS 1998). NMFS has determined this assessment to be adequate for assessing EFH (Frank Bird pers. com.). Potential impacts from both the Hwy 42 alternative and proposed action were determined to "Not Adversely Effect" with respect to EFH. 



\section{Appendix F. U.S. Fish and Wildlife Service Endan- gered Species Consultation Letter of Concurrence}




\section{Appendix F. U.S. Fish and Wildlife Service Endan- gered Species Consultation Letter of Concurrence}

NOT YET RECEIVED 


\section{Appendix G. Questions and Concerns from the Public}




\section{Appendix G. Questions and Concerns from the Public}

The questions and comments listed below are derived from the many questions and comments sent from the public as a result of the public meetings and publications made available to the public. In many instances, the questions and comments of various individuals addressed the same issue. These questions or comments were addressed with a single question or comment. Some of the questions were received while an Environmental Assessment (EA) was being worked on and some were received during the public comment period (and later) for this EIS. Thus, there are references to both an EA and EIS within this Appendix.

As much as possible, the questions and comments (within their respective sections) are arranged keeping similar topics together.

\section{Questions from the Public}

Question 1):

Why is the pipeline route changed from the route proposed in the referendum (Hwy 42) submitted to the voters in November of 1999 ?

Answer: The Highway 42 route was chosen by the County's bond issue consultant RMI Navigant, who also assessed the Coos Bay Wagon Road (CBW Road) route. Navigant said the choice between the two routes was difficult but they narrowly preferred the Highway 42 route because of their belief environmental permitting would be easier - such is probably not the case. Relative to the original Highway 42 route, the now-preferred CBW Road route is about 25 miles shorter, about \$20 million less expensive to construct, and the pipeline will be much less susceptible to third-party dig-in damage. The currently proposed route impacts far fewer streams and wetlands, and will not disrupt traffic on Highway 42 for thousands of travelers per day during construction. Additionally, worker safety will be greater on the CBW Road route versus working on the Highway 42 route.

The questions of two individuals are addressed together in Question 2.

Question 2):

Given the current BPA moratorium on installation of pipelines in their right-of-way, what are the risks of having a natural gas pipeline in the vicinity of a power line right-of-way? Why are the risks not significant? Is it wise to use utility corridors for the pipeline corridor?

Answer: The primary perceived risk of locating a gas pipeline near a power line is related to a gas explosion or fire which could possibly damage a tower or a conductor. Such events could also cause a forest fire, which could spread and cause damage to the electrical system. Natural gas pipeline incident statistics indicate that the risk for significant damage to occur to the BPA electrical system is very small. In fact, there has never been a report of such an incident in the history of gas pipeline safety regulation 
by the US DOT since 1970. Because the risk is insignificant compared with reduced impact on environment and population, most Federal, state and local government agencies prefer to have gas pipelines located in existing utility corridors, such as the preferred CBW Road/BPA/PP\&L route.

Question 3): $\quad$ Is it true the pipeline will be installed under an elementary school and within its playground located within the eastern end of the corridor? If so, what direct, indirect, or cumulative effects are involved at this location?

Answer: The pipeline will not be installed under a school, nor will it be installed closer than 50 feet to any occupied building. The preferred route follows a PP\&L power corridor which passes about 300 feet south of the Lookingglass School in Douglas County. Even a catastrophic failure of the pipeline could not be expected to damage the school at that distance.

The questions of two individuals are addressed together in Question 4.

Question 4): Is the Environmental Assessment study assessing the impacts on county and private lands (including infringement of rights held by private land owners) located along the proposed pipeline corridor?

Answer: The environmental study must, by law, assess the impacts of the proposed pipeline on all lands, regardless of ownership. The entire 60 -mile route is reviewed, even though the current proposal will only impact approximately 3 miles of BLM land.

Question 5): $\quad$ Will this pipeline cause future problems if roads in which it is constructed are closed, restored or recontoured?

Answer: There is almost no chance of any road along the preferred route being closed. If the road is closed, the pipeline will not be impacted. If restored or recontoured, the location of the pipeline will be considered when the work is done.

Question 6):

What rural fire protection access is available along the pipeline route (in the event of an pipeline accident causing a fire)?

Answer: Rural Fire Departments are located at Lookingglass, Dora and Fairview. Fire equipment is also located at Winston and Roseburg in Douglas County, and Coquille, Myrtle Point, Millington and Coos Bay in Coos County. Federal regulations (49CFR 192.615) provide that local emergency response personnel be informed about the pipeline location and operations and be involved in the development of emergency response plans for the pipeline. 
The questions of two individuals are addressed together in Question 7.

Question 7):

In the event of a gas line explosion or a leakage causing stream pollution, will the county have insurance coverage for such an event? Could you please explain the likely process for cleaning up surface or ground water polluted from a natural gas leakage? What consideration will be given to fish kill and fish or marine habitat destruction? Will such an event be a taxpayer liability?

Answer: Natural gas is composed of inert components and consequently does not pollute or dissolve into water. Natural gas is 35\% lighter than air. Any gas leak from the pipeline would pass through the soil or groundwater and then dissipate into the air. There is usually no effect of a gas leak on habitat, fish or wildlife. A catastrophic failure of this 12 -inch pipeline at its usual operating pressure may cause surface damage within about 50 feet of the rupture. The gas escaping from a pipeline rupture could explode or otherwise burn if a source of ignition is contacted by the gas; therefore, a larger area could be affected by a fire. Once the gas flow is shut off, there would be no residue left from the gas. In comparison, a petroleum liquids pipeline rupture would spill products that could leave behind residual product that would require a "clean-up" operation even after the pipeline had been shut off. With regards to taxpayer liability, Coos County will carry general liability insurance to cover potential losses and to limit taxpayer liability.

Question 8):

Given the fact construction activities are noisy, are the sensitive raptors, protected under the Endangered Species Act, given full consideration in the Environmental Assessment regarding their need for quiet nesting habitat (Spring survey requirements, for example)?

Answer: Any effects of construction, including noise and dust, will be of a short duration. For a typical quarter-mile section of pipe, the entire construction sequence will likely be started and finished within a week. Coos County has agreed to abide by any time-of-day and time-of-year restrictions on work for raptors and other species. All sensitive and T\&E sites have been identified through surveys, and these are directly addressed in the Terrestrial Biological Assessment (for the U.S. Fish \& Wildlife Service Letter of Concurrence) and the Environmental Assessment.

Question 9):

What are the current decisions and contingencies of the communities of Coquille, Myrtle Point, Bandon and North Bend regarding their commitment to hook up secondary (feeder) pipelines to the proposed pipeline?

Answer: $\quad$ Refer to the answer given for Question 10 for information regarding North Bend hookups. Coquille and Myrtle Point are included in the NW Natural's exclusive service territory. NW Natural has agreed to terms with Coos County that will require NW Natural to perform market surveys in each community and to construct a substantial distribution system in each town within 3 years of Coos County starting construction of the pipeline. Bandon distributes electricity within its incorporated 
area, and they have asked to be removed from NW Natural's expanded territory application with OPUC. Bandon will be asked to decide who (if any entity) will distribute gas in Bandon, before their pipeline lateral is built from Coquille.

Question 10): Exactly where (street location) are the "city gates" for the pipeline's natural gas deliveries to the cities of Coos Bay, North Bend, Coquille and Myrtle Point?

Answer: The exact location of "gate stations" will depend on the availability of a small parcel (about 50 feet square) of land. A gate station is currently planned near Ocean Blvd. in the Coos Bay / North Bend area on Water Board property. The Coquille and Myrtle Point gate stations would be along Highway 42 or existing railroad grade corridors.

Question 11): $\quad$ Is Bandon planning to hook up to the proposed pipeline?

Answer: There are no definitive plans for Bandon, until it decides its fate (refer to the answer given for Question 9).

Question 12): Will all the pipeline laterals (to areas other than Coos Bay) be in place when taxpayers begin paying down the bond for the pipeline's costs?

Answer: Yes. The laterals are included in the current project plan and cost estimates, and will be built soon after the mainline construction begins.

Question 13): Will the lateral pipelines to these "gates" impact more BLM lands?

Answer: The laterals will not be located on BLM or other Federal land.

The questions of several individuals are addressed together in Question 14.

Question 14): Given the fact (the policy decision) the proposed natural gas pipeline is supposed to attract heavy industry to the County, due to the newly available supply of "cheaper energy" (natural gas), how are the following questions answered:

a. What is driving this desire for attracting heavy industry as opposed to being content with attracting industries whose needs are met with the fiber-optic line recently established?

Answer: Natural gas will benefit ALL energy users in the service area, from existing industries to schools, hospitals and public buildings, restaurants and other businesses and individual homes. Any business "heavy" or "light" - will benefit if energy costs are lower. 
b. What are the motives of the major participants promoting this policy?

Answer: Coos County government and community leaders wish to stabilize the local economy by making the area more attractive to new and established commerce through lower energy costs.

c. Are land use planning considerations (state regulations) being utilized to determine industrial siting?

Answer: Coos County is required to follow all land use regulations.

d. Will the U.S.A. trend toward more tourism and less manufacturing cause this policy to fail simply because it is based on a false premise for promoting economic development?

Answer: Without regard to the "U.S.A. trend toward to more tourism and less manufacturing", "manufacturing" is not the only type of economic development that could possibly be attracted to Coos County as a result of the natural gas pipeline project.

e. Does the Environmental Assessment assess heavy industry's impacts (direct, indirect and cumulative effects) to the estuary, to the waters of Coos Bay, and to the waters of the oceanline?

Answer: No. The Environmental Assessment must consider impacts enabled by the pipeline construction, but it does not address speculative issues such as the impact of any or all of the thousands of possible industrial processes which use natural gas. Once a specific project is proposed, the impact of that project would be addressed in a separate document.

f. Does the Environmental Assessment assess industry-caused impacts to the visual, sound and air quality of the region surrounding the industrial park (the airport area and the North Spit)?

Answer: No. It is not possible to know what future industries, if any, will locate in the area. It is accurate to state that any use of natural gas will reduce air pollution from existing processes and energy uses.

g. Does the Environmental Assessment assess the impact to the County if retirees move out of the County to get away from the heavy industry?

Answer: No. It is not possible to state whether a possible future industry would change the quality of life in Coos County, as this is speculative. If a new industry or business is recruited for Coos County, the environmental impacts (if any) will have to be weighed against the economic impacts (if any) of the quality and quantity of jobs brought in.

h. Does the Environmental Assessment assess the impact of new heavy industry on the fishing and tourism industry already established in the County?

Answer: No, that would be a speculative assessment. 
i. Does the Environmental Assessment assess the potential for increases in the already-high risk and high incidence of lung cancer, bronchial asthma and other respiratory problems known to exist in the County?

Answer: Yes. Since most existing energy needs other than from electricity are supplied through fuel oil, bunker fuel and wood waste, the use of cleaner-burning natural gas is expected to improve air quality.

The questions of two individuals are addressed together in Question 15.

Question 15): $\quad$ Are the road systems and the railroad system leading to the potential industrial sites (the North Spit and the airport areas) adequate for the required shipments of raw materials and finished products.

Answer: This issue is not pertinent to this Environmental Assessment.

Question 16): What will be done with the industrial waste produced by the heavy industry this pipeline is supposed to attract? What level of toxic wastes from these newly introduced industries (utilizing natural gas) will be allowed to flow into the waters, the air or the soils? Will the release of such toxic wastes cause a transition from "acceptable" to "significant and unacceptable" levels of change in the ecosystems of the bay (including its estuaries) and the population (people and wildlife)?

Answer: These issues are not addressed in the Environmental Assessment, since they are not pertinent to the proposed action, which is construction and operation of a natural gas pipeline. The question issues regarding toxic wastes would be addressed through the permitting process when a specific project is proposed.

The questions of two individuals are addressed together in Question 17.

Question 17): Since the private sector found this pipeline project to be economically infeasible, and since the County failed to properly manage the land fill/incinerator facility (referring to the recent embezzlement case), what makes the County believe it will succeed in proper management of the proposed pipeline operation (which should include economic success)?

Answer: No private company would bear the risk of the pipeline investment without a guaranteed market. The Coos County project cannot be slowly developed - it is 50 miles of pipe to the first customer of any size. Most pipeline and utility companies, such as Williams and NW Natural, have dozens of projects which can earn their expected rates of return, so there is no reason for them to take much risk. The State of Oregon granted the project $\$ 24$ million to aid in economic development. With that grant covering most of the risk, the project is feasible. The County plans to contract operations and maintenance of the pipeline to experienced pipeline operators. Additionally, the County will have contracts with shippers that will ensure recovery of operating expenses. 
Question 18):

Answer: Without speculating on the "principles of Socialism", the concept of publicly owned utilities is very well proven. Most cities and towns own and operate their own water and sewer systems. Much of the country's electricity distribution is done by not-for-profit public agencies such as City of Bandon, Coos-Curry Electric and the Bonneville Power Administration. Also, the "utility" function will be served by NW Natural, not Coos County. Coos County will not be directly involved with the distribution of natural gas to the public, but rather only the transportation of natural gas to NW Natural.

Question 19):

Is there really enough evidence to support a likely improvement to the economic status of Coos County once the proposed pipeline is established?

Answer: There are dozens of pipeline extensions around the U.S. with which to compare the Coos County pipeline. In each case, natural gas captures a significant portion of the heating load within the first few years. Refer to the economic analysis in this Environmental Assessment for quantitative evidence supporting economic improvements to the County from the pipeline. (Note: The economic analysis is contained in Chapter 4 of the EIS).

The questions of several individuals are addressed together in Question 20.

Question 20):

Does the Environmental Assessment include an assessment for each of the tax implications listed below?

a. The tax burden to the County residents will be increased, due to the passage of ballot measure \# 6-63 (Nov. 1999). Indirect tax increases may result, due to the need for road improvements to accommodate the needs of heavy industry, which might be attracted to the County.

Answer: The EA is not required to review a ballot measure already voted upon. The County residents voted in a 1999 double majority (i.e., more than half the registered voters voted, and a majority of those voting approved the measure) to authorize up to $\$ 27$ million in county bonds to fund the balance of the pipeline project. Roads and road improvements are paid for with gas tax monies only.

b. The tax burden could shift if new large employers - coming to invest in the "Enterprise Zone" of the Coos Bay/North Bend area - are given 15 years of exemption from real estate taxes, plus a $62 \%$ payroll tax credit.

Answer: This issue is not pertinent to the EA. 
c. The impact of the tax burden (imposed from passage of the bond initiative approved for the pipeline project) as it relates to the scenario which lacks major industrial commitments to purchase natural gas.

Answer: The county has committed that the pipeline will not be built unless the annual operating expenses will be covered by gas transporters. NW Natural has agreed to this concept. Thus, the lack of a major industrial commitment will not affect the County's coverage of operation and maintenance costs (O\&M costs), nor will it change the cost of the project or repayment of county bonds.

d. Changes to real estate values (especially to properties of the North Spit, where heavy industry is expected to locate its facilities).

Answer: This issue is highly speculative and it is not part of the EA.

Question 21): $\quad$ Does the proposed action have potential of causing deregulation of electrical utilities in the state of Oregon?

Answer: No.

The questions of several individuals are addressed together in Question 22.

Question 22): Does the Environmental Assessment address the economic concerns listed below?

a. $\quad$ Changes to current market conditions - due to supply and demand - can and do occur; is the proposed action economically viable when such conditions change (including the pricing of natural gas, the pricing of alternate forms of energy and the pricing of manufacturing raw materials, which new industries attracted to Coos County might depend upon)?

Answer: We do not expect the economics of the pipeline project to change over time. Please review the economic assessment in this EA (Chapter 4 of the EIS). Wholesale prices of energy media (natural gas, propane, fuel oil, electricity, bunker fuel, coal, wood waste) fluctuate widely. The major energy media are traded on the commodity markets, but the prices of each of the media are related closely to one another (i.e., pricing of propane relates to pricing of natural gas and oil, and pricing of electricity relates to pricing of coal and natural gas) and they are loosely related to all of the others. In the last three decades, those price relationships have been out of synchronization only briefly. There is no fundamental reason or mechanism which should change the relationship between natural gas and its alternate forms of industrial energy. Raw materials prices are largely connected to energy prices. Therefore, the component costs of manufacturing and commerce rise and fall together (in general). 
b. The proposed action could have adverse impact to existing businesses in Coos County.

Answer: The EA includes an updated economic analysis done by ECONorthwest, which published earlier studies for use in the bond election (see Chapter 4 of the EIS). This analysis lists several propane and fuel oil businesses which may be adversely affected by natural gas availability. There are no other entities which are expected to be significantly and negatively impacted by this project.

c. The gas distribution company's actions could adversely affect future pipeline operations. (Lack of commitment, for example, to invest sufficient funds for marketing and delivering the natural gas to a suitable customer base within the County).

Answer: NW Natural has agreed to a contractual commitment to a significant construction and marketing effort which will result in widespread availability and use of natural gas.

Question 23): What arrangements will ensure the pipeline's self-sufficiency (i.e., operating costs and contingency funds will be paid on an on-going basis)?

Answer: $\quad$ Refer to the answer given for Question 20c.

The questions of two individuals are addressed together in Question 24.

Question 24):

The proposed action needs "firm capacity demands" (For example, potential customers giving Letter of Intent to purchase natural gas, or the natural gas distribution company obligates itself to purchase the amount of gas required to make the County's costs for operating the pipeline economically viable) to assure its success over the first 5 years of its operation. Are such assurances being given?

Answer: As long as the O\&M costs are a contractual obligation paid by shippers (see 20c, 22c and 23 above), the County does not need "firm capacity demands" in order to pay operating and maintenance costs.

Question 25): $\quad$ Will NW Natural pay the cost to extend the pipeline across the bay to the "North Spit"?

Answer: $\quad$ Yes - NW Natural or some entity other than Coos County will pay for the cost of the connection to the North Spit.

Question 26): What "surcharges" could be applied (by Northwest Natural Gas) to the gas users? Under what conditions would these surcharges be applied?

Answer: There is currently no plan by NW Natural to charge a "surcharge" to Coos County gas customers. 
Question 27):

Answer:

Question 28):

Answer:

Why was the MOU between the County and BLM not available to the public until four months after it was created?

The MOU is a public document, which has been discussed for months. It has been available upon request since its execution last summer (2000).

Where is the County's "Plan of Development" for the proposed action?

There is no section titled "Plan of Development" in the EIS, but wording equivalent to that required by a "Plan of Development" is included in EIS; incorporating descriptions of the project, the project route and the construction processes required to complete the project.

Question 29):

Are the BPA studies (for the Draft EIS for the 500 kilowatt [Kw] transmission line project) truly qualified as a source of data for the Environmental Assessment of the proposed corridor, since this Draft EIS never received public review?

Answer: The BPA process gathered a lot of pertinent information on the exact route now deemed the preferred route. The information also received public review through public meetings, although the EIS was never finalized. The Project Advisors and B.I.S., Inc. have added much pertinent information to the BPA efforts. All of the old and new data will be analyzed and available for review.

Question 30): What assurances (documentation) can the following entities give to show an unbiased approach to the EIS (no financial interest will accrue to them upon acceptance of this project, and they have no other interest driving them toward causing the acceptance outcome of this project)?
a). Coos Bay BLM District
b). Pipeline Solutions Inc.
c). Industrial Gas Services, Inc.
d). BIS, Inc.
e). Coos County Commissioners

Answer: A statement of financial disclosure was submitted to the BLM for the Project Advisors (Pipeline Solutions, Inc. and Industrial Gas Services, Inc.) and for the environmental contractor, BIS, Inc. The Coos County Commissioners represent Coos County. Although Coos County will economically benefit from the proposed action, the Coos County Commissioners, as publicly elected officials, are prohibited by state law from personally receiving economic benefit from the proposed pipeline project. The Coos Bay BLM District is the agency overseeing development of the EA (and subsequent EIS) and thus can have no financial interest or benefit accruing from approval of the proposed action. 
Question 31):

Answer:

Question 32):

Answer:

Question 33):

Answer:
There have been indications that the proposed route will cross some Indian campgrounds and burial grounds. Have the affected tribes been consulted?

The pipeline rights-of-way were purposely chosen to avoid known Indian archaeological sites. The Indian tribes in Coos County have been consulted throughout the entire permitting process and will identify any areas of concern. Additionally, representatives from the Indian tribes will be on site or readily available during construction to help identify any archaeological sites located during construction.

Will the EIS determine the effects to the environment if the pipeline were subject to rain storms causing normal and abnormal landslides in the notoriously unstable Coastal Mountain range? The 100 year flood event must be considered.

The pipeline rights-of-way were purposely chosen to avoid potential slide areas. Geotechnical concerns, including the possible impact of a "100 year flood event", have been addressed in the geotechnical report.

I am confused about the relationship of the different players, specifically: BLM, the County, Project Advisors, Pipeline Solutions, Inc., Industrial Gas Services, Inc. and Biological Information Specialists. The Information for Environmental Assessment states that the "Project Advisors cannot prepare the EA." But the project advisors and the regional firm selected to prepare the EIS, BIS, have the same e-mail address. Is it true that the consultants, Industrial Gas Services and Pipeline Solutions have no financial or other interest in the outcome of the Environmental Analysis? Did they also sign a Statement of Financial Interest as required by 40 CFR 1506.5 (c)?

Steve Shute is principal of Pipeline Solutions, Inc., and Steve and Bob Oxford are Vice President and President, respectively, of Industrial Gas Services, Inc. Both companies are jointly under contract with Coos County as Project Advisors.

Neither company has a financial ownership interest in the pipeline project nor has the BLM required either company to file a Statement of Financial Interest. In order to address the concern presented above, both companies have signed a Statement of Financial Interest and that Statement is on file with the BLM. Biological Information Specialists, Inc. (BIS) is a contractor hired by the County to perform the environmental work required by the BLM's MOU and revised MOU. As a contractor performing environmental services, BIS has signed and filed a Statement of Financial Interest with the BLM. Brian Cox is the principal contact with BIS for the EIS work.

The "coosproj" e-mail address was set up as a convenient site to use when collecting comments during the EA process. All comments received at the coosproj address were also forwarded to the BLM 
and to BIS. Occasionally, a Project Advisor responded directly to comments received at the coosproj e-mail address but those comments were also forwarded to others involved in the project.

Question 34): Will the Environmental Assessment be released by the BLM for public review?

Answer: The EA was never completed and is not considered a final document by the BLM. Because the EA was not completed, it will not be released to the public. An EIS is being prepared and will be available to the public for review and comments.

Question 35): I have concerns regarding the fact that the Environmental Assessment study plans to utilize studies done by BPA for the Transmission Line EIS but which have not even been published in draft form for public perusal. I question the use of such studies in a process which has the potential for bypassing public input.

Answer: Questions about an EA are moot because the Coos Bay BLM has decided to abandon work on an EA and to begin work on an Environmental Impact Statement. The terms under which that work will be performed were clearly stated to the public and are addressed in the BLM's revised Memorandum of Understanding (MOU) with Coos County. Terms and conditions under which Coos County may construct a pipeline in the BPA corridor are still under negotiation.

Question 36): When the leak or explosion occurs deep in the back country, will we have insurance to cover such a disaster, and will this infringe on private property owners as well?

Answer: Coos County will carry general liability insurance to cover damage incurred to property owned by others in the event of a pipeline leak or explosion.

Question 37): $\quad$ Since the taxpayers bond is only to take the pipeline to the gates of the cities, is everyone in agreement that NW Natural will pay the cost to cross the bay and not the taxpayers?

Answer: We do not know if "everyone is in agreement" but NW Natural has agreed with Coos County that NW Natural rather than Coos County will construct a pipeline across Coos Bay to the North Spit. Coos County pipeline construction funds will not be used to construct the Coos Bay pipeline crossing. 


\section{Comments from the Public}

The following comment is a compilation of the sentiments of several individuals.

1.) Comment: WE DON'T NEED THE PIPELINE! The rationale supporting heavy industrial development, which the pipeline is supposed to attract, does not address the needs of the public. The chief asset to coastal Southern Oregon - a high quality of life - will be threatened by the pollution of heavy industry. There are many concerned citizens who did not want the pipeline bond; the measure passed by a margin of $300+$ votes - this is a small margin.

Response:The EA does not address speculative issues or voting margins.

2.) Comment: We strongly support construction of the pipeline. Please do all you can to further this project.

Response:Thank you for your positive support.

3.) Comment: I favor getting natural gas to Coos County, but I have concerns about the project's appearance of economic irrationality.

Response:Please see the economic assessment in this EA (Chapter 4 of the EIS).

4.) Comment: The County officials have listed the following industries as "desirable heavy industry" for the County: Steel mills, and manufacturers of plastics, glass and gypsum. It appears they will welcome any heavy industry. These heavy industries are also heavy polluters. There is no evidence the regulatory agencies (EPA and DEQ) will provide the County any locally tailored protection against these toxins.

Response:The EA does not address speculative issues. It is unknown which industries may or may not attempt to develop facilities in the future. 
5.) Comment: The availability of natural gas in Coos County will not, in and of itself, attract industry to the area.

Response:Please see the economic assessment in this EA This question has been addressed in numerous public meetings and it has been publicly stated that the availability of natural gas, in and of itself, is not the sole factor that any new business ("industry") would use to determine whether or not to choose a site in Coos County.

The following comment is a compilation of the sentiments of several individuals.

6.) Comment: We feel the process currently underway - Environmental Assessment of the pipeline project - is flawed. The public deserves ample opportunity to provide input after the release of the Environmental Assessment. When the Environmental Assessment explores the possible direct and indirect environmental and socio-economic effects of enabling establishment of heavy industry on the North Spit and near the airport, the need for a full Environmental Impact Study (an EIS) will be evident.

Response:Please see the economic assessment in this EA (Chapter 4 of the EIS) and the response to Comment \#4. Additionally, the BLM and Coos County have decided to prepare an EIS in consideration of these comments. The public will have the opportunity to review and comment on the EIS.

7.) Comment: This gas line is a very bad thing. It destroys the CBW Road and it causes grave damage to the creatures inhabiting the proposed pipeline corridor.

Response:Virtually no damage to the CBW Road or creatures in the corridor is anticipated. Any effects will be so insignificant as to be unmeasurable (i.e., negligible).

8.) Comment: The way natural gas prices are soaring, no one will be able to afford hooking up to the gas.

Response:All forms of energy presently used in Coos County have suffered significant price increases during the past year. 
9.) Comment: I would like to see this issue resubmitted to the voters of Coos County. The County Commissioners failed to properly inform the voters of all the pertinent factors prior to the original vote.

Response: EAs do not assess public votes.

10.) Comment: We should ask for the help of Representative Peter DeFazio. He should oversee this Environmental Assessment process.

Response:He is welcome to comment on this EA, as are all citizens.

11.) Comment: My family and I strongly support construction of the natural gas pipeline. The few noisy people...want nothing that will cost any taxes regardless of the long-term benefits of any project. They do not represent the majority of us in Coos County. Please do all you can to further this project.

Response:Thank you for your support. 


\section{Appendix H. Erosion Control Plan}




\title{
Appendix H. $\quad$ Erosion Control Plan
}

\begin{abstract}
NOTE: A pipeline-utility construction ECP for the Army Corps of Engineers is being developed and will be included in this Appendix for the final version of the Coos County Pipeline EIS
\end{abstract}

Table H-1: Fish-bearing Streams Identified for Avoiding Ground Disturbance within them.

\begin{tabular}{|c|c|c|}
\hline Stream & Description & \\
\hline East Fork & East Fork Coquille Watershed & place on 2 bridges \\
\hline Brummit Creek & East Fork Coquille Watershed & directional-drill \\
\hline China Creek & East Fork Coquille Watershed & in road over culvert \\
\hline Steel Creek & East Fork Coquille Watershed & place on bridge \\
\hline Hantz Creek & East Fork Coquille Watershed & in road over culvert \\
\hline Cherry Creek & East Fork Coquille Watershed & directional-drill \\
\hline North Fork & North Fork Coquille Watershed & directional-drill \\
\hline Panther Creek & Lower Coos River/Coos Bay Watershed & in road over culvert \\
\hline Cardwell Creek & Lower Coos River/Coos Bay Watershed & in road over culvert \\
\hline Catching Creek & Lower Coos River/Coos Bay Watershed & directional-drill \\
\hline Isthmus Slough & Lower Coos River/Coos Bay.Watershed & directional-drill \\
\hline Shinglehouse Slough & North Fork Coquille Watershed & directional-drill \\
\hline
\end{tabular}

\section{Best Management Practices (BMPs)}

The BMPs are measures used during construction activities to minimize potential impacts to the aquatic environment to the point where those impacts become negligible. The BMPs for the proposed actions are as follows:

- Prior to activities, apply an additional lift of rock to the area of road that can influence the stream if rill erosion is evident in the road tread near live stream crossings.

- Contain any offsite movement of sediment from the road or ditchflow near streams using silt fence or sediment entrapping blankets. Such control measures must allow for the free passage of water without detention or plugging. These control structures and applications should receive frequent maintenance and will be removed upon completion of that pipeline construction segment.

- All construction operations will utilize sediment barriers throughout the entire CBW Road corridor and within 100 feet of all stream crossings when working in the utility corridor.

- All streams except Rock Creek, Morgan Creek and Tenmile Creek, with greater than 0.2 cubic foot per second (cfs) flow-rates, will be directionally-drilled, trenched in road fill or have the pipe placed on bridges to avoid sedimentation impacts. 


\section{Active Stream Crossing Project Design Criteria (PDC)}

PDCs are preventive measures applied to project activities to minimize potential detrimental effects to proposed, listed, or candidate species.

\section{Minimization and Avoidance}

BMPs for surface and shoulder activity types will include:

- Eliminating diesel as a releasing or cleaning agent.

- Using environmentally sensitive cleaning and releasing agents.

- Using heat sources to heat and clean tack nozzles during operations.

- Carrying adequate erosion control supplies and keep materials out of water bodies.

- Disposing of excess material at appropriate sites, depending upon material being disposed.

\section{Timing}

All in-stream work activities will take place during the "work-in-the dry period" of July 1 through September 15.

\section{Utility Stream Crossing}

Definition: A strategy for crossing small waterways when in-stream utility construction is involved. Purposes:

1) To prevent sediment from entering the stream from construction within approach areas.

2) To minimize the amount of disturbance within the stream and riparian area.

\section{Conditions Where Practice Applies:}

Generally applicable to small perennial and intermittent streams with drainage areas less than 130 hectares (ha). Methodology for crossing streams with larger drainage areas or to avoid designated sensitive crossings, will be directional-drilled, hanging pipe on bridge or trenching above culverts on CBW Road fill.

\section{Planning Considerations:}

Directionally-drilling a pipe below the streambed, which would avoid disturbance within the watercourse, is the preferred method if it is practical. However, in cases where it is impractical and where in-stream work is unavoidable, consideration must be given to providing adequate mitigation of sediment loss while minimizing the amount of encroachment and time spent working in the channel. There is some "give and take" as far as the installation of controls. Sometimes there is less damage to the environment created by providing substantial controls for the approach areas and by refraining from installing extensive measures in the stream itself. However, if the installation of the utility line within the streambed and its banks will take an extended period of construction time (more than 72 hours), substantial in-stream controls or stream diversion is necessary to prevent excessive sedimentation damage. For the action alternatives, all stream-crossings that will not be directionally-drilled will take far less than the 72-hour recommendation for utility line crossing using the "Bag and Flume" technique. The "Bag and Flume" method utilized in pipeline construction will take 6-8 hours per stream crossing.

The following is the method the action alternatives would use for dealing with utility stream crossings; these criteria allow for "work in the dry" conditions to prevent sedimentation in flowing streams ( 21 total for the proposed action):

- The water flow will not exceed $0.2 \mathrm{cfs}$.

- Filter cloth should be used in the construction of the utility crossing.

- Water diverting structures ("Bag and Flume") should be used at all trenching and/or construction road approaches 30 meters (100 feet) on either side of the crossing. 


\section{For "Bag-and-Flume" Stream Trenching:}

1) The drainage area should be no greater than 130 ha (320 acres).

2) Filter cloth should be used in the construction of the utility crossing.

3) Water diverting structures should be used at all trenching and/or construction road approaches 30 meters (100 feet) on either side of the crossing.

\section{"Bag and Flume" Construction Specifications}

\section{Flume Pipe Crossing (Bag \& Flume)}

To be used when in-stream construction will last less than 72 hours and stream is narrow, with less than $0.2 \mathrm{cfs}$ flow, making "directional-drilling" construction impractical. This will be the method used to trench flowing streams. See Figure H-1, next page.

The flume pipe crossing must be made operational prior to the start of construction in the stream.

A large flexible flume pipe of an adequate size to support normal water channel flow shall then be installed in the streambed across the proposed action's trench centerline. Sandbags shall be placed close to each end of the flume pipe so as to dam off the creek forcing the water to flow through the flume pipe (see Figure $\mathrm{H}-1$ on next page).

The entrapped water can then flow from the creek within the dammed-off area and in the trench centerline back into the bypassed stream. The trench can then be dug adjacent to the flume pipe. The pipe sections will then be installed to the proper depth. After pipeline sections are installed, the ditch will be back-filled and restabilization shall be carried out. Turbid water in newly dug trenches will be pumped onto a vegetative floodplain or gentle hillslope, where it can filter-out fine sediments naturally.

Restabilization shall consist of the installation of ungrouted riprap on all disturbed streambank areas (or on the area 3 meters on both sides of the centerline of the utility trench, whichever is greater) with slopes of 3:1 or greater. For slopes of 3:1 or less, vegetative stabilization with mulching may be used. Stabilization of streambeds, banks and the approach areas will occur immediately following the attainment of final grade.

After completion of back-filling operation and restoration of stream/creek banks and leveling of streambed, the flume pipe can then be removed. The gravel can be removed or spread in the streambed depending on permit requirements. Sediment control in approach areas shall not be removed until all construction is completed in the stream/creek crossing area. All ground contours shall be returned to their original condition.

\section{Maintenance}

Care must be taken to inspect any stream crossing area at the end of each day to make sure that the construction materials are positioned securely. This will ensure that the work area stays dry and that no construction materials float downstream. 
Figure H-1: Stream Crossing: Trenching across an active stream bed

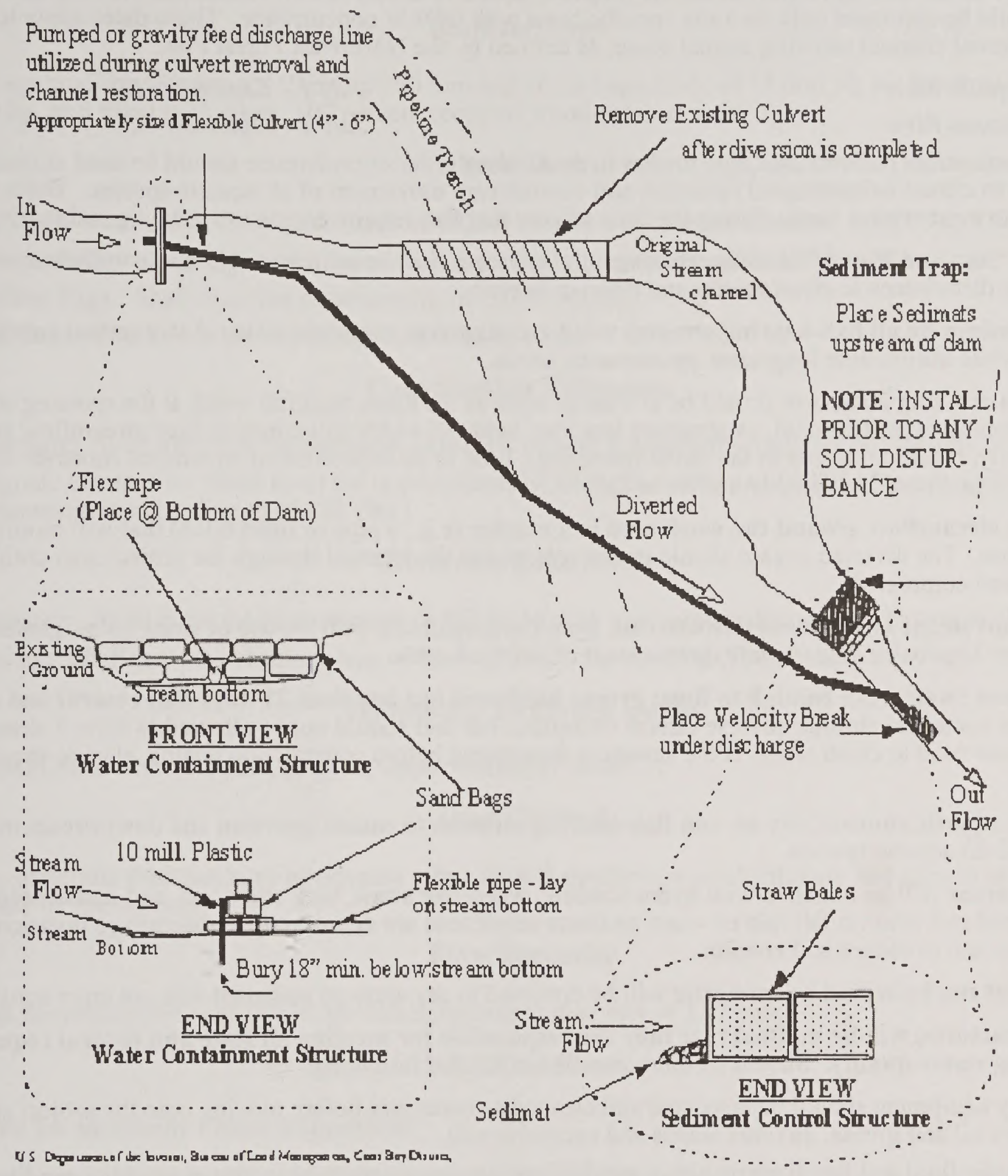




\section{Project Design Criteria for Culvert Installation and Removal}

-The ODFW in-stream work period for the proposed action is shown below. Needs for working outside these time periods would be approved only on a site specific basis with ODFW concurrence. These dates apply to any intermittent or perennial channel showing annual scour, as defined by the Northwest Forest Plan.
Coquille River
July 1 - September 15
Umpqua River
July 1 - September 15

-Bridges, bottomless culverts and pipe arches in descending order of preference should be used at road crossing on fish habitat to ensure uninterrupted upstream and downstream movement of all aquatic species. Water velocity is generally the most critical factor during the time of year that fish require access to spawning and rearing areas.

- At all 21 "Bag and Flume" stream crossings, the approach will be as near a right angle to the stream as possible to minimize disturbance to streambanks and riparian habitat.

- Road crossings on all fish-bearing streams will be designed to maintain natural streambed substrate and site gradient, while minimizing long-term maintenance needs.

-Width of a crossing structure should be at least as wide as the mean bankfull width at the crossing site; to be measured by a qualified professional. A structure less than bankfull width will constrict high streamflow and increase water velocity, resulting in sour at the outlet (perching), little to no deposition of streambed substrate in closed bottom structure and possible velocity barrier to fish.

-Divert the streamflow around the work area in a manner (e.g., a pipe or lined ditch) that will minimize stream sedimentation. The diverted stream should not be returned to the channel through the project area until all in-stream work has been completed.

- Reduce movement of sediment downstream from the project site with the use of straw bales, geotextile fabric or coconut fiber logs/bales immediately downstream of the work area.

-Wet or green (wet: fresh enough to flow; green: hardened but less than 21 days old) cement and new or old asphalt have acute and chronic adverse effects on aquatic life and should not be allowed to enter a stream. This includes water used to clean tools. If the stream is de-watered before construction begins, aquatic species will be unaffected.

- Maintain aquatic connectivity on non fish-bearing streams. to ensure upstream and downstream movement of other (non-fish) aquatic species.

- Bare soil areas will be mulched with hydro-seeding, weed-free straw, bark chips, etc. and native seed or other approved seed mix prior to fall rain or when moisture conditions are appropriate to discourage invasion of noxious plant species and to reduce soil erosion.

- Location of stockpile and borrow sites will be confined to dry areas so sediment will not enter aquatic resources.

- The contractor(s) will be notified that they are responsible for meeting all state and federal requirements for maintaining water quality. Standard contracts will include the following:

- Heavy equipment should be inspected and cleaned as necessary before moving onto the project site in order to remove oil and grease, noxious weeds and excessive soil.

- Hydraulic fluid and fuel lines on heavy mechanized equipment must be in proper working condition in order to minimize leakage into streams

- Waste diesel, oil, hydraulic fluid and other hazardous materials and contaminated soil near the stream will be removed from the site and disposed of offsite and in accordance with DEQ regulations. Areas that have been saturated with toxic materials would be excavated to a depth of 12 inches beyond the contaminated material or as required by DEQ.

- Equipment refueling would be conducted within a confined, secured area outside the stream channel such that there is minimal chance that toxic materials could enter a stream.

- Use spill containment booms or kits as required by DEQ.

- Equipment containing toxic fluids should not be stored in a stream channel anytime.

- Construct a rock apron at a culvert outlet as insurance that water velocity through a new culvert will not cause "perching": a rock apron consists of burying 1-3 foot diameter rock at the culvert outlet across the stream channel. 


\section{Approved Materials for Use - ODOT Construction Manual}

\section{Biofilter Bags}

Biofilter bags shall be $460 \mathrm{~mm} \times 150 \mathrm{~mm} \times 760 \mathrm{~mm}$ minimum bags made of $13 \mathrm{~mm}$ plastic mesh, weighing approximately $20 \mathrm{~kg}$, and filled with clean, 100 percent recycled wood-product waste.

\section{Check Dams}

- Aggregate: Shall meet the requirements of 00330.16 with a maximum diameter from 75 to $150 \mathrm{~mm}$.

- Straw Bale: Standard rectangular bales shall meet the requirements of 00280.10 (n)(6).

- Biofilter Bags: Shall meet the requirements of 00280.10(a).

- Sand Bags: Shall meet the requirements of 00280.10(1).

\section{Construction Entrances}

- Aggregate: Shall meet the requirements of 00330.16 with a maximum diameter of $150 \mathrm{~mm}$.

- Subgrade Geotextile: Shall meet the requirements of Sections 00350 and 02320. Provide written "Level B" documentation according to 02320.10 (c).

\section{Diversion Dike/Swale}

- Aggregate: Shall meet the requirements of 00330.16 with a maximum diameter of $25 \mathrm{~mm}$ to $100 \mathrm{~mm}$.

- Seeding: Shall meet the requirements of Section 01030 for Seeding (Temporary).

\section{Temporary Drainage Curbs}

Commercial Grade Concrete shall meet the requirements of 00480.11.

\section{Dust Control}

Non-toxic materials shall not have an adverse effect on soil structure or establishment and growth of vegetation, and be approved by the Agency.

\section{Flow Spreader}

Shall meet the requirements of 00330.16 with a maximum diameter of $150 \mathrm{~mm}$.

\section{Inlet Protection}

\section{Geotextile for Sediment Fence, Supported:}

Shall meet the requirements of Sections 00350 and 02320. Provide written "Level B" documentation according to $02320.10(\mathrm{c})$.

\section{Aggregate:}

Shall meet the requirements of 00330.16 with a maximum diameter of $25 \mathrm{~mm}$ to $100 \mathrm{~mm}$.

\section{Biofilter Bags:}

Shall meet the requirements of 00280.10 (a). 
4. Stakes: Shall be as follows:

- Supported Sediment Fence: Commercial grade metal posts weighing at least $2 \mathrm{~kg} / \mathrm{m}$.

- Unsupported Sediment Fence: $38 \mathrm{~mm} \times 38 \mathrm{~mm} \times 1,200 \mathrm{~mm}$ minimum wooden posts.

- Bio-filter Bags: $25 \mathrm{~mm} \times 50 \mathrm{~mm} \times 450 \mathrm{~mm}$ minimum wooden posts.

\section{Wire Mesh:}

Shall be one millimeter gauge steel-wire mesh with $10 \mathrm{~mm} \times 10 \mathrm{~mm}$ openings.

\section{Concrete Masonry Unit:}

Shall be $200 \mathrm{~mm} \times 200 \mathrm{~mm} \times 400 \mathrm{~mm}, 70 \mathrm{~kg}$ concrete building blocks with two $140 \mathrm{~mm} \times 140 \mathrm{~mm}$ openings and $25 \mathrm{~mm}$ minimum outer wall thickness.

\section{Sod}

Grass sod shall be grown on agricultural land that is cultivated specifically for turf sod. Sod shall be free of weeds, diseases, nematodes and insects. Sod shall be mature and not less than 10 months old.

Sod shall be machine cut to a uniform thickness of $16 \mathrm{~mm}$ or more, excluding top growth and thatch. Broken pieces and torn or uneven ends will not be accepted. Sod shall be planted within 36 hours of harvest.

\section{Prefabricated Filter Insert:}

Shall be manufactured specifically for collecting sediment in drainage inlets. The insert shall consist of a porous, geotextile material and include handles and/or fasteners sufficient to keep the insert from falling into the inlet during maintenance and removal of the insert from the inlet (such as rebar, per 02510.0, sewn into the fabric).

\section{Matting:}

Materials tested by Texas DOT/TTI Hydraulics and Erosion Control Laboratory shall meet the performance criteria for the following categories:

- (a) (Type A) - Slope protection mat for slopes 1:3 or flatter - clay soils

-(b) (Type B) - Slope protection mat for slopes 1:3 or flatter - sandy soils

- (c) (Type C) - Slope protection mat for slopes steeper than 1:3 - clay soils

-(d) (Type D) - Slope protection mat for slopes steeper than 1:3 - sandy soils

- (e) (Type E) - Flexible channel liner for shear stress from 0-96 Pa.

-(f) (Type F) - Flexible channel liner for shear stress from 0-192 Pa.

- (g) (Type G) - Flexible channel liner for shear stress from 0-287 Pa.

- (h) (Type H) - Flexible channel liner for shear stress from 0-383 $\mathrm{Pa}$.

- (i) Check Slot - Shall be as follows:

a) Channel Application: Compacted class 25 riprap shall meet the requirements of Section 00390 .

b) Slope Application: Compacted native material.

- (j) Staples: Shall be heavy duty pins or U-shaped wires staples as follows:

a) Staples: $2 \mathrm{~mm}$ gage steel wires staples. $25 \mathrm{~mm}$ "U" width with a length of $150 \mathrm{~mm}$ for cohesive soils and $200 \mathrm{~mm}$ minimum for non-cohesive soils.

b) Pins: $4.75 \mathrm{~mm}$ diameter steep pin with a $50 \mathrm{~mm}$ diameter steel washer secured at the head of the pin. The length shall be $450 \mathrm{~mm}$ minimum.

All mat blanket, staple and other materials shall meet or exceed the manufacturer's specifications and recommendations. Provide the manufacturer's material and installation specifications to the Agency prior to installation. 


\section{Temporary Mulching:}

Shall be free of noxious weed seeds, plants and other substances detrimental to plant life. The kind of mulch material(s) acceptable for use will be as shown, specified or approved.

A) Hydromulching: Cellulose fiber shall be produced from a single, or combination of, virgin wood or straw, or paper fiber product(s) approved by the Agency.

Process the wood or straw mulch so that the fibers remain uniformly suspended under agitation in water. The processed mulch shall have the ability to cover and hold grass seed in contact with soil and shall exhibit no growth or germination-inhibiting factors. The wood or straw fiber shall have moisture-absorption and percolation properties to form a blotter-like ground cover.

Ship wood or straw cellulose fiber in packages of uniform mass (plus or minus 5 percent) and label with the manufacturer's name and air-dry mass.

B) Straw: Straw mulch for non-hydroseeding applications shall be straw from bentgrass, bluegrass, fescue or ryegrass singly or in combination. If no grass seed straw is available, straw from barley, oat, or wheat is allowed if approved by the Agency. The straw shall not be moldy, caked, decayed or of otherwise low quality. Submit verification from the supplier that the straw is free of noxious weeds. Acceptable documentation submitted shall show either (1) that the straw source is from an "Oregon Certified Seed" field, or (2) the seed lab test results of the seed harvested from the straw meet minimum Oregon Certified Seed quality for weed seed content. The minimum requirements of Oregon certified seed are as published in the current year's Oregon Certified Seed Handbook available from County Extension Offices or Oregon State University.

C) Tackifier: Shall be commercially available, containing no agents toxic to plant life. The tackifier shall be either a liquid stabilizing emulsion or a dry powder tackifier complying with the following:

Liquid Stabilizer Emulsion - Shall be a liquid polyvinyl acetate using emulsion resins and containing 60 percent (plus or minus 1 percent) total solids by mass. When diluted with water, and upon drying, the emulsion shall form a transparent, net-like film having a permeability that allows exchange of air and moisture and has an effective life of one year or more.

Dry Powder Tackifier - Shall consist of one or more active hydrocolloids from natural plant sources which will hydrate in water and blend with other slurry materials. Upon application and drying it shall tack the slurry particles to the soil surface, and exhibit no growth or germination-inhibiting factors.

\section{Plastic Sheeting:}

Plastic slope protection, anchor system and erosion protection at the toe of the plastic shall conform to the following:

A) Plastic Sheeting - Polyethylene plastic with a minimum thickness of $0.15 \mathrm{~mm}$.

B) Anchoring System - Shall conform to the following:

Anchoring weights - $30 \mathrm{~kg}$ minimum each, with non-puncture characteristics.

Tethers - Cords or ropes with adequate strength to support the anchoring weights on the slope.

C) Chain Link Fence - New or used material shall meet the requirements of 03010.20.

D) Stakes - Commercial grade metal posts shall weigh at least $2 \mathrm{~kg} / \mathrm{m}$.

E) Toe Protection - Class 25 rip rap shall meet the requirements of Section 00390.

\section{Sandbags:}

$610 \mathrm{~mm} \times 300 \mathrm{~mm} \times 150 \mathrm{~mm}$ durable, weather-resistant, tightly woven bags sufficient to prohibit leakage of filler material. Bags shall be filled with firmly packed sand filler material weighing at least $34 \mathrm{~kg}$.

\section{Temporary Scour Holes:}

Class 50 riprap shall meet the requirements of Section 00390. 
14. Sediment Barrier:

A) Bio-filter Bag - Shall meet the requirements of 00280.10(a).

B) Brush Barrier - Shall consist of woody debris $150 \mathrm{~mm}$ in diameter maximum, or topsoil strippings. Sediment Fence Geotextile shall meet the requirements of Sections 00350 and 02320 . Provide written "Level B" documentation according to 02320.10(c).

C) Filter Berm and Rock Filter - Aggregate shall; meet the requirements of 00330.16 with a maximum diameter of $25 \mathrm{~mm}$ to $100 \mathrm{~mm}$. Subgrade Geotextile shall meet the requirements of Sections 00350 and 02320. Provide written "Level B" documentation according to 02320.10(c).

D) Sand Bags - Shall meet the requirements of 00280.10(1).

E) Stakes - Shall conform to the following:

Biofilter Bags - $25 \mathrm{~mm} \times 50 \mathrm{~mm} \times 450 \mathrm{~mm}$ minimum wood posts.

Brush Barrier - $25 \mathrm{~mm} \times 50 \mathrm{~mm} \times 450 \mathrm{~mm}$ minimum wood posts.

Straw Bales $-38 \mathrm{~mm} \times 25 \mathrm{~mm} \times 900 \mathrm{~mm}$ minimum wood posts.

Wattle $-25 \mathrm{~mm} \times 25 \mathrm{~mm} \times 600 \mathrm{~mm}$ minimum wood posts.

F) Straw Bale - Shall be standard $20 \mathrm{~kg}$ to $30 \mathrm{~kg}$ rectangular bales that are wire-bound or string-tied. Straw material shall be straw from bentgrass, bluegrass, fescue, or ryegrass singly or in combination. If no grass seed straw is available, straw from barley, oat or wheat is allowed if approved by the Agency. The straw shall not be moldy. caked, decayed or of otherwise low quality. Submit verification from the supplier that the straw is free of noxious weeds. Acceptable documentation submitted shall show either (1) that the straw source is from an "Oregon Certified Seed" field, or (2) the seed lab test results of the seed harvested from the straw meet minimum, Oregon Certified Seed quality for weed seed content./ The minimum requirements of Oregon certified seed are as published in the current year's Oregon Certified Seed Handbook available from County Extension Offices or Oregon State University.

G) Wattle - Shall be manufactured from rice or coconut straw and shall be between $200 \mathrm{~mm}$ and $260 \mathrm{~mm}$ in diameter. The straw shall not be moldy, caked, decayed or of otherwise low quality. Submit verification from the supplier that the straw is free of noxious weeds. Acceptable documentation submitted shall show the seed lab test results of the seed harvested from the straw meet minimum Oregon Certified Seed quality for weed seed content. The minimum requirements of Oregon certified seed are as published in the current year's Oregon Certified Seed Handbook available from County Extension Offices or Oregon State University. The straw shall be wrapped in a tubular plastic netting. The netting shall have a minimum strand thickness of $0.08 \mathrm{~mm}$, a knot thickness of $1.4 \mathrm{~mm}$, and a weight of 32.6 grams per meter (plus or minus 10 percent) and shall be made from 85 percent high density polyethylene, 14 percent ethyl vinyl acetate and 1 percent color for UV inhibition.

15. Sediment Fence:

A) Geotextile - Shall meet the requirements of Sections 00350 and 02320 . Provide written "Level B" documentation according to 02320.10 (c).

B) Posts - Shall conform to the following:

Sediment Fence, Supported - Commercial grade metal posts weighing at least $2 \mathrm{~kg} / \mathrm{m}$.

Sediment Fence, Unsupported - $38 \mathrm{~mm}$ x $38 \mathrm{~mm}$ x $1200 \mathrm{~mm}$ minimum wooden posts.

C) Wire Mesh - $2 \mathrm{~mm}$ gauge steel-wire mesh with $51 \mathrm{~mm}$ x $51 \mathrm{~mm}$ openings. A perforated polymeric mesh of equivalent grab tensile strength $(3100 \mathrm{~N})$, in accordance with ASTM D4632, may be substituted for the steel-wire mesh.

16. Temporary Sediment Trap:

A) Geotextile - Shall meet the requirements of Sections 00350 and 02320. Provide written "Level B" documentation according to 02320.10 (c).

B) Aggregate and Rock - Shall meet the requirements of 00330.16 with a maximum diameter varying from 19 to $38 \mathrm{~mm}$ for aggregate and 75 to $150 \mathrm{~mm}$ for rock. 


\section{Temporary Slope Drains:}

Shall meet the requirements of Section 02410 for plastic pipe, or Section 02420 for metal pipe. End sections, pipe stubs and elbow sections shall be from 150 to $300 \mathrm{~mm}$ in diameter. Refer to the plans and special provisions for contributing area and diameter. If the contributing area is not established, use $300 \mathrm{~mm}$ diameter.

\section{Slope Berm:}

Shall be common material used for embankment construction or aggregate.

A) Aggregate: Aggregate Base material shall meet the requirements of 00330.16 with a maximum diameter of $25 \mathrm{~mm}$ to $100 \mathrm{~mm}$.

19. Tire Wash Facility:

A) Aggregate: Aggregate Base material shall meet the requirements of Sections 00641 and 02630.

B) Reinforcing Steel: Reinforcing steel shall meet the requirements of 02510.10 , with a minimum diameter of $22.2 \mathrm{~mm}$.

C) Geotextile: Subgrade geotextile shall meet the requirements of Sections 00350 and 02320 . Provide written "Level B" documentation according to $02320.10(\mathrm{c})$.

\section{Mulching Application Specifications}

\section{Straw Mulch}

Apply on slopes 1:1.5 or flatter. Spread straw mulch by hand or blower. Place approximately $50 \mathrm{~mm}$ deep, in loose condition, at a rate between 4.5 and $6.7 \mathrm{Mg} / \mathrm{ha}$ of dry mulch. Place straw mulch so that it is loose enough for sunlight to penetrate and air to circulate, but dense enough to shade the ground, reduce water evaporation, and materially reduce soil erosion. Anchor using hydraulically applied tackifier, crimping disc, or sheep's-foot roller approved by the Agency or methods specified in the special provisions.

- Blower - Blower equipment shall use air pressure with an adjustable spout that uniformly applies dry mulch at constantly measured rates. Apply the materials using a sweeping, horizontal motion of the nozzle.

\section{Hydromulch}

Place waterborne cellulose fiber material using hydraulic equipment which continuously mixes and agitates the slurry and applies the mixture uniformly through a pressure-spray system providing a continuous, nonfluctuation delivery. Distribution and discharge lines shall be large enough to prevent stoppage and be equipped with a set of hydraulic discharge spray nozzles that will provide a uniform distribution of the slurry. Apply the materials using a sweeping, horizontal motion of the nozzle. Hydraulically apply at the following spread rates:

- Slopes $1: 1.5$ or flatter $-2.7 \mathrm{Mg} / \mathrm{ha}$ based on dry fiber weight.

- Slopes steeper than $1: 1.5-3.4 \mathrm{Mg} /$ ha cellulose fiber material that incudes a tackifier.

\section{Tack - Hydraulically Applied}

Hydromulch or straw mulch may be tackified using hydraulically applied liquid stabilizer emulsions or dry powder tacking agents at the following rates of application:

a) Liquid Stabilizer Emulsions - Apply at the following liters per hectare rates unless the manufacturer recommends a greater rate of application:

- Long term control of exposed soil surfaces: 325 1/ha diluted at 20:1. For steep slopes with raveling small rocks: 435 1/ha diluted at 10:1. 
- Seeding, Fertilizing or Mulching: 270 1/ha diluted at 30:1.

- Dust Control: 270 1/ha diluted with water at a ration of 30:1.

b) Dry Powder Tackifier - Apply at the following kilograms per hectare rates unless the manufacturer recommends a greater rate of application:

- $1: 2$ slopes and flatter: $67 \mathrm{~kg} / \mathrm{ha}$ mixed with hydromulch fibers at the rate specified.

- Slopes steeper than 1:2: $112 \mathrm{~kg} / \mathrm{ha}$ mixed with hydromulch fibers at the rate specified.

- Overspray for tacking pre-applied combinations of or singularly applied straw mulch, seed, or fertilizer: 90 $\mathrm{kg} / \mathrm{ha}$ with $880 \mathrm{~kg}$ of hydromulch fiber.

- Dust control and short term stabilization of exposed soil surfaces: $157 \mathrm{~kg} / \mathrm{ha}$.

\section{Tack - Mechanically Applied}

Straw Mulch may be mechanically tackified using a crimping disk or sheep's-foot roller.

a) Crimping Disc - A heavy disk with flat, scalloped discs approximately $6 \mathrm{~mm}$ thick, having dull edges and spaced no more than $230 \mathrm{~mm}$ apart.

b) Sheep's-foot Roller - Modified sheep's-foot roller equipped with straight studs, made of approximately 20 $\mathrm{mm}$ steel plate, placed approximately $200 \mathrm{~mm}$ apart and staggered. The studs shall not be less than $150 \mathrm{~mm}$ long nor more than $150 \mathrm{~mm}$ wide and shall be rounded to prevent withdrawing the straw from the soil. The roller shall be of such mass as to incorporate the straw sufficiently into the soil providing a uniform surface cover.

\section{Plastic Sheeting}

Place plastic sheeting on disturbed, temporary slopes where immediate protection is required and mulching or other methods of soil stabilization are not feasible. Steep slopes include vertical excavations for retaining walls and other temporary soil excavations and embankments related to structural work.

Cover exposed soils and secure tightly in place using an anchoring system consisting of sandbags, chain link fence, or other approved methods. The anchoring system shall not puncture the plastic. Trench plastic at the top of slope and secure adequately to maintain cover during reasonably expected conditions in the area. Direct water away from areas above the plastic to prevent erosion from undermining the plastic.

Control drainage from areas covered by the plastic sheeting so that the discharge occurs onto the toe protection.

Table H-2 Specified ODOT Seed Mixture for Coast Range

\begin{tabular}{|c|c|}
\hline Botanical Name (Common Name) & $\begin{array}{c}\text { Minimum *(PLS) } \\
\text { per surface hectare } \\
\text { (kg/ha) }\end{array}$ \\
\hline \hline Festuca rubra (Creeping Red Fescue) & 11 \\
\hline Festuca rura commutata (Chewings Fescue) & 11 \\
\hline Lolium perenne (Perennial Ryegrass) & 17 \\
\hline Agrostis tenuis (Colonial Bentgrass) & 3 \\
\hline Trifolium repens, Grassland Huia (New Zealand & 2 \\
\hline White Clover) & 44 \\
\hline Total & \\
\hline
\end{tabular}

*PLS - Pure Live Seed 


\section{Appendix I.}

\section{Watersheds and Streams}




\section{Appendix I.}

\section{Watersheds and Streams}

Table I-1. Stream and Wetland Crossings Within The Proposed Project Corridor

\begin{tabular}{|c|c|c|c|}
\hline \multirow{2}{*}{ Name } & \multirow{2}{*}{ Type } & Watershed & \multirow{2}{*}{ Size } \\
\hline & & Segment (East to West) & \\
\hline 8 Unnamed tributaries & Intermittent & $\begin{array}{l}\text { Lower South Umpqua Watershed } \\
\text { Segment A }\end{array}$ & Small \\
\hline 14 Unnamed tributaries & Intermittent & $\begin{array}{l}\text { Olalla Creek/Lookingglass Creek Watershed } \\
\text { Segment A }\end{array}$ & Small \\
\hline 1 Unnamed tributary & Perennial & $\begin{array}{l}\text { Olalla Creek/Lookingglass Creek Watershed } \\
\text { Segment A }\end{array}$ & Small \\
\hline Morgan Creek & Perennial & $\begin{array}{l}\text { Olalla Creek/Lookingglass Creek Watershed } \\
\text { Segment A }\end{array}$ & Small \\
\hline 1 Unnamed tributary & Perennial & $\begin{array}{l}\text { Olalla Creek/Lookingglass Creek Watershed } \\
\text { Segment A }\end{array}$ & Medium \\
\hline 18 Unnamed tributaries & Intermittent & $\begin{array}{l}\text { Olalla Creek/Lookingglass Creek Watershed } \\
\text { Segment B }\end{array}$ & Small \\
\hline Tenmile Creek & Perennial & $\begin{array}{l}\text { Olalla Creek/Lookingglass Creek Watershed } \\
\text { Segment B }\end{array}$ & Small \\
\hline 10 Unnamed tributaries & Perennial & $\begin{array}{l}\text { Olalla Creek/Lookingglass Creek Watershed } \\
\text { Segment B }\end{array}$ & Small \\
\hline 2 Unnamed tributaries & Intermittent & $\begin{array}{l}\text { Olalla Creek/Lookingglass Creek Watershed } \\
\text { Segment C }\end{array}$ & Small \\
\hline 31 Unnamed tributaries & Intermittent & $\begin{array}{l}\text { East Fork Coquille River Watershed } \\
\text { Segment D }\end{array}$ & Small \\
\hline Dead horse Creek & Intermittent & $\begin{array}{l}\text { East Fork Coquille River Watershed } \\
\text { Segment D }\end{array}$ & Small \\
\hline Knapper Creek & Perennial & $\begin{array}{l}\text { East Fork Coquille River Watershed } \\
\text { Segment D }\end{array}$ & Small \\
\hline 16 Unnamed tributaries & Perennial & $\begin{array}{l}\text { East Fork Coquille River Watershed } \\
\text { Segment D }\end{array}$ & Small \\
\hline Hantz Creek & Perennial & $\begin{array}{l}\text { East Fork Coquille River Watershed } \\
\text { Segment D }\end{array}$ & Small \\
\hline & & & (Sheet \\
\hline
\end{tabular}


Table I-1. Stream and Wetland Crossings Within The Proposed Project Corridor

\begin{tabular}{|c|c|c|c|}
\hline \multirow{2}{*}{ Name } & \multirow{2}{*}{ Type } & Watershed & \multirow{2}{*}{ Size } \\
\hline & & Segment (East to West) & \\
\hline Steel Creek & Perennial & $\begin{array}{l}\text { East Fork Coquille River Watershed } \\
\text { Segment D }\end{array}$ & Small \\
\hline Bills Creek & Perennial & $\begin{array}{l}\text { East Fork Coquille River Watershed } \\
\text { Segment D }\end{array}$ & Small \\
\hline China Creek & Perennial & $\begin{array}{l}\text { East Fork Coquille River Watershed } \\
\text { Segment D }\end{array}$ & Small \\
\hline Brummit Creek & Perennial & $\begin{array}{l}\text { East Fork Coquille River Watershed } \\
\text { Segment D }\end{array}$ & Medium \\
\hline $\begin{array}{l}2 \text { Crossings on the East } \\
\text { Fork Coquille River }\end{array}$ & Perennial & $\begin{array}{l}\text { East Fork Coquille River Watershed } \\
\text { Segment D }\end{array}$ & Medium \\
\hline 1 Unnamed tributary & Intermittent & $\begin{array}{l}\text { East Fork Coquille River Watershed } \\
\text { Segment E }\end{array}$ & Small \\
\hline 1 Unnamed tributary & Perennial & $\begin{array}{l}\text { East Fork Coquille River Watershed } \\
\text { Segment } E\end{array}$ & Small \\
\hline Cherry Creek & Perennial & $\begin{array}{l}\text { North Fork Coquille Watershed } \\
\text { Segment E }\end{array}$ & Medium \\
\hline Cherry Creek & Perennial & $\begin{array}{l}\text { North Fork Coquille Watershed } \\
\text { Segment } F\end{array}$ & Medium \\
\hline 5 Unnamed tributaries & Perennial & $\begin{array}{l}\text { North Fork Coquille Watershed } \\
\text { Segment G }\end{array}$ & Small \\
\hline Unnamed tributary & Intermittent & $\begin{array}{l}\text { North Fork Coquille Watershed } \\
\text { Segment G }\end{array}$ & Small \\
\hline $\begin{array}{l}\text { North Fork Coquille } \\
\text { River }\end{array}$ & Perennial & $\begin{array}{l}\text { North Fork Coquille Watershed } \\
\text { Segment G }\end{array}$ & Large \\
\hline 3 Unnamed tributaries & Intermittent & $\begin{array}{l}\text { North Fork Coquille Watershed } \\
\text { Segment } \mathrm{H}\end{array}$ & Small \\
\hline 11 Unnamed tributaries & Intermittent & $\begin{array}{l}\text { Lower Coos River/Coos Bay Watershed } \\
\text { Segment H }\end{array}$ & Small \\
\hline Evans Creek & Intermittent & $\begin{array}{l}\text { Lower Coos River/Coos Bay Watershed } \\
\text { Segment H }\end{array}$ & Small \\
\hline 13 unnamed tributaries & Perennial & $\begin{array}{l}\text { Lower Coos River/Coos Bay Watershed } \\
\text { Segment H }\end{array}$ & Small \\
\hline Panther Creek & Perennial & $\begin{array}{l}\text { Lower Coos River/Coos Bay Watershed } \\
\text { Segment H }\end{array}$ & Small \\
\hline & & & (Sheet 2 of 3 ) \\
\hline
\end{tabular}


Table I-1. Stream and Wetland Crossings Within The Proposed Project Corridor

\begin{tabular}{|l|l|l|l|}
\hline \multirow{2}{*}{ Name } & \multicolumn{1}{|c|}{ Type } & \multicolumn{1}{|c|}{ Watershed } & \multirow{2}{*}{ Size } \\
\cline { 3 - 4 } & & \multicolumn{1}{|c|}{ Segment (East to West) } & \multirow{2}{*}{ Small } \\
\hline \hline Cardwell Creek & Perennial & $\begin{array}{l}\text { Lower Coos River/Coos Bay Watershed } \\
\text { Segment H }\end{array}$ & Small \\
\hline Catching Creek & Perennial & $\begin{array}{l}\text { Lower Coos River/Coos Bay Watershed } \\
\text { Segment H }\end{array}$ & Small \\
\hline 6 Unnamed tributaries & Intermittent & $\begin{array}{l}\text { Middle Main Coquille River Watershed } \\
\text { Segment H }\end{array}$ & Small \\
\hline 11 Unnamed tributaries & Perennial & $\begin{array}{l}\text { Middle Main Coquille River Watershed } \\
\text { Segment H }\end{array}$ & Small \\
\hline 2 Unnamed tributaries & Intermittent & $\begin{array}{l}\text { Lower Coos River/Coos Bay Watershed } \\
\text { Segment I }\end{array}$ & Small \\
\hline 2 Unnamed tributaries & Perennial & $\begin{array}{l}\text { Lower Coos River/Coos Bay Watershed } \\
\text { Segment I }\end{array}$ & Large \\
\hline Isthmus Slough & Perennial & $\begin{array}{l}\text { Lower Coos River/Coos Bay Watershed } \\
\text { Segment I }\end{array}$ & Small \\
\hline 5 Unnamed tributaries & Intermittent & $\begin{array}{l}\text { Lower Coos River/Coos Bay Watershed } \\
\text { Segment J }\end{array}$ & $\begin{array}{l}\text { Lower Coos River/Coos Bay Watershed } \\
\text { Segment J }\end{array}$ \\
\hline 3 Unnamed tributaries & Perennial & $\begin{array}{l}\text { Lower Coos River/Coos Bay Watershed } \\
\text { Segment J }\end{array}$ & Small \\
\hline
\end{tabular}




\title{
Appendix J
}

\section{Construction, Operation and Maintenance Plan}

\author{
Prepared by: \\ Steve Shute \\ Pipeline Solutions, Inc. \\ P.O. Box 1054 \\ Glenwood Springs, CO 81602
}




\section{Appendix $\mathbf{J}$ \\ Construction, Operation and Mainte-}

\section{nance}

\section{Construction Methods and Operations}

\section{General Methods}

1. Safety

a) Fire hazard (in situ flammables and flammable materials) - During construction, the contractor will be required to abide by state fire regulations. Any flammable materials must be transported, contained, and used in accordance with Office of Safety and Health Administration (OSHA) requirements. Any empty containers (if applicable) must be dispositioned properly, in accordance with EPA requirements.

b) Toxic materials hazard - All toxic materials must be used in accordance with OSHA standards.

c) Explosive materials hazard - All explosives must be used in accordance with OSHA requirements.

d) Mechanical hazard: The construction contractor would be required to follow OSHA requirements for operation of all equipment at the construction site.

e) Electrical Hazard: Within BPA and PP\&L rights-of-way, the high voltage powerlines could induce a current in the pipeline, especially long welded sections exposed in or above the trench. The construction contractor shall be required to have and follow a plan to continuously ground the pipe, such that construction workers would be protected from electrical shock by these induced currents.

f) Susceptibility of hazard to public - The public is susceptible to hazard under the following conditions:

- If the contractor fails to follow required safety procedures during public's presence at or near the construction site;

- If the public enters the construction site without proper approval;

- If, during the public's presence at or near the construction site, an act of God occurs.

\section{Access Road Construction Methods}

No new roads would be built. All roads on the proposed route are existing and accessible access roads currently maintained by BPA and PP\&L.

\section{Pipeline Construction Methods}

1. Work area:

Pipeline construction would require a working space, which varies from 20 to 60 feet wide. In the CBW Road, construction would take place entirely within the roadbed, which is about 20 feet wide. In a few areas along the power corridor with steep side slopes, the disturbed area could be 60 feet wide. In most sections, the area of disturbance would be 30 to 40 feet wide. Some grading would be required to install the pipe, but the grade would be substantially restored to its original state before revegetation. 


\section{Assembly and Refueling Areas:}

Assembly and refueling activities would be confined to designated roads.

\section{Road Closures:}

Roads would be closed only when construction is active and within the road right-of-way. No night construction is expected and crews normally work 6 days per week. Most paved road crossings would be bored-under, which would require traffic control (flaggers) but no road closure. Work within the CBW Road would force road closure during the ditch, lay and backfill stages. In the remote section east of Sitkum (10 miles), the CBW Road would be closed during daytime working hours and re-opened in the evenings and off-days. There may be some night closure in the most difficult sections. In the canyon section from Sitkum to Dora (4 miles), the wider working space should allow limited traffic flow during the day, such as on the hour. Most work along the CBW Road would require traffic control for other operations, such as preparation and final cleanup.

\section{Site preparation prescriptions:}

In the powerline corridor, herbaceous vegetation within 20 feet of the trench is removed. The following list of sites are expected to occur along the proposed pipeline route. Each type of construction has an estimated amount of time to prepare the right-of-way and excavate the ditch. After the ditch is prepared, then stringing, welding, laying and backfill can be done at up to one mile per day.

a) Level or gently sloping surfaces on clay or silty soils: Site preparation consists of clearing of brush and trees mentioned above. Typical progress would be 4,000 to 10,000 linear feet per day.

b) Moderate to steep topography: Temporary grading would be required in topography too steep for safe operation of trenching and pipe laying equipment. The scope and nature of soil disturbance would be consistent with that found in the Erosion Control Plan (Appendix H). Progress along slopes is slower than progress on soils of the same type on level or gentle slopes, depending upon the slope gradient, but would typically range from 2,000 to 4,000 feet per day. The very steep approach to Reston Ridge would be slower.

c) Road bed site: Pipeline construction within or near the road bed (the width between the road shoulders) requires traffic management (signs and flaggers), pavement cutting and pavement disposal. Typical progress is 1,000 to 2,000 linear feet per day.

d) Bedrock or rock face situations: Burial of the pipeline within rock sites requires extra work ripping, rock sawing or trenching, or drilling and blasting. Rock sawing and trenching typically progress at 500 to 1,000 feet per day. Drilling and blasting activities normally progress at 200 to 400 feet per day.

e) Talus sites: Digging within talus sites requires site preparation similar to that of steep slopes (temporary grading to enable safe equipment operations), with the additional requirement of constructing pre-engineered soil retention structures (usually rock-filled cages) at the foot of the cut slope, which prevents soil movement above the work area. There are no known talus sites along the corridor.

f) Along streams: Construction parallel to streams would be planned to avoid operation of equipment within riparian zones. Procedures would follow the Erosion Control Plan (Appendix H), using sediment barriers to prevent materials from entering the stream. The rate of progress depends upon soil conditions and topography; a typical maximum rate is 1,000 to 2,000 linear feet per day.

g) Stream crossings: Stream crossings would be accomplished using one of the following methods, depending upon existing conditions.

Large or particularly sensitive streams, estuaries and large wetlands would be crossed with directional-drilling equipment. Site preparation is usually minimal - the entry and target locations are carefully chosen to be flat and open and the entry point would have a small excavation for the initial drill entry. Directional-drill activity takes from 3 to 10 days, depending on length, rock strata and complexity. See subsection 7 a for details, as well as Figures J-1 through J-3.

Small streams with active flows, would be crossed using a Bag-and-Flume method. The stream is dammed with sandbags to temporarily contain stream flow and a flume directs flow around the construction area. After 'bagging and fluming', the streambed is trenched using conventional excavators and rock removal techniques. The stream banks may be cut back to soften the approach angle, then restored after construction to original grade. Such a crossing would typically take less than a day (6-8 hours). 
Trenching across a dry stream bed or runoff channel does not require additional site preparation. Site preparation and pipeline crossing of an inactive small streams (intermittent) would take between one and two hours.

h) Wetland crossings: Wetland crossings would be directionally-drilled to avoid impacts. See Figures below.

\section{Directional-Drilling and Reaming Procedures}

Figure J-1 Directional-Drill Crossing: Pilot Hole

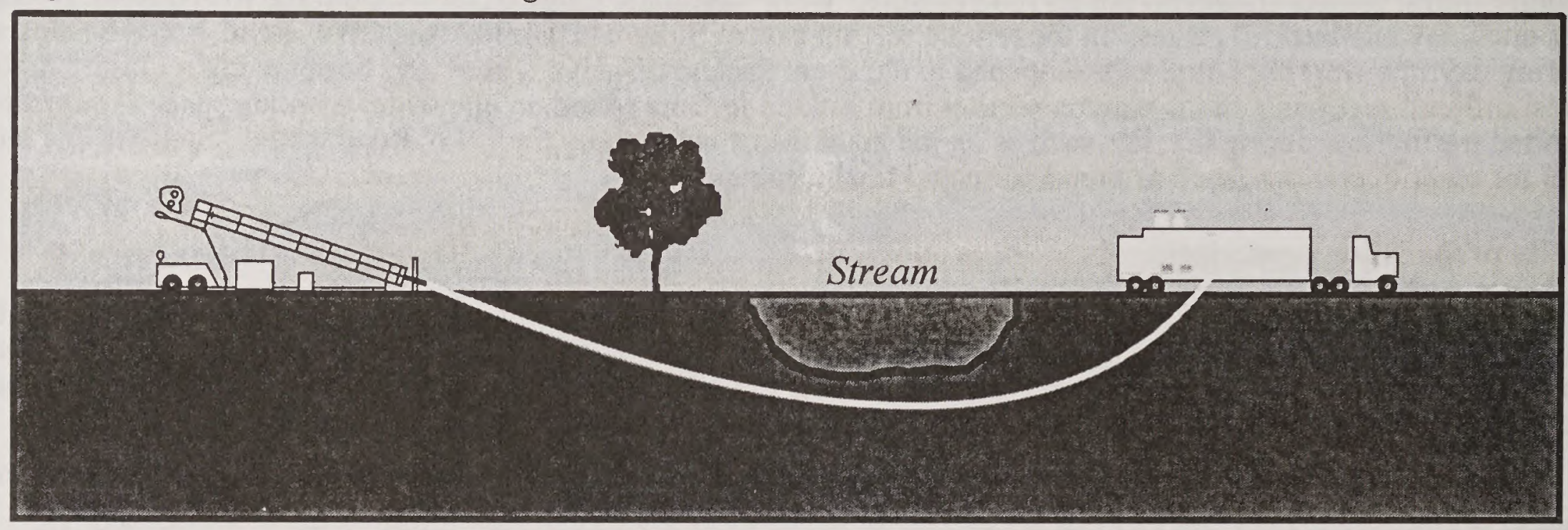

Figure J-2: Reaming Process

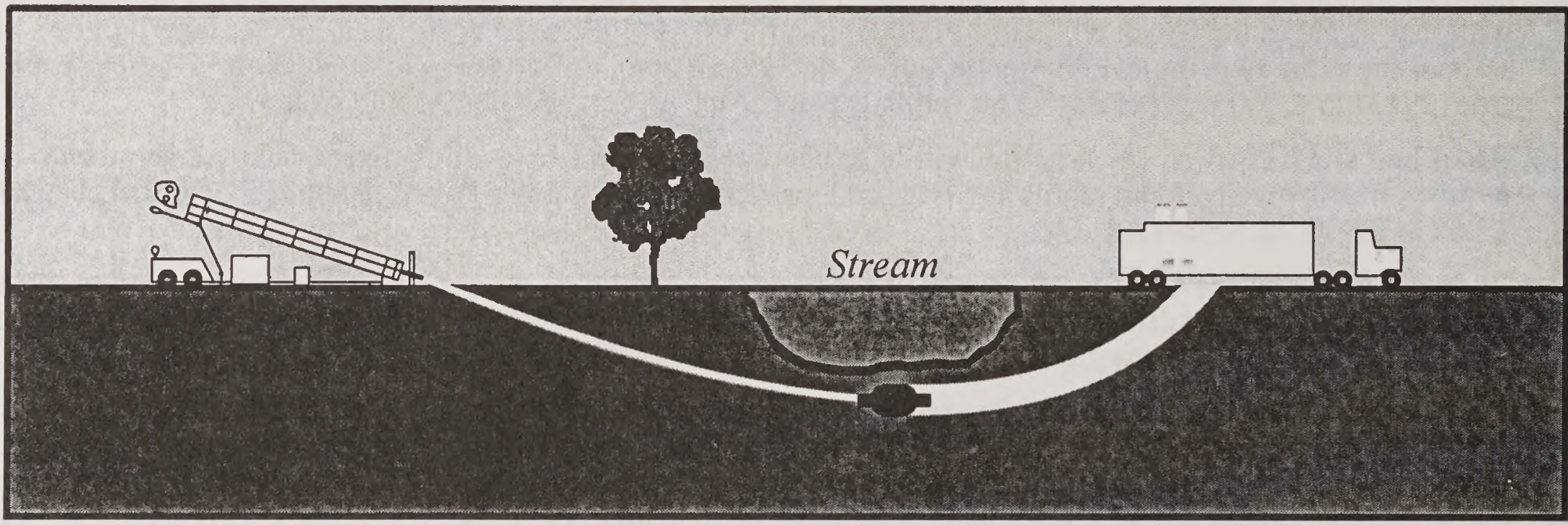

Figure J-3: Pull-Back

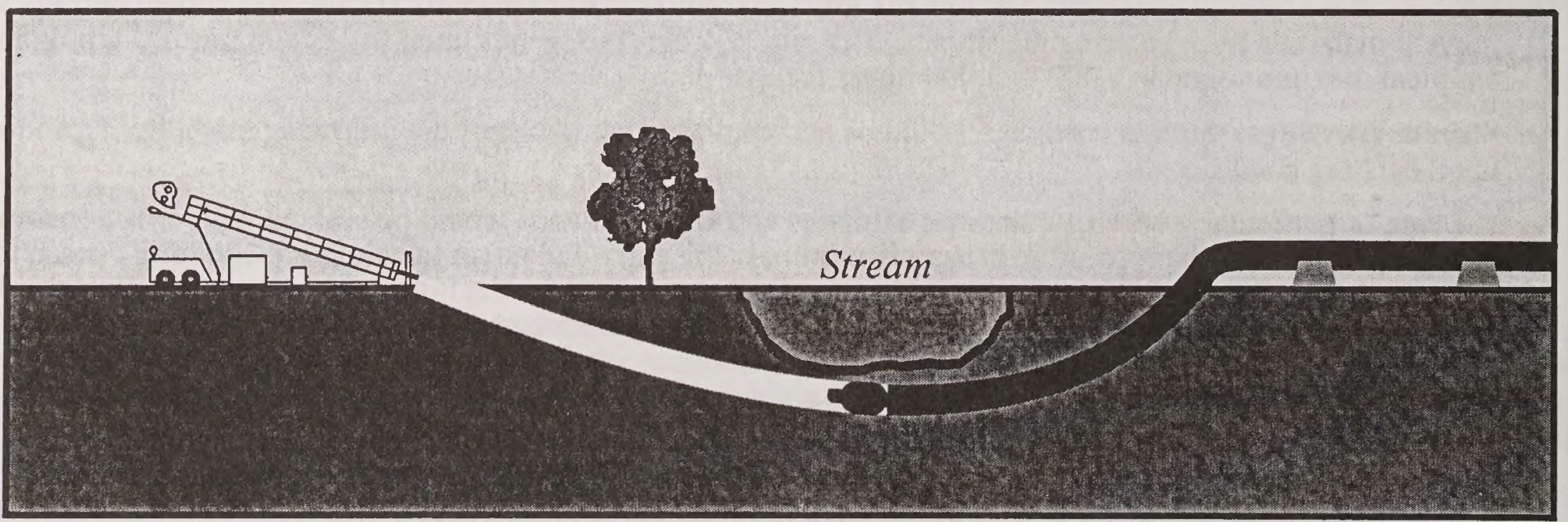




\section{Installation:}

The pipe would be installed to a minimum depth of 36 inches to top of pipe. Installation into bedrock would be a minimum of 24 inch depth to top of pipe. Bedrock is expected for 10-20 percent of the route between Reston and Dora.

Installation process: All equipment would be operated in accordance with OSHA and DEQ standards and guidelines. This includes procedures for operating equipment in or near streams, wetlands, talus slopes, steep terrain and exposed bedrock sites. The following operations are included in the installation process:

a) Ditch digging

b) Pipe joint welding

c) Lay pipe and backfill ditch (replace and compact original soil)

d) Tie-ins (includes installation of block valves, road bores and stream crossings)

e) Testing \& Cleanup (hydrostatic testing, install line markers and cathodic test stations, painting and locking of block valves)

\section{Pipeline bedding:}

Along most of the route, the native soil would be returned to the ditch and compacted around the pipe. In areas where the backfill is too coarse or rocky and would damage the coating, then pipe padding material (such as sand or volcanic ash) is imported to compact around the pipe, with native backfill above that. In the segment within the CBW Road, most of the backfill would be imported road base. The excess native soil would be hauled and stored for use by Coos County in its ongoing road department operations.

\section{Pipeline installation procedures for sensitive or difficult sites:}

a) Directional boring of stream and wetland crossings: Horizontal drilling beneath the stream bed requires drilling at a shallow angle from one side of the stream, boring at a safe distance beneath the stream bed, and exiting on the other side well away from the stream channel. A small "pilot" hole is drilled first, typically about 4 to 6 inches in diameter (Figure J-2). From the exit point, a larger reamer is pulled back through the pilot hole to enlarge the bore. This process continues until the bore is 30 percent to 50 percent oversize, such as a 16 -inch bore for this 12-inch pipeline (see Figure J-3). The pipeline for the entire length of the bore is welded together on the opposite side of the drilling unit. After the joints are coated and pipe is pressure tested, it is pulled back through the ground-bore in a continuous operation. (see Figure J-4)

b) Steep terrain and sharp turns require the pipe to be bent with specialized pipe bending equipment. After backfill, water bars and other erosion control measures will be applied in steep areas.

c) Narrow roadway requires use of smaller crews and equipment working more slowly due to the reduced width of the working space.

d) Bedrock sometimes cannot be broken with a tractor-mounted excavator. Specialized techniques for rock removal are used, depending on the hardness and fracturing of the rock layer. Rock trenchers have carbide teeth and are effective on softer rock. Rock saws are also used to cut a well-defined trench wall. The hardest rock requires drilling and blasting.

\section{Testing and Inspection:}

- Weld testing and inspection: Each weld will be visually inspected by a certified welding inspector and X-rayed to detect invisible defects.

- Hydrostatic leak test: Every joint of the pipe is hydrostatically tested (e.g., pressure-tested with water at the factory) to comply with the DOT and American Petroleum Institute (API) specifications. The finished pipeline would be hydrostatically pressure tested to at least $1,500 \mathrm{psi}$, to detect leakage or failure. This is 150 percent of pipeline's MAOP. Because of the elevation differences, testing must be done in sections to avoid exceeding the Specified Minimum Yield Strength (SMYS) of the pipe (2,039 psi). 


\section{Grade restoration and site revegetation:}

Each site would be restored to original grade; the surface would be reseeded to establish native plants in accordance with the ECP (see Appendix H).

\section{Cleanup:}

All litter and materials remaining after completion of construction would be removed from the site. Equipment would be removed from the right-of-way as soon as possible, after completion of its assigned task.

\section{Construction Related to Ancillary Facilities}

The EIS describes in detail the construction of the 12 inch pipeline to Coos Bay, including the block valves, delivery and city gate stations and other appurtenances. Coos County also plans to build smaller pipeline laterals to Coquille, Myrtle Point and Bandon. NW Natural and possibly the City of Bandon plan to build gas distribution networks in those towns. The present plans for laterals and distribution networks are described in this document and are subject to change. Apart from these projects, there are no ancillary facilities planned.

The following assemblies are required in the proposed action:

a) Meter Station - required at the delivery points from Williams near Roseburg and to NW Natural in Coos Bay. Each meter station would be fabricated offsite in a controlled welding facility. The station site would need to be leveled, graveled and fenced. Construction of modest concrete supports will be required for the piping and metering building. Site preparation, installation and testing take about two weeks for each station.

b) Block valve with blowdowns - required at 5 strategic locations along the route. Each block valve will require about one day for site preparation, installation and testing (see also Block Valve Assembly, next page).

\section{Pipeline design specifications}

Pipe sections are 12.75 inch outside diameter, with a 0.25 inch pipe wall thickness. The sections would be manufactured to API 5LX-52 standards or better, capable of a SMYS of 2,039 psi. The MAOP is 1,000 psi. The outside of the pipe section would be coated with a suitable protective coating.

Extra pipeline protection would be as follows:

- Crossing pipe (for drilled portions beneath streams and wetlands) would be coated with an additional layer of protective coating.

- Rock shield or select padding would be required to protect the coating in very rocky sections.

- Corrosion protection: Magnesium anodes would be attached directly to the pipe with copper wires. These 17 or 32 pound magnesium bars form a simple battery circuit when attached to the steel pipe and buried nearby. The anodes corrode slowly over 20 years or more, generating a small electrical current that protects the steel pipeline "cathode" from corrosion. The process is called "cathodic protection" and is required on all U.S. gas pipelines. Pipe coating is also required, which greatly reduces exposure of steel to moisture and the amount of protective current required. Anodes would normally be spaced at 1,000 to 3,000 foot intervals. Additional clusters of anodes would be installed as needed to dissipate induced current on facilities near power lines.

\section{Pipeline Joining system}

The pipe sections would be welded together. A suitable protective coating would be applied over the welded joints to prevent corrosion of the uncoated weld area. 


\section{Block valve assembly}

This assembly is approximately 4 feet long and it includes the following (also, see Figure J-4, on next page):

- Block valve: A 12-inch ball valve is welded directly inline with the buried pipeline. The stainless steel ball rotates around a steel axle or "stem", which is turned by hand or (for valves 6-inch and larger) a series of gears. On buried valves such as this, the stem is extended above ground in a pipe casing. These 12 -inch valves would be fitted with gear boxes and hand wheels for manual operation, or with pneumatic or gas-powered operators for automatic or remote operation. The valve operator would be 30 to 48 inches above grade and would be about the same size as a five gallon bucket.

- Blowdown valves: A "blowdown" valve would be positioned vertically from the pipeline, one on each side of, and about 2 feet away from, the block valve. Each valve consists of a 4-inch pipeline stem extending above grade. Near its upper end is a valve and a heavy threaded cap (Refer to "Operation Description" or "Pipeline Shutdown" for a description of the purpose for a blowdown valve.)

- Block valve protection: All valves will be locked with a key available only to pipeline operators. The entire footprint will be surrounded with a chain link fence with locked gate. Depending on location and traffic volume, the fence and valve will be protected with concrete or pipe barricades. 
Figure J-4: Typical Block Valve Setting

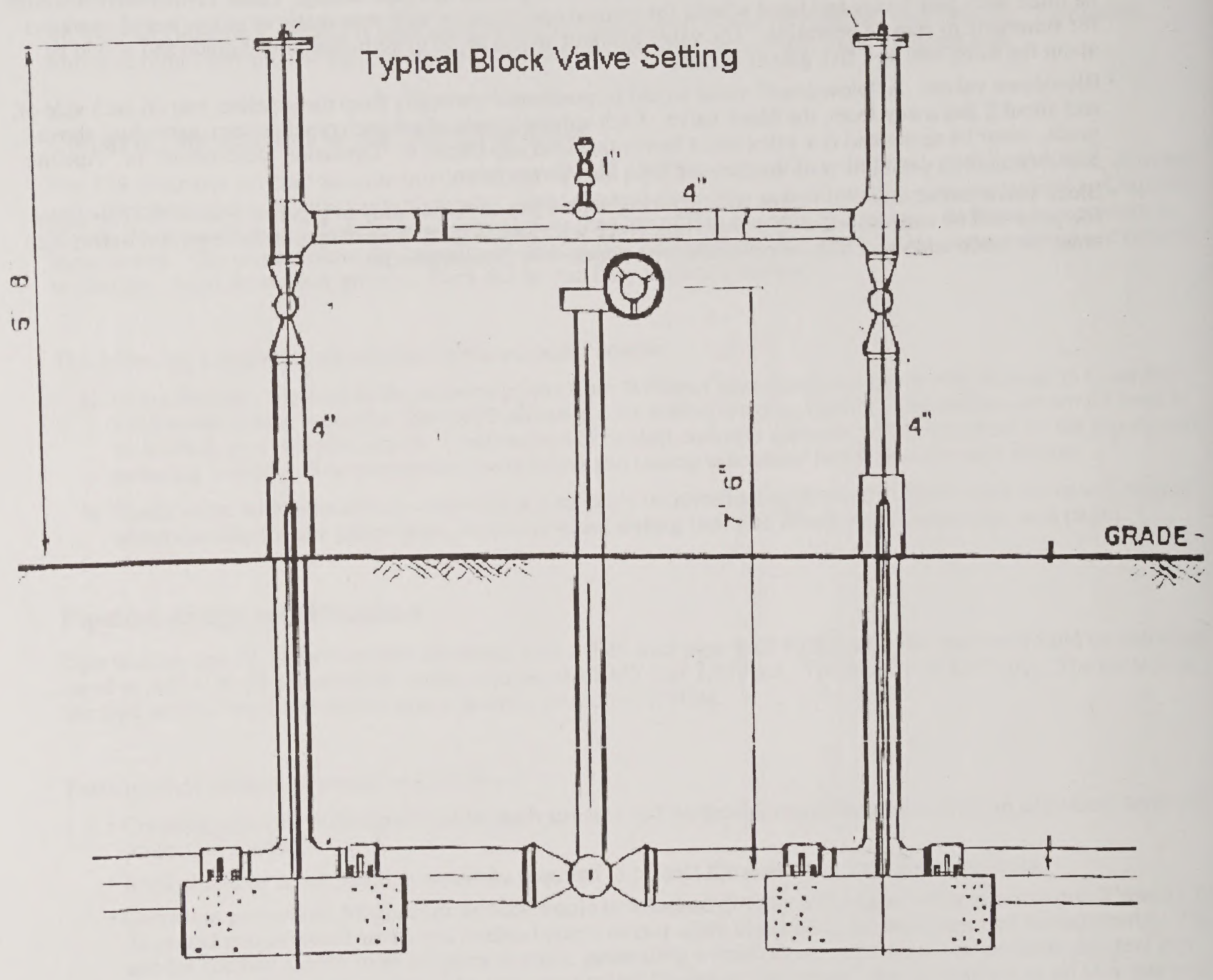


Block valve Protection: The entire block valve footing (about 2 feet wide and 8 feet long) would be suitably protected from physical damage, vandalism and unauthorized operation.

Pipeline Supporting Materials: Native soil, or imported gravel and roadbase material.

Fuels: Diesel would be used for most of the large equipment in the construction project. Gasoline would be used in transport vehicles.

Chemicals (coolant, lubricants, cleaning materials, etc.): as needed to support the construction machinery and equipment.

Pipeline markers: DOT requires pipeline markers as needed to delineate the route. These are typically bright yellow composite plastic line markers showing location information (station number) and a warning, spaced at about 10 per mile, or more in difficult terrain or populated areas.

Cathodic test stations: Plastic support pipe with copper wire leads to the pipeline would be spaced at intervals of approximately one mile, to provide for pipeline location and periodic cathodic protection testing.

Erosion control construction materials: Riprap, soil stabilizing fabric, 18-inch soil staples (fastening the fabric into place), sandbags and straw bales. Also, see the ECP in Appendix $\mathrm{H}$.

\section{Equipment Required During Construction}

Diesel freight truck with flat-bed trailer and low-boy trailer options, backhoe, bulldozer, side-boom pipe-layer, frontend loader, air driven tools, impact wrench, various hand tools and equipment necessary for welding the pipeline segments together.

\section{Hauling Schedule}

The pipeline segments would arrive at either Roseburg or Coos Bay (depending upon the way it is shipped from the factory). Materials delivery from a Roseburg or Coos Bay storage area would arrive on a just-in-time basis; these materials would then be placed into their permanent configuration at the construction site within a few days of delivery. Deliveries of pipe and materials would be expected to occur every day. One full truck load of pipe carries about 1,200 feet of pipe. Therefore, deliveries should not exceed one to two trucks per day.

\section{Construction Schedule}

The entire construction sequence - clearing, trenching, pipe string and weld, laying in and backfill, cleanup and mulching - would typically take place over just a few days for any particular 200 yard segment. Each of those steps would take about 1 or 2 hours for a short segment, then the noise and dust from the next segment would be greatly diminished and quickly return to normal. The steps are not usually consecutive, though, as the construction group or "spread" literally spreads down the corridor. A typical sequence could be: ground clearing in the morning, ditching early afternoon, pipe stringing late in the day, weld and backfill next day, cleanup and mulch the third day.

The total length of time for completing of any local segment depends on the type of terrain and speed of travel. On most of the segments along PP\&L or BPA, the entire process would usually be finished over a span of 1 to 3 days. Steeper sections and road sections could span 3 or 4 days, as digging and logistics are more difficult. The narrowest, rockiest portions of the CBW Road could take up to 7 days from start to finish. There are just a few short sections where this could be expected, in the canyons both directions from Sitkum.

The directional-drilling crews and tie-in crews are independent of the mainline spreads. The bores could be done weeks or months ahead of the mainline (or vice versa), then a separate tie-in crew would tie together the loose ends, backfill and cleanup. For any particular short segment, however, the cumulative local impact will be much less than 7 days.

Construction can be scheduled in accordance with specific time-of-day or time-of-year restrictions applicable to wildlife or other concerns on public lands. 


\section{Labor Force}

The construction contractor could employ up to 200 workers distributed among several separate construction groups or "spreads" in the pipeline corridor. Spreads would merge or divide as needed. In the corridor portions characterized by open terrain, each spread could employ a large workforce (30 or more workers). When the terrain is narrow canyons or steep slopes, the spread would likely be closer to a dozen workers. Additional crews - with just a few workers each - would accomplish specialized aspects of the project, such as manage road traffic, boring and drilling, tie-ins, hydrostatic testing, meter station and block valve construction, and erosion control/revegetation tasks.

All work would take place during daylight hours, which are adjustable to any justifiable need throughout the course of the construction. The operations of the spreads would be managed by the construction contractor's supervisors.

\section{System Description}

\section{Pipeline}

The pipeline's expected life span is unlimited. The system components are as follows:

- Delivery station from Williams Gas Pipeline near Roseburg.

- Pipeline (entirely buried except for bridge crossings).

- Block valves, including above-ground "blowdown" valves.

- Magnesium corrosion prevention anodes are buried below the pipe.

- Cathodic test stations are plastic above ground test stations with copper wire leads to a pipeline connection below ground.

- Line markers (above-ground).

- End-point to City Gates Station at Ocean Boulevard.

\section{A Delivery Station consists of:}

- A steel pipe manifold and pigging facilities;

- pressure regulators (if required);

- electronic measuring instruments to relay critical parameter data (gas pressure, gas temperature, gas flow rate and alarms) to Williams' Supervisory Control and Data Acquisition (SCADA) facility in real-time sequence;

- a meter building (approximately 240 sq. ft.);

- a steel fence surrounding the plot.

\section{A Block Valve Setting consists of:}

- A block valve the size of the mainline (12-inch), buried in line with the pipeline;

- Two smaller diameter "blow down" valves, one on each side of the block valve.

- Fence and barricades.

\section{City Gate Station}

A city gate station is usually built at the edge of a city, to deliver gas from the high-pressure transmission pipeline to a lower pressure local distribution system. In many ways, the city gate station is exactly analogous to an electrical substation. A city gate station includes the following:

- Block Valve and Blowdown: A ball valve and single blowdown are the end of the transmission pipeline. The block valve is the same size as the pipeline and the blowdown is usually two or three pipe sizes smaller. The block valve could be buried inline or above-ground, and could be fitted with pneumatic or gas-powered operators for automatic or remote operation.

- Meter: A gas meter would be installed to measure the volume of gas flowing to the customer. Meters are usu- 
ally fitted with electronic totalizing computers and SCADA equipment to relay flow and pressure information to a remote monitoring center.

- Pressure Regulators: The city gate stations for the Coos Pipeline will not include pressure regulators. The distribution entity (NW Natural or Bandon) will install regulators as needed to reduce the pressure to distribution pressure, which is typically 60 psi or less.

- Station Protection: All valves will be locked with a key available only to pipeline operators. The entire footprint will be surrounded with a chain link fence with locked gate. Depending on location and traffic volume, the fence and valve will be protected with concrete or pipe barricades.

\section{Associated Facilities}

The Coos County Pipeline would have no other facilities.

\section{Operation Description}

The pipeline would operate continuously. The County plans to contract the pipeline operation to an experienced pipeline operator. A crew of trained operators employed by the pipeline operations contractor would operate and maintain the pipeline in accordance with DOT requirements and a comprehensive O\&M Plan tailored to this system. The Oregon Public Utilities Commission would routinely inspect the pipeline operations.

\section{Pipeline Capacity:}

The 12-inch pipeline can transport natural gas at a flow rate of up to 70 million cubic feet per day, assuming a line pressure of $800 \mathrm{psi}$. This capacity could be expanded 20 percent by boosting the pressure to 1,000 psi, with the addition of a compressor station near the Williams delivery connection in Douglas county. At the Williams' current operating pressures, the Coos pipeline would operate with stresses around 30 to 40 percent of the SMYS of the pipeline steel. The addition of a compressor station is allowable and within the prescribed safety limits of the pipe, but this added capacity is not likely to become necessary.

\section{Pipeline Shutdown:}

Any or all block valves can be used to interrupt the flow of the gas in the pipeline. If the pipeline needs to be emptied, the natural gas is "bled off" by opening the "blow down" valve within the isolated segment of pipeline.

\section{Maintenance Description}

\section{Access roads}

All access roads would be maintained to the degree necessary to provide access for pipeline inspection and maintenance. These roads are currently maintained by BPA and PP\&L.

\section{Vegetation Removal}

Minimal vegetation removal would be required for pipeline maintenance because brush removal is periodically done for powerline corridor maintenance.

\section{Pipeline Patrols}

DOT requires an annual inspection of the entire pipeline right-of-way for encroachments, unauthorized digging activity, soil erosion, earth movement, drainage problems and gas leaks. 


\section{Corrosion Control Survey}

Cathodic test stations would be located along the pipeline at regular intervals up to a mile. Test stations allow a direct connection for electronically locating the pipeline and for checking the corrosion control system. A survey of the level of cathodic protection is required once per calendar year under DOT Part 192 regulations.

\section{Maintenance of Facilities}

Apart from regular patrols, corrosion inspections and painting, the pipeline requires very little other maintenance. Block and blowdown valves must be cycled closed and open once per year and lubricated, if possible. Erosion (such as sunken ditches) will be addressed as needed with water bars, mulching or other measures taken as necessary to stop it. There is usually no reason to excavate a section of pipe after construction, except to expose a few feet for utility crossings or to repair damage done by a third party excavator.

\section{Abandonment Description}

In the event the proposed pipeline is permanently abandoned, it would remain empty in its constructed configuration with all valves in a closed position. If a portion of this abandoned pipeline were to obstruct future construction projects, or otherwise interfere with the environment, the County would contract an operator to remove the portion(s) causing the impact, and the resultant openings in the pipeline would be capped. 


\section{Appendix K. $\quad$ Survey and Manage Species}




\section{Survey and Manage Species}

Table K-1. Survey and Manage Fungi, Lichens, Bryophytes and Vascular Plants

\begin{tabular}{|l|l|}
\hline \multicolumn{1}{|c|}{ Species } & \multicolumn{1}{|c|}{ Fungi } \\
\hline \multicolumn{1}{|c|}{} \\
\hline Albatrellus avellaneus & Collybia racemosa \\
\hline Albatrellus caeruleoporus & Cordyceps capitata \\
\hline Albatrellus ellisii & Cordyceps ophioglossiodes \\
\hline Albatrellus flettii & Cortinarius barlowensis \\
\hline Arcangeliella camphorata & Cortinarius cyanites \\
\hline Asterophopra lycoperdoides & Cortinarius depauperatus \\
\hline Asterophora parasitica & Cortinarius olympianus \\
\hline Baeospora myriadophylla & Corinarius tabularis \\
\hline Balsamia nigrens & Cortinarius valgus \\
\hline Boletus pulcherrimus & Craterellus tubaerformis \\
\hline Bondarzewia mesenterica & Cudonia monticola \\
\hline Cantharellus subadbidus & Cyphillostereum laeve \\
\hline Catasthelasma ventricosa & Dermocybe humboldtensis \\
\hline Chalciporus piperatus & Destuntzia fusca \\
\hline Chamonixia caespitosa & Destuntzia rubra \\
\hline Chromosera cyanophylla & Endogone oregonensis \\
\hline Chrysomphalina grossula & Fayodia bisphaerigera \\
\hline Clavariadelphus ligula & Galerina atkinsoniana \\
\hline Clavariadelphus occidentalis & Galerina cerina \\
\hline Clavariadelphus sachalinensisn & Galerina heterocystis \\
\hline Clavariadelphus truncatus & Galerina sphagnicola \\
\hline Clavulina castanopes v. lignocola & Galerina vittaeformis \\
\hline Clitocybe senilis & Gastroboletus turbinatus \\
\hline
\end{tabular}




\section{Species}

\section{Fungi (continued)}

\begin{tabular}{|l|l|}
\hline Gomphus bonarii & Phaeocollybia kauffmanii \\
\hline Gyromitra californica & Phaeocollybia olivacea \\
\hline Gyromitra esculerita & Phaeocollybia oregonensis \\
\hline Gyromitra infula & Phaeocollybia picea \\
\hline Gyromitra meloaleucoides & Phaeocollybia pseudofestiva \\
\hline Gyromitra montana & Phaeocollybia scatesiae \\
\hline Helvella elastica & Phaeocollybia sipei \\
\hline Helvella maculata & Phaeocollybia spadicea \\
\hline Hydnum umbilicatum & Phellodon atratus \\
\hline Hydropus marginellus & Pholiota albivelata \\
\hline Hygrophorus karstenii & Plectania melastoma \\
\hline Hypomycs luteovirens & Podostroma alutaceum \\
\hline Leucogaster citrinus & Pseudaleuria quinaultiana \\
\hline Leucogaster microsporus & Ramaria abientina \\
\hline Macowanites chlorinosmus & Ramaria celerivirescens \\
\hline Mycena quinaultensis & Ramaria concolor f. tsugina \\
\hline Mycena tenax & Ramaria conjunctipes v. sparsiramosa \\
\hline Mythicomyces corneipes & Ramaria coulterae \\
\hline Neolentinus kauffmanii & Ramaria cyaneigranosa \\
\hline Neournula pouchetii & Ramaria gelatiniaurantia \\
\hline Omphalina ericetorum & Ramaria gracilis \\
\hline Otidea leporina & Ramaria rainierensis \\
\hline Otidea onotica & Ramaria rubella v. blanda \\
\hline Otidea smithii & Ramaria rubribrunnescens \\
\hline Phaeocollybia attenuata & Ramaria rubrievanescens \\
\hline Phaeocollybia californica & Ramaria rubripermanens \\
\hline Phaeocollybia dissilens & Ramaria stuntzii \\
\hline
\end{tabular}




\begin{tabular}{|c|c|}
\hline Species & Species \\
\hline Fungi (continued) & Lichens \\
\hline Ramaria suecica & Bryoria subcana \\
\hline Ramaria verlotensis & Bryoria tortuosa \\
\hline Rickenella swartzii & Buellia oidalea \\
\hline Russula mustelina & Calicium abientinum \\
\hline Sarcodon fuscoindiscus & Calicium glaucellum \\
\hline Sarcodon imbricatus & Calicium viride \\
\hline Sarcosoma latahense & Cetrelia cetrarioides \\
\hline Sarcosphaera coronaria & Chaenotheca chrysocephala \\
\hline Sowerbyella rhenana & Chaenotheca ferruginea \\
\hline Sparassis crispa & Chaenotheca furfuracea \\
\hline Spathularia flavida & Chaenothecopsis pusilla \\
\hline Stagnicola perplexa & Cladonia norvegica \\
\hline Thaxterogaster pavelekii & Hypogymnia duplicata \\
\hline Thaxterogaster pingue & Lobaria linita \\
\hline Tremiscus helvelloides & Nephroma bellum \\
\hline Tuber asa & Pannaria saubinetii \\
\hline Tuber pacificum & Peltigera pacifica \\
\hline Bryophytes & Platismatia lacunosa \\
\hline Buxbaumia viridis & Psuedocyphellaria rainierensis \\
\hline Diplophyllum albicans & Ramalima pollinaria \\
\hline Diplophyllum plicatum & Ramalina thrausta \\
\hline Encalyptra brevicolla v. crumiama & Stenocybe clavata \\
\hline Schistostega pennata & Usnea longissima \\
\hline \multirow[t]{2}{*}{ Tetraphis geniculata } & Vascular Plants \\
\hline & Cypripedium faciculatum \\
\hline
\end{tabular}




\section{Appendix K1. Special-Status Species}




\section{Special-Status Fungi, Lichens, Bryophytes and Vascular Plants}

Table K1-1. Special-Status Plants Within the Coos Bay District

\begin{tabular}{|c|c|}
\hline Species & Common Name \\
\hline \multicolumn{2}{|c|}{ Fungi } \\
\hline Bridgeopoprus nobilissimus & Giant Polypore Fungus \\
\hline \multicolumn{2}{|c|}{ Bryophytes } \\
\hline Andreaea schofieldiana & Moss \\
\hline Calypogeia sphagnicola & Liverwort \\
\hline Campylopus schmidii & Moss \\
\hline Cephaloziella spinigera & Liverwort \\
\hline Crumia latifolia & Moss \\
\hline Cryptomitrium tenerum & Liverwort \\
\hline Diplophyllum plicatum & Liverwort \\
\hline Encalypta brevicolla var.crumiani & Moss \\
\hline Funaria muhlenbergii & Moss \\
\hline Limbella fryei & Moss \\
\hline Lophozia laxa & Liverwort \\
\hline Pholia sphagnicola & Moss \\
\hline Polytrichum strictum & Moss \\
\hline Pseudolenskeella serpentinense & Moss \\
\hline Tayloria serrata & Moss \\
\hline Tripterocladium leucocladulum & Moss \\
\hline \multicolumn{2}{|c|}{ Lichen } \\
\hline Bryoria pseudocapillaris & Lichen \\
\hline Bryoria spiralifera & Lichen \\
\hline Cladidium bolanderi & Lichen \\
\hline Erioderma sorediatum & Lichen \\
\hline Hypogymnia pulverata & Lichen \\
\hline
\end{tabular}


Table K1-1. Special-Status Plants Within the Coos Bay District

\begin{tabular}{|c|c|}
\hline Species & Common Name \\
\hline \multicolumn{2}{|c|}{ Lichen (continued) } \\
\hline Hypogymnia subphysodes & Lichen \\
\hline Leioderma sorediatum & Lichen \\
\hline Nephroma occultum & Lichen \\
\hline Pilophorus nigricaulis & Lichen \\
\hline Sulcaria badia & Lichen \\
\hline Teloschites flavicans & Lichen \\
\hline \multicolumn{2}{|c|}{ Vascular Plants } \\
\hline Arabis koehleri var. koehleri & stipitate rockcress \\
\hline Arctostaphylos hispidula & hairy manzanita \\
\hline Artemisia pycnocephala & coastal sagewort \\
\hline Aster vialis & wayside aster \\
\hline Bensoniella oregana & vensonia \\
\hline Botrychium minganense & gray moonwort \\
\hline Brodiaea terrestris & dwarf brodiaea \\
\hline Calochortus coxii & crinite mariposa-lily \\
\hline Calochortus umpquaensis & mariposa-lily \\
\hline Camissonia ovata & golden eggs \\
\hline Cardamine nuttalii var. gemmata & toothwort \\
\hline Carex comosa & bristly sedge \\
\hline Carex gigas & Siskiyou sedge \\
\hline Carex macrochaeta & bighead sedge \\
\hline Carex serratodens & saw-tooth sedge \\
\hline Cicendia quadrangularis & timwort \\
\hline Cimicifuga elata & tall bugbane \\
\hline Cochlearia officinalis & spoonwort \\
\hline Cordylanthus maritimus ssp. palustris & salt-marsh bird's-beak \\
\hline
\end{tabular}


Table K1-1. Special-Status Plants Within the Coos Bay District

\begin{tabular}{|c|c|}
\hline Species & Common Name \\
\hline \multicolumn{2}{|c|}{ Vascular Plants (continued) } \\
\hline Cypripedium fasciculatum & clustered lady's-slipper \\
\hline Ericameria arbortescens & golden fleece \\
\hline Erigeron cervinus & Siskiyou daisy \\
\hline Eriophorum chamissonis & russet cotton-grass \\
\hline Erysimum menziesii ssp. concinnum & pacific wallflower \\
\hline Festuca elmeri & Elmer's fescue \\
\hline Frasera umpquaensis & Umpqua swertia \\
\hline Gentiana setigera & Waldo gentian \\
\hline Gilia millefoliata & seaside gilia \\
\hline Horkelia congesta ssp. congesta & shaggy horkelia \\
\hline Hydrocotyle verticillata & whorled marsh-pennywort \\
\hline Isopyrum stipitatum & Siskiyou false rue-anemone \\
\hline $\begin{array}{l}\text { Kalmiopisis fragrans (Douglas Co. } \\
\text { Pop) }\end{array}$ & fragrant kalmiopsis \\
\hline Lasthenia macrantha ssp. prisca & large-flowered goldfields \\
\hline Liamna latibracteata & California globe-mallow \\
\hline Lilium occidentale & western lily \\
\hline $\begin{array}{l}\text { Limnanthes floccosa ssp. bellingeri- } \\
\text { ana }\end{array}$ & swarf meadow-foam \\
\hline Limnanthes gracilis var. gracilis & slender meadow-foam \\
\hline Limonium californicum & western marsh-rosemary \\
\hline Lupinus sulphureus var. kincaidii & Kincaid's lupine \\
\hline Lycopodiella inundata & bog club-moss \\
\hline Microseris bigelovii & coast microseris \\
\hline Monardella purpurea & Siskiyou monardella \\
\hline Montia howellii & Howell's momtia \\
\hline
\end{tabular}


Table K1-1. Special-Status Plants Within the Coos Bay District

\begin{tabular}{|c|c|}
\hline Species & Common Name \\
\hline \multicolumn{2}{|c|}{ Vascular Plants (continued) } \\
\hline Oenothera wolfii & Wolf's evening-primrose \\
\hline Ophioglossum pusillium & adder's-tongue \\
\hline Pellaea andromedifolia & coffee fern \\
\hline Perideridia erythrorhiza & red-root yampa \\
\hline Phacelia argentea & silvery phacelia \\
\hline Plagiobothrys hirtus & hairy popcorn flower \\
\hline Poa unilateralis & San Francisco bluegrass \\
\hline Polystichum californicum & California sword-fern \\
\hline Rhynchospora capitellata & brownish beakrush \\
\hline Romanzoffia thompsonii & Thompson's mistmaiden \\
\hline Salix delnortensis & Del Norte willow \\
\hline Scirpus subterminalis & water clubrush \\
\hline Sedum laxum ssp. heckneri & Heckner's stonecrop \\
\hline Sidalcea malviflora ssp. patula & coast checker-bloom \\
\hline Sisyrinchium hitchcockii & Hitchock's blue-eyed grass \\
\hline Trillium angustipetalum & Siskiyou trillium \\
\hline Triteleia hendersonii var. leachae & Leach's brodiaea \\
\hline Utricularia gibba & humped bladderwort \\
\hline Utricularia minor & lesser bladderwort \\
\hline Viola primulifolia ssp.occidentalis & western big violet \\
\hline Wolffia borealis & dotted water-meal \\
\hline Wolffia Columbiana & Columbia water-meal \\
\hline
\end{tabular}




\section{Special-Status Fish}

Table K1-2. Special-Status Fish

\begin{tabular}{|l|l|}
\hline \multicolumn{1}{|c|}{ Species } & \multicolumn{1}{c|}{ Common Name } \\
\hline \hline Oncorhynchus keta & chum salmon \\
\hline Oncorhynchus kisutch & coho salmon \\
\hline Oncorhynchus mykiss ssp. & steelhead \\
\hline Oncorhynchus tshawytscha & chinook salmon \\
\hline Oncorhynchus clarki clarki (Oregon Coast) & cutthroat salmon \\
\hline
\end{tabular}

Table K1-3. Special-Status Invertebrates

\begin{tabular}{|l|l|}
\hline \multicolumn{1}{|c|}{ Species } & \multicolumn{1}{c|}{ Common Name } \\
\hline \hline Pisidium ultramontanum & montane peaclam \\
\hline Helminthoglypta hertleini & Oregon shoulderband (snail) \\
\hline Lanx subrotundata & rotund lanx (snail) \\
\hline Megomphix hemphilli & Oregon Megomphix (snail) \\
\hline Monadenia fidelis beryllica & green sideband (snail) \\
\hline Mondanenia fidelis celeuthia & travelling sideband (snail) \\
\hline Pristiloma arcticum crateris & Crater Lake tightcoil (snail) \\
\hline Prophysaon dubium & papillose tail-dropper \\
\hline Bombus franklini & Franklin's bumblebee \\
\hline Icaricia Icarioides fenderi & Fender's blue butterfly \\
\hline Incisalia polia obscura & obscure elfin \\
\hline Plebejus saepiolus insulanus & insular blue butterfly \\
\hline Polites mardon & Mardon skipper (butterfly) \\
\hline Driloleirus (= megascolides) macelfreshi & Oregon giant earthworm \\
\hline
\end{tabular}


Table K1-4. Special-Status Wildlife

\begin{tabular}{|c|c|}
\hline Species & Common Name \\
\hline \multicolumn{2}{|c|}{ Birds } \\
\hline Oceanodroma furcata & Fork-tailed Storm-Petrel \\
\hline Phoebastris albatrus & Short-tailed Albatross \\
\hline Brachyramphus marmoratus & Marbled Murrelet \\
\hline Pelecanus occidentalis & Brown Pelican \\
\hline Branta canandensis leucopareia & Aleutian Canada Goose \\
\hline Haliaeetus leucocephalus & Bald Eagle \\
\hline Accipiter gentilis & Northern Goshawk \\
\hline Falco peregrinus anatum & American Peregrine Falcon \\
\hline Falco peregrinus tundrius & Arctic Peregrine Falcon \\
\hline Speotyto cunicularia hypugaea & Burrowing Owl \\
\hline Strix occidentalis caurina & Northern Spotted Owl \\
\hline Charadrius alexandrinus nivosus & Western Snowy Plover \\
\hline Charadrius montanus & Mountain Plover \\
\hline Melanerpes lewis & Lewis' Woodpecker \\
\hline Pooecetes gramineus affinis & Oregon Vesper Sparrow \\
\hline \multicolumn{2}{|c|}{ Mammals } \\
\hline Corynorhinus touwnsendii & Townsend's Big-Eared Bat \\
\hline Martes pennati & Fisher \\
\hline Balaenoptera musculus & Blue Whale \\
\hline Balaenoptera physalus & Fin Whale \\
\hline Eubalaena glacialis & Northern Right Whale \\
\hline Balaenoptera borealis & Sei Whale \\
\hline Physeter macrocephalus & Sperm Whale \\
\hline Megaptera novaeangliae & Humpback Whale \\
\hline Escrichtius robustus & Gray Whale \\
\hline Enhydra lutris & Sea Otter \\
\hline
\end{tabular}




\begin{tabular}{|l|l|}
\hline \multicolumn{1}{|c|}{ Species } & \multicolumn{1}{c|}{ Common Name } \\
\hline \multicolumn{2}{|c|}{ Mammals (continued) } \\
\hline Eumetopias jubatus & Northern (Stellar) Sea Lion \\
\hline \hline \multicolumn{2}{|c|}{ Amphibians } \\
\hline Aneides flavipunctatus & Black Salamander \\
\hline Batrachoseps attenuatus & California Slender Salamander \\
\hline Plethodon stormi & Siskiyou Mountains Salamander \\
\hline \hline \multicolumn{2}{|c|}{ Reptiles } \\
\hline Chrysemys picta & Painted Turtle \\
\hline Clemmys marmorata & Western Pond Turtle \\
\hline Caretta caretta & Loggerhead Sea Turtle \\
\hline Chelonia mydas & Green Sea Turtle \\
\hline Dermochelys coriacea & Leatherback Sea Turtle \\
\hline Lepidochelys olivacea & Pacific Ridley Sea Turtle \\
\hline
\end{tabular}




\section{Appendix L. \\ Glossary of Terms}




\section{Appendix L.}

\section{Glossary of Terms}

Alluvium - A general term for clay, silt, sand, gravel or similar unconsolidated material deposited by a stream or other body of running water.

Anadromous Fish - Fish that are born and reared in freshwater, move to the ocean to grow and mature, and return to freshwater to reproduce. Salmon, steelhead and shad are examples.

Anode - The electrode at which oxidation or corrosion occurs. (opposite of cathode)

Anthropogenic - Relating to or resulting from the influence humans have on the natural world.

Areas of Critical Environmental Concern (ACEC) - A designated area on public lands where special management attention is required (1) to protect and prevent irreparable damage to fish and wildlife, important historic, cultural, or scenic values, or other natural systems or processes; or (2) to protect life and safety from natural hazards.

Arkosic - Sedimentary rock formed by the cementation of sand-sized grains of feldspar and quartz.

Artifacts - Any product of human cultural activity; more specifically, any tools, artwork, or objects found in an archaeological context.

Backfill - (noun) Material used to replace soil and earth removed during mining. (verb) To fill excavation ditch after pipeline placement.

Basalt - Dark colored extrusive igneous rock composed chiefly of calcium plagioclase and pyroxene. Extrusive equivalent of gabbro; underlies the ocean basins and comprises oceanic crust.

Bedrock 1) - Any solid rock exposed at the Earth's surface or overlain by unconsolidated material.

Bedrock 2) - The solid rock beneath a layer of soil, rock fragments, or gravel. Also called substratum.

Bentonite - Light-colored valuable clay that expands with the addition of water and is used as oil-well drilling mud and as filler in the building, paper, soap and pharmaceutical industries.

Berm - The space between the toe of a slope and excavation made for intercepting ditches or borrow.

Block Valve - When closed, the valve can block gas flow in both directions.

Blowdown - The venting of pressure from a pipeline.

Bore - A generally horizontal opening produced underground primarily for the purpose of installing services.

Bryophytes - A nonflowering plant, often growing in damp places, that has separate gamete-bearing and spore-bearing forms.

Cathodic protection - A process by which the corrosion of a metal pipeline is prevented by the use of an electrical current through replaceable anodes.

City Gate - A city gate station is usually built at the edge of a city to deliver gas from the high-pressure transmission pipeline to a lower pressure local distribution system. In many ways a city gate is analogous to an electrical substation.

Chert - A mainly opaque, fairly granular, silicate rock with a dull shiny luster and a great range of colors, used as raw material for the manufacture of chipped stone artifacts.

Climax Vegetation - The final vegetation community and highest ecological development of a plant community that emerges after a series of successive vegetational stages. The climax community perpetuates itself indefinitely unless disturbed by outside forces.

Colloids - Very small, finely divided solids (that do not dissolve) that remain dispersed in a liquid for a long time due to their small size and electrical charge.

Colluvium - Loose rock and soil at the base of a cliff or steep slope. 
Consultation - Formal consultation is a process that occurs between the Fish and Wildlife Service or the National Marine Fisheries Service and a federal agency that commences with the federal agency's written request for consultation under Section 7(a)(2) of the ESA regarding a federal action which may affect a listed species or its critical habitat. It concludes with the issuance of the biological opinion under Section 7(b)(3) of the Act. Informal consultation is an optional process that includes all discussions, correspondence, etc., between the Fish and Wildlife Service and the federal agency, or the designated non federal representative, prior to formal consultation, if required. If the listing agency determines that there is no likely adverse affect to the listed species, it may concur with the action agency that formal consultation is unnecessary.

Critical Habitat - Under the ESA, critical habitat is defined as (1) the specific areas within the geographic area occupied by a federally listed species on which are found physical and biological features essential to the conservation of the species, and that may require special management considerations or protection; and (2) specific areas outside the geographic area occupied by a listed species, when it is determined that such areas are essential for the conservation of that species.

Cryogenic - Having or relating to extremely low temperatures.

Cumulative effects - Those effects on the environment that result from the incremental effect of the action when added to the past, present and reasonable foreseeable future actions regardless of what agency (Federal or non federal) or person undertakes such other actions. Cumulative effects can result from individually minor but collectively significant actions taking place over a period of time.

Danger tree - Any tree (leaning or otherwise) considered as having potential to fall against the power lines.

Directional drilling - A steerable system for the installation of pipes, conduits and cables in a shallow arc using a surface launched drilling rig.

Drilling fluid - a mixture of water and usually bentonite and/or polymer continuously pumped to the cutting head to facilitate cutting, reduce required torque, facilitate the removal of cuttings, stabilize the borehole, cool the head and lubricate the installation of the Product Pipe. In suitable soil conditions water alone may be used.

Easement - Anon-ownership interest in a land parcel that provides the interest-holder with rights to perform designated actions. It may also limit actions by a landowner.

Effects - Effects, impacts and consequences, as used in this environmental impact statement, are synonymous. Effects may be direct, indirect or cumulative.

Estuaries - The wide lower course of a river where the tide flows in, causing fresh and salt water to mix.

Extirpation - The elimination of a species from a particular area.

Fauna - The animal life of a region or geological period.

Fish-Bearing Streams - Any stream containing any species of fish for any period of time.

Flakes - Small pieces and chips of rock and stone that have come off a larger rock, as a result creating stone tools.

Floodplain - Level lowland bordering a stream or river onto which the flow spreads at flood stage.

Flora - The plant life of a region or geological period.

Flow Spreader - A device used to dissipate concentrated water flow into sheet flow.

Flume - (Flume Pipe) A pipe or lined channel used to divert water from a stream while construction activities occur in the streambed.

Groundfish - A species or group of fish that spends most of its life on or near the sea floor.

Hydrocarbons - An organic compound made up of the elements of carbon and hydrogen that exists as a gas or liquid at ambient conditions.

Hydrocolloids - A substance that forms a gel when mixed with water.

Hydroelectric - Generated by converting the pressure of falling or running water to electricity by means of a turbine coupled to a generator.

Hydrostatic Test - A test of the strength and leak resistance of a vessel or pipe by internal pressurization with a test liquid, such as water. 
Indigenous - Originating in and typical of a geographic area.

Interdisciplinary Team (IDT) - A group of individuals with varying areas of specialty assembled to solve a problem or perform a task.

Intermittent - Any non-permanent flowing drainage feature having a definable channel and evidence of annual scour or deposition.

Knoll - A small rounded hill or mound.

Lateral - A service line that transports a product from individual buildings to a main pipeline.

Late-Succession Forest - Forest seral stages which include mature and old-growth age classes.

Late-Successional Reserve (LSR) - A forest in its mature and/or old-growth stages that has been reserved under each option in this report.

Liquefaction - A general term applying to any linear feature in a metamorphic rock.

Lithics - Artifacts or ecofacts made of stone or rock. Sometimes the term lithics refers to the raw materials used to make stone tools.

Mains - Pipe used to deliver natural gas to an end user.

Mitigation - Modifications of actions that (1) avoid impacts by not taking a certain action or parts of an action; (2) minimize impacts by limiting the degree or magnitude of the action and its implementation; (3) rectify impacts by repairing, rehabilitating, or restoring the affected environment; (4) reduce or eliminate impacts over time by preservation and maintenance operations during the life of the action; or (5) compensate for impacts by replacing or providing substitute resources or environments.

Monitoring - A process of collecting information to evaluate if objective and anticipated or assumed results of a management plan are being realized or if implementation is proceeding as planned.

Noxious Weed - According to the Federal Noxious Weed Act (PL 93-629), a weed that causes disease on has other adverse effects on humans and their environment and is therefore detrimental to public health and the agriculture and commerce of the United States

Off-channel habitat - Channels or ponds in a floodplain, at least seasonally connected to the primary channel that are in addition to and frequently parallel the primary flowing channel.

Old-growth forest - A forested stand usually at least 180-200 tears old with moderate to high canopy closure; a multilayered, multispecies canopy dominated by large overstory trees and high incidence of large trees.

Palustrine Emergent Wetland - Better known as marshes - are usually dominated by grass-like plants - such as cattails, sedges or bulrush - which are rooted in bottom sediments, but "emerge" above the surface of the water.

Palustrine Forested Wetland - Forested system including any inland wetland which lacks flowing water and contains ocean derived salts in concentrations of less than $0.05 \%$.

Parent rock - The unconsolidated and more or less chemically weathered mineral or organic matter from which the solum of soils is developed by pedogenic processes.

Pedological features - Recognizable units within a soil material which are distinguishable from the enclosing material for any reason such as origin (deposition as an entity), differences in concentration of some fraction of the plasma, or differences in arrangement of the constituents (fabric).

Pelagic - Of or in the open ocean or open water.

Perennial Stream - A stream that typically has running water on a year-round basis.

Pig - A device inserted and forced through a pipeline to clean, dry, or measure characteristics of a pipeline.

Pilot hole - A hole excavated at the beginning of the directional drill crossing.

Piping Manifold - A configuration of pipes used to direct natural gas in different directions or through different pieces of equipment.

Polyethylene (PE) - A ductile, durable, virtually inert thermoplastic composed of polymers of ethylene. 
Protohistoric - A period prior to the beginning of written records in an area, but after that area has been initially mentioned in reports written elsewhere.

Pullback - When the pipe is pulled into the reamed hole back to the drill rig.

Radiocarbon Dating - An absolute dating method based on the radioactive decay of Carbon-14 contained in organic materials.

Reamer - A downhole tool used to smooth the wall of a borehole, enlarge the borehole, stabilize the drill bit and straighten the borehole axis where kinks or doglegs are encountered.

Record of Decision (ROD) - A document separate from but associated with an environmental impact statement that states the management decision, identifies all alternatives including both the environmentally preferable and selected alternatives, states whether all practical means to avoid environmental harm from the selected alternative have been adopted, and if not, why not.

Refugia - Locations and habitats that support populations of organisms that are limited to small fragments of their previous geographic range.

Research Natural Areas - An area set aside by a public or private agency specifically to preserve a representative sample of an ecological community, primarily for scientific and educational purposes.

Residual Soil - Soil presumed to have developed in place as the product of decomposition and disintegration of bedrock.

Rill erosion - Rill erosion is the removal of soil by concentrated water running through little streamlets, or headcuts. Detachment in a rill occurs if the sediment in the flow is below the amount the load can transport and if the flow exceeds the soil's resistance to detachment.

Riparian reserves - Designated riparian areas found outside Late-Successional Reserves.

Ripping - The process of breaking up or loosening compacted soil and rock to facilitate excavation.

Riprap - Rough stone of various sizes placed compactly or irregularly in a channel to prevent scour by water or debris.

Riverine wetland - The riverine system...includes all wetlands and deepwater habitats contained within a channel, with two exceptions: (1) wetlands dominated by trees, shrubs, persistent emergents, emergent mosses, or lichens, and (2) habitats with water containing ocean-derived salts in excess of $0.5 \mathrm{ppt}$.

Saprolite - soft disintegrating igneous rock that remains where it was located when solid, formed by heavy weathering in a humid environment.

Scoping - An early and open process for determining the scope of issues to be addressed in an environmental impact statement and for identifying the significant issues related to a proposed action. Scoping may involve public meetings; field interviews with representatives of agencies and interest groups; discussions with resource specialists and managers; and written comments in response to news releases, direct mailings and articles about the proposed action and scoping meetings.

Scour - Evidence of movement of material, erosion or deposition, in a downslope direction due to transport of water.

Second Growth - Relatively young forests that have developed following a disturbance.

Seeps - Places where water oozes from the ground to form a pool.

Special-Status species - Those species that (1) have appeared in the Federal Register as proposed for classification and are under consideration for official listing as endangered or threatened species or (2) are on an official state list or (3) are recognized by the BLM or other management agencies as needing special management or prevent their being placed on Federal or state lists.

Solum - The upper layers of a soil profile where the formation of new soil takes place and where most plant roots and soil animals are found.

Subduction - To be carried under the edge of an adjoining continental or oceanic plate, causing tensions in the Earth's crust that can produce earthquakes or volcanic eruptions.

Substrate - Any object or material upon which an organism grows or is attached. 
Tackifier - A chemical used to help mulch stick to bare soil.

Tapping Tee - A device used to physically connect a customer's plastic service line from a plastic main to the customer's facility.

Talus - A slope landform, typically covered by coarse rock debris forming a more or less continuous layer that may or may not be covered by duff and litter.

Tectonic - Relating to the forces that produce movement and deformation of the earth's crust.

Trenching - Method in which access is gained by excavation from ground level to the required level underground for the installation, maintenance or inspection of a pipe, conduit or cable. The excavation is then backfilled and the surface reinstated.

Turbidity - Suspended matter in water that scatters or otherwise interferes with the passage of light through the water.

Valve - Mechanism that controls the volume or direction of flow. A valve can be closed, partially open, or fully open.

Watershed - The drainage basin contributing water, organic matter, dissolved nutrients and sediments to a stream or lake. 


\section{Appendix M. \\ List of References.}




\section{Appendix M.}

\section{List of References.}

Beissinger, S.B. 1995. Population trends of the marbled murrelet projected from demographic analysis. Pages 385394 in Ralph et. al. (eds.). Ecology and Conservation of the Marbled Murrelet. Gen. Tech. Rep. PSW-GTR-152.

Betlejewski, Frank. 1994. Port-Orford Cedar Management Guidelines. USDI, BLM. 32 pages.

Burnham, K.P., D.R. Anderson, and G.C. White. 1994. Estimation of vital rates of the northern spotted owl. Appendix J, 1-26 in USDA Forest Service, Final Supplemental Environmental Impact Statement. Portland, Oregon. Vol.II.

BLM, Coos Bay District. 1997. Watershed Analysis - Middle Main Coquille, North Coquille Mouth, and Catching Creek. 52 pp.

BLM Manual 3100. 1999. Code of Federal Regulations. Title 43, Vol. 2, Part 3100-Oil and gas leasing, subpart 3101-Issuance of leases, sec. 3101.1-2-Surface use rights.

BLM, Roseburg District. 1998. Olalla-Lookingglass Watershed Analysis. 127 pp.

BLM, Roseburg District. 2000. Lower South Umpqua Watershed Analysis. 134 pp.

Coos County. May 17, 2000a. "Application for transportation and utility systems and facilities on Federal lands." STD Form 299 (BLM Form).

Coos County. May 17, 2000b. "Supplement to Application for a Natural Gas Pipeline to Coos County, Oregon"; Supplement to STD Form 299 (BLM form). 17 pp.

Coos County. August 2000c. "Supplement to Application for a Natural Gas Pipeline to Coos County, Oregon Supplement to STD Form BPA F 4300.03e". 8 pp.

Coos County. December 1, 2000d. Coos County Natural Gas Pipeline Project - Information for Environmental Assessment." http://www.co.coos.or.us/ngas/gasea.htm. 5 pp.

Coos/Curry/Douglas Regional Investment Board and CCD Business Development Corporation (Roseburg, OR). 2000. "Coos, Curry and Douglas Regional Investment Plan." http://www.co.coos.or.us/regplan.htm.

ECONorthwest. 1999; The Economic and Fiscal Impacts of Building and Operating a Natural Gas Pipeline in Coos County.

ECONorthwest. 2000; The Economic Impact of Building and Operating a Natural Gas Pipeline in Coos County, Oregon. 
Forsman, E., and R. Anthony. 1999. Analysis of demographic rates of northern spotted owls, executive summary, 19 March 1999. Unpublished preliminary report on file at Coos Bay District Office.

Helvoigt, Ted. 2000. "Oregon's Rural Unemployment Rate". Oregon Labor Market Information System (OLMIS). http://olmis.emp.state.or.us/olmisj/ArticleReader?itemid=00001071.

Holzman, S. 1995. Personal communication. U.S. Fish and Wildlife. Portland, Oregon.

Jones \& Stokes Associates, Inc. 1998. "Biological Resources Technical Report - South Oregon Coast Reinforcement Project". Bellevue, Washington. Chapters 1 - 3;40 pp.

Marshall, D.B. 1988. Status of the marbled murrelet in North America; with special emphasis on populations in California, Oregon, and Washington. Audubon Society of Portland. 42 pp.

Maser, Chris. 1998. Mammals of the Pacific Northwest: from the coast to the high Cascades. Oregon State University Press, Corvallis, OR. Pp. 306-314.

Maxwell, Duchemin, Hallis \& Trotter LLC. 1999. "Coos County Annual Financial Report". CPA Report. Eugene, Oregon. http://www.co.coos.or.us/auditrpt.doc. 89 pp.

NIOSH. 2000. "Online NIOSH pocket guide to chemical hazards" http://www.cdc.gov/niosh/npg/nengapdx.html.

O’Dell, T.E. 1999. Survey Protocols for Seven Protection Buffer Fungi Version 1.3 USDA and USDI, Portland, Oregon.

Oregon Department of Fish and Wildlife. 2000. Oregon Guidelines for Timing of In-Stream Work to Protect Fish and Wildlife Resources.

Prior, Don. January 2000. Designing For Stream Simulation At Road Crossings.

Ralph, C.J., G.L. Hunt Jr., M.G. Raphael, and J.F. Piatt, Technical Editors. 1995. Ecology and conservation of the marbled murrelet. Gen. Tech. Rep. PSW-GTR-152. Albany, California. Pacific Southwest Research Station, Forest Service, U.S. Department of Agriculture. 420 pp.

Ralph, C.J., and S.L. Miller. 1995. Offshore population estimates of marbled murrelets in California. Pages $353-$ 360 in Ralph, et al. (eds.). Ecology and Conservation of the Marbled Murrelet. Gen. Tech. Rep. PSW-GTR-152.

Spiech, S.M., and T.R. Wahl. 1995. Marbled murrelet populations of Washington - marine habitat preferences and variability of occurrence. Pages 313-326 in Ralph et al. (eds.). Ecology and Conservation of the Marbled Murrelet. Gen.Tech.Rep.PSW-GTR-152.

Strong, C.S., B.K. Keitt, W.R. McIver, C.J. Palmer, and I. Gaffney. 1995. Distribution and population estimates of marbled murrelets at sea in Oregon during the summers of 1992 and 1993. Pages 339-352 in Ralph et al. (eds.).

Ecology and Conservation of the Marbled Murrelet. Gen. Tech. Rep. PSW-GTR-152. 
Thomas, J.W., E.D. Forsman, J.B. Lint, E.C. Meslow, B.R. Noon, and J. Verner. 1990. A conservation strategy for the northern spotted owl. A Report by the Interagency Scientific Committee to address the conservation of the northern spotted owl. U.S. Department of Agriculture, Forest Service, and U.S. Department of the Interior, Fish and Wildlife Service, Bureau of Land Management, and National Park Service. Portland, Oregon. 427 pp.

U.S. Department of Agriculture, Forest Service. 1973. Protection of Fish Habitat During Forest Road Development.

U.S. Department of Agriculture. 1983. Forest Ecosystem Management: An Ecological, Economic and Social Assessment. Report of the Forest Ecosystem Management Assessment Team. Pg II-73.

U.S. Department of Agriculture Forest Service and U.S. Department of Transportation. November 1990. Fish Passage Through Culverts. 67pp.

U.S. Department of Agriculture, Forest Service. 1991. Road Construction and Maintenance In: Influences of Forest and Rangeland Management On Salmonid Fishes and Their Habitats. W.R. Meehan, editor. pp. 297-323.

U.S. Department of Agriculture, U.S. Department of Interior. 1994. Standards and Guidelines for Management of Habitat for Late-Successional and Old-Growth Forest Related Species Within the Range of the Northern Spotted Owl Record of Decision.

U.S. Department of Agriculture, U.S. Department of Interior. 1994a. Record of Decision for amendments to Forest Service and Bureau of Land Management planning documents within the range of the northern spotted owl. Forest Service, Bureau of Land Management. Portland, Oregon.

U.S. Department of Agriculture, U.S. Department of the Interior. 1994b. Final supplemental environmental impact statement on management of habitat for late-successional and old-growth forest related species within the range of the northern spotted owl. Forest Service, Bureau of Land Management. Portland, Oregon.

U.S. Department of Agriculture, U.S. Department of Interior. 1996. Draft Management Recommendations for Buxbaumia viridis. Section 3 In Draft Management Recommendations for Bryophytes Installment 2. Portland Oregon.

U.S. Department of Agriculture, U.S. Department of Interior. 1997. Late-Successional Reserve Assessment Oregon Coast Range Province - Southern Portion.

U.S. Department of the Interior, U.S. Department of Agriculture. 1998. South Coast - Northern Klamath Late-Successional Reserve assessment. May 1998. 109 pp plus appendices.

U.S. Department of Agriculture, U.S. Department of Interior. 2000. FSEIS: For Amendment to the Survey and Manage Protection Buffer, and other Mitigation Measures Standards and Guidelines.

U.S. Department of Agriculture, U.S. Department of Interior. 2001. Record of Decision and Standards and Guidelines for Amendments to the Survey and Manage, Protection Buffer, and other Mitigation Measures Standards and Guidelines. Portland Oregon. 
U.S. Department of Energy. 1995. Research conducted by the Pacific Northwest National Laboratory. http://www.pnl.gov/fta/5_nat.html.

U.S. Department of Interior, BLM. 1986. Northwest Area Noxious Weed Control Program Record of Decision. Portland Oregon.

U.S. Department of Interior, BLM. 1987. Supplement to the Northwest Area Noxious Weed Control Program Record of Decision. Portland Oregon.

U.S. Department of the Interior. 1994. Final biological opinion for the proposed action of the supplemental environmental impact statement on management of habitat for late-successional and old-growth forest related species within the range of the northern spotted owl. U.S. Fish and Wildlife Service. Portland, Oregon.

U.S. Department of Interior, BLM. 1995a. Record of Decision and Resource Management Plan. Roseburg Oregon.

U.S. Department of Interior, BLM. 1995b. Integrated Weed Control Plant Environmental Assessment. Roseburg Oregon.

U.S. Department of Interior, BLM. 1996. Partners Against Weeds, An Action Plan For the Bureau of Land Management Washington DC.

U.S. Department of the Interior, BLM. 1996. "Revision of Timber Sale E-4 Special Provision for Protection of Threatened and Endangered Species, and Suspension, Modification, and Termination of Timber Sale Contracts." Instruction Memorandum No. OR-96-78. Attachment 2.

U.S. Department of the Interior, U.S. Department of Agriculture. 1998. South Coast - Northern Klamath Late-Successional Reserve assessment. May 1998. 109 pp plus appendices.

U.S. Department of the Interior. 1986. Pacific bald eagle recovery plan. U.S. Fish and Wildlife Service. 163 pp.

U.S. Department of the Interior. 1987. The northern spotted owl; a status review. U.S. Fish and Wildlife Service. Portland, Oregon. 47 pp.

U.S. Department of the Interior. 1989. The northern spotted owl; a status review supplement. U.S. Fish and Wildlife Service. Portland, Oregon.

U.S. Department of the Interior. 1990a. 1990 Status Review: northern spotted owl; Strix occidentalis caurina. Report to the Fish and Wildlife Service. Portland, Oregon. 95 pp.

U.S. Department of the Interior. 1990b. Endangered and threatened wildlife and plants; determination of threatened status for the northern spotted owl; final rule. Pages 26114-26194, Federal Register, June 26, 1990. 
U.S. Department of the Interior. 1992a. Endangered and threatened wildlife and plants; determination of critical habitat for the northern spotted owl; final rule. Pages 1796-1838, Federal Register, January 15, 1992.

U.S. Department of the Interior. 1992b. Endangered and threatened wildlife and plants; determination of threatened status for the Washington, Oregon, and California population of the marbled murrelet; final rule. Pages 4523845337, Federal Register, October 1, 1992.

U.S. Department of the Interior. 1994a. Coos Bay District Proposed Resource Management Plan Environmental Impact Statement. vol. II, appendix W. Bureau of Land Management. North Bend, Oregon.

U.S. Department of the Interior. 1994b. Roseburg District Proposed Resource Management Plan/Environmental Impact Statement. Appendix EE. Bureau of Land Management. Roseburg, Oregon.

U.S. Department of the Interior. 1994c. Final biological opinion for the proposed action of the supplemental environmental impact statement on management of habitat for late-successional and old-growth forest related species within the range of the northern spotted owl. U.S. Fish and Wildlife Service. Portland, Oregon.

U.S. Department of the Interior. 1995a. Coos Bay District Record of Decision and Resource Management Plan. Bureau of Land Management. North Bend, Oregon.

U.S. Department of the Interior. 1995b. Roseburg District Record of Decision and Resource Management Plan. Bureau of Land Management. Roseburg, Oregon.

U.S. Department of the Interior. 1996. Endangered and threatened wildlife and plants; determination of critical habitat for the marbled murrelet; final rule. Pages 26255-26320, Federal Register, May 24, 1996.

U.S. Department of the Interior. 1997. Recovery Plan for the Marbled Murrelet (Washington, Oregon, and California Populations). U.S. Fish and Wildlife Service. Portland, Oregon. 203 pp.

U.S. Fish and Wildlife Service. 1999. Endangered and Threatened Wildlife and Plants; Proposed Rule To Remove the Bald Eagle in the Lower 48 States From the List of Endangered and Threatened Wildlife; Proposed Rule. Fed. Reg. vol. 64, number 128 (July 6): 36453-36464.

U.S. Government Printing Office. 2000. http://www.gpo.org. December.

Varoujean, D.H., and W.A. Williams. 1995. Abundance and distribution of marbled murrelets in Oregon and Washington based on aerial surveys. Pages 327338 in Ralph et al. (eds.). Ecology and Conservation of the Marbled Murrelet. Gen. Tech. Rep. PSW-GTR-152.

Wall Street Journal. January 5, 2001. "Jobless Claims Continued to Rise Last Week". Article including a summary of the U.S. Labor Department report for November, 2000. 


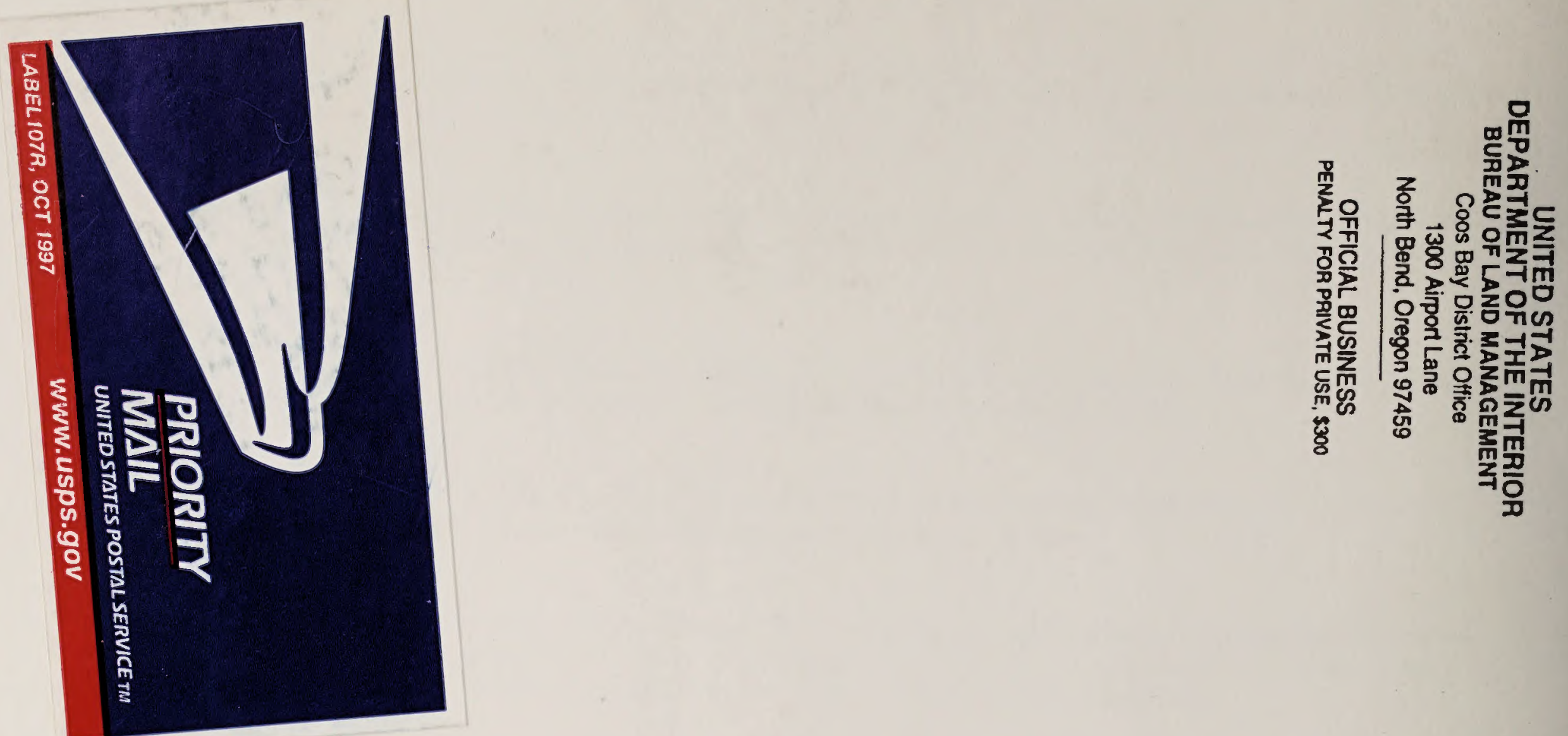

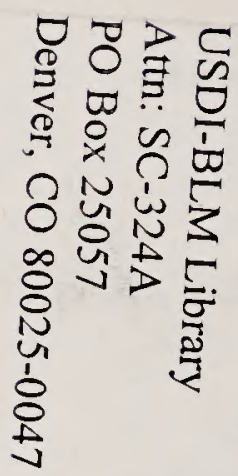

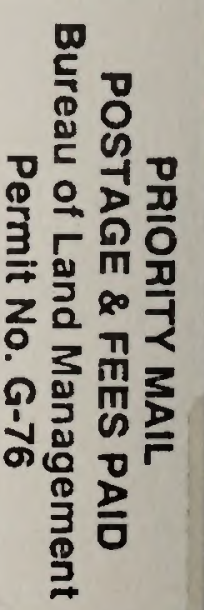

